January 2021

\title{
REMOISTENABLE TEMPORARY SUPPORTS FOR FACING OF CANVAS PAINTINGS
}

\author{
PhD candidate:
}

Alba Paola 

"To exchange one orthodoxy for another is not necessarily an advance." George Orwell 



\section{Abstract}

Although facing is widely used for multiple purposes, there is still little information about it. At first glance, facing seems to be an almost neutral and simple intervention. Its application, however, entails complex consequences including changes to a painting's strata, and it can have potential repercussions on the conservation of the paint itself. In most cases, it would be better to recur to alternative and less intrusive methods, but sometimes the use of facing is strictly necessary.

For this reason, during this $\mathrm{PhD}$ a research protocol addressed the design of remoistenable temporary supports (RTS) for the facing of canvas paintings, an alternative method that enables a higher control of the adhesive penetration into the substrate, and thus the easier removal of residues. Great attention was given in this assessment to the needs of restorers, in terms of not only availability and the cost-effectiveness of materials, but also for the concerns of the safety of the operator as well as the environment.

In the first section of this dissertation, a historical review is made starting from the first indirect sources of the 18th century up to the present day. Then facing's adhesive and penetrative mechanisms are analysed, focusing on conservative issues related to the used materials and application methodologies.

The second section describes the assessment of the innovative RTS methodology, tested according to a meticulous research project adapting advanced analytical technologies to the specific needs. During the first experimental stage, chemical, physical and mechanical analyses of the different classes of materials (adhesives and temporary supports) and their compatibility for the preparation of remoistenable tissues were carried out. The second step of the investigation focused on the evaluation of the application of remoistenable temporary supports on mock-ups reproducing a canvas painting, in order to test those considered the most relevant factors. Observations with optical microscope in visible and ultraviolet (UV) light and analyses with fieldemission scanning electron microscopy (FESEM) were carried out to evaluate the permanence of residues and the assessment of the possible modifications that may have occurred on the painted surface. Micro-Raman spectroscopy associated with a high-resolution microscope was used to determine the penetration of the adhesive into the cracks of the mock-ups. Finally, peeling tests at different environmental conditions were carried out to assess the adhesion strength of the selected RTS. 


\section{Resumen}

Aunque el empapelado es una técnica ampliamente utilizada en restauración con diversos propósitos, todavía no se dispone de mucha información técnica sobre la misma. A primera vista, acarrea consecuencias complejas, incluyendo cambios en las capas pictoricas, pudiendo tener también potenciales repercusiones en la propia conservación de la obra. En la mayoría de casos, sería más adecuado recurrir a otras técnicas alternativas y menos intrusivas.

Por este motivo, a lo largo de esta Tesis Doctoral se ha desarrollado un protocolo de investigación orientado al diseño de Soportes Temporales Rehumectables (remoistenable temporary supports: RTS) para la protección de pinturas sobre lienzos, un método alternativo que permite un mayor control de la penetración de adhesivo en el sustrato, y por tanto una remoción de residuos más sencilla y eficaz. Durante este estudio se prestó especial atención a las necesidades de los restauradores, no solo en términos de disponibilidad y eficiencia económica, sino también en lo concerniente a la salud de los operadores y el cuidado del medio ambiente.

En la primera sección de esta tesis se ha realizado una revisión histórica, comenzando por las primeras fuentes indirectas del Siglo XVIII hasta la actualidad. A continuación, se analizan los mecanismos adhesivos y de penetración del empapelado, focalizándose en aspectos relacionados con la conservación relacionados con los materiales empleados y metodologías de aplicación.

En la segunda sección se describe el estudio de la metodología innovadora de los RTS, ensayada de acuerdo a un meticuloso proyecto de investigación adaptando tecnologías analíticas avanzadas a las necesidades específicas del estudio realizado. Durante la primera etapa experimental, se realizaron análisis químicos, físicos y mecánicos de las diferentes clases de materiales (adhesivos y soportes temporales) y su compatibilidad para la preparación de tejidos rehumectables. La segunda etapa de la investigación se centró en la evaluación de la aplicación de Soportes Temporales Rehumectables en maquetas simuladoras pinturas en lienzo, con el fin de ensayar aquellos factores considerados más relevantes. Se realizaron observaciones con Microscopía Óptica empleando luz visible y UV, Microscopía electrónica de barrido de emisión de campo (FESEM) para evaluar la permanencia de residuos y el estudio de posibles modificaciones que podrían darse en la superficie de la pintura. Se empleó Micro-espectroscopía Raman asociada a un microscopio de alta resolución para determinar la penetración del adhesivo en las grietas de las maquetas. Finalmente, se realizaron pruebas de desprendimiento (peeling test) en diferentes condiciones ambientales para estudiar la fuerza adhesiva de los RTS seleccionados. 


\section{Resum}

Tot i que la protecció del color és una tècnica àmpliament utilitzada en restauració amb diversos propòsits, encara no s'hi disposa de molta informació tècnica. A primera vista, implica conseqüències complexes, incloent-hi canvis en les capes pictòriques, que poden tenir també potencials repercussions en la mateixa conservació de l'obra. En la majoria de casos, seria més adequat recórrer a altres tècniques alternatives i menys intrusives.

Per aquest motiu, al llarg d'aquesta tesi doctoral s'ha desenvolupat un protocol d'investigació orientat al disseny de suports temporals rehumectables (remoistenable temporary supports: RTS) per a la protecció de pintures sobre llenç, un mètode alternatiu que permet un major control de la penetració d'adhesiv en el substrat i, per tant, una eliminació de residus més senzilla i eficaç. Durant aquest estudi es va prestar especial atenció a les necessitats dels restauradors, no solament en termes de disponibilitat i eficiència econòmica, sinó també pel que fa a la salut dels operadors i la cura del medi ambient.

En la primera secció d'aquesta tesi s'ha realitzat una revisió històrica, començant per les primeres fonts indirectes del segle XVIII fins a l'actualitat. A continuació, s'analitzen els mecanismes adhesius i de penetració de l'empaperat, i es focalitza en aspectes relacionats amb la conservació futura dels materials emprats i metodologies d'aplicació.

En la segona secció es descriu l'estudi de la metodologia innovadora dels RTS, assajada d'acord amb un meticulós projecte d'investigació que adapta tecnologies analítiques avançades a les necessitats específiques de l'estudi realitzat. Durant la primera etapa experimental, es realitzaren anàlisis químiques, físiques i mecàniques de les diferents classes de materials (adhesius i suports temporals) i la seva compatibilitat per a la preparació de teixits rehumectables. La segona etapa de la investigació es va centrar en l'avaluació de l'aplicació de suports temporals rehumectables en maquetes simuladores de pintures en llenç, amb la finalitat d'assajar aquells factors considerats més rellevants. Es realitzaren observacions amb microscòpia òptica emprant llum visible i UV, Microscòpia electrònica d'escaneig d'emissió de camp (FESEM) per a avaluar la permanència de residus i l'estudi de possibles modificacions que podrien donarse en la superfície de la pintura. S'empraren microespectroscòpia Raman associada a un microscopi d'alta resolució per a determinar la penetració de l'adhesiu en les clivelles de les provetes. Finalment, es realitzaren proves de despreniment (peeling test) en diferents condicions ambientals per a estudiar la força adhesiva dels RTS seleccionats. 


\section{Sommario}

Nonostante sia impiegata per molti scopi, sono ancora poche le informazioni a disposizione sulla velinatura. Ad un primo sguardo, essa può apparire come un'operazione semplice e priva di rischi. Tuttavia, la sua applicazione è regolata da meccanismi complessi che coinvolgono l'intera stratigrafia del dipinto e che possono avere ripercussioni anche gravi sulla sua stessa conservazione. In molti casi sarebbe possibile e preferibile ricorrere a soluzioni alternative e meno invasive, ma a volte un suo uso risulta strettamente necessario.

Per questo motivo, nel corso di questo dottorato è stato realizzato un protocollo di ricerca indirizzato alla progettazione del metodo della rigenerazione di supporti interinali pre-collati (remoistenable temporary supports: RTS) per la velinatura dei dipinti su tela, un metodo alternativo che consente un maggior controllo della penetrazione dell'adesivo nel substrato, e quindi una più facile rimozione dei residui. Grande attenzione è stata rivolta alle esigenze dei restauratori, in termini non solo di disponibilità ed economicità dei materiali, ma anche di sicurezza dell'operatore e dell'ambiente.

Nella prima parte di questa tesi viene fatta una valutazione dell'evoluzione della velinatura nel corso della storia a partire dalle prime fonti indirette del Settecento fino ai giorni nostri. Quindi vengono analizzati i meccanismi adesivi e penetrativi di velinatura, con particolare riferimento alle questioni conservative in relazione ai materiali utilizzati e alle metodologie di applicazione.

Nella seconda sezione viene descritto invece lo studio compiuto per la valutazione dellinnovativa metodologia degli RTS, testata secondo un meticoloso progetto di ricerca, adattando tecniche analitiche avanzate alle specifiche esigenze. La prima fase sperimentale è consistita nell' esecuzione di analisi chimiche, fisiche e meccaniche volte alla valutazione delle caratteristiche delle diverse classi di materiali (adesivi e supporti provvisori) e della loro compatibilità per la preparazione dei supporti interinali pre-collati. La seconda fase dell'indagine è stata, invece, focalizzata sulla valutazione dell'applicazione di supporti provvisori riattivabili su provini riproducenti un dipinto su tela, al fine di testare quelli considerati i fattori più rilevanti. Sono state effettuate osservazioni con microscopio ottico in luce visibile e UV e analisi con microscopio elettronico FESEM per valutare la permanenza dei residui e la valutazione delle possibili modifiche incorse sulla superficie verniciata. La microscopia Raman associata all'osservazione tramite un microscopio ottico ad alta risoluzione è stata, invece, impiegata per determinare la penetrazione dell'adesivo nelle porosità e crepe dei provini velinati. Infine, sono stati effettuati test di peeling per valutare la forza di adesione degli RTS, variando i parametri termoigrometrici. 


\section{Acknowledgments}

This work would not have been possible without the help of a number of people, who I need to acknowledge:

First and foremost, I would like to thank my three supervisors. I wish to acknowledge Professor Susana Martín Rey PhD (Universitat Politècnica de València, Spain) who believed in me and my proposal, and helped me to set up the research project suggesting the right path. Thanks to Professor María Teresa Doménech Carbó PhD (Universitat Politècnica de València, Spain), who made it possible to plan and carry out the research project, as well as to solve the technical and bureaucratic problems: thanks for the time spent helping me and for the long and pleasant discussions to plan the research in the best possible way. Thanks also to Professor Annarosa Mangone PhD (Università degli Studi di Bari "Aldo Moro" - UniBA, Italy), who supported me for the micro-Raman and microscopic analyses, teaching me to juggle in a field far from my comfort zone. I am very grateful for the time and knowledge that all of them shared with me.

I wish to thank Cristina Robles de la Cruz and Assistant Professor Antoni Colomina-Subiela PhD (Easel paintings laboratory of the Instituto de Restauración del Patrimonio - UPV, Spain), who gave me precious advices in the very first months at the UPV. A truly thanks to Associate Professor Laura Osete Cortina PhD, Jorge Redondo Marugán PhD, Carla Álvarez Romero PhD and Carolina Mai (Chemistry laboratory of the Instituto de Restauración del Patrimonio - UPV, Spain), who supported me in good and bad times, becoming great friends that I could not do without. I wish to thank José Luis Moya López PhD, Alicia Nuez Inbernón and Manuel Planes Insausti (Electron Microscopy Service of the Universitat Politècnica de València, Spain). An acknowledgment to the financial support from the Spanish "I+D+l" project CTQ2017-85317-C2-1-P, which is supported by the Ministerio de Ciencia, Innovación y Universidades, Fondo Europeo de Desarrollo Regional (ERDF) funds and Agencia Estatal de Investigación (AEI).

The time spent in Bari would not have been the same without the help of Assistant Professor Lorena Carla Giannossa PhD (Department of Chemistry UniBA, Italy) friend and reference point who helped me to overcome the difficulties faced during my stay. A great thanks to Cristina Caggiani PhD, who helped me with her advise on Raman technique. My acknowledge goes to Assistant Professor Giacomo Eramo PhD (Earth and Geoenvironmental Sciences Departments - UniBA, Italy). 
I am truly grateful to Professor J.A. Poulis PhD (Adhesion Institute - TU Delft, The Netherlands), who gave me the great chance to carry out peeling tests at the Adhesion Institute. I acknowledge him for believing in me almost without knowing me and for his advice and help. I need to thank also all the staff, who looked after me during my unfortunately short stay, making it enjoyable.

Last but not least, a big and sincere thanks goes to Antonio laccarino Idelson, who started this project with me as supervisor for the Master's thesis and who taught me so much over the years. I thank him for always being there when I needed it, for advice, opportunities, friendship and laughs. Thanks also to Silvia Fioravanti, colleague and dear friend, for the long chats, the debates and the confidence in my project.

Anyway, I could not finished this PhD without the many loved ones who supported me during these years.

My love and gratitude firstly goes to my parents, who taught me to dream and to fight for what I believe and what I care, trying never to lose hope and smile. They taught me to stand on my own feet, remaining behind the scenes ready to help, advice and comfort me in times of difficulty. I owe everything to them.

Huge thanks to Antonio, for his infinite patience and for his unconditional love. Thank you for always believing in me, even when I doubted. Thank you for having the strength and courage to always support me and push me on my path, even when it temporarily strays from yours. Thank you for the endless revisions and translations in multiple languages of reports, presentations, papers, and of course the thesis. I could not imagine a better companion by my side. Heartfelt thanks also to Pedro, Susi and all the rest of my other family, for having "adopted" and loved me from the beginning, giving me their affection and all the help they could.

Finally, I thank all the friends of all the small parentheses of life that I had the opportunity to live, for helping me with their affection, but also their irony, and that made many moments lighter. 


\section{Index}

I. Forewords

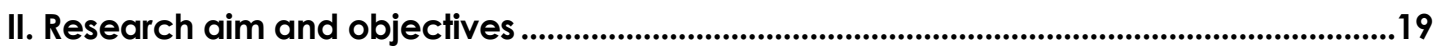

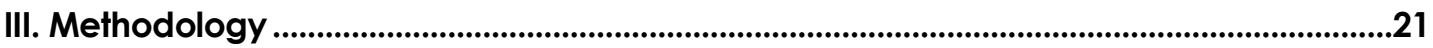

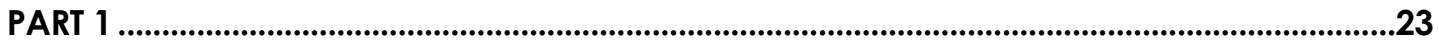

1. Current facing methods: a historical review ..........................................................................25

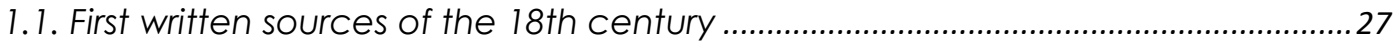

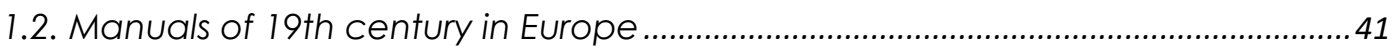

1.2.1. The flourishing Prussian written production and Koester's manual .................42

1.2.2. The French example and Horsin-Déon handbook .............................................48

1.2.3. The situation in the Italian peninsula and Bedotti's manual.............................51

1.2.4. The noteworthy contributions of Forni and Secco Suardo ................................58

1.2.5. Conservation in Spain. The Example of the Prado Museum and the treatises of Vicente Poleró y Toledo ....................................................................72

1.3. The 20th century between wars and technological progress ................................ 79

1.4. The $21^{\text {st }}$ century and the last shaky developments................................................ 104

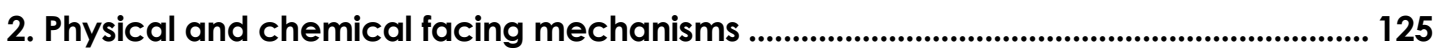

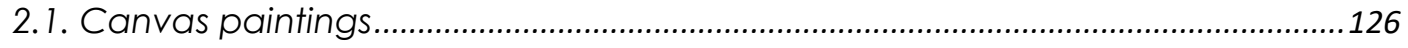

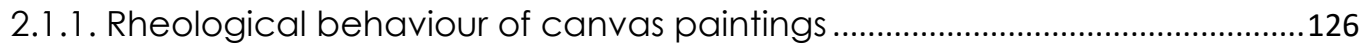

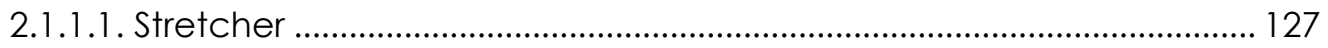

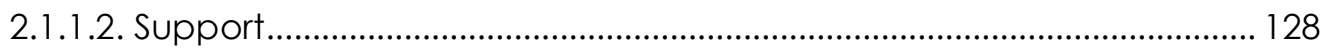

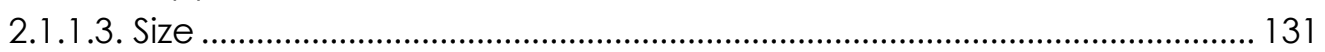

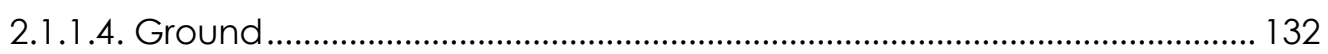

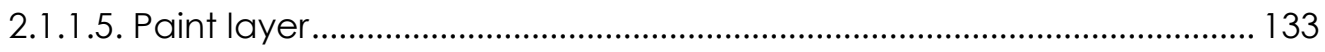

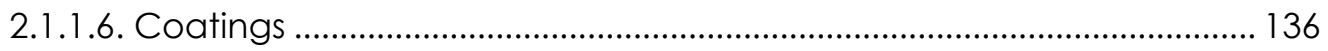

2.1.2. De-adhesion phenomena and cracking mechanisms ................................138

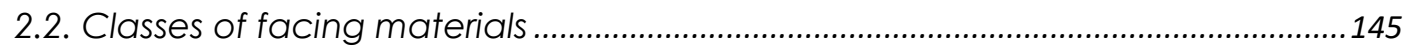

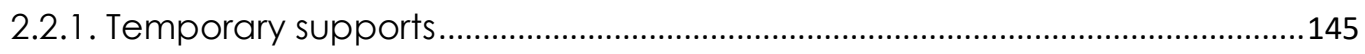

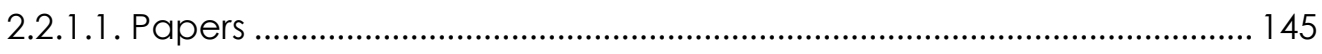




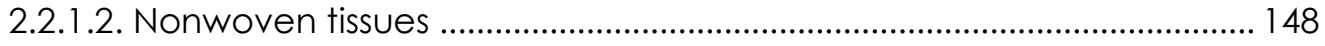

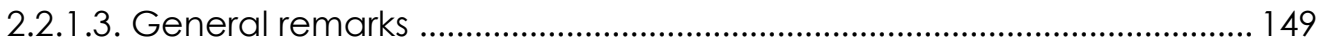

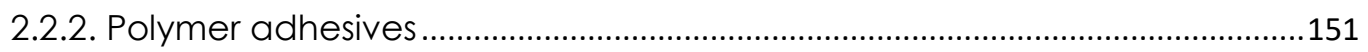

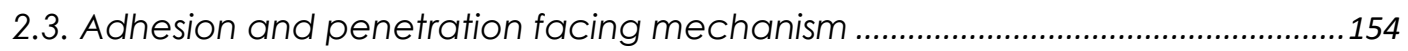

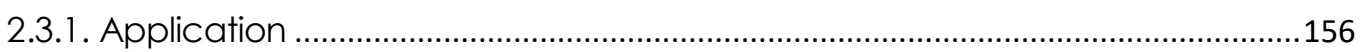

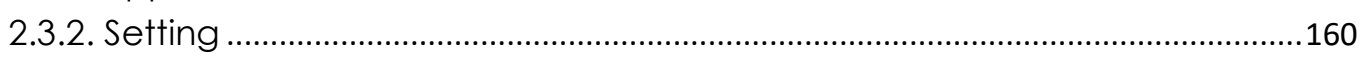

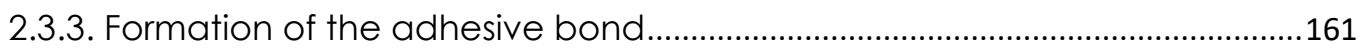

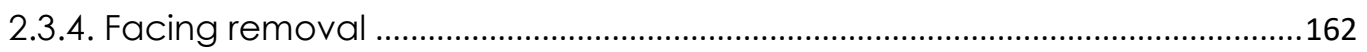

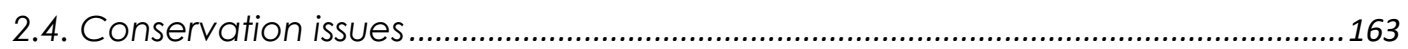

2.5. The great misunderstanding: protective and consolidating facing ....................166

PART 2

3. The alternative: Remoistenable Temporary Supports (RTS) ................................................ 171

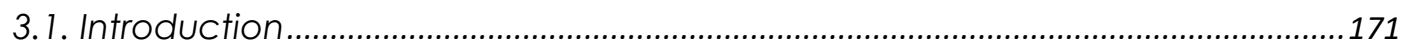

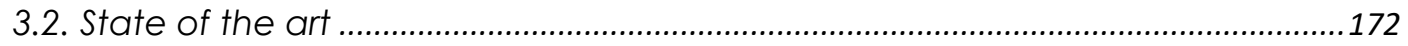

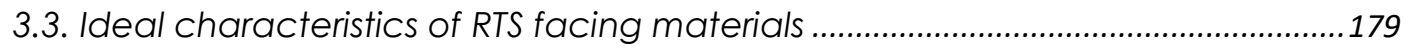

3.4. Selection of temporary supports, adhesive dispersions and reactivation solvent....181

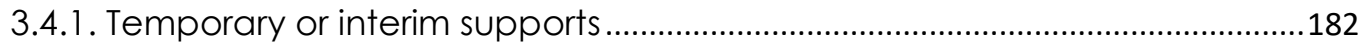

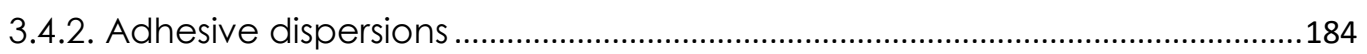

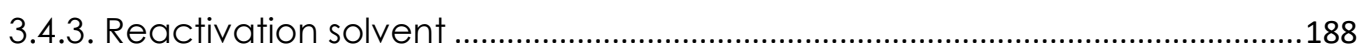

3.5. Preparation of remoistenable temporary supports, application and removal from

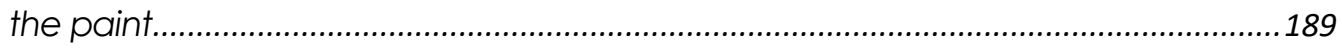

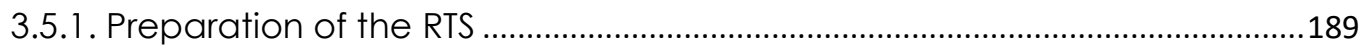

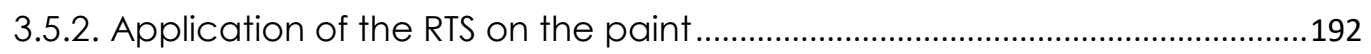

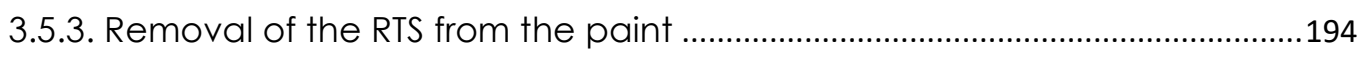

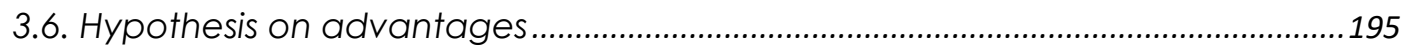

4. First experimental stage: remoistenable tissues characterization...................................... 197

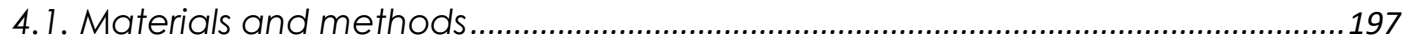

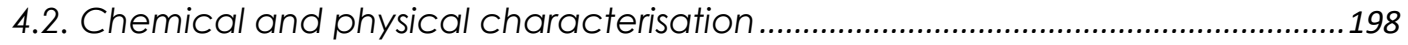

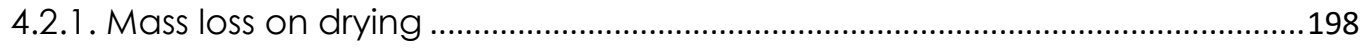

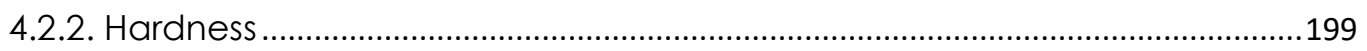

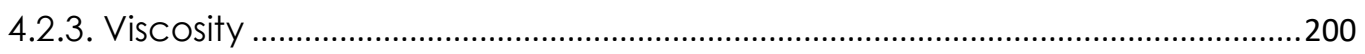

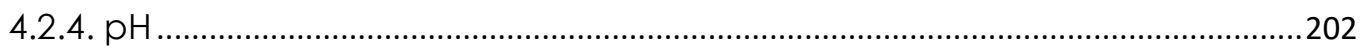

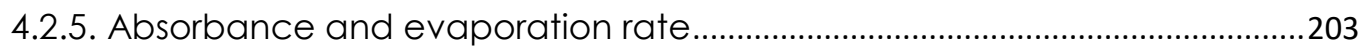

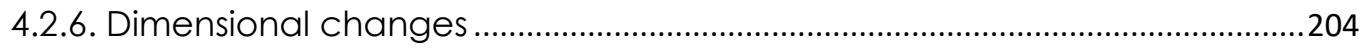

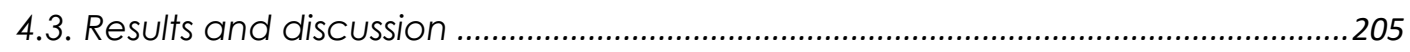




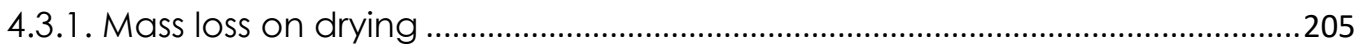

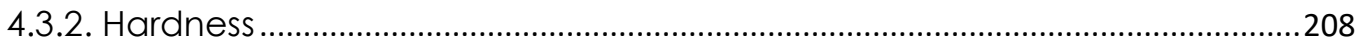

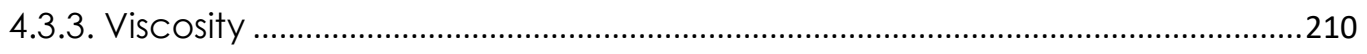

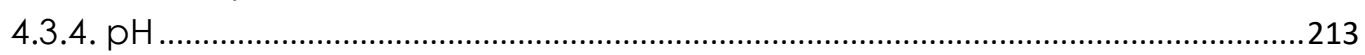

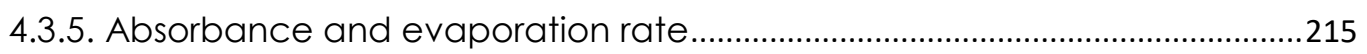

4.3.6. Dimensional changes of supports and remoistenable tissues........................216

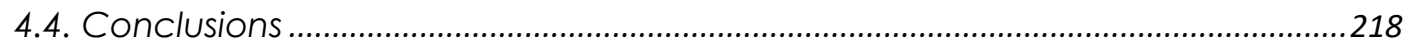

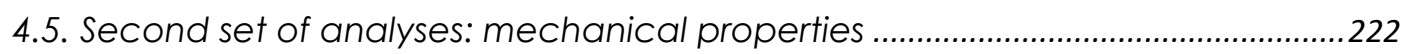

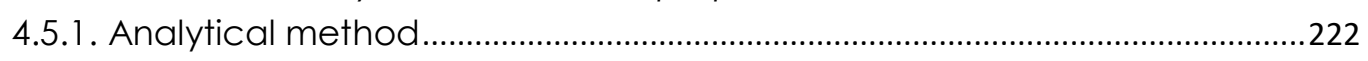

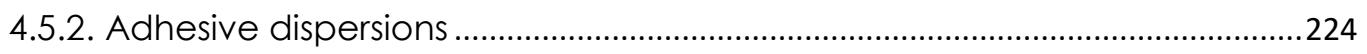

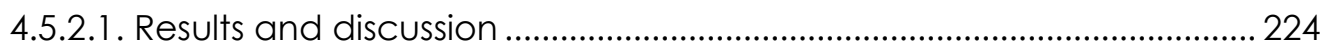

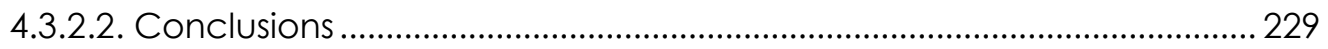

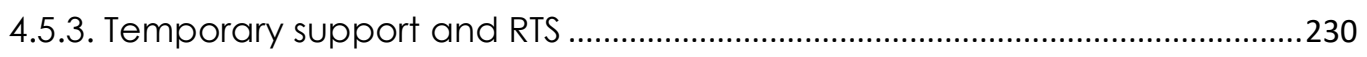

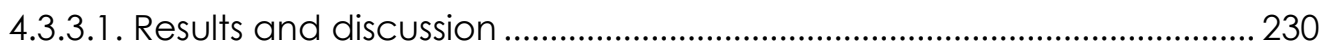

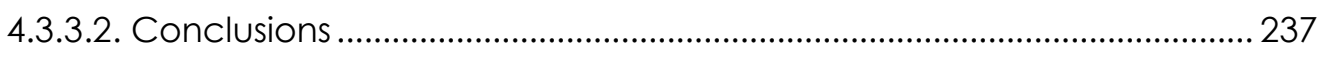

5. Second experimental stage: evaluation of the efficiency of remoistenable tissues... 239

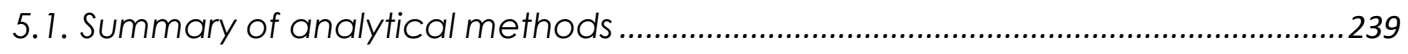

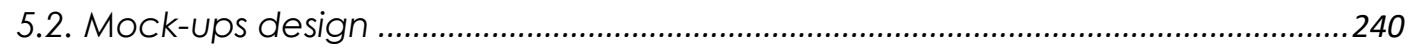

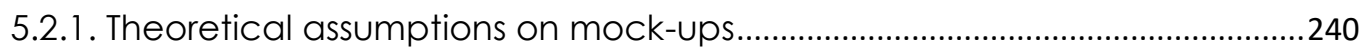

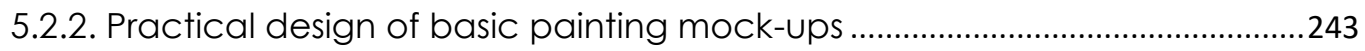

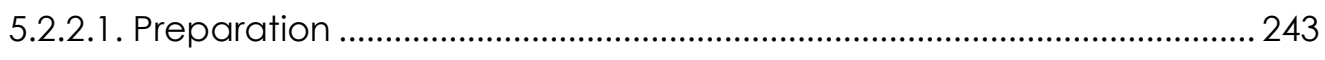

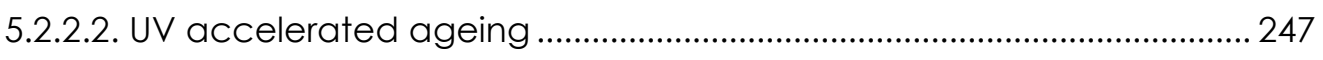

5.2.3. Painting mock-ups: specific treatment for the evaluation of the permanence of residues and the state of the substrate after the removing of facing.........248

5.2.4. Painting mock-ups: specific treatment for the evaluation of adhesive penetration in the substrate.

5.2.5. Painting mock-ups: specific treatment for the evaluation of RTS adhesive strength

5.3. Permanence of residues and modification in test specimens surface .........250

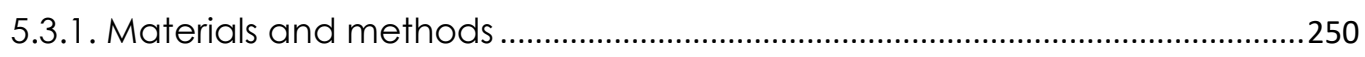

5.3.2. Results of the observation of the first set of specimens with visible light optical microscopy

.251

5.3.3. Results of the observation of the second set of specimens with UV/visible

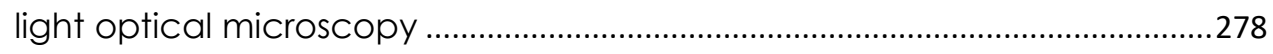

5.3.4. Results of the observation of the first set of specimens with FESEM .............2291

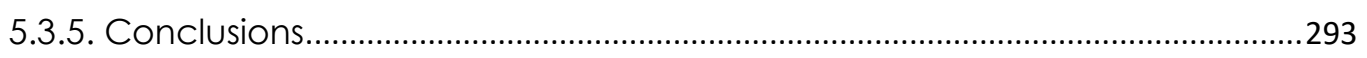

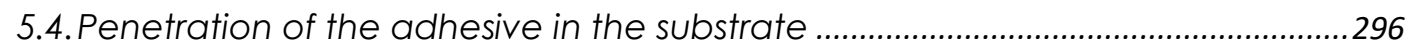

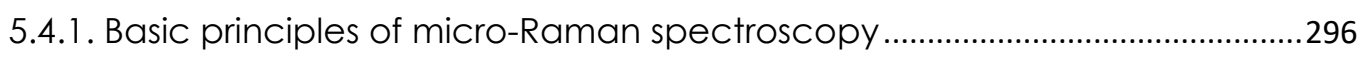

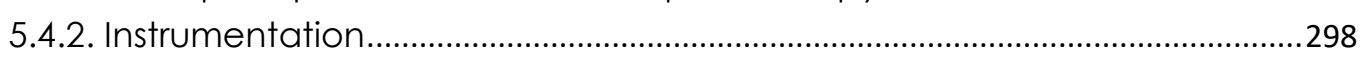

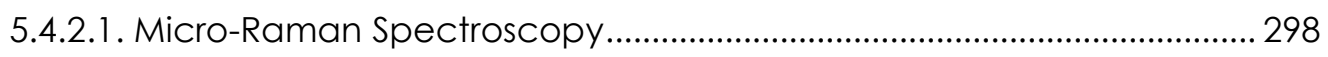

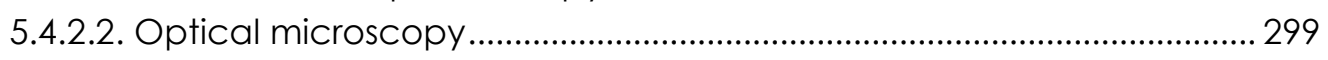

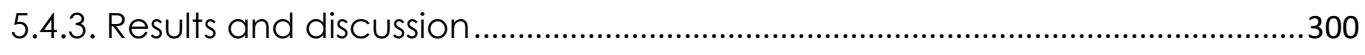


5.4.3.1. Characterization of Raman spectra of specimens prepared with

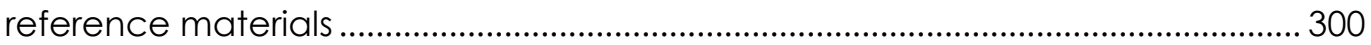

5.4.3.2. Characterization of Raman spectra of materials used in the mock-ups 300

5.4.3.3. Characterization of Raman spectra of materials used in facing........ 309

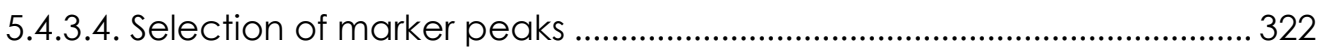

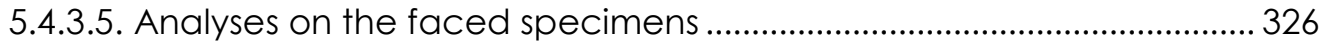

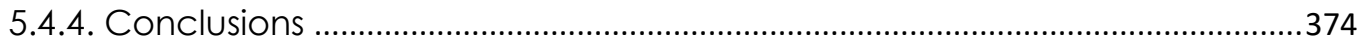

5.5. Assessment of the adhesive strength of selected RTS (Peeling Test) ....................375

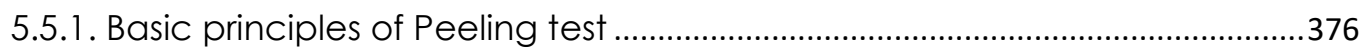

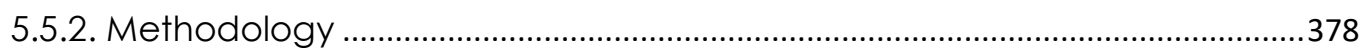

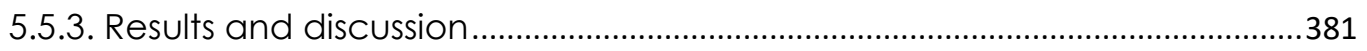

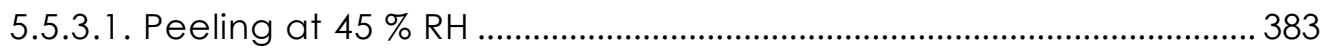

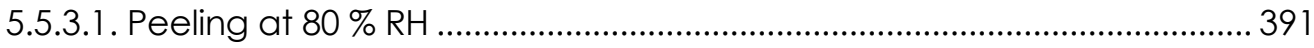

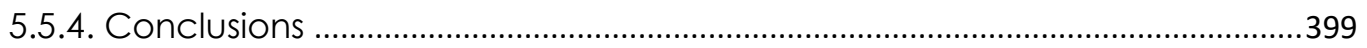

6. General conclusions and further developments ................................................................403

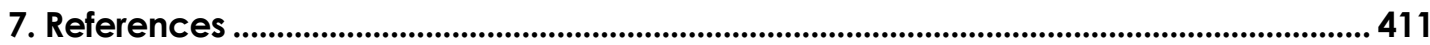




\section{Figure index}

All the figures and tables are of author's property, except from the listed below:

Figure 2.1.1. Schematic representation of warp and weft in weaving(https://www.domus-home.com/wp-content/uploads/2015/09/fabricwarp-weft.jpg).

Figure 2.1.2. Hypothetical swelling of a cylindrical cellulose element (Capriotti and laccarino-Idelson 2004).

Figure 2.1.3. Radial swelling contribute to thread shortening (Capriotti and laccarino-Idelson 2004).

Figure 2.1.4. Canvas shrinkage and thickening (Capriotti and laccarino-Idelson 2004).

Figure 2.1.5. Force per width versus strain (Mecklenburg 2005).

Figure 2.1.6. Stress strain tests of 15 years old hide glue at different levels of relative humidity (Mecklenburg 2005).

Figure 2.1.7. Stress strain tests of sample of gesso $10 \mathrm{~A}$ and 10B, made with the strong Williams and Higgins hide glue (Mecklenburg 2007).

Figure 2.1.8. Stress strain tests of basic lead carbonate paint made with cold pressed linseed oil at different ages (Mecklenburg 2005).

Figure 2.1.9. Stress strain tests conducted on paints made with different pigments at $48 \% \mathrm{RH}$ and $23^{\circ} \mathrm{C}$ (Mecklenburg 2005).

Figure 2.1.10. Difference in the aspect of paint layers made of white lead and earth colours (laccarino-Idelson 2012).

Figure 2.1.1 1. Inner tensions of the individual constitutive layers (stretcher, canvas, and animal glve size) and total tensions of the painting (Capriotti and laccarinoIdelson 2004). 
Figure 2.3.1. Different kinds of interactions between the fluid and the solid surface (https://www.igvp.uni-

stuttgart.de/img/forschung/plasmatechnologie/plasmaprozesse/Surface_Wett ability_Bild_1.png?_scale=w:1000,h:1000,q:100,t:3).

Figure 3.2.1. Microfabricated aligned multiwalled carbon nanotube setae and spatulas (Liehui Ge, et al. 2007).

Figure 3.2.2. Application of Aquazol 500 remoistenable tissues after the reactivation with spray (Picture taken from: Borgioli, Boschetti, and Tortato 2016).

Figure 4.5.1. Graphic of tensile designation (ASTM D638).

Figure 4.5.2. Graphic of offset yield strength (ASTM D638).

Figure 5.4.1. Schematic representation of the different possible energy transitions (https://www.azom.com/article.aspx?ArticlelD=13372).

Figure 5.4.2. Schematic representation of a Raman spectrum (https://iopscience.iop.org/book/978-1-627-05288-7/chapter/bk978-1-62705288-7ch8). 


\section{Forewords}

Beside their esthetical value, cultural heritage artefacts are a key element of the history and identity of our societies, in which they also play a relevant political role. Their transmission to the future generations, and their use in the present one, are a complex issue, since they involve the conservation of their meaning along with the materials they are made of: a body that makes them unrepeatable. Thus, the collaboration between professionals from different fields of conservation is imperative for the preservation of all levels of meaning of an artwork.

As a conservator-restorer, I have always been interested in increasing my knowledge starting from the most assumed but fundamental theory and technique of conservation, passing through the history of art and entering the world of science of cultural heritage. This is because a vision as diversified as possible is essential not only to intervene thoroughly on an artwork, but also because the acquisition of interdisciplinary knowledge facilitates the dialogue between professionals and allows a collaboration whose results go far beyond those obtained by each one individually. These believes guided my studies for the Master's degree in conservation and restoration at the University of Urbino "Carlo Bo" (Italy), with specialisation in easel paintings, wooden sculptures and poly-material artefacts. My interest was addressed to the causes of degradation phenomena and the mechanisms triggered by restoration interventions. I began to approach the study of the technology of constitutive and restoration materials, especially those related to structural interventions on easel paintings and wooden sculptures. The theoretical and technical revision process of materials and methods begun in the second half of the last century and not yet finished fascinated me. However, I was surprised when I discovered that there were no studies on facing. There were many examples of works seriously damaged by facing, made uncritically in the erroneous belief that it was a simple and harmless operation. It was almost impossible to find a bibliography on the subject, which was simply ignored. Facing had not been considered worthy to being studied and investigated, as it happened for other 'minor' interventions such as the tear mending on canvas paintings. 
Given the above, I chose facing of canvas paintings as topic for my Master's thesis. The work began in 2014 and consisted of a bibliographic research and a theoretical study of facing mechanisms, accompanied by a first experimentation aimed at the mechanical characterisation of the adhesive joints of four facings by performing peeling tests and control analyses by micro-Raman spectroscopy on surfaces. The study brought interesting results, but at the same time shed light on the large gap left about facing and the need to sensitise restorers to a more prudent use of this operation. There was the need to carry out in-depth studies to obtain concrete alternatives, creating facings with well-defined characteristics, allowing a greater control on the distribution of the adhesive.

Therefore, in 2016 I decided to carry out my investigation, presenting a PhD proposal at the Universitat Politècnica de València, with the aim of projecting remoistenable temporary supports (RTS), which provide superficial protection with adequate bond strength and easy reversibility. The first part of the PhD was carried out within the laboratories of the Institute for the Heritage Restoration (IRP) and the Microscopy Service of the Universitat Politècnica de València (Spain). The analyses concerning the evaluation of the permanence of the residues and the penetration of the adhesives were performed at the Chemistry Department and the Earth and Geoenvironmental Sciences Departments of the Universita degli Studi di Bari "Aldo Moro" - UniBA (Italy). The peeling test to evaluate the adhesive strength of the tested RTS was carried out at the Adhesion Institute of TU Delft (The Netherlands).

The results obtained were satisfactory and made it possible to achieve the set objectives. This PhD was undoubtedly a stimulating experience. The design and development of such a complex research, which involved the analysis of a huge number of samples with the most diverse techniques, put me in front of brandnew challenges. I walked a tightrope, on the border between my specific area of expertise, that of the conservator-restorer, and others that I knew little about and which I could not have approached without the help of professionals from different sectors.

I would like to specify that the research was not conducted with the aim of finding a universal alternative to traditional facings. As I will never tire of repeating, facing is a fully-fledged operation, and it must be carefully assessed the actual need to apply it, choosing the materials and techniques to be used according to the artwork to be restored. I am convinced the research conducted during this PhD can be of considerable help for restorers. It could be also used as a starting point for new researches, which would erase the belief that facing is a harmless intervention that can be performed without the necessary precautions and that it can be left for years on a painting. 


\section{Research aim and objectives}

In the current state of things, most facing techniques do not allow performing a superficial action, and it is believed that this is mainly due to the application methods used. The overall aim of the research presented in this thesis is to contribute to the understanding of the conservation issues related to the current facing techniques on easel paintings, and the elaboration of an alternative application system based on the use of Remoistenable Temporary Supports (RTS), which permits to obtain a more superficial adhesion and an easier removal.

The objectives we set ourselves for the first part of the investigation were:

- The study of the evolution of facing techniques from the first indirect sources of the 18th century and the main European restoration manuals of the $19^{\text {th }}$ century, moving forward to the analysis of relevant sources on the facing techniques related to significant events in the history 20th century conservation (exodus of the works of the Prado Museum during the Spanish civil war, Florence flood in 1966, Greenwich Conference in 1974), and finally with the critical study of the latest information found in conference proceedings and conservation journals.

- Investigate the differential rheology of the constitutive materials of canvas paintings, which contributes to the formation of the types of degradation phenomena for which facing is required.

- Analyse the characteristics of the classes of materials used for facings, namely temporary supports and adhesive polymers, with the aim of clearly defining the adhesive and penetrative mechanisms of traditional facings and their related conservation issues, as well as highlighting the inconsistencies and limits of techniques used nowadays.

For the design of the RTS the following objectives were set:

- Selection of restoration materials that are easily available and costeffective, as well as not harmful neither to the operator nor the 
environment, and the development of a unique, clear and easily replicable application methodology.

- Analysis of the chemical, physical and mechanical characteristics of the different classes of materials used (temporary supports and adhesive polymers) and their combination to form the RTS, to determine their compatibility with oil canvas paintings and their suitability for the purposes of the PhD.

- Assessment of the suitability of Remoistenable temporary supports for their application on oil canvas paintings. For this purpose, the specific objectives of this second step of the experimentation were:

- The choice of mock-ups with suitable characteristics for the purposes of the experimentation that could be used for all the designed analyses.

- The evaluation of the permanence of residues and the state of the substrate after removing the RTS.

- The assessment of the penetration of the adhesive in the substrate, exploring the capabilities of the raman microscopy technique applied to complex organic samples typical of the field of conservation science

- The measurement of the adhesive strength of the selected RTS through peeling test. 


\section{Methodology}

The methodology followed for this $\mathrm{PhD}$ can be resumed in the following flowchart:

\section{Preliminary study:}

Literary review and analisys of physical and chemical facing mechanisms

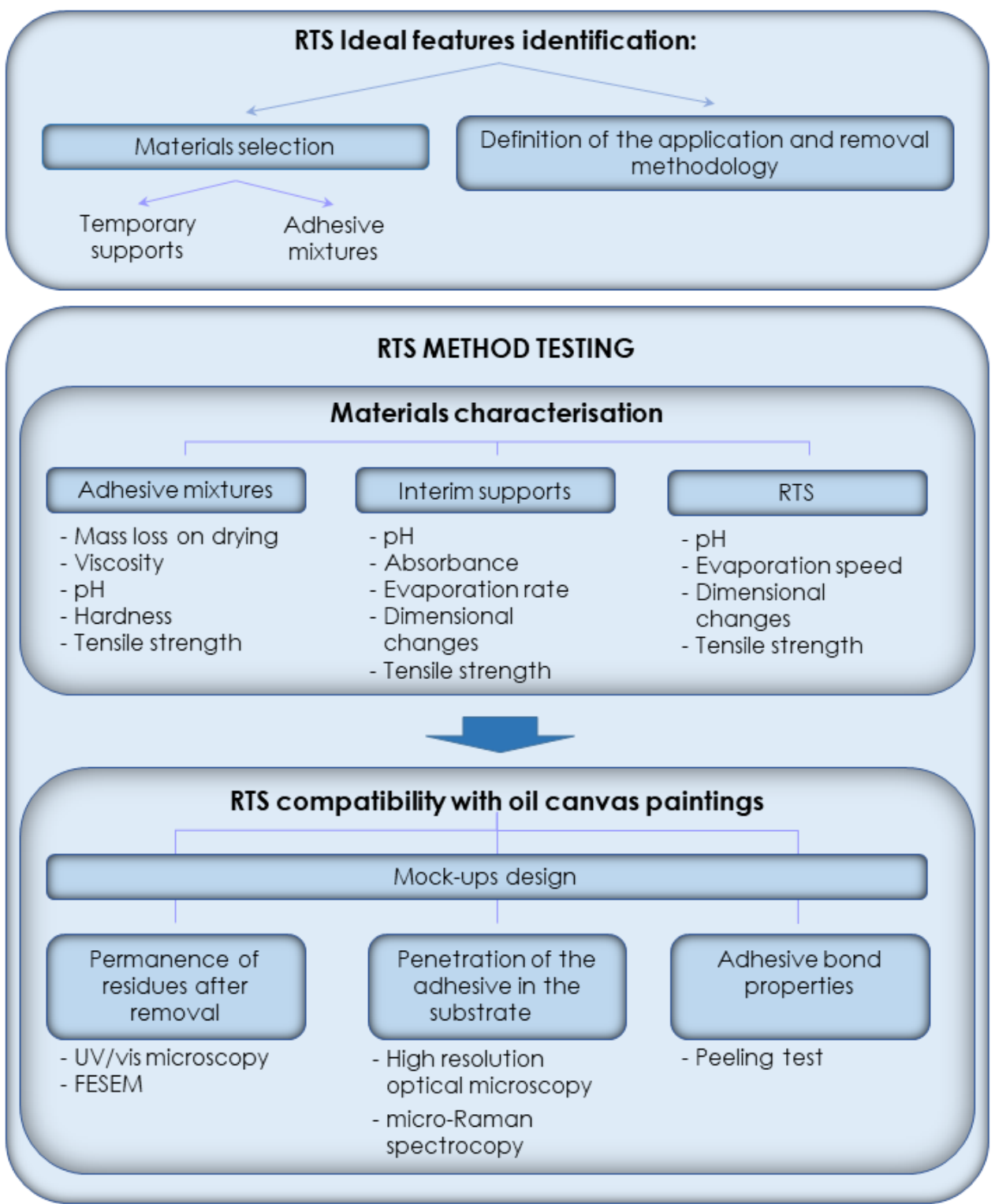





\section{PART 1}





\section{Current facing methods: a historical review}

Facing is a temporary measure during a painting's treatment that supports and prevents crumbling or fracturing of paint layers during a treatment. According to the most widespread facing techniques, the pictorial surface is covered with a temporary support glued with an adhesive of natural or synthetic origin. According to the most employed techniques, the entire surface or only a portion of it could be faced, with a single sheet or with several overlapping sheets, generally made of Japanese paper or other thin tissues. The adhesive, of natural or synthetic origin, can be spread on the pictorial surface to receive the temporary support while it is still fresh. Alternatively, the temporary support can be positioned first on the painting, brushing the adhesive over it. If a very resistant or rigid support is required, or if specific characteristics and functions are needed, it is possible to make composite facings using different materials in successive layers.

Although the theoretical and technical review of conservation materials and methods started in the seventies, as well as the awareness of the importance of concepts such as reversibility and minimal intervention, there is still little information about facing. Unfortunately, still today facing is very often used uncritically, with the mistaken belief that it is a harmless, temporary and perfectly reversible operation. As it will be shown in more detail in the chapter dedicated to the analysis of facing mechanisms, these are erroneous beliefs, as its application has complex consequences involving changes to a painting's strata and it can have potential repercussions on the conservation of the paint itself. Therefore, before applying a facing, it is necessary to reflect first on the possible consequences, to avoid that the urgency of securing the painting becomes the cause of complications for future operations, or even irreversible damage. An uncritical intervention, without a preliminary study of the components of a work and the development of a project in which all the phases of the restoration are assessed in advance, could prove extremely risky.

The almost total absence of information on the subject confirms the little importance given to facing and to the possible harmful effects that could derive from its application. In fact, facing has always been considered one step in a multi-step 
intervention, which is why written documentation and didactic literature about facing are hardly found. Restoration handbooks and conservation journals offer little to no information on the materials and techniques used for facing or the reasoning behind the decision to face a painting. The lack of historical information on the use of this technique is due to the fact that it was rarely considered necessary to write, share, comment, or transmit experiences and opinions on the topic. Especially, because a facing is usually removed during an intervention, making it difficult to obtain data through diagnostics.

Even if more and more conservators have been starting to re-think the process by designing facings with characteristics for the specific needs of a painting's surface, only few reflections and experiences are published in conservation journals and congress proceedings, so that the debate remains connected with oral tradition. Furthermore, these examples represent an exception, since many conservators still frequently use traditional adhesives for facings, such as rabbit skin glue, bone glue, colletta, sturgeon glue, starch or wax-resin applied with brush. Furthermore, conservators use the same application methods for synthetic facings.

In the next pages, the results of a complex bibliographic research will be displayed. As it will be possible to see, in the absence of direct bibliographic sources, it was necessary to search for information in writings concerning the structural operations to which facing has always been connected, such as the lining of canvas paintings. The rare written witnesses and the often elusive citations led us to weigh silences and omissions, which certainly cannot give indications on materials and techniques, but represent a testimony of the importance attributed (or not) to this operation over time.

The presentation of the results will start from the review of the first indirect testimonies (travelers' tales, payment lists and cards of various kinds) of the $18^{\text {th }}$ century, period in which the theoretical debate derived from the interest in the mechanical arts was still constrained by the hereditary transmission of the workshops' secrets.

The information reported in some of the main nineteenth-century Europe manuals will then be compared. It will be carried out an in-depth assessment on materials and application methods, on the cases in which the authors considered it necessary to resort to this technique, and on the precautions to be taken case by case, up to reread the existing relationships with the techniques defined today traditional.

Finally, sources from the $20^{\text {th }}$ and $21^{\text {st }}$ century will be analysed, with the aim of understanding the changes occurred in the international context with the introduction of synthetic materials and the differences between facings made with natural and synthetic polymers. Particular attention will be given to the influence of the enthusiasm for new materials and the development of an approach focused on minimal intervention. 


\subsection{FIRST WRITTEN SOURCES OF THE 18TH CENTURY}

It is not possible to define with precision the origin of facing. It is supposed in ancient time it arouses the intuition of secure flacking portion of paintings by gluing pieces of canvas or other materials. Through experimentations and the sum of successes and mistakes, the most suitable materials were selected. The most efficient methodologies were defined with more accuracy and facing began to be commonly associated to other operations.

First written sources on facing date back to the $18^{\text {th }}$ century and they arose out from indirect evidences of other structural interventions to which facing was associated. With the beginning of the age of the Enlightenment and the increasing interest in mechanical arts, it started a theoretical debate that led to the increase of written records on these issues. The technical development of structural interventions led to the differentiation between the figure of the painter restorer and the mechanical or structural restorer. Reading letters and travel diaries, but also documents directly addressed to describe, remark or critic restoration intervention (CIATTI 1995; 2009), it is possible to find important information on structural interventions. The principal topics covered were the detachment of mural paintings and the transfer of panel paintings, and shortly after the topic of lining was discussed as well. In these documents, it is possible to find the witnesses of two kinds of paint layer protections, which were applied for the transfer of mural and easel paintings. These techniques are respectively named by their Italian and French term: intelaggio and cartonnage. These two techniques differ from facing because of the materials and the scope for which they were used. In fact, for intelaggio one or more canvases (tela in Italian) of different weaving and stiffness were glued on the surface of the painting with a strong adhesive. Cartonnage consisted, instead, in gluing a thin-woven canvas and one or more layer of thick and absorbent paper (carton in French). It is a traditional French technique and it was used mainly for the transfer of panel paintings. Therefore, the temporary supports and the adhesive used are much more strong that the ones used for facing. The superficial reinforcement has to be sufficiently strong and rigid to sustain the paint layer during the removal of the support. Differently from these techniques, facing has a function of partial and localised supporting, since it has to fix and sustain only the partially detached paint flakes: it would not be sufficient to maintain the whole paint layer during the removal of the support. However, the study of the information on intelaggio and cartonnage can be useful to understand their connection with facing and its evolution, so that a brief overview on the transfer of mural and easel painting 
will be done before proceeding with the review of the written sources on linings dated to the $18^{\text {th }}$ century.

The detachment of mural paintings can be considered as an antecedent of the transfer of easel paintings. Three main methods were used during time and they are typically referred to by their Italian terms: stacco a massello, stacco and strappo.

The stacco a massello, that involves the detachment of all the render and some of the mural support, was already known in Roman times: Vitruvius and Plinius wrote about the transfer of mural paintings from Sparta to Rome in the 59 B.C. (Conti 1988). This technique was abandoned for many centuries and again revived during the Renaissance. Giorgio Vasari gave detailed information on the detachment with the stacco a massello of the mural paintings of Botticelli and Ghirlandaio made in the Ognissanti church of Florence in 1564. He described also the transfer of a fresco of Giotto from one point to another of the Vatican Basilica, made by Pierin del Vaga (Vasari 1568).

In the $18^{\text {th }}$ century, the technique was widely used in the Italian peninsula. However, since the painting was detached with the whole support, it was not necessary to recur to a superficial protection and reinforcement. As it is possible to read in the description of a Neapolitan technique made by Carlo Ruspi (Conti 1988), a wetted sheet of paper was adhered to the painting surface without the use of an adhesive before proceeding with the application of a gesso counterform.

Things changed with the introduction in the $18^{\text {th }}$ century of the stacco and later of the strappo technique. The stacco consisted in the detachment of the painting and of the most superficial layers of render, while the strappo consisted in the tearing of the only paint layer attached to an intelaggio. The ideation of strappo technique is usually addressed to the Italian Antonio Contri (Baruffaldi 1740), who was used to apply on the painting a resistant canvas soaked with a glve or a bitumen.

Strappo technique began to be increasingly used because of its functionality. In fact, differently to the other systems, it permitted the detachment of big portions of mural paintings: the tearing of the paint layer using overlapped canvas permitted to roll-up and transport the painting. The diffusion of this technique was connected also with a phenomenon typical of the historical period in which it was invented. In fact, in the 16-17 th centuries the transfers of mural painting were made only for devotional purposes, to save paintings from the architectural renovation of churches and other buildings in which they were painted. 
In the $18^{\text {th }}$ century, detached paintings began to be considered precious and rare, and to be targeted by collectors. Furthermore, it was believed that the transfer would have permitted a better conservation of the paintings and that the impregnation with bitumen and adhesives would have protected them from the action of moisture. In this period, restoring operation started to be combined with scientific studies on the nature of conservation problems related to constitutive materials. This happened first in France and later in Italy, especially because of the discovering of Herculaneum and Pompeii during the Spanish reign in the Kingdom of Naples. As a consequence of the discovering of the Roman frescoes, transfer technique was implemented and it started to change the way of conceiving restoration, which was not longer connected only to the artistic technical competences, but also to chemistry and physics.

The developments in chemistry and physics, and the progresses in technical fields led to an increase of the interest in the structural aspect of restoration and the figure of the structural restorer joined the painter-restorer. In fact, in this period it became common the transfer of panel paintings, which had been already discovered in the $17^{\text {th }}$ century.

The success of the transfer of mural and panel paintings was connected with the historical events of the $18^{\text {th }}$ and $19^{\text {th }}$ century that made necessary the mobility of the works of art. As a consequence of political twisting, in all the Europe there were changes in the ownership of big religious complexes and consequently of the masterpieces that were preserved there. In Italy, the first religious expropriation dates back to the eighties of the $18^{\text {th }}$ century, when the Granduca Pietro Leopoldo of Tuscany confiscated and sold religious buildings and related possessions. The second round of expropriation happened between the 1799 and the 1800, consequently to the Napoleonic invasion. In this occasion, many masterpieces were taken away to France, and they would have come back only after difficult negotiations, and many times with precarious conservative conditions. The third ecclesiastic expropriation in Italy dates to the period of the Unification of Italy, in response to the necessity to build the new infrastructures needed for the new brand nation (Ciatti 2009). Also in Spain, the French invasion in the 1808 and the consequent Independence War caused many problems to the cultural heritage. A part of the injury of the war, French troops stole many valuable possessions from the Real Palace, the Real Library, the Natural History Museum and other buildings, and many artworks were damaged because of the continuous handling (Macarrón-Miguel 2013).

Building transformations, expropriations and the development of the art market made it necessary an easy mobility of the artworks. In this period, the transfer of panel paintings was improved to solve issues connected with artworks 
displacements. In fact, panel paintings could not stand continuous handling under instable environmental conditions, since the movements of the support caused flaking of paint and ground layers. Furthermore, panel paintings, as well as wall paintings detached with stacco a massello technique, were difficult to transport. In the $18^{\text {th }}$ and $19^{\text {th }}$ century, it was believed that the transfer of panel paintings to canvas would have definitively solved its conservation problems. In addition, a canvas painting could be rolled-up for an easier handling.

The origin of the transfer of easel paintings has long been disputed between France and Italy, but today also French academics states that this technique was already performed in some Italian workshop at the beginning of the $18^{\text {th }}$ century.

It is thought that this technique was first employed in the roman context. In fact, during the $18^{\text {th }}$ century in Rome there were artisans specialised in the different sectors of painting restoration and there were workshops dedicated to the structural interventions. In this context, it stood out the figure of Domenico Michelini. Authors of that time, such as Pier Leone Ghezzi, described him as an artisan that did not paint, but was very good in transfer and clean paintings (Marinetti 2007). In the 1769 Joseph-Jerome de la Lande ascribed to Michelini the transfer of a Tiziano painting in Altieri Palace in Rome, made in the 1729 (Conti 1988). His signature and the date 1714 were found on the back of the Climbing to Calvary of Paolo di Giovanni Fei, as declared by Adolfo venture in a printing of the 1906 (Marinetti 2007). The account books of the Pamphilij family attest that Michelini restored many paintings of the gallery, executing structural intervention cleaning operations (Rinaldi 2007). He was also appreciated by Albani family and some foreign visitors became aware of his work thanks to these contacts.

Charles Francois Poerson, director of the French academy in Rome, was used to write letters where he reported the artistic novelties of the city to his homeland. In the 1721, he described enthusiastically the technique employed by Michelini to transfer panel paintings. He was surely updated on the technical innovation of his country, so that is quite sure that the transfer was not performed yet in France. Furthermore, the president of the Bourgogne parliament Charles De Brosses, described in a letter the work of a Roman artisan who was used to perform the transfer of easel paintings, returning the old canvas or panel at the end of the operation (Marinetti 2007). According to De Brosses, the artisan glued a flexible but resistant material on the front of the painting, with a glue with a secret composition. Then, he impregnated the paint with a liquid that detached the paint layer from its support, to glve it to a new one (Conti 1988).

Even if the origin of the transfer of panel painting has to be attributed to the Italian context, it was thanks to the French Robert Picault that this technique became famous. It seems that Picault learned it from the Italian restorer Riario 
(Borrelli-Vlad 1950). He started his experimentation detaching the wall paintings in Choisy castle in the 1744-45, as reported in the "Mercure de France", and then in the 1748 transferred the panel painting of the Deposition by Palma il Vecchio and another attributed to Parmigianino. Between the 1749 and the 1750 he also transferred the Charity by Andrea del Sarto (Martín-Rey 2006).

Picault never revealed his technique, neither when Diderot and D'Alambert asked him some information to insert it in the "Enciclopedie" (Massing 2012), but thanks to the numerous documents, letters, newspaper articles and thanks to the analyses made during the restoration of the paintings transferred by Picault, it is possible to make some hypothesis on the technique and the materials used. It seems the paint layers were softened with liquid solvents or with solvent vapours with constant heat supply, to obtain the detachment of the paint layer. According to Jean Petit, director of the research laboratories of the CNRS (France), Picault let penetrate vapours of nitric acid from the back of the painting, leading to the modification of the organic and mineral substances of the ground and to the consequent separation of the paint layer. Since this process could have been very dangerous, according to Petit, Picault did not apply a cartonnage to check the state of the paint layer during the process of distruption of the ground (Agostinelli 2013). No information were found on the use of a protection of the paint layer during the transfer process, but it is hard to believe that no front protection was employed during the whole process since the paint layer would have had no support. It is possible that a kind of protection was applied after the chemical detachment of the paint, using a resinous maroufle, similar to the one used to glue the painting to the new support.

During his career, Picault transferred scores of paintings. In a first moment, his work inspired awe and admiration, but his popularity rapidly declined in the fifties, also because after some decades some of the paintings he transferred had to be transferred again. His technique started to be considered too dangerous and his fees too high, since various artisans already performed this operation.

For instance, Jacques Gautier d'Agoty questioned the originality of the work of Picault in the journal "Memories de Trévoux", asserting that a transfer technique was invented by an Italian restorer in Marseille for a Judith by Domenichino (Massing 2012). According to this technique, it was first applied on the painting an intelaggio made with an old canvas and warm bone glve. Then, the painting was putted facedown and the canvas was soaked with aqua fortis (nitric acid) mixed with water since it was easily detachable from the other constitutive layers. Therefore, the canvas was removed and the surface cleaned with water and dried. The new canvas was applied using animal glue added with spirit of wine to make it stronger and let it drying under pressure. The 
intelaggio was therefore removed using a solution of nitric acid and water and then pure water. According to Gaurtier, the process for panel painting was similar, except for the initial mechanical removal of most of the support (Conti 1988)' 1 .

In a further response in the "Memories de Trévoux" Gautier would have state that he preferred the technique used by the Italian artisan because even if it involved the destruction of the support, it did not affect the paint layer. It is however necessary to point out that the system used by the Italian artisan was dangerous too, since an acidic solution was used as well, causing the depolymerisation of the glue contained in the ground and damaging other constitutive materials.

Other criticisms were moved by Jacob Marie van Merlen Godefroid, native to Antwerpen and moved to Paris in 1727-28. Widowed in 1741, she worked with François Louis Colins in the restoration atelier of the Apollo Gallery in the Louvre, dealing with mechanical interventions. She criticised Picault work and asserted to use another method based on the mechanical removal of the wooden support, and on the use of water to dissolve the ground layer and the consequent delamination of the paint layer from the support. Nevertheless, this method only could be used on water-based grounds. A similar system was described by D'Arclays de Montamy, in his treatise of 1756 (Borrelli-Vlad 1950). The witness of de Montamy is interesting because it include the description of the

\footnotetext{
1 "This Italian had skilfully laid his painting (despite its great size) face down onto a large and smooth panel, and having cleaned it [the reverse] well, softened the canvas with boiling water; when this canvas was sufficiently softened, he turned the painting over onto the same large panel so that he was now able to stretch it with his arms and nail it all the way round. The painting being thus well stretched and secured, he applied a hand of hot glue onto it, covering it with a piece of worn canvas the same size as the painting. Having stuck this canvas to the painting, he then proceeded to nail it down all the way round, then exposing the painting to the sun to make it dry as quickly as possible. The Italian then removed the painting held between the two canvases, and nailed it face down with its original canvas on top. Having made a border out of wax all the way round, and having placed the panel on a perfectly level surface, he covered the original canvas with a 'second' water, that is, etching acid mixed with pure water, the dosage adapted so as not to consume the painting (this is easy to check, as when you place a finger into this 'second' water, it should not yellow). He allowed the 'second' water to work until the canvas had been consumed, which could be seen when it detached easily. At this point he poured off the 'second' water into earthenware bowls, and with a spatula removed the threads out of which the canvas had been made, thus freeing the layer of paint which remained attached, face down, onto the worn canvas I spoke about earlier. It is not difficult to guess what the 'virtuoso' did next: he cleaned off the paint layer with fresh water and a dried it with a soft sponge, allowing it to become perfectly dry. The following day he passed a hand of glve on the painting into which he had added a little distilled alcohol or spirits of wine ('acqua-vite') to make it stronger, and in this manner, with the greatest of ease attached the painting onto its new canvas, being careful to press it all over with his hands to ensure that the canvas was perfectly adhered to the painting in all places. He then took the precaution of applying pressure to the whole, with slabs of lead or marble, or some such material, whilst every so often wiping the reverse of the canvas with a cloth to prevent it from sticking to these slabs. Having dried the whole, he removed the nails to detach the first canvas from the panel; having done this he then turned it over once again and with the 'second' water moistened the worn canvas which covered [the painting], which was very easy to do at this point. Finally, he removed any remaining glue from the surface of the painting with some warm water and when it was dry, I painted in the heads and the draperies which were missing. The Italian told me that when the paintings are on panel, the process is much the same, and that with the painting face down, it is easy to remove the deteriorated wood. When the wood has not deteriorated, then it is thinned with a plane to a thickness which can be corroded away by the 'second water' with ease..." (Gautier d'Agoty cit. in Conti 1988).
} 
cartonnage used to support the paint layer during the removal of the old canvas that consisted in the application of layers of sheets of a resistant white paper applied with bone glve. Since the paper would have swollen after it was wetted, de Montamy suggested to use a pestle, as that used for pigments, to adhere the paper layers without creating wrinkles. After the removal of the old canvas through the use of water and the application of a new canvas with the use of bone glue, the cartonnage was removed with pure water.

In the sixties, another important figure made his entry in the laboratories of the Louvre, Jean Louis Hacquin, who stated that he could have transferred an oil paint on gesso by Vouet in Vicennes for half the price required by the widow Godefroid. He started his career as private restorer, and later started to work as employed in the Real Galleries. Nevertheless, after the dead of Godefroid in 1775, he had to leave the private practice for the huge amount of work. To him are attributed the transfer of a painting by Domenichino in 1768, of the Raffaello's Holy Family in 1776, and many other transfers and linings of easel paintings (Martín-Rey 2006).

Differently from Picault, Jean Lovis Hacquin openly declared the methods used. His system involved the disruption of the support and the mechanical thinning of the ground. Then, two layers of gauze were applied before gluing a sheet of paper and then a canvas, using a glve-paste made with amylaceuos and proteinic materials in a specific proportion (Cecchini 2009).

The international success of French methods is to be attributed to some historical events that transformed France in a reference for all the European countries, for both the positive and negative aspects: even those who criticised French methods had to take them as reference point. In fact, the year 1789, with the Storming of the Bastille, was a crucial date for the entire old continent. With the instauration of the Republic, also in French there were many expropriations of royal and ecclesiastic possessions: many artworks changed location or were severely damaged. Other paintings were radically transformed to be adapted to satisfy the collecting demand, or located in public museums with a didactical aim (Ciatti 2009). In 1793, the Musée Central des Arts in the Grande Galerie of the Louvre was opened, where many royal collections were exposed, later joined by the masterpieces expropriated to the other countries by French troops.

In this period, the structural intervention techniques had developed thanks to the decennial experiences and investigations. Jacques-Louis David and JeanMichel Picault, son of Robert, advocated making a public contest to employ restorers for the laboratories of the Louvre (Cecchini 2009). At the same time, François Toussaint Hacquin who had replaced his father Jean Louis in the Louvre laboratories, developed a new adhesive for adhering the painting to a new 
canvas, which was based on the use of resinous and oleos materials that made it resistant to humidity. Furthermore, for the transfer of paintings his technique did not include the application of the paper interleaf before gueing the new canvas (Barres 2005). François Toussaint Hacquin worked in a period in which the tradition of the workshop's secrets was giving way to scripts in which intervention methodologies were clearly described. The same Hacquin wrote several reports in which he reported all the details of his interventions, mentioning also materials and recipes. Among them, the most important one is perhaps that on the Madonna di Foligno by Raffaello, that was transferred by Hacquin in 1800-01 and that is today exposed in the Vatican Museums in Rome. It is the only condition report on a French transfer of an Italian panel painting. The redaction of this script was edited by a commission made of two painters, Vincent and Taunay, and two scientists, Guyton e Berthollet. According to Licia Borrelli-Vlad (1950), the method there described is very similar to the traditional one that is employed still today in France. Thanks to the accuracy of this report, that made it similar to modern technical reports, it can be extrapolated interesting information on the facing used for the transport from Italy to France and on the cartonnage made for the transfer from panel to canvas.

Due the importance of this report, it was considered of worth to translate a part of it, which was included in a publication of Prunetti in 1818:

"When the commissioners for Italian Arts received the painting, it was in such a
terrible state that they doubt to send it to Paris, so that they ordered the transport
only after the paint flakes were fixed in several points through the application of
veils on the surface of the painting. [...] It was therefore urgent to try to save this
precious picture from destruction, and the administration decided to transfer it,
sure that it was not possible to re-adhere the colour without transferring it to another
support. Since it was not possible to permit such an important operation without a
religious respect, especially since it was a Raffaello's painting, the same
administration asked to the Minister of the Interiors to exhort the National Institute 2
to select a committee composed by members of the same Institution, to execute
the projected restoration and make a report, in order to reassure scrupulous
people, to silence that of bad faith, but especially to make public the most simple
operations and remove charlatanisms and chatters related to them. This
committee was composed by the chemists Sir Guiton and Sir Bertholet, and the

2 The Institut National is the most important French cultural institution. Founded in 1795, after the suppression of the Royal Accademies, it gather the Académie Française (founded in 1635), the Académie des inscriptions e belleslettres (founded in 1663), the Académie des sciences morales et politiques (founded in 1795) and the Academie des Beaux-Arts (founded 1816) (Perusini 2013). 
painters Sir Vincent e Sir Taunay. They acknowledged the necessity to transfer the painting"3 (Prunetti 1818).

In the relation were later described the damages to which the panel had been subjected: in the central part of the support a big fissure was present, and there were a lot of detached paint flakes. Therefore, the operations carried out by Haquin were described. The first part of the intervention consisted in the protection of the front of the paint layer with a gauze, made before straightening the support to facilitate latter operations. Once this phase was concluded, the restorer proceeded with the cartonnage, applying a second gauze on the surface, and then two layers of paper that Prunetti defined sughe mischie. The support was therefore removed through perpendicular sawing and with a plane, while the last layer was removed with water and a knife. The ground was substituted with a new oil-based one:

\begin{abstract}
"After three months of drying, a gauze was applied on the oil-based ground, and a thin canvas was applied on it. When the canvas had dried, the painting was detached from the table [on which it had been previously nailed], and it was turned over to remove the cartonnage, that means the abovementioned sughe mischie papers, with water. Once this operation was concluded, it was thought how to remove the irregularities of the surface due to the folding; to do that, the Artist applied a warm flour glue on the irregularities; then he applied a papier gras on the humidified part and passed an iron on abovementioned irregularities [...]. The painting still had to be attached to a new stable support, to do this a new cartonnage was applied, removing then the provisional gauze that had been applied on the ground; a new ground composed by oil and lead oxide was applied, and a very flexible gauze; and on that a single raw cloth already coated with another layer of ground was applied, and soaked with a resinous mixture to fix it on a similar cloth that was stretched on a stretcher." 4 (Prunetti 1818).
\end{abstract}

\footnotetext{
3 Translated from Prunetti 1818: "Quando dai commssarj francesi per le Arti in Italia fu ricevuto il Quadro, egli era in tal pessimo stato, che i medesimi dubitarono se dovevano, o nò inviarlo a Parigi, eglino non di determinarono ad ordinarne il trasporto, se non dopo aver fermata il più luoghi la pittura, che lasciava il fondo, col mezzo di veli incollati sulla superficie del Quadro. [...] Era dunque urgente il procurare di salvare questo prezioso Quadro dalla rovina, che lo minacciava, e l'amministrazione si decise di farlo levare, ben convinta, che se non si poteva ristabilire la Pittura, se non che riportandola sopra un altro fondo. Ma siccome senza un religioso rispetto non può permettersi un'operazione di questa importanza, e sopra tutto trattandosi di un Quadro di Raffaello, la medesima domandò al Ministero dell'Interno d'invitare l'Istituto Nazionale92 a nominare una commissione composta di membri dell'Istituto medesimo per effettuare il ristauro progettato, e di fargliene un rapporto, a fine di tranquillizzare le persone scrupolose, o di far tacere quelle di mala fede, e sopra tutto per render pubbliche le operazioni e le più semplici, e tener lungi la ciarlataneria, e le ciancie, delle quali queste operazioni erano circondate avanti la di loro esecuzione. Questa commissione fu composta dei signori Guiton, e Bertholet chimici, e dei signori Vincent e Taunay pittori. Eglino riconobbero insieme l'urgente necessità di trasportare il Quadro" (Prunetti 1818, pp. 139-41).

${ }^{4}$ Translated from Prunetti 1818: "Dopo tre mesi di disseccamento fu incollato un velo sull'impressione a oglio, e sopra questo una tela fina. Quando questa tela fu disseccata, il Quadr fu distaccato sopra la tavola, e fu rivoltato per levargli le Cartonnage, cioè quelle carte sughe mischie di sopra dette, con dell'acqua. Eseguita questa operazione si pensò alla maniera di far sparire le disuguaglianze della superficie, che provenivano dalla ripiegatura delle sue parti; per far questo, l'Artista successivamente, applicò della colla di farina stemperata
} 
This report is very important in the context of this investigation because, even if there no detailed information on materials was given, it is possible to find a description of two surface protection techniques. The first one consists of a protection made in an emergency situation, before deciding how to operate on the painting. In fact, paint flakes were fixed with a gauze. This is, therefore, one of the first written witnesses on emergency facing. Since there are no coeval written sources, it is not possible to draw precise conclusions. However, it is tempting to hypothesise that emergency facing have been employed since a long time, as supposed at the beginning of this chapter.

The second kind of protection is the same that was described in the other documents displayed before. It is a cartonnage directly related to transfer of easel paintings, which is very similar to other employed for French linings (Ciatti 2009). It is of worth noting that the scope of the described cartonnage was of supporting the painting, and that it did not have other functions such as consolidating or flattening of the paint layer, since it had to be removed and then substituted to carry out these operations with the flour glue.

In the report it was not described the initial removal of the coating commonly made before applying the cartonnage to guarantee a better adhesion. The same Haquin described this step in other paintings reports (Conti 1988).

The Madonna di Foligno report became a model for the education of European restorers during all the $19^{\text {th }}$ century. Even the first Italian handbooks published at the beginning of the century will refer to this report, referring to the French techniques to describe the transfer process (Ciatti 2009).

If the origin of the transfer of easel paintings seems to be ascribable to Italy, the same does not apply to lining process, that is still contented between Italy and France, and recently Belgium entered in this quarrel as well. It seems that the first lining was practiced in the $17^{\text {th }}$ century. There is, for instance, a witness of 1660 of a lining made by the restorer Lamorlet of Antwerp. It is also known that in 1686 Chigi family from Rome payed Nicola Carioli for the lining of a David by Lanfranco. The same operation was executed on the Venere del Prado by Tiziano in the Prado Museum in 1688 and on many other French

sopra le disuguaglianze; poi avendo messo un papier gras sopra la parte umettata, appoggiò un ferro scaldato sopra le dette disuguaglianze, le quali si spianarono, ma questo non fu fatto, se non dopo aver impiegati gl'indizj più certi per assicurarsi del grado conveniente di calore del ferro, che si permette di accostare alla pittura. [...] il Capo d'Opera doveva ancora essere applicato con solidità su di un nuovo fondo, per far questo, convenne di nuovo le cartonner, incartonarlo, sbarazzarlo del velo provvisorio, che era stato posto sopra l'impressione; aggiungere un nuovo letto d'ossido di piombo, e di oglio, applicarvi un velo reso flessibilissimo; e sopra questo, di già egualmente intonacato di una preparazione di piombo, apporre una tela cruda tessuta tutta di un pezzo, ed impregnata nella superficie esterna di un mischio resinoso, che doveva fissarla ad una tela simile stabilita sul Telajo". 
paintings in the 1698 (Ciatti 2006). In all the Europe the end of the century was a prosperous period for restoration: the traditional technique was refined and new techniques were experimented. To this development did not correspond the growth of scientific production, so that for information related to this period has to be obtained from archival researches, relying on travellers descriptions, payment books, letters and other documents of various kinds.

An example is the epistolary exchange that took place in 1677 between Torquato Montauti, delegate of the grand duke of Tuscany in Rome, and Apollo Bassetti, state secretary in Florence. In this letters, they discussed about the Saint John the Baptist in Glory by Annibale Carracci of the Grand Ducal Academy of Rome that had to be moved to Florence. In some letters, Montauti mentioned the description on the state of conservation made by Ciro Ferri, designated to fix the paint before its transportation to Florence. The paint layer was detached in several points and there was a little hole in the canvas. The painting was too fragile to be rolled up, so that the artisan had suggested to transport it in a box, applying a patch on the hole, considering unnecessary other interventions. Nevertheless, there was a debate on the issue. In fact, Bassetti replied that: "[the Grand Duke] relies on the expertise and affection [of Ciro Ferri] to mend the hole. When canvases are old and poorly maintained here there is the custom of putting them on a new canvas, that give them strength and safety" 5 (Bassetti 1677 cit. in Marinetti 2007). This demonstrates that lining was commonly practiced in Florence. Lining was surely known also in Rome, since Ferri fixed the painting as it was finally ordered to him.

In these letters, the term 'lining' is not used, but a periphrasis is used to describe the operation. This could mean that a specific term for this intervention had not been already defined. However, there are also cases in which specific terms were used. An example of this can be found in Bellori book "Le vite de' pittori, scultori ed architetti moderni" of 1672, when he described some interventions made by Maratti on the paintings of the Basilica of Loreto, especially on the Nativity of the Virgin by Carracci. Describing the poor conservative state of the painting, the biographer related that the painter "accelerated the solution, and considering it was not sufficient to line the painting and to add panels, moved it to a safer place"6 (Bellori 1672 cit. in Zanardi 2007).

\footnotetext{
5 Translated from Bassetti 1677 cit. in Marinetti 2007: "[ll Gran Duca] si rimette alla [...] perizia et amore [di Ciro Ferri] circa l'accomodare il difetto del buco che c'è. Quando le tele sono tanto vecchie e mal tenute qui si costuma riportarle sopra una tela nuova, che serve loro di fortezza e di guardia".

6 Translated from Bellori 1672 cit. in Zanardi 2007: "Accelerò il rimedio, e non giudicando sufficiente il foderar la tela e munirla con tavole, pensò di collocarla in più sicuro luogo".
} 
These two documents demonstrate that lining was already practiced in $17^{\text {th }}$ century, but no technical information was provided on methodology and materials. On the contrary, in a Venetian treatise of 1640 by Leonardo Fioravanti it was described the recipe of a glue-paste made of flour, warm water, finely ground arsenic, cooked since the paste became ticker (Fioravanti 1596). From this first source it is not possible to know if a facing was applied before lining the painting. Other documents of the same period provide interesting spark to make some hypotheses. In the Abcedario Pittorico of 1704, Pellegrino Antonio Orlandi illustrated the procedure. The old canvas had to be wetted and left some time in a humid place, then a glue-paste made with vinegar had to be applied to a new canvas. The painting was then glved to the new canvas and a sheet of oiled paper was placed on the paint layer to facilitate the adhesion exerting pressure with a flat pebble or a piece of wood (Orlandi 1704). In the system described by Orlandi there was no reference to some kind of facing. On the contrary, only a sheet of oiled paper was interposed to exert a local pressure. There can be two different explications: the idea of associate facing to lining did not already occurred, or it was not considered necessary to make a facing. The written sources of this period seems to indicate an approach respectful of the originality of the artworks, that differs from the coeval French trend, bur especially from the ones that would have been developed in the next century.

Even in the case of the paintings from the collection of the Real Alcázar of Madrid lined by the Spanish restorer Juan García de Miranda after the palace fire of 1734, it seems it was not applied a facing, but the painting was simply leaned face down on the work table before proceeding with the lining (Macarrón-Miguel 2013). It is also known that his colleague and successor Andrés de la Calleja, director of the Real Academia de San Fernando since 1778, lined many paintings of the royal collections, such as the equestrian portrait of the Count-Duke of Olivares now exposed in the Prado museum.

The most interesting information related to linings of the $18^{\text {th }}$ century is probably related to the Venetian context. During the Greenwich conference held in 1974, Percival-Prescott hypothesised that lining technique was first adopted in this geographical area, because of the huge dimension of the paintings. Percival-Prescott asserted that large-scale Venetian paintings of the $16^{\text {th }}$ century could not have a lifetime higher than 150-200 years, after which they started to present conservative problems such as deformations, loss of tensioning and detaching of superficial layers. It is therefore possible that the conservative condition of these painting stimulated the research of an effective system to solve the problem (Percival-Prescott 1974 cit. in Villers 2003). The most ancient recipe for lining dates back to the $17^{\text {th }}$ century, 
exactly the period in which Venetian paintings started to present conservative problems (laccarino-Idelson 2007).

In this period in Venice there was a very interesting example of preservation and conservation of the artistic heritage, thanks to the figure of Pietro Edwards (Loreto 1744-1821). Conservator during 50 years, he covered important official positions during the succession of five Governments. It still appears astonishing his work, and the clarity, the rationality and the modernity of his approach, based on a complex and modern conservation theory. His activity was documented by a score of reports in which comes out the importance given to the technical and scientific support to overcome the limit connected to the artisan tradition (Tranquilli 1996).

In 1778 Edwards commissioned the installation of a restoration laboratory in the mess hall of the convent of Saint John and Paul. The work in the laboratory was carried out in an atmosphere of collaboration and dialogue, promoted also because every restorer was specialised in one specific aspect of restoration (lining, cleaning, retouching).

From the technical point of view, it is important to analyse the so-called referte, that means the detailed technical reports in which Edwards examined the state of conservation of the paintings and indicated the most suitable methodology to follow. Unfortunately, little attention was given to the most technical aspects, since these reports were addressed to people without a specific expertise in the sector of restoration7. On the contrary, some documents cited by Gloria Tranquilli (1996) are interesting for this purpose. One of them included an introduction on the technical education of the restorer, and a technical description of the principal interventions on panel paintings was given. Other details were extrapolated from payment policies of restorations carried out under the supervision of Edwards and from lists of the materials from the laboratory. However, the most relevant written source for this work is the witness referred by M. P. Merrifield in her "Original Treatises On The Arts Of Painting" (1849), based on the information given by O'Kelly Giovanni Edwards, Pietro's son (Percival-Prescott 1974 cit. in Villers 2003).

Merrifield cited in a note to her work the recipe used for the glve-paste and the lining methodology. This information was taken from a document of the $21^{\text {st }}$ February of 1816 , and it referred to the restoration of the Assumption of the Virgin by Tiziano carried out by the restorer Floriani:

\footnotetext{
7 Edwards was used to send the referte to the Magistrati al Sal, who were the responsible of the preservation of public heritage since the middle of the $17^{\text {th }}$ century.
} 


\begin{abstract}
"The paste used for lining the picture was composed of flour paste, Flenders glue, and ox-gall. The use of the latter ingredient was to preserve the paste from the attacks of insects. [...] The process was described to me by his son; it was as follows: the face of the picture being secured by pasting paper over it, it was laid on the polished Venetian floor (...) and the lining was fixed to it. Hot send was than laid all over it, beginning always in the middle of the picture, whence the sand gradually spread to the edge, and the picture was covered to a certain height. By this means the air was pressed out from between the canvas and the picture, and an equal degree of warmth and pressure was communicated at the same time to the whole surface, much more safely and effectually than with a hot iron" (Merrifield 1849).
\end{abstract}

Merrifiel described the facing using the words: "the face of the picture being secured by pasting paper over it". The expression 'pasting paper' let think to a thick adhesive, that form a 'paste', as flour or starch glue. This supposition is confirmed by a document rediscovered by Gloria Tranquilli in the Library of the Correr di Venezia, where the same Edwards described the lining process. Thanks to this witness, it is possible to know that the painting was protected with a paper called sugarina, glued to the paint surface with starch paste. When necessary, a preventive consolidation of the colour was made. Once the lining was applied and the canvas tensioned on the stretcher, the paper was removed by wetting and rubbing it with the finger (Tranquilli cit. in Martín-Rey, Guerola-Blay, and Castell-Augustí 2010).

In the "Vocabolario bresciano e toscano" written by Pellizzari in 1759, the sugarina peper, or sugante paper is a paper that adsorbs ink. A more detailed description was given by Giacinto Carena in the "Nuovo vocabolario italiano domestic" of 1846, where he defined the paper called sugante, succhiante, succhia, or straccia a paper that was not apt for writing, but it was used to absorb the excess of ink resulting from writing. According to Carena, this paper was usually interposed between the sheets of notebooks, registers and similar writing-books where it was needed to alternate the writing in the different pages.

These definitions give exhaustive information on the paper used in Edwards laboratory for facing. It seems to be a paper similar to the ones used up today. However, the facing employed in the Venetian laboratory had a merely protective function, since it was made with a weak adhesive and a light and absorbing paper. It had no consolidating function, since the consolidation was made before facing if necessary. As it will be possible to read in further sections, facing described in the Italian handbooks of the $19^{\text {th }}$ century showed similar characteristics. 


\subsection{MANUALS OF 19TH CENTURY IN EUROPE}

As already mentioned in the previous section, the period from the end of the eighteenth century including much of the nineteenth century was extremely flourishing in terms of development of science and culture in general, and particularly restoration.

In fact, starting from the end of the 18th century, the interest in techniques, materials and scientific notions was growing all over Europe. This phenomenon led to the development of an extremely lively cultural climate. New technologies were experimented and numerous studies were conducted on artistic techniques and related issues, and on degradation phenomena.

At the same time, because of the development of the Enlightenment spirit, it took hold for the first time the idea that the works of art were not private property, but they belonged to the nation that produced them. Paradoxically, it was thanks to the despised Napoleonic campaigns that these ideas were exported all over Europe. Furthermore, with the spread of the culture of Romanticism and with the wars of liberation, European nations also acquired awareness of their own cultural identity, which they sought first of all in national art and literature. The first museums had been opened to the public, such as the Museo Capitolino in Rome (1734), the Uffiizi in Florence (1737), the British Museum in London (1753), the Louvre in Paris (1793), the Museo Real de Pinturas (today known as Prado Museum) in Spain (1819), and the Altes Museum in Berlin (1830). Archaeological campaigns were carried out in Herculaneum, Pompeii and Egypt, in which numerous scientists such as biologists, physicists and chemists participated. In this way, the new link between art and science was definitively established.

In the early decades of the $19^{\text {th }}$ century, the Germans were at the forefront of the use of scientific analyses applied to the study of artistic techniques. This type of investigations had started in the second half of the $18^{\text {th }}$ century thanks to researches on the technique of Roman wall paintings and, at the end of the century, they were also extended to easel paintings, in particular to studies on the origin of oil painting. Starting from this date, numerous researches followed one another and soon, alongside the recognition of written sources, these studies began to make use of the chemical investigation (Perusini 2012).

Thanks to the collaboration of specialists of different sectors, in 1828 it was published that which could be considered as the first diagnostic book, the Traite de Chimie appliquée aux arts. The work was also very successful in other European countries and it stimulated the publication of other scripts of the same 
genre. The diffusion of these treatises and the publication of numerous dissertations in magazines facilitated the creation of a more homogeneous lexicon. Thanks to the legacy of the Enlightenment culture and the consequent revaluation of manual labour, the interest in the restoration activity increased. In fact, the great nascent national museums started to need the continuous work of professionals who could satisfy the needs of conservation and fruition (Ciatti 2009). Public laboratories specifically aimed at restoration were therefore created inside museums or in buildings connected to them. In this fervid climate, there were triggered debates on the numerous restoration works and on the role and skills of the outstanding professionals at the time. Thus, a considerable contribution was made to the definition of art, conservation and restoration (Parodi 2008).

In addition to the birth of national public institutions, the aforementioned suppressions of monastic orders and ecclesiastical expropriations brought an incredible amount of works of art on the market at ridiculously low costs. This situation, combined with the growing wealth of the bourgeoisie, led to the formation of several important private collections, whose owners had the strong interest of restoring and protecting.

In this stimulating period, the incentive to shear new discoveries typical of the positivist spirit, the commercial needs deriving from the development of the antique market, and the influence of the pragmatic positivist spirit of the second half of the nineteenth century, led to an increase of written testimonies and restoration handbooks were published in all Europe.

In this section, some of the main restoration handbooks of the $19^{\text {th }}$ century will be reviewed, with a focus on information provided on facing techniques. Particular attention will be given also to the historical-geographical context in which they were published and to authors' background.

\subsubsection{The flourishing Prussian written production and Koester's manual}

Even though manuals on artistic techniques containing some information on restoration were published in France from the early $19^{\text {th }}$ century, it was in the Prussian Empire, i.e. in present-day Germany, that the first European restoration handbook, "Über Restauration alter Oelgemälde" (On the restoration of ancient oil paintings) by Christian Koester, was published. The three notebooks that make up the manual were published respectively in 1827, 1828 and 1830 (Perusini 2012). 
In those same years, other German restoration treatises were published. The 1828 the noteworthy book about oil painting by M. B. L. Bouvier was translated by Christoph Friedrich Prange, who added an appendix about paintings restoration, called "Vollständige Anweisung zur Ölmalerei für Künstler und Kunstfreunde" (Foundamentals and practice of the secret art of restoring and conserving ancient paintings), which was reprinted in the subsequent editions both in Prussia and in France, thus becoming a fundamental text for both French and German restorers. In 1832, Friedrich Lucanus, connoisseur and pharmacist in Halberstadt, published his own handbook "Grundliche und vollständige Anleitung zur Brbaltung, Reinigung und Wiederberstellung der Gemalden in Oel, Tempera-, Leim-, Wasser-, Mi niatur-, Posteli- und Wachsfarben" (Instructions for the restoration of oil, wax, tempera, watercolor paintings, for miniatures and pastels). The restoration books by the painter and restorer Friedrich Welsch published in 1834, and by J.C. Gottfried Hampel, published in 1846, are also important (Schiessl 1998).

A part from of these five German treaties published just in the first half of the nineteenth century there were the numerous publications that appeared in newspapers and in the specialist press on the most important restoration campaigns. It can be concluded that the German literature of the first decades of the nineteenth century was probably the richest and most interesting in Europe, and it is surprising that it is almost unknown in countries such as Spain and Italy (Perusini 2012).

The reasons for this exceptional written expression on restoration must be sought first of all in the view of the historical and cultural European context mentioned above. The suppression of monastic orders (which took place in Prussia in 1803) threw an incredible amount of works of art on the market at ridiculously low costs. This phenomenon, associated to the growing power of the Prussian bourgeoisie, led to the creation of several important collections, such as those of the Broisserée brothers, Edward Solly and Richard Wallralf, consisting essentially of late Middle Ages and early Renaissance paintings, which would have been sold to public institutions and exhibited in museums (Perusini 2012).

Even in Prussia, because of the awareness of the public ownership of the artistic heritage and because of the prestige it brought to the rulers, the most important dynastic collections were exposed to the public, often housed in purpose-built buildings, such as the Gipsoteca (1916-1830) and the Alte Pinakothek (1826-30) in Munich and the Altes Museum (1823-30) in Berlin.

The idea of exhibiting the most important works of art of the royal collections in a public museum in Berlin had already been suggested by the art historian Aloys Hirt in 1796. The project had to be abandoned in 1806 following the defeat 
of Jena, when Berlin's best works of art were brought to the Louvre. After the fall of Napoleon, the Prussians recovered them with a determination that served as an example for other countries. In 1810, King Friedrich Wilhelm III, who had been fascinated after his visit to the Louvre, entrusted Christian von Mechel to compile the inventory of all the works of art of the crown, with the intent to revive the ancient project of the Museum and to increase the existing artistic heritage with further acquisitions. The first major purchase was from the Giustiniani collection in 1815, but even more relevant was the purchase of Edward Solly's private collection in 1820, which included more than 3000 of mostly Italian and Flemish paints of the XIV and XV centuries (Skwirblies 2012). These collections were temporarily housed in some rooms of the Academy, since the new museum, finished in 1830, was ready. However, the paintings of both the royal and the Solly collection were in a very poor state of conservation.

There were so many paintings to be restored that the punctual interventions of individual restorers would not have been sufficient. Furthermore, the paintings had to be exhibited in a public museum for educational purposes and not in a private building, making a restoration campaign necessary. In 1824, it was therefore decided to open an officially controlled laboratory based on a hierarchical division of labour. The painter Carl Waagen was superintendent of the restoration laboratory and he appointed the director and restorers who were to take care of the conservation of the museum's works. Among these, with the qualification of "master painters", there were Koester and his colleagues Schlesinger and Hirt. They were then involved in the formation of the future museum's restoration atelier in Berlin that was planned to be a "school for restorers" as well. According to a report wrote by Hirt in the October 1824, the work was progressing fast and efficiently. Concrete measures were coordinated and harmonised by the experts, artists and restorers alike. Six years later, in another report to the minister wrote by Uhden it was stated the success of the restoration campaign and it was proposed to establish the restoration workshop with regularly employed restorers as a permanent institution of the Altes Museum that had just opened its gates to the public (Skwirblies 2012).

Therefore, in the late 1830s, Koester was offered the position of permanent restorer at the Altes Museum. However, he refused to return to his city, Heidelberg, both to assist the old mother and, probably, because of nostalgia for his city. This choice was possible thanks to the good economic conditions of the family. Koester was in fact the son of a wealthy and culture-loving family, who favoured his intellectual curiosities and allowed him to never be conditioned by material needs. The wealth and vastness of Koester's cultural interests were always a hallmark of his personality. He was not only passionate about restoration, but he was a landscape painter himself, and especially in the last 
part of his life, he became very interested in music. In 1828, Koester became a member of the Wissen-schaftlicher Kunstverein (Artistic-cultural Association) of Berlin, which brought together all the most prominent personalities both from the cultural world (Hegel, Hirt, von Rumohr, Wilhelm and Alexander von Humboldt etc.) and from the world artistic (Schinkel, Daniel Rauch, Gottfried and Wilhelm Schadow etc.) of the city and this undoubtedly contributed to its cultural growth (Perusini 2012).

The complex and multifaceted culture of Koester was reflected in his manual, "Über Restauration alter Oelgemälde" (on the restoration of ancient oil paintings), divided into three notebooks published in 1827, 1828 and 1830 respectively. Reading Koester's manual is not easy, because he dealt with different topics without any order. His contemporaries pointed out this lack of a systematic approach, but he replied in his latest notebook that those who "have a bit of constancy and know what to look for sooner or later find what they need"8 (Koester 1830 cit. in Perusini 2012). Koester also said that "it would be pure pedantry to face every problem and I also deliberately left out the simplest things"9 (Koester 1830 cit. in Perusini 2012). In fact, Koester's manual was addressed to painters who wanted to devote themselves to restoration that is why his manual had a mainly theoretical character, which over time determined its poor editorial luck.

The first notebook appeared to be the most orderly. In fact, he described the individual restoration operations, i.e. lining, cleaning, retouching and painting. The author then analysed the most frequently used pigments, with particular reference to that employed for oil painting, passing by a description of the coatings used as a final protective and as a binder for retouching. The notebook then ended with a section entitled final considerations, in which Koester collected short notes on the most varied topics related to art and restoration.

The other two notebooks, which are less interesting for the purpose of this study, seemed to have no obvious order. The second notebook followed an internal logic focused on the execution techniques and on the restoration of panel paintings and ended with some final observations always on the pigments used in the restoration, and on some considerations on the antiques market. The third notebook was a miscellany of the most varied topics, in which Koester declared that he intended to integrate what he did not say in the two previous publications. This third book contains the author's reflections on fundamental theoretical problems, on the artistic market, and on the characteristics of the

\footnotetext{
8 Translated from Koester 1830 cit in Perusini 2012: "ha un po' di costanza 'e sa cosa cercare' prima o poi trova quello che gli serve".

9 Translated from Koester 1830 cit in Perusini 2012: "Sarebbe pura pedanteria voler "affrontare ogni problema ed ho inoltre volutamente tralasciato le cose più semplici".
} 
profession and education of the restorer that will not be treated here, but that are of great interest.

As regards to the topic this research, the passages related to lining are interesting. It was likely that Koester delegated the execution of structural interventions to other specialists, as it happened in other European museums and in antiquarian restoration. Despite this, he still had a good knowledge of the methods used.

Koester's approach to lining was prudent. In fact, he stated that:

"Regarding the canvases, if necessary, they are lined, but if the old support is still in a fairly good state of preservation, the tears and gaps are simply restored." 10 (Koester 1830 cit. in Perusini 2012).

Later in the text, the author reported a concise but effective description of lining system:

"The glue composed of flour and animal glue is used for lining. The painting is placed face down on a table, the glue is spread on the back, and then the new canvas is placed on it. The air bubbles in the glue are eliminated by passing a cylinder or a rolling pin on the back, pushing them towards the edges in order to obtain a better adhesion between the two canvases. The lining canvas fixed on an interim frame must not be stretched since the glue is not dry. If there is a risk that the tension may cause some raised fragments of the paint film to fall, the colour can be protected by gluing sheets of paper on the surface of the painting, as it should also be done for the transport of paintings that are in a bad state of conservation."11 (Koester 1830 cit. in Perusini 2012).

What follows from this description is that, according to Koester, facing was not considered as a preliminary operation necessary for lining. This operation was used only in case of possible detachment of some fragments during the retensioning of the painting, and it had to be carried out by gluing some sheets of paper on the surface of the painting. Unfortunately, Koester did not provide information on the type of materials to be used for this operation. Koester did not

\footnotetext{
10 Translated from Koester 1830 cit in Perusini 2012: "Per quanto riguarda le tele, se necessario, esse vengono forderate, ma se il vecchio supporto è ancora in discrete statodiconservazione, vengonosemplicemente restaurati gli strappi e le lacune".

11 Translated from Koester 1830 cit. in Perusini 2012: "Come collante per la foderatura di un dipinto su tela si utilizza colla di farina e colla animale. Il quadro viene posto a faccia in giù su un tavolo, la colla viene spalmata sul retro, e quindi su di esso viene adagiata la nuova tela. Passando un cilindro o un mattarello sul retro si eliminano le bolle d'aria formatesi nella colla spingendole verso i bordi, al fine di ottenere una migliore adesione tra le due tele. La tela di rifodero, fissata su un telaio interinale, non deve essere tesa fintanto che il collante non è asciutto. Se vi è il rischio che il tensionamento possa far cadere qualche frammento sollevato della pellicola pittorica, si può proteggere il colore incollando dei fogli di carta sulla superficie del dipinto, come si dovrebbe fare anche per il trasporto di quadri che si trovano in cattivo stato di conservazione".
} 
even refer to some type of consolidation directly related to lining, but it can be supposed that in case of the deadhesion of the pictorial film, a system similar to that described for the consolidation of panel paintings was used:

\begin{abstract}
"If the support of a panel painting appears to be damaged and the colour is severely detached, before proceeding with the restoration of the support, the pictorial film must be fixed and flattened to avoid losing some fragments of the polychromies. To this end, very diluted and rather hot glue is used. A few drops of glue are poured into the cracks or under the flakes also using a thin and elastic stick or a whale bone to spread the glue. Where there is no hole for the glue to penetrate, as happens when the colour has bubble lifting, the paint film is carefully pierced using a needle. The adhesive is then allowed to penetrate and if necessary the operation is repeated. A greaseproof paper is then placed over these areas and pressed with the iron. For this purpose, metal rollers of different calibres can also be used to press the pictorial surface. If this treatment is not sufficient, some well-smoothed metal plates can be placed on the flakes since to keep the colour pressed until the adhesive is completely dry."12 (Koester 1830 cit. in Perusini 2012).
\end{abstract}

As it will be possible to see, the method described is very similar to that indicated in the other European manuals analysed below. It is possible to imagine that a similar system was used to consolidate the paintings on canvas. As pointed out by Giuseppina Perusini and Patrizia di Leonardo (Perusini 2012), in German language the term 'glue' is identified with two distinct words: leim, which is the glve of animal origin, and kleister, which is the starch glve (nowadays it refers also to the synthetic ones). In this passage, the term leim is used, and it is therefore evident that Koester referred to animal glve, that was besides the most used glue for colour consolidation, as it can be deduced also reading the other manuals.

It is a shame that we cannot have more detailed information regarding the materials used to make the lining. It is not possible to establish whether the type of paper to which Koester referred was thin or thick, or whether the glve used was animal glue or starch glue. Considering that the passage of the consolidation is described separately in the manual, it is possible to imagine that

\footnotetext{
12 Translated from Koester 1830 cit. in Perusini 2012: "Se il supporto di un dipinto su tavola appare molto danneggiato e il colore presenta numerosi sollevamenti, prima di procedere al risanamento del supporto va fissata ed appianata la pellicola pittorica per evitare che si perdano alcuni frammenti della policromia. A tal fine si impiega della colla assai diluita e piuttosto calda. Si versano alcune gocce di questa colla nelle spaccature o sotto i sollevamenti impiegando anche uno stecco sottile ed elastico oppure un osso di balena per spargere bene il collante. Dove non esiste alcun foro per far penetrare la colla, come accade quando la policromia presenta dei sollevamenti a bolla, si fora con molta attenzione la pellicola pittorica utilizzando un ago. Si lascia quindi penetrare il collante e se necessario si ripete l'operazione. Sopra queste zone si pone quindi una carta oleata e si preme con il ferro da stiro. A tal fine possono essere impiegati anche rulli metallici di calibri diversi con cui si preme la superficie pittorica. Qualora questo trattamento non fosse sufficiente, si pongono sopra i sollevamenti piastre metalliche ben levigate che tengano premuto il colore fino a che il collante non sia completamente asciutto".
} 
consolidation and facing were considered two distinct phases, as it happened in other European restoration laboratories. It could be possible to make this hypothesis even because of what Koester stated:

"If there is a risk that the tension may cause some raised fragments of the paint film to fall, the colour can be protected by gluing sheets of paper on the surface of the painting."13 (Koester 1830 cit. in Perusini 2012).

Koester indicated this system to protect the painting during the stretching of the painting, but it was not specified that it was used to consolidate the paint layer. It was seen that in the Edwards's laboratory the facing was a different step to that of consolidation. In other European manuals, these two passages were separated as well. It is therefore possible to suppose that it was the same in the case of Koester manual.

Given the vast German written production of the $19^{\text {th }}$ century, it is a great pity not to be able to analyse the other texts, due to the lack of translations into other languages. It is hoped that in the future the other German restoration handbooks will be published in other languages as the Koester's one, to be able to make comparisons between the techniques used by the various restorers and make hypotheses on the chronological evolution of some techniques, such as for example, the subject of this study. The possibility of analysing the other manuals could give useful information regarding the use of facing and clarify the doubts deriving from the reading of the Koester manual. Only in this way, it would be possible to make a mature and complete comparison with the other European treatises.

\subsubsection{The French example and Horsin-Déon handbook}

French restoration was certainly the most updated and the extensive practice of restoration on the French artworks expropriated during the revolution, and on those stolen during the Napoleonic invasions contributed to the development of the sector. As mentioned above, the Napoleonic invasions themselves and the subsequent return of the paintings confiscated and then restored in Paris, contributed to creating a remarkable admiration for their technical skills. Many manuals were published in the $19^{\text {th }}$ century in France. The theme of restoration, however, was not the only one treated in early handbooks, but it was often associated with considerations on the artistic techniques of the various artists or

\footnotetext{
13 Translated from Koester 1830 cit. in Perusini 2012: "Se vi è il rischio che il tensionamento possa far cadere qualche frammento sollevato della pellicola pittorica, si può proteggere il colore incollando dei fogli di carta sulla superficie del dipinto".
} 
pictorial schools. These considerations were related to easel paintings, since the handbooks were written for the sphere of collecting and antiques. Therefore, the public to whom these manuals were addressed was varied, formed not only by professionals, but also by collectors and lovers of fine arts.

For example, in the first manual published in 1808, the "Traité théorique et pratique des connoissances qui sont necessaires a tout amateurs de tableaux" by François Xavier de Burtin, an analysis was made on everything that revolved around the world of art; a small space was dedicated to the restoration within an in-depth study of arts and crafts. It was not a text addressed to professionals of the sector, but to amateurs who wanted to develop specific knowledge to avoid cheating by art dealers and restorers. In Fact, the latter were considered unscrupulous operators by the author, and they had to be consulted only if they were really trusted and only for operations such as lining, transfer and repainting. The precepts on the art of restoration were addressed in nine articles contained in chapter XV. At the basis of de Burtin's treatise it was the knowledge of the artwork and the degradation cases. Following this logic, the most appropriate remedies were indicated, dictated by the situation illustrated in the book.

Next manuals also placed the restoration in a wider context. For example, Jacques Nicolas Paillot De Montabert wrote the "Traité de la peinture e du sculpteur" between 1829 and 1851, which consisted of ten volumes, seven of which were dedicated to the art of oil painting. The manual was structured following a particular scientific and methodological rigor that followed an encyclopaedic scheme. The aim of the treatise was the knowledge of the causes of deterioration that made restoration necessary. Another text dedicated to oil painting was "De la peinture a l'huile" by Jean François Léonor Merimée, of 1830. Even in this case, the recipients of the manual were cultured men, connoisseurs, collectors, especially painters and artists of the academy. The author was interested in the study of the techniques that allowed the great artists to create lasting works, and not in finding remedies to restore those already degraded. The restoration was considered as a useful tool to investigate the artistic techniques and procedures of each school and each teacher. Chapter $\mathrm{VI}$ was dedicated to the conservation of the paintings and their restoration, but in a discursive and not schematic way. Only a few lines were dedicated to the glve-paste lining. However, it is possible to find an interesting reference to facing that had to be performed using a fine and smooth paper, frayed along the edges, which was sometimes glved in overlapping layers (Macarrón-Miguel 2013). However, also in this handbook the restoration appears as something extremely generic, confused, and left in a heterogeneous magma of practical experiences (Parodi 2008). 
The manual that had perhaps the greatest impact was that of Simon HorsinDeon 14, "De la conservation et de la restauration des tableaux", published in 1851. The great success that the text gained abroad was mainly due to the accurate description of the French painting techniques. Differently, in Italy it was given importance to the information on the restoration techniques contained in the manual. Indeed, the treatise of Horsin-Déon provided a valuable update on everything that had been experienced and written in the country beyond the Alps in the previous twenty years.

As stated by the author himself in the introduction, the text constituted a collection of notes prepared to instruct illustrious and curious visitors on restoration. It was schematically divided into three parts: the restoration of the supports, the cleaning and the retouching.

In the first section, Déon described lining operations, including the transport of the paintings. For Horsin-Déon the intervention "consisits of fixing an old painting on a new canvas or in carrying the pictorial film on a definitive canvas that is practically the same thing"15 (Déon 1851 cit. in Perusini 2013). The restorer believed that the lining was the optimal solution for restoring paintings with heavily degraded supports or with accentuated cracking. He distinguished between three types of lining:

"1) Lining with single or double canvas;

2) Transport [i.e. removing the old canvas] which is the most delicate operation;

3) Fixing."16 (Déon 1851 cit. in Perusini 2013).

There were two types of protection of the front of the painting based on the type of lining. In the first case, the procedure included the protection of the front of the painting with a layer of non-glved paper before the painting was removed from its stretcher. Once the new canvas was glued, the intervention described by Déon involved prolonged ironing of the painting. It was therefore necessary to frequently replace the facing to guarantee a protection of the pictorial film also in this final phase:

\footnotetext{
${ }^{14}$ Simon Horsin-Déon (1812-1882): painter and restorer. At the age of sixteen, he made a trip to Italy. Returning to France in 1829, he devoted himself to painting, but he did not excel in this art. In 1836, during a trip to Belgium, he learned the basics of restoration by the painter-restorer Augustine Verlinde. As a restorer he had more luck. In 1850 he was one of the winners of the competition for restorers launched by the Louvre museum, but he did not work there for a long time, due to contrasts with the conossiveur of the museum. In 1849 he published an essay in which he bitterly criticized both the methods of the competition and the paintings catalogue published by Villot (Pesusini 2013).

15 Translated from Déon 1851 cit. in Perusini 2013: "Consiste nel fissare un vecchio dipinto su una tela nuova o nel trasportare la pellicola pittorica su una tela definitiva che è praticamente la stessa cosa"

16 Translated from Déon 1851 cit. in Perusini 2013: "1) La foderatura con tela singola o doppia; 2) II trasporto [cioè la rimozione della vecchia tela] che è l'operazione più delicata; 3) II fissaggio."
} 
"It will be necessary to iron [the painting] with the hot iron in order to recompact the pictorial surface of the painting and to flattening the craquelure and cupping. To obtain this result, the painting must be ironed several times. But it is clear that the paper that was initially glued on the paint will be preserved and will be renewed with each ironing"17 (Déon 1851 cit. in Perusini 2013).

The facing of Déon had the function of protecting the front of the painting and facilitating the re-adhesion of the surface layers. Repeated replacement allowed the glue applied at each step to creep inside the cracking during ironing, firmly consolidating the paint film. There is no mention of the type of glve. However, since strong glue was used for lining, it is plausible to assume that the substance used was water-based and that it was the same strong glue used for lining.

In the case of transport, it was necessary to fix the detached colour applying a thin gauze, to which were then superimposed "sheets of soft and porous paper, thus forming a resistant cartonnage with an absolutely flat and uniform surface and taking care that the sheets of paper are exactly juxtaposed"18 (Déon 1851 cit. in Perusini 2013). Once the support was removed, a gauze was temporarily glued on the back. At this point, the cartonnage could be replaced with paper and the painting was lined as previously described. The paper used for the cartonnage was much thicker than that used for facing. In fact, if the sheets had been superimposed and not placed side by side, the pictorial film would not have been supported on a single contiguous plane, but on several staggered planes. This would have caused serious damages to the painting, especially during the removal of the support.

\subsubsection{The situation in the Italian peninsula and Bedotti's manual}

The decades between the $18^{\text {th }}$ and $19^{\text {th }}$ centuries represented a complex period of change for the Italian states, which had decisive consequences on the future conservation of the Italian artistic heritage. In fact, with the changes in ownership and mode of use, many artworks were destroyed, sold or transformed.

The Italian governments promoted public restoration campaigns to redeem themselves from a dark period and they used the propaganda medium of

\footnotetext{
17 Translated from Déon 1851 cit. in Perusini 2013: "Bisognerà stirarlo [il dipinto] con il ferro da stiro caldo in modo da ricompattare la superficie pittorica del quadro e di appianare la craquelure ed altri eventuali sollevamenti. Per ottenere questo risultato bisogna stirare il dipinto più volte. Ma è chiaro che la carta che è stata incollata inizialmente sulla pittura verrà conservata e sarà rinnovata ad ogni stiratura".

18 Translated from Déon 1851 cit. in Perusini 2013: "Fogli di carta morbida e porosa131, formando così un cartonnage resistente con la superficie assolutamente piana ed uniforme ed avendo cura che i fogli di carta siano esattamente giustapposti".
} 
culture, as it happened in Rome after 1814, the year of the triumphal return of Pope Pius VII to the city. In this period, the Colosseum and the arch of Titus were restored and numerous transfers of wall paintings were made.

As regard to easel paintings, the situation was different. After their return, many works changed their destination. Sometimes the cause was the inability to relocate them to the original location. Furthermore, the establishment of Enlightenment thought encouraged musealisation also for educational purposes. For example, in Florence the Grand Ducal collection in the Uffizi began to be organized as in a real museum. Following the example from the Louvre, a structured laboratory with salaried internal restorers was organized. In Milan, following the suppressions of the late $18^{\text {th }}$ century by Joseph II of Habsburg Lorraine, it was decided to create a public collection, strongly desired by the new secretary of the Academy of Fine Arts Giuseppe Bossi.

The great social change introduced by the French revolution, and the economic and political transformation of the industrial revolution triggered the process of conquest of power from the bourgeoisie. The birth of this important group of users, owners of artworks and restoration commissioners was at the basis of the development of bourgeois collecting ${ }^{19}$.

In the mid-nineteenth century, there were strong discrepancies between the methods for conservation, restoration and exhibition of the bourgeois collectors and the official one of the Italian states. In amateur restoration for private collectors, the concept of a work of art understood as pure hedonistic and private use began to prevail. In public restoration, however, the concept of a work of art intended as a document gradually roused. This dualism would have persisted and it would have found a synthesis only in the first decades of the twentieth century.

The agitation of the beginning of the century became a stimulus in the cultural field. The numerous historical events and the coexistence of different ideas and approaches in the field of restoration led to lively debates useful for the development of the figure and the profession of the restorer. At the beginning of the $19^{\text {th }}$ century, there was a fervent climate, but the ideas were still immature and it would have been necessary to wait halfway through the century for them to mature, giving their most promising fruits. A contribution was made by the contact with the French culture of restoration, due in particular to two events. The first was the repeatedly mentioned return of the requisitioned works, thanks

\footnotetext{
19 This phenomenon led to a great and tremendous development of the antiques market, which significantly increased the phenomenon of spoliation. The Papal State was the first to provide a system to combat the phenomenon, issuing in 1820 an organic and well-structured corpus legis, the Pacca edict, which was also adopted by other Italian states.
} 
to which it was possible to observe closely the interventions carried out by the Parisian restorers. The second was the circulation of French manuals in which the ideas, techniques and technological developments made across the Alps were enclosed. These texts represented a starting point for the elaboration of writings of the same genre. The publication of the handbook "De la restauration des tableaux", written by the Piedmontese Giovanni Bedotti is an example. Native of Biella, Bedotti was a restorer who lived mainly in Turin. During his life, he visited many Italian cities and developed relationships with restorers, artists and collectors from the cities of Florence and Venice. He lived in Paris from around 1830 and to 1841, where in 1837 he published his manual for the first time. The book was then translated into Italian and republished in Turin in 1845, allowing it to be known in various cities of the centre-north of Italy.

The contact with the French culture was important for the growth of Bedotti's thinking. The possibility of drawing from a rich and heterogeneous context allowed him to reflect for a long time on the figure of the restorer in the dual meaning of painter and artisan, and to define his thoughts on restoration. Within the handbook, it is possible to find precise links that connect the author to the antiquarian and collector's environment of the peninsula. There are cities, which Bedotti himself indicated in the introduction of the text, which marked the fundamental stages of his formation, such as Milan and Bologna. Milan represented an emblematic case in the passage between the Enlightenment trend and the new needs of antiques market, with the simultaneous transformation of important collections from private to public fruition. The Milanese environment and culture undoubtedly marked Bedotti's professional training.

It must be said, however, that during his life Bedotti mainly frequented the environment of the antiquarian restoration and much less that of the 'public' restoration, something that Giuseppina Perusini (2012) has foreseen from the reports made by Bedotti himself in his treatise. In fact, there were no mention of practices in use in the 'public' laboratories of Florence, Milan and Venice. His background is reflected in the manual, which has a more pragmatic style than that of Koester for instance, even if it has a less erudite register. This is partly due to the commercial and self-celebratory purpose of the manual, necessary for Bedotti to make himself known and to publicise his work among his possible clients. Despite this, "De la restauration des tableaux" is an important testimony, since it was the first manual written by an Italian and it represents the result of the fusion of two cultures. In addition to the early dating, it is interesting because it represents both an important source of information on the technical and material aspects of a sort of artisan knowledge, and the testimony of a complex, transitional culture in which the figure and professionalism of the restorer was 
defined. This text represents a fragment of that missing link that connects the restoration of the $18^{\text {th }}$ century to the meticulously investigated one of the second half of the $19^{\text {th }}$ century. Bedotti can be therefore considered an intermediate figure between the restorer-painter and the skilled craftsman, between the academic and workshop culture (Parodi 2008).

The setting of his professional path is reflected in the manual. It is evident the need to overcome the dichotomy between mechanical and pictorial restoration to achieve multifaceted knowledge in the field of restoration.

The handbook is structured in three parts. The first, corresponding to the "Preliminary Reflections", consists of a rather celebratory autobiography, in which the author told of his studies and practice. Through his experiences, he outlined a training process, implicitly suggesting it as role model. Academic training was considered necessary because it allowed learning the noblest operations such as cleaning and retouching, as well as the history of art, and the movements and styles of the various artists. However, workshop work was equally important for a restorer, and it had to be carried out at artist-restorers workshops in different Italian and foreign cities. In fact, direct experience was fundamental and so it was the comparison and exchange of experiences and ideas. In this part, reference was also made to several Italian restorers of the first half of the century. This allows to understand some aspects of the relationships between the professionals, and the position of the author with respect to the problems of the time.

The second and third parts deal with the theme of restoration operations in a double meaning. The second section, General Principles, has a strong theoretical connotation: the strengths and weaknesses of a specific methodological choice were expressed and the precautions to be taken to avoid risks were indicated. In the third section, Application, Bedotti addressed the practical aspect of the topics previously discussed and described the different methods, but also the materials and tools used. Valentina Parodi, author of a study on the Bedotti handbook, describes this chapter as follows:

"The author proudly dwells on actions, materials and tools, specifying details, giving us a vivid cross section of the working and workshop life of a skilled craftsman of the first half of the $19^{\text {th }}$ century. The explanations are not always clear and precise, but they reflect a practical knowledge, organized in a theoretical structure with interpretative principles, accompanied by ethical considerations. A theory not focused on the problems of degradation and the analysis of phenomenology, but rather on ethics and the formulation of method principles [...]. Unlike all the other 
coeval texts, this structure identifies a solid didactic construction with a didactic purpose, in addition to the highly self-celebratory one."20 (Parodi 2008).

Bedotti's passion arises from the great interest he reserved for lining. The second part contains some interesting considerations on the causes and on the real need to carry out this operation:

"The operation that consists in relining a painting is one of the most important. Because it is from this operation, from the way it is done, that the destiny of a good picture most often depends. In fact, I believe that more paintings are lost due to relining than to cleaning. Last year I was amazed to see that in Paris, the centre of civilisation, the system had not yet changed in this respect. I was witness to this fact: the colour of a painting by Guido was completely raised, the liner did not know how to act to reinforce it. I told him that this was a very simple operation, and that if he wanted to let me do it, in an hour his picture would be strengthened, solidified. I put irons on the fire and in less than an hour the painting had become flat as ice. Nevertheless, I could not explain to him how such an inconvenience could not happen again. Indeed, as long as canvases similar to those still used in Paris are used, the paintings will always be subject to peeling and lifting. In Italy, some progress has been made in this direction, and canvases are currently being manufactured in Florence, the weaving of which is flat and not very tight, which are suitable for relining [...]. All the inconveniences happen because the new canvas is stronger than that of the painting [...]. The essential point is therefore that the new canvas yields to that of the painting: because if the old painting is subjected to the whims of a new canvas, there is the risk of having it lifted and fall apart. If, on the contrary, care is taken not to make use of flat and clear canvases in which the pasta can pass through, there will be neither thickness nor compressed air, so that the painting, being not subjected to any foreign action, will no longer be brought to detach and rise"21 (Bedotti 1837 cit. in Parodi 2008).

20 Translated from Parodi 2008: "L'autore tende a soffermarsi in modo compiaciuto sulle azioni, sui materiali e sugli utensili, specificandone particolari, regalandoci a tratti un vivo spaccato della vita lavorativa e di bottega di un artigiano specializzato della prima metà dell'Ottocento. Le spiegazioni non sono sempre chiare e precise, ma rispecchiano un sapere pratico, organizzato in una struttura teorica con principi interpretativi accompagnati da considerazioni etiche. Una teoria non incentrata sui problemi del degrado e l'analisi delle fenomenologie, quanto piuttosto sull'etica e la formulazione di principi di metodo [...]. Struttura che, a differenza di tutti gli altri testi coevi, individua una solida costruzione didattica con un intento divulgativo, oltre a quello fortemente autocelebrativo".

21 Translated from Bedotti 1837 cit. in Parodi 2008: “"'L'operazione che consiste nel rintelare un quadro è una delle più importanti. Perché è da questa operazione, dal modo in cui essa è fatta, che dipende il più sovente la sorte di un buon quadro. lo credo infatti che si perdano più quadri a causa della rintelatura che per la pulitura. Io fui stupito, l'anno scorso di vedere che a Parigi, centro della civiltà, non si era, sotto questo aspetto, ancora cambiato sistema. Sono stato testimone di questo fatto: il colore di un quadro di Guido era tutto sollevato, il rintelatore non sapeva come ci si comporta per rinforzarlo. Gli dissi che questa era un'operazione molto semplice, e che se voleva lasciarmi fare, in un' ora il suo quadro sarebbe stato rinforzato, solidificato. Feci mettere sul fuoco dei ferri da stiro e in meno di un'ora il quadro era diventato piatto come del ghiaccio. Ma non potei spiegargli come un tale inconveniente non potesse ricapitare. In effetti, finché si farà uso di tele simili a quelle di cui ci si serviva ancora allora a Parigi, i quadri saranno sempre soggetti a scrostarsi e sollevarsi. In Italia si è fatto qualche progresso in questo senso, e attualmente si fabbricano a Firenze delle tele di cui il canovaccio è piatto e poco serrato che sono adatte per la rintelatura [...]. Tutti gli inconvenienti capitano 
Bedotti believed that thin canvases should be used, which could be glued using less glve-paste than for a thick canvas. In this way, the painting remained lighter. Furthermore, the sparse canvas did not undergo the same contractions as the canvases used across the Alps. The restorer was convinced that in this way the forces generated by the new canvas would not have been unloaded on the painting. This theory clearly differs from today's understanding of the laws of mechanics, according to which an inextensible, medium-rigid and not thermohygrometric sensitive auxiliary support allows to download the internal tensions of a painting. However, the explanations given by Bedotti demonstrate a reasoned approach to the problem of lining and it recalls the image of a 'gentle' lining, which does not change the behaviour and appearance of the unlined painting. This is clearly a reasonable option, with the only disadvantage of providing less protection for the painting. The reflections on the importance of the materials to be used for the success and the prolonged effectiveness of a lining operation are surprisingly current.

The author's considerations continued by analysing the behaviour of the constituent materials of a painting, since in some cases the nature of the painting was itself the cause of the continuous occurrence of a certain type of damage, therefore the lining could not represent a solution to the problem.

The sensitivity to adapt the intervention to the type of degradation was then developed in the application part of the manual. Bedotti described his lining method and suggested an alternative for those with serious adhesion problems of the pictorial film, which consisted of an integral facing. Bedotti wrote as follows:

\begin{abstract}
"The way to paint the paintings. Once the paste has been prepared, it will be examined whether the painting that has to be lined threatens to lose the paint layer; then you will begin to apply the paste on the [new] canvas and then on the painting. It is necessary to make sure that this paste has been applied equally and uniformly; in the event that the painting is subject to skinning, it will be necessary to hurry as much as possible because the moisture of the paste could contribute to detaching the painting even more. Once the painting is mounted on the canvas, it will be softened with a sponge soaked in water by the side of the painting; after which, the picture will be turned on a large table specially made for the painting (a marble table would be better); and then taking a kind of knife [...] it is passed in all directions on the canvas. Once this operation is completed, the keys will be pull out. If the painting still threatens to detach then you will take a hot iron, put a piece
\end{abstract}

perché la tela nuova è più forte di quella del quadro [...]. Il punto essenziale è dunque che la tela riportata ceda a quella del quadro: perché se il quadro vecchio è sottomesso ai capricci di una tela nuova, si corre il rischio di farlo sollevare e cadere a pezzi. Se al contrario si ha cura di non far uso che di tele piatte e chiare che la pasta possa attraversare, non si avrà né spessore né aria compressa, di modo che il quadro, non essendo assoggettato a nessun azione estranea, non sarà più portato a staccarsi e a sollevarsi". 
of paper on the detaching point, and pass the hot iron three or four times, without stopping. If the piece of paper has attached and glued to the painting with this operation, it will be left there until the painting is completely dry, and then with a sponge moistened with water I will rub this paper until it disappears completely"22 (Bedotti 1837 cit. in Parodi 2008).

If the painting did not present serious lifting, it was possible to make a lining by spreading the glve-paste ${ }^{23}$ first on the canvas and then on the painting. This description diverged from that in Déon's manual, in which only one way of lining the paintings was described, which included the covering of the entire surface with paper and glve, and its subsequent repeated ironing. Referring to the paintings without serious detachments of the pictorial film, Bedotti indicated to perform a localized consolidation with the iron by placing a sheet of thin paper. As Parodi (2008) observed, Bedotti seems to indicate ironing as a technique not to be used unconditionally for each lining but only in specific cases, thus making us hypothesize other methods that are not well clarified for drying. She assumes that Bedotti probably let dry in the air without the use of pressure or heat, as can be done with a traditional Roman lining, for which it is not mandatory to use ironing. In fact, the sparse canvas that is prescribed to be used, similar to the Roman flap, facilitates the evaporation of the water.

After describing the recipe for the glve-paste, it was explained how to behave if there were very serious detachments of the painting film. In this case, it was prescribed to make an integral facing with a single sheet of thin paper, applied with a diluted flour glue:

"If the paint layer of a painting were entirely cupped and threatened to fall apart, it would be necessary to place a very thin sheet of paper with a glue of flour on it; once this is done, you will take a stretcher a few inches larger than the picture, stretch a canvas of the size of the picture and then the canvas will be tensioned around the stretcher with a rope, like embroidery frames. It will be pulled as much as possible since it will be well stretched, then the picture will be placed on it; in this

\footnotetext{
22 Translated from Bedotti 1837 cit. in Parodi 2008: "Il modo di rintelare i quadri. Una volta preparata la pasta si esaminerà se il quadro che si vuole rintelare minaccia di scorticarsi; allora si comincerà a stendere la pasta sulla tela e dopo sul quadro. Bisogna fare in modo che questa pasta sia stesa in maniera uguale ed uniforme; nel caso in cui il quadro fosse soggetto a scorticarsi, bisognerà sbrigarsi il più possibile perché l'umidità della pasta potrebbe contribuire a far sollevare ancor di più il dipinto. Quando il quadro sarà montato sulla tela, si ammorbidirà con una spugna impregnata di acqua dalla parte del dipinto; dopo di che si girerà il quadro su una grande tavola ben unita fatta appositamente (sarebbe meglio un tavolo di marmo); ed in seguito prendendo una specie di coltello [...] la si fa passare in tutti i sensi sulla tela. Terminata questa operazione si metteranno le chiavi al telaio. Se il dipinto minacciasse ancora di staccarsi allora si prenderà un ferro caldo, si metterà un pezzo di carta sul punto che si distacca, e ci si passerà il ferro caldo tre o quattro volte, senza fermarsi. Se il pezzo di carta si è attaccato ed incollato al dipinto con questa operazione, lo si lascerà lì fino a quando il dipinto sia completamente secco, e allora con una spugna inumidita di acqua si fregherò questa carta finché essa dispaia completamente".

${ }^{23}$ The glue-paste recipe indicated by Bedotti is as follows: flax wheat flour to be diluted in water and cooked until it becomes a firm and solid paste. Then add a little verdigris and a few drops of vinegar and filter it with a gauze to remove the lumps.
} 
way, it will be possible to pass the iron on all parts of the picture without the obstacle of the stretcher [...]. When all this will be finished, the picture is let to dry and then it is put on its stretcher, always taking care not to leave the keys that must be put after fixing the picture. I invite people who, after these explanations have not yet understood this operation, to come and visit me at my house, I will show them not only how it should be done, but also everything that needs to be used, and also how tools and utensils commonly used have to be made" 24 (transl. from Bedotti 1837 cit. in Parodi 2008).

When a painting had to be lined, the operation had to be adapted to the specific case therefore it was not essential to apply a facing, that had to be made only in case of real need. It was not necessary to repeatedly and prolonged iron the painting, therefore it could be assumed that it was a 'gentle' operation, in which the administration of heat was minor. Facing was carried out with the aim of fixing and consolidating the pictorial film, not with that of protecting it during the lining phases, because in this case it would have been indicated to face all the paintings indiscriminately. It should also be noted that the facing described by Bedotti resembles that made with flour glue and 'sugarina' paper in Edwards' laboratories. At the same time, considering the references inherent in the theoretical technical choices on the lining, it could be supposed that this technique was also practiced in Florence.

\subsubsection{The noteworthy contributions of Forni and Secco Suardo}

In the wake of the spread of the French manuals, in 1866 two other restoration handbooks were published in Italy, which are now widely known internationally. These are the Manuale del pittore restauratore (Manual of the painter restorer) by Ulisse Forni and the Manuale ragionato per la parte meccanica dell'Arte del Ristauratore di dipinti (Raisonné manual on the mechanical part of the Art of the Restorer of paintings) by the count Giovanni Secco Suardo of Bergamo, later

\footnotetext{
24 Translated from Bedotti 1837 cit. in Parodi 2008: "Se la pittura di un quadro fosse interamente sollevata e minacciasse di cadere a pezzi bisognerebbe in questo caso posarvi sopra un foglio di carta molto sottile con un poco di colla di farina ben slegata; fatto ciò, si prenderà un telaio di qualche pollice più grande del quadro, si tenderà la tela della grandezza del quadro e poi si attaccherà la tela intorno al telaio con una corda, come i telai a ricamo. Si tirerà il più possibile affinché essa sia ben tesa, in seguito si poserà il quadro sopra, in questo modo non essendo disturbato dal telaio si passerà il ferro su tutte le parti del quadro. Il telaio non solo impedisce che si possa posare il quadro su un piano perfettamente liscio, ma è ancora a causa del suo spessore un ostacoli molto scomodo e ingombrane in questa operazione. Quando tutto questo è terminato si lascia asciugare il quadro e poi lo si mette sul suo telaio, sempre avendo riguardo di non lasciarvi le chiavi che non si devono rimettere che dopo aver fissato il quadro. Invito le persone che, dopo queste spiegazioni non avessero ancora ben capito questa operazione, a venirmi a trovare a casa mia, mostrerò loro non solo come si debba fare, ma anche tutto ciò che bisogna usare, ed anche il modo come devono essere fatti gli strumenti e gli utensili di cui ci si serve normalmente".
} 
enlarged and published posthumously in 1894 with the title II Restauratore di dipinti (The Restorer of paintings).

These handbooks were influenced by the positivist spirit of the second half of the XIX century, and by the desire to describe the restoration operations neatly and meticulously. In fact, these manuals are extremely valuable because they contain detailed information on different restoration operations, and on the often forgotten facing. Furthermore, they had a strong resonance in the contemporary world. As it will be further shown, the facing techniques described here will continue to be used over time with small modifications up to the present day as 'traditional' facing, being employed in the Italian conservation institutes (ISCR of Rome and OPD of Florence), in other European conservation centres. For these reasons, it was decided to dedicate a specific section to compare the two manuals in relation with the historical background of their authors.

Ulisse Forni (1814-1867) was of humble origins. Thanks to the noble family where his parents work, he had the opportunity to attend the Institute of Fine Arts in Florence from 1827 to 1835. He then moved to Rome until 1841 and continued his studies at the Academy of San Luca. After participating in several competitions, he was noticed by the Director of the Royal Galleries of Florence, who in 1845 made him hire as assistant restorer. In the 1950s and 1960s, Forni wrote articles in newspapers and specialized magazines, showing great interest in new chemical products that were being industrially produced. During his career he devoted almost all his energy to the work inside the laboratories of the Galleries (only one privately restoration work is known), where he continues to work hard, until he was appointed first restorer in 1865.

Giovanni Secco Suardo (1798-1873), on the other hand, came from an ancient Bergamo family, studied law and resided for a long time in Milan for an administrative position. Here he knew important art historians, collectors and restorers. He personally tried to paint, but his interest was mainly focused on the study of degradation and on restoration. He therefore created an equipped laboratory in his residence. The numerous trips to Flanders, Germany, Austria and Paris allowed him to visit the main collections, to evaluate the set-up methods and the conservation and restoration policies. After years of theoretical research and practical tests, Secco Suardo chose to devote himself to teaching, with the aim of spreading the knowledge acquired throughout his life through a textbook that he hoped it should become a reference point for restorers in the unified Italy ${ }^{25}$. In 1864, he was authorized by the Ministry of Education to hold a refresher course for Florentine restorers on the transfer of easel and wall painting

25 The Italian Unification consolidated different states of the Italian peninsula into the single state of the Kingdom of Italy in late 1861. 
techniques. Ulisse Forni took part in the course as auditor to report to the Director of the Galleries. In the Florentine environment, the course was perceived as an undue intrusion and the unsuccessful strappo of the mural painting with the Temptation of Saint Anthony of the Cloister of the Florentine Badia became a further source of controversy.

The issue of the refresher course in Florence only severely exacerbated the relationship between Forni and Secco Suardo, who a few years earlier had already had the opportunity to meet and confront each other. It follows from a letter written by Forni to the Director Feroni dated 15 December 1863:

\begin{abstract}
"I did not hide this little opera of mine from various friends, and in early 1862, being the Conte Secco Suardo in Florence and speaking with him about the Art of the restorer, I told him of the script I had prepared and which I was expecting to be able to publish and $\mathrm{He}$ also made me know that he was concerned with this matter, and had already put together many notes. Having come to a wider confidence in the studies that we had both made, I had to realize that although we agreed in many points, we found ourselves not of equal opinion even in others..."26 (Forni 1863 cit. in Rinaldi 2000).
\end{abstract}

Probably the episode of 1864 triggered a competition for the publication of the manual. Actually, as demonstrated by some documents, Forni had already completed his text in 1861, but, due to the economic constraints, he could not publish it before 1866. In the same year, Secco Suardo published the first part of his manual.

The Manuale del pittore restauratore by Ulisse Forni (republished by Bonsanti and Ciatti in 2004) is composed of a proem and three main sections. The first section is divided into three parts, each of them dedicated to the restoration of a typology of paintings: fresco, tempera and oil. The second section is complementary to the first one and consists of a meticulous and accurate description of the materials used for the different operations. Finally, the third section is dedicated to colours. The restorer divided the manual according to the type of execution technique and addressed separately the issues of wall paintings, as well as that of panel and canvas paintings. He provided a schematic report, starting from the description of the standard procedure that is followed to restore a painting, and then inserting annotations on the possible

\footnotetext{
26 Translated from Forni 1863 cit. in Rinaldi 2000: "Pure io non ho nascosto questa mia operetta a varj amici, ed ai primi del 1862 essendo in Firenze il Sig. Conte Secco Suardo e parlando seco lui dell'Arte del restauratore gli faceva la confidenza del lavoro che aveva in pronto e che attendeva l'opportunità di pubblicare ed Esso pure mi faceva conoscere che s'occupava di tale materia, ed aveva già messi insieme moti appunti. Venuti ad una confidenza più amplia degli studi che ambedue avevamo fatti dovetti accorgermi che sebbene in molti punti fosse concordi, pure in altri ci trovavamo non di uguale parere...".
} 
variants connected with the technical characteristics of the work and its conservative conditions.

The II Restauratore di dipinti27 by Secco Suardo is also divided into three sections, which reflect the division made by the author in the introduction Sul ristauro in generale. According to Secco Suardo, the restoration was divided into three parts: mechanical, i.e. the set of structural interventions; chemistry, with reference to the preparation of paints and cleaning; artistic, that is the pictorial restoration. In the first part, which is the interesting one for the purposes of this research, the issues of the restoration of the supports of panel paintings, the colour transfer, the tearing of wall paintings and the lining of canvas paintings are described. The second is consequently dedicated to cleaning methods and the third to pictorial restoration. The first and third sections conclude with a recipe book of the materials used for each type of intervention previously listed. Secco Suardo organized the manual starting from the analysis of the execution technique and the type of degradation of the painting: he described in detail every single case that could be found and for each one he indicated the best method to follow. In some paragraphs, he also dwelled on the description of the techniques used by other Italian and foreign restorers, providing a comparison between some of the techniques used in the second half of the nineteenth century.

The two handbooks were written with two different registers because of the different training and the different experiences of the two restorers, but also because of the public to whom they were addressed. Furthermore, a different approach to restoration operations can be observed.

Forni used simple and clear style and described the operations schematically. He chose not to describe all in details and he overlooks the indication of the materials to be used for some operations. It seems he did not consider it necessary to explain everything. It is a manual written by a specialist for other specialists with some skill and experience. It is also for this reason that he described dangerous or poorly tested techniques, such as some cleaning methods, because he knew how to speak to expert artisans who were able to evaluate and manage the risks they tackle with (Conti 1988).

Regarding to restoration methodologies, Forni adopted a less invasive approach than Secco Suardo. As it will be possible to see below, in most cases in Forni's manual, structural interventions are limited to the consolidation from the front or the back, possibly associated with a localised facing. Only in specific

\footnotetext{
27 In 1866 Secco Suardo published only the first part of his manual, entitled Manuale ragionato per la parte meccanica dell'arte del restauratore dei dipinti del conte Giovanni Secco Suardo. The full text was published posthumously in 1894.
} 
cases it is indicated to face the whole painting. This type of approach reflects other testimonies of the Florentine context, where it seems that, already in the first half of the nineteenth century, in the institutional laboratories there was the tendency not to intervene heavily on the artworks, which were already beginning to be seen as a testimony and document. Forni's handbook is pragmatic. In his manual he divided the various operations and illustrated them in a concise but exhaustive way. He did not tried to find a universal order that allowed explain everything. His indications arouse from the identification of the degradation phenomenology to be solved to provide the most suitable solution, without seeking the synthesis of the absolute order.

The abundance of examples and details that characterise the Secco Suardo manual and differentiate it from other coeval manuals is due to the fact that the count was an amateur free from deadlines who had the opportunity to travel and to know many ways of doing restoration. The knowledge he acquired thanks to the visits to laboratories throughout Europe, to the observation of the restored artworks and even thanks to the experiments he conducted, allowed him to compare, verify and select the methods he deemed most appropriate. In the manual, the count reported what he learned, comparing different methods and taking care of descriptions down to the smallest detail. He was attentive to the comprehensibility of what he wrote: his indications could still be followed step by step, without the need to interpret what it is prescribed. It is a handbook written by a restoration amateur who was also a connoisseur, who wanted to show and share his knowledge and skills with a large audience, made up not only of restorers looking for a complete vademecum to follow, but also by collectors and connoisseurs of the arts interested in being informed about restoration techniques. This form of text guaranteed him a wide success with audiences and critics, considered an important point of reference at least until after the foundation of the ICR.

In Secco Suardo's handbook it is evident the influence of the Positivist philosophy, derived from Enlightenment and Romanticisms. It could be also supposed that his legal training led him to search for a comprehensive order and logic that could act as a common thread throughout the manual. Son of his age and of his social class, he wrote a manual where everything could be perfectly placed in an easy understanding scheme. This has a dual effect. On the one hand, it is excellent because it allows to have all the necessary information, to be followed step by step. As in a decree, articles, paragraphs and corrections are provided. On the other hand, however, sometimes it seems that Secco Suardo strove to include each individual and peculiar case in a global order. As it will be further shown, this happens, for instance, for the facing of water sensitive paintings. 
The great confidence in progress and in science, and in the methods he experimented, compared, modified and improved also thanks to the confrontation with international professionals, led him to give indications that today we could partly consider excessive. Although in some cases he showed a certain sensitivity for the material aspect of artworks by criticizing some French systems, such as prolonged ironing during the lining, he hardly ever renounced to the facing or the ironing, even though 'gentle', of the painting. This 'invasive' approach might also had been influenced by the antiquarian environment he often frequented.

Despite all this, the testimony of the Secco Suardo's manual is something unique, because it is the only manual among all those analysed that provides extremely detailed information and that allows to know after a century and a half how certain operations were performed. It is certainly also one of the best documentary sources on facing, since in no other manual are given so precise information and exhaustive explanations of the how and why of certain operations.

However, regardless of the differences, both manuals represent a rich source of information for the purpose of this study. The descriptions of materials and application methodology are exhaustive and it is possible to understand how and in what situations the two restorers deemed it necessary to carry out this operation. It urge to underline that the restorers described two facing techniques that are very similar to those used today, with some important differences. As it will be shown below, in the facings made by Forni and Secco Suardo the consolidating and protective phase were, at least in theory, divided into two steps. The consolidation was performed with a fluid adhesive, and subsequently the paper was applied with an adhesive different from the previous one, with a protective aim.

In the manual of Forni it is rarely prescribed to completely facing a painting. For example, in the case of panel paintings with separated or curved axes, or in the case of a lining of a painting with a sufficiently folded and well preserved ground, some precautions are sufficient. In the first case, the workbench should be covered with a woollen cloth or sheets of fine paper. For the lining, the workbench should be constantly cleaned from the glue-paste that comes out during the flattening operations, to prevent the paint layer from sticking on the desk.

For the consolidation and adhesion of colour flakes of panel and canvas paintings, Forni prescribed the use of parchment glve, made of white sheepskin, obtained by boiling the scraps with twelve parts of distilled rainwater until its volume halves, reaching the right consistency. This glve is very similar to hide glve, 
which the author called gelatine or limbellucci glue and which was obtained from cuttings of dry, degreased and non-tanned hides. Nevertheless, parchment glue was a finer quality glue then hide glve.

The application method varied case by case. For example, in the case of cracked or powdery paint films, the glve should be applied with a brush and then ironed with a warm plate or with a burnisher. If weights had to be left for extended periods, paper should be interposed to prevent sticking. In these cases, therefore, the sole consolidation of the pictorial film was sufficient.

Instead, in the case of a localised serious flacking, a local facing had to be combined with the consolidating action, made with thin tissue paper (carta velina) and starch glue subsequently ironed interposing thick sheets of paper:

"If the humidity or the woodworm had damaged the priming and the painting, [...] it can be remedied by pouring under the swollen parts some parchment glue, making it penetrate by a light and gentle pressure of the fingers or the brush. [...] Once the glue has thickened, cover the glued parts with pieces of tissue paper of equal size, sticking them with starch paste: then pass over a warm plate, placing a sheet or two of strong and dry paper, to let the iron do not stop on moist sheets, but flow easily. In this way, the glue melts, and spreads under the swellings, consolidating them firmly. [...] After this operation, day by day remove the glued papers with water, and wash the painted surface, so that there is no trace of glue or starch. In the glue already mentioned, it will be good to mix a twelfth part of purified ox-gall, or candied sugar: in this way you will have it more elastic and less vitrified"28 (Forni 1866 cit. Bonsanti and Ciatti 2004).

If these 'swellings' were 'closed', in the case of a panel painting Forni suggested to cut the raised part, to apply a piece of paper or canvas with an unspecified adhesive, and to remove the fragment once the facing was dried. Then, some adhesive had to be applied on the back of the fragment to fix it in its original position. If the artwork was a canvas painting, the consolidation should be carried out from the back after applying a local facing on the most precarious portions of the paint film.

28 Translated from Forni 1866 cit. Bonsanti and Ciatti 2004: "Se l'umidità o il tarlo avessero danneggiato la imprimitura e il dipinto, [...] vi si rimedia, colando sotto le parti gonfiate della colletta calda di carta pecorina, facendola penetrare per mezzo d'una leggera e delicata pressione delle dita o del pennello. [...] Allorché la colla è rappresa, coprite le parti incollate con pezzetti di carta velina di ugual grandezza, attaccandoli con pasta d'amido: poi passatevi sopra una lastra tiepida, interponendovi un foglio o due di carta forte e asciutta, onde il ferro non si arresti su quegli umidi, ma vi scorra facilmente. In tal modo si fonde la colla sottoposta, e si spande sotto gli spanci o gonfiezze, consolidandole stabilmente. [...] Terminata questa operazione, giorno per giorno levate coll'acqua le carte incollate, e lavate la superficie dipinta, perché non ci resti traccia né di colla né di amido. Nella colletta già detta sarà bene mischiare una dodicesima parte di fiele depurato, o di zucchero candito: così l'avrete più elastica e meno vetrina". 
The facing of the whole painting was recommended only in the case of a lining of a painting in a bad state of conservation. The precise and concise indications on facing provided by Forni are as follows:

"To proceed with this operation, always start by facing the paint with paper or muslin to protect the artwork under restoration. [Once the lining has being applied and dried], the temporary facing is detached from the painting and it is checked whether one or the two canvases adheres well together."29 (Forni 1866 cit. Bonsanti and Ciatti 2004).

Local or total facing was done with a starch based adhesive. In the recipe book, Forni gave the recipe and the procedure necessary to obtain the flourpaste glue, which as he claims, could be easily replaced with that of starch or rice:

\begin{abstract}
"This glue is made by dissolving the flour with very little quantity of cold water to dilute it well; then hot water is gradually added until a light milk is obtained; in this way it can boil over the fireplace in less time; thus it does not thicken or burn; which can hardly be done by dissolving it with cold water: preparing it in a water bath avoids any inconvenience. [...] This can also be replaced by that of potatoes and rice."30 (Forni 1866 cit. Bonsanti and Ciatti 2004).
\end{abstract}

As it will be seen later, Secco Suardo was used to use a similar glve for facing. On the contrary, the temporary support used by the count from Bergamo was different. Forni used a carta velina (tissue paper). Reading a chapter of his manual dedicated to the papers to copy drawings, paintings and prints we understand that it is a very thin paper, similar to the Chinese papers on the market: "today the British, French and Italian paper mills make veline and emporetiche papers, like the Chinese, which are excellent at making perfect tracing papers"31 (Forni 1866 cit. Bonsanti and Ciatti 2004).

The term carta velina derives from the French papier vélin and the ancient French véel (calf), hence from the Latin vitellus. This word originally designated a type of very fine and extremely valuable parchment, obtained from the skin of

\footnotetext{
29 Translated from Forni 1866 cit. Bonsanti and Ciatti 2004: "Per procedere con questa operazione, s'incomincia sempre dal foderare la pittura colla carta o cola mussolina per garantire l'opera in riparazione. [...]. Asciutta la rintelatura, si stacca la fodera provvisoria dal dipinto e si guarda se l'una o l'altra tela aderiscono bene insieme".

30 Translated from Forni 1866 cit. Bonsanti and Ciatti 2004: "Questa colla si fa sciogliendo la farina con pochissima acqua fredda per bene stemprarla; poi se ne aggiunge a poco a poco della bollente finché riesca quasi un latte chiaro; in tal modo in minor tempo può bollire al fuoco; così non si addensa e non si abbrucia; il che difficilmente si può fare sciogliendola con dell'acqua fredda: preparandola a bagnomaria si evita ogni inconveniente. [...] A questa si può altresì sostituire quella di patate e di riso".

31 Translated from Forni 1866 cit. Bonsanti and Ciatti 2004: "Oggidì le cartiere inglesi, francesi e italiane, fanno delle carte veline o emporetiche sottilissime, quanto le cinesi, le quali sono ottime a far lucidi perfetti".
} 
dead born calves. The lemma was subsequently used to indicate a type of very thin and not-glved paper, whose whiteness and smoothness are similar to those of parchment. Furthermore, according to the Vocabolario etimologico della lingua italiana, the term emporetico refers to "a sort of paper, in which merchants wrap the goods and which is also used by chemists and pharmacists to filter liquids: which would somehow give reason to the different etymology suggested by em (en) and peiro, penetration beyond, passing away"32 (Panigiani 1937). It seems that these are thin and absorbent papers, therefore not glved, perhaps similar to the sugarina paper used in the Venetian context. This is confirmed by reading the Dizionario delle scienze naturali of 1840, where under the item 'filter' is written:

\begin{abstract}
"Paper filters are made with emporetica paper or sugante paper. Working on small quantities of liquids and wanting to collect all the liquid and all the solid matter without loss, it is possible to use filters of emporetica paper [...]. Sugante paper filters are generally used to filter large quantities of liquids."33 (Dizionario delle Scienze Naturali 1837).
\end{abstract}

From this description, it can be deduced that the emporetica paper is thinner and less resistant than the sugante one. Therefore,Forni used very thin papers.

An important consideration to make is that Forni's handbook is the only one in which there is a description of some alternative recipes for specific kinds of paintings. For instance, for the consolidation of the powdery grounds of oil paints on wood, he recommended using an adhesive more in line with the genre of such paints. The recipe is as follows:

\footnotetext{
"Prepare a composition of one part of cooked walnut or linseed oil, with four parts of turpentine; or a part of the first with three of mastic, melt to a boil [...]. The way to make penetrate one or the other of these materials into the ground underlying the painting is the same already indicated for tempera paintings, in chapter XXIV of this Part One."34 (Forni 1866 cit. Bonsanti and Ciatti 2004).
}

\footnotetext{
32 Translated from Panigiani 1937: "Una sorta di carta, in cui i mercanti involgono le merci e che serve pure ai chimici ed ai farmacisti per filtrare i liquidi: lo che darebbe in qualche modo ragione al diverso etimo suggerito da em (en) e peìro, penetro al di là, trapasso".

33 Translated from Dizionario delle Scienze Naturali 1837: "I filtri di carta si fanno con carta emporetica con carta sugante. Operando sopra piccole quantità di liquidi e volendo raccogliere senza perdita tutto il liquido e tutta la materia solida, si fa uso di filtri di carta emporetica [...]. I filtri di carta sugante sono adoprati in generale per filtrare grandi quantità di liquidi".

34 Translated from Forni 1866 cit. Bonsanti and Ciatti 2004: "Preparasi dunque una composizione di una parte d'olio cotto di noce o di lino, con quattro parti di trementina; ovvero una parte del primo con tre di mastice, scioltovi a bollore [...]. La maniera di far penetrare l'una o l'altra di queste materie nella imprimitura sottostante al dipinto, è la stessa già indicata per i quadri a tempera, nel capitolo XXIV di questa Parte Prima".
} 
A differentiation of methods based on the type of painting is also found with regard to the consolidation phase associated with the protection of the paintings. In fact, in the chapters dedicated to the transfer of oil paintings, Forni suggested two different methods as regards the preliminary stages for the transfer intervention. The system described for panel paintings is that described above, with leather glue and localized facing, with subsequent hot flattening. Regarding oil paintings on canvas ${ }^{35}$, however, the restorer prescribed to apply on the surface several layers of copaiba balm to consolidate, protect and probably make the front of the painting more hydrophobic. In the second part of the manual, Forni described this substance as an oily-resinous substance that is obtained from a leguminous plant from Brazil, with an appearance similar to that of turpentine. After repeated applications,

\begin{abstract}
"The entire surface is covered with velina sheets, which attach to the still fresh balm, and can be ironed with warm plates, interposing a strong paper in order to flatten the rough colour of the painting [...]. Once the flattening is complete, the sheets are removed by wetting them with turpentine: then with the cotton soaked in the same essence, the remaining balm is removed and the paint is dried with soft and clean cloths, in order to remove any resinous trace."36 (Forni 1866 cit. Bonsanti and Ciatti 2004).
\end{abstract}

Forni prescribed this different treatment probably because he thought the materials used were more compatible with an oil painting. Therefore, on the one hand they made the paint film hydrophobic and resistant to the subsequent transport phases. On the other hand, as wrote the restorer himself "this operation makes painting is more flexible and elastic, while it fixes the parts of the colour that threatened to detach from the canvas" 37 (Forni 1866 cit. Bonsanti and Ciatti 2004).

Differently from Forni, for Secco Suardo facing was considered an obligatory step, to be carried out before any structural intervention on a painting, except in very rare cases. This can be seen in the first pages of the chapter dedicated to the compensation of the tables, where the general procedures that should be followed are stated. So it begins paragraph $\S 4$ :

\footnotetext{
35 It has to be specified that for Forni it was possible to detach an oil paint on canvas only if some hydrophilic layer was present between the paint layer and the substrate, such as a gesso ground or a glve size. In other cases, it was better to proceed with lining.

36 Translated from Forni 1866 cit. Bonsanti and Ciatti 2004: "Si copre tutta la superficie con dei fogli velini, i quali attaccandosi al balsamo ancor fresco, permettono di stirarli con lastre tiepide, interponendo tra quelli e queste della carta volante e forte, onde spianare il colore scabroso del quadro [...]. Terminata la spianatura, si staccano i fogli bagnandoli coll'acqua ragia: quindi col cotone inzuppato nella stessa essenza si leva il balsamo rimasto e si rasciuga la pittura con pezze line morbide e pulite, onde sparisca totalmente ogni traccia resinosa".

37 Translated from Forni 1866 cit. Bonsanti and Ciatti 2004: "Questa operazione rende più pieghevole ed elastica la pittura, intanto che ferma le parti del colore che minacciavano di staccarsi dalla tela".
} 


\begin{abstract}
"As a general rule, before starting any operation, you will have to take precautions against small accidents, which, during your work, could spoil the painting, gluing one, and sometimes even two sheets of paper on top of the painting, in order to protect it. However, there are those cases that will be mentioned in due course, in which it is necessary to work on uncovered painting." ${ }^{8}$ (Secco-Suardo 1866 cit. in Secco-Suardo 2010).
\end{abstract}

The facing of Secco Suardo consisted of two phases. A first one in which a coat of a glve called colletta was applied, and a second in which a paper with starch glve was attached. However, the restorer indicated two procedures according to the state of conservation of the painting.

In the case there were no flaking portions, only a very light coat of colletta should be applied, which served to facilitate the removal of the paper after the intervention. In presence of a flaking phenomenon of the paint film, it was necessary to proceed with a real consolidation, applying by brush the colletta, diluted to be fluid and to penetrate into all the cracks. In the event that the detachments of the pictorial film appeared in the form of 'puffiness without openings', Secco Suardo prescribed to create a hole in the vesicles to facilitate the penetration of the glue, without resorting to the removal of the colour fragment as recommended by Forni.

At this point, it was possible to proceed with facing, made with a not too strong glued paper, using the least possible number of sheets to avoid conjunctions. Before application on the painting, the paper had to be wetted on both sides and, once it had extended and smoothed out, starch glue was applied on it, before positioning the paper over the painting, applying the pressure necessary to let the air out starting from the centre. If trapped air remained, the bubbles were pricked with a needle. In the case of flaking paintings, the surface was ironed interposing sheets of strong paper. If the painting presents thick brushstrokes woollen cloths were interposed.

The removal of the facing was made wetting the paper with warm water. Then the surface was cleaned with a soft sponge to remove all the impurities, and then dried with a cloth, to prevent moisture from penetrating the cracks and raising the colour again.

The colletta recipe provided by Secco Suardo is incredibly similar to that of the colletta romana, used at the ICR Institute (Italy) since the early years of its

\footnotetext{
38 Translated from Secco-Suardo 1866 cit. in Secco-Suardo 2010: "Per regola generale, prima di dar mano a qualsivoglia operazione, dovrai premunirti contro i piccoli accidenti, che, durante il tuo lavoro, potrebbero deturpare il dipinto, incollando uno, e talvolta anche due fogli di carta sopra la pittura, acciò la difendano. Pur tuttavia ci sono quei casi che verranno a tempo debito accennati, nei quali è necessario lavorare a dipinto scoperto".
} 
foundation. In the recipe book, under the item "N. 8 Colletta for the consolidation of the painting", Secco Suardo indicated materials, quantities and procedures to follow:

"Take 12 parts of that glve in transparent laminates, which is improperly called fish glve: while it is nothing more than a strong glve of more chosen quality, which is used by cooks to make jellies, and let it dissolve in the manner indicated above in 12 parts of 'water."39 (transl. from Secco-Suardo 1866 cit. in Secco-Suardo 2010).

Once swollen, the glue is melted on the fire by adding four parts of molasses and, once removed from the heat, one part of ox-gall. To store the glve, one part of white vinegar was added. According to the author, this glve was very precious for restoration because thanks to the bovine ox-gall it adhered to any surface, even greasy, and thanks to the molasses it remained flexible. However, it was better not to exceed the recommended quantity of vinegar or ox-gall because an excess would have made the glve too fragile and hard. The author also provided a variation to the colletta, inspired by a recipe provided by Merimée, with the addition of some walnut oil was added (recipe "N. 9 Colletta with oil").

However, the facing formulated by Secco Suardo has an additional function, common to almost all facing techniques. In fact, due to the application of an adhesive dissolved in a solvent and the presence of a layer that acts as a support for the solution, there is a cleaning action that is not always easily manageable. This effect is enhanced if an adhesive similar to the colletta just described is used. Secco Suardo was aware of this collateral effect and used it to its advantage:

"Therefore, when you have to clean a painting on canvas, which was not lined yet, before start working examine it carefully, and if you see some part that tends in any way to get up, or even the strong cracks in the colour produced by its contraction when hardening, or some breaking, or even just some little wrinkle or dent, detached it with great diligence from the stretcher, clean it with a brush or sponge, apply the colletta, then the paper, in the known way. And go over it with warm iron to ensure and smooth out the colour, and put it back on the frame. With this operation you will have obtained two advantages. The first is that having made the colour firm and the surface flat, you can work with greater freedom, since you can compress at any point uniformly: and the second is that when you remove the paper you will find the painting much less dirt than before, because the colletta, containing bovine gall, honey or molasses, it will have softened the filth, which will be removed together with the starch glve and the colletta residues. Quite often

\footnotetext{
39 Translated from Secco-Suardo 1866 cit. in Secco-Suardo 2010: "Prendi parti 12 di quella colla in laminette trasparenti, che impropriamente chiamasi colla di pesce: mentre altro non è che una colla forte di qualità più scelta, la quale serve ai cuochi per far gelatine, e falla disciogliere nel modo suindicato in 12 parti d'acqua".
} 
this simple operation is enough to clean the picture sufficiently." 40 (Secco-Suardo 1866 cit. in Secco-Suardo 2010).

The starch paste used for facing is very similar to that of Forni. However, the paper used by Secco Suardo is more similar to that used by Horsin-Dèon. The restorer used a thick paper, which had to be wetted and needed time to dilate and to be later soaked with the adhesive, and only then positioned on the painting and rubbed. It can be deduced that it was a sufficiently resistant paper, since it had to withstand large amounts of water, handlings and mechanical actions. In addition, it was a paper so thick and compact that it did not allow the air to pass through it, in fact it had to be pierced with a pin. Once applied it did not allow to see the painting below. In fact, in paragraph §23, in which Secco Suardo explained how to bring the disjointed boards together, Secco Suardo recommended to rectify the boards before applying the facing, because then the paper would have prevent from seeing the painting.

In the manual it is possible to find information regarding the protection of the front related to lining, an operation that according to Secco Suardo almost always brings advantages for the artwork. It is not clear whether the protection on the front should be applied in all cases in which a painting is lined, or only in the case of particular paintings, such as those made on moisture-sensitive canvases:

\begin{abstract}
"Verifying therefore that you really have to deal with the dreaded case of a canvas that contracts, clean the paint with a slightly damp sponge, and dry it immediately, then apply a good coat of somewhat dense colletta, and overlay the usual paper if the painting it is small, the gauze if it is large." 41 (Secco-Suardo 1866 cit. in SeccoSuardo 2010).
\end{abstract}

\footnotetext{
40 Translated from Secco-Suardo 1866 cit. in Secco-Suardo 2010: "Tu dunque allorchè devi pulire un dipinto su tela, che non fu foderato, prima di accingerti all'opera esaminalo attentamente, e se vi scorgi qualche parte che tenda in qualsivoglia modo ad alzarsi, od anche delle forti fenditure di colore prodotte dalla sua contrazione nell'indurirsi, ovvero delle spezzature, od anche solo delle pieghe alquanto risentite o delle ammaccature, staccato con molta diligenza dal telaio, puliscilo con la spazzola o la spugna, applicavi la colletta, poi la carta, nel modo noto. E ripassalo col ferro tiepido onde assicurare ed appianare il colore, e rimettilo poscia sul telaio. Con questa operazione tu avrai ottenuto due vantaggi. Il primo è che avendo reso fermo il colore e piana la superficie, puoi lavorare con maggiore libertà, poiché hai modo di comprimere egualmente in ogni punto: ed il secondo che al togliersi della carta troverai il dipinto assai meno lordo di prima, perché la colletta, contenendo fiele bovino, miele o melassa, avrà ammollito il sudiciume, il quale a detergersi il dipinto dalla colla d'amido e dagli avanzi della colletta verrà asportato insieme con essa. Assai volte questa semplice operazione basta a pulire sufficientemente il quadro".

41 Translated from Secco-Suardo 1866 cit. in Secco-Suardo 2010: "Verificando dunque che tu abbia essere veramente il caso temuto d'una tela che si contrae, pulisci la pittura con una spugna appena umida, e rasciuga subito, quindi applicavi una buona mano di colletta alquanto densa, e soprapponivi la solita carta se il quadro è piccolo, la mussolina se è grande".
} 
When paper was used, it was always advisable to stretch the canvas until everything was dried. The restorer was aware of the different behaviour of materials:

\begin{abstract}
"While the paper, drying out freely, could roll up the canvas, you have nothing to fear from the muslin for the reason already given, that during drying papers shrink, and fabrics dilate." 42 (Secco-Suardo 1866 cit. in Secco-Suardo 2010).
\end{abstract}

This front protection was used not only for lining, but also to protect the paint film during the cleaning of the back. Whit a stubborn dirt, Secco Suardo suggested to apply a cotton fabric, stronger than the gauze, to prevent the displacement of the colour during the cleaning operation.

Regarding to lining, the application of paper or gauze had an additional function, because it served as a protective barrier during the ironing phase. Since in this case the ironing was prolonged, it was always better to have a layer that protected the paint film and that could be constantly humidified to facilitate the reactivation of the adhesives. Ironing was performed first from the back and then from the front, wetting the paper when it was too dry. Ironing should only be carried out after the application of the lining canvas and it was not strictly connected with the application of the colletta and paper. In fact, the author criticised the French habit of repeatedly ironing the painting before proceeding with the lining, making it similar to "trays to bring cups and glasses" 43 (Secco-Suardo 1866 cit. in Secco-Suardo 2010). Preventive ironing should have been performed only when strictly necessary and it should have never been excessive.

Contrary to what was said in paragraph $\S 4$ cited above, in its manual Secco Suardo did not provide alternatives to the consolidation and facing system with colletta and starch glue. The 'alternatives' proposed by him are limited to small measures to reduce the supply of humidity. However, he did not propose the use of alternative materials as Forni did. In addition, unlike Forni, Secco Suardo rarely renounced to face a work of art, despite he was aware that some types of paintings, such as oil-painted parchments or paintings on taffeta glued on the glass, were very sensitive to humidity. In these cases, he rather indicated small precautions to reduce the risks. For example, in the case of detachment of the oil-painted parchments from their stretcher, he suggested to dry the paper as much as possible before applying it on the painting and to use a colletta added with honey to reduce the supply of moisture. Even for the lining

\footnotetext{
42 Translated from Secco-Suardo 1866 cit. in Secco-Suardo 2010: "Nel mentre la carta, seccandosi liberamente, potrebbe far arrotolare la tela, nulla hai da temere dalla mussolina per la già addotta ragione, che nel seccare le carte si restringono, ed i tessuti si dilatano".

43 Translated from Secco-Suardo 1866 cit. in Secco-Suardo 2010: "a de' vassoj a portar chicchere e bicchieri".
} 
of paintings made on a shadow or red earth based ground, he did not give up on carrying out the preliminary consolidation and protection phases. In this case, a denser colletta coat was applied and the paper was replaced with the gauze, moistening it as less as possible during ironing. Once the lining was finished, any remaining flake could be consolidated with the localised application of colletta and with the subsequent ironing, interposing a sheet of thin paper.

The only case in which Secco Suardo desisted from face the painting before lining is that of tempera paintings:

\begin{abstract}
"Even them are lined like the others, except that neither the colletta nor the paper can be applied to them, and that the caution I have pointed out for sensitive grounds should be kept in mind in order to avoid excess of moist. Do not forget to lay thin sheets of paper on the table you want to work on."44 (Secco-Suardo 1866 cit. in Secco-Suardo 2010).
\end{abstract}

In the $19^{\text {th }}$ century, alternative methods which do not involve the use of aqueous substances had already been tested, and it is assumed that Secco Suardo was aware of these methods, given his numerous travels. It is therefore probable that he did not deem them suitable or that he preferred to use a more well-known technique. However, it is surprising he did not mentioned alternative techniques, explaining the reasons of his preferences, as he did in other contexts.

\title{
1.2.5. Conservation in Spain. The Example of the Prado Museum and the treatises of Vicente Poleró y Toledo
}

In Spain, already in the $18^{\text {th }}$ century artists were no more considered simple artisans, but public and professional figures. This change in attitude led to the formation of the official academies, first of all the Academia de Bellas Arte de San Fernando in 1752, followed by the academy of San Carlos in Valencia (1768) and San Luis in Zaragoza (1792). However, it would have been necessary to wait the first half of the following century for the releasing of the figure of the restorer from that of the artist. The definition of the professional figure within the Spanish institutional environment was subject to the interrelation of multiple

\footnotetext{
44 Translated from Secco-Suardo 1866 cit. in Secco-Suardo 2010: "Esse pure si foderano come le altre, salvo che ad esse non si può applicare né la colletta, né la carta, e che si denno aver presenti la cautele da me additate per le mestiche pericolose allo scopo di evitare l'eccesso di umido. Non dimenticare però di stendere dei fogli di carta sottile sul tavolo sopra il quale vuoi lavorare".
} 
socio-historical elements, decisive in promoting and recognising the profile of the restorer.

Probably what most influenced this change was the spread of romantic and nationalist ideals, which influenced the history of all European states. The development of the National States was based on the construction of an own cultural identity through the recreation of a common past, which was used to legitimize political projects. In this century, Madrid, as the capital of the Spanish State, became a nerve centre. Here they were concentrated the main institutions for the supervision of national conservation and restoration activities. In this sense, Madrid centralism justified the prominence of the Real Academia de Bellas Artes de San Fernando as the main control body for restorations and heritage.

A very important event that marked the future of restoration in Spain was the creation in 1827 of the Sala de Restauración inside the then Real Museo de Pintura y Escultura (Museo del Prado), which had been founded in 1819 with the aim of bringing together all the valuable artworks of all the country that were not adequately preserved. In the first years after the opening of the workshop, two inspectors (the camera painters Vicente López and Juan Antonio Rivera) had to supervise, control and advice three restorers (José Bueno, Victoriano Gómez and Pedro Bueno) with different functions. It was the first Spanish institutional centre that promoted a work structure in the workshop, proposing an organization and hierarchy by categories (Vicente-Rabanaque, Santamarina-Campos, and Santamarina-Campos 2011). In 1831, two guidelines defined functions and powers of each professional: the first and second restorer were responsible for easel paintings transfer, cleaning and reintegration, while the third one was responsible for linings.

Under the direction of José de Madrazo (1838-1857), the number of restorers was increased and modern criteria and techniques were introduced, such as the replacement of oil retouching with the varnish ones, or some changes in the attitude of cleaning to preserve the patina and glazes, although the rough and invasive repaints used to be removed. As well as Madrazo recommended the use of linings to strengthen the fabric supports, this technique was applied profusely even as a preventive measure, with traditional glve-paste adhesives. Transpositions were restricted to extreme cases $^{45}$ (Macarron-Miguel 2018).

\footnotetext{
${ }^{45}$ According to Giuseppina Perusini, it is possible that these methods had come to Spain through the Neapolitan restorer Manuel Napoli who studied in Florence and then moved to Madrid in 1802, where he worked until his death in 1831 as restorer of the royal museums of Madrid. It is possible that José Madrazo himself, who according to Ana Macarrón, is responsible for the introduction of paint colours, learned this method from Manuel Napoli (Perusini cit. in Signorini 2010).
} 
The Sala de Restauración had to deal also with the conservation of the paintings preserved in the other royal buildings of the town, such as the works of the Real Sitio de San Lorenzo de El Escorial. For the restoration campaign started in 1840 and continued for 16 years under the direction of José de Madrazo, a selected group of restorers had to move to the monastery to restore the artworks in situ during summertime, while some paintings were carried to the workshop to continue the work in autumn. During this period many of the painting of the monastery were lined and cleaned.

Under the direction of Federico de Madrazo (1860-1868 and 1881-1894), José's son, there was an intense restoration activity. There are various reports of lined and restored paintings in 1863, such as Nymphs and Satyrs, The rape of Proserpine, Goddess Flora and The Three Graces by Rubens, or also Charles III by Mengs, and View of Tivoli attributed to Jan Both (Macarrón-Miguel 2013). Under the direction of Federico de Madrazo, among the restorers who worked in the workshop there was the conservator, academic and painter Vicente Poleró y Toledo. As well as his European colleagues Köster, Horsin-Déon and Forni who worked in public museums, Poleró is remembered as the writer of some the most important restoration treatises of the $19^{\text {th }}$ century. The first one, The Art of Restoration. Observations regarding the restoration of paintings, was published for the first time in 1853 and, in a second edition, in 1855. The second, titled the Treatise on Painting in general and published in 1866, is more interesting for this study because it contains information on the lining of canvas paintings, but also in the transfer of panel paintings, which had not been included in the previous manual. Poleró also gathered his viewpoint on the acquisitions and state of conservation of the Prado building and artworks in the pamphlet Brief observations on the utility and convenience of bringing together the two Painting Museums of Madrid46, and on the true state of conservation of the Prado Museum paintings, published in 1868.

The first manual, The Art of Restoration, a part of a brief introduction on the method employed in Spain before the beginning of the 19th century, was focused on the practical aspects of cleaning and retouching. The lack of information about the history and theory of conservation present in other European manuals is probably due to the fact that the handbook was addressed to colleagues and experts, and not to collectors and amateurs.

Only few lines were addressed to lining in the first chapter (Articulo 1. Limpieza de los lienzos por medio del agua), in which there are no indication

${ }^{46}$ He referred to the Museo del Prado and the Museo de la Trinidad. 
on the techniques or materials used, but a general consideration on the advantages of recurring to this operation:

"The systems which are available today for the conservation of paintings are a positive advance, a step of immense importance and extremely usefulness, given in the career of art. [...] the canvases, no matter how deteriorated they are, however vicious the position they have acquired, either as a result of the years or as a result of the bad manufacturing of the old stretchers, recover their primitive consistency in favour of the new fabric that adheres them [when they are lined]; and saving the flaking colour by this same method, the colours are settled for an indefinite period without which would have disappeared completely. Therefore, whether or not a canvas has to be restored, at least it is necessary to make a lining to prevent its natural flaws from causing an undeserved ruin by working on it from day to day with increasing influence." 47 (Poleró y Toledo 1853 cit. in Macarrón-Miguel 2018).

This statement confirms the massive use of the lining already attested by documentary sources concerning the activity of the Prado restoration laboratory. We agree with Giuseppina Perusini (2010) regarding the fact that Poleró did not consider the lining an intervention of its competence, which would justify the very brief description made. In fact, as previously stated, until the end of the $19^{\text {th }}$ century the restoration of the support was often entrusted to a lining specialist, and this division of the work is confirmed by the aforementioned regulation of 1831. However, in the subsequent Treatise on Painting in general of 1866, Poleró deepened the topic giving interesting information on materials and techniques, but also on the preliminary operations of consolidation.

In this second treatise, Poleró's sensitivity for the preservation of the artwork original features emerged more clearly. In fact, it is clear that for the author the lining was an important operation, which had to be performed in the best possible way without causing damage to the work:

"Lining [...] requires a particular care, a special touch, which can only be achieved after a long practice. This preliminary operation is so important, indispensable and of such recognised influence on the paintings, that it can well

\footnotetext{
47 Translated from Poleró y Toledo 1853 cit. in Macarrón-Miguel 2018: "Los medios de que hoy se dispone para proveer a la conservación de las pinturas son un adelanto positivo, un paso de inmensa trascendencia y de utilidad suma, dado en la carrera del arte. [...] los lienzos, por muy deteriorados que se encuentren, por viciosa que sea la posición que hayan adquirido, bien a impulso de los años, bien a resultas de la mala fabricación de los antiguos bastidores, recobran su primitiva consistencia a favor de la nueva tela que se los adhiere; y asegurándose por este mismo medio el color ya levantado, quedan asentadas por un plazo indefinido las tintas que a falta de auxilio tan oportuno vendrían a desaparecer totalmente. Por eso pues, haya o no de restaurarse un lienzo, es forzoso a lo menos disponer su forración si se quiere evitar que sus desperfectos naturales, obrando sobre él de día en día con creciente influencia, le arrastren por último a una inmerecida ruina".
} 
be assured that the success of the work entrusted to the restoration artist depends on the on the success of this operation, as well as the perpetuity of the paintings." 48 (Poleró y Toledo 1866 cit. in Macarrón-Miguel 2018).

For Poleró, the intervention had to be adapted to the type of painting, for example to the materiality of the brush strokes, or to the type of ground or canvas (thicker and coarser or thinner). It had great importance the ability of the restorer to understand how and how much to iron the painting, to make sure that the new canvas adhered well to the old one, but without damaging the work.

The close attention for the type of painting would have been reiterated by Poleró in his pamphlet Brief observations of 1868, in which he defended the work of the Prado restoration laboratory from unfair criticisms addressed to the state of conservation of the paintings preserved in it. In fact, he stated that:

"To demand that a canvas [...] remain unscathed, with all the brilliance and beauty of its original colour and in all its purity and integrity [...] would be a reckless and the height of nonsense." 49 (Poleró 1868 cit. in Maccarón-Miguel 2018).

He defended the lining technique adopted at the Prado laboratory, which was respectful of the materiality of the work, and, like Secco Suardo, he criticised the prolonged ironing done in the restoration workshops of the French museums, which made the surface too smooth and shiny:

\begin{abstract}
"The disadvantages of this system are obvious, and they highlight the goodness of the procedure used here as the most brilliant and satisfactory. At the same time that our paintings present the imprint of the brush and the thickness of the colour that distinguishes them, that keeps whole, pure and respected, being able to serve as a north in all occasions to find it out the artist who did it, there, on the contrary, disappears, crushed under the influence of the roller or the plate, therefore remaining in similar conditions the picture of a shy and delicate execution and that other of opposite style, frank and determined. Whereas in other Museums all the paintings seem to present the same aspect as a consequence of the lining and the thick and yellowish varnish that covers them,
\end{abstract}

\footnotetext{
48 Translated from Poleró y Toledo 1866 cit. in Macarrón-Miguel 2018: "La forración [...] requiere un particular esmero, un tacto especial, que sólo llega a conseguirse a merced de una larga práctica. Tan importante es este preliminar, indispensable y de tan reconocida influencia en los cuadros, que bien puede asegurarse que de su buena ejecución depende el éxito de los trabajos encomendados al artista restaurador, como también a la perpetuidad de las pinturas".

49 Translated from Poleró 1868 cit. in Maccarón-Miguel 2018: "Exigir que un lienzo [...] permanezca incólume, con todo el brillo y hermosura de su color primero y en toda su pureza e integridad [...] sería una verdadera temeridad y el colmo de la insensatez".
} 
in ours the authors reveal themselves distinctly." 50 (Poleró 1868 cit. in MacarrónMiguel 2018).

Going back to the analysis of the 1866 manual, after having stated the precautions to be taken before lining a painting, the author started to list the tools necessary and described the preparation of a glve-paste based on flour, honey, garlic, glue and linseed oil, describing the preparation process in detail. Poleró then went on illustrating carefully the steps to follow to make the lining. Unlike other manuals, the author did not prescribe to face the painting before removing the canvas from its stretcher. If there were cuts, these would have been joined with the application of paper strips on the back. The holes of the support would instead have been compensated with inserts of an ancient canvas similar to the original.

Once the new canvas, "of equal and compact fabric, [of] raw linen of pure and brown coloured thread"51 (Poleró 1866 cit. in Macarrón-Miguel 2018)had been tensioned on an interim stretcher, the glve-paste could be applied on both canvases. Once the canvases were joined, the painting had to be turned with the back facing upwards and a grinder was used to exert a uniform pressure and to let the excess of glve-paste come out. The painting was left to air dry for some hours and then ironed from the front of the painting with an iron "no more than temperate" 52 (Poleró 1866 cit. in Macarrón-Miguel 2018):

"In this delicate operation, the iron must be passed very quickly and forcefully, lifting and lowering it continuously in different directions, interposing a thick sheet of paper moistened with walnut oil, which will be moved at every stroke throughout all the length of the painting, until it is completely equal and leveled."53 (Poleró 1866 cit. in Macarrón-Miguel 2018).

Once this phase was completed with all possible precautions, the painting could be tensioned again on a stretcher with wooden keys, in order to be easily

\footnotetext{
50 Translated from Poleró 1868 cit. in Maccarón-Miguel 2018: "Las desventajas de este sistema saltan a la vista y ponen de relieve la bondad del procedimiento aquí empleado con éxito como el más brillante y satisfactorio. Al paso que nuestros cuadros presentan la huella del pincel y el grueso del color que los distingue, entero, puro y respetado, pudiendo servir de norte en todas ocasiones para averiguar el artista que lo hizo, allí, por el contrario, desaparece aplastado bajo el influjo del rodillo o la plancha, quedando por consiguiente en parecidas condiciones el cuadro de una ejecución tímida y deli cada y aquel otro de estilo opuesto, por la manera de hacer franca y decidida. Mientras que en otros Museos todos los cuadros parecen presentar un mismo aspecto a consecuencia de la forración y del grueso y amarillento barniz que los cubre, en el nuestro se revelan distintamente los autores".

51 Translated from Poleró 1866 cit. in Macarrón-Miguel 2018: "de tejido igual y compacto [de] lienzo crudo de hilo puro y moreno de color".

52 Translated from Poleró 1866 cit. in Macarrón-Miguel 2018: "no [...] más que templada".

53 Translated from Poleró 1866 cit. in Macarrón-Miguel 2018: "En esta delicada operación la plancha ha de llevarse con mucha rapidez y fuerza, levantándola y bajándola continuamente en direcciones distintas, interponiendo un medio pliego de papel grueso humedecido con aceite de nueces, el que será movido a cada golpe en toda la extensión del cuadro, hasta que quede del todo bien igual y nivelado".
} 
retensioned in case of need. Poleró's description was very detailed and precise. It can therefore be almost certain that the absence of a description of a facing is not attributable to some lack, but to the fact that for Poleró, and therefore probably for the restorers active at the Prado Museum, it was sufficient to insert a sheet of oiled paper during ironing to protect the painting.

What was subsequently specified for tempera paintings is a confirmation of how wrong it would be to hypothesize that the description of the facing process had been omitted in the illustration of the lining process. The solution proposed by Poleró was moreover an original solution, which was not present in any other manual. In fact, in the case of the lining of tempera paintings, apart from acting with the utmost accuracy to avoid colour loss, it was necessary to protect the paint surface with a sheet of coarse paper, glved only along the edges:

"[The surface] should be covered with a thick paper, adhered to the ends of the painting, so that it does not suffer deterioration or stain during the lining operations."54 (Poleró 1866 cit. in Macarrón-Miguel 2018).

The section of the manual related to lining ended with some indications on the preventive consolidation of the colour. The description of the consolidation is interesting, because it demonstrates a certain sensitivity of the restorer towards the work of art, the same sensitivity shown by Forni. In fact, Poleró prescribed a punctual consolidation, made:

"Introducing a brush underneath [the flaking portions], impregnated with glue with honey, and then passing over the tip of a warm plate, which would help the swollen parts to yield, going back to their original position. The tip of a thick needle, making small fissures in the colour, will serve to introduce the aforementioned honey-glue."55 (Poleró 1866 cit. in Macarrón-Miguel 2018).

However, unlike Forni, according to Poleró the consolidation had to be carried out in almost all cases, due to the type of deterioration of the painting or the execution technique, to prevent further detachments during the application of the paste glve in the subsequent operation of lining.

\footnotetext{
54 Translated from Poleró 1866 cit. in Macarrón-Miguel 2018: "[La superficie] debe cubrirse con un papel grueso, adherido a los extremos del cuadro, para que éste no sufra deterioro o se manche durante las operaciones del forrado".

55 Translated from Poleró 1866 cit. in Macarrón-Miguel 2018: "Introduciendo una brocha por debajo [de la película despegada] impregnada de cola con miel, pasando seguidamente por encima la punta de una plancha templada, con cuyo auxilio irán cediendo las partes abolsadas, viniendo á ocupar su primera posición. El punzón o una aguja gruesa, haciendo pequeñas cisuras en el color, servirá para introducir la antes indicada cola-miel".
} 


\subsection{The 20th Century between WARS AND teChNOlOGical PROGRESS}

The $20^{\text {th }}$ century was a complex period of changes, including in the field of restoration, on a global level. The first half of the twentieth century was a flourishing period from the point of view of the development of new theories. On one hand, the ideals that would have led to the development of the aesthetic theories of the mid-twentieth century began to be pursued. On the other hand, the link between conservation and science began to become ever closer. In 1930, the International Museum Office (IMO, today known as ICOM) organised the International Conference in Rome for the study of scientific methods for the examination and preservation of works of art (Murphy 2016). It was therefore created a committee of experts to draft the Manual for the conservation and restoration of the paintings: five art historians, five restorers, two chemists and a physicist collaborated for the first time (laccarino-Idelson 2011). In the same decade, the first hot table was invented in England, consisting of heated slate slabs (Ackroyd 2002). In Italy, important restorations were carried out, such as that of the upper basilica of Assisi, which started in 1938. The foundation of the Istituto Centrale del Restauro (ICR), recently renamed Istituto Superiore per la conservazione e il Restauro ISCR) dated back to the same years.

At the same time, the great and sometimes disastrous events of the first half of the twentieth century brought to the fore the importance of the preservation of cultural heritage, seen as an identity symbol of certain cultures and nations as early as the eighteenth and nineteenth centuries. The war conflicts and the new strategy of 'total war' experienced during the Spanish civil war and then perpetuated in other European countries during the Second World War, endangered the entire symbolic heritage not only of individual nations, but of all Western culture. Following those conflicts, the first laws for the protection of heritage at global level were sanctioned (Roerich Pact 1935; Hague Convention 1954). On the other hand, such emergencies highlighted the importance of professional figures linked to the protection of cultural heritage, including that of the restorer. During the wars, they carried out heroic actions to safeguard the heritage in situations of extreme emergency. The serious danger run by the artistic patrimony with the Second World War and the scarcity of means and possibilities in the early 1940s, led to focus mainly on the most urgent problems, such as emptying museums by bringing all the paintings to safe places and protect immovable works (Ciatti 2009). 
In this regard, a great example was given a few years earlier by Spain during the Civil War. In Spain, as in other countries, a great progress had been made in the museum sector in the early decades of the $20^{\text {th }}$ century. The incorporation of scientific laboratories that could support the conservation and restoration work carried out in the various museums had been great news. All these changes led to an increase in the demand for specialised personnel, who was hired through the public competition system. Therefore, the figure of the restorer was a consolidated professional identity. The advent of the second Spanish republic in 1931, with the entry into force of the republican constitution which recognised that patrimony was a social good (Art. 45), and with a series of competitions that promoted the idea of restorers engaged in state centers, contributed to the development of modern restoration.

With the coup d'état of the 17 July 1936 and the outbreak of the civil war (19361939) there was a sudden block in the development of the restoration sector, as well as in all areas. The war would last for years and follow completely new dynamics with a disastrous impact. The war was no longer fought by armies in the open field as it happened in the $19^{\text {th }}$ century, and no longer only in trenches as it happened during the First World War. This was the first 'total war', in which the civilian population turned into a military target, through the systematic bombardment of population centers. Examples are the bombings of Madrid (1936), Barcelona (1937) and the case of Guernica (1937), which became internationally famous, also thanks to Picasso's painting presented at the international exhibition in Paris (1937) in the pavilion of the Spanish republic as a denunciation of what was happening in the country. The city was bombed intensively for about three hours and was almost razed to the ground, and it is estimated that around three hundred people died. This war strategy made necessary to build underground air raid shelters to protect the civilian population.

During those years, the eyes of the whole world were focused on Spain, also because the civil war actually represented a testing ground for what would have been occurred throughout Europe during the imminent Second World War. By force of circumstances, Spain also represented a valid example in this period regarding the highly effective and modern preventive measures and strategies for the restoration and protection of the heritage that were put in place in that situation of extreme emergency. The modernity of these actions is explained by the development that Heritage had acquired in the republican legislation of 1931, which recognised, for the first time, its social ownership. This fact allowed to advance towards a consideration that demanded the participation and involvement of society in the conservation and transmission of a collective Heritage (Vicente-Rabanaque 2013). 
In particular, the argumentation will be focused on the mobile heritage rescue operations that were carried out in Madrid. In fact, in Madrid, as well as in other cities and countries where the coup did not triumph, the assault and fire of churches and other monastic complexes by independent rebel groups led to the destruction of numerous ecclesiastical goods and Religious symbols. It was therefore necessary to confiscate and close the main religious buildings, in order to preserve them from further destruction. In the first months of the conflict, propaganda campaigns were launched to raise the awareness of the population for the importance of protecting the national artistic heritage. At the same time, the movable assets contained in them were brought together in different buildings, such as the Archaeological Museum, the church of San Francisco el Grande, and the Museum of Modern Art. Among these was also the Prado Museum, whose officials played a fundamental role in safeguarding the collections of the mobile heritage museum. In fact, after the museum closed on the 30th of August 1936, the museum's restorers worked hard in two distinct directions. On the one hand, they took care of carrying out the appropriate maintenance and restoration operations on the works of the museum and on those left there in storage. On the other hand, they carried out the necessary operations to prepare the works for what would have turned into a long exodus of a large part of the museum's collections. In fact, during the whole civil war period the works would have been moved first from Madrid to Valencia, then transported to Catalonia, and finally to the League of Nations in Geneva. From here, some of the most famous works were exhibited in the exhibition "Les Chefs d'oeuvre du Musée du Prado", finally returning to Madrid on the $9^{\text {th }}$ of September 1939. The decision to evacuate the best works housed in the Prado Museum was not alien to political-economic interests: in addition to conservation-related issues, this prevented much of the National Heritage from being in the custody of the enemy camp.

The director Sánchez Cantón and the other museum officials opposed to the transport of works until the end, especially the most important and large ones, and particularly those that had a precarious state of conservation and were very sensitive to thermo-hygrometric changes. In order to prevent or delay the delivery of some works that would have been heavily affected by transport, they tried several times to delay shipments using reports on the state of conservation of the works, which today represent a precious testimony. Sometimes they delayed the location of the paintings, subjecting them to restoration treatments to prevent, at least for the moment, the paintings from traveling. Thus, they were able to avoid the departure of Fra Angélico's Annunciation or Rafael's Christ falls on the Way to Calvary, for example (Alonso-Alonso 2009). 
Despite the attempts made, transportation was inevitable for most of the works, especially following the escalation of the conflict and after the Prado Museum was bombed on the $6^{\text {th }}$ of November 1936. The first works were transported between the $7^{\text {th }}$ and the $11^{\text {th }}$ of December, without the mediation of the Committee for the Artistic Treasury and by an unqualified staff ${ }^{56}$. After the controversy and problems that prompted this choice, the Committee was in charge of supervising the operation and assessing what works it was advisable not to transfer according to the professional criteria of the museum's restorers and managers. The works continued to be transported in several shifts, until the $2^{\text {nd }}$ of January 1939. Only 56 works never left the museum.

Since it was directly responsible for the transfer of the works, the Committee showed great respect and concern for the works of art, using the help of the Prado restorers. In fact, it was they who had the technical knowledge of both the pictures and the preventive conservation procedures and their consequences for subsequent restoration interventions. When the departure was already inevitable, they prepared the most delicate works so that they would not suffer further deterioration. In addition to the punctual consolidations of the pictorial layer of some works, some of the most fragile pictures had to be specially conditioned, that means they had to be faced with engasados and eventually removed from the stretchers and rolled into curlers (Alonso-Alonso 2009). According to Alonso-Alonso, the so-called engasados were facings made with a natural silk gauze adhered with an adhesive based on animal glue added with honey to bring elasticity and flexibility to the protection.

From the reports compiled on this occasion, a great sensitivity emerges for the characteristics of the constitutive materials of the works and the conservation problems related to environmental conditions, with an extremely modern approach. In a report written on behalf of the Committee for the Artistic Treasury on the $2^{\text {nd }}$ of January 1937, it was advised not to carry the panel paintings, due to the risks that environmental changes and handling during the trip entail for wooden supports. Regarding paintings on canvas, the ones that needed to be faced due to the fragile state in which they were, but at the same time they warned of the possible consequences of this treatment. An exemplary case is that of The Spinners by Velazquez. The report reads:

56 On the 7th of December 1936, María Teresa León visited the museum, belonging to the Alliance of Antifascist Intellectuals, as responsible for selecting and preparing the dozens of paintings and centenarians of drawings by Goya that had to travel to Valencia. Apparently, this ignored the recommendations of the museum staff and decided to make the transport without the packaging to speed up the operation, placing only paddings on the corners of the canvases. Two days later, in similar conditions, another 30 paintings were transported, including the Equestrian Portrait of Carlos V de Tiziano and Las Meninas de Velázquez. This way of proceeding motivated the complaints issued by Alejandro Ferrant and José María Rodríguez Cano, members of the Artistic Treasury Board, who obtained the removal of León. 


\begin{abstract}
"Due to defects in the lining dating back to years ago, it presents such an evident danger of deterioration that, in our opinion, it should not be moved [...]. It can be said that there is no $\mathrm{cm}^{2}$ free of cracks or folds in the paint, due to contractions of the fabric. The paint layer appears detached, and it would come off as a result of the vibrations [during the transport]. It should be faced with engasado but in this case, if adopted, this measure would be highly questionable since it would offer a problematic future for a fundamental work in the history of art [...]. It cannot be faced due to the change it would produce during the subsequent cleaning. It has been wrapped in a layer of wadding fabric for the transfer." 57 (Maccarrón-Serrano, Macarrón-Miguel, and Macarrón-Larrumbe 2009).
\end{abstract}

They also indicated the pictures that in the opinion of the Committee for the Artistic Treasury should not have traveled, explaining their reasons. At the end of the writing, it was indicated that the Philip IV on Horseback by Velázquez had been faced with engasado for deliverying and that it could travel, operation that, as it will be seen later, would have avoided irreparable damage in an accident occurred during its transfer to Catalonia. From the indications that were reported, it seems that facing was not provided for all the paintings.

In fact, it is clear that Prado restorers were fully aware of the consequences deriving from facing and its limits, as can be seen from a writing by Cantón sent to the delegate of the Ministry of Public Instruction on the $21^{\text {st }}$ of March 1937 , denouncing the bad state of conservation of The Feast of Bacchus by Velazquez. In fact, with the aim to take time and dissuade the ministry from moving the painting, Cantón claimed that a simple engasado would not have been enough, but the picture should have been lined:

\begin{abstract}
"Because of it is unlined and the canvas is very old and insufficient to support the color that is largely detached [...], because of the cracking of the color is visible from the back, giving the impression of being held only by the varnish. [...] Only a simple engasado would be insufficient, since the glue could not be as strong as the state of the color needs, because it would pass uselessly through the back of the canvas without setting the color, with the danger of causing color detachments during the esengasado removal, and other harmful reactions it would suffer when wetting the paint (which is an essential operation to remove the facing). Therefore, we consider that only a good lining could guarantee the firmness of the painting to be able to transfer it, of course, without forgetting what works of such
\end{abstract}

\footnotetext{
57 Translated from Maccarrón-Serrano, Macarrón-Miguel, and Macarrón-Larrumbe 2009: "Por defectos de forración hace años, presenta un peligro tan evidente de deterioro, que en nuestro concepto, no debe ser trasladado [...]. Puede afirmarse que no hay un $\mathrm{cm} 2$ libre de grietas o pliegues de la pintura, debidos a contracciones de la tela. Aparece la capa de color desprendida, y se des prendería por efecto de la trepidación [...]. Habría que engasarla pero en este caso esta medida sería muy discutible, de adoptarse, ofrecería un problemático futuro para una obra fundamental en la historia del arte [...]. No se puede engasar por el cambio que produciría al lavarlo. Se ha envuelto en una capa de guata para el traslado".
} 
importance demean when losing the purity printed by the master's hand." 58 (Sanchez-Contón 1937 cit. in Maccarón-Serrano, Macarrón-Miguel, and MacarrónLarrumbe 2009).

Cantón did not really seem to have intention of lining the picture, because this would have affected its value. In another writing of the $22^{\text {nd }}$ of March 1937, he further specified that it was one of the few paintings by Velázquez that were still preserved without lining, with all the singular and precious value of the intact. He further bagged the painting not to be unpacked and kept in a dry place with a low temperature. He specified that painting had been kept in the same atmospheric environment since its creation in 1628, so that the stability of the painting would have been hardly affected if it would have been lined in such a wet environment like Valencia's (Alonso-Alonso 2009). Notwithstanding Cantón advices, the Ministry rejected the proposal in view of the urgency of the transfer, since lining operations would have taken a month and a half. Therefore, the urgent preparation of the paintings and objects was ordered. On the $7^{\text {th }}$ of April, The Spinners and The Feast of Bacchus left the Prado Museum along with other ten paintings. The expedition report shows indications on how the paintings were prepared:

"Observations and state of conservation of some of these works:

GOYA - The Threshing Ground - The Wedding - The Game of Pelota - A Fight at the Venta Nueva - Because they are large paintings, they have had to be removed from their stretchers and rolled up for their transportation, which caused few cracks in the seams, and the detachment of the stucco along the edges of the stretcher.

VELÁZQUEZ - The Feast of Bacchus - It is unlined, the canvas is deteriorated, being visible behind the very pronounced cracks of the paint layer, which seems to be held only by the varnish; For its transfer, it had to be faced and packed putting it between two boards padded with wadding and waterproof paper.

VELÁZQUEZ - The Spinners - The fabric of the lining has contracted, producing cracks with raised edges. Since it has many glazes and the paint layer is very thin, it cannot be faced due to the change it would produce when washing it. It has been wrapped in a layer of wadding fabric for its transfer.

VERONÉS - VenUs and Adonis - It has been faced to prevent the colour from leaping, which was very detached.

58 Translated from Sanchez-Contón 1937 cit. in Maccarón-Serrano, Macarrón-Miguel, and Macarrón-Larrumbe 2009: "Por estar sin forrar y la tela muy pasada siendo ya insuficiente para sostener el color en gran parte desprendido [...] notándose el craquelado del color por detrás, dando la impresión de estar sujeto sólo por el barniz. [...] Solamente un simple engasado sería insuficiente, pues la coleta no podría hacerse lo suficientemente fuerte como el estado del color necesita porque pasaría inútilmente al reverso de la tela sin asentar el color, con el consiguiente peligro de desprendimiento de éste al desengasar y otras no menos peligrosas reacciones que sufriría al humedecer la pintura (operación imprescindible para quitar la gasa). Por lo tanto estimamos que solamente una buena forración podría asegurar con todas las garantías la firmeza del cuadro para poder trasladarlo, claro que sin olvidar lo que desmerecen obras de tal importancia al perder la pureza impresa por la mano del maestror. 
RUBENS - The Three Graces - Due to the humidity and lack of heating during this winter, its deterioration has increased. It has four vertical slits up to more than half of the height and two small cracks, the bottom right corner detached from the stretcher. For its transfer it has been wrapped with paper and a layer of wadding fabric. A note has been placed on its wrapper stating that it would be dangerous to remove it from the frame, as it is compromised.

MURILLO - Saint Anne Teaching the Virgin to Read — In the lower left corner, a blow with a small hole, probably made when it was moved from its place in the same museum.

MURILLO - Saint Elizabeth of Hungary - An adhering cracking.

GOYA - Blind Man's Buff - A general cracking with two horizontal seams (sic), and a cracked stucco of one of them.

VELÁZQUEZ - Vulcan's Forge - The colour is firm, although it presents a pronounced crack on the back of the blacksmith.

GOYA - St Joseph Calasanz - Unlined; canvas with very poor ground, with the danger of the detaching of the colour in some points." 59 (Alonso-Alonso 2009).

From a report of the 15th of April 1937 by Alejandro Ferrant, further information on the type of engasado performed on The Feast of Bacchus was provided. This type of packaging was made with a first layer of Manila paper in contact with the paint layer, then another layer of wadding, and over this one a cardboard covering the surface of the board, to which the leftover wadding returned. Then the work was wrapped in waterproof (tarred) paper and held inside the box with paper pads filled with cork shavings so that they did not have any movement. The lid was screwed down to avoid hammering and to avoid shocks and vibrations that could cause paint detachments. The boxes were protected with fireproof silicate paint brought from France (Maccarón-Serrano, MacarrónMiguel, and Macarrón-Larrumbe 2009).

\footnotetext{
59 Translated from Alonso-Alonso 2009: "Observaciones y estado de conservación de algunas de estas obras: GOYA.-La era.-La boda._-Juego de pelota.- y Riña en la venta.-, por ser cuadros de grandes dimensiones han tenido que desclavarse de sus bastidores y enrollarlos en cilindros, para su traslado, lo cual ha hecho que se pronunciaran algunas grietas en las costuras, y saltara el estuco en las orillas del bastidor. VELÁZQUEZ.-LOS borrachos.-Está sin forrar, la tela pasada, notándose por detrás el craquelé pronunciadísimo del color que da la impresión de estar sujeto, únicamente por el barniz; Para su traslado ha tenido que engasarse y empanelarlo, forrado con guata y papel impermeable, entre dos tableros. VELÁZQUEZ.-Las hilanderas.-Se ha contraído la tela del forrado produciendo el color un craquelé de cordón en relieve. Por estar muy patinado y la capa de color muy fina, no se puede engasar por el cambio que produciría al lavarlo. Se le ha envuelto en una capa de guata para su traslado. VERONÉS.- - Venus y Adonis. - Se ha engasado para evitar que salte el color, que estaba muy desprendido. RUBENS.-Las tres Gracias.-Debido a la humedad y falta de calefacción durante este invierno ha aumentado su deterioro. Presenta cuatro rajas verticales hasta más de la mitad y dos grietas pequeñas, el ángulo inferior derecho desencolado del bastidor. Para su traslado se ha envuelto con papel y una capa de guata. En su envoltura se ha puesto una nota haciendo constar que sería peligroso sacarlo del marco, por estar desencolado. MURILLO.--Santa Ana y la Virgen.-En el ángulo inferior izquierdo un golpe con un pequeño agujero, hecho probablemente al trasladarlo de lugar en el mismo museo. MURILLO.-_Santa Isabel de Hungría.- Un craquelé sujeto. GOYA.—La gallina ciega.—Un craquelé general con dos costuras orizontales (sic), de una de ellas agrietado el estuco. VELÁZQUEZ.-L La fragua de Vulcano.-El color firme, aunque presenta un pronunciado craquelé en la espalda del herrero. GOYA.-San José de Calasanz.--Sin forrar; lienzo con muy mala reparación, que amenaza desprender el color en algunos puntos».
} 
A great sample of the professional maturity of the Prado restorers in this historical epoch emerges from these writings. As can be seen in the report of the $7^{\text {th }}$ of April 1937, not all the paintings were faced, but only those who really needed it, even creating specific facings adjusted to the specific need of problematic paintings like The Feast of Bacchus. Regarding this picture, a new sensibility emerged from Cantón's writing, as opposed to the interventionism of the previous century. In fact, great importance was given to the fact that the painting had not been lined yet and that this represented an added value of uniqueness and originality. In addition, there was great awareness of the risks related to thermo-hygrometric changes, to the point that it was not recommended to transport panel paintings. Furthermore, there was awareness of the risks of facing, openly expressed in the report on The Spinners, which was not faced due to the damages the removal and cleaning of the residues would have caused.

However, considering the conditions of the transports, it was not always possible to disregard the facing of paintings as a preliminary operation for transport, considering the difficulties of making suitable packaging and the conditions in which some of the most representative works of the Spanish heritage would have traveled. In fact, the time and materials to make the packaging were often lacking. Several times old packaging were reused, whereas materials had to be recovered from different cities to make new ones, since there was no wood, shavings, nails, screws or ropes in Madrid, nor waterproof wrapping paper either. Transportation conditions were extremely risky. The paintings traveled on military trucks, at speeds of 10 or $15 \mathrm{~km} / \mathrm{h}$, enduring inclement weather, stopping and protecting trucks from the action of the wind and even snow (Maccarón-Serrano, Macarrón-Miguel, and MacarrónLarrumbe 2009). The transport was also carried out by military personnel who often lacked the necessary sensitivity and knowledge. Manuel de Arpe $y$ Retamino, restorer of the Prado museum and member of the Committee for Art Conservation, followed the works in all their wanderings for three years together with his colleague Tomás Pérez Alférez. In his diary, he told of some extremely difficult situations he had to deal with.

It is thanks to his testimony that it was awareness of some details of the tragic transport of the paintings from Valencia to Catalonia, carried out precipitously when military operations threatened to cut roads and communications at the height of Tortosa, at the end of March 1938. Military trucks, on which the driver was traveling with an escort, were loaded quickly, and traveled day and night until all the paintings were transported to the Peralada Castle, near Girona and the border with France. Arpe and Pérez were the only qualified technicians of the expedition who could have intervened on those works and had to fight 
against the reticence of the military to be able to accompany personally the works. There were various accidents during the transport, which caused damage to some of the most important pieces. Among these, there were the Philip IV on Horseback by Velasquez, and on The Second of May 1808 and The Third of May 1808 by Goya.

The crate containing the equestrian portrait of Felipe IV slammed against a branch during transport, and when Arpe was able to open the crate, he found that the canvas had been detached from the stretcher and it had been folded and deformed. However, the preventive facing proved to be fundamental, because thanks to the presence of the engasado there were no major losses of the pictorial film, and the canvas could be re-tensioned with relative ease.

Unfortunately, the same cannot be said of Goya's two paintings, which were fragmented by the fall of a ruined balcony of a bombed house in Benicarló. According to the testimony of Arpe, one of the two arrived in Peralada divided on 18 fragments. Given the competence required by the task and the importance of correctly carrying out the lining, it was essential to bring Pérez Alférez by boat, since the cut of the road in Tortosa prevented him from reaching the destination with the rest of the expedition. Some of the materials they needed had to be brought from abroad as well. Tomás did the lining and then Arpe started cleaning and restoring the works.

The fall of Barcelona on the $26^{\text {th }}$ of January 1936 and the imminent advance of Franco troops made the latest transport operations even more complicated. The works were first moved to France, and from there to the headquarters of the League of Nations in Geneva. The most significant works would have been exhibited there from the $1^{\text {st }}$ of June to the $31^{\text {st }}$ of August 1939, before returning to Spain, facing another very dangerous train journey through France immediately after the outbreak of the Second World War, with the risk that the train could be bombed. Manuel de Arpa returned with the latest works, while Peréz had returned a few months earlier with the paintings that had not been selected for the exhibition (Vicente-Rabanaque 2013).

The emergency measures adopted during the Spanish Civil War were of enormous importance. Along with the conservation and restoration works, the prevention criteria and strategies that were put in place were highly effective and modern. Thanks to them, it was possible to preserve the Heritage in a singularly dramatic moment. Furthermore, they were also considered clear precursors from which they would take place, a few years later, in the European context (Vicente-Rabanaque 2013). 
The tragic situation faced during the post-war with lack of resources and materials, and under a dictatorship that led to the isolation of the country for several decades, stalled the advances in patrimonial protection and care stated in the early thirties. This situation of precariousness and stagnation was further aggravated by the contemporary development of the Second World War (19391945) in the international context. In the midst of this bleak, devastating and isolated landscape, post-war restorers were forced to resort to traditional formulas to make their own materials or carry out technical procedures. The country would remain isolated from the rest of the world until the 1960s, when it began to have an international opening. Thanks to the 1959 National Stabilization Plan, the deployment of the Spanish economy began, ending the Francoist regime's autarkic policy, producing a notable economic recovery. But it was from the seventies that the definitive opening of Spain to the exterior took place. With it, the exchange of knowledge between specialists and the integration of the country in the international, mainly European, cultural context would have been promoted.

In the rest of Europe, at the end of the war, the situation was disastrous, but humanity reacted to the violence and the devastation with a lively activity in all sectors. In the immediate post-war period, the ICR made a contribution of fundamental importance for the growth of the sector from a practical point of view, with numerous restorations, and from a theoretical point of view, with the deepening of a new methodological approach developed by Brandi, becoming an international reference point.

The effects of the economic boom of the 1950s in USA and of the 1960s in some European country were felt also in the field of restoration: synthetic materials were introduced and new techniques aiming once again to permanent interventions were developed. However, the results were not only positive. In fact, the enthusiasm for technology and new materials that were believed to have an indefinite duration was sometimes excessive, leading in some cases to place an excessive trust in innovation. The natural consequence of this attitude was the re-proposition of interventions thought of as 'definitive', despite history had already demonstrated that nothing can be eternal, as well as Picault's transfers of panel paintings had not been 'immortal'.

There are several scholars who look at the 50 s and 60 s as an insidious period. For example, this is how Erasmus Weddigen stated in the introduction to the second International Colour and Conservation Congress held in Milan in November 2004: 


\begin{abstract}
"After the middle of the last century, a kind of innovation frenzy has grown: there were made available chemical-physical information and methodologies, ingenious equipment although aimed at the maximum intervention that made the operator more and more distant from his patient. Even an electron microscope does not replace the psychological and physical approach of the attentive observer who encounters the object, perhaps degraded to a pure material object, or underestimated and subjugated without the possibility of reacting."60 (Weddigen 2005).
\end{abstract}

In addition to the enthusiasm for new plastic materials and new technologies, in those years there was also the enthusiasm for the theories enunciated by Cesare Brandi. In fact, it almost seems that his Theory of restoration, which had been and is still considered by several restorers to be an 'aesthetic' theory, was non fully understood. The consequence of this misunderstanding was that it was not given the right importance to the structural aspects, so that to the reflection on a 'conservative' aesthetic restoration did not follow that on a 'conservative' structural restoration. Giorgio Torraca, an internationally renewed conservation scientist who was assistant director of the ICCROM from 1965 to 1985, in an interview conducted by Bruno Zanardi, stated that :

"In the 1950s, the Institute had the illusion of having solved the technical problems of restoration forever. So it was just a matter of illustrating the operating procedures in a manual."61 (Torraca cit. in Zanardi and Torraca 2011).

The sensitivity and the attention to conservation problems remained in the background only for a short time. In fact, the problems related to such a conceived way of understanding the restoration activity were not long in coming. It was in these years that Giovanni Urbani, director of ICR from 1973 to 1983, elaborated his thought on preventive and planned conservation, convinced that it was of primary importance to intervene on the surrounding environment, designing short and long-term programs, to limit direct intervention on the heritage.

A confirmation of the correctness of the theories born in that period that were hardly put into practice came in 1966. In this year, two environmental catastrophes dramatically highlight the need to review all the conservation and

\footnotetext{
60 Translated from Weddigen 2005: "Dopo la metà del secolo scorso è cresciuto una specie di delirio dell'innovazione: furono messe a disposizione informazioni e metodologie chimiche e fisiche, apparecchiature pur ingegnose, ma finalizzate al massimo intervento di restauro che hanno reso l'operatore sempre più lontano dal suo paziente. Persino un microscopio elettronico non sostituisce l'approccio psicologico e fisico dell'osservatore attento che incontra l'oggetto, degradato magari a puro oggetto materiale o sottovalutato e sottomesso senza possibilità di reagire".

${ }_{61}$ Translated from Torraca cit. in Zanardi and Torraca 2011: "Negli anni Cinquanta, all'Istituto c'era l'illusione d'aver risolto per sempre i problemi tecnici del restauro. Che quindi si trattasse solo di illustrare le modalità operative in un manuale".
} 
restoration processes. These episodes were the flood of Florence and the "high water' of Venice, which endangered no longer a single artwork, but the entire heritage of two very important cities of art.

The flood of Florence represented a worldwide exemplary case in the history of restoration and conservation because, as Marco Ciatti claimed, it brought to a paradoxical level a series of problems which are current in restoration and conservation, but never with a such serious intensity, considering that the only the paintings were about a thousand (Ciatti 2009). It was an absolutely unique event also because of the aid received from many countries. For the world of restoration, it was an extraordinary opportunity to share experiences at an international level. Conservation and restoration works were attended by American, Russian, German, English, Norwegian, Danish, Swedish, Finnish, French, Hungarian, Yugoslavian, Austrian, Romanian, Greek, Czechoslovakian, South African, Portuguese, Swiss, Australians, Spanish, Dutch, and Belgians (Baldini 1972).

A few hours after the overflow of the Arno, there were sought solutions to proceed with the first emergency interventions, in order to remedy to the serious damage suffered above all by panel paintings after the permanence in environments with a very high humidity or even in direct contact with water. This had caused a differential swelling of the panels constituting the supports and of the ground and paint layers. During the drying phase, it would have led to even more serious problems, because the substrate would have shrunk during drying, reaching a smaller size than the original one and no longer offering sufficient space for the preparation and the preparatory layers ${ }^{62}$.

\footnotetext{
62 The high humidity causes the swelling of the wood fibres. This phenomenon is manifested by differential swelling and deformation, due to its anisotropy. The animal glve of the ground layer is highly hygroscopic too, so that the ground also undergoes considerable dilation. In this phase, it can undergo a faster and greater expansion than that of the support. If the compressive forces exceed those of adhesion to the substrate, the ground detaches from the substrate creating flaking phenomena. When the humidity is very high or the work remains in direct contact with the water for a long time, the glue and the gypsum dissolve, they are washed out or migrate. The ground therefore loses its cohesive strength and disintegrates. Furthermore, animal glues are an excellent culture medium for bacteria and fungi, which can colonize them in a short time and further weaken the preparatory layers. The pictorial layers swell less and more slowly, but humidity causes an increase in their plasticity. Therefore, the expansion of the substrate and the preparatory layers, to which the colour is attached, causes the expansion of the paint film and, when the expansion forces exceed its breaking point, the exasperation of cracking phenomena. During drying, the wood releases the retained moisture to the environment and undergoes a differential shrinkage, due to its anisotropy and its structural anomalies. Due to the internal compressions that the material underwent during swelling, the wood undergoes a shrinkage that goes even beyond its starting size. Therefore, the support no longer offers sufficient space for the ground and the pictorial film which, having undergone a plastic deformation, have a slightly larger overall surface than the initial one. The combination of the forces exerted by the support shrinkage and the decohesion of the ground cause the detachment and fall of fragments of the superficial layers.
} 
Even canvas paintings had been heavily damaged by the high humidity, due to the differential behaviour of the constituent materials, causing strong tensions within the painting system (for more information see Chapter 2).

In order to hold together the paint film and to avoid the loss of flaking portions during drying, first of all it was thought to make emergency facings. The adhesive chosen for this operation was the Paraloid B72, an acrylic resin introduced in the United States of America in the field of restoration in the 1960s. It was not considered possible to use traditional materials such as the Florentine colletta or the wax-resin due to the high humidity of the surface. Although Urbani, then assistant director of the ICR, and other experts did not deem it appropriate (Zanardi and Torraca 2011 ), it was decided to proceed with a facing campaign. Given the emergency situation, facings were not always done with suitable materials. Other papers easily available, for example Kleenex (Pasti 1986), often replaced Japanese paper. In addition, facings were not always well performed, since also guided volunteers, and not only the professionals, carried out the operation.

After the first intervention, it was decided to transport all the works in an environment with an air conditioning system that would have allowed the wooden support of the boards to undergo a very slow and controlled dehumidification process, and would have facilitate the adjustment of the constituent materials to the dimensional variations in a less traumatic way. The Limonaia di Boboli was chosen for this purpose, which was adapted to maintain the right level of environmental parameters, by means of two large air conditioning machines that arrived from the Alitalia hangar. Everything was possible thanks to the coordination of Urbani, Baldini and Procacci and to the collaboration of physicists Gino Parolini and Marcello Paribeni of the engineering faculty of Rome (Agostinelli 2013).

During the eight months at the Limonaia, each painting was constantly controlled and treated on the basis of its specific needs, even following a single project and direction. Some facings were replaced and others removed. Some paintings were consolidated locally with glve, wax, varnish, Paraloid B72. An attempt was always made to operate without prejudice to future interventions, but it was not always successful. The most worrying period came two months after the permanence of the works in the Limonaia: new ground and paint layer flaking portions appeared. In most cases, it was possible to solve the problem with immediate and targeted interventions, in others it was decided to consolidate the facings because the direct fixing of the paint flakes could have caused more damages. In extreme cases, colour transfer was the only solution. 
The choice of facing made in the first moments of the emergency it was justifiable: with a shortage of materials and qualified personnel, it was necessary to devise a univocal and easy system for all the artworks, which could have been practiced also by an unskilled staff. However, the distrust of Urbani and others experts towards facing is also understandable, especially with regard to panel paintings. In fact, it could have been possible to monitor constantly the paintings by carrying out localised consolidations and fixings only where strictly necessary and limiting the partial or total facing to cases where there was a real need. In this way, facing could have been carried out in conjunction with the critical phase of shrinkage of the substrate, assessing its real need on a case-by-case basis. At this point, the pictorial surface would have been even drier and there would have been possible to intervene with different types of material, chosen only after the planning of a targeted conservative intervention.

For the purpose of this study, it worth to mention the case of the Crucifix of Cimabue, because of the numerous facing techniques mentioned in the reports and articles published on its restoration. The work was recovered two days after the flood, after it had been almost completely submerged in water. It was positioned horizontally on a surface, faced with Paraloid B72 and kept in situ to avoid sudden changes in humidity. After a month, it was brought to the Limonaia di Boboli, where it was subjected to a very slow variation of humidity range, to allow the pictorial film to withstand the shrinkage of the substrate. The new flakes were fixed day by day. It was not possible to make a first de-facing before three months, due to the excessive softness of the ground and paint layer. On this occasion, the fragments of colour that had moved were replaced and fixed with colletta (it is supposed the terms colletta referred to the rabbit glue used by the Florentines for these operations). A second facing removal was necessary after the appearance of significant colour lifts caused by wood movements. On this occasion, the whole Paraloid B72 was removed and the raised paint layer was fixed. A third facing was then carried out by applying rice paper in two layers with wax-resin (virgin wax and mastic) adhered with a heated spatula.

Once brought back to normal conditions of humidity and temperature, the support had shrunk by $3 \mathrm{~cm}$. The only possible solution seemed to be the transfer, which was carried out without destroying the support, thanks to the presence on the entire surface of the cloth 63 used for the preparation of the ground layer. After proceeding with the separation from the support, the facing was replaced for the fourth time, using mastic resin as a rather thick adhesive, and the necessary consolidation operations were carried out. The transfer was handled

\footnotetext{
${ }^{63}$ As atated by Luca Uzielli, "up to the fourteenth century, great care was used in preparing the ground layer, which, as described by Cennino, was basically made of glve, cloth, gesso grosso, and gesso sottile. The cloth, generally made of large, overlapping pieces, was often applied not only over the whole panel but over the engaged frame as well" (Uzielli 1998).
} 
by Sergio Taiti and Gastone Tognaccini. The two restorers attributed the loss of cohesion:

\begin{abstract}
"Both to the degradation of the right glve-plaster ratio of the ground, due to the large alluvial bath, and to the presence of various substances which had been used in the long conservative process, to which the work had been subjected in its variables and often contradictory transitory stages (Paraloid B72 in diluent, mastic in chloroform, wax-resin), and which had transformed the ground in a sort of heterogeneous agglomerate of various materials without any elasticity. The colour itself, that was in many parts separate from the preparation, had become rigid and extremely fragile."64 (Taiti and Tognaccini 1981).
\end{abstract}

The subsequent application of heterogeneous materials and the repeated application of different types of protective facings had therefore caused damage to the paint film and the ground. The introduction of many different types of materials, which could not be completely removed, had compromised the state of conservation of the painting, making it difficult to carry out the intervention. The two restorers chose to do not remove the superimposed materials, because it was impossible to remove all the residues and anyway it would have been necessary to use a great variety of solvents. In fact, the cleaning operation would have prejudiced the already damaged colour.

Nevertheless, Taiti and Tognaccini were obliged to make the fifth facing of the painting before proceedings with the intervention. After a first impregnation from the back, it was therefore necessary to proceed once again with the replacement of the fragments and with a facing with thin Japanese paper Wangerow n.500 and wax-resin.

The Florence flood was a catastrophe that could have had a minor impact if only prevention, forecasting and environmental protection systems had been studied. However, the collaboration that took place on this occasion allowed to elaborate a restoration project in some respects very innovative for that time. It was in a sense a demonstration of the birth of a new sensitivity in the field of conservation. However, as demonstrated by the choices made for facing, it was just the beginning of a still in progress path.

\footnotetext{
64 Translated from Taiti and Tognaccini 1981: "Sia alla degradazione del giusto rapporto colla-gesso dell'imprimitura per via del gran bagno alluvionale, sia anche alla presenza di varie sostanze delle quali si era fatto uso necessario nel lungo iter conservativo cui era andata incontro l'opera nei suoi variabili e spesso contraddittori stadi anche di transizione (Paraloid B72 in diluente, mastice in cloroformio, cera-resina) e che avevano finito col configurare l'imprimitura ad una specie di agglomerato eterogeneo di varie materie che avevano finito con il far perdere ogni elasticità all'insieme. Il colore stesso, in molte parti separato dalla preparazione, era divenuto rigido ed estremamente fragile".
} 
The experience of the Florence flood probably gave a further boost to Urbani's thought. He felt the need to tackle the conservative problem with actions aimed at preventing damage, rather than treating it with direct intervention, as well as he claimed the need of a "science that serves to make not to make better retouching, but to put the paintings in the conditions for which they need less and less retouching"65 (Urbani cit. in Zanardi and Torraca 2011). According to these ideas, he edited the publication of "Problemi di Conservazione" in 1973, a very important text because it was one of the first books in which there were investigated the scientific aspects of the restoration of different materials, with collaborations between restorers, art historians, chemists and physicists, who studied and revised traditional restoration techniques. As Giovanni Urbani wrote in the introduction to the work, there was:

\begin{abstract}
"The increasingly pressing need to revise all procedures currently in use. Because it is inadmissible that, for example and just to be in the ordinary administration, we continue to lining the canvas as it has always been done and only suspecting that traditional lining involves serious phenomena of compression and displacement of the paint and ground layers." 66 (Urbani cit. in Zanardi 2012).
\end{abstract}

These were still unknown problems in an era characterized by a rich culture, but still far from the technical-scientific problems of conservation. Even the lining techniques used at the ICR, as stated by Walter Conti and Enzo Tassinari, "although conducted at the highest level at the time, [...] were still those historically used on empirical basis" 67 (Conti and Tassinari cit. in Zanardi 2012a).

The issues exposed by Urbani, the need to investigate the world of restoration and the techniques used, were took up by various restorers. Among them, there was Vishwa Raj Mehra, the Indian restorer of the Central Research Laboratory of Art, Object and Science in Amsterdam. As he said in his speech at the ICOM congress held in Madrid in 1972, it was necessary to pursue a radical revision of the lining methods. In order to promote a less invasive approach for the conservation of works of art, he invited to reflect on the real need to perform a lining:

\footnotetext{
65 Translated from Urbani cit. in Zanardi and Torraca 2011: "scienza che serva a far meglio i ritocchi, ma d'una scienza che serva a mettere i dipinti nelle condizioni per cui abbiano sempre meno bisogno di ritocchi".

66 Translated from Urbani cit. in Zanardi 2012: "La necessità, sempre più stringente, di sottoporre a uguale revisione tutti indistintamente i procedimenti oggi in uso. Perché è non meno inammissibile che, ad esempio e tanto per stare nell'ordinaria amministrazione, si seguiti a foderare le tele come si è sempre fatto e solo vagamente sospettando che la foderatura tradizionale comporta gravissimi fenomeni di compressione e di dislocamento dello strato dipinto e di quelli preparatori".

${ }_{67}$ Translated from Conti and Tassinari cit. in Zanardi 2012": "Seppur condotte al massimo livello d'allora, nei fatti erano ancora quelle storicamente utilizzate su basi empiriche dagli altri normali bravi 'artigiani restauratori'".
} 
"Firts of all we should crub a certain tendency to solve a painting's problems with a horse-drench. When only the paint layer or ground have become wakened and lost cohesion with the supporting canvas, the nit might be sufficient to limit oneself to consolidation or impregnation with a suitable, thoroughly tested consolidant." (Mehera 1972).

Following the same principle, Mehra avoided the use of facing unless it was strictly necessary. In fact, according to a phrase often attributed to Mehra, "the restorer applies facings to protect himself more than the painting"68 (Mehera cit. in Cremonesi, Fratelli and Riggiardi 2006). Mehra's main concern was that the application of facing precluded the visual control of the pictorial surface, which would have invalidated the efforts made to develop a lining technique that allowed operating with the pictorial film upwards. Therefore, he preferred to carry out a local consolidation or fixing of the paint film when necessary, before proceeding with the lining. After testing several consolidants, all applicable at very low concentrations, Mehra selected Plexisol P550®, in percentages ranging from $5 \%$ to $10 \%$ dissolved in white spirits, to be applied from the front and the back, before the painting was removed from the frame. In the event that there were lifts and detachments, he suggested to fix them with the punctual application of a water-based adhesive, even the same used for the lining.

In the description of the intervention made during the fourth ICOM triennial meeting held in Venice in 1975, Mehra's distrust of facing was tangible. Indeed, he stated: "if the restorer feels that there is a need for facing to be applied to the painting's surface as a protection, then he will do so" (Mehera 1975). Mehra did not express direct judgments about it, but it seems that he wanted to communicate indirectly to carefully evaluate the real need to resort to facing. Therefore, if it was deemed indispensable to face the painting, the surface could be covered with a gauze and the same Plexisol P550 used for consolidation, rather than using traditional adhesives.

Mehra was one of the delegates of an international conference that had great consequences on the way of conceiving the conservation practice, the Greenwich conference of 1974, where he also presented his low-pressure table for cold-relining. The Greenwich conference was the first one exclusively dedicated to the structural conservation of the paintings, and on this occasion, many lining techniques from the traditional to the most recent were analysed and compared, encouraging the exchange of ideas. Restorers from different parts of the world were invited to illustrate their techniques, to compare them with those of their foreign colleagues and to develop the guidelines to follow in

68 Translated from Mehera cit. in Cremonesi, Fratelli and Riggiardi 2006: "il restauratore applica la velinatura più per proteggere se stesso che non il dipinto". 
the future. It was making his mark the idea that lining had not be conceived as a unicum of operations to solve all the structural problems of a canvas painting, but an operation aimed at giving mechanical sustain to a canvas that was no longer able to support the preparatory and pictorial layers. Furthermore, all the additional operations to restore the adhesion and cohesion of the ground and paint layers, to put in plane the painting, or to solve tensioning issues, could be carried out separately from the lining, or in some cases they could also represent themselves a solution for the conservation of the painting.

In the spirit of describing in detail the lining operations to facilitate the comparison with the other methods, many restorers also illustrated the facing they were used to apply during lining intervention. There was a greater attention than in the past for the application methods and for the materials choice, and in some presentation, experiments on different materials used for facing were even described. In the 70s, there were many products on the market that could be used for conservation. There was therefore the awareness of the need to study old and new materials to understand which could be the most suitable for any specific case. The restorers knew that they could no longer choose the materials without any objective parameters or following the principle of tradition. Nevertheless, traditional materials were still often preferred for facing, but there was also one of the first descriptions of a Beva 371 facing. The English restorers described several facings made with very thin, long-fiber papers, of local origin or from Japan. It seems that the use of this type of paper was widespread and that it was not a novelty for English restorers. The widespread use of these papers was probably due to the contact with China and Japan in the colonial era.

The interest to small preliminary operations follows from the presence of the term 'facing' within the glossary present in the appendix:

\footnotetext{
"Facing: a process whereby an adaptable material (very often a thin tissue e. $\mathrm{g}$. Eltoline Tissue, mulberry paper, sulphite paper, fine silk, very thin cartridge paper) is glued to the face of picture to protect the paint layer during lining or other treatment to the support. A chosen facing adhesive is applied either directly through the facing fabric on the paint surface, or separately to the tissue which is then carefully applied to the paint avoiding wrinkling." (Villers 2003).
}

However, another definition of front protection was also included in this definition, namely the intelaggio or cartonnage: "In major support treatment, such as transfer, composite facings may be necessary using different types of material and adhesive in successive layers" (Villers 2003). 
It was recommended to use a facing adhesive that should have been ready reversible that means it should have a high reactivation speed. For this purpose, hot-melt adhesives, resins in solution or water-soluble glues could be used.

There was not a term to define the interim support, but another referred to a type of damage directly related to it, that is, the impression of the texture or the fibres of the fabric:

\begin{abstract}
"Facing patterns: markings left on the surface of a painting by the facing material during or after the lining. May be caused by excessive heat softening the final paint layers, or by the facing mix having an affinity for a soft paint surface [...] or by excessive pressure imprinting the edges, joints or wrinkles in the facing material into the paint texture." (Villers 2003).
\end{abstract}

Some work presented at the conference were oriented to the description of the investigation carried out on lining materials and on the new technologies that could be employed for lining. Others were directly addressed to the description of lining techniques, most of which were still prepared with traditional methods that have been sometimes modified.

One of the few description of synthetic linings was presented of course by Gustav A. Berger, inventor and promoter of one of the few materials made specifically for the restoration of the paintings: the Beva 371. In his presentation, Berger described a lining intervention that he made on the painting The first sorrow by Rembrandt Peale, a canvas with cuts and tears. This particular condition led the restorer to decide apply the facing only after it had been removed from its stretcher, and after the edges had been outstretched and realigned. In fact, facing would have covered the pictorial film and would have prevented to correctly align the edges of the tear. In addition, the application of facing adhesive would have saturate the fibres of the canvas around the edges, preventing good adhesion.

To fix the tears, Berger used a mixture consisting of a polyamide, an epoxy resin and an aromatic hydrocarbon. According to what the restorer said, at this point of the intervention facing was necessary non only because of the precarious state of conservation of the canvas, but also as protective barrier, to prevent the resin from coming into contact with the paint film. Although in some cases the problem could have been solved by applying a strip of surgical tape, according to Berger it was always better to face the painting. For this operation, he used a 'Promatco lining' and the Beva371. The Promatco was a very tough, flexible, nonwoven fabric with a pH of 7.0-8.0, easily tensioned and extremely adaptable. It was sufficiently inert to changes in temperature and humidity and it was rigid enough to allow it to be handled without creasing. For facing, Berger used a 
single piece of tissue of about $15 \mathrm{~cm}$ wider than the painting, and put it on a table to hold it in place while drawing the perimeter of the painting with a few centimetres in excess. Then he applied a thin layer of undiluted Beva with a roller. This layer served to prevent the penetration of the Beva through the TNT. When it was dried, he applied the second layer. The number of layers of Beva changed according to the painting. For example, those with raised brush strokes provided three or more drafts of drink. The restorer then placed the paper face up on a sheet of silicone-coated plastic film, and put the painting face down, aligning the cuts. Protmaco could be adhered to the painting by passing a heated spatula. At the end of the intervention, the adhesive was reactivated with mineral spirit using the low pressure table, and removing the residues with petroleum oil. Berger himself admitted that, since the purpose was to create a barrier between the paint film and the epoxy resin used for the cuts, it was not always necessary to face the whole painting: in many cases it was sufficient face only the area around the cut. The sensitivity of Berger to adapt the intervention to the specific artwork is evident. In fact, the choice of facing was explained and justified, that means that Berger was aware of the fact that it was not always necessary to face a painting.

Arthur Lucas, who described the lining methods used at the National Gallery in London, gave another point of view instead. His contribution was interesting not only for the description of the wax-resin ${ }^{69} \mathrm{e}$ and glue-paste ${ }^{70}$ facing, very similar to those described by other restorers, but also for the general rules of the laboratory declared at the beginning of the presentation. Among these, there is one on facing:

\begin{abstract}
"All paintings must be faced in some way before treatment is carried our (for flaking, blistering paint, only the area being treated need be locally faced). The facing should not be taken off until the painting is safely fastened to its stretcher. In fact a painting should never be taken off its stretcher without a satisfactory facing, as the chance of damaging the paint accidentally is very high." (Lucas 1974 cit. in Villers 2003).
\end{abstract}

Therefore, for the restorers of the National Gallery of the 70s, facing had to be done almost in all cases. It was preferable to protect the painting to avoid unpleasant damage. However, in the case of paintings with a porous preparation he advised to do tests before to prevent the adhesive from

\footnotetext{
69 The wax-resin used at the National Gallery of London consists of three parts of beeswax and two of dammar. Venetian turpentine and Elemi gum are not necessary. The author claims that this composition is preferred at the National Gallery over other more modern preparations.

70 The glue-paste was used on paintings that couldn't be lined with wax-resin because it would have impregnate the surface. Since the old traditional compo-lining after 80 years started to become stiff and fragile, they had done several research on materials to improve its characteristics.
} 
impregnating it and darkening its tones. Sometimes a correct analysis revealed that the painting had been transported and that there may be interposed layers such as cotton canvas or a layer of glve-paste. In this case, the operation should have considered as a transfer and therefore a stronger facing was required.

Other English restorers described the method used in their laboratories for lining and de-lining for which traditional materials were used, even though some modifications and innovations in recipes or methodology were detectable. For example, Peter Newman described a traditional facing made for the so-called 'compo-lining', a glue-paste lining similar to those used in Italy. Facing consisted in the application of sulphuric acid paper (but even other kinds of paper could be used) adhered with a diluted 'compo'7l solution. If there was some doubt about adhesion a 10\% PVA emulsion could be used. Newman also claimed never to apply a facing with wax-resin due to the plasticising effect that the adhesive could have on the colour when the painting was heated.

John R. Esse described a method to remove an old lining using the low pressure hot table. According to the restorer, for this purpose it was essential to protect the surface of the painting with a particular type of wax-resin facing, adhered to a Melinex sheet with the help of a hot table. The facing was applied gluing sheets of mulberry paper of $(10 \times 15)$ inch with a wax-resin consisting of a part of dammar resin and one of beeswax. Then the facing was adhered to a sheet of Melinex through the use of a low pressure table is heated up to $60^{\circ} \mathrm{C}$. this system permitted to remove the lining with water-based methods. The Melinex sheet was probably used to enhance the rigidity of the paint layer during de-lining.

The contribution of Ronald Chittenden, Gillian Lovis and Westby PercivalPrescott was of particular interest because it was focused on some preventive treatments, which, as stated by the scholars, in some cases could also solve painting problems without resort to lining. Among these methods, there was the pre-tensioning of the canvas, carried out using perimeter paper strips glued on the front of the painting. For this purpose, localized consolidations were firstly carried on. Then the painting was faced and a second layer of resistant paper was glued over it. This step could be avoided in the pre-tensioning process if the painting was in good condition or had not been lined. According to the authors,

"The optimum conditions are reached when both painting and lining canvas are stretched throughout the process, with the paper facing acting in the double role

71 Compo-adhesive is made of two parts of rye flour and one part of Scotch glue, added with an anti-fungoid agent and Venice turpentine. 
of a protective and tensioning membrane." (Chittenden, Lovis and PercivalPrescott 1974 cit. in Villers 2003).

Therefore, the dual function of facing used as a protective and useful layer for tensioning is explicitly declared by the restorers.

The most interesting aspect of the description of facing is that, unlike many other cases, attention was given also to the choice of the paper for facing. It had to be selected according to the kind of painting in order to adhere perfectly to the pictorial film. Its thickness, softness, texture, adaptability and flexibility had to be assessed. For example, the use of a thicker paper in relation to wax-resin linings where both the original canvas and the lining were very rough, would have prevented the texture of the canvas from being imprinted on the pictorial film:

"The choice of paper is governed by the following:

- It must be soft enough not to cause paint surface change of any sort (e.g. facing patterns, moating) and to cushion the paint surface from the effects of other more rigid layers with which it may come into contact.

- It must be adaptable enough to conform to all the surface irregularities of the painting.

- It must be strong enough to take repeated tensioning of the outer margins." (Chittenden, Louis and Percival-Prescott 1974 cit. in Villers 2003).

The paper chosen by the restorers was the Eltoline tissue, widely used in England in the field of restoration. Eltoline tissue is a thin, light and unpolished paper, with a good wet-strength, sulphur-free, with $\mathrm{pH}$ 6. It consists entirely of long manila fibers, the same used for the production of Japanese paper.

For facing a mixture of wax-resin ${ }^{72}$ was used, which was spread with a brush through the paper. In the case of an oil painting that had never been painted, or whose paint that did not allow the adhesion of the resin wax, a thin waterbased adhesive ${ }^{73}$ could be used (Chittenden, Louis and Percival-Prescott 1974 cit. in Villers 2003).

Other traditional techniques employed by Russian and Italian restorers, were shown respectively by Yashkina, and Baldini and Taiti.

\footnotetext{
72 Wax-resin was made with 7 parts of dammar resin dissolved in Withe Spirit in a 5:1 ratio, 1 part of bleached beeswax, $1 / 6$ part of rubber elemi.

${ }^{73}$ According to the authors, both Cellofas B (sodium carboxymethylcellulose) dissolved at $4-5 \%$ in water, and a very diluted flour pasta could be used. For the preparation of the latter, $40 \mathrm{~g}$ of wheat flour and $400 \mathrm{ml}$ of water were mixed and left to rest overnight. After that, it was boiled for three minutes, stirring until it cooled.
} 
Larisa Ivanovna Yashkina, from the Grabar Art Conservation Centre of Moskow, presented the sturgeon glve lining. In Russia, sturgeon glve had been traditionally used (and it is still used) for the restoration of paintings. It is a glue with different characteristics compared to rabbit glve or other animal glves: it is longer lasting than other gelatine glues, it is more elastic and even at higher humidity range, it retains its mechanical characteristics. The sturgeon glve lining described by Yashina, like all the traditional methods, involved the application of facing. An adhesive made of a 1:1 mixture of $3-4 \%$ sturgeon glue mixed with honey was used. A good adhesion of the tissue was obtained only when the adhesive had a high compatibility with the painting and therefore a good wettability. When the wettability was low, a higher percentage of honey was used (4\% glve, $6 \%$ honey). The cuts and tears were reinforced with the application of a layer of paper above the facing. The tensioning of the painting was also included in this technique. In fact, perimeter strips of streaked kraft paper, with one-way shrinkage, were applied above the facing, the end of which was fixed on an interim stretcher. By drying, the paper contracted and the painting was tensioned.

From this text it is not possible to know which type of paper was used for facing. However, Hilkka Hiiop, restorer of the KUMU Art Museum in Tallinn, kindly provided some additional information. The method described by Hiiop involved the use of a particular type of paper, Mikalent, used in Russia during the cold war for military purposes. It is a thin paper, similar to Japanese paper, but with a synthetic component and greater resistance. Furthermore, the paper fibres, unlike the Japanese one, are oriented in one direction. Due to this feature, the facing was performed by applying two layers of paper with opposite orientation. Alternatively, Japanese paper could be used, as described in the article published by Tatyana Petrukova and Stephen Bonadies (1993).

According to Baldini and Taiti, the linings carried out at the Fortezza da Basso, headquarter of the OPD's laboratories, involved the use of a facing made before the removal of the painting from its stretcher:

\footnotetext{
"The paint is protected with paper, stuck on by rabbit-skin glue and molasses. Japanese paper No. 500 is used because of its absorbent qualities - which in other types of paper are not entirely satisfactory. Exploiting this particular absorbent quality we can spread the glue, placing it on top of the paper and not yet directly on the paint; this allows the facing paper to be applied to paintings whose pictorial layer is completely detached from the support. The adhesive for facing is mixed with molasses in the proportion of $45 \%$ to increase elasticity." (Baldini and Taiti 1974 cit. in Villers 2003).
} 
According to the authors, this facing had a protective and non-consolidating purpose, because given the uneven porosity and absorbency of the pictorial film due to the presence of cracks and different backgrounds, the adhesive could not be distributed evenly below the pictorial film. The consolidation, in the traditional Florentine lining, was carried out in a second phase from the back, with the same adhesive used for facing. It worth to notice that even if the facing was not used with consolidating purpose, the adhesive penetrated anyway, even if unevenly.

The passages described by Baldini and Taiti are very reminiscent of the facing described by Forni in his manual in 1866. In fact, Forni also used a very thin paper, and for the consolidation, which in the case of canvas paintings was made from the back, he prescribed the use of the same animal glue added with honey. There is another analogy, not described by Baldini and Taiti, which can be found in the article by Laroche and Saccarello (1996). In fact, according to the Florentine tradition, the paintings with a water-sensitive ground or pictorial film were coated with an alternative system, which traditionally consisted in the use of a mixture of beeswax and resin dammar (then replaced by Plexisol P550 dissolved in mineral spirits). This particularity is very reminiscent of what had been described by Forni in his 1866 manual, where the author prescribed the use of a mixture based on oil-resinous substances, such as copaiba balm. This is why the practice of using a facing based on non-aqueous materials was adopted in the Florentine laboratory, even if the wax-resin technique may have been learned following collaborations with restorers from France and Belgium after the flood.

It is therefore possible to assume that the facing traditionally employed at the OPD was the result of a simple continuation of a practice that was already in use in the nineteenth century in Florence.

With regard to traditional Italian facings, it is worth highlighting another analogy, namely that existing between that described by Secco Suardo and the facing used for the traditional glue-paste lining at the ICR in Rome. In fact, the colletta $^{74}$ recipe used for Roman facing is very similar to the one that Secco Suardo prescribed to spread on the painting before applying the facing, in order to consolidate the pictorial film. Even the paper that was traditionally used at the ICR was similar: a Kraft paper (namely carta da modello), with a weight of 35

\footnotetext{
74 The colletta recipe is the following: $3 \mathrm{~kg}$ of bone glue (called cervione); $2 \mathrm{~L}$ of water; $2 \mathrm{~L}$ of white wine vinegar; $750 \mathrm{~g}$ of refined molasses; $0.25 \mathrm{~L}$ of ox-gall; $0.3 \%$ of fungicide. Once prepared, the glue can be kept in the refrigerator for a few weeks, or it can be left to dry in the air to be able to keep it longer. In this case, or its reactivation it is left to swell in water, before diluting it at the time of use. As for animal glues in general, it is not possible to provide an exact dilution, because the adhesive strength depends on the quality and degree of purification of the glue used. According to tradition, the collection must 'sing', that is, it must emit a crystalline sound when the brush is lifted from the container the glue falls in it, so it must be very fluid.
} 
$\mathrm{g} \cdot \mathrm{m}^{-2}$, which had to be wet before being applied to the painting. Because of the thickness of the paper, the adhesive was spread over the painting before applying the temporary support, which was adhered by rubbing the surface with a soft brush. Furthermore, also in this case, it was not used an alternative technique in the case of water-sensitive paintings, while a coating was applied with an insulating function.

It is plausible that the choice to use this facing derived from the widespread use of the Secco Suardo manual, published on several occasions and widely known by many Italian restorers. However, the principal reason why the colletta facing was employed at ICR probably depends on the fact that when the Institute was founded, the head restorer was Mauro Pellicioli, native of Lonno di Nembo in the province of Bergamo and custodian of the Bergamo restoration techniques (Rinaldi 2014).

However, there was a significant difference between the facings described in the two nineteenth-century manuals and those adopted in the 70s by the two main Italian restoration Institutes. In fact, in the first case the consolidation phase and the protection phase were two distinct phases. First, a consolidating agent was applied on the front of the painting (parchment glve by Forni, colletta by Secco Suardo) and then it was applied the facing with protective purpose, made with paper (carta velina in the case of Forni and a thicker paper for Secco Suardo) and glue starch. It was applied also to provide the right degree of humidity to the animal glue and to allow its better penetration during ironing. It is therefore possible to assume that over time there had occurred a synthesis of the two steps and that the starch and flour glue had been substituted by the sole animal glve, renouncing to the dichotomy, albeit only theoretical, between consolidation and protection. However, both the facings became very popular, in particular that of Secco Suardo, so much to be described in the most recent manuals.

According to a questionnaire submitted to Italian restorers in 2015, these two facing techniques are still the most popular (Alba and laccarino 2016). Furthermore, it seems that the choice between the two techniques derives from geographical context of the restorers' educational path. This highlights the uncritical use of facing and the scarce consideration that is still given to this operation, at least in the Italian context. Otherwise, it would not be possible to explain the extensive use of an adhesive with the characteristics of colletta, made with the animal glue with the worst characteristics, the bone glve (Schellmann 2007), consisting of a mixture of an excessive number of natural materials, which characteristics are difficult to detect with accuracy, with an aggressive $\mathrm{pH}$ and strongly coloured. 
The publication of "Problemi di Conservazione" and the Greenwich Conference represented in a certain way a fundamental step in the evolution of the relationship between conservation and science born in the late $19^{\text {th }}$ century, which led to the organization of the 1930 IMO Rome conference. However, there were substantial differences with the positivist approach of the $19^{\text {th }}$ century. With the end of the 60s, it started an era in which there were no certainties, dogmas and maximum systems. It was the era of the post-modernism, characterized by a disenchanted reinterpretation of history and the abandonment of large projects developed starting from the Enlightenment. The awareness of the relativity of our actions growth and restorers started to be aware of the transience of their interventions. Concepts such as 'retractability' (also understood as simple respect for freedom of intervention for those who come later) and 'reversibility' gained importance, with the awareness that this represented an aspiration rather than a truly achievable goal (Seeley 1999). A less invasive approach was developed, that of 'minimal intervention', devoted to acting consciously on the work of art, trying to limit the most invasive direct operations when not necessary. This orientation consolidated in the Anglo-Saxon nations around the 1980s, while it was assimilated more slowly in the Mediterranean and Latin American regions, where it remained connected to aesthetic theories (Muñoz-Viñas 2005).

\subsection{THE $21^{\text {ST }}$ CENTURY AND THE LAST SHAKY DEVELOPMENTS}

In the 1970s it started the theoretical and technical review of conservation materials and methods that continues still today. Efforts have been made to understand and catalogue what has been and is still done, through the support of specialists from different sectors, to overcome the difficulties inherent the interdisciplinarity of the conservation field. In order to avoid generalised and nonessential interventions, numerous researches have been carried out on those topics that had previously been overlooked because apparently of a minor entity, such as tear mending or punctual consolidation, or the wider topic of cleaning, retouching and coating materials. Unfortunately, unlike other topics, the theme of facing has almost never been taken in account. Recent literature including the most recent restoration handbooks and conservation journals offer little to no information on the materials and techniques used for facing or the reasoning behind the decision to face a painting. 
Fortunately, something has changed in recent decades: some restorers have been starting to think about the real necessity to recover this operation and facing with characteristics for the specific needs of a paint are being designed. The idea that it is not possible to continue thinking at facing as an easy and safe solution is spreading nowadays, and there are several restorers who try to find solutions aimed at different needs. Unfortunately, only a few part of these reflections and experiences have been published in conservation journals and congress proceedings. The few published articles have not managed yet to draw the attention of the scientific community and to turn up a written debate on the theme. It is still necessary to find information on the facing techniques, and in most cases, it is necessary to consider the silences to speculate on what could be the thought by those few authors who have dedicated themselves to the topic. These sporadic appearances of facing as a relevant topic in an article have fallen on deaf ears, like words spoken in a desert.

This is the case, for example, of one of the most significant articles explicitly dedicated to facing, written by Paolo Cremonesi, Maria Fratelli and Davide Riggiardi, on the occasion of the National Conference of the Italian Group of the International Institute for Conservation (IGIIC) in 2006, entitled "Opere senza veli - Le criticità delle velinatura dei dipinti e le alternative possibili" (Artworks without veils - The criticalities of facing on paintings and possible alternative). In this article, the authors appealed to the restorers' community, highlighting the consequences and risks of facing, indicating possible alternatives in order to awaken them to a more prudent use of this operation.

The article opens with a definition of facing and a description of its possible uses. This is how facing is defined:

"Facing is done by adhering a light support material to the front of the painting in order to fix the detached or raised polychrome. The pictorial surface is generally protected with Japanese paper (or with very thin materials), glued with a natural or synthetic adhesive. This is an operation to safeguard the pictorial film, which is carried out both for preventive purposes and as a phase of the restoration intervention, to avoid that during some procedures (lining, cleaning the back, etc.) part of the colour may rise and fall. It is also a method of consolidation, partial or total." ${ }^{75}$ (Cremonesi, Fratelli and Riggiardi 2006).

\footnotetext{
75 Translated from Cremonesi, Fratelli and Riggiardi 2006: "La velinatura si effettua facendo aderire un leggero materiale di supporto al fronte del dipinto in modo da fissare la policromia distaccata o sollevata. La superficie pittorica viene protetta generalmente con carta giapponese (o con materiali molto sottili), incollata con un adesivo di origine naturale o sintetica. È questa un'operazione di salvaguardia del film pittorico, che viene eseguita sia a scopo preventivo che come fase dell'intervento di restauro, per evitare che, durante alcune procedure (foderatura, pulitura del retro, ecc.) parte del colore possa sollevarsi e cadere. È anche un metodo di consolidamento, parziale o totale".
} 
According to the authors, in most cases facing is used as a useful tool to stop or prevent damage in case of emergencies or transport, or even to safely handle a painting during some stages of the intervention. They also specified the partial or total consolidation action of facing, in combination with the traction of the paper and the adhesive during the drying phase, which helps to lower the colour flakes made more plastic by the humidifying action of the adhesive.

Attention was then drawn to its disproportionate use of the last decades, also in the preliminary stages of control and conservation of entire collections of paintings, as it happened and still happens for the facing campaigns implemented by public institutions and museums, as tools of prompt emergency when there is no time or money for a complete intervention. They believed, with good reason, that facing was considered as a temporary remedy for the lack of time, equipment and funds for a decisive intervention. However:

"The haste to secure the works can be the cause of irreversible degradation and the choice of an emergency operation which, although being the most economic at the moment, implies a risk of having an impact on the cost of the subsequent restoration [...], given the implications and difficulties that this entails."76 (Cremonesi, Fratelli and Riggiardi 2006).

For this reason, the restorers advised to select in advance the adhesive and the solvent for the application and removal of the facing, as well as the most appropriate application methodologies. In fact, a poor evaluation of their chemical-physical characteristics in terms of suitability and compatibility with the constituent materials could cause the swelling and morphological alteration of the materials, the removal of the colour glazes, the irreversible adhesion of the facing.

The prolonged permanence of facings on paintings, which unfortunately happens with a certain frequency, is always inadvisable. In fact, the application of a layer extraneous to the painting, either hydrophilic or lipophilic, inevitably changes the chemical and mechanical characteristics of the surface that remains in contact with the environment, altering the balance of the internal forces of the painting. The facing layer could even become the most hygroscopic in the stratigraphic sequence of the painting, while usually the outermost layer (the paint) is the one with the least hydrophilic/hygroscopic character and therefore less frequently it is responsible for the onset of biodeterioration. In addition, oxidation and crosslinking reactions of the

\footnotetext{
76 Translated from Cremonesi, Fratelli and Riggiardi 2006: "La fretta di mettere in sicurezza le opere può essere causa di degradi irreversibili e la scelta di un'operazione di emergenza al momento più economica rischia di ripercuotersi sul costo del successivo restauro [...], viste le implicazioni e le difficoltà che questa comporta".
} 
restoration materials may arise over time, which would cause a decrease in solubility compromising the reversibility of the treatment. The adhesive should be able to continue being reactivated completely with a small amount of solvent, because otherwise there would be the risk that the paper will tear the paint film or that residues remain on the surface. For example, in the case of the removal of an unaltered animal glve, which still needs a large supply of hot water, the authors recommend using an aqueous gel to limit the heat input and increase the surface action. However, in the case of an altered animal glue, acidic or basic solutions or enzymes may be required. However, it is specified that the reversibility of synthetic adhesives also decrease over time, making it necessary to use more polar solvents.

No less danger derives from local facings left for long periods, cause of a localized variation of the refractive index, but above all of localised mechanical tensions. It is clear that the longer a facing is left on a painting, the greater the risks that will be taken.

Another aspect reported by Cremonesi and his colleagues is the cleaning effect that occurs with the application and removal of the tissue. For example, they pointed out that several biocides contained in some glves are surfactants. However, solvents used for application or removal can also have the same effect. This action is not necessarily harmful, and it could be even captivating because it allows performing 'two-operations-in-one', as already stated by Secco Suardo in his nineteenth-century manual. However, the authors warned readers, because the resulting cleaning is a 'parasitic action', uncontrollable because it is not an operation itself, aimed at a single purpose.

To the explanation of the risks of facing, it follows the illustration of some less invasive alternative methods, such as the punctual consolidation that permits to apply the adhesive only where it is needed and not on the entire surface, interposing the paper during application if necessary. However, this last solution would still lead to an uncontrollable cleaning action and it would prevent seeing the surface during the operation. Another valid method would be that of application by spraying, possibly combined with the use of the low pressure table to increase penetration. For the consolidation of the entire surface they proposed the alternative of consolidation from the back, which is however often used in these cases. However, as the authors rightly claimed, this operation requires the same caution necessary for facing. In fact, it is always necessary to question the changes in the mechanical properties of the substrate caused by the introduction of restoration materials and the degenerative processes triggered with aging. The last alternative provided for temporary fixing was the use of a volatile consolidant such as cyclododecane (Cremonesi, Fratelli, and 
Riggiardi 2006). According to their paper, written when the Cyclododecane was still an absolute novelty, this type of consolidation could be very useful to transport a painting or in cases of urgent interventions on a large scale, such as natural disasters, or waiting for funds for a more decisive intervention. As it will see later, this statement appears today dictated by a perhaps excessive enthusiasm for a material whose use has implications that have not yet been analysed with sufficient attention or lucidity.

Other solutions listed by the authors concerned interventions involving the use of humidity and pressure, in order to reduce the pictorial deformation (e.g. supply of humidity and pressure on the front), or to reduce the deformations of the support (e.g. low pressure table, differential tension by means of elastic tears in correspondence of lacerations). However, it is considered of worth to specify that it is good to act with extreme caution, even if these systems have the advantage to not introduce materials extraneous to the painting. In fact, it is necessary to carefully evaluate the effect of humidity or liquid water not only from a purely chemical aspect, but also from the mechanical point of view, reflecting on the dimensional variations and the forces that are generated in the constituent materials.

In conclusion, according to the authors it is always important to evaluate case by case which is the most appropriate solution according to painting state of conservation, without taking refuge in the usual practices. It is important to reflect on the real need for such treatments, which could have an impact greater than that of the extent of the existing damage:

"Is it likely to affect more the problem to be treated or the treatment consequent to facing that must be compulsorily extended and generalized to the whole surface?"77 (transl. from Cremonesi, Fratelli and Riggiardi 2006).

With this article Cremonesi Fratelli and Riggiardi tried to bring attention to an operation that has not yet been seriously considered as others as a real intervention, that implies a consolidating action, which in addition, must be further 'handled'. The intent of the article was to stimulate reflection on an operation whose importance and effects are still often overlooked:

"Even the common methodologies, the ordinary operating practices must be rethought and re-evaluated, every time, in their effectiveness without being applied slavishly. The lack of bibliography on the subject of facing is already a witness of how much this operation has not yet been sufficiently investigated and

77 Translated from Cremonesi, Fratelli and Riggiardi 2006: "Rischia di incidere di più il problema da trattare o il trattamento conseguente alla velinatura che deve essere obbligatoriamente esteso e generalizzato a tutta la superficie?" 
carefully evaluated in the methodology, in the case studies, and in the materials."78 (Cremonesi, Fratelli and Riggiardi 2006).

Unfortunately, despite the alarm raised by the authors, the hoped-for debate was not followed neither nationally nor internationally. Even today, there are few cases in which there has been systematic interest in the protection of the front of the painting. An exemplary case is that of cyclododecane, introduced in the field of conservation by Hans Hangleiter and Erhard Jagers in 1995 with the name of 'volatile binder'. It is a saturated acyclic hydrocarbon with similar properties to wax (or perhaps rather to camphor), which has the important advantage of sublimating from solid to gas. Sublimation can be explained by the compact shape and non-polar character of the molecules, which leads to low cohesion in the solid material. It melts at $58-61{ }^{\circ} \mathrm{C}$ and solidifies from the molten state in a compact and water-repellent layer. It is not soluble in water or in polar solvents such as ethanol and acetone, but dissolves very well in the most non-polar saturated, aromatic or halogenated hydrocarbons. Due to its stability and insolubility, it is not harmful to the environment and aquatic organisms. It is not known to be toxic to humans and animals, although perhaps it would be necessary to investigate this topic further. It can be applied in different forms (melted, as a saturated solution and as an aerosol) and each application mode allows to obtain layers with different characteristics and mechanical properties. Its ability to sublimate has led many restorers to research and test its applicability for several purposes. Great interest was paid to its applicability as a temporary consolidant of the pictorial surface, replacing the facing (Hangleiter and Jagers 1995).

To achieve a light surface protection, probably the best method of application is in the aerosol state. The description of the characteristics of the aerosol cyclododane is provided by Hans Hangleiter and Leonie Saltzmann:

\footnotetext{
"For most aerosols the propellant is propane or butane. The peculiarity of cyclododecane aerosols is that the propane-butane liquid is both propellant and solvent. As soon as the propane-butane cyclododecane solution is nebulised, the propellant evaporates rapidly and the cyclododecane remains as a white amorphous residue. Sprayed on the surface, the cyclododecane will form an amorphous white layer that hardens when the propellant evaporates. These types of layers cannot be penetrated by water, but are permeable to other polar solvents. They dissolve easily in non-polar solvents, are fairly stable to pressure and abrasion and show good elasticity. [...] Cyclododecane applied as an aerosol

78 Translated from Cremonesi, Fratelli and Riggiardi 2006: "Anche le metodologie ordinarie, le prassi operative ormai consuete devono essere ripensate e rivalutate, ogni volta, nella loro efficacia senza essere applicate pedissequamente. La mancanza di bibliografia sul tema della velinatura è già una testimonianza di quanto questa operazione non sia ancora stata a sufficienza indagata e attentamente finalizzata, nella metodologia, nella casistica, e nei materiali".
} 
does not completely penetrate the structures and is not recommended for consolidation. Due to the very large surface of the amorphous material, sublimation is much faster than on fusion-formed films. A $1 \mathrm{~mm}$ layer can evaporate in 2-3 days or can be easily removed with a hot air gun or solvent."79 (Hangleiter and Saltzmann 2008).

This application method has also been used to create facings with the application of an interim membrane. For example, Leonardo Borgioli, Enrica Boschetti and Arianna Splendore (2009) published the report of an intervention in which a cyclododecane facing was used for the removal of a glve-paste lining that had also caused numerous adhesion defects of the pictorial layer, requiring a facing. According to the authors, all 'traditional' systems (for example rabbit glue or Beva 371) had contraindications because they needed an aqueous vehicle or a solvent to be applied, thus making it difficult to control the penetration of the adhesive and the permanence of the residues. The use of cyclododecane spray would not have required an additional supply of solvent for the removal of the tissue and seemed to eliminate the problem of the permanence of the residues. The use of a hydrocarbon would have made it possible to remove the lining and proceed with cleaning the substrate with aqueous gelled media while keeping the paint film safe. To make the layer more compact and resistant, they chose to proceed with its fusion also taking advantage of an interim tissue to keep the material on the surface and to increase its elastic power thanks to the fibres of the tissue itself. Therefore, after having applied the cyclododecane on the whole surface, they positioned the painting on the low pressure table and placed on the surface with cyclododecane first a tissue and then a sheet of silicone coated polyethylene terephthalate film (Melinex®). The applied pressure was the minimum necessary to obtain good adhesion, heating the surface with the aid of a dryer without exceeding the $60^{\circ} \mathrm{C}$. It was decided not to heat the table to prevent prolonged and constant heat from favouring the penetration of the cyclododecane. The facing has been removed by favouring the sublimation of the cyclododecane through a slight passage of air on a low pressure table (Borgioli, Boschetti and Splendore 2009).

\footnotetext{
79 Translated from Hangleiter and Saltzmann 2008: "Per la maggior parte degli aerosol il propellente è propano o butano. La particolarità degli aerosol di ciclododecano è che il liquido propano - butano è propellente e solvente al tempo stesso. Non appena la soluzione di ciclododecano in propano-butano viene nebulizzato, il propellente evapora rapidamente e il ciclododecano resta come un residuo amorfo bianco. Spruzzato sulla superficie il ciclododecano formerà uno strato bianco amorfo che indurisce quando il propellente evapora. Questi tipi di strati non possono essere penetrati dall'acqua, ma sono permeabili ad altri solventi polari. Si disciolgono facilmente in solventi apolari, sono abbastanza stabili alla pressione ed abrasione e mostrano una buona elasticità. [...] II ciclododecano applicato coma aerosol non penetra del tutto nelle strutture e non è raccomandabile per il consolidamento. A causa della superficie molto ampia del materiale amorfo la sublimazione è molto più veloce che su film formati da fusione. Uno strato di $1 \mathrm{~mm}$ può evaporare in 23 giorni o può essere rimosso facilmente con una pistola ad aria calda o solvente."
} 
A facing system for handling the paintings was suggested by Hangleiter and Saltzmann. The method involves the preventive preparation of the Japanese paper used for the facing:

"Cyclododecane can be sprayed on Japanese paper and ironed between two hostaphane films. As soon as the cyclo-dodecane becomes rigid, the drained paper can be cut into pieces and applied on sensitive surfaces with a heated spatula. With this method, the cyclododecane film is very thin and evaporates in a few days leaving the surfaces unaltered for storage." 80 (Hangleiter and Saltzmann 2008).

These two experiences show the great advantages of using cyclododane for the protection of the front of the painting. It should be borne in mind, however, that cyclododecane is not an easy-to-use material and that it would be better to know it better before applying it on a work of art. In particular, cautions seem necessary for organic materials such as the binders used for easel paintings, with which the organic molecule of cyclododecane could establish interactions or bonds that are still little investigated. Still few publications underline how further tests are necessary to explore this aspect to assess the risk of solubilisation or leaching of some components of the paint layer (Papini et al. 2018).

For the fresco wall paintings, or rather for the stone, the stuccos and the mosaics, probably the tranquillity with which it is generally used seems more justified.

The characteristics of the film that this material forms are strongly influenced by the application method. In fact, when applied in the state of aerosol on the surface, without a consequent supply of heat, it does not present great cohesion or adhesion to the support. It can therefore be applied in this way in the case of a transport, but not in the case in which subsequent mechanical operations are foreseen, such as for example a cleaning of the back of the painting. For mechanical interventions, restorers usually prefer to use cyclododecane to make a facing with an interim membrane. However, in order to obtain a film adhering to the substrate and capable of incorporating the interim support, it is possible to apply it diluted in solvent or in the form of an aerosol, but it is then necessary to melt it, with similar methods to those described by Borgioli, Boschetti and Splendore. If this process is done without a containment film, part of the

80 Translated from Hangleiter and Saltzmann 2008: "Il ciclododecano può essere spruzzato sulla carta giapponese e stirato tra due film di hostaphane. Non appena il ciclododecano diventa rigido, la carta drenata può essere tagliata a pezzi e applicata su superfici sensibili con una spatola riscaldata. Con questo metodo il film di ciclododecano è molto sottile ed evapora in pochi giorni lasciando le superfici inalterate per la conservazione". 
cyclododecane sublimates, therefore it is advisable to carry out this operation under vacuum, and it is necessary to apply the right amount of material.

The speed and completeness of sublimation still remain problematic. There are many variables involved in the sublimation process and, therefore, it is difficult to calculate how long the material can perform its consolidating function while remaining in the solid state. For this same reason, it seems difficult to reliably predict when the material in which it has been inserted will have recovered its initial characteristics of polarity following the complete sublimation of the nonpolar cyclododecane. There is a risk that most of the material will sublime too quickly by missing its fixative function earlier than necessary. In a precarious situation such as the current ones, in which the deadlines for the delivery of the works are not always respected, all the permits can be obtained in time and that the drafted projects are put into practice, it cannot be done always relying on a material such as cyclododecane. Another problem is related to the permanence of the residues. In fact, it seems that even in cases where the painting is placed in ventilated rooms or its surface is heated, it is not easy to obtain a total sublimation of the cyclododecane, which remains within the pictorial film and the other constituent layers hinders the execution of interventions with polar materials (Papini et al. 2018).

However, apart from the research carried out on this new material, there are no other recent systematic research on painting protection techniques. Even in the most recent conferences on the conservation of canvas paintings supports, and therefore inherent in the operations of lining, transport, cleaning of the back that have always provided for the use of facing, it is not easy to find extensive and reasoned references on facing. This is the case, for example, of the International Conference on Painting Conservation held at the Universitat Politècnica de València in March 2005. Even in this case, despite the interesting contributions of renowned restorers from all over the world, few restorers spoke expressly, widely and specifically of facing, as Giovanna Scicolone and Matteo Rossi Doria.

The noteworthy aspect of Scicolone's reflections was more inherent in the theoretical-enunciative plane than in the purely practical one. In her speech at the International Conference on Painting Conservation held in Valencia in 2005, Scicolone brought attention to the functions of facing and the purposes for which it should be performed. According to the restorer the facing has always been defined as the method to consolidate the powdery or flaking colour. However, it must be considered that it is not the tissue that performs the consolidating function, but the adhesive. It is therefore necessary to conceptually and methodologically separate the consolidation operation from 
that of facing. As the restorer stated, facing constitutes a temporary protection structure for constituent parts of the work, or portions thereof, which must undergo dangerous manipulations. It must therefore only be carried out when the artwork must undergo a transportation (for restoration or displacements) that is absolutely inevitable and that could affect to its conservation. Thus the facing, widely used in traditional restoration, is presented as an exceptional intervention in restoration carried out with a 'contemporary' approach. Indeed,

"If the purposes of the different phases of conservative restoration are clarified, it will become impossible to plan operations that are not unequivocally intended to solve those only conservative problems present in the work."81 (Scicolone 2005).

It is therefore important to define in advance some parameters that allow to evaluate the need and the modalities of execution of a facing. The identification of these evaluation parameters also allows to share choices and compare them with those of other restorers, based on objective data. In this regard, the restorer reports a list of the parameters she selected for the facing:

- The parameters concerning the feasibility cases;

- The evaluation parameters for the choice of the adhesive;

- The parameters concerning the choice of the support medium (those for the chemical type, thickness, porosity, consistency);

- The evaluation parameters for choosing the application method.

Unfortunately, since it is an article in which the broader topic of interventions on canvas supports is treated, no further practical indications or recommendations followed this list, but it would be interesting to deepen the topic from this point of view. Some additional information can be found in a book written by Scicolone in 1991 on the restoration of contemporary paintings. It is possible to find some references to facing related to the consolidation and the lining. In this regard, it is interesting to consider facing from the point of view of the restoration of contemporary paintings, for which additional precautions regarding the aesthetic aspect of the work of art are necessary in case of restoring an uncoated painting, whose paint layers have a heterogeneous appearance. As the restorer wrote, the application of an adhesive would change the refractive index, saturating the colours or making them brighter, irreversibly changing the original optical effect and thus irremediably damaging the work of art. Scicolone was, however, aware that sometimes the facing can be indispensable. In these cases, according to the author, an adhesive that did not alter the refractive index of the painting could be used. However, it is

\footnotetext{
81 Translated from Scicolone 2005: "se si chiariscono gli scopi delle diverse fasi di restauro conservativo diventerà impossibile progettare operazioni non destinate inequivocabilmente alla soluzione di quei soli problemi conservativi presenti nell'opera".
} 
considered appropriate to underline the difficulty in selecting the adhesive based on a specific refractive index, which makes this advice not very useful from a practical point of view, as well as using very low percentages of adhesive, which, however, would be insufficient to perform its dual protective and consolidating function. The solution of performing the facing and then reestablishing the refractive index with the application of specially designed mat varnishes is also questionable.

Finally, the importance given by the restorer to the choice of paper, which must be done, needs to be underlined:

\begin{abstract}
"Taking into account the following parameters: thickness, softness, texture, adaptability, flexibility. It must be soft and resistant, since its function is not only protective: it also serves as a tensioning membrane; it must not leave facing patterns on the film (remember however that in addition to the thickness of the tissue, the density of the applied glue significantly accentuates the risks of fingerprints); it must be sufficiently protective against all those stresses, and those mechanical damages the work undergoes during the lining phase; it must be able to adapt perfectly also structurally to the most uneven surfaces and must not deform during use or drying or create tension; it must be uniform and easy to remove."82 (Scicolone 2005).
\end{abstract}

The restorer's reflections on the facing and the unusual space given to the topic in an article dedicated to the structural operations on a painting on canvas, as well as the importance given to the choice not only of the adhesive but also of the type of paper are indicative of the interest in this operation. However, these are reflections that cannot be considered comprehensive and complete as in the case of the article by Cremonesi and his colleagues, but rather indications that indirectly invite to reflect on the issue. There is no desire to criticise the restorer's thought, who thanks to her experience will surely have a global vision on facing, being indeed one of the few who have reserved an unusually large space on the topic. Actually, it must be highlighted the fact that still in this context the exposition of the concepts related to this operation in a comprehensive and global manner are still not felt as a need.

Matteo Rossi Doria is probably one of the few restorers who reported his reflections about the facings he used in his contributions to various congresses. In

\footnotetext{
82 Translated from Scicolone 2005: "Tenendo conto dei seguenti parametri: spessore, morbidezza, tessitura, adattabilità, flessibilità. Deve essere soffice e resistente poiché la sua funzione non è solo protettiva: serve anche come una membrana tensionante; non deve lasciare impronte sulla pellicola (ricordo comunque che oltre allo spessore della velina, è la densità della colla che si applica ad accentuare notevolmente i rischi di impronte); deve essere sufficientemente protettiva nei confronti di tutte quelle sollecitazioni, di quei danneggiamenti meccanici ai quali va incontro l'opera durante la fase di foderatura; deve potersi adeguare perfettamente anche strutturalmente alle superfici più irregolari e non deve deformarsi durante l'utilizzo o l'asciugatura né creare tensioni; deve essere uniforme e di facile rimozione".
} 
fact, in his presentation at the 2005 International Conference in Valencia focused on conservative issues and methodological solutions adapted to outsize paintings, a sensitivity and an unfortunately uncommon foresight emerged regarding the topic of facing. Rossi Doria was aware of the numerous factors that influence the work of most restorers, such as the character of the local technical culture, the environmental, logistical and organizational implications and the economic resources invested. He also recognized the need to be able to deal with all the methodological hypotheses and above all with those that favour the minimal intervention on such fragile and delicate artefacts too often damaged by drastic and unsuitable methods:

\begin{abstract}
"A greater knowledge of researches and studies, minimal intervention, scheduled maintenance and preventive conservation push us to a more thoughtful and prudent approach. Therefore, the need to encourage a serene reflection on these issues appears evident, enhancing the communication between the operators, and stimulating the institutions responsible for the protection to pay greater attention to all the phases that make up the restoration project."83 (Rossi Doria 2005).
\end{abstract}

However, as stated by the author, restorers are often forced to adapt and tackle problematic situations in emergency conditions that are almost never optimal, seeking a satisfactory balance between the different needs of good success, economic compatibility, organization logistics and availability of materials. For this reason, it is always important, especially in the case of the restoration of outsize paintings, to evaluate carefully some executive phases. Among these, there is the facing performed as a preliminary operation on large paintings that must be rolled up for transport. The choice of the facing application method and its easy removal are very important elements that must be appropriate for the characteristics of the constitutive materials without affecting subsequent operating phases. The project must also evaluate the ease of application in conditions that are almost never optimal, the toxicity of the solvents used, the right proportions between the consolidant and the solvent. According to the author, on non-depolymerized oil paintings on canvas, it is possible to resort to the traditional facings with animal glues, while for other types of paintings, such as tempera or other water-sensitive artworks, alternative solutions must be used, (i.e. synthetic materials).

\footnotetext{
83 Translated from Rossi Doria 2005: "Una maggiore conoscenza delle ricerche e degli studi, il minimo intervento, la manutenzione programmata e la conservazione preventiva ci spingono ad un approccio più meditato e prudente. Appare quini evidente la necessità di incentivare una serene riflessione a tutto campo su questi temi, potenziando la comunicazione fra gli operatori, e stimolando gli enti preposti alla tutela ad una maggiore attenzione a tutte le fasi che compongono il progetto di restauro.
} 
An alternative solution is the one that the restorer used to transport the tempera preparatory cartoons for the Barberini tapestry (1640-1680) painted various artists including Pietro da Cortona. The linings made in 1963 were no longer suitable to perform their function and a replacement was therefore necessary. Given the state of conservation, it was necessary to create a protective facing, a fact confirmed by the negative results of the tests conducted to proceed with a lining removal without protecting the painted surface. The specific characteristics and the great sensitivity of the pictorial material prevented the use of traditional and synthetic adhesives soluble both in water and in aromatic solvents. In this case, therefore, after tests conducted to check the variation of the refraction and the colorimetric indices, it was decided to use a rather dense Klucel $G$ alcohol solution (unfortunately, the percentages are not reported) and a polyamide paper. At the end of the intervention, the tissue was removed with cotton wool and pure alcohol swabs.

However, the specialisation field of Rossi Doria is that of traditional practices. In fact, he conducted researches on traditional lining methods, both from the point of view of materials and from that of application methodologies. His work consisted in revising various operational phases of lining, therefore also of facing with animal glves. Rossi Doria chose to use materials that differ slightly from those of the Roman and Florentine tradition. In fact, already in his presentation at the 2005 conference in Valencia, he brought as a further example the case of the facing made for the transport of The apostles dispute on the assumption of the Virgin by Francesco Bassano kept in the church of St. Louis of the French in Rome. In this case, the choice fell on a traditional facing using cold-applied modified Roman colletta and a polyamide paper.

More information on this kind of facing can be found in a more recent article, presented on the occasion of the $11^{\text {th }}$ National Congress of the Italian Group of the International Institute for Conservation (IGIIC) held in 2013. The type of paper that the restorer used instead of traditional Japanese paper or Kraft paper offered some advantages in the application and subsequent removal. The paper is called English tissue ${ }^{84}$ and it is a cellulose tissue paper submitted to a calendering process based on polyamide derivatives that increase its wetstrength, making it able to resist water and leave less residue during tissue removal (for more information, see Chapter 3).

\footnotetext{
84 The analyses to determine the composition and characteristics of the English tissue paper were conducted by Scott Williams (CCl Scientific Department) and Debra Daly Hartin of the Canadian Conservation Institute Ottawa. The supply comes from the Bresciani company of Milanocarta.
} 
Furthermore, the restorer chose to no longer use the 'ICR colletta' 85 traditionally used for tissue coating in the Roman area from which he came, but to use rabbit glve added with honey in varying percentages. The glve selected by the restorer, however, had to meet certain quality standards. In particular, he selected the type of glue on the basis of his degree of Bloom ${ }^{86}$, varying it according to the specific needs of the facing:

\begin{abstract}
"We can decide whether the facing should only provide protection, and therefore 'put' the glue only between the pictorial film and the paper or already begin at this stage to consolidate the paint layers. The solution lies in the control of the animal glue mixture used. In the first option, we can use a denser and therefore less penetrating glue, in the second 'facilitate' the penetration operating on the factor of the lower viscosity. The options are various: from the choice of a glue with high or medium-low Bloom values (from 300 to 150), to the application temperature (without cheating on the real ones) or to the addition of surfactants. The preconsolidation process can be managed later, trying not to wet the support, varying the drying times, handling the surface with localised or generalised pressure in the final setting stages."87 (Rossi Doria 2013).
\end{abstract}

The restorer explained that a glve with a higher Bloom had a lower penetration capacity and that applying it cold in the gel state it was possible to obtain a more superficial action. If it was necessary increase the adhesion, he suggested to add a small percentage of surfactants such as the Tween 20 to increase the wettability. However, these are theoretical hypotheses. For example, the use of a glve with a higher Bloom could allow to have a more superficial adhesion, but no researches have been carried out in this specific regard, therefore it is not possible to determine the effective reduction of the penetration of the adhesive, especially inside the cracks. Furthermore, since the pros and cons of each

\footnotetext{
85 According to the author, vinegar was used to limit the biological attack in the initial phase. Molasses increased the possibility of a biological attack due to its hygroscopicity, that increased the supply of humidity. 86 Bloom's strength is equal to the weight in grams (g) or Bloom grams (gB) that must be applied on a surface of a gel by means of a $12,7 \mathrm{~mm}$ diameter piston to produce a $4 \mathrm{~mm}$ drop; the gel must have a concentration of $6,67 \%$ and it has to be stored for $16-18 \mathrm{~h}$ at $10^{\circ} \mathrm{C}$. Before using an animal glue, it is useful to know the value of the stiffness of the gelled glue, i.e. its Bloom strength (gB). This usually has values ranging from $30 \mathrm{gB}$ for weaker glues to $500 \mathrm{gB}$ for stronger ones. Bloom's strength is influenced by various factors, including the average molecular weight of the constituent proteins, their degree of renaturation during gelation and the presence of salts that contribute to lowering this value. Since Bloom's strength depends on the factors that influence almost all the characteristics of the glues, knowing this measure it is possible to have an idea of the viscosity, the gelation temperature, the water absorption capacity of the glue, but also the hardness, strength and elastic modulus that the resulting joint will have.

87 Translated from Rossi Doria 2013: "Possiamo decidere se la velinatura debba fornire solo protezione, e quindi "posizionare" la colla solo fra film pittorico e velina 0 , invece, cominciare, in questa fase, a operare alla soluzione dei problemi di impoverimento. La soluzione risiede nella gestione della miscela di colla animale utilizzata. Nella prima opzione possiamo utilizzare la colla più densa, e quindi meno penetrante, nella seconda "facilitare" la penetrazione, operando sul fattore della minore viscosità. Le opzioni sono varie: dalla scelta di una colla con valori alti o medio-bassi di Bloom (da 300 a 150), alla temperatura di applicazione (senza barare su quelle reali) o all'addizione di tensioattivi. II processo di pre-consolidamento può essere gestito successivamente, cercando di non bagnare il supporto, variando i tempi di asciugatura, manipolando la superficie con pressioni, localizzate o generalizzate nelle fasi di presa finale".
} 
application phase must be assessed, it has also to be considered that a glue with high Bloom has higher reactivation temperatures.

Regarding the purposes of facing, Rossi Doria cited first the protection/preconsolidation dichotomy. In addition, according to the restorer during consolidation from the back facing acts as a barrier, preventing the solvent from migrating uncontrolled to the surface. However, it has to be noticed that even if the risk of an excessive impregnation is avoided by facing, there is always the risk of impregnating the surface with the adhesive used specifically for facing. A final function of facing was to reduce the deformations of the paint layers affected by an evident cracking phenomenon. According to Rossi Doria, glve glazing had the specific characteristic of optimizing the stabilization of surface deformations.

The study of traditional techniques is important because the understanding of traditional facing mechanism could also permit to improve the facing systems with synthetic adhesives. However, it has to be considered that animal glues have characteristics (e.g. ability to quickly gel even at room temperature) which are not found in any synthetic adhesive. Therefore, until synthetic polymers capable of reproducing the same characteristics as the glves are devised, it will not be possible to totally exclude them from the field of restoration. As the restorer stated:

\begin{abstract}
"Facing with animal glve remains and will remain a factual option and it should become the subject of a more in-depth reflection related especially to the management of emergencies, which often occurs in Italy. Many times, I have intervened on works damaged by seismic events, floods, vandalisms, extreme degradation, kept in deposits for years and decades. Although faced in the most wrong ways, these protections have had the ability to save the pictorial text and allow subsequent interventions."88 (Rossi Doria 2013).
\end{abstract}

Nevertheless, there are several witnesses of partially faced works that were stored for decades in museums deposits, under thermo-hygrometric variable environments, which were heavily affected by the presence of a hydrophilic and hygroscopic layer superimposed on the pictorial film, as described by Cremonesi and his colleagues. Therefore, it should be necessary to improve the performances of affordable techniques, made with easily available and not too much expensive materials. To do this, it would be necessary to carry out researches aimed to objectively compare the characteristics of different facings,

\footnotetext{
88 Translated from Rossi Doria 2013: "La velinatura a colla rimane e rimarrà una reale opzione ed è bene che diventi oggetto di una riflessione più approfondita soprattutto nella gestione delle emergenze, che l'Italia spesso produce. Molte volte sono intervenuto su opere danneggiate da eventi sismici, alluvioni, vandalismi, degrado estremo, custodite in depositi per anni e decenni. Sebbene velinate nelle maniere più sbagliate, queste protezioni hanno avuto la capacità di salvare il testo pittorico e consentire successivi interventi".
} 
in order to determine which could be the most suitable in a given situation. This responsibility should no longer be left to individual private restorers, who cannot afford extensive and complex researches, due to the lack of time, money, equipment and obviously a lack of a universal knowledge of all technicalscientific aspects. These researches should be conducted in large public institutions on an interdisciplinary level, through the collaboration of the various professional figures who deal with the conservation of cultural heritage.

This unusual episode happened for the restoration of the five canvases that cover the ceiling of the Galería Dorada of the ducal palace of Gandia for over $200 \mathrm{~m}^{2}$ of surface managed by a research team of the Instituto de Restauración del Patrimonio of the Universitat Politècnica de València (Martín-Rey, GuerolaBlay and Catell-Augustí 2010). To deal with oversize paintings forces to reflect longer and in more depth on how to carry out the restoration operations. The greater risk of causing damage to the work and the greater economic resources available for projects of great importance can be an excellent opportunity to conduct experiments, which in daily application practice are not always feasible. In this occasion, it was possible to conduct studies and preliminary tests on all the operations to be carried out on the painting. The research team developed an organic and controlled project, ensuring the conservation for the future of emblematic and unique works in the Valencia Region.

The restoration carried out from June 2009 to December 2010 was particularly complex due to the need to remove the artworks from their original location without intervening on the large golden frames that enclosed them, whose light was too limited for the passage of the paintings. To reassemble them, the possibility of creating a technical compartment in the upper floor with a system of rails and trolleys was used, which allowed them to be moved to their final position using a single room as an access (laccarino-Idelson and Serino 2012).

The technical and material complexity of the intervention favoured the development of quality controls that allowed to evaluate the intervention processes and materials to undertake the restoration works without risks, also with regard to those operations often overlooked, such as the facing carried out for the transport before and after the intervention (Castell-Augustí et al. 2010; MartínRey et al. 2012). It is in fact one of the few cases known to the author in which a carefully studied experimental protocol was followed to allow the physicalmechanical characterization of the materials used (adhesives and interim supports) and the adhesion between the substrates. In one of the articles published on this restoration work, the importance of a correctly performed facing in the aim of the painting preservation is explicitly declared: 
"The rheological interaction that occurs between the pictorial layers of a painting on canvas, and the materials used by the restorer in the treatment of colour protection, is essential as it is one of the most important procedures when dealing with the intervention of a painting."89 (Castell-Augustí et al. 2010).

The research was carried out by designing the analyses according to the current national and international standards such as ISO/IEC 17025: 2005 and the principles of ISO 9001:2000. They were adapted to the specific needs of the study in question, and obtaining valid analytical results, therefore with a defined and verified degree of precision and accuracy, and which were reproducible and repeatable.

The materials to be tested were selected according to the specific needs of the case. The main objective was to select high viscosity adhesive mixtures that would allow to reduce the supply of humidity and heat during the intervention. Given the large surface area of the paintings, great importance was given to the maximum reduction of the toxicity parameters, preserving the health of the restorers and the environment. In the same way, other issues were taken into consideration, such as the reversibility of the treatment and their material stability over time. The other parameters taken into consideration were the chemicalphysical (low dimensional variation, wettability and poor penetrability, mediumhigh viscosity) and mechanical (adequate adhesive strength assessed through peeling tests) parameters. According to all these needs, mixtures of high molecular weight base polymers (methylated acrylic dispersions of ethyl and methyl of Plextol B500 and Linecoß) and high viscosity thickening agents (cellulose ethers such as Klucel $\mathrm{G}$ and Tylose $\mathrm{MH} 300{ }^{\circledR}$ ) were selected. Deionised water was used as solvent for the various polymers and additives (Martín-Rey et al. 2012).

Interim supports were then selected among them that could allow an adequate response to the internal mechanical stresses provided by the natural movements of the pictorial film, with good properties of humidification, capillarity and adsorption. The Papier Bolloré and the non-woven fabric TNT 30B and TNT 54 were selected as possible temporary supports.

A large series of analyses were conducted on the individual adhesive components and their respective mixtures. Some of the characteristics of the materials considered most important were the properties of cohesion, flexibility, no modification of the pictorial surface, reversibility and good rheological

\footnotetext{
89 Translated from Castell-Augustí et al. 2010: "La interacción reológica que se produce entre los estratos pictóricos de una pintura sobre tela, y los materiales empleados por el restaurador en el tratamiento de protección del color, resulta fundamental al tratarse de uno de los procedimientos más importantes al abordar la intervención de una pintura".
} 
response to environmental changes. Some of the analyses carried out there were that of $\mathrm{pH}$, hardness, mass loss on drying.

The selected facings were tested on mock-ups reproducing the degradation of the original paintings, to carry out the mechanical tests and the analyses on the state of the surfaces after removal. The peeling tests allowed to obtain data on the adhesive and mechanical characteristics. The control analyses on the surfaces carried out with a photometer allowed to evaluate the variation of the surface of the paintings, before and after the protection, to obtain data on the percentage of adhesive residues on the pictorial layer.

According to the results obtained, a mixture of Klucel $G$ and Plextol B500 was finally selected, used in different percentages in combination with the TNT 50 for the facing applied before the restoration and before rolling up the paintings for the transport at the end of the intervention. In addition to giving positive results for everything related to low toxicity, compatibility with the painting, adhesive strength, the facings were made with mixtures that contained a quantity of Plextol B500 up to $30 \%$ proved to be easily reversible. However, on the paintings there were no used mixtures with a quantity of Plextol B500 higher than $15 \%$.

This short description gives an idea of the work just illustrated, which is unfortunately something extremely unusual. To the author knowledge, this is the only case in which a comprehensive and detailed organised research was conducted. The analyses were focused on the characterisation of the individual materials and their combination. Great attention was also given to the characteristics of the interim supports. It is a research done with the same seriousness and following the same methodological scheme that is usually reserved to the study of adhesives and materials used for operations considered more important, such as the lining.

As it will be possible to notice further, this research was of interest for the development of the current investigation, as another experimentation published by Leonardo Borgioli, Enrica Boschetti and Claudia Tortato in 2016, where the authors proposed an alternative facing based on remoistenable supports of Aquazol 500, used to protect the paint layer during the removing of non-polar linings. Further information on this method will be given in Chapter 3, dedicated to the description of the alternative facing method proposed for this investigation.

In conclusion, progresses have been made in the past few decades with regards to facing, but there is still a long way to go. Some private restorers have shown a greater, more reasoned and sincere interest in facing. There are also some cases of researches carried out by research teams of public institutions, 
aimed to choose the most suitable type of facing. However, these rather sporadic cases have still not find a concrete and continuous response in the scientific community. Attempts to make a contribution on the topic, the incitement to take this topic more seriously, have not been caught by the scientific community as deemed of a debate.

A demonstration is that of the case of the Conserving Canvas project, which is an international grant initiative focused on the conservation of paintings on canvas promoted by The Getty Foundation in the very last years. Conserving Canvas aims to ensure that conservators remain fully prepared to care for canvas paintings, even on lining techniques that have been progressively abandoned after the introduction of alternative methods. Even if the shift towards minimal intervention is positive overall, it has also produced a knowledge gap among today's museum conservators and curators in how to treat lined paintings. Reading the descriptions of the Grands awarded it and the programme of the symposium held in Yale University in the October 2019, no references to facing are detectable. It seems that nor in this important occasion for the study of the structural intervention on canvas paintings facing has been taken into account seriously and no complaint have been made on its problematic issues, nor innovative method have been proposed regarding this step of lining process. Unfortunately, the proceedings of the symposium have not yet been published, but it is hoped that there will be found some clues in the papers that prove the opposite of what was stated.

The new generations of restorers seem more sensitive to the topic. One of the studies to which it is referrred is that started by the author in 2014 with a Master's thesis at the University of Urbino in Italy (Alba 2015; Alba, and laccarino-Idelson 2016; Alba, laccarino-Idelson, and Martín-Rey 2017). Other restoration students in recent years have focused their postgraduate dissertations on facing, or in any case they have shown a greater sensitivity as regards the choice of the facing to be used in the restoration works presented for their theses. Among these, representative is a Final Year Postgraduate Dissertation presented at the Cortauld Institute of London in 2018 by Edward Battle, on the de-lining of BEVA 371 adhered polyester sailcloth, using the T-peel method, and on the possible effects of isinglass and Japanese tissue facings, to see whether their presence could affect results or mitigate possible damages (Battle 2018).

These are small contributions, but they are a sign that something is changing. It is hoped that in the coming decades a different emphasis can be given to facing, so that it can be known how to act if it proves indispensable. It is essential that restorers begin to share their experiences and thoughts in a more widespread way, through the publication of papers or participation in 
congresses, to sensitise other colleagues and provide ideas for subsequent research. If there were more publications on the subject, ideas would circulate not only in a larger area, but longer in time. If someone were to look for the same information after years, having a bibliography from which to start their investigations, they would be facilitated in their work and their work would facilitate that of others. In fact, it should not always be necessary to repeat the same experiments starting from scratch, but it could lead others by contributing to the expansion of knowledge on the subject. At the same time, there would be the opportunity to see who was interested in the matter before and to get in touch to ask for opinions and share experiences. In this way, communication would generate communication and the progress made by individuals would not fall on deaf ears, but would become functional for a broader and longerlasting development. 



\section{Physical and chemical facing mechanisms}

As it was possible to see in chapter one, facing have been used for many reasons during the centuries. Since today, paintings have been faced (1) in case of emergency, or (2) to move them to other places when there is no time and equipment for resolute interventions. In other cases, facing have been used to (3) protect the paint layer before structural interventions, but also to (4) re-adhere or consolidate flaking or powdery paint layers. Nevertheless, the most common reason that leads restorers to face a painting is probably related to (5) traditional linings, where facing represents a necessary part of a multi-step intervention.

These are just some example, but there are many other reasons that lead conservators to face a painting. Generalising, restorers recur to facing in case of deadhesion, delamination or de-cohesion of the most superficial layers, with two principal purposes: a protective one and a consolidating one. In the first case, the conservator wants to avoid displacement or the loss of detached fragments through temporary gluing, in order to postpone the solution of the problem. In the second case, the purpose of the treatment is the consolidation of superficial layers, which means that the problem is fixed with facing itself. As it will be possible to see further in this chapter, in this distinction lies the greatest misunderstanding of facing issue.

In this chapter, rheological behaviour of canvas paintings will be first described, in order to give the necessary information for the understanding of physical phenomena that cause cracking, cupping and delaminating. Later, the principal characteristics of the two classes of materials used for facing will be analysed, and the aspects considered fundamental for the understanding of facing mechanisms will be described. This will permit to clearly understand the conservation problems related with the current facing application methods, which it is hoped to remedy with the use of the proposed remoistenable temporary support system. 


\subsection{CANVAS PAINTINGS}

\subsubsection{Rheological behaviour of canvas paintings}

A painting is as a structure formed by the superimposition of different layers, constituted by scores of materials combinations. The way in which materials are prepared and applied influences the degradation processes to which the painting will be subjected during its lifetime. It is important to know the historical evolution of materials and techniques to understand every painting in its unicity.

However, to understand how canvas paintings interact with the environment it is useful to make some simplification and to focus on their common fundamental characteristics. In fact, even if paintings from different artists or periods might seem very different, they all have a considerable number of common features. Many painters of different centuries and geographical areas used linen canvases, animal glve sizes, gypsum, kaolin or oil-based ground, and oil paintings. The main differences lied in drawings, colours, layers thickness, and application procedures (Mecklenburg 2008).

It can be state that a canvas painting consist of an animal glve size applied as warm fluid or a cold gel on a linen canvas stretched on a wooden stretcher. A ground is applied on the size to create a smooth surface, suited for the application of the paint. This means that many layers constituted by different materials with different characteristics have to co-exist in the extremely reduced thickness of a canvas painting. How do these materials interact each other and what lies at the bottom of degradation processes?

As for every object of art, conservation of canvas painting depends on many issues. For example, the degradation of the most superficial layers of canvas paintings can be due to several factors, such as natural ageing, environmental conditions, biological action, and conservative interventions. Nonetheless, the alterations in the ground and in the paint layer are strictly related to the mechanical deterioration of canvas pictures, as stated by Marion Mecklenburg. With his pioneering work started in the eighties (Mecklenburg 1982, 2007, 2008; Mecklenburg, Tumosa and Erhardt 1998; Mecklenburg and Fuster-Lopez 2008; Mecklenburg, Fuster-lopez and Ottolini 2012; Tumosa and Mecklenburg 2013), he demonstrated that many of the structural problems of canvas paintings are related to the opposing mechanical behaviour of the different layers as a function of relative humidity. Latter analyses carried out by different professionals (Hedley1981, 1988; 
Michalski 1993, 2007, 2008; Young 1999; Young and Hibberd 1999; Roche 2008, 2015; Capriotti and laccarino-Idelson 2004; laccarino-Idelson 2012; Hackney 2020) gave also important contributions to the study of this issue.

Thanks to all these studies, it is possible state that the differential contraction and expansion of constitutive materials, and the variation of their mechanical characteristics are the primary cause of degradation phenomena, such as cupping, flaking, and cracking of paint and ground layers. The stresses generated in the section of a paint layer associated to the fluctuation of relative humidity can be very strong. Changes in temperature does not causes large changes in constitutive material dimensions, but low temperature can influence their rigidity. The stress exerted on a constitutive material can affect its conservation, causing breaking or permanent deformations, depending on its mechanical characteristics. To understand what happens in the extremely reduced thickness of a canvas painting it can be useful to analyse the constitutive layers one by one.

\subsubsection{Stretcher}

The stretcher of a canvas paintings is usually made of wood, a highly hygroscopic and orthotropic material (its hygro-mechanical behaviour differs in its three anatomical directions: tangential, longitudinal, and radial) (Arends et al. 2018). This means that wood fibres elongates differently in the three directions with the increase of humidity. Although elongation is negligible in longitudinal direction, in the radial direction wood fibres swell up to forty times more than longitudinal one, and twice in the tangential direction compared to the radial one (Ciatti, Castelli, and Santacesaria 2006; Allegretti and Raffaelli 2008). Swollen fibres exert a high strength, called 'swelling pressure'. The influence of changes in stretcher dimension is decisive. For example, a common spruce stretcher of $(1 \times 1) \mathrm{m}$ with bars of $(10 \times 3) \mathrm{cm}$ increases its dimensions up to one centimetre when the humidity increases from 30 to $80 \%$ $\mathrm{RH}$ (Capriotti, and laccarino Idelson 2004). This means that a stretcher can exert strength much higher than that exerted by all the other constitutive materials. Nevertheless, if the structure of the stretcher is too slender, it can yield under the stress exert by the canvas. 


\subsubsection{Support}

The support of this kind of paintings is usually made of canvas, a highly porous and hygroscopic material. These characteristics may vary according to the yarn, the number and the disposition of the fibres, but they depend also on the torsion, the density and the kind of the weaving (Rossi Doria 2006).

The more widespread canvases

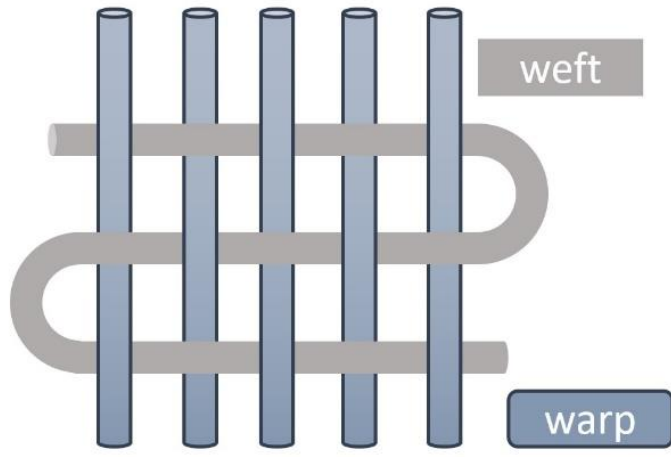

Figure 2.1.1. Schematic representation of warp and weft in weaving.

in painting field are linen

canvases. As well as wood, linen is mainly constituted by cellulose, a polymer consisting of a linear chain of several hundred to many thousands of $\beta$-glucose units.

Cellulose fibrils are the base-unit of a canvas. They are twisted together forming a helix to constitute the thread. To make a canvas, some threads are tensioned in parallel (wrap) on a stretcher, while another continuous thread (weft) is weaved passing up and down among them (Fig. 2.1.1). The way to weave the weft and the wrap determine the kind of armour. Generally, it is possible to distinguish between the wrap and the weft because the threads of the first are thickener and have a higher torsion of the fibres to sustain the tension on the stretcher during fabrication process.

Cellulose is a hygroscopic material with a distinctive moisture absorption curve: as soon as it exceeds the anhydrous state, it quickly adsorbs humidity and then it keeps equilibrium since to $65-70 \%$ of $\mathrm{RH}$. With a further increase in relative humidity, its hygroscopicity rapidly increases and cellulose swell. In the fibres, this swelling is higher in the radial direction because of their anatomy.

The torsion of the threads and the way they are weaved, determine the rheological behaviour of the canvas. The fibres swell around their axes and that they are twisted around the axis of the thread to form a helix. The result is that the thread contracts with the increase of humidity. Threads contract proportionally to their torsion degree (Fig. 2.1.2-3). 


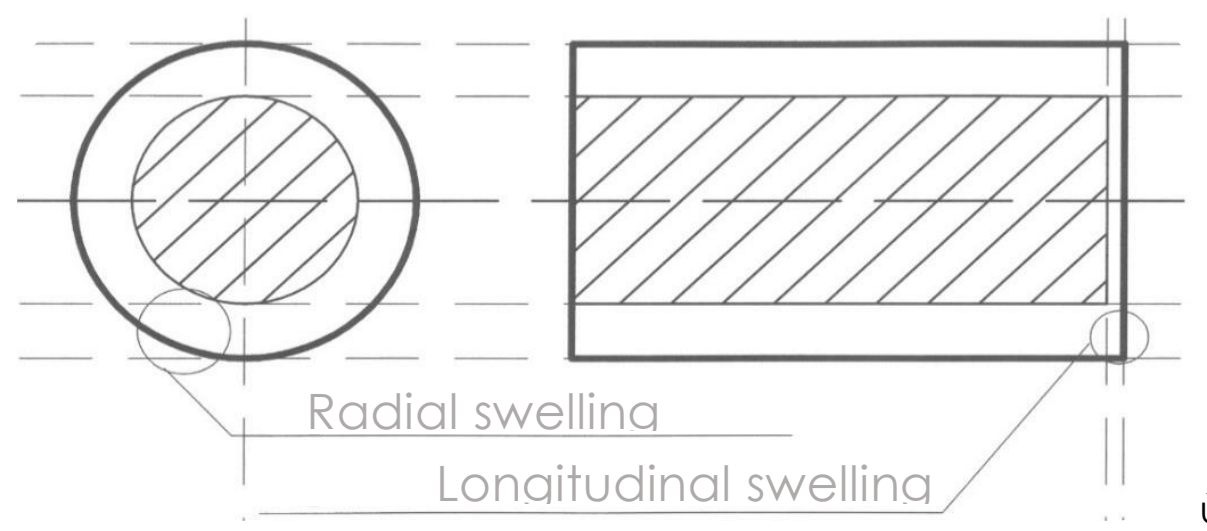

ن̀

Figure 2.1.2. Hypothetical swelling of a cylindrical cellulose element (Capriotti and Iaccarino-Idelson 2004).

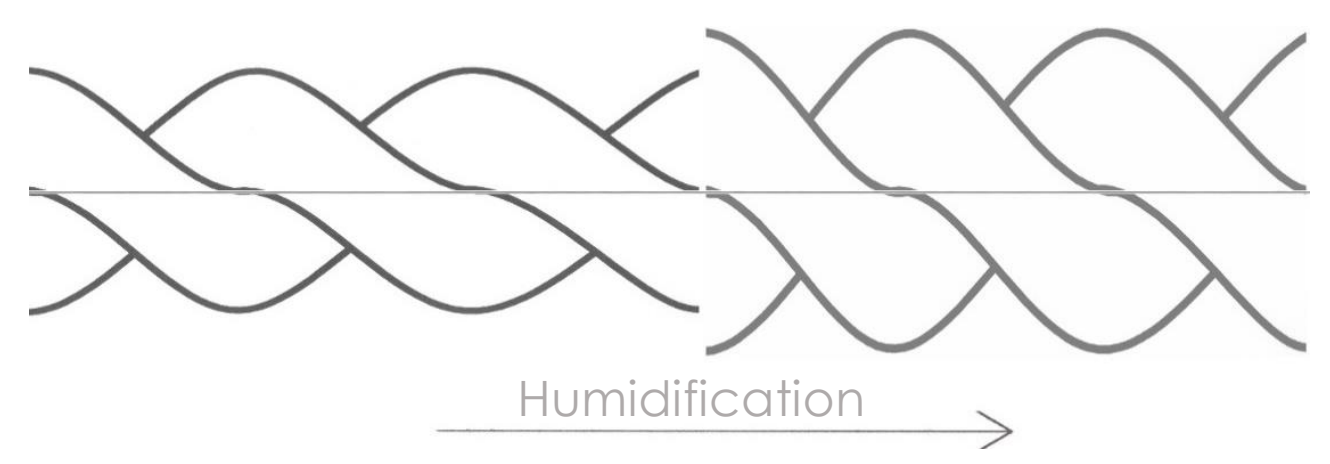

Figure 2.1.3. Radial swelling contribute to thread shortening (Capriotti and laccarino-Idelson 2004).

The same phenomenon is increased in the behaviour of an unrestrained canvas, which is formed by woven threads forming a sinusoid (Fig. 2.1.4). This happens when the canvas is free to move. On the contrary, when a canvas tensioned on a stretcher is wetted, the inner tension in the canvas increases since it is not free to shrink. If the stress at high humidity is maintained constant, the spun stretches and lose all the imperfections and crimps produced during the weaving process. The strength opposed by the restrained canvas keeps constant up to $75 \% \mathrm{RH}$, then it suddenly decreases because of the so-called 'creep phenomenon': at this range of RH, the fibres are lubricated and they slide one upon the other, causing an irreversible increase in canvas dimensions (Fig. 2.1.5). 


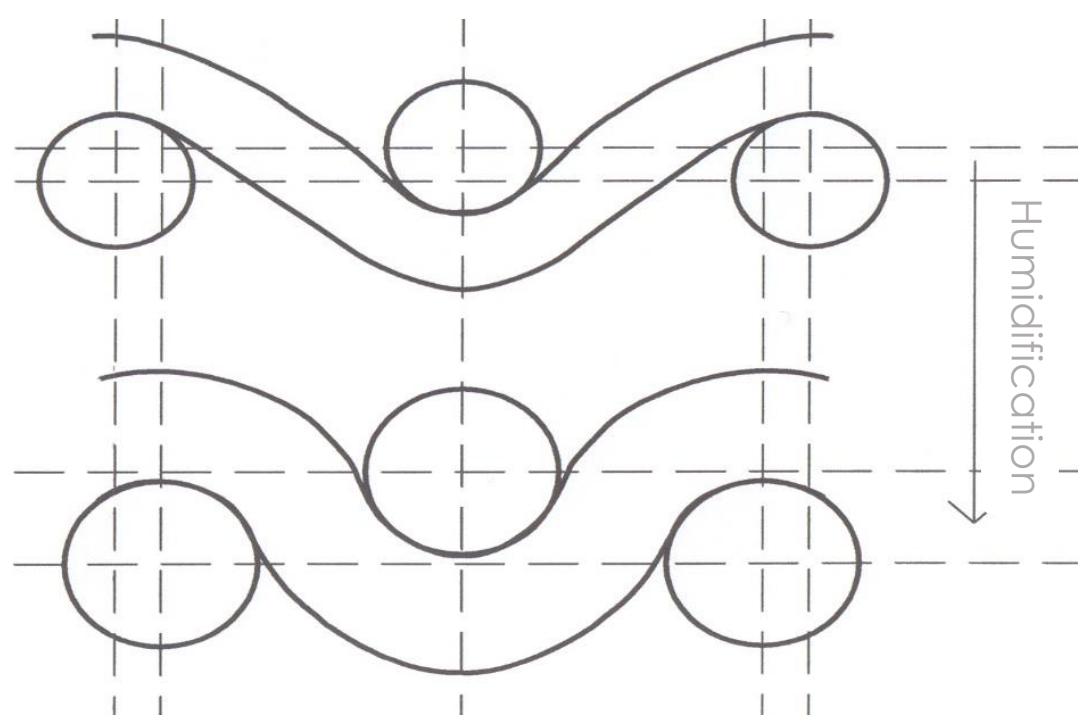

Figure 2.1.4. Canvas shrinkage and thickening (Capriotti and laccarino-Idelson 2004).

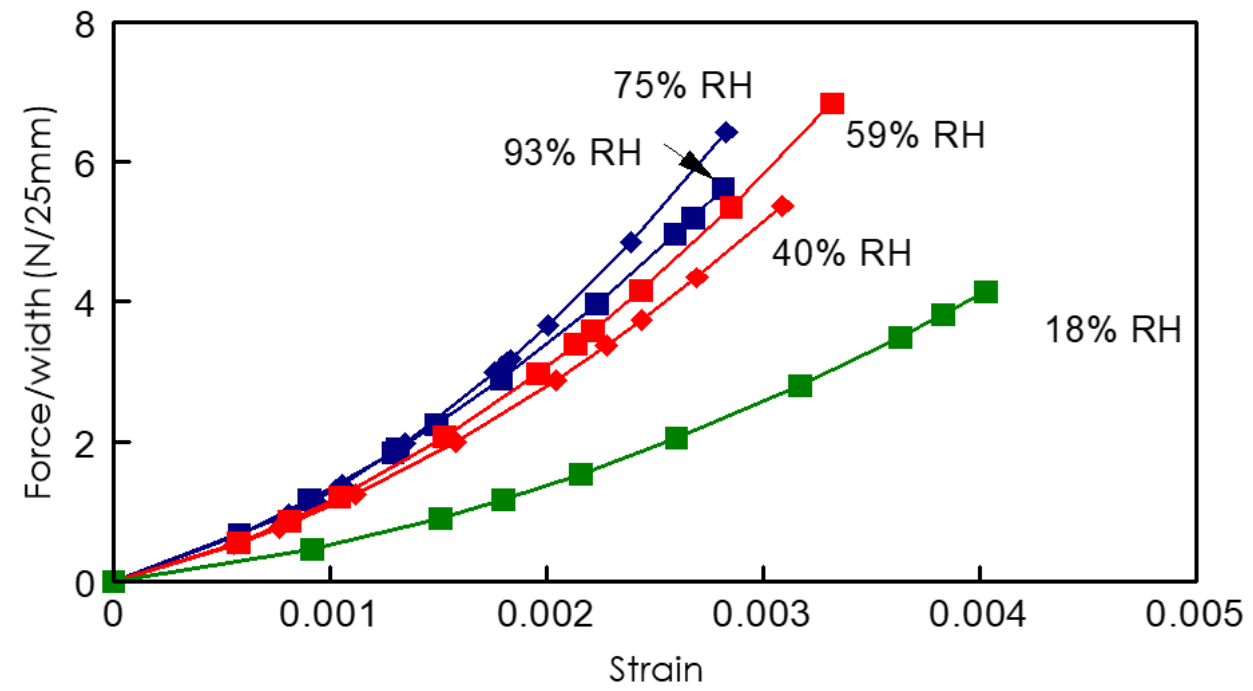

Figure 2.1.5. Force per width versus strain. The tests were conducted while the samples were at equilibrium at different relative humidity levels (Mecklenbura 2005). 


\subsubsection{Size}

When a canvas is sized with an animal gelatine glve, its properties change significantly. Animal glues are natural polymers derived from the denaturation of mammalian or fish collagen. These glves may exhibit extremely diverse physical, chemical and mechanical properties depending on the source materials (bones, rabbit skin, pork or cow hide), and on the extraction process (for example acid or basic pre-treatment, extraction temperature and duration) (Schellmann 2007; Melià-Angulo, Fuster-López and Vicente- Escuder 2017). In fact, these factors strongly influence the chemical composition (Pro and Hyp content), average molecular weight (AMW), the degree of renaturation and network structure, which are crucial for the most important technological characteristics.

In general, animal glues are one of the most hygroscopic materials. Hide glve has a dimensional change of about 4,5\%, with a change of RH from $10 \%$ to $90 \%$. From $30 \%$ to $60 \%$ RH the dimensional change is of $1 \%$. At low RH levels, glue is generally stiff and strong, but with the increase of relative humidity, its tensile strength decreases, and above $75 \% \mathrm{RH}$ it has no strength. Fig. 2.1.6 shows the force per width of a restrained sample of hide glve desiccated from $85 \%$ to 15\% RH (Mecklenburg 2005). These short examples give an idea of the great forces that glue can develop and how they are strongly influenced by relative humidity.

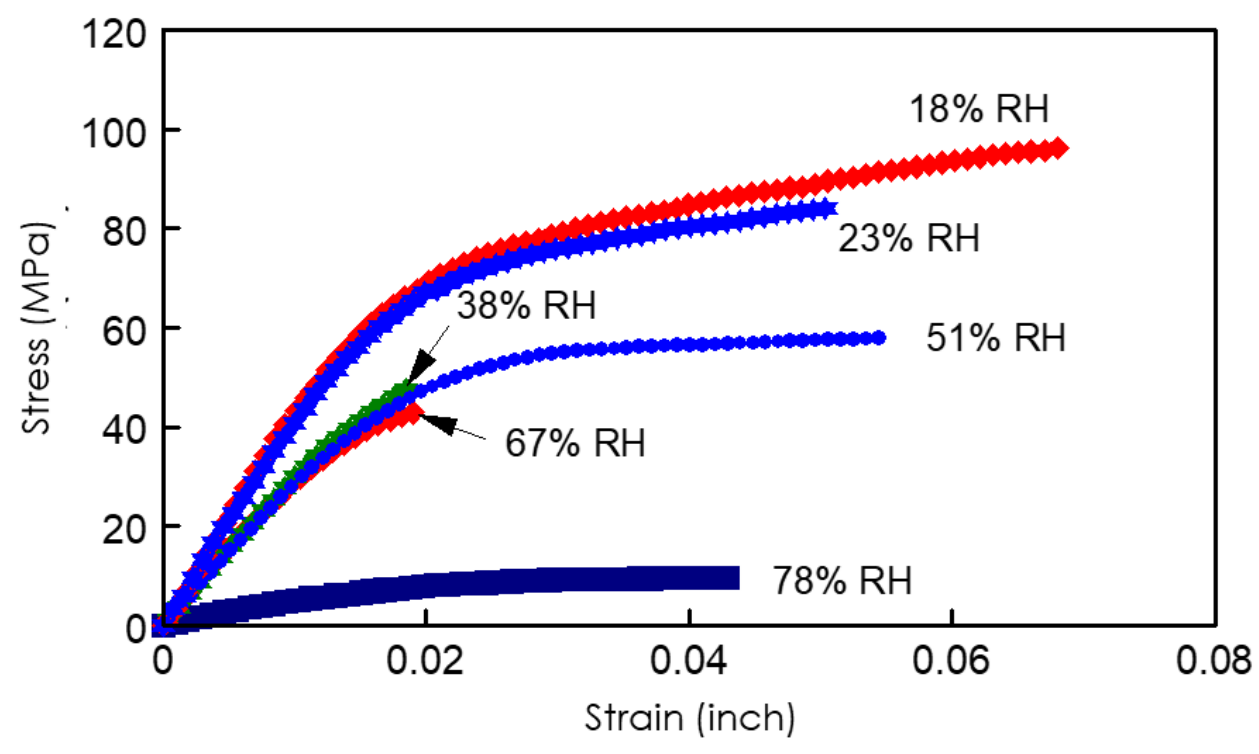

Figure 2.1.6. Stress strain tests of 15 years old hide glue at different levels of relative humidity (Mecklenburg 2005). 


\subsubsection{Ground}

Ground layer has a wire fence, like a sponge, and can be difficult to recognize the different components with the investigation with optical microscope because it can be made by a series of irregular layers. The rheological behaviour of the ground varies according to its constitutive materials, but also depends on its thickness, porosity and the fillers/medium ratio. Grounds of canvas paintings can be made with animal glues and white calcium-based minerals, like gypsum (calcium sulphate dihydrate) and kaolin (calcium carbonate). The first have been widely used in the Mediterranean Europe, the latter in the Central and Northern Europe. In more recent times titanium dioxide pigment has been used. In some of the traditional recipes for gesso, molasses was added to improve its flexibility. Other grounds are constituted by oils and some kind of fillers and some are coloured.

Since the possible formulations of the existing ground differ considerably, it is difficult to analyse them all to determine similarities and differences. In glvebased grounds, Mecklenburg assessed that both the dimensional response and the mechanical properties of gesso depend on the strength of the hide glue used and the ratio of glve to inert materials (pigment volume concentration, PVC): the higher the PVC, the more brittle the ground and less the responsive to moisture with respect to dimensional changes. The mechanical properties will change significantly, however, when the RH levels are changed (Fig. 2.1.7). (Mecklenburg 2007).

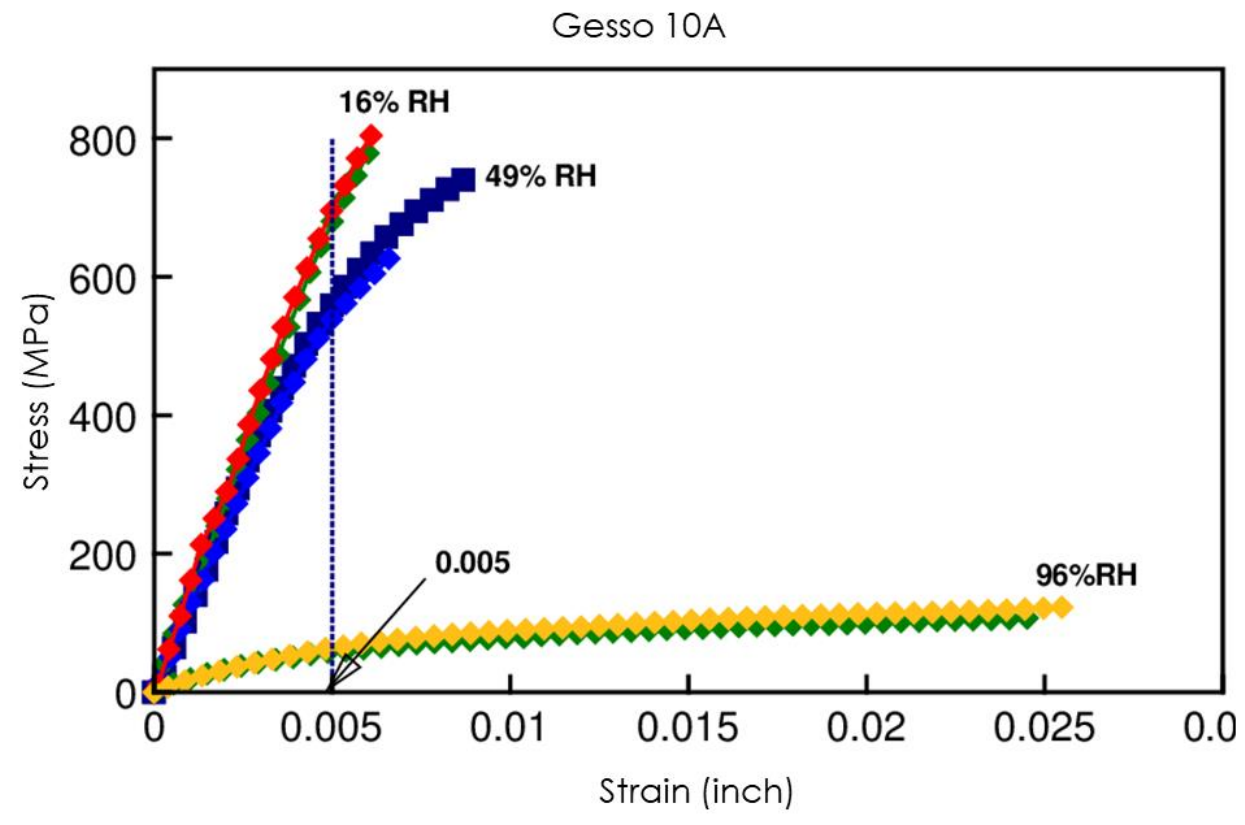




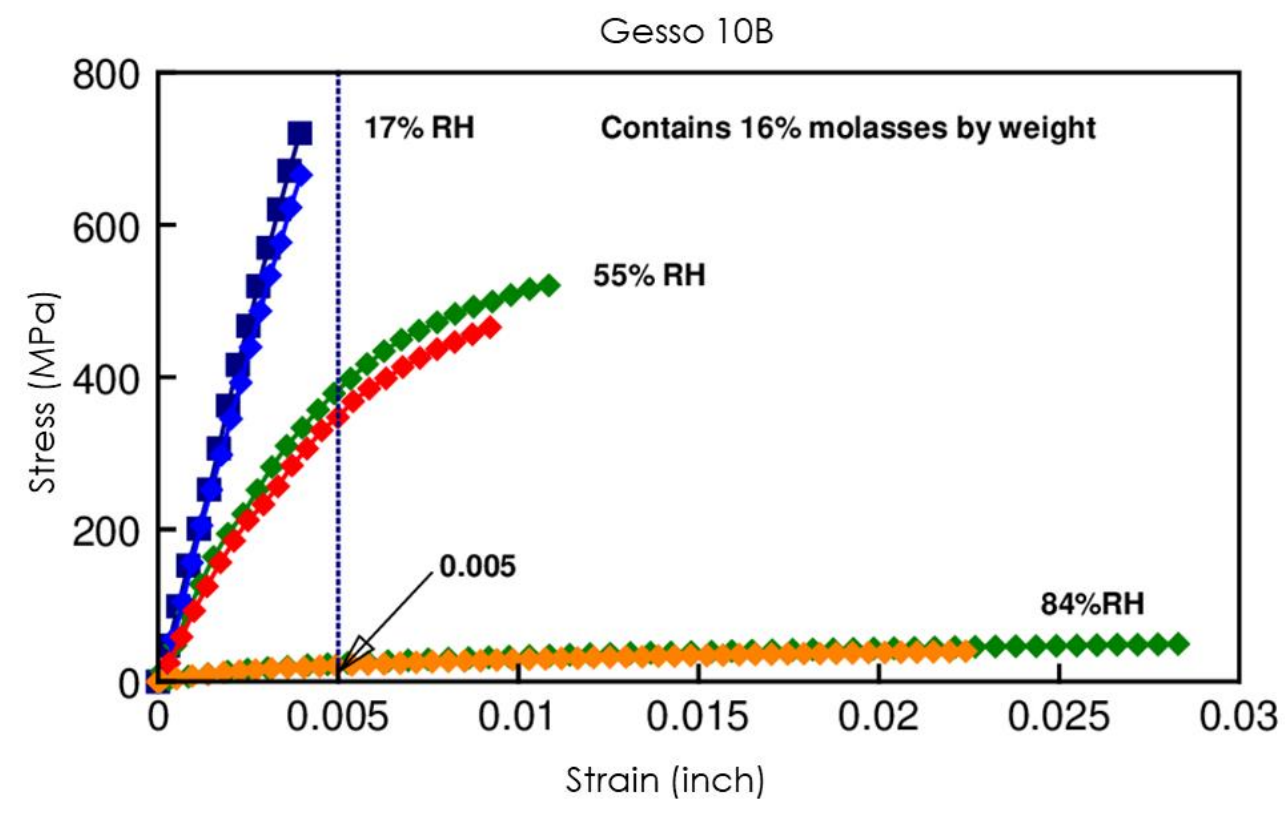

Figure 2.1.7. Stress strain tests of sample of gesso 10A and 10B, made with the strong Williams and Higgins hide glve. The PVC of the gesso was $71 \%$. Gesso $10 B$ has as added 16\% (by weight) molasses (Mecklenburg 2007).

\subsubsection{Paint layer}

Paintings are constituted by a binding medium that gives elasticity to the layer and pigments that are mineral particles with peculiar characteristics (e.g. dimension, hardness, and porosity).

Drying oils, linseed oil in particular, have been the most employed binders for hundreds of years in the creation of canvas paintings. Different formulas have been used in the aim of maximize the desired properties, leading to considerable alterations from the basic formula of a simple oil/paint mixture. These modifications might have immediate or long-term consequences on paint characteristics (Tumosa and Mecklenburg 2010), increasing the variability of their behaviour.

Drying oils are composed by vegetal unsaturated triglycerides and a small percentage of saturated fats. Oil triglycerides, in addition of long chain saturated fatty acids, mainly palmitic an stearic acids, are formed by oleic, linoleic, and linolenic unsaturated long chain fatty acids, which have respectively one, two, or three double bonds. The reactivity of double bonds is the basis of some important transformations to which oils might undergo, and among them the oxidation process, which lead to the cross-link of the polymers to form a tangled three-dimensional network. 
Because of the nature of its components, an oil paint has a viscoelastic behaviour such as many linear polymers, but it looses these characteristics with ageing, becoming brittle (Fig. 2.1.8). The characteristics of a paint layer are strongly influenced by the nature of all its constituents and their heterogeneity. For example, the mineral particles size is important. If particles are much smaller than the thickness of the layer, it can be considered that they will not have any influence, but if particles or agglomerates of particles are equal or bigger than one third of the layer thickness, they could cause stress concentration and could weaken the mechanical strength of the paint film (Roche 2015). Furthermore, the shape and the orientation of the particles affect the cohesion of the paint film also (Roche 2008). Added to this, is the fact that pigments are not inert and their chemical nature influences oil polymerisation. For example, pigments made with lead, iron, titanium, and manganese dry in a short time to two to 15 days). Zinc paints dry more slowly, while paint layers containing organic colorant such as alizarin never fully dry (Mecklenburg 2008).

Another important factor of influence is the pigment volume concentration $(P \vee C)$, since the amount of the filler influences the mechanical behaviour of a paint layer independently of its nature. Films with high PVC are underbind, which implies air gaps around the pigment particles. The presence of air gaps surrounding the pigment particles affects several physical properties of the paint film. Variations in the refractive index among the air, binding medium and pigment influences the reflectance. Paints with a high PVC are more porous due to the presence of air in the paint film (Lee et al. 2018).

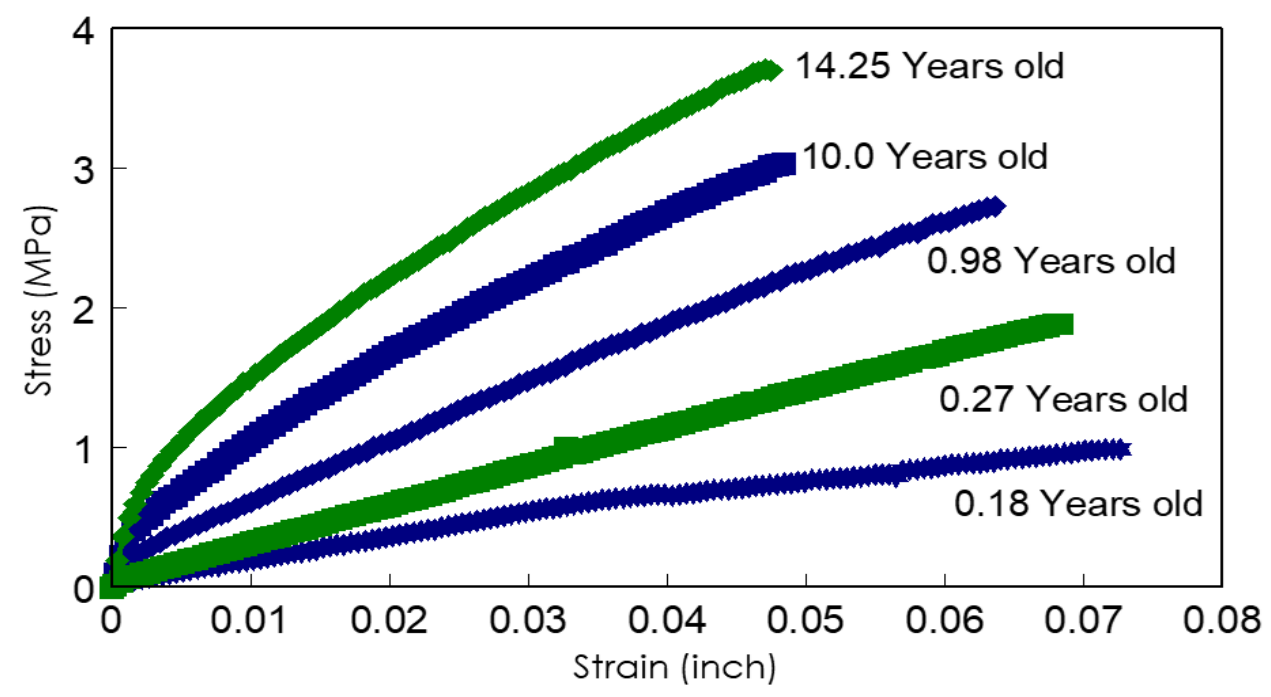

Figure 2.1.8. Stress strain tests of basic lead carbonate paint made with cold pressed linseed oil at different ages (Mecklenburg 2005). 


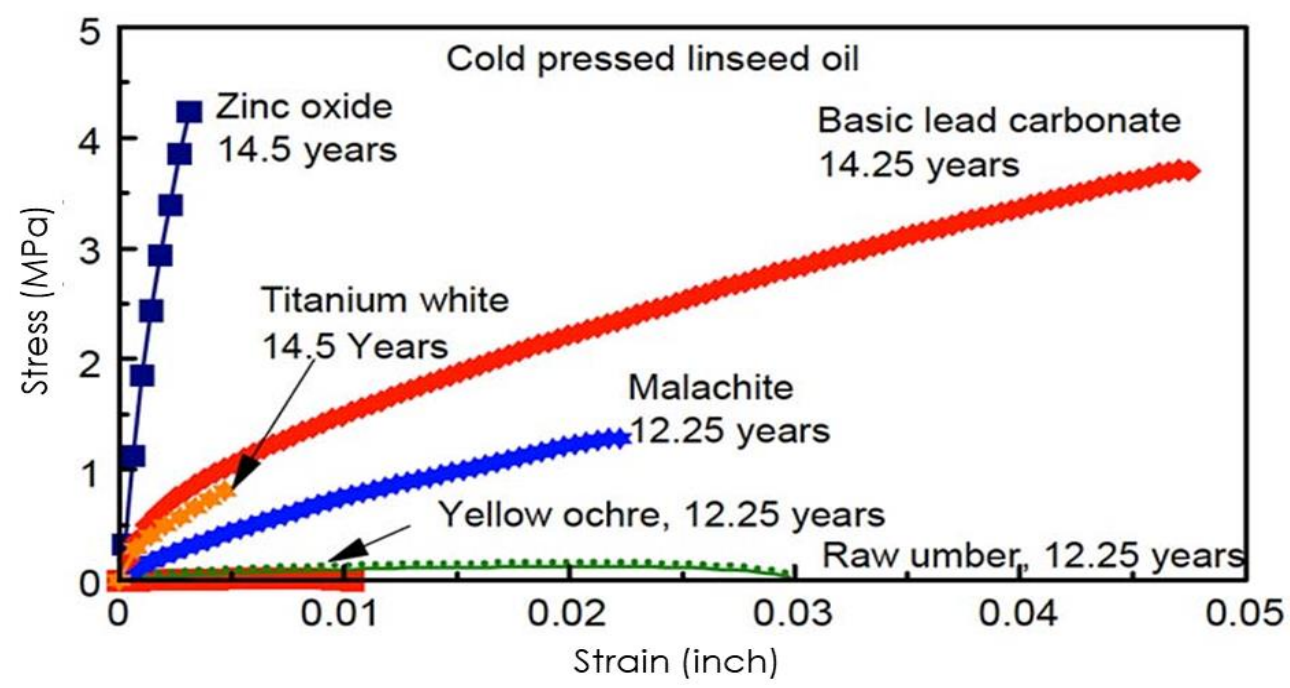

Figure 2.1.9. Stress strain tests conducted on paints made with different pigments at48 \% $\mathrm{RH}$ and $23^{\circ} \mathrm{C}$ (Mecklenburg 2005).

In general, it is possible to state that the behaviour of oil paint layers is similar to that of hide glue: with the increasing of humidity, they increase their dimensions and become more flexible and yielding. Nevertheless, the rheological behaviour of aged paint layers is extremely varied, and it is affected by the nature of the pigments (Fig. 2.1.9). Polymerised oil can adsorb moisture until $5-10 \%$ of its weight. White lead and the other white pigments adsorb nearly zero moisture, while earth pigments can adsorb humidity until the $10 \%$ of their weight. This means that with the increase of moisture, a paint layer made with an earth colour increases its weight and swells, changing its dimensions up to $2,5 \%$, that means more than two centimetres for each meter (laccarino-ldelson 2012).

The different behaviour of the paint layers determine the different aspect of colour fields. In fact, in a paint subjected to long-term environmental fluctuations, brown clay-based grounds and colour fields are characterised by a pronounced cracking because of their high moisture reactivity, while most of the white colours are better preserved. Furthermore, according to a study presented by Mecklenburg at the Cleaning International Conference held in Valencia in 2010 (Tumosa and Mecklenburg 2013), the ions present in some layers (lead, cobalt, manganese) accelerate the exsiccation of the paint layer. They also reduce their water solubility and dimensional variations due to moisture fluctuation, increasing the mechanical strength of the layer. The most interesting thing is that it seems they can migrate to contiguous layers during the polymerisation process, changing the characteristics of the other colours (Fig. 2.1.10) (Iaccarino Idelson 2012). 

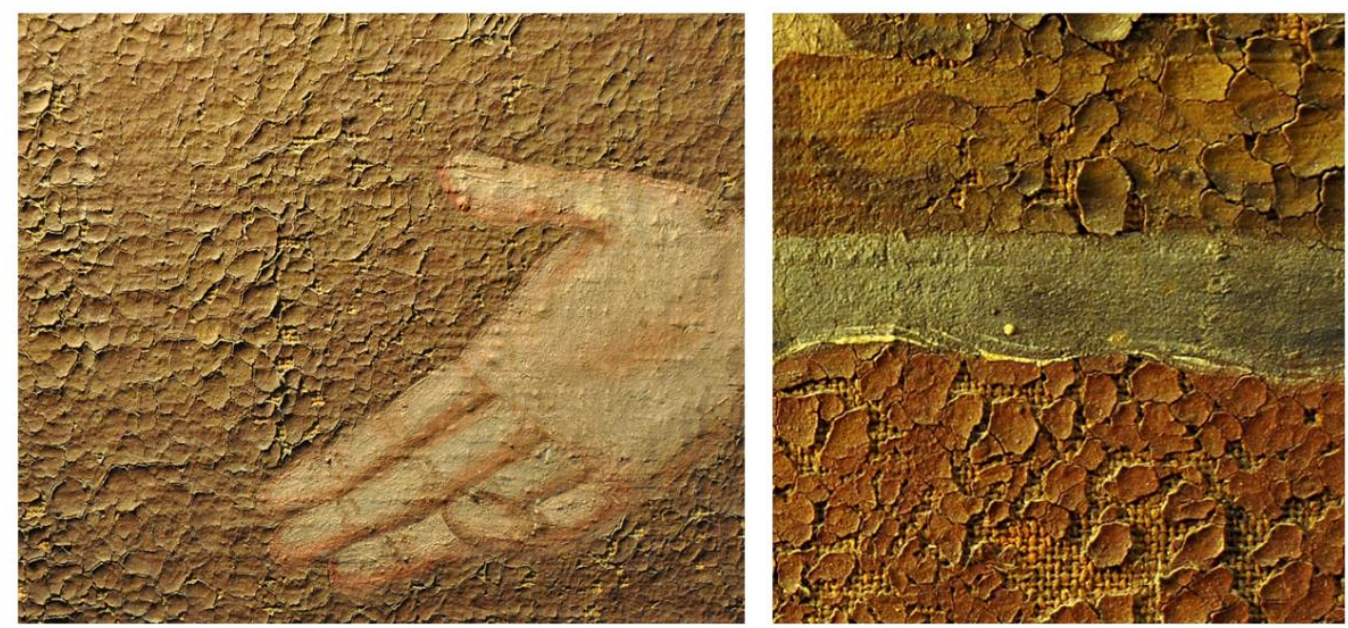

Figure 2.1.10. Difference in the aspect of paint layers made of white lead and earth colours. As it is possible to see in the colour fields representing a) the hand and b) the decoration of a tablecloth, the use of a thin layer of white lead stabilized the underneath earth colours thanks to the migration of active ions (laccarino-Idelson 2012).

Mechanical tests carried out by different researchers in these last decades permitted to extrapolate general information on paint layers. As it is possible to observe comparing the previous graphs, paint layers are much less resistant that the other layers. A common characteristic to all the paint layers is that their rigidity increases with ageing. Nevertheless, aged paint layers made with different pigments, show very different mechanical characteristics. For example, zinc paints become extremely rigid ad fragile with the passing of time, while the titanium ones become weak and fragile. Raw umber remains yielding, even if its strength increases three times with drying. Earth colours in general remain strongly reactive to humidity: after two years, they can still be hydrolysed. Some earth colours can also be subjected to strong deformations under the influence of high relative humidity levels.

\subsubsection{Coatings}

Many paints have an original or a restoration coating over the paint layer. They can be made of an oil/solvent-based resin dispersion, or also of other materials, such as egg white. In many cases, triterpenoid resins have been used, which are made of low molecular weight polymers. Resins are subjected to a chemical degradation, which leads to oxidation and degradation processes that increase their brittleness. They also undergo a mechanical degradation, because the thin and brittle layer cannot stand the movements of the other layers. However, since their weak strength does not influence the mechanical behaviour of a canvas painting, this issue will not be deepen in this work. 


\subsubsection{Canvas painting}

The study of the dimensional and mechanical response of the individual materials to relative humidity fluctuations permits to draw some interesting conclusions about the entire painting. Since the structure of the painting is made of several layers locked together, it can be considered as a stressed laminate. The stretcher and the initial stretching define the dimensions and initial stress. Part of the total stress passes to the adjacent layers. The stiffest layers, therefore, carry the most of the stress. For a specific painting, data about the thickness of each layer, response time, and initial tension can be used to calculate predicted changes in behaviour in response to changing humidity (Hackney 2020).

With his studies, Mecklenburg demonstrated that the mathematical addition of the curves that describe the tensions of the individual constitutive layers generates a curve that is almost identical to that obtained studying the tension of a real painting made with the same materials. This means that the behaviour of a painting is the sum of the behaviour of its components.

In Fig. 2.1.1 1, it is possible to see that the inner tensions of the painting are lower in the range that is usually considered suited to a correct conservation. In fact, within the range of 35-60\% RH almost all the constitutive materials are subjected to smaller deformations. With the increasing or decreasing of relative humidity beyond these values, the overall tension increases, endangering the ones that are the weakest constituents in that given environmental condition.

According to Mecklenburg studies, an increase in humidity above $70 \% \mathrm{RH}$ is dangerous because the expansion of almost all the constitutive materials is opposed to the contraction of the canvas. At such high humidity range, glues are completely softened and they have almost no strength to counteract canvas shrinkage, compromising the adhesion between the support and the ground.

On the contrary, at very low relative humidity levels, animal glues can generate very high stresses in the painting, since at this range of relative humidity it contracts and is very strong and stiff. At the same time, canvas is flexible and does not make a stand to glue action. The contracted size layer plays the support function, increasing the stress in the weakest ground and paint layers, which are brittle and fragile at low humidity range. 


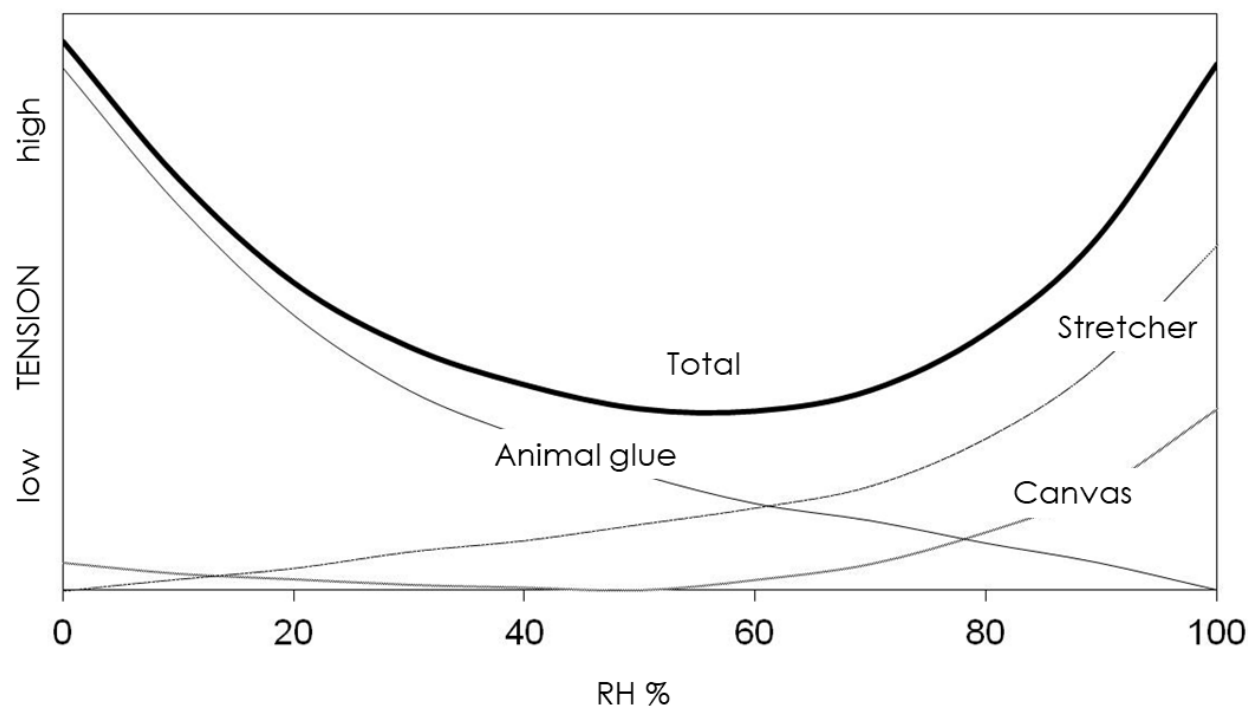

Figure 2.1.11. Inner tensions of the individual constitutive layers (stretcher, canvas, and animal glve size) and total tensions of the painting. Inner tensions of the painting are lower in the range that is usually considered suited to a correct conservation (Capriotti and Iaccarino Idelson 2004).

\subsubsection{De-adhesion phenomena and cracking mechanisms}

In the previous section, it was possible to understand how the rheological behaviour of the single layers of a canvas painting determines the behaviour of the entire system. A painting attached to a stretcher is subject to the initial strains applied in stretching. Initial tension gradually relaxes until the painting is next keyed out and tensions are regenerated, predominantly at the corners. Handling, transport, or accidents further expose paintings to stress. In addition, even when external stresses and strains remains steady, moisture fluctuations cause internally strains in restrained hygroscopic material, such as size and canvas (Hackney 2020). The size layer is responsible for stress development during humidity decrease, while the high stiffness of fabric at high humidity levels dominates on the other layers. Since part of the stress is carried in the continuous layers, the most weak and brittle components of the painting (ground and aged oil paint) fail when movements in the supporting size and fabric exceed their rupture strains (Karpowicz 1990).

A painting attached to a stretcher is subject to the initial strains applied during stretching; at its most extreme, this tends to create distortions near tacks or staples. Initial tension, which remains for many years, gradually relaxes until the painting is next keyed out and tensions are regenerated, predominantly at 
the corners. In addition, a painting is subject to internally generated strainis caused by changes in moisture content and temperature (Hackney 2020). Furthermore, on aging most materials undergo irreversible changes to their mechanical properties. Information on material changes and their mechanical consequences permits to make hypothesis on the deterioration of paintings. Models of possible behaviour over time can also improve reliable identification and interpretation of flaws and damage.

The deformation of the layers can produce two kind of ruptures: a cohesive rupture of the inner part of a layer, or an adhesive fail between two layers. The continuous and repeated expansion and contraction movements, whatever the origin of the rupture is, lead to its propagation causing the formation of cracking, cupping and flacking.

If the ground and paint layer are subjected to a tensile force higher than that they can stand, they undergo to a cohesive rupture in order to assume a more suitable position in terms of energy. This break occurs where there is an uneven stresses distribution, which means in correspondence with the defects of the layer ${ }^{90}$. The further rheological deformations will bring to the crack expansion and the strength will be always focused at the end of the crack. The direction of the propagation will be determined by the heterogeneity of the layer and the direction of exerted forces (Roche 2015).

When cracking starts in the ground, a wrinkle typical of closed cracks might be visible on the paint layer, and it could expand and open up. Nevertheless, the cracking of the ground is not always visible on the surface of a painting, so that even if the surface appears in condition, a web of cracks could lay under the paint layer.

The loss of adhesion at the interface starts with a rupture between two layers, leading to cracking and cupping. The understanding of the adhesion phenomena is rather difficult, because they are governed by chemical, physical and mechanical factors that combine to form an adhesive joint. As explained by Alain Roche (2008), the adhesion strength between the layers of a canvas painting could be explained as the result of mechanical anchoring to porous materials and weak intermolecular bonding.

From the point of view of physics, adhesion is the sum of more forces with distinct directions: a tangential force, parallel to the adhesion plane, and a normal force, perpendicular to the plane. Then, there is an interface force,

\footnotetext{
90 There are different kind of imperfections: 1) microbubbles formed during the realisation of the painting, 2) cavities filled with soft degradation materials or residues of not-dried oil, or 3) hard and stiff defects constituted by pigment agglomerations, big pigment crystals or other impurities (one-third or more of paint layer thickness).
} 
opposed to the adhesion one. It iscomposed by a shear force (opposed to the tangential one) and a cleavage force (opposed to the normal one) (Fig. 2.1.12). As long as adhesion forces are higher than the interfacial ones, the adherends, that is the painting constitutive layers, keep adhering. However, with ageing and the continuous cyclic stresses outlined above, adhesion forces become weaker. When a painting is therefore subjected to a fatigue involving an increasing of shear and cleavage forces, adhesion forces equilibrium breaks, leading to adhesive fail of the constitutive materials in correspondence with the areas weakened by layer imperfections. Adhesive fail can occur in two distinct modality.

The first modality occurs following a cohesive rupture in a constitutive layer, such as the ones previously described. While two adherent layers are intact, there is an equilibrium of the forces (Fig. 2.1.13-a). However, when one of the layers is subjected to a cohesive rupture there is a realignment of forces (Fig. 2.1.13-b). In this moment, the cleavage strength near to the crack increases and it can exceed that of the normal adhesion (Fig. 2.1.13-C). If this happens, an adhesive fail occurs between the layers. As soon as adhesive force is released, the upper layer undergoes a distortion forming a flake of ground or paint (Fig. 2.1.13-d).

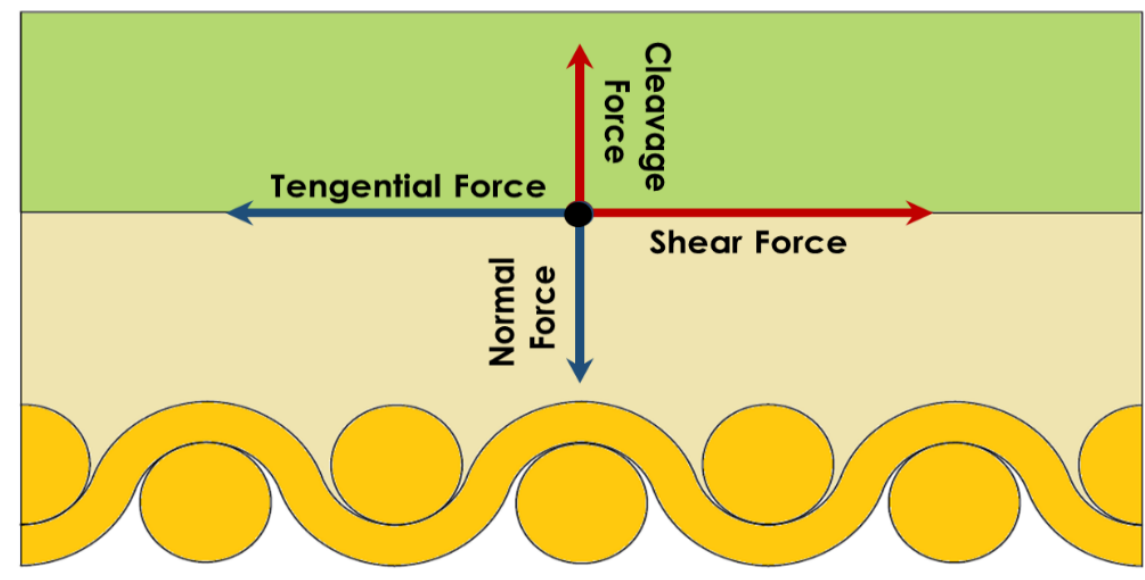

Figure 2.1.12. Adhesion forces distribution in a painting. 

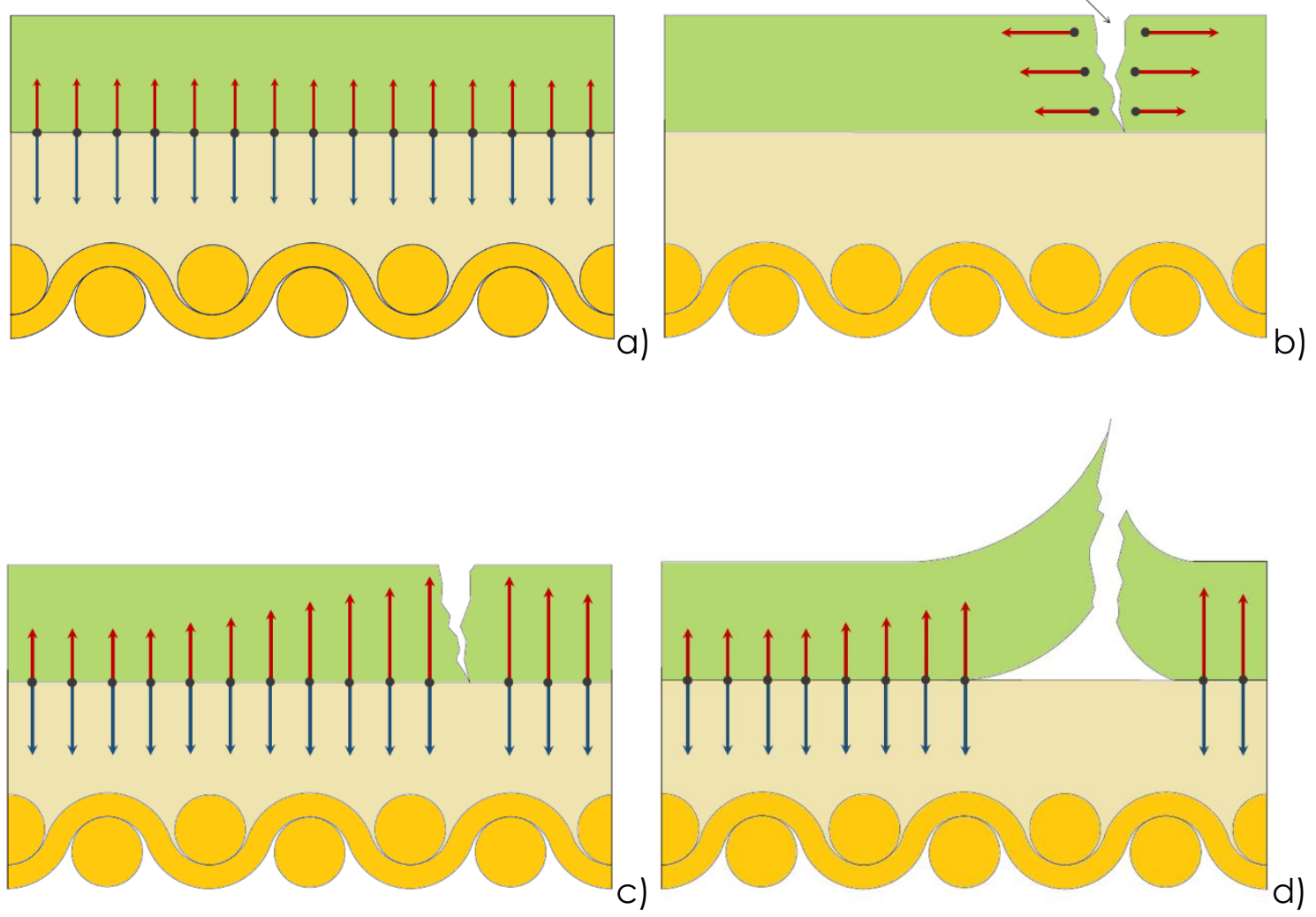

Figure 2.1.13. Adhesive fail consequent to a cohesive rupture.

The increases in deformation of paint flakes and their subsequent detachment can be explained in terms of stress realignment. Since the greatest tensile stress in paintings is carried by the layers with the highest stiffness, Mecklenburg concluded that in ambient conditions and below, the stress tends to be primarily situated in the middle of the glue size (Fig. 2.1.14-a). Nevertheless, with the occurrence of cracking, the geometric center of force is segmented (Fig. 2.1.14b). In the resulting fragments of ground and paint layer the force is collocated in the middle of the segments, while in correspondence to the cracks, the force is placed in the canvas layer. When the paint is subjected to tensile strength, there is a natural tendency to a realignment of forces. This has the effect of pulling the canvas upwards, lifting the ground and paint layer into a cupped configuration (Fig. 2.1.14-c). Subsequently, when the paint layers undergo compression at low humidity, the edges of the cracks became raised. 


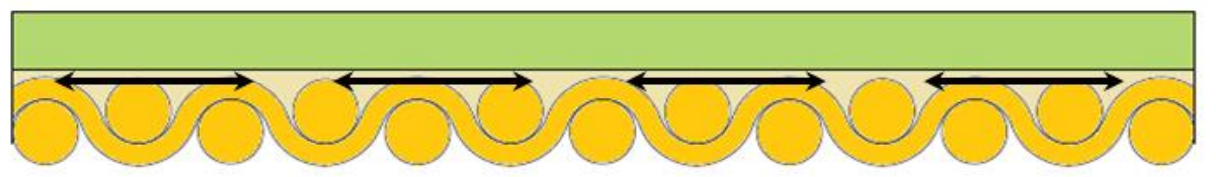

a)

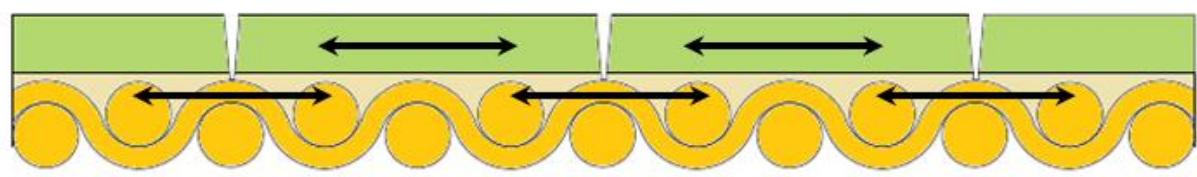

b)

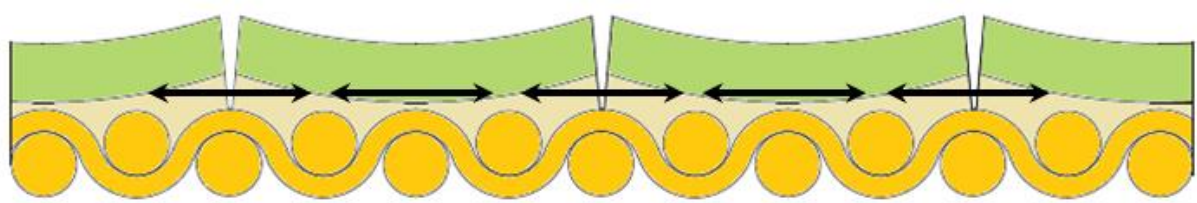

c)

Figure 2.1.14. Mecklenburg's model for the generation and growth of cupping in canvas paintings (reproduced from Mecklenburg).
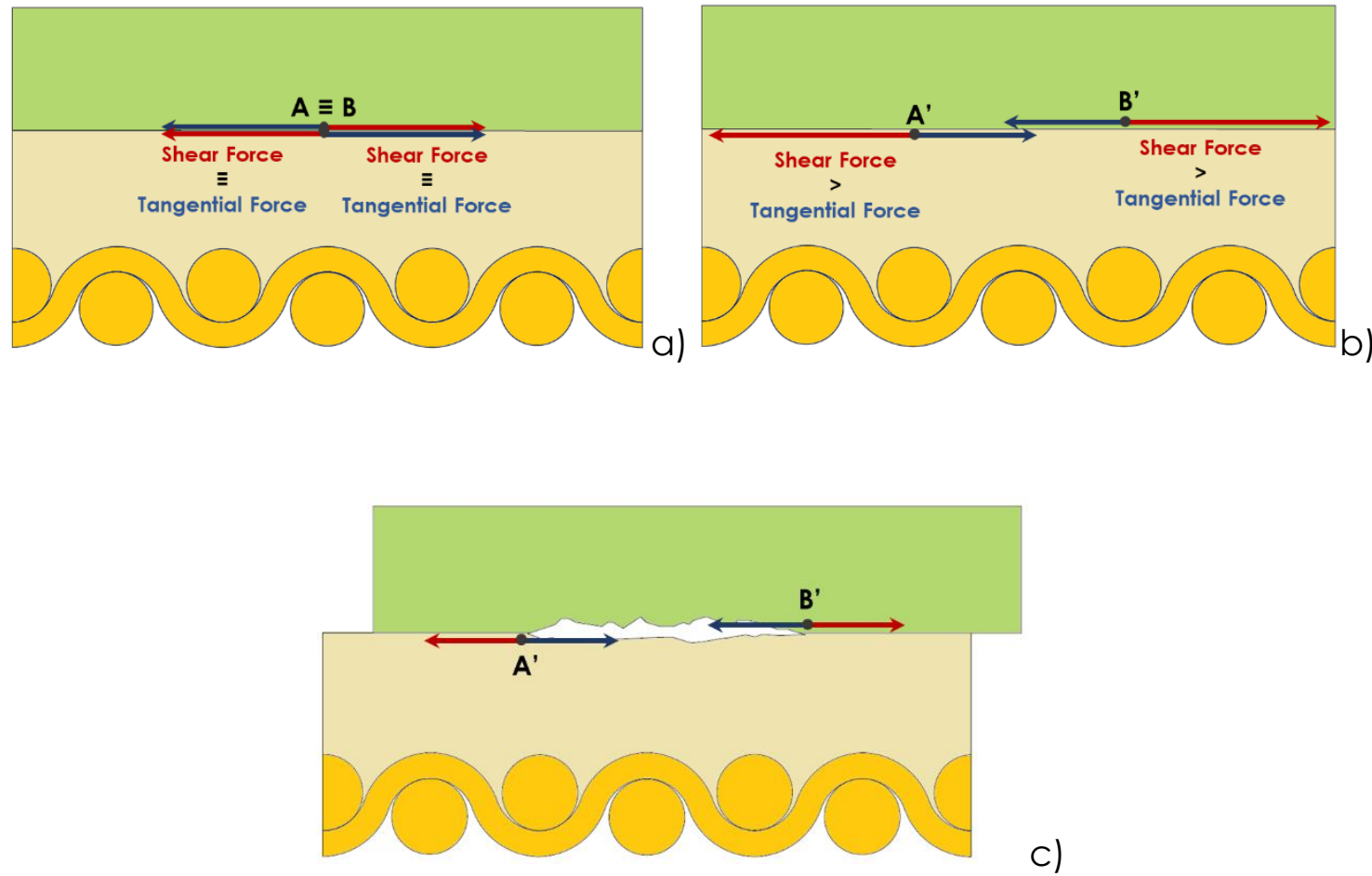

Figure 2.1.14. Adhesive fail consequent to an increase in shear strength subsequent to a differential expansion and contraction of two joined layers (reproduced from Roche 2008). 
In the second modality of adhesive fail, de-adhesion is directly caused by the differential expansion and contraction of two joined layers. In order to understand this phenomenon, let us image two point $A$ and $B$ at the interface between the two layers. In an intermediate environmental conditions (30-65\% UR), there is an equilibrium of the tangential and shear forces in all the directions (Fig.2.1.15-a). While one of the two layers expand or contract, shear forces increase (Fig.2.1.15-b) and the points A and B start to slide in opposite direction, reaching the new positions $A^{\prime}$ and $B^{\prime}$. When shear forces exceed significantly tangential adhesion forces, an adhesive rupture occurs (Fig.2.1.15-c).

This physical explication permits to understand the mechanisms of formation of cracking, but the causes of the formation of the stresses that lead to this phenomenon are numerous. They are not always clear, but sometimes it is possible to speculate on the origin of specific crack patterns. Cracking mechanism can arouse because of exsiccation processes, ageing or accidental causes.

Cracking resulting from exsiccation processes are cause by executive defects due to the artist practice, such as the use of an excess amount of binder. It can also happen that the paint layer dries quickly at the surface resulting dry at touch, while an amount of solvent is still present in the inner part of the layer. This phenomenon lead to a plastic deformation of the paint layer and to the formation of cracks with rounded edges. Alligatoring cracks are the result of erroneous executive techniques. Some authors address the origin of these cracks in and erroneous drying time, and the non-observance of the rule of 'fat-on-loan', suggested in many manuals. In fact, when the underneath layer has a high amount of binder and, therefore, has low porosity, the overlaid paint has a cohesive strength higher than the adhesive one and slides without gripping. With the passing of time this cracks will thicken assuming a concave shape, and they will tend to detach from the paint (Scicolone 2004). Another example of drying cracks is that of cracks resulting from the application of a fat paint applied too thickly, especially if applied on a fresh coat. These cracks are usually localized to the paint field. They cause the painting surface disruption, but they barely represent a problem in terms of structural loss (Hackney 2020).

These examples shows that exsiccation cracking phenomena can involve the rupture of only one layer. On the contrary, ageing cracks usually interest all the paint layers, the ground and sometimes also the size. The formation of ageing cracks may depend on different internal and external factors. They can be determined by the rheological mechanism previously described, 
because of a great tension promoted by the stretcher or the canvas, or because of the dimensional changes of the ground and the paint layers. In fact, the tension of a canvas painting plays a fundamental role with respect to crack patterns, since mechanical cracks are perpendicular to applied tensile force. For example, an excessive tensioning on a fixed stretcher causes diagonal corner cracks. The pattern of cracking margin cracks changes if cracks form during humidity decrease or during humidification. The pattern formed at low tension is the most typical cracking on paintings: often the regular 'waves' and lines perpendicular to edges of a painting become random or disappear toward the centre (Karpowicz 1990).

Nevertheless, external factors are other cause of cracking. For example, impact cracks have a concentric pattern with marked edges. This is because the impact is rapid, so that the response of constitutive materials differs from long-term responses to changing conditions (Mecklenburg and Tumosa 1991a, from Hackney 2020). This depends on the viscoelastic behaviour of the materials: when the forces are applied rapidly, the materials behave as it is much more brittle than when a slow increasing force is applied.

Other crack patterns are ascribable to erroneous conservation treatments. For instance, an animal glve (that has a high tensile strength during drying) applied on the painting surface can tear-off the paint layer as a consequence of its contraction during drying. Furthermore, a wrong cleaning method could remove also the non-polymerised part of a paint film, leading to the decrease in the saturation of the colour but also to an increase in the brittleness of the paint, thus to a higher chance of cracking.

In conclusion, many studies have been carried out with the aim of founding a comprehensive system to catalogue the different crack patterns and other studies are in progress. It is important to study cracking patterns before restoring a painting because they can give important information on its conservation problems in order to understand how to operate. In fact, not all the cracks, although visually intrusive, are an evidence of immediate instability as long as the paint and ground remain fixed to the sized canvas. It is also true that once cracking has occurred, cupping and flacking phenomena are likely to occur. Contraction and expansion movement, like that described before as a function of Mecklenburg cracking model, can lead to the progressive detachment of important portions of paint or ground layers. 


\subsection{Classes of facing materials}

In the previous sections, it was possible to deepen the understanding of cracking, flaking and cupping formation, which are the phenomena on which restorers operate with facings to try to fix temporarily or to solve directly the problem.

Before continuing with the explanation of facing mechanisms and the scopes of facing, as well as with the description of the risks and the conservative problems deriving from this operation, it is of worth to explain something about the characteristics of the two classes of materials employed for this operation, and the variables that influence the performance of a facing.

\subsubsection{Temporary supports}

To understand how a facing works, it is important to know the characteristics and the behaviour of the temporary supports employed for facing. During the history, scores of different supports have been used for this scope. Most disparate kind of papers have been the most frequently used, and among them, the different kind of Japanese papers are surely the most popular. In the last decades, restorers started to use also papers with some synthetic components that improve paper performances, or synthetic tissues like nonwoven fabrics.

\subsubsection{Papers}

As it was possible to see in the previous chapter, many kinds of papers with different characteristics have been used during the centuries. Paper is a very ancient support, invented in china around the I-II century, by felting macerated silk fibres, and then macerated bushes bark fibres and rags. From there, paper was first exported to Korea and Japan, and then, through the Silk Road, to the Arabians, who brought it to the Mediterranean region around the VIII century (Grantham 2002; Priori and Quattrini 2007).

Since the beginning, occidental paper-mills used manufacturing techniques and materials different from the oriental ones. In China, bamboo and mulberry were used, while in Japan paper was and it is still produced using local plants 
(mitzumata, gampi, kOzO91). Instead, Arabian and European used macerated rags until the XIX century, when the use of the wood pulp 92 was introduced to supply to the need of a cheaper paper in a great quantity, at the expense of its quality (Lorusso 2006).

The different raw materials and manufacturing determine different technological features of oriental and occidental papers. In fact, even if oriental papers are softener, they have better mechanical characteristics. As explained by Dard Hunter, the reasons of this difference lie in the different scopes addressed to the papers:

\begin{abstract}
"The papers of Orient are used in great quantities for brush writing, which requires a soft, rather, absorbent, paper, the direct antithesis of what the occident considers suitable. In the occident a heavily-sized, non-absorbent paper is required. With pointed metal pens and rapid flowing chemical ink in which the colouring is dissolved, a hard, impervious paper is needed, and in occident this form of writing paper has been developed. In orient, however, as before stated the writing instrument for many centuries has been the brush, and the fluid used for writing a suspension of fine particles of carbon in water; for this combination the best results are had by the use of soft, absorbent paper" (Hunter 1978).
\end{abstract}

Different kind of papers with different grammages and strengths were and are still employed for facing, but since their introduction in European context, oriental papers were considered the most suitable ones for this operation. Oriental papers were known since the $16^{\text {th }}$ century, due to the relations maintained by the Jesuit missionaries from Portugal and Spain with China. With the treading reopening with Japan in the $19^{\text {th }}$ century, Japanese papers spread all over the Europe. Anyway, oriental manufacturing techniques remained a mystery until the $18^{\text {th }}$ and $19^{\text {th }}$ century, since Chinese and Japanese sold the paper without revealing the secrets of its production. It is probably thanks to the renewed relations between England and China in the $18^{\text {th }}$ century that the production of occidental paper made a qualitative leap. By mid-century, in England it was produced a new kind of paper: the wove-paper, better known as papier velin (probably the same named by Ulisse Forni in his manual). This paper had better characteristics compared to the other occidental papers, but it remains technologically worse than the oriental ones. Still today the so-called Japanese

\footnotetext{
91 Nowadays, a Philippines plant named manilla is frequently used for the production of the so-called Japanese papers because of is cheapness and rapid growth.

92 Wood pulp is produced with three main processes: mechanical pulping, chemical pulping and chemimechanical pulping. In mechanical pulping process, pulp is produced by grinding. The high percentage of impurities and the excessive wearing out of the fibres reduce paper strength. Chemical pulps are produced by treating wood with specific chemicals (Sulfate, Sulfite, or Soda) to break the chemical bonds of wood fibres and thus separate lignin from cellulose. Papers produced with this system have good mechanical properties, but is more expensive. The chemi-mechanical process is a combination of the other two. This system permits to produce a paper with discrete mechanical properties and low cost.
} 
papers used for the restoration of canvas paintings (which are usually produced in Europe) and the other occidental papers used for facing (e.g. Papier Bolloré, English tissue, and Eltoline tissue) do not have the same characteristics of the oriental ones.

This is because oriental papers are made from plants with long and elastic fibres (kozo: $12 \mathrm{~mm}$; gampi: 3-4 mm, mitzumata: 3-4 mm, manila: 5-6 mm), and because of the different manufacturing process that does not destroy the fibres as it happens in the occidental processes. One of the most famous traditional Japanese method (used since the XIII century) is probably the nagashizuki (Priori and Quattrini 2007). This system require a previous steam cooking of the stems (usually of kozo). Later the stems are macerated in water, boiled in an alkaline solution, and let dry at the sun. The big difference with the occidental production process lies in fiberizing process: it is made hitting the fibres, without cutting them. The greater length of the fibres permits to obtain a more flexible and strong paper, even with a reduced grammage. The obtained pulp is mixed with a high percentage of water and sometimes with a small quantity of vegetable mucilage is added to promote the dispersion of the fibres without using other additives. A screen-mould 93 is inserted in the dispersion and moved backward and forward to let the pulp deposit on it. Then the pulp on the screen is let dry. Only for some processes the sheet of paper are pressed. Sometimes they are just brushed to remove the excess of water, like in the tamezuki process (Vangerow 1989).

Unfortunately, the oriental-like papers produced in Europe used for facing do not have the same quality of the Japanese papers because many times the production processes used are the result of a combination of oriental and occidental fabrication processes. Raw materials and manufacturing process strongly influence the characteristics of the different kind of papers.

In general, papers are made of cellulose, whose rheological behaviour was described in the previous section. Paper is constituted by a nonwoven aggregation of cellulose fibres, so that the behaviour of a sheet of paper differs from that of a waved canvas: with the increase of relative humidity, paper increase its weight and it swells. As well as the other hygroscopic materials, the mechanical characteristics of paper changes with relative humidity fluctuations. Under the $50 \%$ of $\mathrm{RH}$, paper fibres become stiff, their elongation capacity decrease and their tensile strength increase. Some studies demonstrated that

\footnotetext{
${ }^{93}$ Screen-mould is a wire mesh, which is fixed to a solid frame. In Japan and in China, moulds are made of bamboo or pampa slats tied together with horsehair, hemp or silk. Every paper mill has its mould format of different dimensions. In Japan they have a maximum length of $120 \mathrm{~cm}$, in China of $150 \mathrm{~cm}$.
} 
with an increase of humidity, paper resistance to tearing increase because the fibres become more elastic.

Papers can be analysed and classified according to grammage, thickness, presence of additives or impurities, $\mathrm{pH}$, or alkaline reserve. The knowledge of this and other characteristics is fundamental to choose suitable papers for conservation (Ansalone et al. 1986).

Grammage is the ratio of the mass of a pressed specimen versus its volume $\left(\mathrm{g} \cdot \mathrm{m}^{-2}\right)$. Many technological paper characteristics depend on grammage, so that it is very important to know this value.

Thickness is expressed by the distance between the two faces of a sheet of paper. It depends on the constitutive fibres, the density of the paper, the degree of cellulose refining, and other production processes, especially on pressing. Voluminous fibres, poorly refined cellulose, small pressing determine a greater thickness, so that a higher thickness does not always correspond to a higher grammage.

The degree of cellulose refining, the percentage of lignin, the presence of some additive such as the ones used for sizing or colouring, can decisively influence the mechanical and ageing behaviour of a paper. For example, for the production of some modern papers a quantity of synthetic polymers is added to cellulose during the fabrication process to increase the resistance and the weight-strength of paper. This happens for example in the case of Papier Bollorè, which is made of manila fibre, wood pulp and polyamine-epichlorohydrin. In other cases, synthetic polymers are used after the sheet formation, during the calendering process.

For facing purpose, it is important to choose a paper without additives, such as alkaline reserves, that could interact with the painted surface and affect its conservation. Furthermore, it is important to evaluate paper resistance to solvents and heat employed during conservative interventions.

\subsubsection{Nonwoven tissues}

With the introduction of synthetic materials in conservation field during the last decades, the quantity of temporary supports used for facing increased a lot. The first non-woven fabrics were produced in the early thirties, as the result of experimentations with cotton waste. The first commercial production of nonwovens dates back to 1942. Since then, the market of nonwoven fabrics has experienced tremendous growth (Abu Sayed 2014). Today there are scores of 
nonwoven tissues used for different purposes in conservation field (lining, tear mending, transport packaging). Some of them, such as TNT tissues distributed by CTS Europe S.r.l., are largely employed for facing or canvas paintings in different countries. Others, which are well known in other conservation fields (e.g. textile and paper), have been empirically used by some restorers.

Nonwoven synthetic tissues are engineered fabric-like materials made from polymeric fibres, continuous filaments, or cut yarns bonded together by chemical, mechanical, heat or solvent treatment. They are flexible, porous, products consisting of one or more fibre layers. A nonwoven tissue can be made of fibre preferentially oriented in one direction or deposited in a random manner (Rofiquzzaman Raju 2015).

Properties of nonwoven fibres depends on combination of factors in their production, so that the range of characteristics is wide. They may be soft and resilient, or they may be hard and stiff, with different thickness. They may be hygroscopic or hydrophobic, with different grades of porosity.

Polyester is the most frequently used fibre. Olefin and nylon are used for their strength, and cotton and rayon are used for absorbency. Viscose can be added to increase elasticity and softness. Some acrylic, acetate, and vinyon are also used (Abu Sayed 2014).

As papers, nonwoven tissues can be classified on the basis of grammage, thickness, presence of additives or impurities, $\mathrm{pH}$, or alkaline reserve. However, the great variety of these materials make it very difficult to give an overview of the different kind of nonwoven fabrics.

\subsubsection{General remarks}

Whatever the support employed for facing, it is important to have information on their characteristics to understand the differences between the different supports.

For example, the knowledge of the constitutive materials and of the presence of some additive can be fundamental to assess the compatibility of a support with the constitutive materials of a painting. Is would be also important to know its rheological behaviour, for example its dimensional variation with humidity fluctuation and its tensile strength, which could help to determine the stress the support will exert on a painting surface during facing drying.

Unfortunately, many times manufacturers do no give sufficient information on the characteristics of papers and the other supports they sell. The information they give 
is limited to generic composition (which is not always exact), grammage and sheet dimension.

There is a lack of studies on papers, as well as on the new synthetic supports. As denounced with regard to Japanese papers by M. Ansalone and his colleagues (1986) and later by G. Priori and V. Quattrini (2005), materials used in conservation field should be better characterised. Manufacturers and dealers should be required to give specific information on papers meant to be used in conservation field.

Japanese papers are used since decades in occidental conservation practice because of their chemical-physical characteristics. The uncertain origin of some products led to confusion and there is the need of a greater clarification. In an interview conducted in 2015 by the author of this report, Priori confirmed that the situation had remained unchanged: manufacturers still gave limited information, insufficient to understand the short-term and long-term behaviour of sold materials.

The same goes for the synthetic tissues, for which it is difficult to find specific information for conservation purposes. In fact, the market of conservation products is rather limited (there are few companies producing materials specifically dedicated to conservation), so that restorers have to find new products intended for other scopes. Nonetheless, specific information useful for conservation purposes are rather found.

In this context, it is necessary to underline that the problem lies also in the attitude of canvas restorers. In fact, many restorers of easel paintings do not give the right importance to the choice of the temporary support used for facing. They usually use the same two or three kind of supports to which they are accustomed, without questioning on the influence of their characteristics. For example, in the choice of paper supports, they are usually interested in the grammage of the tissues they use, wrongly believing that this characteristic is directly proportional to its mechanical strength. On the contrary, mechanical strength depends on other factors, such as the constitution and the length of cellulose fibres, the presence of additives and many other factors.

Starting from these remarks, the necessity of deepened studies on materials used as temporary supports for facing appears obvious. The choice of the temporary tissue, as it will be shown in the latter section, can be crucial for the conservation of a paint. The most used supports should be analysed and characterised to give restorers another instrument to control the performance of his intervention. A collaborative attitude between conservation scientist and conservator-restores, but also with conservator-restorers of different sectors (e.g. paper, contemporary art) should represent a strong point for the development of conservation filed. 


\subsubsection{Polymer adhesives}

Polymers are film-forming materials that, once applied in a fluid state, settle creating a continuous and homogeneous solid film, thorough chemical and physical filming mechanisms.

It is difficult to make a univocal classification. Polymers can be classified according to chemical nature (e.g. organic, inorganic, natural, artificial, synthetic polymers), application methodology (e.g. hot-melt, in solution, in dispersion, tackymelt), setting process (e.g. by evaporation of the solvent, by evaporation of dispersing agent and coalescence, by cooling, by chemical reaction), polymerisation process (e.g. by addition, by condensation), or thermal behaviour (thermoplastic, thermosetting). These classifications helps to distinguish among the different polymers in order to understand which could be the most suitable for some operations. Nevertheless, they are limiting for a more comprehensive understanding of polymer properties.

The characterisation of the materials according to their specific properties permits to break away from the classical distinctions and to understand how do they behave. In fact, in addition to their composition, factors such as molecular weight and glass transition temperature are determinant for the resulting viscosity, film-forming properties and their long-term stability (Mecklenburg, Fuster-López, and Ottolini 2012).

The molecular weight ( $\mathrm{MW}$ ) can be found by adding up the atomic weights of one of the monomeric units that compose the polymer, and multiplying it by the Degree of Polymerisation (Horie 2010). However, in a real-life situation, the molecule chains that compose the polymer have different length. It is therefore necessary to insert a medium value. The most used model is the weight average molecular weight (MW), which is the sum of the squares of the weights divided by the sum of the molecular weights. This value is indicative of other properties, such as viscosity or mechanical strength.

Polymers are amorphous solids (partially or totally) and when they are subjected to heat do not present first-order phase transition like crystalline solids, but they are subjected to a phenomenon called glass transition, that extend over a range of temperature $\left(10-20^{\circ} \mathrm{C}\right)$. The range of temperature at which this phenomenon occurs is called Glass Transition Temperature (Tg) (Borgioli and Cremonesi 2005). The convention is to define the Tg when a polymer has a viscosity of 1012,3 Pa. Tg increase a bit with the molecular weight, since the chains have less freedom of movement. Many of the polymers employed in conservation practice are totally amorphous and thermoplastics, so that they have only one transition temperature. Some others, such as wax or polyethylene, have a crystalline portion that melt at 
a higher temperature (Tm) than Tg, causing a second transition in properties on heating or cooling.

Glass transition temperature, as other chemical-physical characteristics, can be influenced also by the solvent used to dissolve a polymer. The two most relevant aspect to the solvent influence are the degree of interaction and the speed of interaction. The first one depends on the solubility parameters while the speed of interaction depends on the size and shape of the molecules.

Polymers form viscous solution. Viscosity usually increase with the molecular weight of the polymer or with its concentration, but also with the viscosity of the solvent. Furthermore, viscosity of a polymer solution depends on the degree of interaction of the solvent with the polymer (solubility parameters). In a diluted solution made with a 'good' solvent, the polymer molecules are stabilized and expanded. This means that a polymer in a 'good' solvent occupies more volume and therefore has a higher viscosity relative to one of a 'poor' solvent. Nevertheless, if the concentration is higher than 15-30 \%, 'poor' solvents generate higher viscosity solutions. The polymer molecules interact more strongly with each other than with the solvent and they tend to agglomerate. This generate lager cluster that hardly flow. Therefore, a high degree of interaction between the solvent and the polymer permits a better flowing when the concentration of the polymer is higher, for example during the last stages of drying. Combinations of 'good' and 'poor' solvents can be used to change the characteristics of the polymer solution according to the scope of its use. For this reason, Horie (2010) suggests to use a combination of a volatile 'poor' solvent with a small amount of a 'good' slower evaporating solvent for applying an adhesive formulation. The requirements for consolidation are different, since the constant of diffusion of a polymer in a 'good' solvent is higher than that in a 'poor' solvent.

The solvent used to dissolve a polymer can influence its Tg: a 'good' solvent has a greater effect in reducing Tg than a 'poor' one. This phenomenon was demonstrated by a study carried on in 1991 at the Getty Conservation Institute (GCI). For instance, it is possible to modify considerably the Tg of two kind of PVAC (AYAC and AYAT) changing the solvent. 'Poor' solvents (ethanol, acetone and water) increase the $\mathrm{Tg}$, creating a polymer film rigid and brittle at room temperature, while 'good' solvents (tolvene and chloroform) decrease PVAc Tg, making it weaker and softer than the values reported in literature. This phenomenon is probably due to the retention of the solvent in the polymeric film. In fact, until a quantity of solvent is retained in the polymer, it has a plastic behaviour. When all the solvent evaporates, mechanical properties of the polymers come back to the values shown in literature. The time of solvent retention 
depends on the interaction solvent/solute and it can last hours, months, or also years (Wolbers 2008).

The molecular weight, the glass transition temperature, and the solvent employed to dissolve the polymer influence the mechanical properties of a polymer. The increasing in molecular weight increases strength only up to a limiting value. The glass transition temperature is important to determine the elastic modulus of a polymer.

In general, all polymers have a similar mechanical behaviour: when they are subjected to a tensile strength, at the beginning they undergo an elastic and reversible deformation, then they start to have a plastic and irreversible distortion, until they break. However, polymers are viscoelastic materials and their mechanical behaviour variate with thermo-hygrometric environmental conditions. When the temperature is lower than its Tg, a polymer is rigid and brittle, and it has the mechanical characteristics of a solid; when the temperature is higher than its Tg, it is plastic and rubbery, and it has the mechanical characteristics of a fluid with a very high viscosity.

Most of the polymers used in conservation practice have a Tg similar to room temperature. However, resins vary from extremely flexible but strong rubbers to brittle weak materials, and these polymer properties have considerable effects on the object. For instance, when a polymer with a high elastic modulus is applied on a painting, a tension is set up between the two layers when the latter expand with the increase on humidity. The strong polymer will resist to stretching and it will tend to weaken the paint layer, and if the adhesion strength between the paint layer and the polymer is higher than the one with the other constitutive layers, it will be detached. Instead, if the polymer is weak (low ultimate strength), the movement in the painting will cause the polymer to crack. Otherwise, if the polymer is relatively strong and its elastic modulus is not too high, the polymer will follow the movement of the substrate without breaking.

The mechanical properties are very important in choosing a polymer. Highly specified standard tests are widely used for industrial evaluation, but these are rarely of direct relevance to conservation applications. In fact, many times the strength of polymers applied for conservation purposes is greater than needed, and sometimes it can be even dangerous (Horie 2010).

Another important factor to take into account to choose a polymer is the stability over time. Even when temporary intervention is made on a painting (such as facing), the employed polymers have to be durable because a part of them will never be removed from the painting. Even optical properties, such as colour, 
refractive index and gloss have to keep constant as time went by, especially when the polymers have to be used on the surface of a painting.

Degradation refers to every change that makes the polymer unsuitable for its scope. A polymer can undergo a variety of deterioration processes: yellowing, stiffening, weakening, irreversibility, or harmful chemicals releasing. Degradation phenomena can be caused by chemical changes in the polymeric film, with consequent physical modifications. The main chemical reactions are: depolymerisation, reticulation, or formation of new functional groups (Borgioli and Cremonesi 2005). In terms of physical changes, a polymer can undergo plastic deformation, permanent expansion or contraction, break, viscoplastic sliding, or dirt absorption. Polymers with a Tg similar to environmental temperature can follow the dimensional variations of constitutive materials, but sudden or frequent environmental changes can lead to their deterioration. Polymers with volatile plasticisers that evaporate over time become brittle and more sensitive to environmental changes. Furthermore, low-weight plasticisers can migrate and thus alter the substrate.

\subsection{ADHESION AND PENETRATION FACING MECHANISM}

In the previous sections, the characteristics of the single materials (painting, temporary support, adhesive polymer) were described. However, adhesion and penetration facing mechanisms depend also on the interaction of these three classes of materials. The deepened knowledge of how these materials interact during the different steps of facing permits the partial modification of some variables to steer and promote certain mechanisms.

When a painting is faced, the temporary support is applied on the surface using a fluid polymer. This polymer has to exert an adhesive force between the temporary support and the surface of the painting, while a part of it can penetrate in the substrate. Sometimes, as it will be further explained, restorers want to gain a good penetration, in order to consolidate the superficial layers. Therefore, during facing the adhesive action is always present and desired, while penetration can be desired, or an inevitable collateral action.

There are two main categories of adhesion: adherend-adherate combinations or adhering systems, and adhesive joints. In the first case, an adherate adheres to one adherend only. In the second, two adherends and an adhesive are involved. 
The adhesive joint systems are intuitively more complex than adhering systems (Mittal 1977). Facing belongs to this second category, since a thin adhesive layer holds together the paint surface and the temporary support. Therefore, adhesion strengths are exercised on the interfacial transition zone between adhesive and adherends (temporary support and painting substrate).

Adhesion is a multi-disciplinary topic including surface chemistry, physics, rheology, polymer chemistry, polymer physics and fracture analysis. The complexity and the evolving understanding of this subject make it difficult to describe adhesion mechanisms in simple terms. There is no one theory on what causes adhesion or on how it works, but rather a number of concurrent causes of adhesive properties (Wake 1977; Chung 1991; Mittal 1977; Horie 2010; Awaja et al. 2009; Martín-Rey 2012). For this reason, different adhesion models have been developed:

- Mechanical model. It was one of the first adhesion theories. Adhesion is explained by mechanical interlocking: the liquid adhesive penetrates in the porosity of the substrate and then sets. The adhesion strength increases with the contact surface area and the porosity of the substrate is very important.

- Electrostatic model. This theory claims that the attractive forces are due to electostatic effects between adhesive and adherend in very close contact. According to it, all the adhesion phenomena are charge transfer across the interface.

- Adsorption, wetting, or thermodynamic model. According to this theory, the adhesion is created through the intimate contact between the molecules of the adhesive and the substrate. For this reason, the liquid adhesive should have good wetting properties towards the substrate. This model predicts adhesion strength from thermodynamic work through the formation of close secondary bonds (van der Waals, Hydrogen Bonds).

- Chemical bonding model. It explains adhesion through the attractive forces existing between molecules, involving all the types of chemical bonding (covalent, hydrogen, van der Waals, metallic, and ionic). According to this theory, the intimate molecular contact is not a fundamental requirement in order to have strong adhesion. It use the parameter of the bond energy and bond length to characterise the bond strength.

Penetration mechanisms are strictly linked to adhesion mechanisms, since the fluid adhesive applied to obtain the adhesion partially penetrate in the substrate. 
Facing process can be divided in four main steps: application and diffusion of the fluid adhesive; setting; formation of the adhesion bond; facing removal. For every step, some crucial properties for a successful outcome can be identified.

\subsubsection{Application}

In traditional facings, the adhesive is applied in a fluid state before applying the temporary support or is brushed through it. Adhesive has to cover uniformly all the irregularities of the substrate without an excessive penetration and without forming airlock which would weaken the adhesion. The extent of penetration mainly depends on three factors: viscosity, wettability and porosity of the substrate.

Viscosity is determining to obtain a good adhesion and it has to be calculated according to the porosity and the roughness of the substrate. An excessive fluidness would lead to an excessive penetration in the substrate, preventing the film-forming, while an excessive viscosity would prevent a uniform distribution of the adhesive. It is also important to calculate viscosity according to the selected application system. Michalski (2008) demonstrated that the use of different application systems determine a change in viscosity and concentration ${ }^{94}$.

Viscosity influences one of the most important properties that permits a good adhesion: the wettability. The best joint between a liquid and a surface is gained when the liquid covers the whole surface. The magnitude of this phenomenon depends on the forces exerted in the same fluid and between it and the surface. These forces are expressed by surface tension and interfacial tensions.

Surface tension depends on the cohesion of the molecules of the fluid that tends to contract into the minimum surface area possible. Therefore, surface tension is the result of a greater attraction of liquid molecules to each other than to the surrounding molecules of the air, that lead to the formation of a 'film' that prevent the expansion of the fluid.

\footnotetext{
94 In the case of an application with brush, it is possible to influence partially the adhesive release by changing the brush or the application system. In fact, when the solvent evaporates from the solution present on the brush bristles, the concentration of the adhesive solution increase. The increase in concentration will be faster in little brushes because of the higher ratio surface/volume. Furthermore, if too much time pass between the impregnation of the brush and the application on the substrate, or if the brush is not completely soaked every time that it is immersed in the solution, the concentration on its bristles will increase and the viscosity of the applied solution will be therefore higher than that of the prepared solution.

When the adhesive is applied with a spryer, adhesive drops that reach the painting surface have a concentration and therefore a viscosity higher than that of the initial solution, because the solution drops are mixed with a high pressure air flow and the solvent evaporate on the way. On the contrary, solutions applied with more advanced systems such as ultrasonic nebuliser do not change to much their viscosity.
} 
The interfacial tension depend on the solid in contact with the fluid and on their affinity: the lower the affinity, the greater the tendency of the liquid to contract reducing the contact surface with the solid. The molecules in a drop of liquid at the junction with the surface of a solid are subjected to three forces along the interface:

- The attractive forces acting from within the liquid itself;

- The attractive forces acting from the surface of the solid and the surrounding vapour;

- The attractive force between the liquid and the solid (Horie 2010).

When the cohesive forces of a fluid are greater than the ones that attracted it to the solid surface, it will ball up to form droplets sitting on the surface, forming an obtuse angle $\left(\Theta>90^{\circ}\right)$. Instead, if the forces between the fluid and the surface are higher than the fluid cohesive forces, the fluid will spread out completely and wet the surface $\left(\Theta<90^{\circ}\right)$. This is valid for ideally plane and smooth surfaces (Fig. 2.3.1). However, it has to be considered that painting surfaces are irregular and full of pores, in which the polymer solution must flow to achieve complete wetting. Air trapped in pores obstacles fluid penetration, but if air has the time to diffuse out while the polymer is setting, the penetration will be deeper. Of course, adhesive solutions with low viscosity achieve a deeper penetration. However, most of the adhesive solutions used for conservation lower surface energies than many of the restored materials, so that initial wetting and adhesion is rarely a problem.

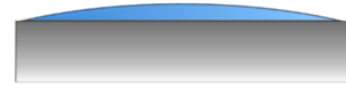

very favorable

$\theta_{c}<10^{\circ}$

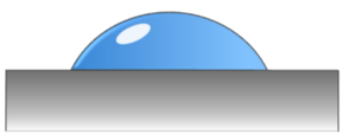

favorable $10^{\circ}<\theta_{c}<90^{\circ}$

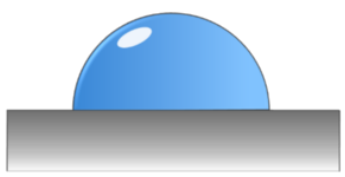

neutral

$\theta_{c}=90^{\circ}$

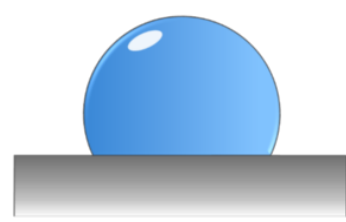

unfavorable

$\theta_{\mathrm{c}}>90^{\circ}$

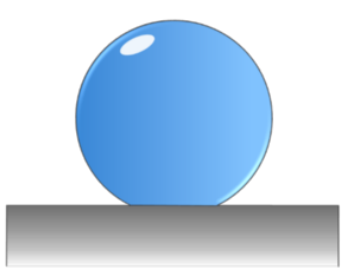

very unfavorable

$\theta_{\mathrm{c}}>150^{\circ}$ 
From the foregoing, it is clear that the wettability and the consequent setting of an adhesive depend also on the substrate on which it is applied. Chemical affinity is clearly fundamental, but porosity, permeability and absorbency of the substrate are also important. Porosity is a measure of the quantity and the dimension of the pores and voids of a material. It affects the speed of diffusion of a fluid in the substrate: the lower the porosity, the lower the migration of the fluid into it. Permeability is the measure of the grade of interconnection of pores and voids of a substrate and it permits the migration of the fluid from pore to pore. Both porosity and permeability determine the absorbency of a material, that is to say its retention capacity.

Wettability, adhesive viscosity and substrate absorbency determine capillarity and penetration in general. At a theoretical level, adhesion can be described by the interfacial interaction between two surfaces. Nevertheless, arts object are mostly constituted of porous materials, so that the understanding of capillarity and penetration is important to know how actuate to promote or to inhibit these phenomena.

First requirement for capillarity is the wettability of the adhesive solution towards the substrate. The moving speed of a capillary front through the pore network is the result of a balance between two forces: the wetting of dry pores, which pulls the liquid forward, and the resistance to flow of the wet pores. The pulling force remains constant, while the resistance grows as the penetration grows. Therefore, the capillarity speed decreases with penetration. The penetration of an adhesive is not easy to calculate. On the contrary, it is possible to be misled by the initial capillarity speed that occurs during the application of a low-viscosity adhesive. As explained by Michalsky:

"First, there is a square law effect: 10 times the penetration will take 100 times as long, not 10 times. Second, there is a very strong effect from concentration change: when solution concentration increases five times due to evaporation, penetration slows by a factor of a hundred or more, and will stop completely (this is good when we want to limit spread of consolidant)." (Michalsky 2008).

It is therefore very difficult to calculate the extent of the capillarity and penetration effect in a cracked painting. In his study, Michalsky deal with the phenomenon in relation to consolidation, describing the different steps of a polymer applied with brush on a cracked and laminated painting. When the adhesive is applied and the brush touch the crack, solution moves rapidly into the substrate along the crack, without jumping through the canvas (Fig. 2.3.2 a). If there is a sufficient quantity of solution in the brush, the crack starts to fill sideways far enough to allow some solution under the brush to move below the 
crack (Fig. 2.3.2 b). In this way, the solution finally touch the canvas (Fig. 2.3.2 c) and then may enter the delamination void (Fig. 2.3.2 d). During drying, the solution may become very viscous during drying, forming some adhesive bridges (Fig. 2.3.2 e-f). The solvent in the paint films will spread out before drying, and the paint will be soft for several times longer than it took to absorb solvent. It follows that the difficulty in evaluate penetration is complicated by the fact that every paint layer has a specific porosity and capillary strength. In fact, ground layers are much more porous than the paint layer, leading to a lower penetration. In fact, the penetration in paint and ground layers of little to medium particle size is possible only with low molecular weight, especially in the case of dispersions. Nevertheless, in voids bigger than $10 \mu \mathrm{m}$, as most of the cracks, also macromolecules can easily penetrate.
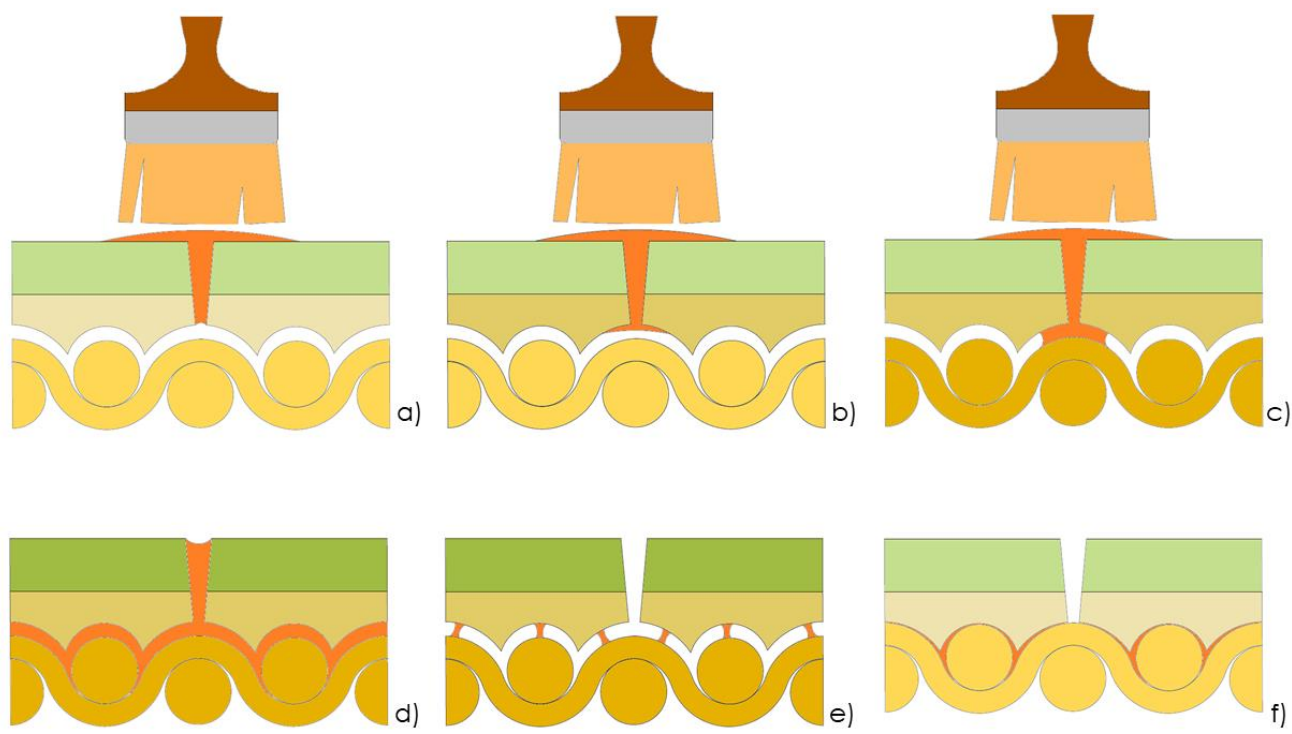

Figure 2.3.2. Steps of the penetration process of a fluid adhesive applied with brush in the cracks of a painting (reproduced from Michalski 2008).

During a facing, the understanding of the distribution of the adhesive on the substrate and its penetration is complicated by the coexistence of the temporary support. During the first applicative phase, the behaviour of a facing applied on the substrate changes according to the application method. If the adhesive is applied on the surface of the painting before applying the temporary support, the 
polymer diffuses on the surface and a part penetrates in the substrate. Once applied the temporary support, it adsorbs a part of the adhesive laying on the surface, and attract a part of the adhesive that has penetrated in the substrate. The phenomenon is influenced by the absorbency of the support and its affinity with the polymer. Instead, if the polymer is applied through the temporary support, the latter acts as a supportant, as it happens for cleaning interventions, and it retains the adhesive on the surface facilitating the uniform distribution of the adhesive.

Therefore, the polymer particles dimension and the viscosity of the solution have to be selected according to the temporary support. The viscosity of the solution has to permit a uniform distribution of the adhesive through the support fibres. Furthermore, the support has to adapt to the irregularities of the substrate to maximise the contact and reduce the quantity of solution required for adhesion.

\subsubsection{Setting}

The properties change during setting is caused by the transition from liquid to solid (actually fluid with very high viscosity), with and intermediate gel-phase. Furthermore, during this step, the support contracts with the polymer, tensioning the paint layer.

Setting process and time depend on both the adhesive and the support. Regarding the adhesive, a thermoplastic polymer in solution sets when the solvent evaporates and the temperature is lower than its Tg, while a thermoplastic polymer in dispersion when it starts the coalescence of the molecules. A longer phase for the setting of the polymer follow the first rapid solvent evaporation. The setting time depends on the evaporation speed of the solvent or dispersing agent and its retention time in the polymer and the substrate, as well as in the temporary support. An important phenomenon to take into account is the return migration of the polymer solution (Michalski 2008). The return migration refers to the stage while the polymers which has penetrated in the substrate starts to come back to the surface attracted by solvent evaporation. The return migration is facilitated by the use of solvents with high evaporation speed. Changing the solvent is therefore possible to have a higher or lower penetration. Of course, the presence of the temporary support can obstacle this phenomenon, acting against the surface permanence of the adhesive on the surface. It follows that the denser the support, the higher the penetration.

Furthermore, setting process implies a volume reduction of facing materials. For instance, a polymer in a $2 \%$ solution will lose $98 \%$ of its volume (Horie 2012). In a 
first moment, this reduction does not cause tensions because the polymer solution flows. The tension begins when a considerable part of the solvent evaporates, the polymers gels and it cannot flow anymore. Since the shrinking is obstacled by the adhesion to the substrate and to the support, the polymer undergoes to inner stresses. However, the polymer is not the only one that shrinks. During the application and the setting of the polymer, the temporary support undergoes expansion and later contraction movement. If the expansion during the application does not create tensions in the system because of the flowing of the polymer, its contraction during setting can pull the adhesive and consequently the substrate. The overall stress exerted on the painting depends, therefore, on the mechanical behaviour (strength, elastic modulus, ultimate strength) and the contraction of both polymer and support.

\subsubsection{Formation of the adhesive bond}

The adhesive joint resulting from the setting process should be as thin as possible, in order to ensure a suitable elasticity and flexibility. The Tg of the polymer should be intermediate (around $40^{\circ}$ and anyway never higher than $65^{\circ}$ ). In fact, a polymer with a low Tg would be to sticky and it would attract dirt, but also would penetrate in the substrate during the permanence of facing on the painting. On the contrary, a polymer with a high Tg would be too rigid. It should be applied the smallest quantity of adhesive necessary to create an adequate bond, in order to reduce the dimensional variations during the permanence of the facing: the small the adhesive quantity, the small the dimensional change. However, both the adhesive and the support should not be sensitive to environment changes.

Adhesive strength has not to be high, since facing adhere to the weakest layers of a painting and it is usually applied on degraded paint and ground layers. At the same time, the adhesion should be adjusted to the latter projected interventions. For example, for the painting transportation, a weak adhesive could be selected, while a strongest one should be chosen when structural intervention on the back of the painting are planned. Furthermore, in this case the adhesive should have a good elasticity, in order to absorb the stress and limit paint-flakes movement.

In general, the flexibility on the adhesive should be higher than that of the substrate, in order to avoid the occurrence of high stresses in the painting, but also in the facing layers. The strength of joint depends on the combination of the adhesive bond strength, the cohesive strength of the adhesive and the cohesive strength of the adherend. This means that a joint can fail in three distinct ways. If the tensions developed during the setting process and during the permanence of the facing are too strong, they can lead to the fail of the joint. 
Joint failure may take place at the interface between two layers (substrateadhesive; adhesive-support), or in the bulk of the weakest layer. These two failure mechanisms are called adhesion failure and cohesive failure. However, a clear interfacial failure hardly occurs. Usually it happens that interfacial failure occurs together with the cohesive failure of one or more the materials involved in the adhesion (Fig. 2.3.3). For this reason, it is important to use materials with a cohesive strength lower than that of the paint layer. In this way, the failure will occur in the adhesive layer or in the temporary support (or at least at the interface) rather than in the painting.

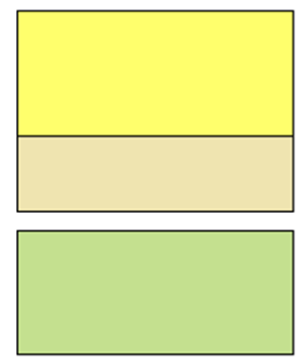

(a)

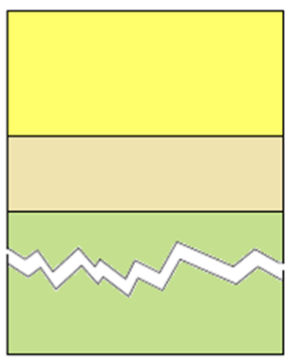

(b)

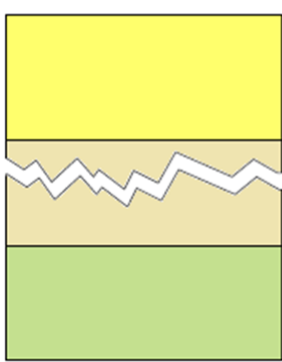

(c)

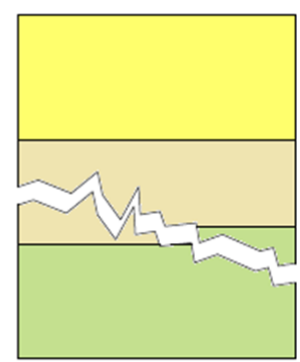

(d)

Figure 2.3.3. Failure forms of a bonded joint: a) failure at the interface; b) failure in the adherend; c) failure in the adhesive; d) complex failure.

\subsubsection{Facing removal}

The removal of a facing has the same importance of the other steps. In fact, during the reactivation the adhesive could penetrate in the substrate. Furthermore, the solvent used for removal could interact with the constitutive layer or with the restoration materials used during the restoration. For these reasons, the removal should be limited to the surface as much as possible. A 'good' solvent should be used to reactivate the adhesive, in order to have a quick, superficial and safe reactivation, since the peeling strength during removal is minimal when the polymer is completely reactivated. The temporary support would act as supportant and will facilitate the permanence if the solvent on the surface. 


\subsection{CONSERVATION ISSUES}

The knowledge of adhesive and penetrative facing mechanisms make it clear that facing is a full-fledged intervention with complex consequences involving changes to painting strata, and that it can have potential repercussions on the conservation of the paint itself. It would be always better to try to recover to other less invasive and localised interventions. If facing is necessary, all the risks connected to the different steps of this operation have to be taken in account.

It has to be clear that a completely superficial action, especially with the traditional systems (application with brush), is impossible to obtain. The impregnation of porous structures is thus an irreversible measure. Restoration materials can interact with the paint, or influence latter operations. For this reason, the restorer has to be sure that the polymer and the solvent are compatibles with the constitutive material of the painting and that the temporary support does not have soluble additives that could affect the substrate. The most common problems arise with the use of water, that can be a very dangerous and effective solvent. However, organic solvents can also damage the painting. The solution could react with the constitutive materials, causing swelling, solubilisation, or leaching. Facing materials could also have diverse effects on some specific colour fields constituted by different pigments (see the section relative to the behaviours of the paint layer constituted for example by earth colours and lead colours). Furthermore, the ground could swell or partially dissolve, causing the detaching of the whole paint layer. This happens, for instance, when a traditional facing made with warm animal glue is applied on a paint with a bolus ground. In addition, without reaching the solubilisation, the delamination of some layer could be promoted by the differential dimensional change caused by the solvent action. The most serious problems arise when some paint layers detach from the painting, adhering to the temporary support with a consequent accidental colour transport. In addition, the adhesive solution chemically reacts with the superficial layers (coatings or final glazes) making necessary their removal. Before facing, it would be better to remove the superficial dirt, to avoid its migration through the porosity of the paint layers and in cracks, and to avoid some other reaction with the painting.

Facing adhesives can cause changes in both the colour and the refractive index of the paint layer, especially when materials such as wax-resins are used for facing. This could be a risk especially for tempera or guache paintings, or for 
contemporary paintings, where the relation between mat and glossy surfaces could be significant. The changes of optical properties could depend not only on painting constitutive materials, but also on their porosity and conservation. In fact, a powdering paint layer where the original medium has depolymerised and disappear, present a mat surface. To re-establish the cohesion, a certain quantity of consolidant has to be added and this will change the refractive index, even if carefully selected. The same happens with facing. This phenomenon is emphasised in local facings: after the patch removal, the faced part could appear with a higher colour saturation. When all the painting is faced, it can happen the same.

As it is possible to guess from the explanation of the previous sections, damages during settings or even during the permanence of facing, could be caused by the dimensional variation of both adhesive and temporary support, that associated to a high elastic modulus and high ultimate strength, could tear off the paint layer. However, the shrinking during setting always causes tension in the painting, probably increasing cracking, flaking or delaminating phenomena.

Facing has to be projected according to the other operations. For example, in the case of the removal of some substance from the back of the painting, such as a lining adhesive, it would be better to use an adhesive with a solubility different from that of the lining one. However, it would be better to use some gel solution during the lining adhesive removal to avoid penetration.

A prolonged application of the facing on a painting should be avoided as much as possible, since it causes many problems to the artwork, especially when it is stored in unstable environmental conditions. To leave a facing on a painting for a long time means to leave it under continuous unnecessary stresses. The application of an adhesive and a temporary support on the weakest layers of a painting can be dangerous. The most employed supports are made of paper, a highly hygroscopic material that swells and shrinks with the increasing and decreasing of relative humidity. The same is for the adhesive, especially when traditional animal glves are employed. These strengths are anyhow higher in the junction points between the sheets of temporary support.

The choice of the adhesive affect the rheology of the superficial layer. According to the employed adhesive, facing can be hydrophilic (e.g. animal glve, Klucel, Aquazol) or hydrophobic (e.g. wax-resin, Plexisol). If the characteristics of the materials used for facing are very different from that of the paint layer, this can alter the equilibrium of the forces of the painting. When a hydrophilic facing is applied to an oil paint layer, which is usually the more 
hydrophobic, the surface starts to have a different mechanical behaviour, and in the worst cases this could lead to a biological attack in a layer that hardly experiment this kind of degradation.

Furthermore, if a facing is leaved for a long time on a painting, the adhesive could undergo to chemical transformations, such as depolymerisation and radical release, oxidation, or even reticulation. This would compromise the reversibility of facing. It could be difficult to reactivate completely the adhesive. A long reactivation time could be required, or it would be necessary to recur to the use more aggressive substances.

During the removal of a facing, a solvent is applied on the entire surface. This means that its application necessarily involves the further cleaning of the entire surface. In some cases, surfactant agents are added to the adhesive formulation (for example for the roman colletta. For further information, see Chapter 1), and this increases the cleaning action. Cleaning is not necessarily dangerous for the painting. The problem is that the application of a facing obliges the restorer to an invasive cleaning extended indiscriminately to the entire surface.

Some remarks on local facings are indispensable. Local facing is usually applied as patches in emergencies to consolidate or to fix flaking portions. This kind of operation should be avoided for different reasons. First of all, even if many efforts are made for a continuous work of conservation, it happens many times that a restoration cannot be finalised for lack of found, changes in political and administrative leaderships, or for many other reasons. It happens frequently to see patches applied on exposed paintings, which were applied since years and never removed. The author noticed this phenomenon in several museums of different nations, and I recollected witnesses about painting with local facings never removed, left for years in the storerooms of museums and other official institutions.

When a patch-facing is applied on a painting the damage is localised, but in a certain sense it is bigger. The perimeter of the patch and the surrounding area are subjected to differential stresses because of drying and setting process and of dimensional changes due to environmental fluctuations. This causes the deformation of the superficial layers. If the tension is repeated and prolonged in time, it can lead to the propagation of cracking and flaking phenomena that the facing was supposed to stop. Furthermore, when the local facing is removed, the print of the patch remains stamped on the paint layer. 


\subsection{THE GREAT MISUNDERSTANDING: PROTECTIVE AND CONSOLIDATING FACING}

Usually restorers define facing technique using a generic explication that refers to the materials used or to the operation to which it is associate. Nowadays it is necessary to stop referring to this operation in relation to the interventions to which it is associated and to give the right importance to facing, which is not only a corollary of other operations, but a proper conservative intervention. To do this, it would be necessary to focus primarily on the term used.

The English word facing is a generic term, which indicates that an outer layer is literally covering a surface. The same happens in other languages. For instance, it is called velinatura in Italian, empapelado in Spanish, and cartonnage in French. All these terms are merely functional, as they refer to the act of covering a surface with something or gluing something onto a surface. There are no references to the reasoning behind the decision that leads the conservator to face a painting, or to the measure's aim.

Is it not even useful to refer to facing in relation to the operation to which it is associated. It does not give an exhaustive explication of the reasons behind the choice of facing. To do this, it is necessary to think to the aim that a restorer wants to achieve with facing.

As mentioned before, there are two principal purposes in facing: a protective one and a consolidating one. These fundamental aspects are of uttermost importance and an often neglected distinction. In the first case, the conservator wants to avoid displacement, or the loss of detached fragments through temporary gluing: the detachment of the paint flakes is temporarily stopped, and it is possible to postpone the solution of the problem. The polymer should ideally settle at the interface between the interim support and the paint layer without penetration and eventually be reversible. In the second case, the purpose of the treatment is the consolidation of superficial layers. The temporary support is supposed to act like a barrier on the surface against external mechanical action. The adhesive should partially penetrate the paint layers and consolidate them superficially. At the end of the intervention, only adhesive residues on the surface should be removed (Fig. 2.5.1). 


\section{Protection of the paint layer}

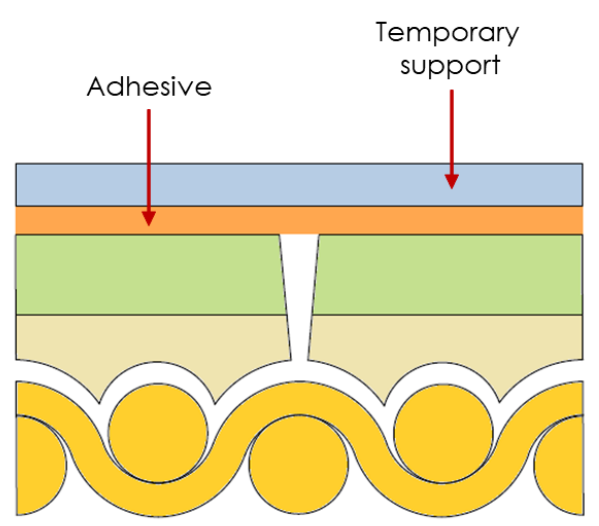

Protection of the

paint layer

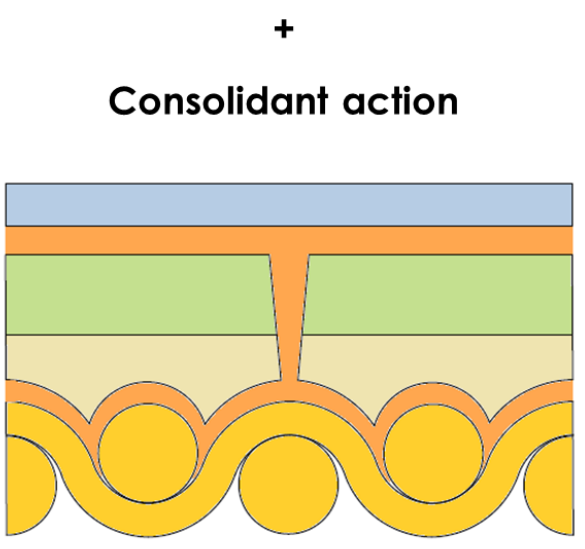

Figure 2.5.1. Distinction between protective facing and consolidating facing.

It is, therefore, necessary to make the distinction between protective facings and consolidating facings, thereby declaring the specific pursued purpose of each facing. However, this remains a theoretical distinction, since the same application methods are used in both cases. In fact, restorers usually recur to brush application of a low-viscosity adhesive solution both when they want to obtain a superficial, temporary and removable protection, and a consolidating action. Furthermore, there is no distinction between the protective and consolidating effects when traditional application systems are used, because the porosity of materials and the presence of cracking in the paint layers leads to its partial penetration, making it impossible to have a superficial action. Restoration materials can interact with the paint, or influence latter operations. Facing also implicate a subsequent cleaning of the entire surface. Changes in the colour or in the refraction index of the paint layer may even occur. The contraction of the facing support in association with strong adhesives can stress or even damage the paint, especially in case of long stay in instable environmental conditions. This could also affect the reversibility of the adhesive.

It is clear that facing is not an almost neutral intervention, but is ruled by complex mechanisms involving the entire painting's stratigraphy, with potential undesired effects on conservation. In principle, it would be better to use alternative and less intrusive methods, especially when we want to consolidate the paint. Facing should be used just in extreme circumstances, when it is not 
possible to find other solutions. We believe it should be used just with protective purposes. Nonetheless, with the current application methods superficial adhesion is not possible.

The following chapters will be therefore focused on the research carried out to design remoistenable temporary supports, an alternative method aimed to translate the theoretical distinction between the two kinds of facing into practice, enabling a higher control of the adhesive penetration in the substrate, and consequently easier removal of the residues. 



\section{The alternative: Remoistenable Temporary Supports (RTS)}

\subsection{INTRODUCTION}

As shown in the previous chapter, traditional facing systems can be dangerous and their use should be limited to extreme circumstances. In the case of a consolidating facing, it would be better to substitute it with a consolidating intervention, limiting its use for protection purposes. Nevertheless, with the current techniques a barely superficial adhesion is impossible. It surely depends on facing materials, but it mainly depends on the application method. That motivated the present research focused on finding an alternative method for the protection of the paint layer during conservation treatments.

The alternative application method proposed is based on the use of remoistenable temporary supports (RTS), turning to factual the theoretical distinction between the two kinds of facing. Remoistenable supports are thin tissues precoated with an adhesive film which can be reactivated with a very small quantity of solvent, before applying them on the surface of a painting (Fig. 3.1.1). RTS method implies the use of a very small quantity of solvent and it permits a greater control over some of the crucial parameters described in the previous chapter.

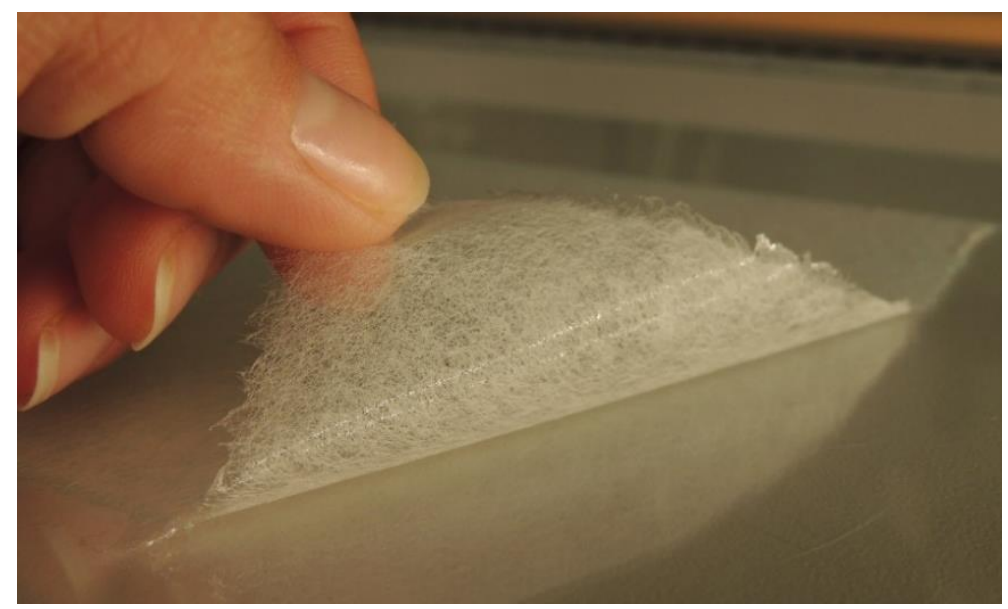

Figure 3.1.1. Remoistenable temporary support after the application and the drying of the adhesive. 
As will be further shown, the research project started with a critical evaluation of previous investigations and experiences on remoistenable tissues. Ideal characteristics required to the materials used were assessed, as well as reactivation and removal methods. In addition, the aspects concerning the field of application were estimated.

The experimental part of the research was divided in two principal steps. The first part was oriented to the characterisation of selected material, while the second one was focused on the evaluation of the efficiency of the developed remoistenable tissues on aged mock-ups reproducing an oil painting.

The research was organized in two main stages:

- The first experimental stage was oriented to the evaluation of the different characteristics of the two facing materials, namely adhesives and temporary support, and their compatibility for the development of remoistenable temporary supports.

- The second stage consisted in:

- The estimation of the permanence of adhesive residues and the alteration of the surface of the painting after removing the protective facing.

- The assessment of the penetration of the adhesives.

- The evaluation of the adhesive properties of facings.

\subsection{STATE OF THE ART}

Remoistenable temporary supports are not a brand new invention. This method is used, with some variations, in paper conservation on water-sensitive or solventsensitive materials. In fact, in paper restoration it is important to control the moisture parameter, particularly in the case of local treatments, because it can cause considerable deformations. The control of adhesive penetration is also fundamental, in order to prevent the colour saturation of the paper.

The first attempts to use remoistenable tissues date back to the eighties, with the purpose of lining paper, as stated Buckle: 
"The idea of preparing lining papers in advance of treatment by coating them with an adhesive film that is dried and later remoistened evidently was first experimented with in the 1980s by Bob Futernick, and was further developed by Cathy Baker. Her short, explanatory article appeared in 1990 in the Paper Conservation News." (Buckle 1997).

According to Buckle, there are no previous written sources on this technique that can be useful for treatments on moisture-sensitive objects, such as mending of paper and photographic documents, as proposed in the same number of Topics in Photographic Preservation by Wagner (1997).

During the years, different kinds of remoistenable tissues have been tested to repair or to stabilize water-sensitive objects and several adhesive systems have been used for treating different damages on these materials. Among others, Pataki (2009) tested the most used adhesives for consolidation of friable paint films on paper, such as Gelatine, Methylcellulose, Hydroxypropyl Cellulose as Klucel G, and also Paraloid B72 and Aquazol. The article of Pataki is useful because it gives information on the essential characteristics of the materials used for the realization of remoistenable tissues. In the paper, the author describes different reactivation processes with water and other organic solvents.

While Pataki investigated several adhesives, the work of Lechuga (2011) is focused on Aquazol remoistenable tissues. In fact, Lechuga tested 28 formulations of Aquazol-coated tissues, subjecting them to aggressive handling and elevated humidity conditions in order to assess their efficacy. The reversibility of mends was also evaluated (Lechuga 2011).

In a very recent article, Bedenikovic, Eyb-Green and Baatz (2018) give an overview on previous experiences and describe an investigation on the use of various materials and application systems, with the aim of:

"Develop facing systems which have sufficient adhesive strength to stabilize a paper-based object during a conservation treatment while at the same time being easily reversible after treatment without leaving any residues on the original." (Bedenikovic, Eyb-Green and Baatz 2018).

They measured maximum adhesive strength by a peel test with a spring force meter, while penetration was evaluated with microscope observation, after adding specific dyes to the adhesives.

Regarding the observation of the penetration, some notes are necessary. In fact, penetration is notoriously one of the most difficult aspect to evaluate in the case of canvas paintings. In the case of papers without a paint layer, it is easier to characterize the penetration because of the uniformity of the substrate. In the case 
of a canvas painting, it is much more difficult, because of the presence of different layers, with different characteristics. The presence of cracks makes the evaluation more complicated. Furthermore, the use of a dye is not always appropriate because it is dissolved in the solvent with the adhesive, but it is not chemically bonded to the polymer. This means that the dye may probably mark the penetration of the solvent and not that of the adhesive. Without the possibility of marking the adhesive some way, with the microscope observation it is very difficult to distinguish the adhesive in the stratigraphy of a canvas painting.

For this research, the authors prepared the remoistenable tissues applying the adhesives by brushing, immersing, spraying, stencilling and stamping. Subsequently, they used different methods for reactivation, such as application of solvent vapours, application of solvents with a sponge or direct application of solvents. In addition, the reactivation was carried out by pressure and/or heat. For the removal, they used the same methods and, in addition, mechanical removal.

It is interesting to see a similarity with our investigation, regarding one of the reactivation systems described in the paper:

"Solvents were applied with a sponge according to Jacobi et al. (2011). This method was developed for remoistenable tissues and allows reproducible, even moistening. Instead of the sponge cloth which does not swell with solvents, a synthetic non-woven (Poroflex fleece, $220 \mathrm{~g} / \mathrm{m} 2$ ) was used. Two pieces of nonwovens $(100 \times 100 \mathrm{~mm})$ were soaked with $30 \mathrm{ml}$ of the respective solvent (or solvent mixture). Two blotting papers cut to the same dimensions were placed on the non-wovens and were lightly pressed down. The facing tissues were then placed on the blotting papers with tweezers, brushed out until they were evenly moistened and were lifted off. Subsequently, the facing tissues were positioned on test papers and carefully brushed out. Facing tissues reactivated with $96 \%$ ethanol were held in the air for about five seconds to allow the adhesive to slightly dry." (Bedenikovic, Eyb-Green and Baatz 2018).

As it will be explained below, also for our investigation it was pursued a reactivation system, based on the use of a humidified reactivation cloth, alternative to the most common reactivation with spray. In fact, the reactivation with spray does not permit to have a reproducible system: it is impossible to determine the quantity of solvent sprayed on the surface, because it depends on the employed tool, the distance from which the solvent is sprayed and on the direction of the jet. The system employed by Bedenikovic, Eyb-Green and Baatz permits a higher reproducibility of the method.

The authors say that, for the application, reactivation by heat or pressure, or direct application of the adhesive, should be preferred to the solvent one, which seems to give strongest bonds. In the case of canvas paintings, the required strength 
has to be higher than that required for paper. Anyway, it may be interesting to test facing tissues reactivable by heat, to assess potential differences between different methods. In this way, it would be possible to choose among different pre-coated tissues depending on the specific needed of every single case.

In the field of paper restoration, many progresses have been made in the last decades. Some of the most innovative systems are still at the experimental stage, but it is of worth to mention one of them, based on the use of various adhesive-free Gecko tapes, proposed for the first time during the 2011 symposium of the Canadian Conservation Institute on Adhesives and Consolidators for Conservation: Research and Application. Gecko Tapes are based on the mechanism of gecko feet (Fig.3.2.1). Unlike traditional pressure-sensitive adhesives, which are based on viscoelasticity for adhering to surfaces, Gecko tapes rely on a concept known as draping adhesion. Draping adhesion is created with materials that can drape to create conformal contact with a surface while still maintaining high, elastic stiffness in directions where forces will be applied. This design enables a uniform distribution of the adhesive loads across the pad surface.
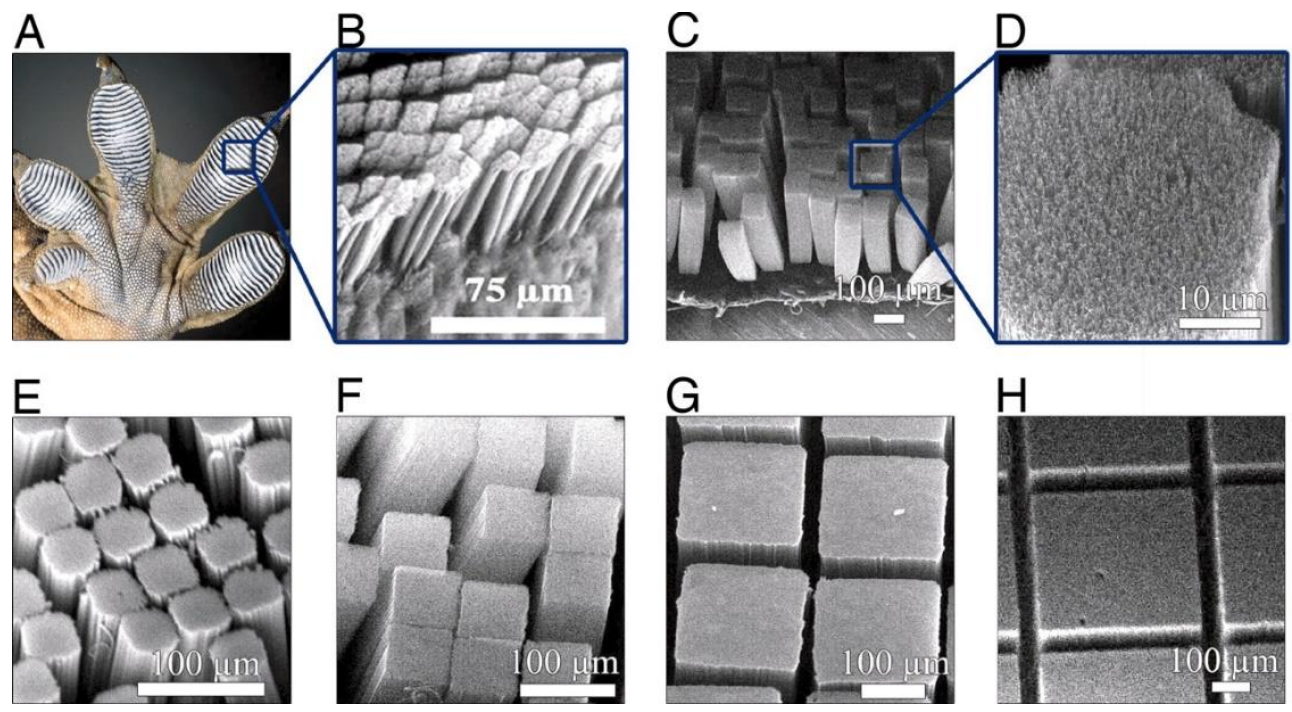

Figure 3.2.1. Microfabricated aligned multiwalled carbon nanotube setae and spatulas. (A) Optical picture of gecko foot showing that the setae are arranged in many lobes along the foot. (B) SEM image of natural gecko setae terminating into thousands of smaller spatulas (4). (E-H) SEM images of synthetic setae of width $50(E), 100(F), 250(G)$, and $500(H) \mu m$. (C and D) Side views (C) and higher-magnification SEM image (D) of the 100- $\mu \mathrm{m}$ setae (Liehvi Ge, et al. 2007). 
As explained by Olender, Gecko-tapes:

"do not require heat or solvents for curing, and no apparent adhesive migration or chemical interaction occurs with the adherend surfaces. The resulting adhesive bond has relatively high adhesive shear strength and low peel strength, leaving a surface without residue." (Olender 2017).

The long-term performance of Gecko-Tapes has not been tested, so that only short-time use can be regarded as safe. At the moment, these adhesives have been tested for the creation of temporary connections between fragments of photographs (or similar flat surfaces). It would be interesting to test these adhesives for temporary facing on canvas painting, looking also at their interaction with other operations, such as the consolidation from the back of the painting. The use of Gecko-tapes for facing of canvas paintings could solve many of the problems related with this intervention. However, as these materials are still under development and they have not been tested yet for canvas paintings, this is only mentioned as an outlook and possible approach for further researches.

In the field of canvas paintings, facing is still strictly connected with traditional systems. In fact, to the author's knowledge, nowadays there is only one publication about remoistanable tissues used for facing of canvas paintings, written by Borgioli, Boschetti e Tortato (2016). The authors propose an alternative facing based on remoistenable supports of Aquazol 500, used to protect the paint layer during the removing of non-polar linings. The aim of the paper is to demonstrate the efficacy of this kind of facing, and to warn against the possible risks of the use of this technique.

Remoistenable tissues proposed by the authors are prepared with Bollore paper $\left(22 \mathrm{~g} \cdot \mathrm{m}^{-2}\right.$ ), brushed with Aquazol 500 dissolved at $5 \%$ in Solvanol, used to reduce paper deformations. The application of the remoistenable tissue is made through spraying a very little quantity of water, which, compared to other solvents, increases the adhesive properties of Aquazol and reduces the cleaning effect of the remoistenable tissue (Fig. 3.2.2). The facing is removed by applying tablets of Gellano soaked with water. The application and removal of facing is made using a water solution with controlled $\mathrm{pH}$ and ion concentration, in order to reduce the risks for the painting surface. The control of the $\mathrm{pH}$ is achieved with a buffer solution, chosen according to the $\mathrm{pH}$ measured on the surface of the painting. Since conductivity cannot be measured directly 95 , the authors propose

95 Experimental researches are ongoing for the development of contact conductivitymeter that will let restorers to measure directly ionic concentration of surfaces. Current instruments are expensive and they permit only indirect measurements, which require the management of complex technical processes 
ranges of values based on literature: $3000-2000 \mu \mathrm{s} \cdot \mathrm{cm}^{-1}$ for aged and polymerized oil paintings, maximum $2000 \mu \mathrm{S} \cdot \mathrm{cm}^{-1}$ for pretty young oil paintings (100-150 years).

A part of the technical information on the preparation of the facing, the authors give some advices related to the field of application of this method, emphasising on the importance of relating the use of this technique to the whole intervention. In fact, this facing should be used respecting the basics of opposite polarity, which means that it would be used just in view of other operation on the back of the painting made using non-polar materials, such as the removal of a lining prepared with Plexisol P550 described in their case of study. In fact, the association of this facing with operations that require the use of a polar solvent could invalidate the good adhesion of the temporary support or facilitate the penetration of the adhesive in the substrate.
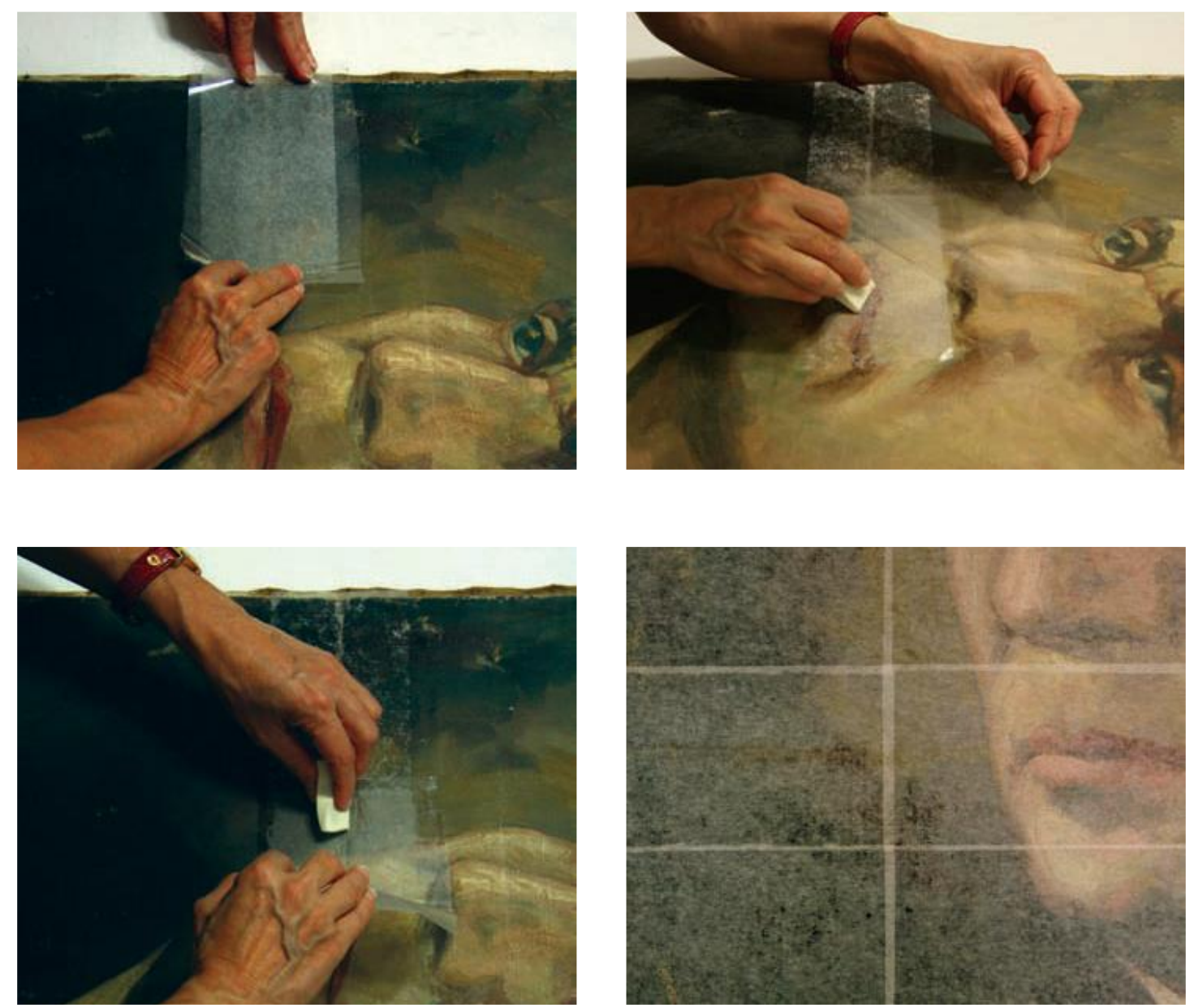

Figure 3.2.2. Application of Aquazol 500 remoistenable tissues after the reactivation with spray (Borgioli, Boschetti, and Tortato 2016). 
The described technique, as confirmed by Borgioli, Boschetti and Tortato, is still under development and further updating will be published.

Still during the initial phase of the investigation, remoistenable tissues of Aquazol 500 were presented by Enrica Boschetti at the Università degli Studi di Urbino "Carlo Bo" in 2012, during the laboratory lessons. This method was, therefore, included in the experimental part of the Master's Thesis (Alba 2015) carried out by the author, focused on evaluation of the adhesive strength of four kind of facings applied to varnished glass, characterised through peeling tests (Fig.3.2.3) and control analysis with stereo-microscopy and micro Raman spectroscopy. Part of the results was included in two papers published in the last years (Alba and laccarino Idelson 2016; Alba, laccarino Idelson, and Martín Rey 2017).

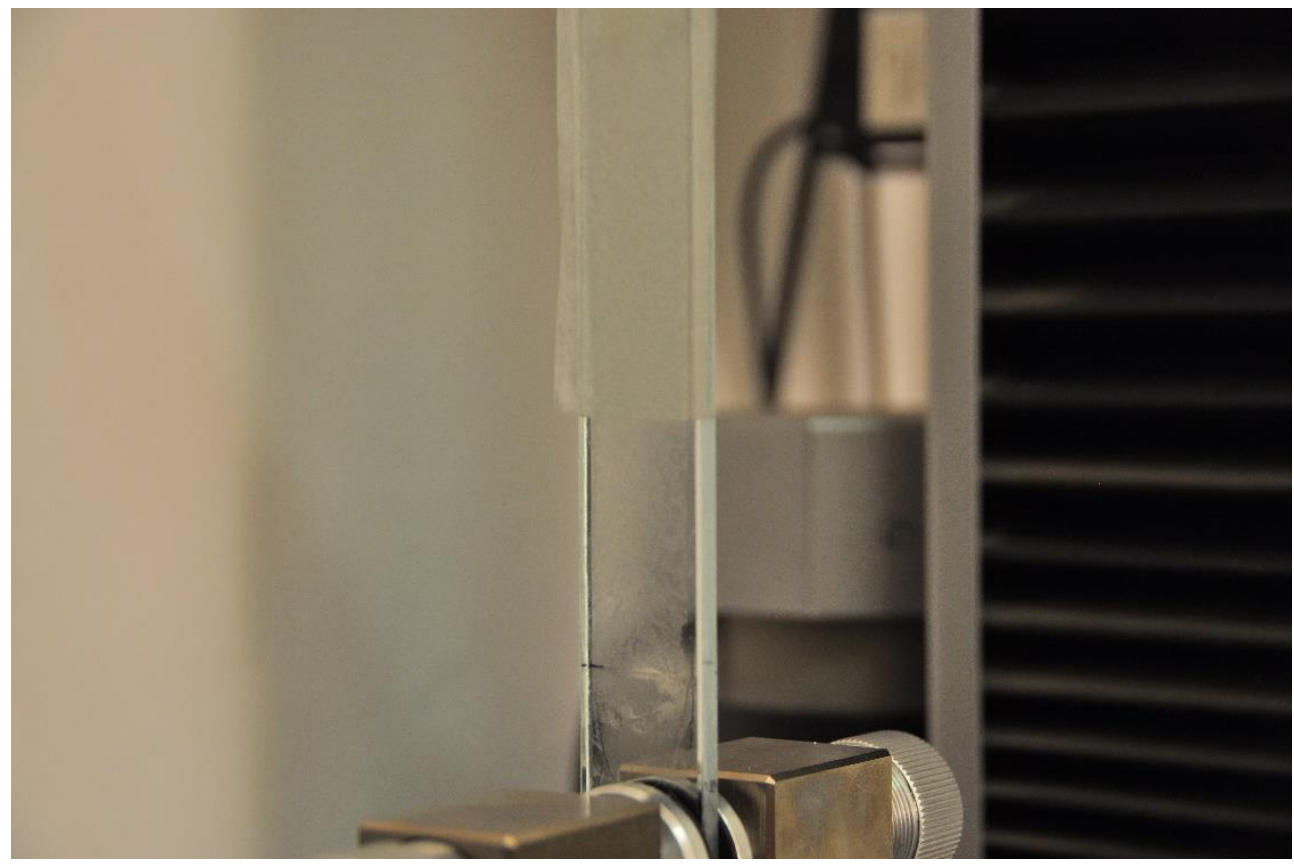

Figure 3.2.3. Peeling tests on Aquazol 500 remoistenable tissues, carried out at the Vatican Museums Diagnostic Laboratory for Conservation and Restoration.

These first tests revealed that Aquazol 500 remoistenable tissues have an adequate bond strength (about $1.5 \mathrm{~N} \cdot \mathrm{cm}^{-1}$ ). The only doubt about the use of this polymer concerns the superficial action of the adhesive. Aquazol 500 is a high molecular weight polymer (500.000). This characteristic should probably limit its penetration in the porosity of the constitutive layers of a painting. Nevertheless, as stated by the same Borgioli, Boschetti and Tortato, this does 
not limit its penetration in the cracks of the paint layer and the ground layer. The use of specific solvents, such as water, should limit the penetration 96 , but the relatively low viscosity of the polymer could affect the superficial permanence. Furthermore, the reactivation of remoistenable tissues by spraying, if not perfectly controlled, could cause the total solubilisation of the adhesive in some points of the temporary support. This could invalidate the efforts made to limit the penetration.

The issue of high viscosity adhesives associated to the use of remoistenable tissues was addressed at the Universitat Politécnica de Valéncia, where an adhesive dispersions constituted by a Cellulose Ether and Plextol are employed, to prepare remoistenable tissues. This system is probably inspired by the cold lining system developed in the seventies by Mehra $(1972,1975)$, who used dispersion of Plextol thickened with Nastrosol as lining adhesive.

\subsection{IDEAL CHARACTERISTICS OF RTS FACING MATERIALS}

The behaviour of a facing applied to a complex system, such as a canvas painting, is difficult to determine through hypothetic reasoning. However, the study of facing mechanisms, and the variables which can be changed to control the penetration, allows for some hypothesis in order to select the materials with suitable characteristics for the preparation of remoistenable temporary supports used as superficial protective facing for oil canvas paintings.

As a general rule for the conservator, it is fundamental to use materials which are: (1) compatible with the painting, but also easily reactivable. Of course, (2) they have to be chemically and physically stable, and (3) they have to be of low toxicity for human health and environment. Furthermore, (4) they should not be too sensitive to thermo-hygrometrical changes. Materials should have been selected also according to (5) their availability

\footnotetext{
${ }^{6}$ Aquazol characteristics are strongly influenced by the solvent used to dissolve it. In fact, the penetration of the polymer in the substrate depends also on its superficial tension. If Aquazol is dissolved in a solvent with low superficial tension as isopropanol, the solution will deeply penetrate in the substrate; if it is solved in water, it will tend to distribute on the surface because of the high superficial tension of the solvent. In addition, the solubilisation speed changes with the solvent. It seems that water dissolves it slower than acetone, which is the quickest in solubilizing the polymer (Arslanoglou 2003).
} 
and affordability, in order to permit an easier reproducibility of the proposed facings.

The support should be (1) adaptable and flexible, in order to guarantee greater surface contact with the substrate. This would reduce the amount of adhesive needed for the adhesion and, consequently, the thickness of the bond. (2) Its mechanical properties should be evaluated according to the characteristics of the paint, its dimensions and the latter operations. The support should also (3) have good wet-strength, with the aim of limiting the permanence of residues after facing removal.(4) It should be thin and with low density, to facilitate the evaporation of the solvent. (5) It should be also absorbing to hold in the adhesive. All these characteristics contribute to reduce the penetration of the polymer. (6) The aspect of dimensional changes is also essential. Every support (Japanese paper, English tissue, Eltoline tissue, Papier Bolloré, TNT, Holytex) presents a characteristic dimensional change when it is wetted. The most of the supports used for facings are nonwoven tissues, made of superimposed and pressed fibre. Since they are not woven, supports tend to expand with the increase of humidity and to contract with its decrease. When facing, the drying stage is the most critical. In fact, in this moment the viscosity of the adhesive increases until it reaches a gel state and its sliding capacity decreases. The contraction of the support provokes a tensile force on the adhesive film, and thus on the paint layer. Slow and little dimensional changes are therefore required especially during the last stage of drying to avoid deleterious mechanical effects.

Concerning the adhesive, (1) the viscosity and the wetting properties are relevant factors for a superficial adhesion. During the preparation of the remoistenable tissues, viscosity of the adhesive should not be excessively high in order to allow a uniform its distribution at the interface between the support and the Mylar foil. For this purpose, it is possible to modify both the kind of solvent and the polymer concentration.

(2) The penetration of the adhesive depends also on the molecular weight $(\mathrm{MW})$. Firstly, a polymer with a high molecular weight has a lower penetration in the porosity of a substrate because of the dimension of its molecules. Secondly, because the MW influences the viscosity: the higher it is, the higher the viscosity is.

Of course, (3) the adhesive and (4) mechanical properties of the dried polymer are fundamental. It would be appropriate to calibrate the adhesion strength according to the kind of paint, its state of conservation and the purpose for which the facing is applied. In general, a polymer with lower medium strength should be used, in order to ensure the adhesion to the paint 
layer, also when mechanical interventions on the back are required. The adhesive bond should be thin and moderately flexible, in order to follow the paint movements without being too much resilient. Furthermore, the polymer should not contract too much when drying.

Some clarification on the role played by the solvent are imperative. (1) The solvent used during the reactivation step should have good wetting properties to facilitate the adhesion. (2) A high evaporation speed should be required to facilitate the return migration phenomenon ${ }^{97}$. During facing removal, it would be better to use a solvent with (3) good affinity, which ensures a good reactivation of the adhesive, reducing the stress inferred to the paint. At the same time, (4) the solvent should not solubilize totally the polymer in order to avoid penetration. In any case, during this stage the support would facilitate the surface permanence of the solvent, acting as supportant. Gelling solutions could be used to further limit solvent penetration.

\subsection{SELECTION OF TEMPORARY SUPPORTS, ADHESIVE DISPERSIONS AND REACTIVATION SOLVENT}

Once the pursued characteristics were defined, it was possible to review the commercially available supports and polymers to select the most appropriated. It is not always easy to find materials with suitable characteristics for restoration. In fact, the market of conservation products is rather limited, so that there are few companies producing products which are specifically dedicated to restoration. The most innovative products usually are too expensive or difficult to find. In addition, it is known that many times restorers are constrained by the low budget provided for conservative operations. Therefore, it was decided to select materials of easy availability and affordable price, in order to propose an innovative system, which could be not only efficient, but also of easy applicability and availability.

97 The return migration refers to the stage while the polymers which has penetrated in the substrate starts to come back to the surface attracted by solvent evaporation. 


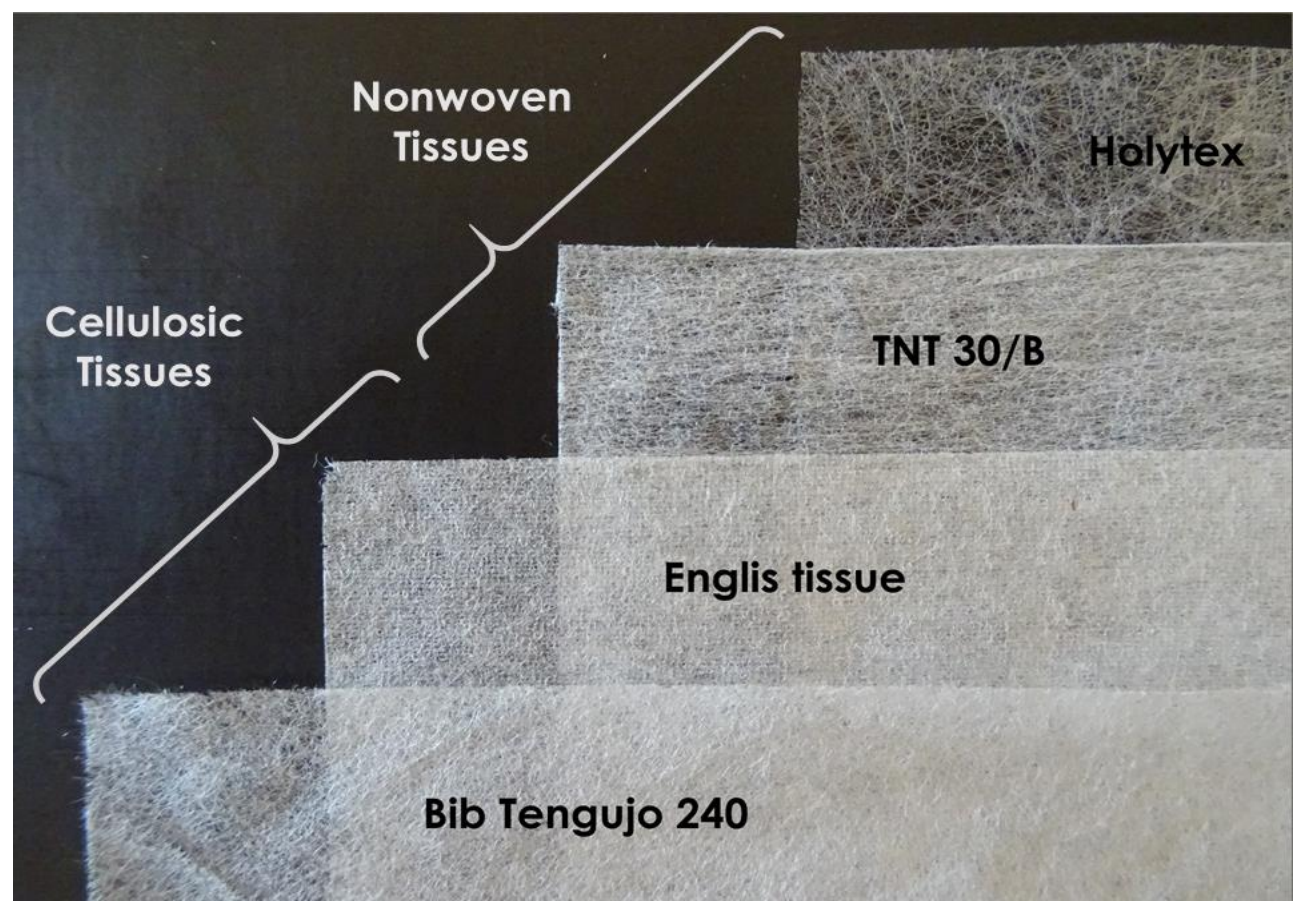

Figure 3.4.1. Temporary supports chosen for the investigation.

\subsubsection{Temporary or interim supports}

As temporary supports, two cellulosic papers and two nonwoven tissues were chosen (Fig. 3.4.1).

The two cellulosic supports chosen were Japanese paper Bib Tengujo 240 and English tissue.

- Bib Tengujo 240 (CTS Europe) is a paper of easy availability in different European countries, considering the widespread use of Japanese papers $^{98}$ for facing of canvas paintings. Bib Tengujo is made of Manila

98 The spread of Japanese papers in England for conservation purposes can be ascribedto the relations with China and Japan during the colonial period. The diffusion of these papers throughout Europe can be instead traced back to the sixties, more exactly to the 1966, the year of the flood of Florence (Ansalone, et al. 1986), for the restoration of flooded book. The use of these paper was extended to other conservation fields over the decades and now Japanese paper is produced also from European companies using Asian row materials. As opposed to rag paper and those made of wood pulp, they are produced with long vegetable fibres of shrubs 
(Musa textilis), a plant produced in Philippines with fibres $5-6 \mathrm{~cm}$ long, and considered the best alternative to the Japanese shrubs (Priori and Quattrini 2005). The characteristics of paper made of Manila are usually worse than those prepared with Japanese fibres, but they are anyway better to those of European papers. Bib Tengujo has a weight of $12 \mathrm{~g} \mathrm{~m}$ 2 and $\mathrm{a} \mathrm{pH}$ of 7.1 .

- English tissue (Bresciani s.r.l.) has a lower distribution than Japanese papers, but different restorers use it. It is of interest for facing treatments because it is easily applied, conforms to surface texture, it seems it does not have high contractile properties and therefore can be applied in large sheets, easy to remove (Matteo Rossi Doria 2013). English tissue is made of cellulose, probably with a very little quantity of amide wet-strength additive ${ }^{99}$. It has a slightly glossy surface and presents a slightly impression of the screen used for its production. It has a weight of $13 \mathrm{~g} \mathrm{~m}^{-2}$, it has higher wet-strength than Japanese papers usually used for facing.

The two synthetic supports selected for the investigation were the nonwoven tissues TNT 30/B (CTS Europe) and Holytex (Holytex).

- TNT/30B is a nonwowen tissue used for different purposes in conservation treatments and it is easy available. It is made of $80 \%$ Viscose and $20 \%$ di Polyester and has a weight of $25 \mathrm{~g} \mathrm{~m}$-2. It has an anisotropic tensile strength, which has been evaluated during the experimentation.

- Holytex, a nonwoven acid-free tissue made of Polyester, with a weight of $17 \mathrm{~g} \mathrm{~m}$-2. It is a very low lint, smooth, high tensile strength material, which is used for a wide variety of conservation treatments on paper artefacts.

and little plants (Kozo, Gampi and Mitsumata from Japan; Manila form Philippines). The characteristics of the source materials and the differences in the production process give better mechanical characteristics than that of occidental paper.

${ }_{99}$ The composition of English tissue was analysed in 2011 at the Canadian Conservation Institute, under request of Matteo Rossi Doria. The analyses revealed the presence of very small amount of amide type wet additive, so low that is unlikely to cause chemical damage to a painting when used as a temporary facing. Furthermore, this additive is no cold-water extractable, while a very small amount of hot-water extract is obtained. (Williams $2011)$. The author warmly thanks Matteo Rossi Doria to supply the results of these analyses. 


\subsubsection{Adhesive dispersions}

With regard to the adhesives, a review of the most employed polymers in conservation was made. As told before, usually polymers are not produced for conservation purposes, but for industrial ones. This means that the properties of commercially available adhesives not always reflect the specific needs of a conservation work. Nevertheless, the knowledge of the ideal characteristics required for a specific technique and of the real features of available materials, permits to combine different polymers, in order to obtain a dispersion which reflects as much as possible the required standards. As Wolbers (Wolbers 2006) says, the restorer can become a 'engineer' himself and project his own adhesive.

In this case, two polymers with thickener properties were combined with other two polymers with good adhesive properties. In fact, the use of thickeners would have permitted to increase the viscosity and the wetting properties of the dispersions, easing the adhesion and reducing the penetration.

Polymers selected to increase the thickness of the adhesive dispersions were two Cellulose Ethers: Klucel G (CTS Europe) and Tylose MH300 (CTS Europe). These cellulose ethers have a high molecular weight, are watersoluble (Klucel is also soluble in polar organic solvents), have good thickening and wetting properties, their $\mathrm{pH}$ is almost neutral, they form elastic and thermoplastic films, and they are not too sensitive to humidity changes. They are alkyl derivate, produced by modifying the molecular structure of cellulose.

- Tylose MH 300 is a Methyl Hydroxyethyl Cellulose (MHEC). Even if exist many types of Tylose ( $\mathrm{MH} 20, \mathrm{MH} 50 \ldots$ ), the most used is Tylose $\mathrm{MH} 300$. The number following $\mathrm{MH}$ refers to the viscosity of an aqueous solution at $2 \%(w / w)$.

- Klucel G is a Hydroxypropyl Cellulose (HPC), with a molecular weight from 80.000-95.000 uma (Klucel G E, L) to 1.000.000 uma (Klucel G H, M). Klucel $G$, the most used in restoration of easel paintings, has a molecular weight of 370.000 uma (Borgioli, and Cremonesi 2005; Horie 2010). Both the polymers are used for facing, even if their adhesion strength is quite low. 
Polymers selected to improve adhesion properties of the adhesive dispersions were Plextol B500 (CTS Europe) and Aquazol 500 (Polymer Chemistry Innovations).

- Plextol, B500, which current trade name is Degalan B500, is an acrylic emulsion (solid content: $50 \pm 1 \%$ ) containing $60 \%$ of ethyl acrylate (PEA) and $40 \%$ of methyl methacrylate (PMMA) with polymer microdrops of 0.1 $0.2 \mu \mathrm{m}$ (Borgioli, and Cremonesi 2005; Horie 2010). It has already been combined with cellulose ethers both for nap-bond system linings (Mehra, 1972, 1975) and facing (Martín-Rey et al., 2012).

- Aquazol (poly (2-ethyl-2-oxazolina) is a relatively new polymer, manufactured by Polymer Chemistry Innovations, introduced in the conservation practice by Richard Wolbers (Wolbers, Mc Ginn, and Duerbeck 1998) at the end of the past century. It is constituted by polyalkylenimine chains formed from 2-ethyl-2-oxazoline. Its chemical formula is -(C5H9NO)n-. The chains are usually synthesized by cationic ring-opening polymerization initiated by an electrophilic initiator (ex. methyl tosylate) and terminated by nucleophiles. The different chemical nature of initiators and terminations produces 2-oxazoline polymers with several proprieties and uses. Aquazol 500 is chemically stable and it has a high molecular weight $(500,000)$. It is soluble in water and other polar organic solvents, it has almost neutral $\mathrm{pH}$ and it has a good water vapour permeability. It has medium bond strength and good mechanical properties. Furthermore, is perfectly miscible with other polymers. Its weakness is its sensitivity to the environmental humidity fluctuations. It has already been tested for the preparation of remoistenable tissues used for facing of canvas paintings (Borgioli, Boschetti, and Tortato 2016).

These four polymers were combined into binary dispersions (thickeneradhesive). Some dispersions were prepared with the use of only Klucel, Tylose or Aquazol, which are currently used as facing adhesives, in order to compare them with the new formulations. For the preparation of the dispersions, preliminary tests were carried out with the help of microscopic techniques, in order to verify the homogeneity of the dispersions and their uniform distribution on the temporary supports. 20 aqueous and five alcoholic dispersions were selected for the preparation of the remoistenable temporary supports (Fig. 3.4.2). 


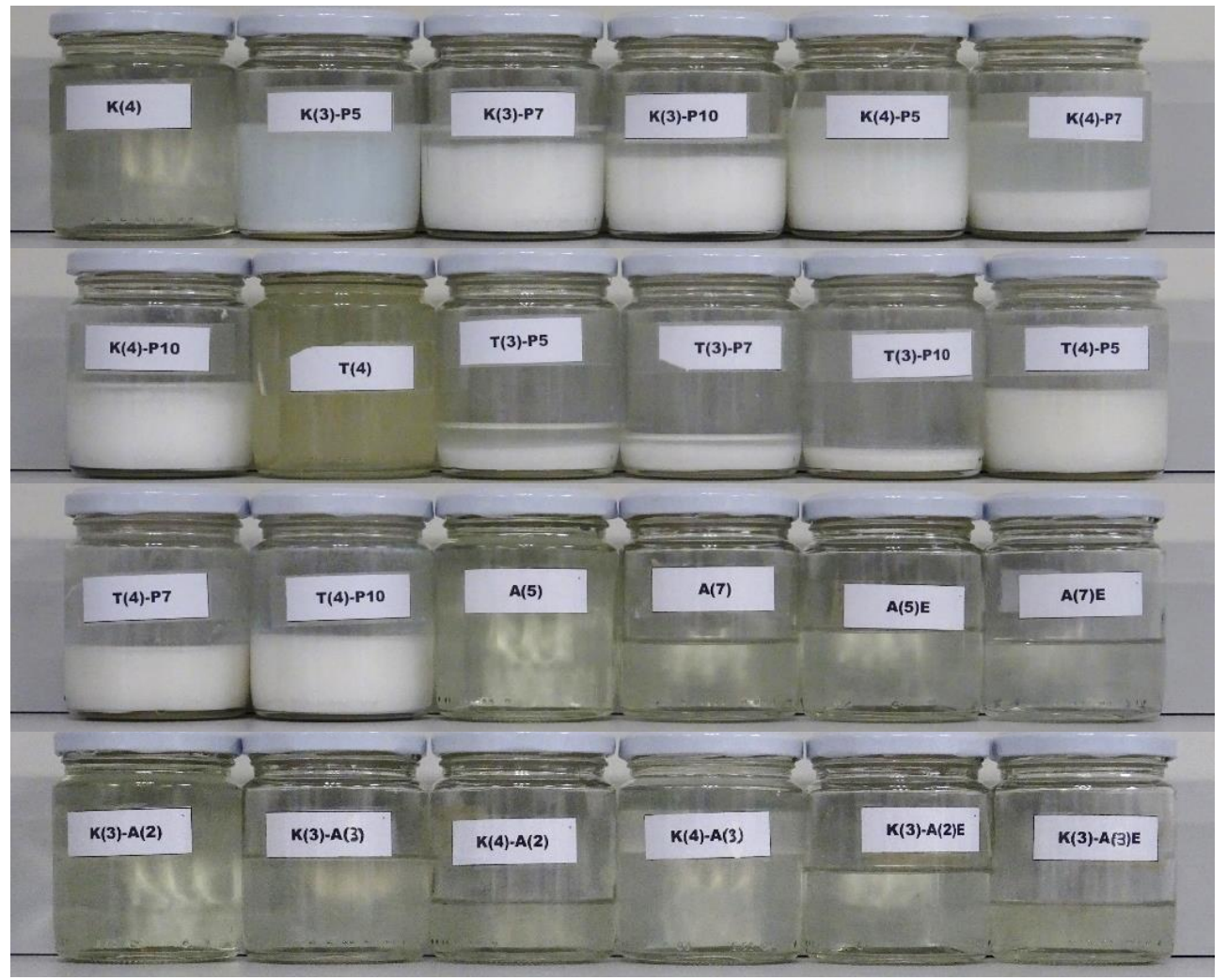

Fiqure 3.4.2. Set of adhesive dispersions prepared.

The nomenclature of adhesive dispersions consist of a first letter of the polymers (eg. Klucel G: "K"). The number in brackets indicates the percentage $\mathrm{W} / \mathrm{V}$ of the adhesive in the dispersion. For example, in the case of the mixture $\mathrm{K}(3)$ $\mathrm{A}$ (3) $3 \mathrm{~g}$ of Klucel and $3 \mathrm{~g}$ of Aquazol were dissolved in $100 \mathrm{~mL}$ of water. For the dispersion containing Plextol (already sold as liquid emulsion), the final number without brackets indicates the percentage $\mathrm{v} / \mathrm{v}$ of the Plextol mixed with an already-made solution of Klucel or Tylose. For example, in the case of K(3)-P7 7 $\mathrm{mL}$ of Plextol were mixed with $93 \mathrm{~mL}$ of a $3 \%$ solution of Klucel. Reference codes ending with "E" indicates adhesive dispersion dissolved in Ethyl Alcohol. Table 3.4.1 summarises the composition of the dispersions finally obtained. 
Table 3.4.1. Composition of adhesive dispersions.

\begin{tabular}{|c|c|c|c|c|}
\hline \multirow[b]{2}{*}{ Reference } & \multicolumn{2}{|c|}{ Dispersion of polymer 1} & \multicolumn{2}{|c|}{ Final dispersion } \\
\hline & Polymer 1 & $\begin{array}{l}\text { w/v proportion } \\
\text { of polymer } 1 \text { in } \\
\text { solvent } \\
\text { dispersion }\end{array}$ & Polymer 2 & $\begin{array}{l}(\mathrm{v} / \mathrm{v}) \text { or } \mathrm{w} / \mathrm{v} \\
\text { proportion of } \\
\text { polymer } 2 \text { in } \\
\text { polymer } 1 \\
\text { dispersion }\end{array}$ \\
\hline $\mathrm{T}(4)$ & Tylose MH300 & $4 \%$ water & - & - \\
\hline T(3)P5 & Tylose MH301 & $3 \%$ water & Plextol B500 & $5 \%$ \\
\hline $\mathrm{T}(3) \mathrm{P} 7$ & Tylose MH302 & $3 \%$ water & Plextol B500 & $7 \%$ \\
\hline $\mathrm{T}(3) \mathrm{P} 10$ & Tylose MH303 & $3 \%$ water & Plextol B500 & $10 \%$ \\
\hline T(4)P5 & Tylose MH304 & $4 \%$ water & Plextol B500 & $5 \%$ \\
\hline $\mathrm{T}(4) \mathrm{P} 7$ & Tylose MH305 & $4 \%$ water & Plextol B500 & $7 \%$ \\
\hline $\mathrm{T}(4) \mathrm{P} 10$ & Tylose MH306 & $4 \%$ water & Plextol B500 & $10 \%$ \\
\hline$K(4)$ & Klucel G & $4 \%$ water & - & - \\
\hline K(3)P5 & Klucel G & $3 \%$ water & Plextol B500 & $5 \%$ \\
\hline K(3)P7 & Klucel G & $3 \%$ water & Plextol B500 & $7 \%$ \\
\hline$K(3) P 10$ & Klucel G & $3 \%$ water & Plextol B500 & $10 \%$ \\
\hline K(4)P5 & Klucel G & $4 \%$ water & Plextol B500 & $5 \%$ \\
\hline $\mathrm{K}(4) \mathrm{P7}$ & Klucel G & $4 \%$ water & Plextol B500 & $7 \%$ \\
\hline $\mathrm{K}(4) \mathrm{P} 10$ & Klucel G & $4 \%$ water & Plextol B500 & $10 \%$ \\
\hline$A(5)$ & Aquazol 500 & $5 \%$ water & - & - \\
\hline$A(7)$ & Aquazol 500 & $7 \%$ water & - & - \\
\hline$A(5) E$ & Aquazol 500 & $5 \%$ ethyl alcohol & - & - \\
\hline$A(7) E$ & Aquazol 500 & $7 \%$ ethyl alcohol & - & - \\
\hline$K(3) A(2)$ & Klucel G & $3 \%$ water & Aquazol 500 & $2 \%$ \\
\hline$K(3) A(3)$ & Klucel G & $3 \%$ water & Aquazol 500 & $3 \%$ \\
\hline$K(4) A(2)$ & Klucel G & $4 \%$ water & Aquazol 500 & $2 \%$ \\
\hline $\mathrm{K}(4) \mathrm{A}(3)$ & Klucel G & $4 \%$ water & Aquazol 500 & $3 \%$ \\
\hline$K(3) A(2) E$ & Klucel G & $3 \%$ ethyl alcohol & Aquazol 500 & $2 \%$ \\
\hline$K(3) A(3) E$ & Klucel G & $3 \%$ ethyl alcohol & Aquazol 500 & $3 \%$ \\
\hline$K(3) A(4) E$ & Klucel G & $3 \%$ ethyl alcohol & Aquazol 500 & $4 \%$ \\
\hline
\end{tabular}




\subsubsection{Reactivation solvent}

A buffer solution was chosen for the reactivation of the remoistenable temporary supports. In fact, aqueous systems permit a higher number of parameters to change than organic solvents, and therefore a higher versatility. Furthermore, they are not toxic for the operator and for the environment. Of course, if not carefully reasoned, the choice of the aqueous solution can be dangerous for the painting. For this reason, it is important to focus especially on the choice of the correct values of $\mathrm{pH}$ and ion concentration.

Undoubtedly, $\mathrm{pH}$ is the most important control parameter. It has to be as closely as possible to that of the painting. It would be always better to measure directly the $\mathrm{pH}$ of the substrate with a contact-pH meter, even if indicative values are reported in literature. In general, the range for easel paintings may be 5.5-8.5, but more material-specific values can be checked in specific literature (Wolbers 200; Cremonesi 2011).

Another important parameter is the total ion concentration (measured by conductivity) from which osmotic processes and ions migration depend on. A solution has to be isotonic, in order to prevent ions exchange with the substrate: with a high difference in conductivity, the excessive ion movement could damage the painting 100 . While the conductivity of a solution can be measured with an easy available and affordable conductivity meter, the direct measurement of ion concentration of solid surfaces as that of a painting is complicated because of the high cost and the technical difficulty of measurements. It is therefore necessary to refer to values reported in literature. For example, for an oil painting in a medium state, it is possible to use solution with conductivity lower than 3-4 $\mathrm{ms} \cdot \mathrm{cm}^{-1}$ (Wolbers 2004).

When using aqueous solutions, it is always better to use demineralised water and not totally deionised of distilled water. In fact, the amount of ions in these two kinds of water is too low and it could influence the $\mathrm{pH}$ and the conductivity of a solution. Therefore, it would be better to use demineralised water.

Since the majority of the constitutive materials of oil canvas paintings are more or less acid, it is always better to use a buffer solution, in order to have a $\mathrm{pH}$ as much as possible similar to that of the painting. Furthermore, the use of a buffer permits to have a stable $\mathrm{pH}$, even when the solution gets in touch

\footnotetext{
100 If the solution is hypotonic, molecules of water will tend to get in the painting stratigraphy and they will cause its swelling and making it weaker. If the solution is hypertonic, water molecules will tend to get out the stratigraphy, exerting an excessive pressure, which could cause the disintegration of the surface.
} 
with the acid substrate. Buffer solutions can be prepared on the basis of indications reported in dedicated literature, where recipes for low molar concentration solutions (25-50 $\mathrm{mM}$ ) are given in order to reduce the risk of the permanence of residues on the surface of the painting (Cremonesi 2011). Usually, buffer solutions like that reported in literature and prepared with demineralised water, have a conductivity of $1-5 \mathrm{~ms} \cdot \mathrm{cm}^{-1}$. If the conductivity of the solution were too high, it would be sufficient to dilute the solution to the desired value of conductivity.

For this study, a buffer solution (Bis-Tris; concentration 20-50 mM) with a pH of 6.4 was prepared. In this case, the $\mathrm{pH}$ value was chosen on the basis of generic ones reported in the literature, referring to intermediate $\mathrm{pH}$ of varnishes and aged oil paint layers, but before restoring it would be always better to check the real $\mathrm{pH}$ of the surface of a paint (e.g. triterpenic or synthetic varnish, oil or tempera paint) (Cremonesi, 2011).

\subsection{Preparation of remoistenable temporary supports, APPLICATION AND REMOVAL FROM THE PAINT}

The information on previous experiences, the analysis of facing mechanism and the reasoning carried out about the material, permitted the development of the remoistenable temporary supports proposed for this research. Fig. 3.5.1 shows a scheme of the different steps in the preparation, application to the paint layer and removal of the remoistenable temporary supports from the paint layer.

\subsubsection{Preparation of the RTS}

For this investigation it was decided to prepare the remoistenable tissues by applying the adhesive on the interim support (cellulosic tissue or nonwoven tissue) lying on a foil of Mylar or Teflon. In this way, the adhesive impregnates the interim support and migrates at the interface between the temporary support and the Mylar, and dries forming a uniform film (Fig. 3.5.2-3). 

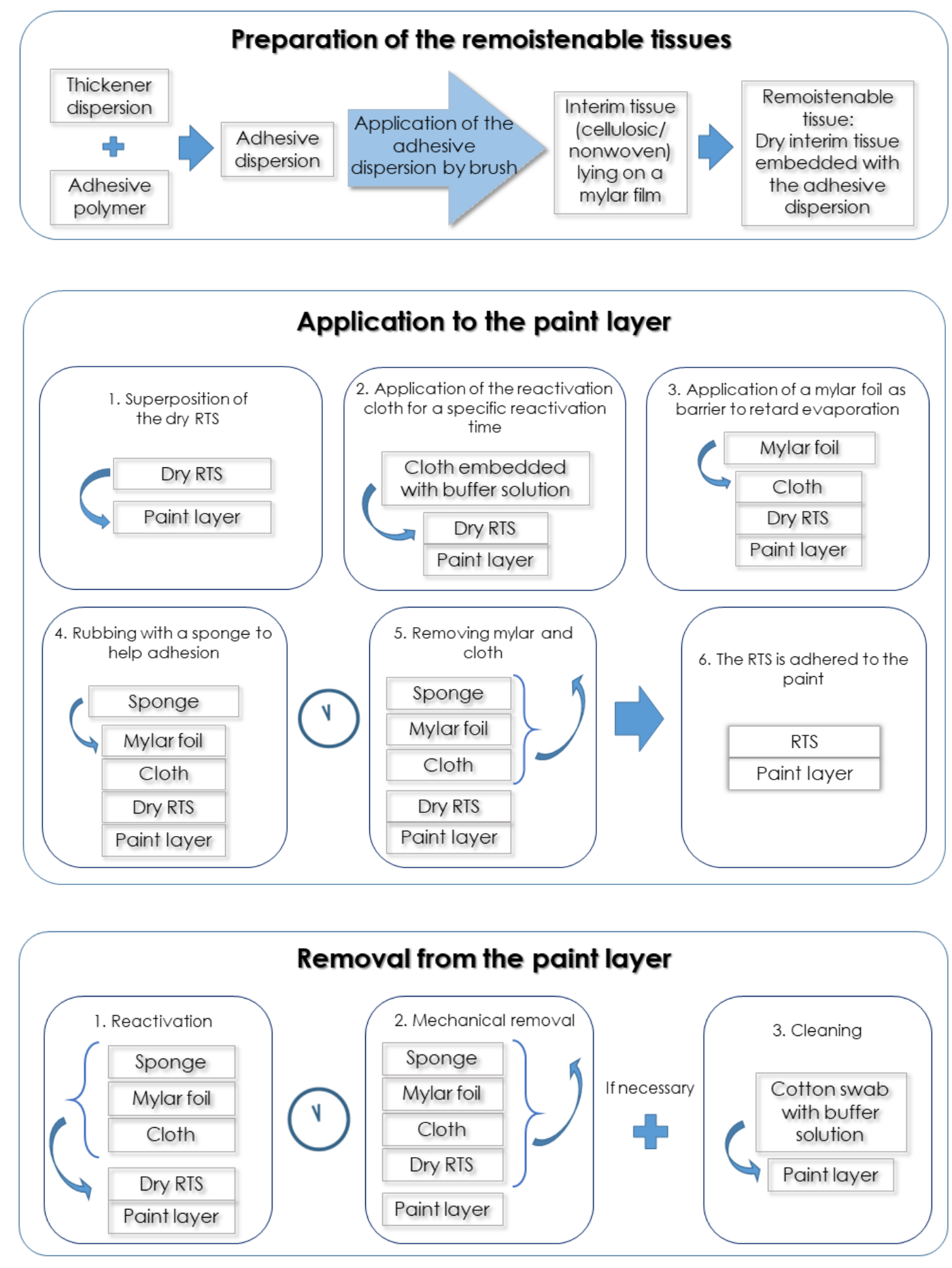

Figure 3.5.1. Scheme of remoistenable temporary supports preparation and reactivation. 


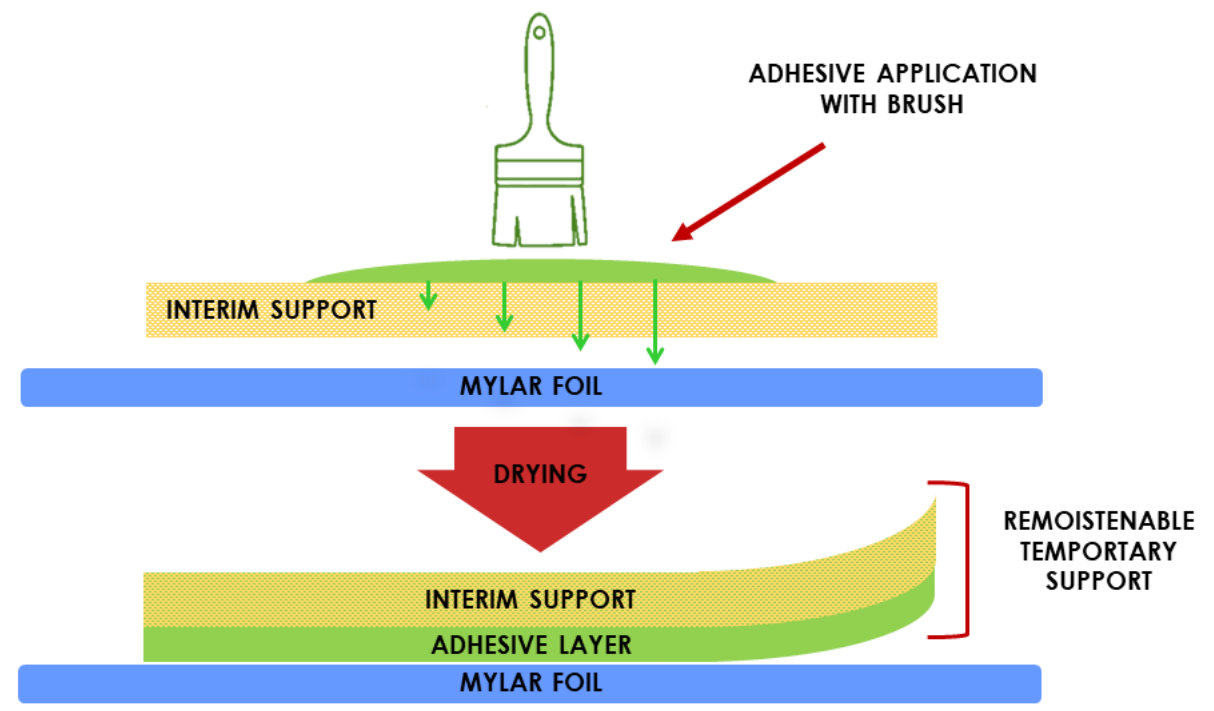

Figure 3.5.2. Scheme of the application and settle of the adhesive on the interim support.

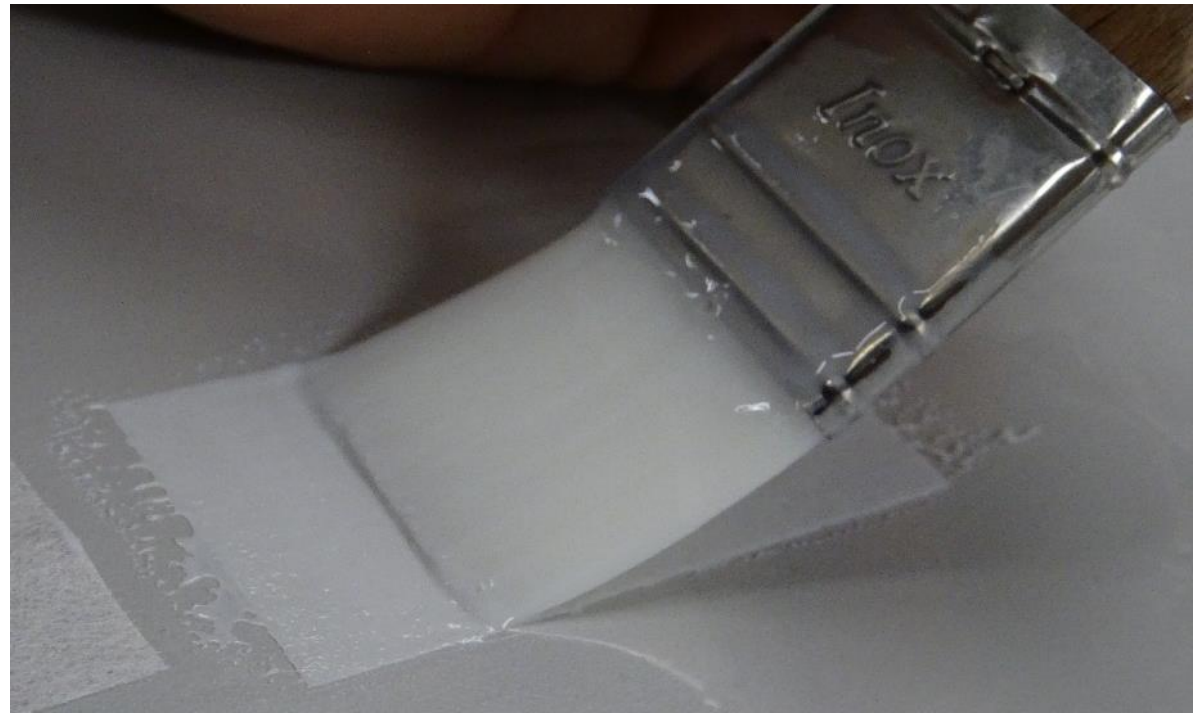

Figure 3.5.3. Application by brush of adhesive dispersion on the temporary support. 


\subsubsection{Application of the RTS on the paint}

Application of the RTS on the paint layer requires reactivation of the dried remoistenable tissue with a solvent. For this purpose we were inspired by the mist lining used by Van Och and Hoppenbrouwers (2003) and modified by laccarino Idelson (laccarino-Idelson and Serino 2014). In fact, it was decided to use a 'reactivation cloth' instead to apply directly the solvent by spraying on the remoistenable tissue.

The cloth is made of nonwoven tissue (TNT 30/B), which is rolled up and wrapped in a polyethylene foil. Then a precise amount of buffer solution is introduced with a needle (Fig. 3.5.4. left top).
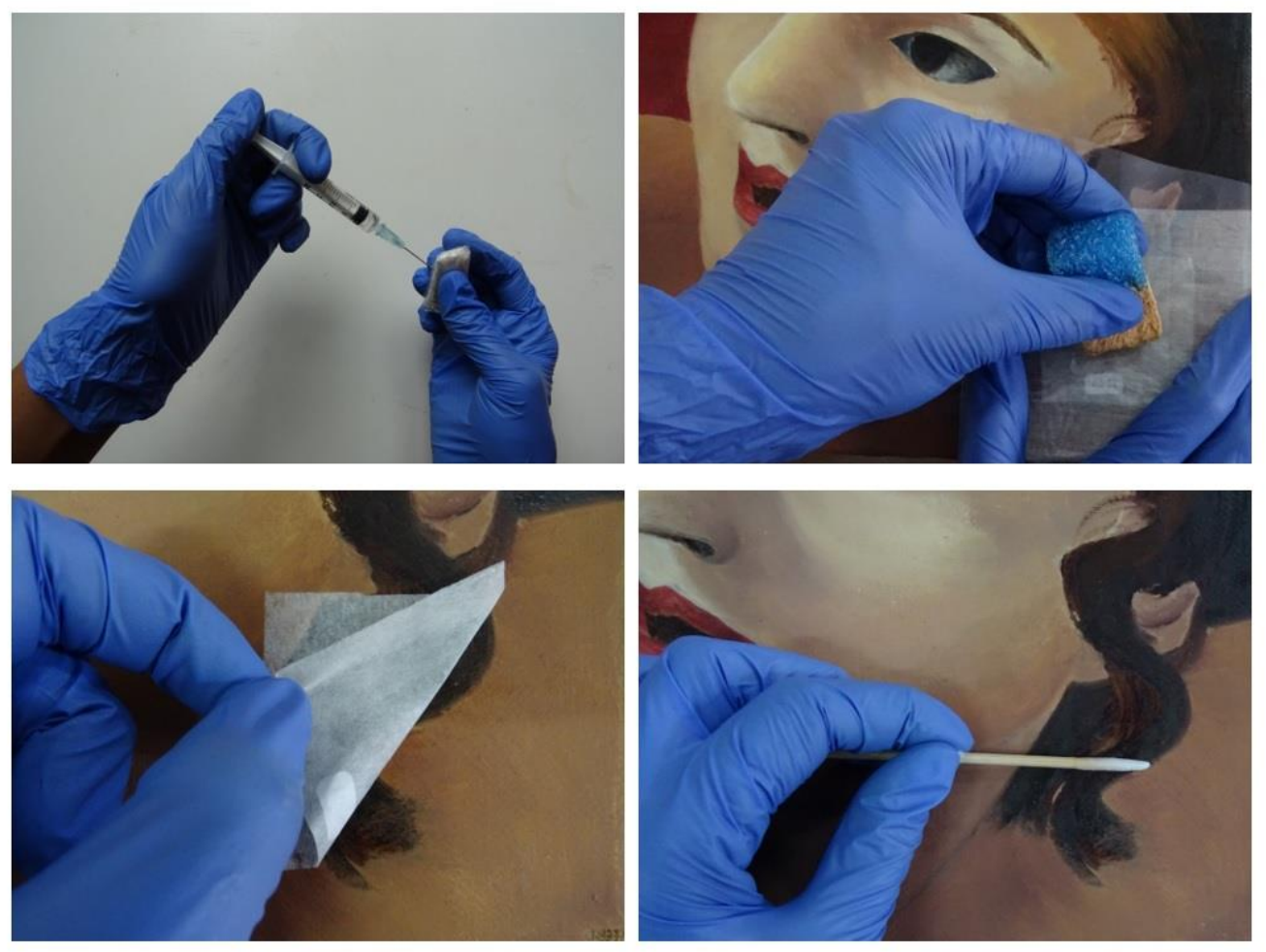

Figure 3.5.4. Steps of application and removal of remoistenable temporary supports, using a remoistenable tissue. Left top: preparation of the reactivation cloth wrapped in a polyethylene foil and embedded with the buffer solution. Right top: rubbing the surface after the superposition of the remoistenable tissue, the reactivation cloth and the Mylar foil. Left bottom: mechanical removal after

the reactivation with the application of the reactivation cloth and the superimposed Mylar foil for a specific time. Right bottom: cleaning of the residues with a cotton swab embedded with the buffer solution. 
After some minutes, the buffer solution has uniformly spread in the cloth and it is apt to reactivate the dried RTS.

The application of the RTS on the paint is carried out as follows:

- The dry remoistenable tissue is applied with the adhesive side in contact with the painting. Then, the cloth is un-wrapped from the polyethylene foil and superimposed to the dried remoistenable tissue during a specific time, for reactivating the adhesive and assuring a satisfactory adhesion to the paint surface (see Table 3.5.1).

- After this, a Mylar foil, which has the function of delaying the evaporation of the buffer solution applied on the cloth, is overlapped to the cloth.

- For improving the adhesion of the RTS to the paint, is also possible to rub the surface with a sponge (Fig. 3.5.4 right top). The time of this operation depends on the temporary support (depending on the nature of the support it can vary from less than a minute to two minutes, as shown in Table 3.5.1). The complete scheme of the application is showed in Fig. 3.5.5.

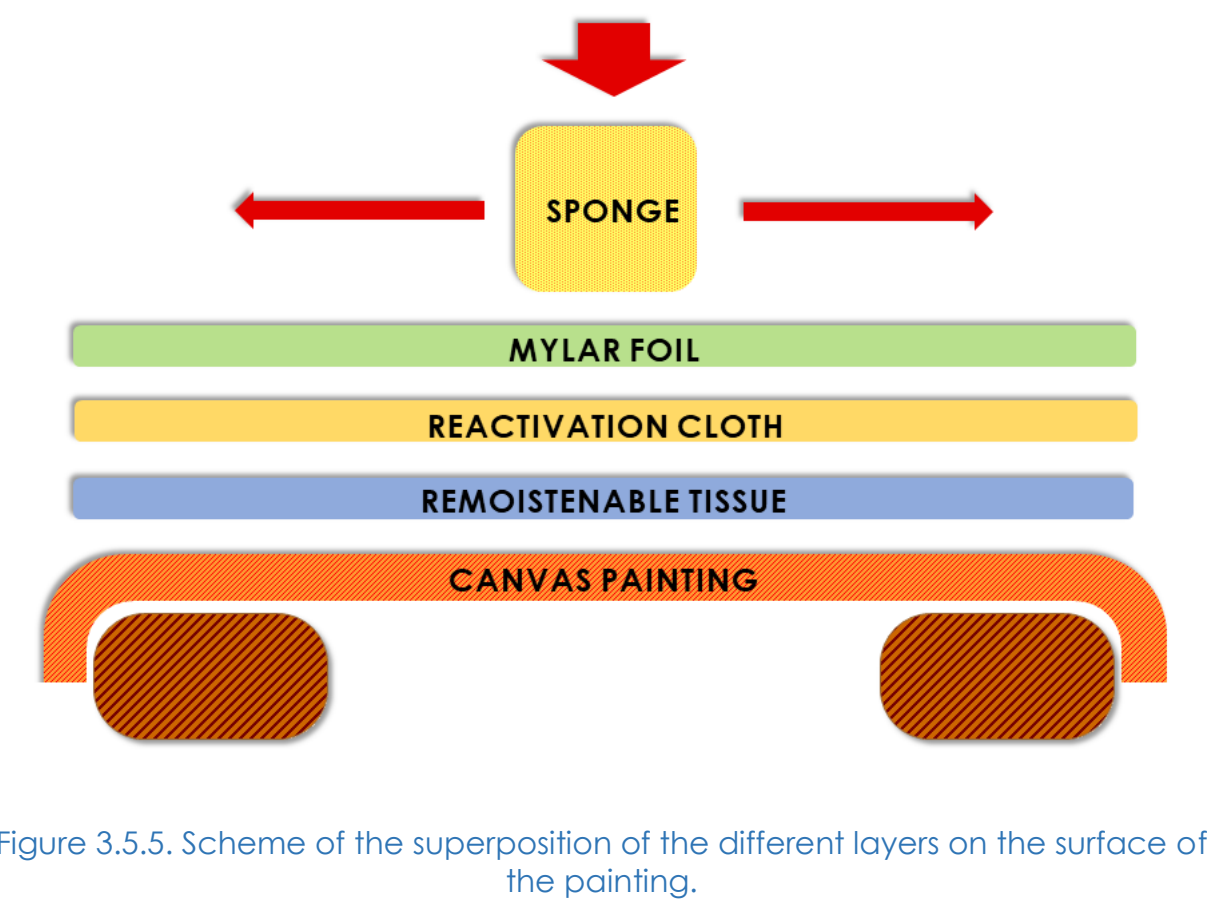




\subsubsection{Removal of the RTS from the paint}

To remove the remoistenable tissue from the paint the is followed a similar procedure to that used for its application: the reactivation cloth is overlapped to the RTS, then the Mylar foil is superimposed and after an adequate time it is possible to proceed with the mechanical removal of the remoistenable tissue (Fig. 3.5.5 left bottom). If necessary, after the elimination of the facing, it is possible to quit the residues of adhesive with a cotton swab with a small amount of buffer solution (Fig.3.5.5 right bottom).

Table 3.5.1. Amount of adhesive and reactivation time required for applying each support to the paint.

\begin{tabular}{|c|c|c|c|c|}
\hline & $\begin{array}{c}\text { Bib Tengujo } \\
240\end{array}$ & English tissue & TNT 30/B & Holytex \\
\hline $\begin{array}{l}\text { Amount of } \\
\text { adhesive }\left(\mathrm{mL} \mathrm{m}^{-2}\right)\end{array}$ & 150 & 160 & 220 & 90 \\
\hline $\begin{array}{l}\text { Reactivation time } \\
\text { for application } \\
\text { and removal of } \\
\text { the RTS (s) }\end{array}$ & 30 & 40 & 90 & 15 \\
\hline $\begin{array}{l}\text { Buffer solution for } \\
\text { reactivation cloth } \\
\qquad\left(\mathrm{mL} \mathrm{m}^{-2}\right)\end{array}$ & \multicolumn{4}{|c|}{25} \\
\hline
\end{tabular}

Previous tests enabled the definition of the suitable amount of adhesive (aprox. $150 \mathrm{~mL} \cdot \mathrm{m}^{-2}$ for the Bib. Tengujo 540; aprox. $160 \mathrm{~mL} \cdot \mathrm{m}^{-2}$ for the English tissue; aprox. $220 \mathrm{~mL} \cdot \mathrm{m}^{-2}$ for the TNT30/B; aprox. $90 \mathrm{~mL} \cdot \mathrm{m}^{-2}$ for the Holytex) necessary for the preparation of the remoistenable tissue, and the determination of the amount of buffer solution required for the reactivation cloth $\left(25 \mathrm{~mL} \cdot \mathrm{m}^{-2}\right)$, 


\subsection{HYPOTHESIS ON ADVANTAGES}

The method here proposed was expected to improve the superficial action of facing mechanisms. It was supposed it would have allowed the use of a very small and well-known quantity of adhesive, but also of the reactivation solvent applied on the reactivation cloth, improving the reproducibility of the method, which, for example, is impossible to obtain with the application with spray. All this would have reduced risks connected to this operation, minimizing the extent of the penetration and the remaining residues. Furthermore, the use of a very small amount of solvent should have limited the expansion and the contraction of the temporary support, reducing the mechanical stress exercised on the paint.

Facings prepared with this method could be a good solution to protect paintings surface before risky transportations or in view of intervention of the back of the painting, such as lining application or removal, or also cleaning of the canvas.

In any case, the choice of the use of remoistenable temporary tissue, as every operation of conservation, should always be well reasoned on the basis of a comprehensive restoration project. 



\section{First experimental stage: remoistenable tissues characterization}

\subsection{MATERIALS AND METHODS}

As previously mentioned, during the first experimental stage analyses of the different classes of materials (adhesives and temporary supports) and their compatibility for the preparation of remoistenable tissues were carried out. Tests made during this stage are summarised in Table 5.1.1. Tensile tests were made after a previous selection of the adhesives, so they will be further described in this chapter.

Tab. 4.1.1. Summary of the tests carried out in the first analytical stage.

\begin{tabular}{|c|c|}
\hline CLASSES OF MATERIALS & ANALYSIS \\
\hline ADHESIVE DISPERSIONS & $\begin{array}{l}\text { - Mass loss on drying } \\
\text { - Viscosity } \\
\text { - } \mathrm{pH}\end{array}$ \\
\hline ADHESIVE FILMS & $\begin{array}{l}\text { - Hardness } \\
\text {-Tensile strength }\end{array}$ \\
\hline INTERIM SUPPORTS & $\begin{array}{l}\text { - pH } \\
\text { - Absorbance } \\
\text { - Evaporation rate } \\
\text { - Dimensional changes } \\
\text { - Tensile strength }\end{array}$ \\
\hline $\begin{array}{l}\text { REMOISTENABLE } \\
\text { TEMPORARY SUPPORTS }\end{array}$ & $\begin{array}{l}\text { - pH } \\
\text { - Evaporation speed } \\
\text { - Dimensional changes } \\
\text { - Tensile strength }\end{array}$ \\
\hline
\end{tabular}




\subsection{ChemicAl AND PHYSICAL CHARACTERISATION}

\subsubsection{Mass loss on drying}

Thermogravimetry was used for the determination of the mass loss on drying. Thermogravimetric analysis (TGA) is an experimental technique employed to measure the mass of a test specimen as a function of temperature or time. The test specimen can be heated at a constant heating rate (dynamic measurement) or held at a constant temperature (isothermal measurement), but it might also be subjected to non-linear temperature programs. The choice of the temperature program depends on the kind of information required for the test specimen (Gabbott 2006).

For this investigation, adhesive films were prepared pouring the liquid polymers in non-stick moulds and letting them dry in stable environmental conditions (25 ${ }^{\circ} \mathrm{C} ; 50 \% \mathrm{HR}$ ) for a month. Two sets of specimens of $(3 \times 3) \mathrm{cm}$ were prepared. The first set was subjected to a heating program of 30 minutes, increasing the temperature uniformly from 25 to $65^{\circ} \mathrm{C}$ in order to evaluate the percentage of loss of water during restoration treatments including the application of heat (which would not exceed $60{ }^{\circ} \mathrm{C}$ ). The second set was subjected to a program of 30 minutes, increasing the temperature from 25 to $105^{\circ} \mathrm{C}$, with the purpose of assessing the total loss of moisture content (Fig. 4.2.1).

As the measurement obtained could include other volatile substances originated by thermal decomposition apart from water, specimens were weighted after $48 \mathrm{~h}$, to assess if they recovered its initial weight. This would have meant that the

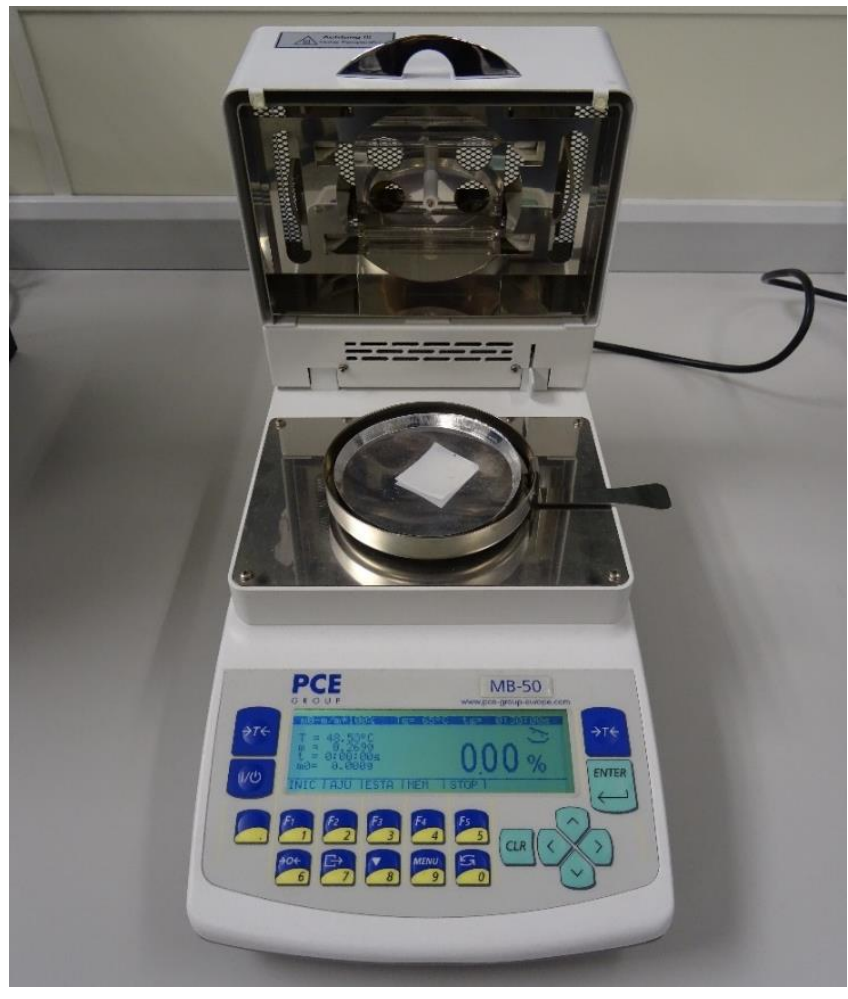

Figure. 4.2.1. Mass loss on drying test. Picture of a sample put in the thermobalance before the test stated. measured loss on drying referred 
to the only water. For this test, a thermobalance PCE-MB 50 (PCE Group) ${ }^{101}$ was used.

\subsubsection{Hardness}

This test measure the resistance to localized plastic deformation of the material under study. Since it is related to the Elasticity Modulus and the viscoelasticity of tested materials, it can be useful as a quick test to check the mechanical properties of a material.

Hardness is measured with a durometer, equipped with an indentator with a specific shape and dimension, which exert a known force on the surface of the test

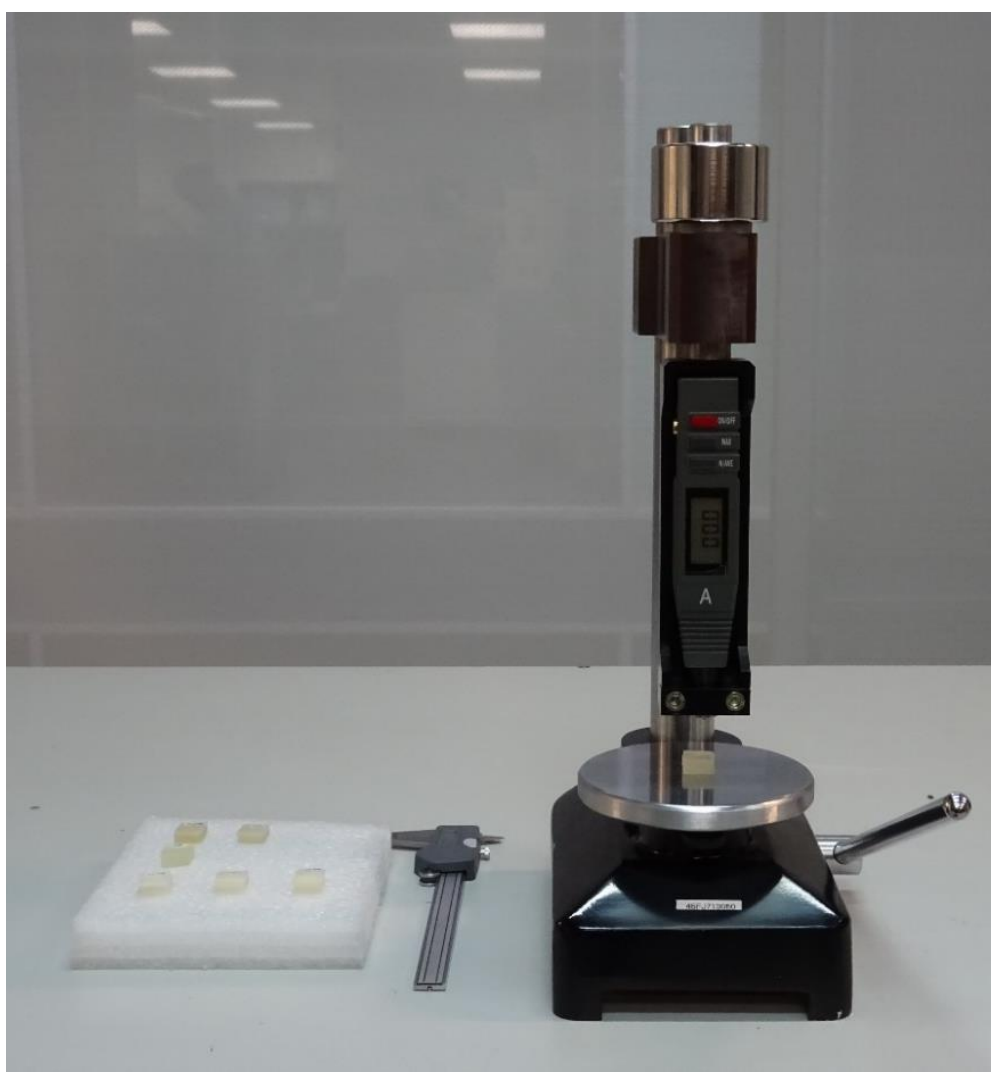

Figure 4.2.2. Hardness test. Measurement of samples of minimum thickness of $6 \mathrm{~mm}$. specimens. There are different durometers and every kind is suited to materials with different ranges of hardness. Hardness is expressed with numbers which refer to conventional scales, related each other by empirical conversion tables.

For this test, adhesive films were used too, overlapping subsequent layers of $(1.5 \times 1.5) \mathrm{cm}$ to obtain specimens with a minimum thickness of 6 $\mathrm{mm}$, as required by ASTM D 2240 standard test. Five measurements for each adhesive dispersion were made (Fig. 4.2.2).

101 The thermobalance, as well as the durometer and the viscometer used for this first step of the investigation belong to the "Research laboratories on adhesive materials and textile fibres employed in structural treatments of canvas paintings", of the Instituto de Restauración del Patrimonio de la Universitat Politècnica de València (Spain). 
In this case, a Shore TH200 (PCE Group) durometer was used. In fact, Shore A durometer are suited for flexible plastic materials and elastomers hardness measurement, and they are usually appropriate to measure adhesive polymers employed in conservation. Here below, a table of Shore hardness comparison chart is given (Table 4.2.1).

Table 4.2.1. Shore hardness comparison chart.

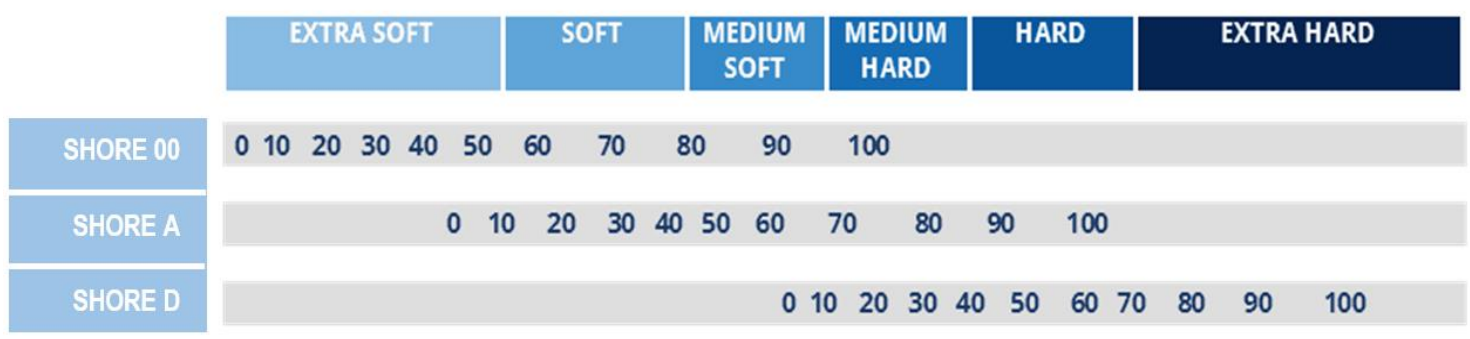

\subsubsection{Viscosity}

Viscosity is a measure that describes a fluid's resistance to flow and it could be useful to understand the film-forming capacity of tested adhesive dispersions when applied on the temporary support. Furthermore, this value was also useful to have an estimation of the viscosity of the adhesive dispersion during the application process and the removal of the facing.

Every fluid viscosity depends on its molecular composition and temperature, and it varies very slowly with pressure. Nevertheless, the viscosity of some fluids, such as some adhesive dispersions used in conservation treatments, is a function of some mechanical variable like shear stress or time. These fluids are called nonnewtonian and they can be divided in different groups:

- Shear-thickening and Shear-thinning liquids, whose viscosity respectively increases and decrease with the rate of shear strain.

- Thixotropic and Rheopectic liquids, that become respectively less and more viscous over time when shaken, agitated, or otherwise stressed.

- Bingham plastics, that behave as a solid at low stresses but flow as a viscous fluid at high stresses. 
Therefore, while for Newtonian fluids viscosity is represented just by a number, for non-Newtonian fluids the apparent viscosity is the result of different measurements. For an accurate viscosity test, a Brookfield Viscometer (rotational viscometer) can be used. Measuring viscosity with this instrument involves inserting a spindle that is cylindrical or disk shaped into the liquid. The spindle is rotated at a selectable RPM, which applies different shear rates to the fluid. The resistance the liquid applies to the rotating spindle is measured as a torque, which is converted to a viscosity. A specification normally would indicate spindle number, RPM, and temperature of the measurement.

In this case, a PCE-RVI 2 (PCE Group) rotational viscometer was used. The ASTM test D2196, "Standard Test Methods for

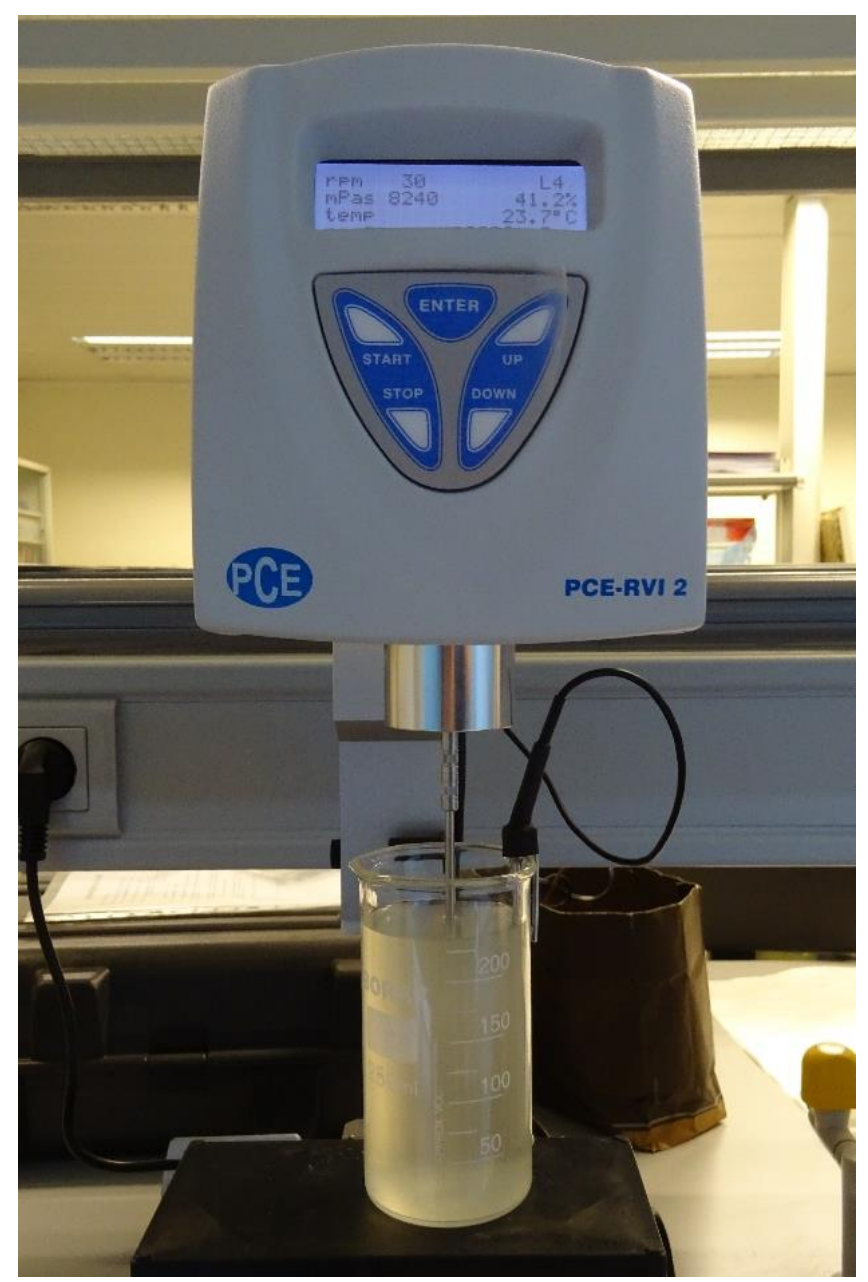

Figure 4.2.3. Viscosity measurement with rotational viscometer.

Rheological Properties of Non-Newtonian Materials by Rotational Viscometer" was taken into account for measurements. In order to determine the apparent viscosity of the adhesive dispersions, viscosity was measured after 30 seconds, one minute and three minutes. The measurements were repeated for three times every three minutes. The measurements were done with the adhesive dispersions at $23^{\circ} \mathrm{C}$ $+/-1,5^{\circ} \mathrm{C}$ (Fig. 4.2.3).

In this case, also Plextol viscosity was measured to better understand the behaviour of adhesive dispersions. 


\subsection{4. $\mathrm{pH}$}

When aqueous dispersions are used for conservation treatments, it is important to control their $\mathrm{pH}$, in order to do not damage or even remove the more superficial constitutive layers.

Different $\mathrm{pH}$ measurements were carried out on:

- The adhesive dispersions in fluid state.

- The adhesives applied and let dry on microscope slides

- Tissue supports.

- Remoistenable tissue (tissue support + adhesive dispersion).

- Remoistenable tissues reactivated with a buffer of pH 6,4 (see section 3.4.3).

For this investigation, a Hanna Precision (model 211) pH meter102 was used, equipped with a glass electrode for the measurement of aqueous solutions and a specific electrode for the measurement of surfaces (Fig. 4.2.4).

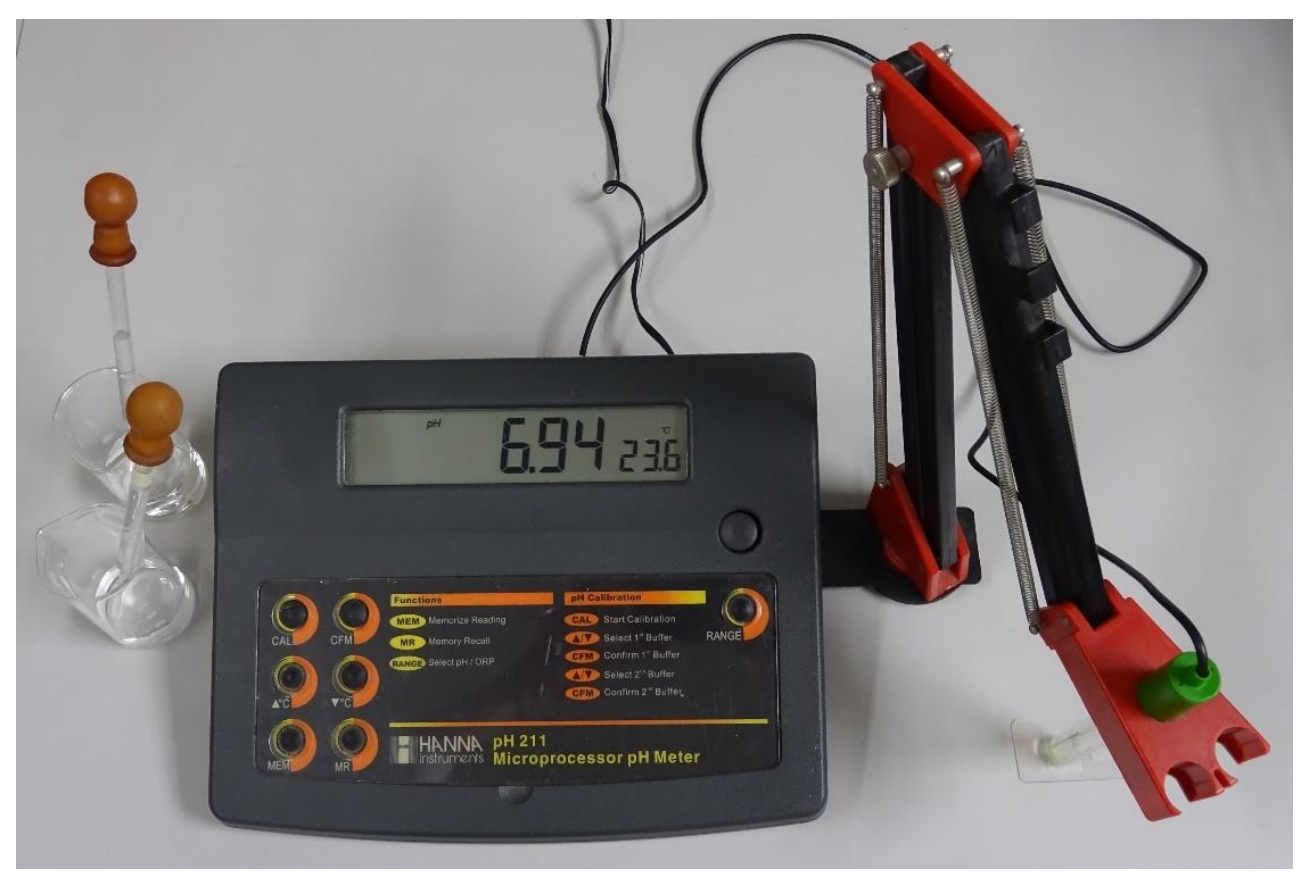

Figure 4.2.4. Measurement of the $\mathrm{pH}$ of dried adhesive dispersion by a specific electrode for measurement of surfaces.

\footnotetext{
102 The $\mathrm{pH}$ meter and analytical balance used for this first step of the investigation belong to the "Environmental physics-chemistry laboratory", of the Instituto de Restauración del Patrimonio de la Universitat Politècnica de València (Spain).
} 


\subsubsection{Absorbance and evaporation rate}

The evaluation of the evaporation speed of the solvent from the remoistenable tissue is a parameter useful to determine how much water stays in contact with the surface of the painting, but it is also useful to have an idea of the penetration of the adhesive.

Previous tests were made with test specimens of remoistenable tissues with different combination adhesive/support. Since no difference were noticed between supports prepared with different adhesives, a second test was made only with free supports. It was decided to use saturated specimens with a high quantity of water, in order to magnifying the differences. It was necessary to find a uniform and repeatable system to obtain supports saturated without an excess of water. For this reason, three strips $(2.5 \times 5) \mathrm{cm}$ each support were prepared, immersing them by $1 \mathrm{~cm}$ in water and letting them absorbing water by capillarity for 24 h. After this time, only the part of each strip soaked with water was selected. Specimens of the same dimensions were cut (Fig. 4.2.5). It was not possible to use this system for Holytex because of the almost totally absence of capillary rise in the specimens. Tests specimens of Holytex where therefore wetted for immersion and drained on a filter paper.

The analytical balance Precisa Serie 320 XT Modelo XT120A (Precisa) was used for these tests.

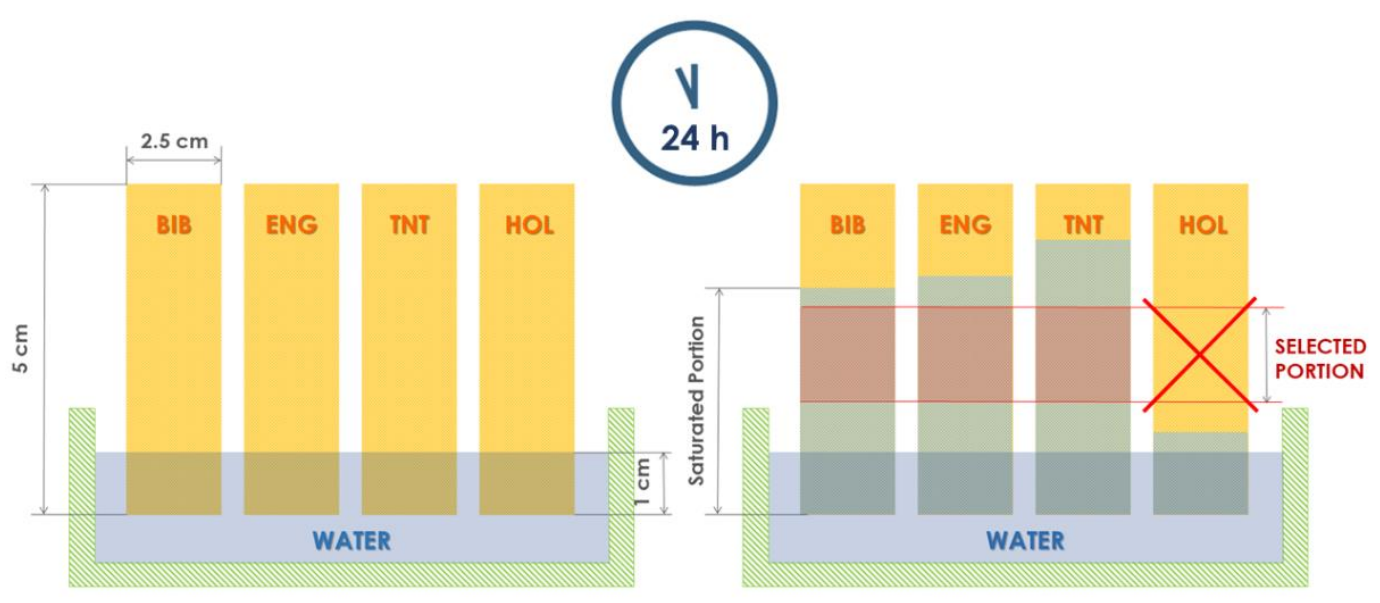

Figure 4.2.5. Preparation of specimens of the different supports for the evaporation rate test. 


\subsubsection{Dimensional changes}

As explained in the previous
chapter, an excessive
contraction of the
remoistenable temporary
support during the drying
phase of the adhesive can
cause a dangerous tensile
force on paint layer, while the
absence of any dimensional
change could be an
impediment for a good
adaptability of the support to
the paint layer, affecting the
correct adhesion of the
remoistenable tissue. For this
reason, it was necessary to
measure the dimensional
changes of the temporary
supports and the

remoistenable tissues.

For the evaluation of dimensional changes, eight adhesive dispersions (one for every kind of adhesive polymer mixture) were selected: $T(4)$, $\mathrm{T}(4) \mathrm{P} 10, \quad \mathrm{~K}(4), \quad \mathrm{K}(4) \mathrm{P} 10, \quad \mathrm{~A}(5)$, $A(5) E, K(3) A(3), K(3) A(3) E$. Three specimens of temporary

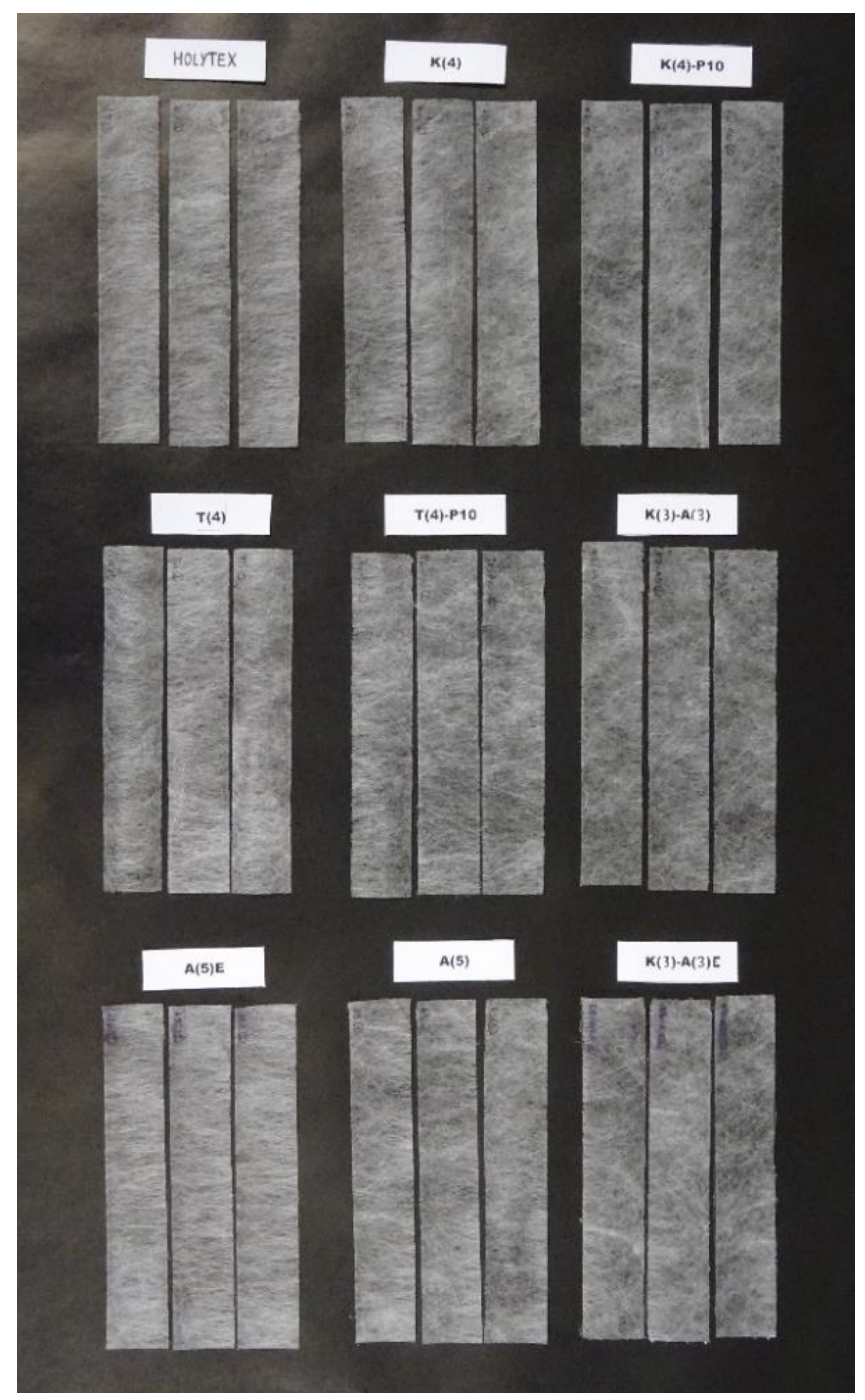

Figure 4.2.6. Specimens used for the measurement of dimensional changes.

support of $(2.5 \times 14) \mathrm{cm}$ were prepared for each kind of remoistenable tissue. In the case of TNT, two sets for each fibre direction were prepared.

Each specimen was measured before the application of the adhesive, immediately after the application, and after $24 \mathrm{~h}$. Then, the measurements were repeated immediately after the reactivation of the remoistenable tissue and after $24 \mathrm{~h}$ (Fig. 5.2.6).

The test was done leaving the specimens on a Mylar foil, to reduce the friction/rubbing and to determine the maximal dimensional variation. A Stainless digital calibre was used. 


\subsection{RESULTS AND DISCUSSION}

\subsubsection{Mass loss on drying}

The results on the thermogravimetric analysis showed that the mass loss on drying at $65^{\circ} \mathrm{C}$ is lower than that at $105^{\circ} \mathrm{C}$. After $48 \mathrm{~h}$, all specimens recovered their initial weight, which means that the loss on drying is related to the loss of water and not to loss of other volatile components. The results also revealed that a part of the free water would be trapped in the test specimens prepared as pure adhesive films during restoring operations including the use of heat (without exceeding the safety temperature). Fig. 4.3.1 shows detailed results.

Looking at the results obtained for the two thickeners, specimens made of Tylose (T(4): $8.8 \%$ at $65^{\circ} \mathrm{C} ; 10.3 \%$ at $105^{\circ} \mathrm{C}$ ) showed a higher mass loss on drying than the ones made of Klucel (K(4): 5.3-5.9\%). The addition of an acrylic polymer strongly reduced the mass loss on drying, especially in the case of Tylose. In fact, the addition of only a $5 \%$ of Plextol, as in T(4)P5, almost halved the mass loss on drying. As a matter of fact, the increase in the percentage of Plextol in the dispersions led to a decrease in the percentage of loss on drying. In the case of dispersions prepared with Klucel, the percentage of loss on drying went from 5.3-5.9\% of K(4), to 4.0-5.9\% of K(4)P5, which is the dispersion between Klucel and Plextol with the highest quantity of Klucel, until 1.4-2.8\% of K(3)P10, which is the dispersion with the lowest content of Klucel. In the case of dispersions prepared with Tylose, the percentage of mass loss on drying went from 8.8-10.3\% of T(4), to 5.2-5.5 \% of T(4)P5, until 2.88-3.75 \% of T(3)P10.

Measurements on solutions of Aquazol dissolved in water and subjected to the heating cycle at $105^{\circ} \mathrm{C}$ gave similar or even higher values than those of $4 \%$ Tylose. Solution of $5 \%$ Aquazol A(5), showed a loss on drying of $11.4 \%$, while $7 \%$ Aquazol A(7) 10.2\%. Nevertheless, when subjected to the heating cycle at $65^{\circ} \mathrm{C}$, Aquazol showed a lower loss on drying (A(5): $6.99 \%$; $A(7): 5.1 \%)$.

Values recorded for the alcoholic solutions of Aquazol were clearly lower. Aquazol dissolved at $5 \%$ in ethyl alcohol $\mathrm{A}(5) \mathrm{E}$, had a mass loss on drying of $5.4 \%$ at $65^{\circ} \mathrm{C}$ and of $7.4 \%$ at $105^{\circ} \mathrm{C} ; 7 \%$ Aquazol $\mathrm{A}(7) \mathrm{E}$, had a mass loss on drying of $5.3 \%$ at $65^{\circ} \mathrm{C}$ and of $6.2 \%$ at $105^{\circ} \mathrm{C}$.

Films prepared with adhesive dispersions of Klucel and Aquazol gave uppermiddle values. Also in this case, the difference between the measurements made for the cycle at $65^{\circ} \mathrm{C}$ and at $105^{\circ} \mathrm{C}$, was higher than the ones recorded for the films of dispersions prepared with Klucel or Tylose, combined with Plextol. The reason of this difference lied in the presence of Aquazol, which is more reactive to water than 
Plextol. In general, it is possible to state that the percentage of loss on drying increased with the increasing of Aquazol content and the decreasing of Klucel content in the dispersion: it went from 6.0-9.7\% of K(4)A(2) (lowest percentage) to 9.5-12.2 \% of $\mathrm{K}(3) \mathrm{A}(3)$ (highest percentage).

It was the same for alcoholic dispersions, even if the percentage was lower: 5.5-8.9 \% for $\mathrm{K}(3) \mathrm{A}(2), 5.7-9.1 \%$ for $\mathrm{K}(3) \mathrm{A}(3) \mathrm{E}$, and 5.9-9.5\% for K(3)A(4)E. As for aqueous and alcoholic solutions of Aquazol, the difference between the percentages of mass loss on drying during the cycles at $65^{\circ} \mathrm{C}$ y $105^{\circ} \mathrm{C}$ decreased.

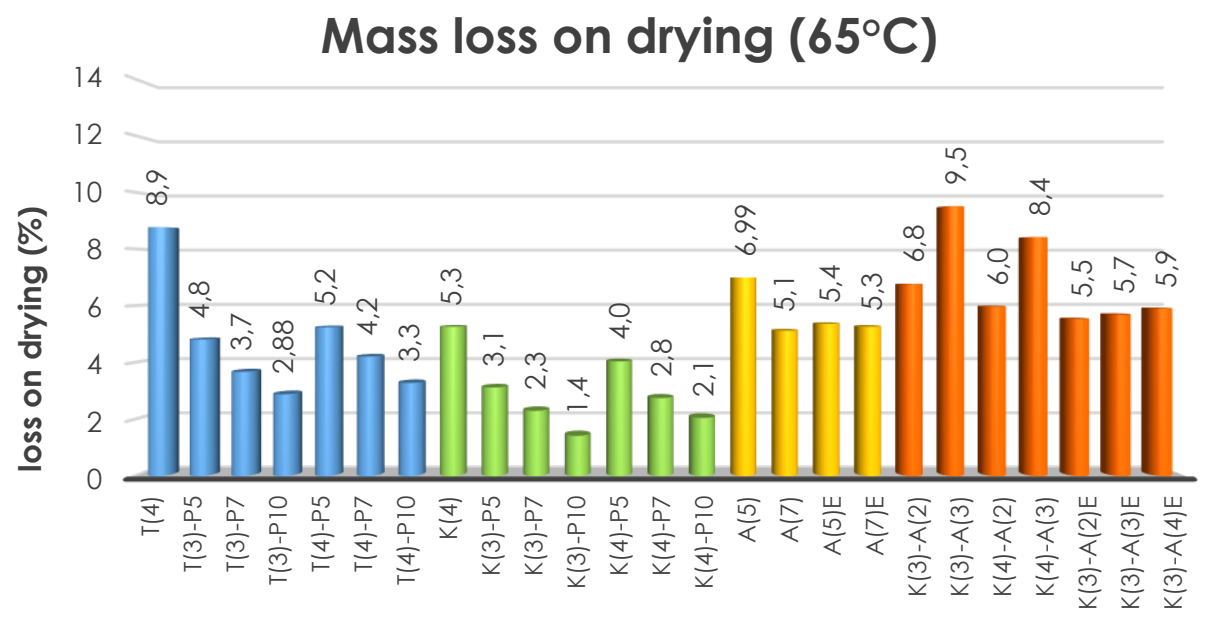

a)

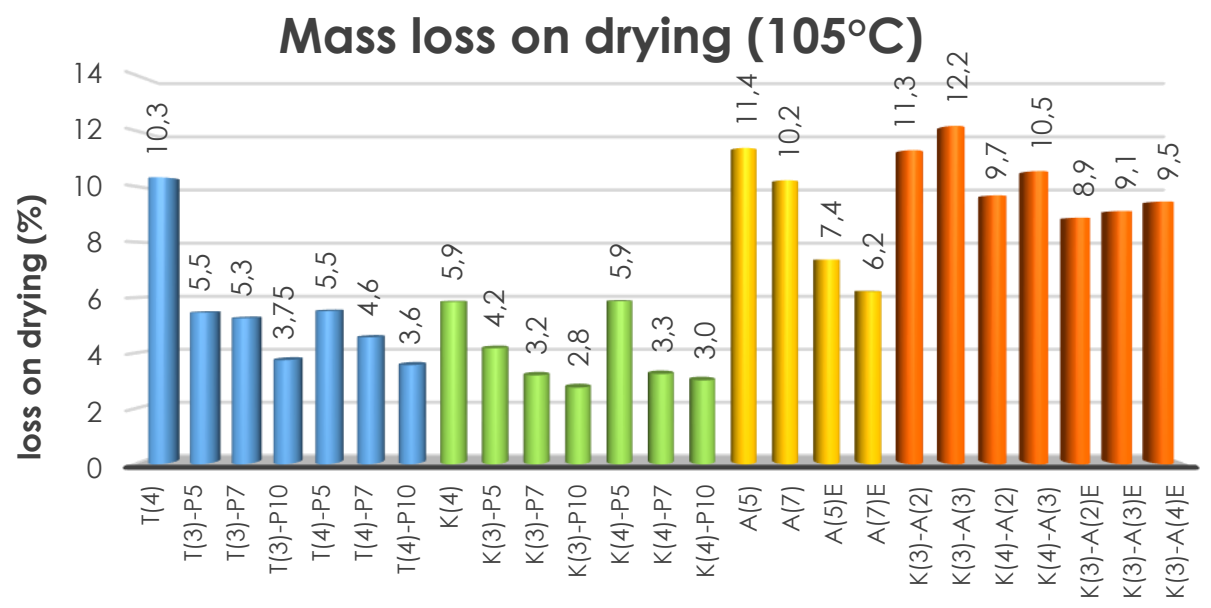

b)

Figure 4.3.1. Mass loss on drying. Results obtained with thermogravimetric analysis: a) samples subjected to the heating program $25-65^{\circ} \mathrm{C}$ : b) samples subjected to the heating program $25-105^{\circ} \mathrm{C}$. 
Table 4.3.1. Mass loss on drying. Results obtained with thermogravimetric analysis

\begin{tabular}{|c|c|c|c|c|}
\hline \multicolumn{5}{|c|}{ Mass loss on drying (M0-m/m*100\%) } \\
\hline \multirow[b]{2}{*}{ Tested materials } & \multicolumn{2}{|c|}{$65^{\circ} \mathrm{C}$} & \multicolumn{2}{|c|}{$105^{\circ} \mathrm{C}$} \\
\hline & Average & $\begin{array}{l}\text { Standard } \\
\text { deviation }\end{array}$ & Average & $\begin{array}{l}\text { Standard } \\
\text { deviation }\end{array}$ \\
\hline $\mathrm{T}(4)$ & 8.8 & 0.6 & 10.3 & 0.9 \\
\hline T(3)P5 & 4.8 & 0.1 & 5.5 & 0.4 \\
\hline $\mathrm{T}(3) \mathrm{P7}$ & 3.7 & 0.1 & 5.3 & 0.5 \\
\hline $\mathrm{T}(3) \mathrm{P} 10$ & 2.88 & 0.04 & 3.75 & 0.02 \\
\hline T(4)P5 & 5.2 & 0.8 & 5.5 & 0.1 \\
\hline $\mathrm{T}(4) \mathrm{P} 7$ & 4.2 & 0.4 & 4.6 & 0.3 \\
\hline $\mathrm{T}(4) \mathrm{P} 10$ & 3.3 & 0.2 & 3.6 & 0.4 \\
\hline$K(4)$ & 5.3 & 0.6 & 5.9 & 0.7 \\
\hline K(3)P5 & 3.1 & 0.4 & 4.2 & 0.5 \\
\hline $\mathrm{K}(3) \mathrm{P7}$ & 2.3 & 0.3 & 3.2 & 0.6 \\
\hline $\mathrm{K}(3) \mathrm{P} 10$ & 1.4 & 0.1 & 2.8 & 0.1 \\
\hline K(4)P5 & 4.0 & 0.8 & 5.9 & 0.8 \\
\hline $\mathrm{K}(4) \mathrm{P} 7$ & 2.7 & 0.1 & 3.3 & 0.2 \\
\hline $\mathrm{K}(4) \mathrm{P} 10$ & 2.1 & 0.1 & 3.0 & 0.3 \\
\hline$A(5)$ & 6.99 & 0.05 & 11.4 & 0.6 \\
\hline$A(7)$ & 5.1 & 0.1 & 10.2 & 0.5 \\
\hline$A(5) E$ & 5.4 & 0.8 & 7.4 & 0.9 \\
\hline$A(7) E$ & 5.3 & 0.5 & 6.2 & 0.5 \\
\hline $\mathrm{K}(3) \mathrm{A}(2)$ & 6.8 & 0.2 & 11.3 & 0.9 \\
\hline$K(3) A(3)$ & 9.5 & 0.7 & 12.2 & 0.8 \\
\hline $\mathrm{K}(4) \mathrm{A}(2)$ & 6.0 & 0.7 & 9.7 & 0.6 \\
\hline $\mathrm{K}(4) \mathrm{A}(3)$ & 8.4 & 0.7 & 10.5 & 0.7 \\
\hline $\mathrm{K}(3) \mathrm{A}(2) \mathrm{E}$ & 5.5 & 0.6 & 8.9 & 0.2 \\
\hline $\mathrm{K}(3) \mathrm{A}(3) \mathrm{E}$ & 5.7 & 0.8 & 9.1 & 0.5 \\
\hline $\mathrm{K}(3) \mathrm{A}(4) \mathrm{E}$ & 5.9 & 0.3 & 9.5 & 0.6 \\
\hline
\end{tabular}




\subsubsection{Hardness}

The results of the hardness test obtained for the different dispersions shown in Fig. 4.3.2 were quite similar. Tylose film (T(4): 99.6) was harder than the Klucel one (K(4): 90.5).

The films prepared with Tylose and Plextol had higher values of hardness than the ones prepared with Klucel and the same adhesive. For example, while T(3)P5 had a hardness of 97.9, K(3)P5 had a hardness of 85.4.

Aquazol had intermediate values between the two thickeners, which went from 94 of $A(5) E$ to 97.2 of $A(5)$. It was possible to observe a little decrease in hardness for the corresponding films prepared from alcoholic solutions.

The hardness of the film dispersions prepared with Klucel and Aquazol decreased with the increasing in the percentage of Aquazol, going from 88.5 of $K(4) A(2)$, to 84.7 of $K(3) A(3)$. In this case, for a given percentage, the values of films from alcoholic dispersions were slightly harder $(K(3) A(2) E: 91.2 ; K(3) A(3) E$ : 86.0) Considering the results of the films prepared with pure Aquazol, this behaviour probably was due to the presence of Klucel. The hardness decreased in the case of K(3)A(4)E (79.4), which had a higher percentage of Aquazol than that present in tested water dispersions.

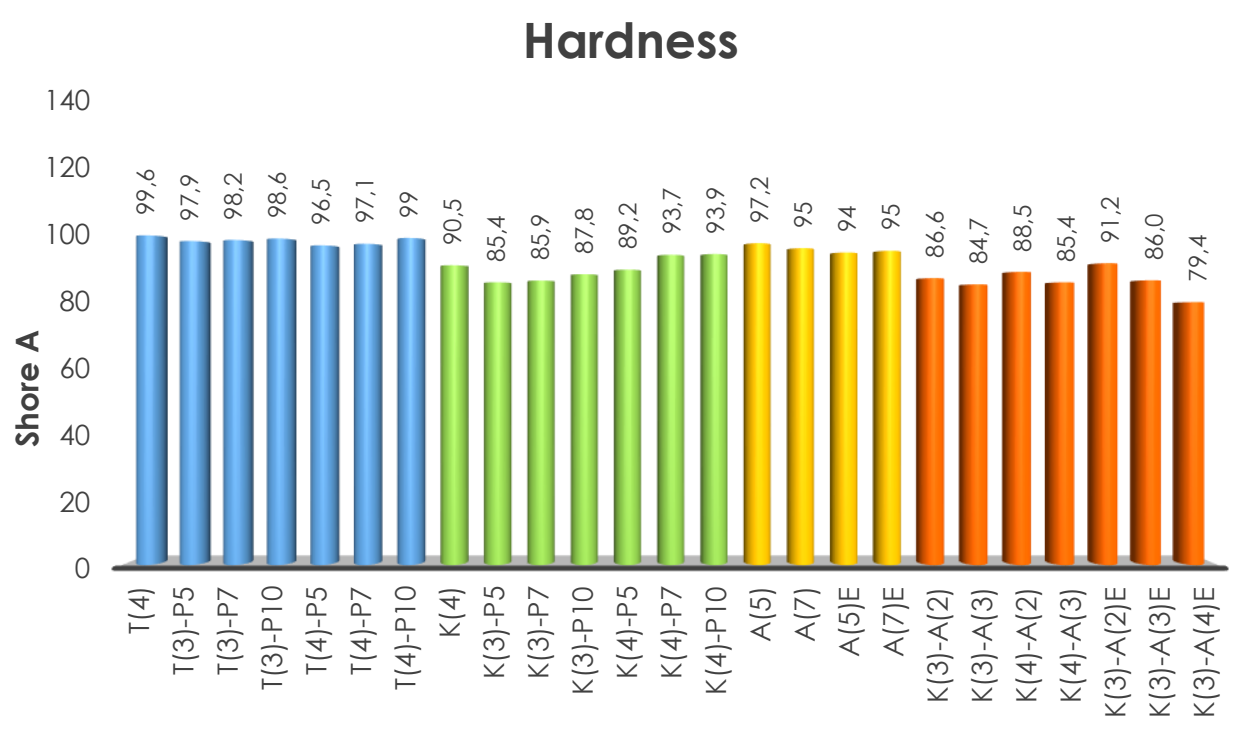

Figure 4.3.2. Hardness test. Results obtained with hardness test with a Shore durometer (class A). 

durometer (class A).

\begin{tabular}{|c|c|c|}
\hline \multicolumn{3}{|c|}{ Hardness (Shore A) } \\
\hline Tested materials & Average & Standard deviation \\
\hline$T(4)$ & 99,6 & 0,2 \\
\hline T(3)P5 & 97,9 & 0,9 \\
\hline $\mathrm{T}(3) \mathrm{P7}$ & 98,2 & 0,9 \\
\hline $\mathrm{T}(3) \mathrm{P} 10$ & 98,6 & 0,5 \\
\hline T(4)P5 & 96,5 & 0,8 \\
\hline $\mathrm{T}(4) \mathrm{P} 7$ & 97,1 & 0,9 \\
\hline $\mathrm{T}(4) \mathrm{P} 10$ & 99 & 1 \\
\hline$K(4)$ & 90,5 & 0,9 \\
\hline K(3)P5 & 85,4 & 0,8 \\
\hline $\mathrm{K}(3) \mathrm{P} 7$ & 85,9 & 0,9 \\
\hline $\mathrm{K}(3) \mathrm{P} 10$ & 87,8 & 0,8 \\
\hline K(4)P5 & 89,2 & 0,7 \\
\hline $\mathrm{K}(4) \mathrm{P} 7$ & 93,7 & 0,6 \\
\hline $\mathrm{K}(4) \mathrm{P} 10$ & 93,9 & 0,7 \\
\hline$A(5)$ & 97,2 & 0,9 \\
\hline$A(7)$ & 95 & 1 \\
\hline$A(5) E$ & 94 & 2 \\
\hline$A(7) E$ & 95 & 1 \\
\hline$K(3) A(2)$ & 86,6 & 0,7 \\
\hline$K(3) A(3)$ & 84,7 & 0,9 \\
\hline $\mathrm{K}(4) \mathrm{A}(2)$ & 88,5 & 0,8 \\
\hline$K(4) A(3)$ & 85 & 1 \\
\hline$K(3) A(2) E$ & 91,2 & 0,9 \\
\hline$K(3) A(3) E$ & 86,0 & 0,8 \\
\hline $\mathrm{K}(3) \mathrm{A}(4) \mathrm{E}$ & 79,4 & 0,7 \\
\hline
\end{tabular}




\subsubsection{Viscosity}

In general, all the analysed dispersion presented very little thixotropic or rheopectic behaviour, reported in Table 4.3.1, which can be neglected.

As shown in Fig. 4.3.3, the solution of Tylose at $4 \%$ (10407 mPa $\cdot \mathrm{s}$ ) was clearly much more viscous than that of Klucel at $4 \%$ (854 $\mathrm{mPa} \cdot \mathrm{s})$. Aquazol had a very low viscosity. In alcoholic solutions, the growth in concentration led viscosity to increase faster than in the aqueous ones. In fact, $5 \%$ water solution presented a higher viscosity (A(5): $23 \mathrm{mPa} \cdot \mathrm{s})$ than the $5 \%$ alcoholic solution (A(5)E $20 \mathrm{mPa} \cdot \mathrm{s})$, while $7 \%$ water solution had a lower viscosity $(\mathrm{A}(7): 28 \mathrm{mPa} \cdot \mathrm{s})$ than its corresponding alcoholic solution (A(7)E: $31 \mathrm{mPa} \cdot \mathrm{s})$. Plextol had a higher viscosity than Aquazol (290 mPa $\cdot \mathrm{s})$.

Dispersions prepared combining the two thickeners and the acrylic emulsion, presented a common characteristic of cellulose ethers: the increasing by $1 \%$ of the concentration of the cellulose ether in the dispersion caused a great increasing in the viscosity. In fact, in the case of Tylose, viscosity went from $2491 \mathrm{mPa} \cdot \mathrm{s}$ of T(3)-P5, to $9323 \mathrm{mPa} \cdot \mathrm{s}$ of T(4)P7; in the case of Klucel viscosity went from $703 \mathrm{mPa} \cdot \mathrm{s}$ of K(3)-P7, to $3206 \mathrm{mPa} \cdot \mathrm{s}$ of K(4)P7.

Dispersions made with $3 \%$ of Tylose and different percentages of Plextol (T(3)P5: $2491 \mathrm{mPa} \cdot \mathrm{s}$; T(3)P7: 2073; $\mathrm{mPa} \cdot \mathrm{s}$ T(3)P10: $1986 \mathrm{mPa} \cdot \mathrm{s})$, and the ones prepared with $4 \%$ of Klucel and Plextol (K(4)P5: $3206 \mathrm{mPa} \cdot \mathrm{s}$; K(4)P7: 3094; $\mathrm{mPa} \cdot \mathrm{K}$ K(4)P 10: $2710 \mathrm{mPa} \cdot \mathrm{s})$ presented a predictable behaviour, given by the decrease of viscosity with the increasing in the percentage of Plextol. Nonetheless, adhesive dispersions prepared with $4 \%$ of Tylose and Plextol showed an opposite behaviour. In fact, the viscosity growth with the increasing of the Plextol content in the mixture. Viscosity went from $9323 \mathrm{mPa} \cdot \mathrm{s}$ of T(4)P5 to $10620 \mathrm{mPa} \cdot \mathrm{s}$ of T(4)P7, until $11728 \mathrm{mPa} \cdot \mathrm{s}$ of T(4)P10. Another peculiar behaviour was represented by the dispersions containing $3 \%$ of Klucel and Plextol, where the dispersion K(3)P10 (744 mPa s), which it was supposed to be less viscous than K(3)P7(640 mPa s), had a viscosity even higher than K(3)P5 (703 mPa s). These anomalies might be caused by some interactions among the molecules of the two polymers. It is plausible to suppose that at given interval of concentrations the quantity of water and the disposition of the molecules is such to promote intermolecular bonds (hydrogen bonds, Van der Waals), which could be the cause of the increasing in viscosity. 
In water dispersions of Klucel and Aquazol, viscosity decreased with the increase in the concentration of Aquazol. Intermolecular bonds could have interfered also in this case. In fact, the viscosity of the dispersion with $3 \%$ of Klucel grow by $656 \mathrm{mPa} \cdot \mathrm{s}$ with the increasing of only $1 \%$ in Aquazol concentration, passing from $2146 \mathrm{mPa} \cdot \mathrm{s}$ of $\mathrm{K}(3) \mathrm{A}(3)$ to $2802 \mathrm{mPa} \cdot \mathrm{s}$ of $\mathrm{K}(3) \mathrm{A}(2)$. In the dispersion made with $4 \%$ of Aquazol this difference was of $1896 \mathrm{mPa} \cdot \mathrm{s}$, almost tree times higher: viscosity went from $3124 \mathrm{mPa} \cdot \mathrm{s}$ of $\mathrm{K}(4) \mathrm{A}(3)$ to 5020 $\mathrm{mPa} \cdot \mathrm{s}$ of $\mathrm{K}(4) \mathrm{A}(2)$.

The corresponding alcoholic mixtures, where Klucel was employed just at 3 $\%$, showed an opposite behaviour: viscosity grow with the increase of Aquazol concentration. It went from $6306 \mathrm{mPa} \cdot \mathrm{s}$ of $\mathrm{K}(3) \mathrm{A}(2) \mathrm{E}$, to 6370 of $\mathrm{K}(3) \mathrm{A}(3) \mathrm{E}$ and to $7024 \mathrm{mPa} \cdot \mathrm{s}$ of $\mathrm{K}(3) \mathrm{A}(4) \mathrm{E}$. This phenomenon probably is due to the different behaviour of Aquazol in aqueous and alcoholic solutions.

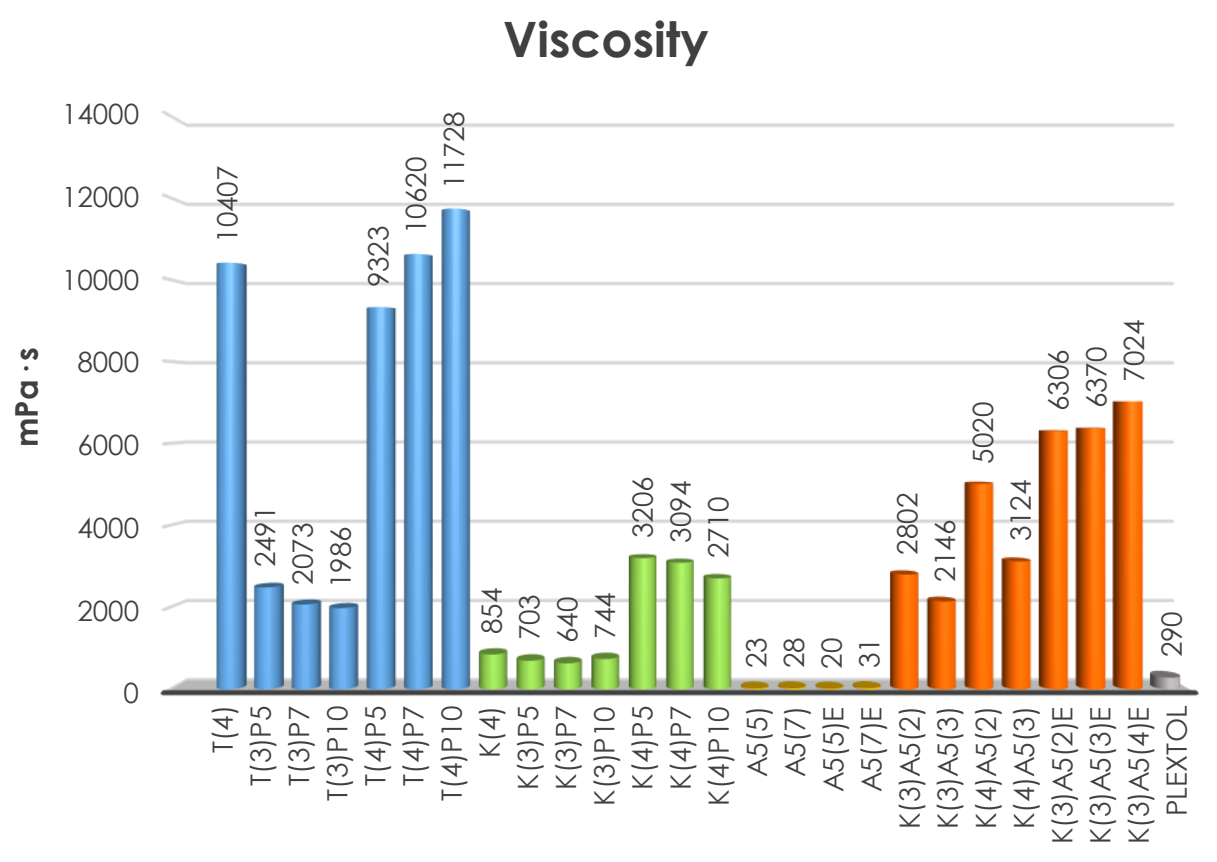

Figure 4.3.3. Graphic representation of viscosity values for the tested adhesive. 


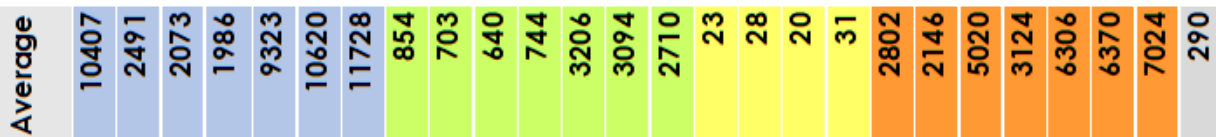

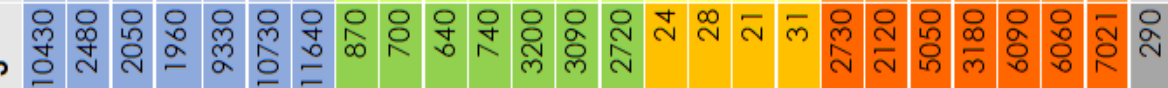

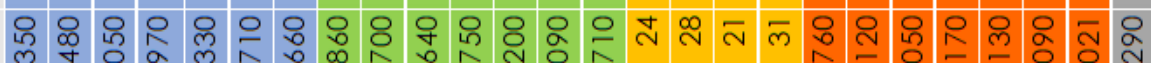
$m=\frac{0}{4}$

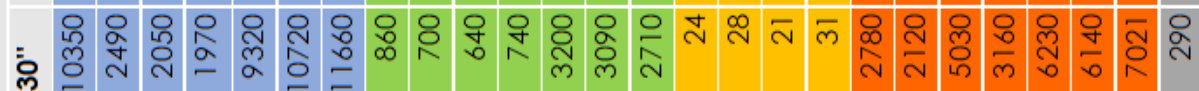

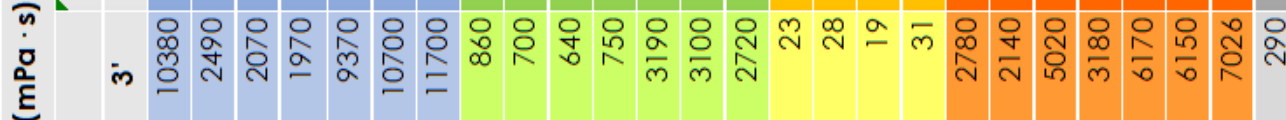

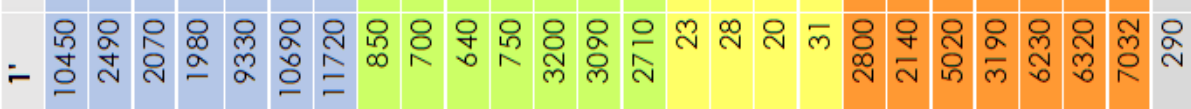

$\stackrel{\leftrightarrow}{>}$

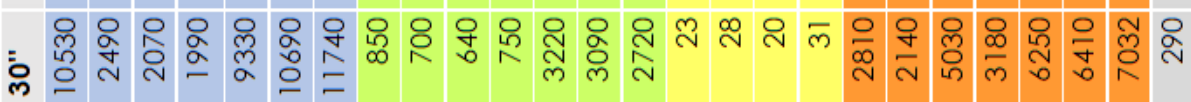

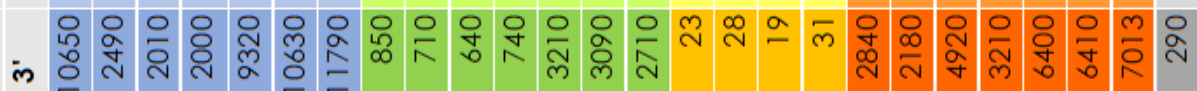

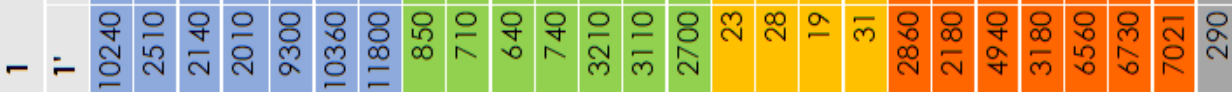

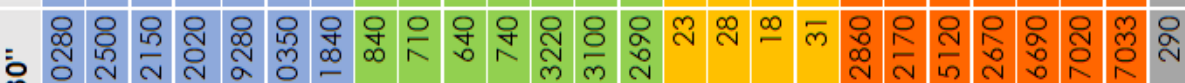

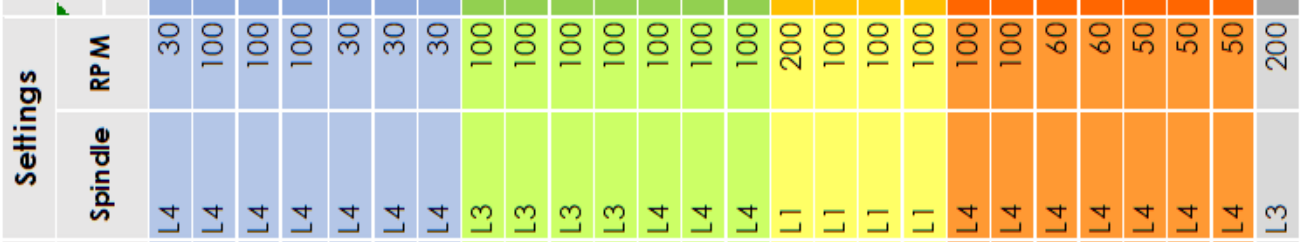
产

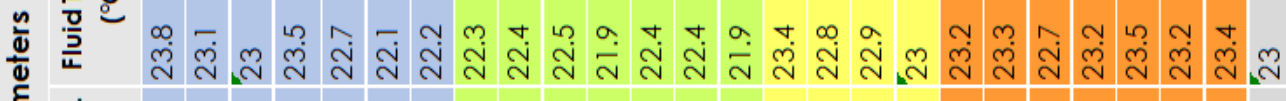
醇

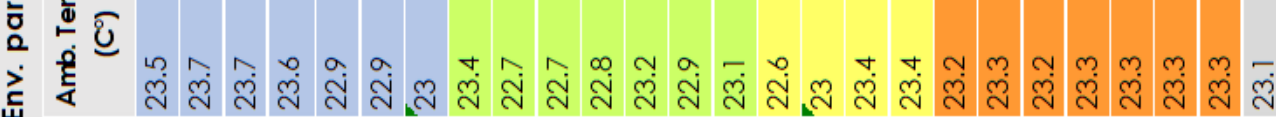

婲

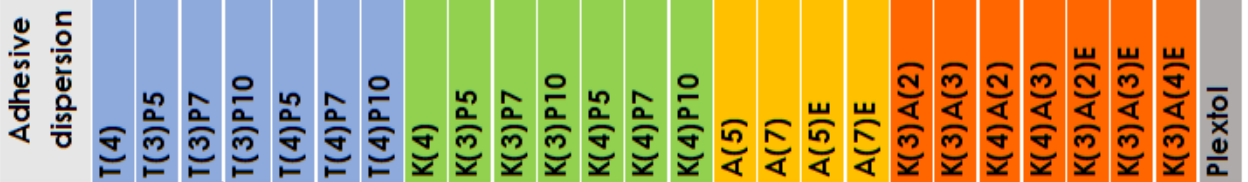




\subsection{4. $\mathrm{pH}$}

The results of the $\mathrm{pH}$ measurements (Table 4.3.2) carried out on the prepared adhesive dispersions in fluid state confirmed the almost neutrality, reported in literature (Borgioli and Cremonesi 2005), for Tylose, Klucel and Aquazol, whose respective $\mathrm{pH}$ was $7.15,6.95$ and 7.23 .

Nevertheless, it is possible to see the influence of Plextol (pH 8.08) in the slight alkalinity exhibited by the dispersions made with Tylose and Plextol (pH between 7.86 and 8.13) and those prepared with Klucel and Plextol (pH between 7.31 y 7.93). Adhesive dispersions of Klucel and Aquazol presented a neutral $\mathrm{pH}(\mathrm{pH}$ between 6.87 y 6.98).

The $\mathrm{pH}$ values of dried dispersions applied as thin films on microscope slides and reactivated with a drop of demineralized water, revealed some changes. While the $\mathrm{pH}$ of Tylose and Klucel remained neutral, that of the dispersions prepared with the two thickeners and Plextol had an acidic pH, between 4.9 and 5.5 for Tylose dispersions, and between 4.92 and 5.5 for Klucel dispersions. This suggests that the alkalinity of Plextol depends on volatile components contained in the emulsion.

While the dispersions prepared with Klucel and Aquazol maintained a neutral $\mathrm{pH}$ (between 6.73 and 7.23), Aquazol was notably basic (pH between 9.02 and 9.44). It would be useful to understand the reasons of this change with further analyses.

Regarding the $\mathrm{pH}$ of the temporary supports, Bib. Tengujo, English tissue and Holytex showed an almost neutral pH (respectively 6.75, 6.91 and 6.8) whereas TNT 30/B had a slightly acidic $\mathrm{pH}$ (5.83).

Concerning the data obtained for the specimens of remoistenable tissues, the $\mathrm{pH}$ of the ones prepared with Bib. Tengujo and English tissue ${ }^{103}$ exhibited almost neutral values (pH respectively 6.33-7.29 and 6.61-7.37). The $\mathrm{pH}$ found in specimens prepared with remoistenable TNT tissues is slightly more acid (pH between 6.18 and 7.15). The influence of the support is evident in the case of Holytex®, where the $\mathrm{pH}$ of the corresponding remoistenable tissues is strongly basic $(\mathrm{pH}$ between 8.1 and 9.6), except of those prepared with $\mathrm{K}(4)$, which had a pH of 7.33. This can be due to an alkaline reserve present in the tissue. Further analyses would be useful to study these results deeply.

The use of a buffer solution for the reactivation seemed to be adequate, since the $\mathrm{pH}$ held steady for every remoistenable tissue ( $\mathrm{pH}$ between 6.36 and 6.48).

${ }^{103}$ Considering that English tissue was included in the experimentation at a later time, it was measured only the $\mathrm{pH}$ of the remoistenable temporary supports which had been already selected. 
Table 4.3.2. Results of the $\mathrm{pH}$ measurement made on fluid and dried adhesive dispersions, on the free supports, and on the remoistenable tissues reactivated with demineralised water and with a buffer solution.

\begin{tabular}{|c|c|c|c|c|c|c|c|c|c|c|c|c|c|c|c|c|c|c|c|c|c|}
\hline & \multirow{2}{*}{\multicolumn{4}{|c|}{$\begin{array}{c}\text { Adhesive } \\
\text { disperions } \mathrm{pH}\end{array}$}} & \multicolumn{16}{|c|}{ Remoistenable temporary supports $\mathrm{pH}$} \\
\hline & & & & & & \multicolumn{8}{|c|}{ Deminaralized water } & \multicolumn{8}{|c|}{ Buffer solution $\mathrm{pH} 6.44$} \\
\hline & & \multicolumn{2}{|c|}{ Fluid } & \multicolumn{2}{|c|}{ Dried } & \multicolumn{2}{|c|}{$\mathrm{BIB}$} & \multicolumn{2}{|c|}{ ENG } & \multicolumn{2}{|c|}{ TNT } & \multicolumn{2}{|c|}{$\mathrm{HOL}$} & \multicolumn{2}{|c|}{$\mathrm{BIB}$} & \multicolumn{2}{|c|}{ ENG } & \multicolumn{2}{|c|}{ TNT } & \multicolumn{2}{|c|}{$\mathrm{HOL}$} \\
\hline & & Av. & $\begin{array}{l}\text { St. } \\
\text { dev. }\end{array}$ & Av. & $\begin{array}{l}\text { St. } \\
\text { dev. }\end{array}$ & Av. & $\begin{array}{l}\text { St. } \\
\text { dev. }\end{array}$ & Av. & $\begin{array}{l}\text { St. } \\
\text { dev. }\end{array}$ & Av. & $\begin{array}{l}\text { St. } \\
\text { dev. }\end{array}$ & Av. & $\begin{array}{l}\text { St. } \\
\text { dev. }\end{array}$ & Av. & $\begin{array}{l}\text { St. } \\
\text { dev. }\end{array}$ & Av. & $\begin{array}{l}\text { St. } \\
\text { dev. }\end{array}$ & Av. & $\begin{array}{l}\text { St. } \\
\text { dev. }\end{array}$ & Av. & $\begin{array}{l}\text { St. } \\
\text { dev. }\end{array}$ \\
\hline \multirow{27}{*}{$\begin{array}{l}\overline{\overline{0}} \\
\overline{0} \\
\overline{0} \\
\bar{\varepsilon} \\
\overline{0} \\
\overline{0} \\
\overline{0}\end{array}$} & Support & l & I & I & l & 6,57 & 0,04 & 6,91 & 0,06 & 5,83 & 0,01 & 6,8 & 0,3 & 6,43 & 0,01 & 6,4 & 0 & 6,44 & 0,02 & 6,44 & 0,01 \\
\hline & $T(4)$ & 7,15 & 0,02 & 7,3 & 0,1 & 6,9 & 0,1 & I & I & 6,81 & 0,09 & 8,1 & 0,3 & 6,43 & 0,01 & I & 1 & 6,47 & 0,01 & 6,42 & 0,02 \\
\hline & $\mathrm{T}(3) \mathrm{P} 5$ & 7,96 & 0,02 & 5,3 & 0,1 & 6,61 & 0,05 & I & I & 6,57 & 0,01 & 9,4 & 0,4 & 6,44 & 0,01 & I & I & 6,46 & 0,01 & 6,44 & 0,01 \\
\hline & $\mathrm{T}(3) \mathrm{P} 7$ & 8,10 & 0,01 & 5,06 & 0,01 & 6,5 & 0,1 & 6,93 & 0,07 & 6,50 & 0,06 & 9,4 & 0,3 & 6,43 & 0,01 & 6,43 & 0,01 & 6,45 & 0,03 & 6,44 & 0,01 \\
\hline & $\mathrm{T}(3) \mathrm{P} 10$ & 8,13 & 0,04 & 4,9 & 0,2 & 6,62 & 0,03 & I & I & 6,23 & 0,05 & 8,9 & 0,2 & 6,43 & 0,02 & I & I & 6,45 & 0,01 & 6,43 & 0,01 \\
\hline & $\mathrm{T}(4) \mathrm{P} 5$ & 7,94 & 0,02 & 5,5 & 0,3 & 6,7 & 0,1 & I & l & 6,42 & 0,07 & 9,4 & 0,4 & 6,43 & 0,03 & I & I & 6,44 & 0,01 & 6,43 & 0,01 \\
\hline & $\mathrm{T}(4) \mathrm{P} 7$ & 7,94 & 0,01 & 5,02 & 0,07 & 6,56 & 0,09 & 6,61 & 0,05 & 6,37 & 0,04 & 9,1 & 0,1 & 6,43 & 0,01 & 6,44 & 0,01 & 6,43 & 0,01 & 6,45 & 0,02 \\
\hline & $\mathrm{T}(4) \mathrm{P} 10$ & 7,86 & 0,01 & 5,0 & 0,2 & 6,33 & 0,01 & I & & 6,18 & 0,02 & 8,4 & 0,3 & 6,43 & 0,01 & I & I & 6,45 & 0,02 & 6,44 & 0,01 \\
\hline & $K(4)$ & 6,95 & 0,03 & 7,37 & 0,05 & 7,29 & 0,02 & 7,35 & 0,11 & 6,88 & 0,06 & 7,33 & 0,07 & 6,43 & 0,02 & 6,43 & 0,01 & 6,48 & 0,01 & 6,46 & 0,01 \\
\hline & K(3)P5 & 7,43 & 0,02 & 6,15 & 0,04 & 6,90 & 0,09 & 1 & I & 6,77 & 0,03 & 8,8 & 0,3 & 6,44 & 0,01 & I & I & 6,48 & 0,01 & 6,45 & 0,01 \\
\hline & $\mathrm{K}(3) \mathrm{P} 7$ & 7,83 & 0,01 & 5,5 & 0,2 & 6,64 & 0,06 & I & I & 6,4 & 0,2 & 8,4 & 0,3 & 6,44 & 0,01 & I & I & 6,45 & 0,01 & 6,47 & 0,01 \\
\hline & K(3)P10 & 7,93 & 0,02 & 5,11 & 0,05 & 6,48 & 0,04 & I & I & 6,42 & 0,02 & 9,00 & 0,05 & 6,44 & 0,01 & I & I & 6,46 & 0,02 & 6,44 & 4,01 \\
\hline & $\mathrm{K}(4) \mathrm{P} 5$ & 7,31 & 0,01 & 5,46 & 0,09 & 6,67 & 0,02 & / & I & 6,54 & 0,03 & 8,6 & 0,3 & 6,43 & 0,02 & I & I & 6,46 & 0,01 & 6,44 & 0,02 \\
\hline & $\mathrm{K}(4) \mathrm{P} 7$ & 7,88 & 0,01 & 4,95 & 0,07 & 6,6 & 0,1 & 7,04 & 0,07 & 6,5 & 0,1 & 8,7 & 0,3 & 6,45 & 0,01 & 6,43 & 0,01 & 6,47 & 0,03 & 6,43 & 0,01 \\
\hline & $\mathrm{K}(4) \mathrm{P} 10$ & 7,90 & 0,02 & 4,92 & 0,08 & 6,43 & 0,07 & I & l & 6,5 & 0,1 & 8,8 & 0,1 & 6,43 & 0,03 & I & I & 6,45 & 0,01 & 6,44 & 4,01 \\
\hline & $A(5)$ & 7,23 & 0,01 & 9,02 & 0,09 & 7,09 & 0,06 & I & I & 6,7 & 0,2 & 8,99 & 0,05 & 6,43 & 0,02 & I & I & 6,44 & 0,01 & 6,43 & 0,01 \\
\hline & $\mathrm{A}(7)$ & 7,27 & 0,01 & 9,44 & 0,09 & 7,0 & 0,1 & I & I & 6,69 & 0,05 & 9,6 & 0,4 & 6,43 & 0,02 & I & I & 6,44 & 0,02 & 6,45 & 0,02 \\
\hline & $\mathrm{A}(5) \mathrm{E}$ & I & I & 9,15 & 0,09 & 7,10 & 0,04 & 6,80 & 0,09 & 7,15 & 0,03 & 8,8 & 0,5 & 6,44 & 0,01 & 6,43 & 0,02 & 6,43 & 0,01 & 6,45 & 0,03 \\
\hline & $A(7) E$ & I & I & 9,22 & 0,08 & 7,10 & 0,05 & I & I & 6,9 & 0,1 & 9,2 & 0,2 & 6,44 & 0,04 & I & I & 6,45 & 0,01 & 6,44 & 0,01 \\
\hline & $K(3) A(2)$ & 6,98 & 0,02 & 7,08 & 0,02 & 6,90 & 0,02 & I & 1 & 6,81 & 0,05 & 9,4 & 0,2 & 6,43 & 0,03 & I & I & 6,46 & 0,01 & 6,43 & 0,01 \\
\hline & $K(3) A(3)$ & 6,96 & 0,01 & 6,73 & 0,09 & 6,9 & 0,1 & l & I & 6,7 & 0,1 & 9,4 & 0,7 & 6,44 & 0,01 & l & I & 6,46 & 0,01 & 6,45 & 5,01 \\
\hline & $\mathrm{K}(4) \mathrm{A}(2)$ & 6,90 & 0,01 & 6,82 & 0,05 & 7,07 & 0,09 & 1 & I & 6,93 & 0,06 & 9,34 & 0,07 & 6,43 & 0,01 & 1 & I & 6,43 & 0,01 & 6,44 & 40,02 \\
\hline & $K(4) A(3)$ & 6,87 & 0,01 & 7,16 & 0,04 & 7,05 & 0,02 & 1 & I & 6,73 & 0,08 & 8,50 & 0,05 & 6,44 & 0,02 & I & I & 6,45 & 50,02 & 6,47 & 0,01 \\
\hline & $\mathrm{K}(3) \mathrm{A}(2) \mathrm{E}$ & I & I & 7,23 & 0,03 & 6,98 & 0,09 & 1 & I & 6,96 & 0,01 & 8,90 & 0,3 & 6,45 & 0,01 & I & I & 6,48 & 0,01 & 6,36 & 0,03 \\
\hline & $K(3) A(3) E$ & I & I & 7,19 & 0,08 & 6,86 & 0,08 & 1 & 1 & 6,73 & 0,06 & 8,96 & 0,09 & 6,44 & 0,02 & I & 1 & 6,44 & 0,02 & 6,40 & 0,01 \\
\hline & $\mathrm{K}(3) \mathrm{A}(4) \mathrm{E}$ & l & I & 7,20 & 0,06 & 6,85 & 0,07 & 7,37 & 0,03 & 6,73 & 0,01 & 9,1 & 0,2 & 6,43 & 0,01 & 6,43 & 0,01 & 6,43 & 30,01 & 6,42 & 0,01 \\
\hline & Plextol & 8,08 & 0,03 & 5,95 & 0,09 & I & I & I & I & 1 & I & I & I & I & I & 1 & I & I & I & l & I \\
\hline
\end{tabular}




\subsubsection{Absorbance and evaporation rate}

Preliminary analyses made on remoistenable tissues demonstrated that the evaporation speed depended on the amount of water itself and on the kind of support, but not on the adhesive dispersion.

As explained before, for the conclusive analysis only free supports were used, getting them wetted by capillarity. This first part of the test permitted to determine the absorbance of the supports. Bib Tengujo and English tissue have a good absorbance, respectively of $332 \%$ and $353 \%$ of their weight. Nonetheless, the support with the highest absorbance is TNT 30/B, which absorbed water for $403 \%$ of its weight. As told before, it was not possible to determine the absorbance of Holytex with the system of capillary rise because the wetted portion was too small. For this reason, Holytex was directly immersed in water for $1 \mathrm{~h}$ in order to calculate the evaporation speed. Also with this system, the support revealed to have a low absorbance power. In fact, it absorbed only $24 \%$ of its weight.

The evaporation rate of every support depended also on the quantity of water absorbed by each one. Holytex, which was the support with the lowest percentage of water, dried very fast. The evaporation rate of water from the two cellulosic supports was similar: both the wetted supports dried completely after 2025 min. Instead, the evaporation speed of water from TNT 30/B was lower, as showed by the curve corresponding to TNT in Fig. 4.3.4, with a lower inclination. The support dried completely in 45-50 min.

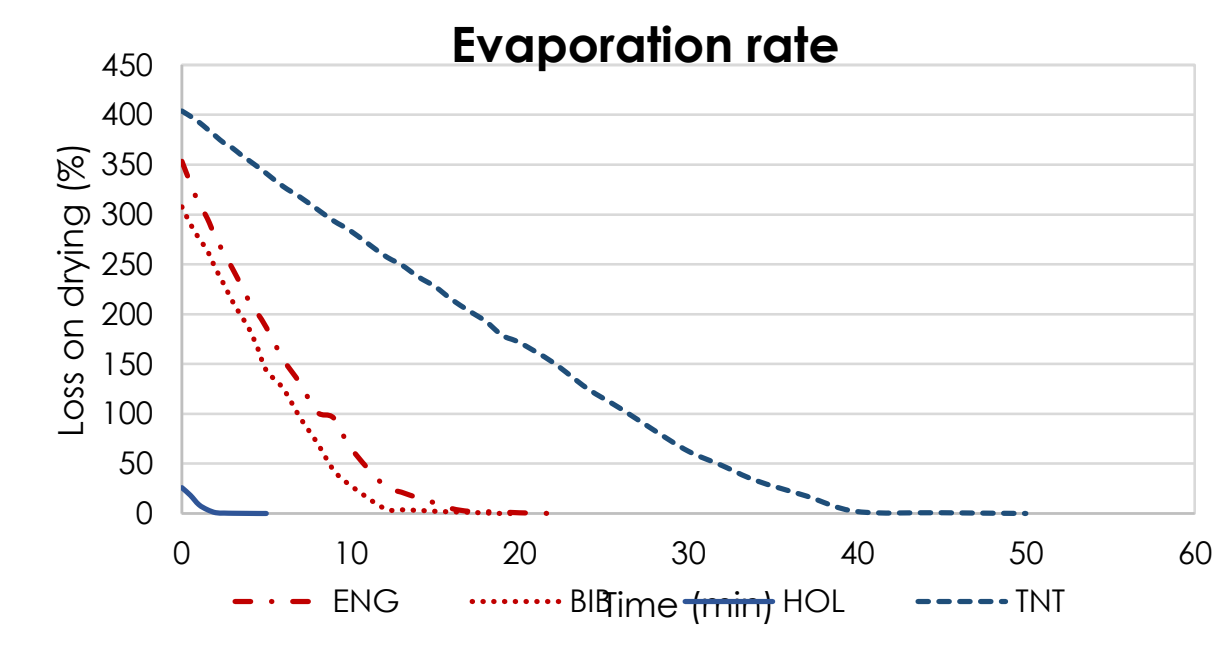

Figure 4.3.4. Graphic representation of the evaporation rate of water from the different supports. 


\subsubsection{Dimensional changes of supports and remoistenable tissues}

Unfortunately, despite measurement were done with accuracy, the results referring to dimensional changes of the remoistenable tissue were not satisfactory. The system used did not have the precision needed to obtain accurate results. Actually, in a first moment it was thought to measure the dimensional changes of little portions of remoistenable supports using the optical microscope. This method revealed to be inappropriate because the dimensional changes were too small to be quantified with this system.

For this reason, a new set of specimens was prepared with the maximum possible length ( $1 \mathrm{~cm}$ shorter than the maximum aperture of the calibre), increasing the number of measurements to reduce the error (specimens were always measured six times).

This method also did not give precise results. In any case, it was considered important to sow also these results, which can give information for future research, or anyway to reflect upon the topic.

It seems the dimensional changes depend on the support but not on the adhesives, since no differences were found among the remoistenable tissues prepared with the same support and different adhesives. It is not possible to state with certainty if is the obtained data are correct or if the repeatability of the measurements depends on the uncertainties inherent to the applied method. However, it is possible to assume that if any difference exists, it might be negligible.

Results of each support are given below in Table 4.3.3.

During the application of the polymer, remoistenable tissues of Bib. Tengujo prepared with water solutions elongated considerably $\left(0.8 \mathrm{~cm} \mathrm{~m} \mathrm{~m}^{-1}\right)$, but their contraction during the drying phase was not excessive $\left(0.2 \mathrm{~cm} \mathrm{~m}^{-1}\right)$. Supports prepared with alcoholic dispersions had smaller dimensional changes. During the application of the liquid dispersion, there was a minimal elongation $(0.2$ $\left.\mathrm{cm} \cdot \mathrm{m}^{-1}\right)$, while the contraction was higher $\left(0.5 \mathrm{~cm} \cdot \mathrm{m}^{-1}\right)$. Remoistenable tissues prepared with alcoholic dispersions had a greater elongation $\left(0.4 \mathrm{~cm} \cdot \mathrm{m}^{-1}\right)$ during reactivation and the same contraction during drying after reactivation $\left(0.5 \mathrm{~cm} \mathrm{~m} \mathrm{~m}^{-1}\right)$ than those of aqueous remoistenable tissues. This behaviour could depend on the fact that the tissues prepared with dispersions in ethyl alcohol were not 'stressed' by water during the phase of the application of the adhesive. This would explain their higher reactivity during the reactivation phase. The smaller values of contraction after the reactivation than after the application of the adhesive, measured for all the specimens, could be due 
instead to a supporting/hardening function played by the adhesive present in the interstices of the fibres network forming the support, which would impede an excessive contraction during drying.

Values of dimensional changes of RTS prepared with English tissue were slightly higher than that of Bib Tengujo. Remoistenable tissues prepared with aqueous solutions had a elongation of $1.07 \mathrm{~cm} \cdot \mathrm{m}^{-1}, 0.25 \mathrm{~cm} \cdot \mathrm{m}^{-1}$ more than Bib Tengujo, while the elongation of tissues prepared with alcoholic solutions was the same of the supports prepared with the Japanese paper $\left(0.1 \mathrm{~cm} \cdot \mathrm{m}^{-1}\right)$. The shrinkage is slightly higher for the aqueous dispersions $\left(0.4 \mathrm{~cm} \mathrm{~m}^{-1}\right)$, while the shrinkage of the tissues prepared whit alcoholic dispersions was too little to be measured. The values recorded for the elongation during reactivation $\left(0.6 \mathrm{~cm} \cdot \mathrm{m}^{-1}\right.$ for aqueous dispersions and $0.5 \mathrm{~cm} \mathrm{~m}^{-1}$ for the alcoholic ones) and the resulting shrinkage $\left(1.3 \mathrm{~cm} \mathrm{~m} \mathrm{~m}^{-1}\right.$ for aqueous dispersions and $0.6 \mathrm{~cm} \cdot \mathrm{m}^{-1}$ for the alcoholic ones) are slightly higher also. Anyway, the shrinkage of the remoistenable tissues prepared with alcoholic mixtures is significantly smaller than the one recorded for tissues prepared with aqueous systems.

TNT 30/B, as expected by its constitution, had an anisotropic behaviour. After the application of the adhesive, it had a significant elongation in the transversal fibre direction, in the case of both water $\left(1.4 \mathrm{~cm} \cdot \mathrm{m}^{-1}\right)$, and alcoholic $\left(1.0 \mathrm{~cm} \mathrm{~m}^{-1}\right)$ dispersions. By contrast, in the longitudinal direction it contracted instead of elongated. Once dried, the dimensional change was small (aprox. $0.1 \mathrm{~cm} \mathrm{~m}^{-1}$ ). When remoistenable tissues were reactivated, the longitudinal elongation was very small $\left(0.16 \mathrm{~cm} \mathrm{~m}^{-1}\right.$ for water dispersions, 0.1 $\mathrm{cm} \mathrm{m}^{-1}$ for alcoholic dispersions), while the transversal elongation was higher for tissues prepared with water dispersions $\left(0.4 \mathrm{~cm} \mathrm{~m}^{-1}\right)$ and remarkable for supports prepared with alcoholic dispersions $\left(1.14 \mathrm{~cm} \mathrm{~m} \mathrm{~m}^{-1}\right)$. During the drying phase after reactivation, the longitudinal contraction was the same for aqueous and alcoholic dispersions $\left(0.4 \mathrm{~cm} \mathrm{~m} \mathrm{~m}^{-1}\right)$; the transversal contraction, instead, is greater for water dispersions $\left(1.0 \mathrm{~cm} \cdot \mathrm{m}^{-1}\right.$ compared with 0.7 $\mathrm{cm} \cdot \mathrm{m}^{-1}$ ).

In the case of remoistenable tissues prepared with Holytex, there were not changes greater than $0.07 \mathrm{~cm} \cdot \mathrm{m}^{-1}$. Dimensional variations seemed to be despicable. 

solutions, "a" indicate alcoholic solutions.

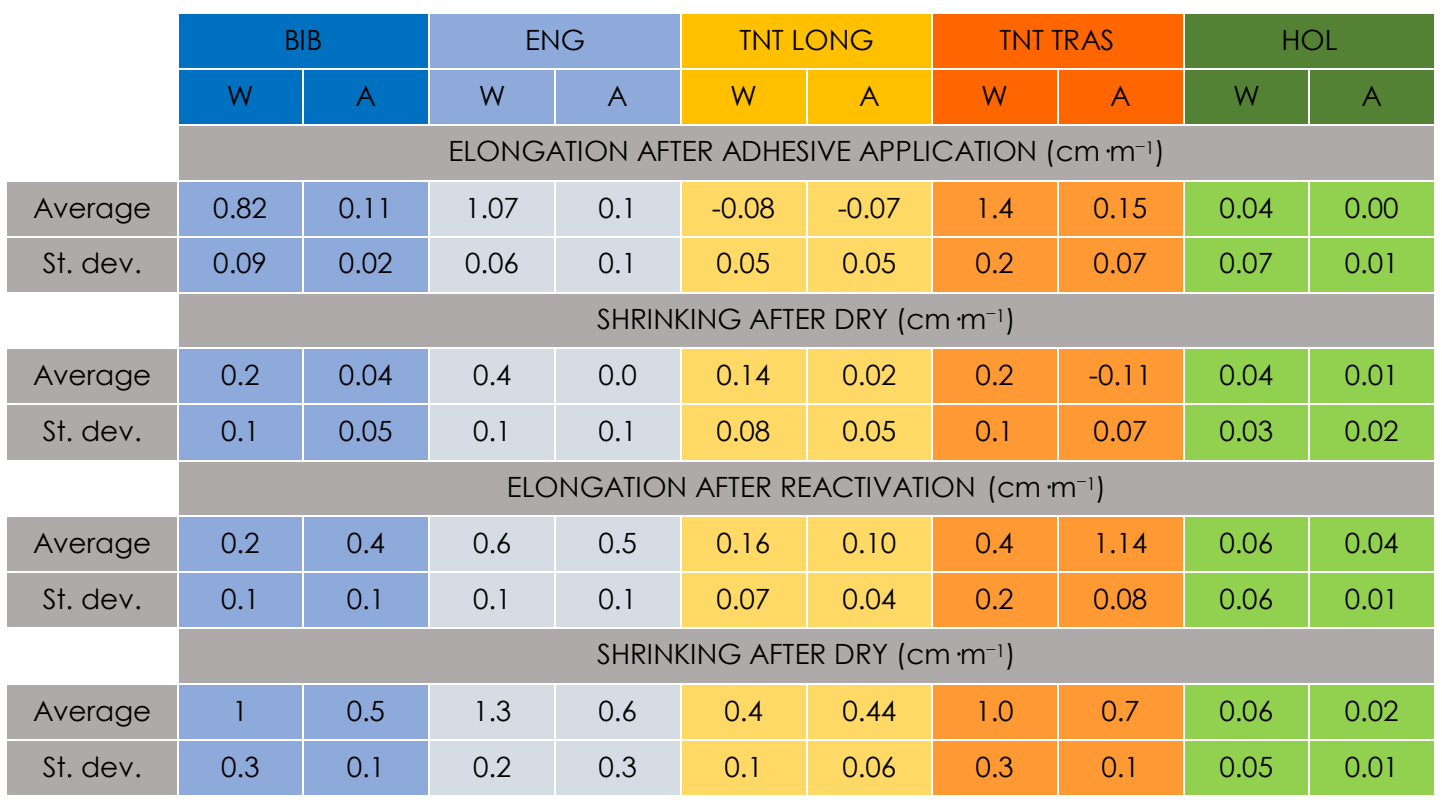

\subsection{CONCLUSIONS}

These analyses permitted the definition of the moisture content, the hardness, the viscosity, the $\mathrm{pH}$, the evaporation rate and the dimensional changes of tested materials (Table 4.4.1), which are essential characteristics that enable the discrimination of adhesives and supports used for facing.

The values of mass loss on drying of all the adhesive dispersions are tolerable. Looking at the specimens submitted to the cycle at $105^{\circ} \mathrm{C}$, the dispersions of KlucelPlextol and Tylose-Plextol were the ones with the lowest content of water, as the films prepared with the only Klucel. Films prepared with alcoholic solutions of Aquazol had intermediate values, while specimens of only Tylose and of Klucel-Aquazol showed the highest values, which anyway did not exceed the cut-off values of moisture content. It was demonstrated that the recorded values were related to the loss of water and not to loss of other volatile components, since all specimens recovered their initial weight after $24 \mathrm{~h}$. The results referred to the heating cycle at $65^{\circ} \mathrm{C}$ (the highest temperature that should be used during conservation treatments) demonstrated that the percentage of water released during a conservation treatment would be small, considering the very small quantity of adhesive employed for the realization of remoistenable tissues. 
All the dispersions have similar hardness, corresponding to medium-hard and hard rubber materials reported in the tables of shore hardness, which is suitable for its use as facing adhesive. Tylose alone and dispersions of Tylose-Plextol were the hardest ones, followed by Aquazol alone, and by Klucel alone and Klucel-Plextol dispersions. Dispersions of Aquazol and Klucel are the softness ones.

About the viscosity, it is important to point out that this parameter can be an indication of the behaviour of the adhesive during the reactivation and the removal of the remoistenable tissue. Previous microscopic analyses demonstrated that all the dispersion permitted to prepare remoistenable tissues with a uniform layer of adhesive. Nevertheless, the most viscous detected values of Tylose and the dispersions of $4 \%$ Tylose and Plextol, should be considered as limit value for their use for remoistenable tissues. Medium-high values recorded for alcoholic dispersions of Klucel and Aquazol should be already considered good for the preparation of remoistenable tissues. The same goes for the less viscous aqueous dispersions of Klucel and Aquazol, of $4 \%$ Klucel and Plextol, and $3 \%$ Tylose and Plextol. Viscosity of dispersions of $3 \%$ Klucel and Plextol, and of only Klucel, could be probably be considered still good, while the viscosity of Aquazol solutions has to be considered possibly too low for the realization of remoistenable tissues.

It is worth emphasising the potential danger of the dispersions prepared with Plextol (except the ones prepared with Klucel and $5 \%$ of Plextol), when applied with a brush to realize a facing, because their $\mathrm{pH}$ values at the fluid state are quite similar to the cut-off value of $\mathrm{pH}$ recommended for the conservation of coatings and oil paint layers of paintings. Anyway, this values changes when the adhesive is applied on the support.

In conclusion, according to the results, almost all the adhesive dispersions seemed safe for their use in the preparation of remoistenable tissues. Furthermore, no evident differences were found between the dispersions prepared with different percentages of the same polymers. For this reason, it was decided to select one adhesive for each class of adhesive dispersion, also according to their class of viscosity. It would have been possible to discard Aquazol solutions because of their low viscosity. Nevertheless, the inclusion of Aquazol in the next steps of the investigation would have permitted a partial comparison with previous investigations, since results on its use as RTS adhesive are reported in literature. Ten dispersions were therefore selected for the next stage of the research. They were: T(4), T(3)P7, T(4)P7, K(4), K(3)P7, K(4)P7, A(5)E, K(3)A(3), K(4)A(3) and K(3)A(4)E.

The most conclusive results of this part of the research were anyway in reference to the influence of the supports (often neglected) in the $\mathrm{pH}$ of the remoistenable tissues, in the evaporation speed of the water used for the reactivation, and in the dimensional changes. In fact, Japanese paper Bib Tengujo revealed to have a 
sensible contraction, especially when combined with aqueous mixtures. English tissue showed slightly bigger dimensional changes in general, contrary to what believed on the basis of the characteristics of the material. For both the supports, the contraction of the RTS prepared with alcoholic solutions is quite lower. This result had not to be considered necessarily negative, since it had to be related with the further results of the tensile test. Both the papers have a neutral $\mathrm{pH}$, perfectly controllable with buffer solutions, good absorption and intermediate values of evaporation speed. TNT tissues revealed to have a strong anisotropic contraction. This value had not to be considered necessarily negative, but it had to be related to the tensile strength in the longitudinal and transversal directions to understand the potential risks related to the use of this support. Even if the support is a bit acidic, $\mathrm{pH}$ values of the corresponding remoistenable tissues are quite neutral. The absorbance of the tissue is higher, while the evaporation rate is consequebtly lower than that of the cellulosic tissues. A further evaluation of the behaviour of Holytex supports was needed. In fact, the $\mathrm{pH}$ of this support associated with selected adhesives was strongly basic, even if it was controllable by the use of a buffer solution. This support showed very low dimensional changes and elevated values of evaporation speed. These two factors could be either positive or negative. In fact, a very low contraction can be good because it reduces the stress exerted on the paint layer. Nevertheless, a very low dimensional change can be a clue of a poor adaptability of the support to the substrate, which would limit the adhesion strength of the facing. The experienced high evaporation speed was good in the measure in which it facilitated the evaporation of the solvent. Nonetheless, Holytex showed a very low absorption power, which could mean that it has a very low affinity with the adhesives and the solvent used for the realization of the remoistenable temporary supports. If that was true, it might led to a poor retention of the adhesive in the support, facilitating its penetration.

Results on the different supports were not sufficient to make a selection. For this reason it was decided to pass all them to the next step of the investigation. 


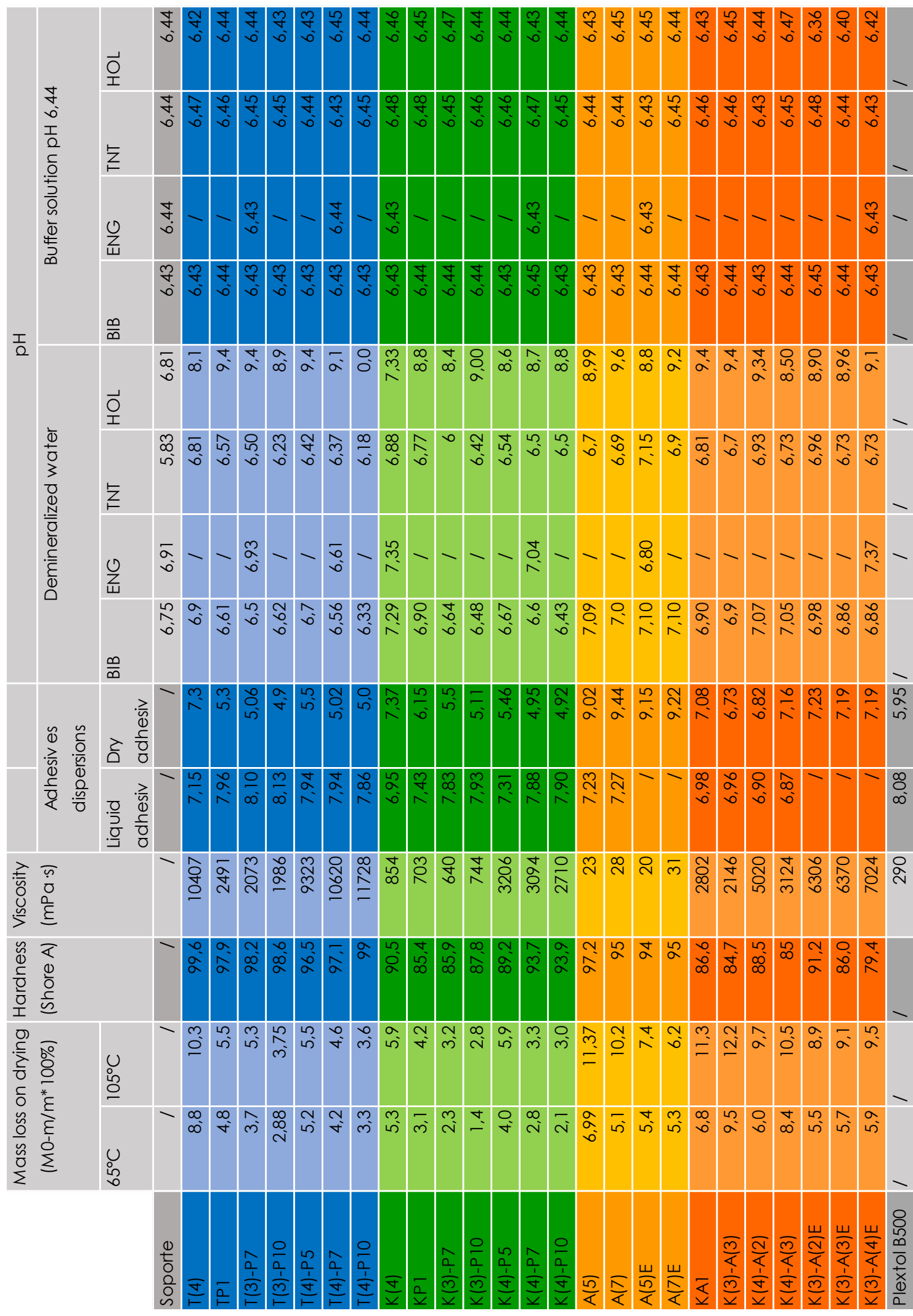




\subsection{SECOND SET OF ANALYSES: MECHANICAL PROPERTIES}

\subsubsection{Analytical method}

It was important to determine the mechanical characteristics of selected materials, in order to understand their suitability for the preparation of remoistenable tissues. In fact, the adhesives had to be strong enough to guarantee good and durable adhesion, but they had to have also a low medium Elastic Modulus (EM) to avoid any risk of the polymer exerting stresses on the paint, particularly when the support is subject to displacement, for example during structural interventions.

Furthermore, these characteristics were important also with a view to the inevitable permanence of a part of the residues after the removal of RTS. For the same reasons, it was important to understand the behaviour of temporary supports and their combinations with the adhesives to form the RTS.

Selected adhesives, temporary supports and remoistenable tissues were therefore subjected to tensile test, to compare their mechanical characteristics. Tensile testing, in which a specimen is clamped between grips which are moved apart at a constant rate, is the most common deformation mode for polymer testing (Swallowe 1999). The resulting stress-strain diagram shows the different behaviour of the tested materials and provides the characteristic values for different properties, such as tensile ultimate strength, yield strength, proportional limit, elongation at fracture and EM.

Adhesives and supports were first tested and a further selection was made before preparing the RTS.

At least three specimens $(10 \times 50 \mathrm{~mm})$ for every class of material (adhesive film, temporary support and remoistenable tissue) were tested. In the case of TNT, two sets of specimens for each fibre direction were prepared. The thickness of every specimen was measured with the help of an optical microscope. The samples were conditioned at $23^{\circ} \mathrm{C}$ and $50 \pm 5 \% \mathrm{RH}$ for $48 \mathrm{~h}$ prior to test them.

Tensile tests were carried out at the the Electron Microscopy Service of the Universitat Politècnica de València (Spain), using a microcomputer controlled electronic testing machine (Deben-Gatan Microtest), equipped with a $2 \mathrm{kN}$ tensile stage. The initial grip separation was set at $10 \mathrm{~mm}$, and the crosshead speed was set at $0.4 \mathrm{~mm} \cdot \mathrm{min}^{-1}$. The mechanical parameters of the specimens were measured in the static mode. 
EM, proportional limit and yield strength (or offset yield strength) of each specimen were measured. EM is the ratio between the incremental increase in applied stress and the incremental deformation, and it is a measure of the stiffness of a material. It is expressed in force per unit area, usually megapascals. As stated in the annex to ASTM D638 standard test method, it has to been specified that:

\begin{abstract}
"The stress-strain relations of many plastics do not conform to Hooke's law throughout the elastic range but deviate therefrom even at stresses well below the elastic limit [...]. Since the existence of a true proportional limit in plastics is debatable, the propriety of applying the term "modulus of elasticity" to describe the stiffness or rigidity of a plastic has been seriously questioned. The exact stressstrain characteristics of plastic materials are very dependent on such factors as rate of stressing, temperature, previous specimen history, etc." (ASTM D638).
\end{abstract}

However, when the test conditions are carefully indicated, such a value is useful to define the mechanical behaviour of a material, because it permits to predict the stress it would exert on the surface once applied on the paint layer.

The proportional limit is the greatest stress that a material is capable of sustaining without any deviation from the proportionality of stress to strain. It is expressed in force per unit area.

On the contrary, yield strength is the measure of the stress at which a material begins to deform plastically and the ratio between the incremental deformation and stress is no longer linear. On a stress-strain graphic (Fig. 4.5.1), the first point at which the increase in strain occurs without an increase in stress is called yield point (YP). Only materials whose stress-strain curves exhibit a point of zero slope maybe considered having an YP. Other materials exhibit a discontinuity in the stress-strain curve after the proportional limit.

This 'break' cannot be properly

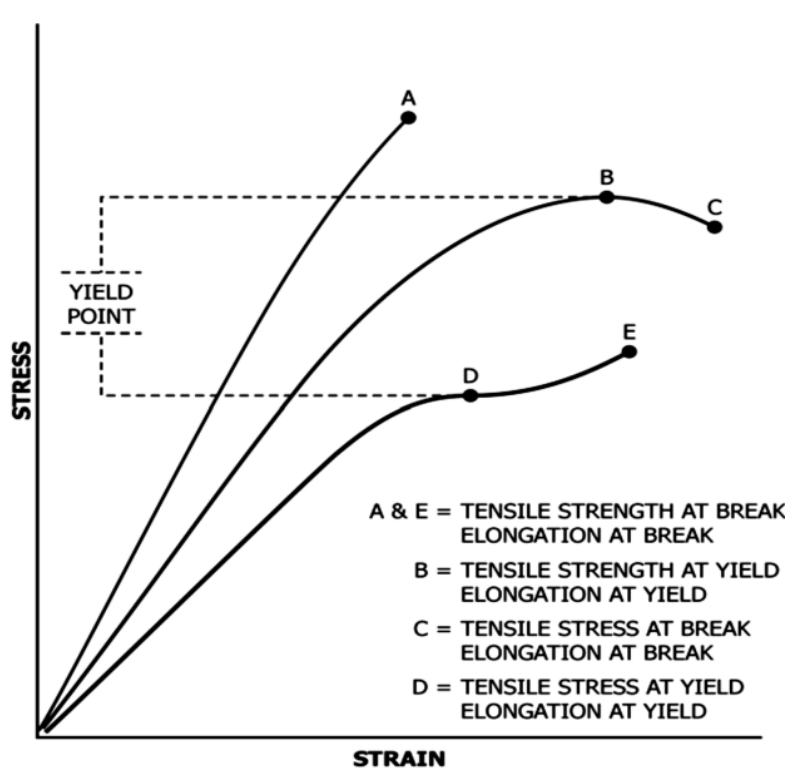

Figure 4.5.1. Graphic of tensile designation (ASTM D638). considered an YP by definition. In these cases, where the stress-strain curve in the yield range is a gradual curvature, it is common to make an approximation, calculating an offset yield 
strength, which is exactly the stress at which the strain exceeds by a specific amount an extension of the initial proportion of the stressstrain curve. The offset yield point (OYP) can be derived from a stress-strain curve, laying down a specified offset $O M$ on the strain axis. To draw a line $O A$ tangent to the initial portion of the stress-strain curve permits to trace the line MN parallel to $O A$ and determine its intersection $r$ with the stress-strain curve, which is the offset yield strength point (Fig. 4.5.2).

It is expressed in force per unit

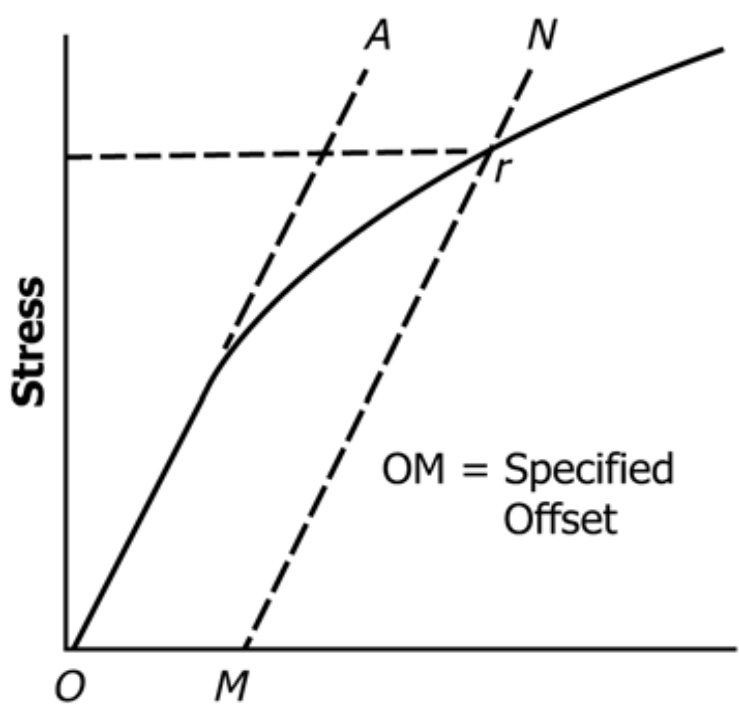

Strain

Figure 4.5.2. Graphic of offset yield strength (ASTM D638). area, usually megapascals. It is important to know also this property of the tested polymers and remoistenable tissues, in order to understand which is their capability to stand deformation, that could be for example caused by mechanical stress exerted during structural interventions.

In order to obtain correct values, during the elaboration of the results a compensation of the toe region 104 was done, for to give zero point on the strain axis. The calculation was done following the indication reported in the ASTM D638 standard test. For all the specimens the $1 \%$ offset yield strength was calculated.

\subsubsection{Adhesive dispersions}

\subsubsection{Results and discussion}

The stress-strain diagrams resulting from the tensile test showed the different behaviour of the individual adhesive dispersions and permitted to determine their characteristic EM and YP.

The results related to the adhesives prepared with the two cellulose ethers were quite different.

104 The toe region corresponds to the first part of a stress-strain graphic, caused by the take-up of slack and alignment or seating of the specimen. 


\begin{tabular}{|c|c|c|c|c|c|c|}
\hline & \multicolumn{2}{|c|}{ Elastic Modulus (MPa) } & \multicolumn{2}{|c|}{$\begin{array}{l}\text { Proportional Limit } \\
\text { (MPa) }\end{array}$} & \multicolumn{2}{|c|}{$\begin{array}{l}\text { Offset Yield Strength } \\
\qquad(\mathrm{MPa})\end{array}$} \\
\hline & Av. & St dev. & Av. & St dev. & $A \vee$ & St dev. \\
\hline $\mathrm{T}(4)$ & 21 & 3 & 15 & 5 & 22 & 8 \\
\hline $\mathrm{T}(3) \mathrm{P} 7$ & 5.2 & 0.7 & 6.2 & 0.4 & 7.8 & 0.6 \\
\hline $\mathrm{T}(4) \mathrm{P} 7$ & 7.3 & 0.7 & 7.1 & 0.2 & 10.5 & 0.9 \\
\hline$K(4)$ & 3.7 & 0.3 & 2.8 & 0.2 & 3.51 & 0.03 \\
\hline $\mathrm{K}(3) \mathrm{P} 7$ & 1.0 & 0.4 & 1.2 & 0.2 & 1.5 & 0.2 \\
\hline $\mathrm{K}(4) \mathrm{P} 7$ & 1.4 & 0.3 & 1.3 & 0.1 & 1.8 & 0.1 \\
\hline$A(5) E$ & 10.4 & 0.3 & 6.6 & 0.1 & 9.0 & 0.2 \\
\hline $\mathrm{K}(3) \mathrm{A}(3)$ & 8 & 1 & 5.9 & 0.9 & 9 & 2 \\
\hline $\mathrm{K}(4) \mathrm{A}(3)$ & 8 & 2 & 4.7 & 0.5 & 7 & 2 \\
\hline $\mathrm{K}(3) \mathrm{A}(4) \mathrm{E}$ & 6.8 & 0.2 & 6.1 & 0.3 & 8.9 & 0.4 \\
\hline
\end{tabular}

Tests on T(4) gave the highest values for the EM (21 MPa), the proportional limit (15 MPa) and the offset yield strength (22 MPa). This demonstrated the high strength, but also the high stiffness of the polymer that could damage the paint surface. Furthermore, the results were disparate, with a standard deviation of 3 for the EM, of 5 for the proportional limit and of 8 for the offset yield strength. It revealed a non-uniformity of the tested specimens and it was a clue for a possible heterogeneous behaviour of the corresponding remoistenable tissues.

Samples of $\mathrm{K}(4)$ exhibited instead low values, revealing to be quite soft but tough. The EM was of 3.7 MPa, the proportional limit of 2.8 MPa and the yield strength of 3.51 .

The addition of Plextol to the cellulose ethers had a plasticising effect on both the polymers. The changes in the values were evident especially in the case of the dispersions prepared with Tylose that showed a less strong but tough nature. The EM decreased to 7.3 MPa in the case of T(4)P7 and to 5.2 MPa in the case of T(3)P7. The proportional limit also decreased: the one of T(3)P7 was of 6.2 MPa and that of T(4)P7 was of 7.1 MPa. The offset yield strength decreased till .8 MPa for T(3)P7 and till 10.5 MPa for T(4)P7. 


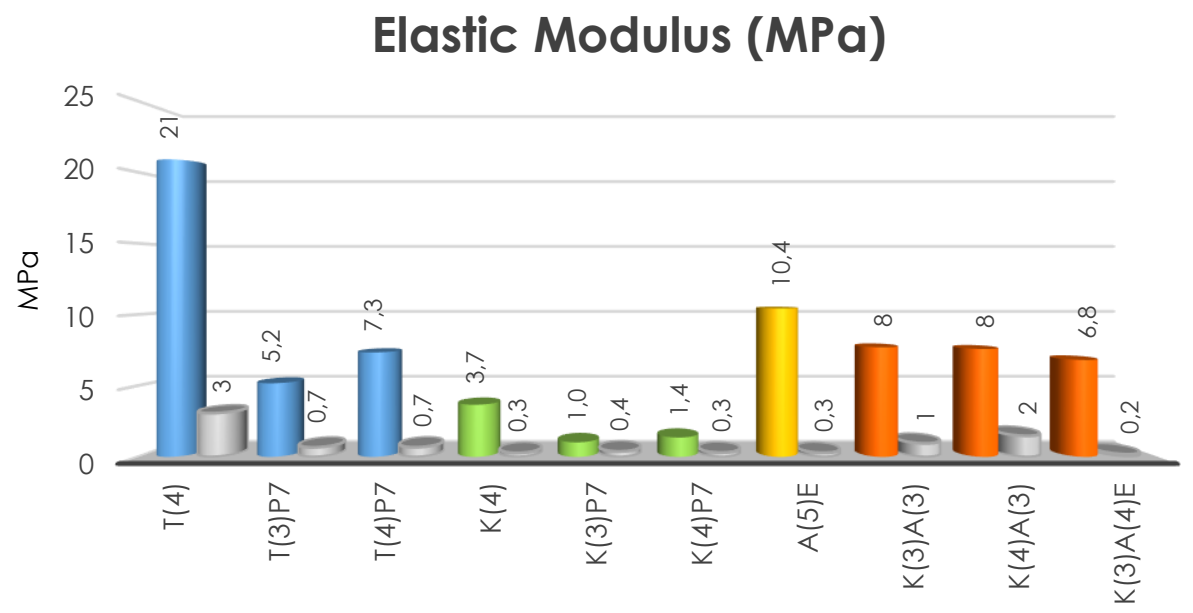

a)

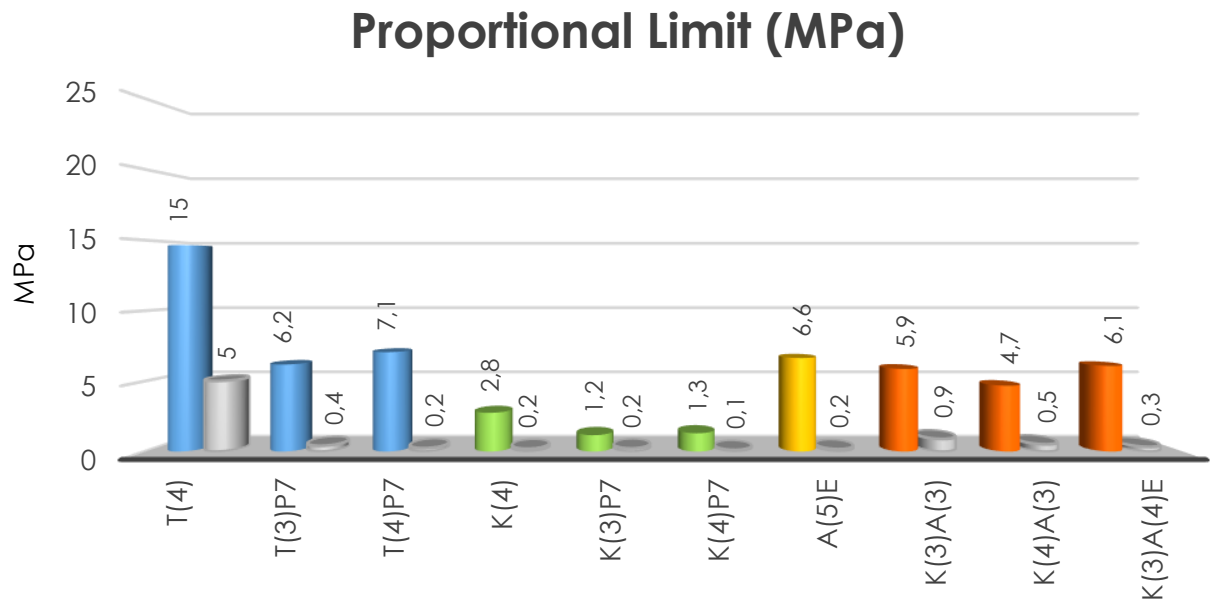

b)

\section{Offset Yield Strength (MPa)}

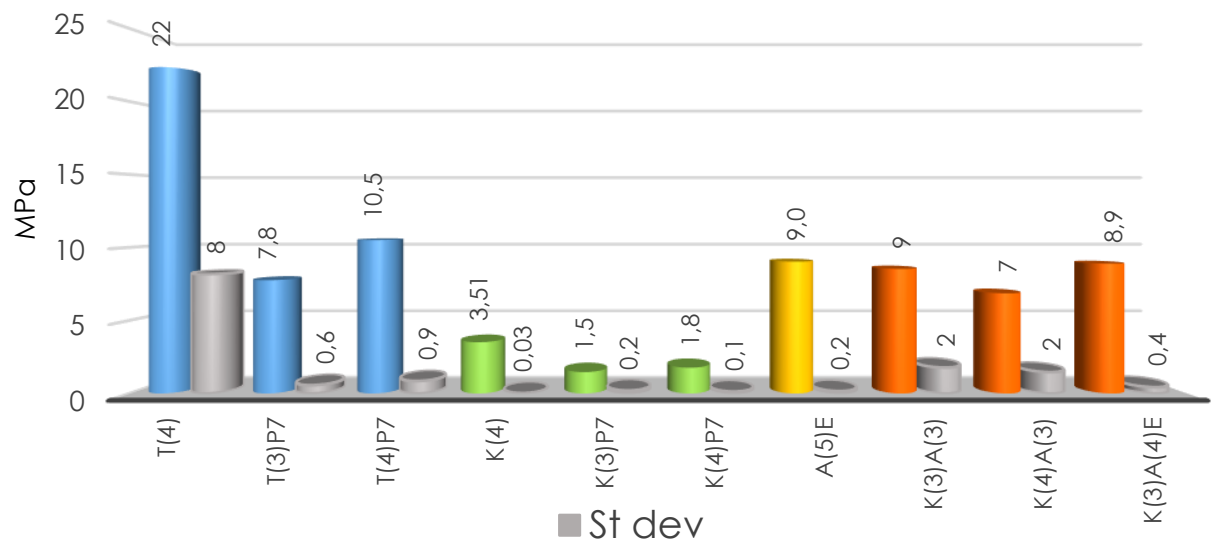

Figure 4.5.3. Results of adhesives tensile tests: a) EM; b) proportional limit; c) offset yield strength. 
Adhesive dispersions of Klucel and Plextol showed to be soft and ductile. In fact, they were affected by a sensitive decrease in the values of the EM. The EM of K(3)P7 was of 1.0 MPa and that of K(4)P7 was of 1.4 MPa, while the proportional limit was respectively of 1.2 MPa and 1.3 MPa. The offset yield strength of K(3)P7 was of 1.5 MPa and that of K(4)P7 was of $1.8 \mathrm{MPa}$.

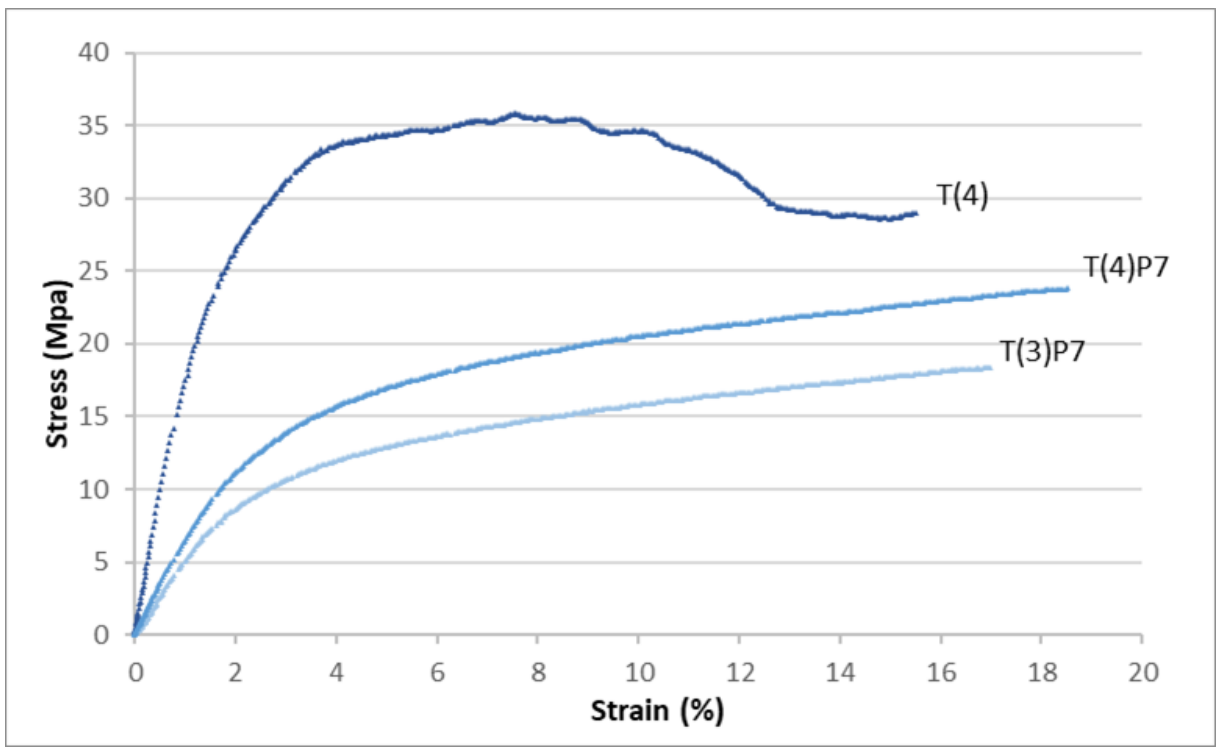

Figure 4.5.4. Stress-strain graphic of dispersions prepared with Tylose and Plextol.

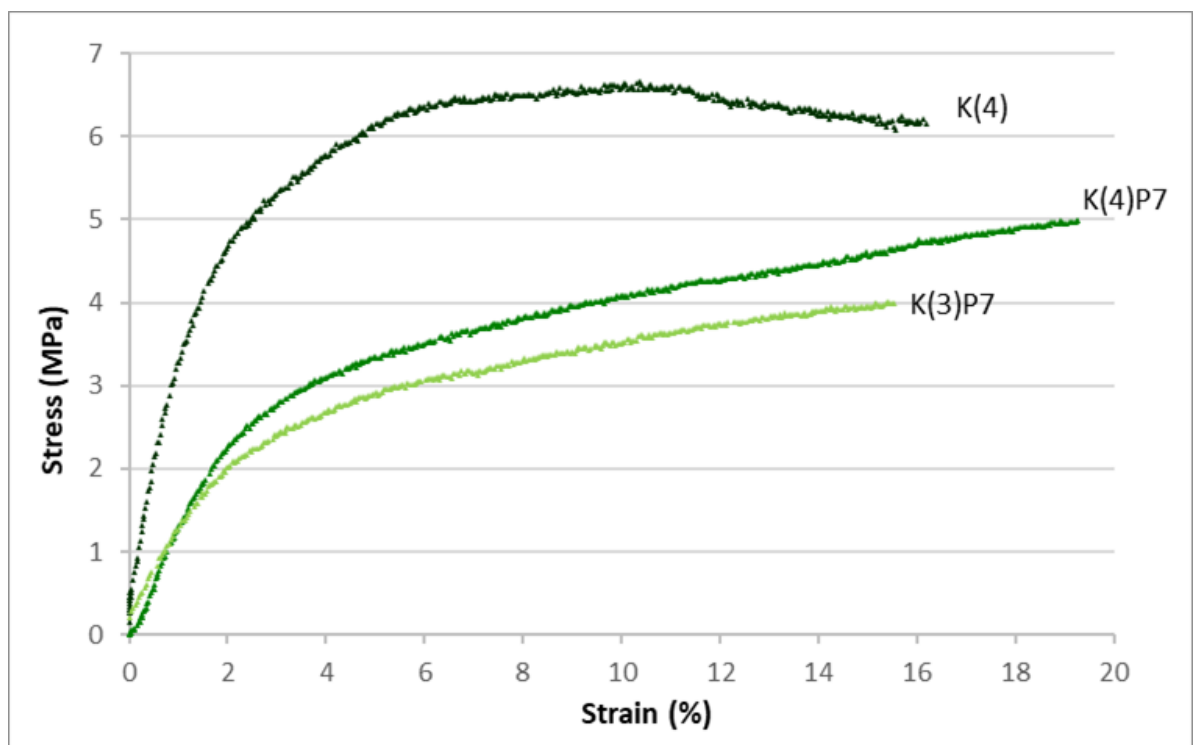

Figure 4.5.5. Stress-strain graphic of dispersions prepared with Klucel and Plextol. 
Adhesive dispersions prepared with the only Aquazol and that prepared with the addition of Klucel showed similar results, with intermediate values and good elastic properties. In fact, tests on A(5)E exhibited intermediate results between that of the two cellulose ethers alone. Its EM was of 10.4 MPa, while the proportional limit had a value of 6.6 MPa. The OYP was of 9.0 MPa.

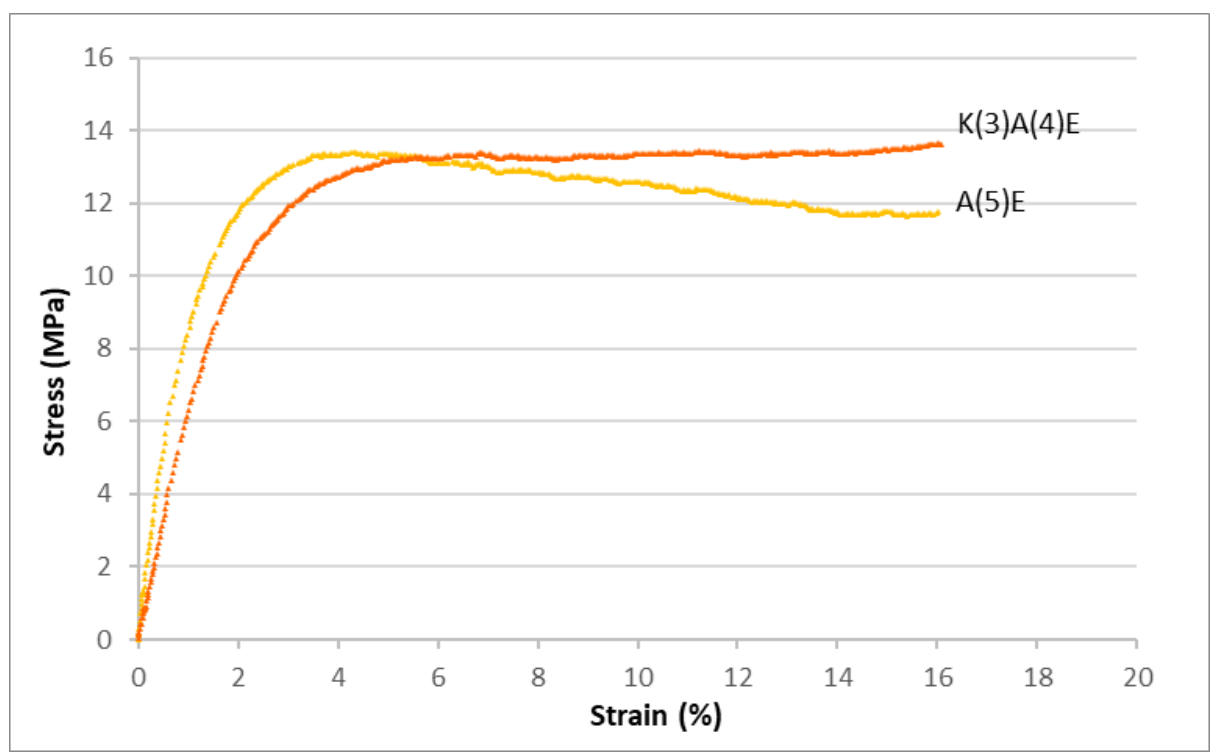

Figure 4.5.6. Stress-strain graphic of alcoholic dispersions prepared with Aquazol and Klucel.

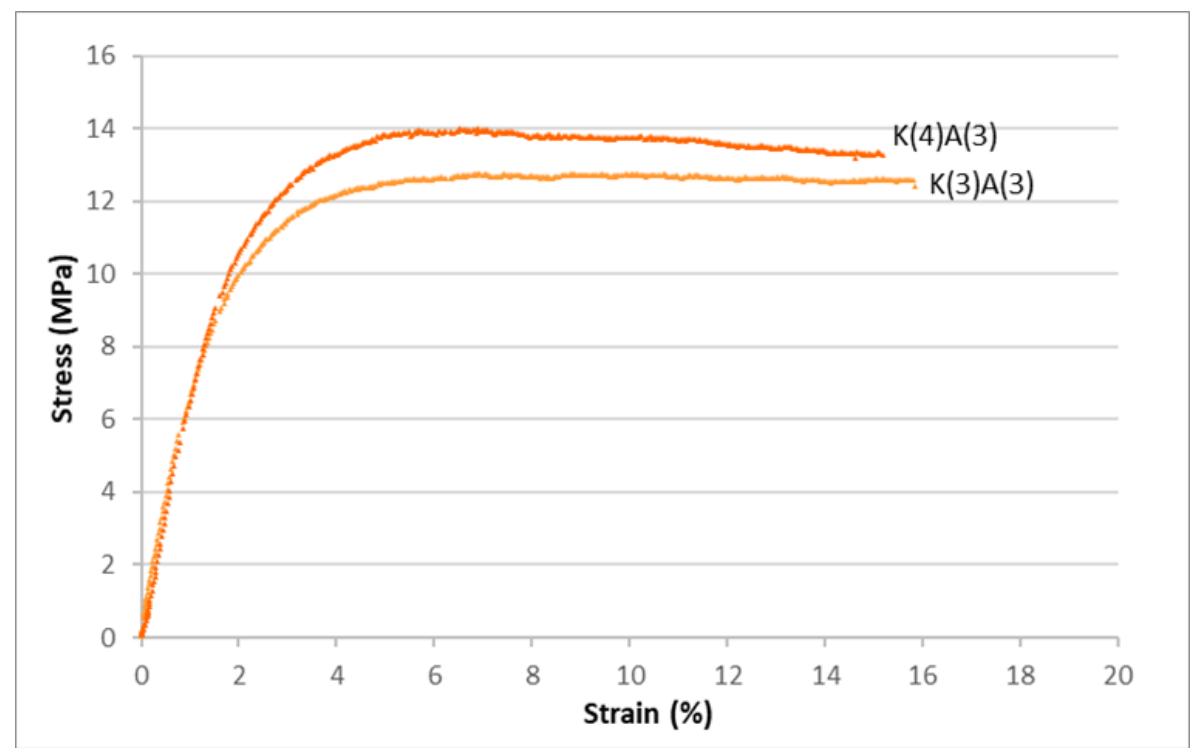

Figure 4.5.7. Stress-strain graphic of aqueous dispersions prepared with Aquazol and Klucel. 
Aqueous dispersions of Aquazol and Klucel showed a lower EM: 8 MPa for both $K(3) A(3)$ and $K(4) A(3)$. The proportional limit was also lower than the one of $A(5) E$. In fact, it was of 5.9 MPa for $\mathrm{K}(3) \mathrm{A}(3)$ and of $4.7 \mathrm{MPa}$ for $\mathrm{K}(4) \mathrm{A}(3)$. The yield strength of $\mathrm{K}(3) \mathrm{A}(3)$ was of $9 \mathrm{MPa}$, while that of $\mathrm{K}(4) \mathrm{A}(3)$ was of $7 \mathrm{MPa}$. Even if both the dispersion revealed to have and intermediate strength and tough, the discrepancy of the results obtained for the EM and the offset yield strength was quite high, in fact the respective standard deviations were of 1 and 2 for $K(3) A(3)$ and of 2 for $\mathrm{K}(4) \mathrm{A}(3)$. As for T(4) this was an indication for the possible unevenness in the behaviour of the resulting remoistenable tissues.

Alcoholic dispersion of $\mathrm{K}(3) \mathrm{A}(4) \mathrm{E}$ showed a lower EM (6.8 MPa)than its corresponding aqueous mixtures, while the proportional limit revealed by the tensile test was higher (6.1 MPa). Also in this case, the graphic showed a YP, the corresponded to a strength of $8.9 \mathrm{MPa}$.

\subsubsection{Conclusions}

Tensile testing on the films prepared with adhesive dispersions gave disparate results and permitted to make a further selection before carrying on with the investigation.

$T(4)$ was discarded because it was too stiff and because the results obtained for the different samples had a high standard deviation, symptom of the heterogeneous distribution of the adhesive and its possible inability to create uniform films on the surface of RTS. On the contrary, adhesive dispersions of Tylose and Plextol were selected because they exhibited a weaker but tough behaviour.

Adhesive dispersions prepared with Klucel, especially the ones with Plextol, revealed to be quite soft and ductile. It was decided to discard K(3)P7 because it was the one with the lowest values among all the adhesives. K(4)P7 was kept even if its values were similar to K(3)P7, because the results relatives to these dispersions were quite good and promising. Furthermore, according to previous results it had also a higher viscosity.

All the specimens prepared with Aquazol showed similar behaviour, with intermediate values and good elastic properties. Nevertheless, aqueous dispersions of Aquazol and Klucel were discarded because the discrepancy of the results obtained was quite high and this was an indication for the possible unevenness in the behaviour of the derived remoistenable tissues. 


\subsubsection{Temporary support and RTS}

\subsubsection{Results and discussion}

Due to the high precision and accuracy of the analytical system employed and the heterogeneity of the analysed specimens, that are composed of a multilayered structure, it was difficult to have univocal results. In fact, even if the specimens were prepared with the greatest possible accuracy, there were many variables that did not permit to have sufficiently repeatable replicates of the different type of specimens. The same temporary supports were very thin and their density was heterogeneous because of their constitution of non-woven materials. Furthermore, even if the quantity of the applied adhesive mixtures was accurately weighted, the uniform distribution of the adhesive film at a microscopic level was not guaranteed. The dispersion of the recorded values was increased by the inevitable defects in the distribution of the adhesives in the supports and for the formation of the adhesive film. Therefore, the analysed materials were complex systems whose mechanical characteristics were difficult to understand starting by the obtained results. Nevertheless, it was possible to recognise some common aspect in the different classes of RTS made with the various supports. In fact, it was possible to make some hypothesis on the different behaviour of the RTS made with the different supports on the basis of the different interaction that these had with the adhesives. A resume of the results is given in Fig. 4.5.8 and Table 4.5.2. 


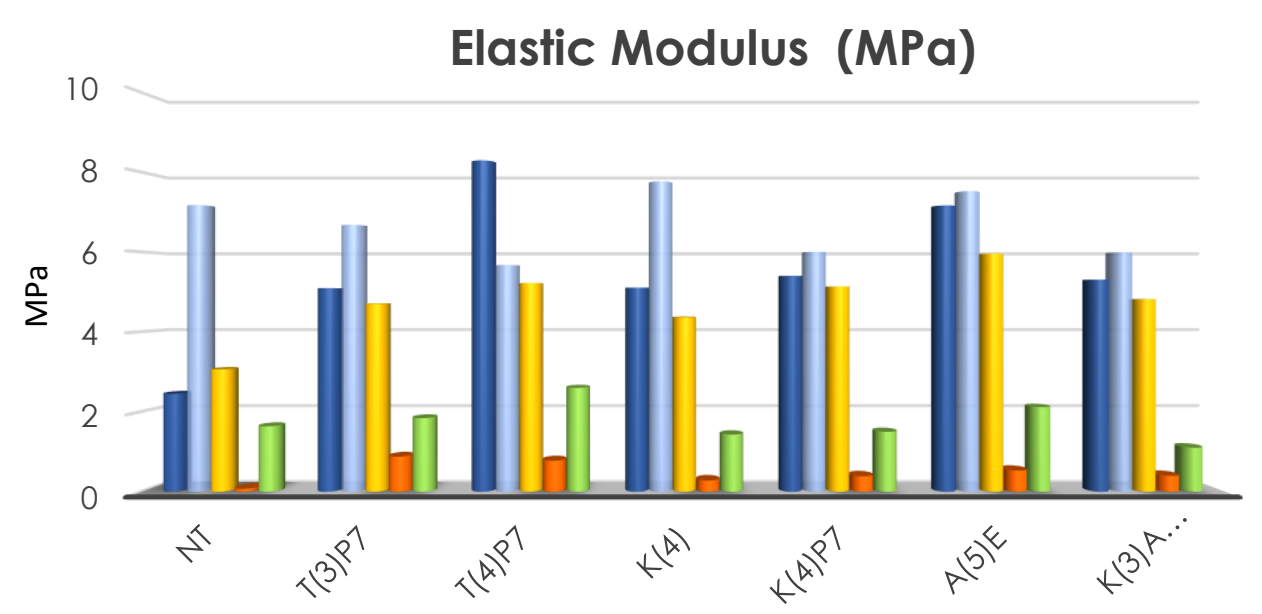

a)

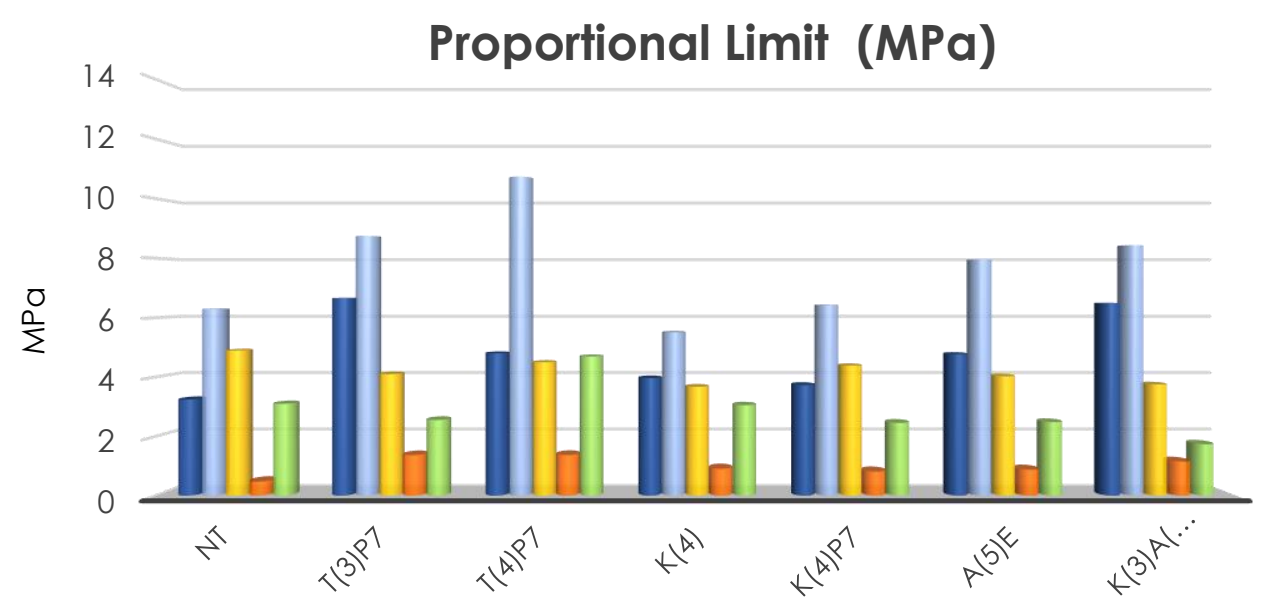

b)

Offset Yield Strength (MPa)

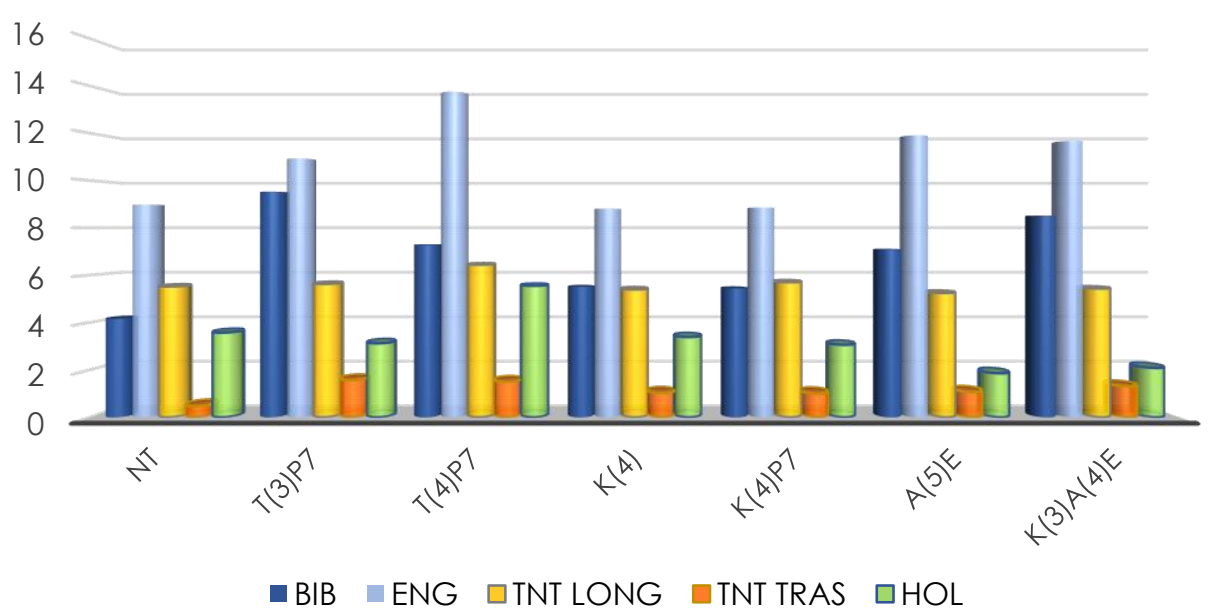

c)

Figure 4.5.8. Results of RTS tensile tests: a) EM; b) proportional limit; c) offset yield strength. 
Table 4.5.2. Results of tensile test on selected RTS.

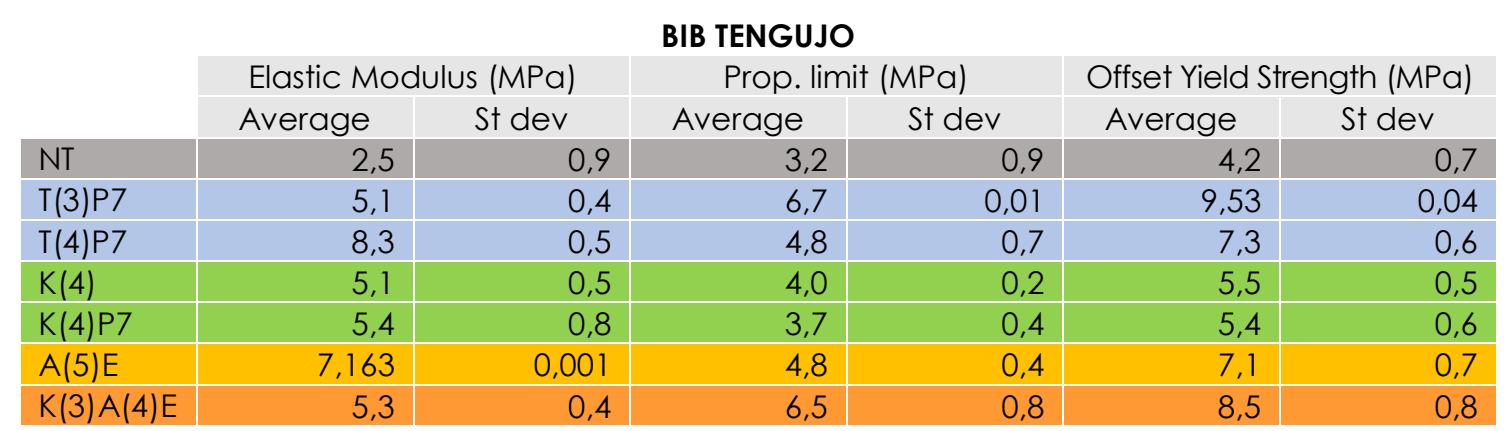

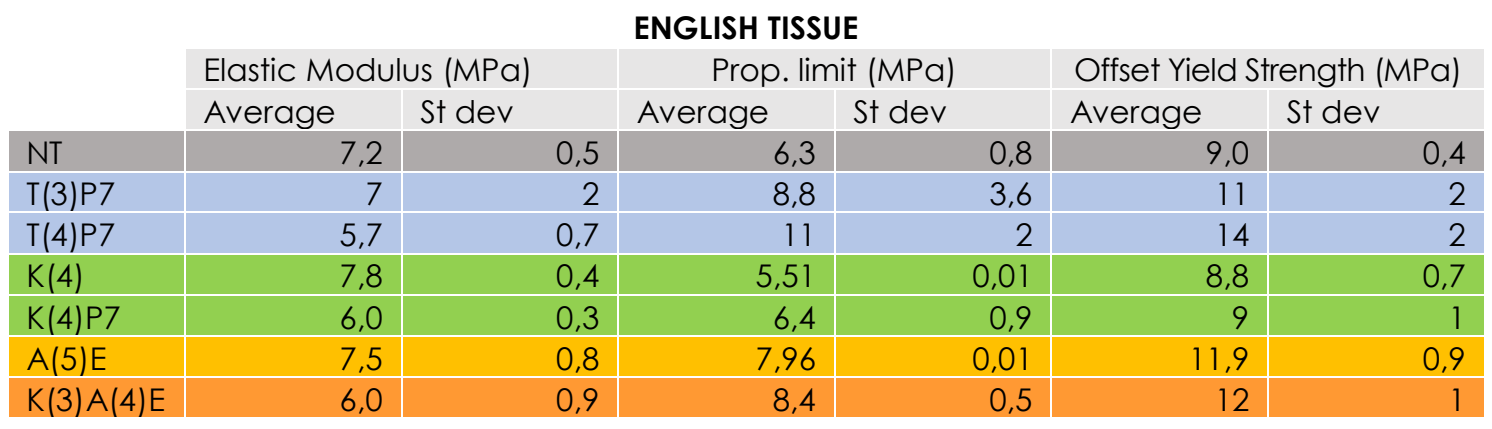

\section{TNT LONG}

\begin{tabular}{|c|c|c|c|c|c|c|}
\hline & \multicolumn{2}{|c|}{ Elastic Modulus (MPa) } & \multicolumn{2}{|c|}{ Prop. limit (MPa) } & \multicolumn{2}{|c|}{ Offset Yield Strength (MPa) } \\
\hline & Average & St dev & Average & St dev & Average & St dev \\
\hline NT & 3,06 & 0,06 & 4,9 & 0,6 & 5,5 & 0,3 \\
\hline T(3)P7 & 4,7 & 0,2 & 4,10 & 0,07 & 5,6 & 0,9 \\
\hline T(4)P7 & 5,2 & 0,4 & 4,5 & 0,3 & 6,45 & 0,09 \\
\hline $\mathrm{K}(4)$ & 4,4 & 0,6 & 3,7 & 0,2 & 5,40 & 0,06 \\
\hline K(4)P7 & 5,1 & 0,4 & 4,39 & 0,06 & 5,7 & 0,2 \\
\hline $\mathrm{A}(5) \mathrm{E}$ & 5,9 & 0,2 & 4,0 & 0,2 & 5,3 & 0,3 \\
\hline $\mathrm{K}(3) \mathrm{A}(4) \mathrm{E}$ & 4,8 & 0,1 & 3,8 & 0,3 & 5,4 & 0,2 \\
\hline
\end{tabular}

\section{TNT TRASV}

Elastic Modulus (MPa)

Prop. limit (MPa)

\begin{tabular}{|l|r|r|r|r|r|r|}
\hline & \multicolumn{2}{|c|}{ Elastic Modulus (MPa) } & \multicolumn{2}{c|}{ Prop. limit (MPa) } & \multicolumn{2}{c|}{ Offset Yield Strength (MPa) } \\
\cline { 2 - 7 } & Average & St dev & Average & St dev & Average & \multicolumn{1}{c|}{ St dev } \\
\hline NT & 0,07 & 0,02 & 0,47 & 0,01 & 0,49 & 0,04 \\
\hline T(3)P7 & 0,88 & 0,03 & 1,4 & 0,2 & 1,6 & 0,3 \\
\hline T(4)P7 & 0,78 & 0,09 & 1,4 & 0,1 & 1,5 & 0,1 \\
\hline K(4) & 0,28 & 0,08 & 0,91 & 0,09 & 1,0 & 0,2 \\
\hline K(4)P7 & 0,39 & 0,05 & 0,81 & 0,08 & 1,02 & 0,07 \\
\hline A(5)E & 0,53 & 0,08 & 0,87 & 0,08 & 1,1 & 0,2 \\
\hline K(3)A(4)E & 0,40 & 0,07 & 1,2 & 0,1 & 1,3 & 0,1 \\
\hline
\end{tabular}

\section{HOLYTEX}

Elastic Modulus (MPa)

Average St dev

Prop. limit (MPa)

\begin{tabular}{|l|r|r|r|r|r|r|} 
& \multicolumn{2}{|c|}{ Elastic Modulus (MPa) } & \multicolumn{2}{c|}{ Prop. limit (MPa) } & \multicolumn{2}{c|}{ Offset Yield Strength (MPa) } \\
\hline Average & \multicolumn{1}{|c|}{ St dev } & \multicolumn{1}{c|}{ Average } & St dev & \multicolumn{1}{c|}{ Average } & \multicolumn{1}{c|}{ St dev } \\
\hline NT & 1,6 & 0,5 & 3 & 1 & 3,58 & 1,03 \\
\hline T(3)P7 & 1,8 & 0,3 & 2,6 & 0,7 & 3,1 & 0,1 \\
\hline T(4)P7 & 2,6 & 0,1 & 4,7 & 0,1 & 5,6 & 0,4 \\
\hline K(4) & 1,4 & 0,4 & 3,05 & 0,02 & 3,40 & 0,01 \\
\hline K(4)P7 & 1,5 & 0,6 & 2,5 & 0,6 & 3,1 & 0,6 \\
\hline A(5)E & 2,12 & 0,07 & 2,5 & 0,5 & 1,9 & 0,3 \\
\hline K(3)A(4)E & 1,1 & 0,2 & 1,73 & 0,05 & 2,10 & 0,01 \\
\hline
\end{tabular}


Bib Tengujo (Fig. 4.5.9) and TNT 30/B (Fig. 4.5.10) tested along the longitudinal direction of the fibres revealed to have a medium to low values for the EM (not-treated Bib Tengujo: 2.5 MPa; not-treated TNT 30/B: $3.06 \mathrm{MPa}$ ), proportional limit (not-treated Bib Tengujo: 3.2 MPa; not-treated TNT 30/B: 4.9 $\mathrm{MPa}$ ) and offset yield strength (not-treated Bib Tengujo: 4.2 MPa; not-treated TNT 30/B: 5.5 MPa). The results observed for the RTS prepared with these two could be ascribed to the combined behaviour of the support/adhesive mixture due to the impregnation of the fibres of the temporary support with the different adhesives. In fact, the EM of these supports grown in relation to the type of adhesive used (the stiffer the adhesive, the higher the EM), because the adhesive insinuates between the fibres of the support and 'cement' them, increasing the stiffness of the system. An increase in the stiffness was observed with the increase of the percentage of the cellulose ether in the mixtures of Plextol and Tylose. In fact, it was recorded an EM of 5.1 MPa for the RTS prepared with T(3)P7 and Bib Tengujo, and of 4.7 MPa for the RTS prepared with TNT30/B, while an EM of 8.3 MPa and 5.2 MPa was observed for RTS prepared with T(4)P7 and respectively with Bib Tengujo and TNT 30/B. On the contrary, the results regarding the proportional limit and the offset yield strength were different for the RTs of Bib Tengujo and TNT 30/B. The values of the proportional limit (T(3)P7: 6.7 MPa; T(4)P7: $4.8 \mathrm{MPa}$ ) and offset yield set (T(3)P7: 9.53 MPa; T(4)P7: 7.3 MPa) recorded for the RTs of Japanese paper were higher than that of the not- treated paper. On the contrary, the proportional limit (T(3)P7: 4.10 MPa; T(4)P7: 4.5 MPa) and offset yield set (T(3)P7: 5.6 MPa; T(4)P7: 6.45 MPa) of the RTs of TNT 30/B were similar to those of the not-treated specimens.

With regard to the mixtures containing Klucel alone and Klucel with Plextol, a plasticising effect of the acrylic polymer was observed. An EM of 5.1 MPa and 5.4 MPa was recorded for RTS prepared with the Japanese paper and with the $K(4)$ and $K(4) P 7$, while the values recollected for the RTS prepared with TNT 30/B were of 4.4 MPa for K(4) and 5.1 MPa for K(4)P7. In this case, the proportional limit and the offset yield strength remained almost unchanged, both for the RTS of Japanese paper (K(4): proportional limit of $4.0 \mathrm{MPa}$, offset yield strength of $5.5 ; \mathrm{K}(4) \mathrm{P} 7$ : proportional limit of $3.7 \mathrm{MPa}$, offset yield strength of 5.4 MPa) and for TNT 30/B (K(4): proportional limit of 3.7 MPa, offset yield strength of $5.4 ; \mathrm{K}(4) \mathrm{P} 7$ : proportional limit of $4.39 \mathrm{MPa}$, offset yield strength of 5.7 MPa).

Also in the case of RTS prepared with Japanese paper and TNT 30/B, the adhesive prepared with Klucel and Aquazol (with and EM of 5.3 MPA for Bib Tengujo RTS and of 4.8 MPa for the TNT 30/B RTS) were more plastic than the ones prepared with the sole Aquazol 500 (with an EM of $7.163 \mathrm{MPa}$ for Bib 
Tengujo RTS and of 5.9 MPa for the TNT 30/B RTS). However, for this mixtures, the proportional limit and the offset yield strength of the RTS of Bib Tengujo increased $(\mathrm{A}(5) \mathrm{E}$ : proportional limit of $4.8 \mathrm{MPa}$, offset yield strength of 7.1 ; $\mathrm{K}(3) \mathrm{A}(4) \mathrm{E}$ : proportional limit of $6.5 \mathrm{MPa}$, offset yield strength of $8.5 \mathrm{MPa}$ ), while the values recorded for RTS of TNT 30/B remained almost unchanged (A) 5 E: proportional limit of 4.0 MPa, offset yield strength of $5.3 ; \mathrm{K}(3) \mathrm{A}(4) \mathrm{E}$ : proportional limit of 3.8 MPa, offset yield strength of 5.4 MPa)

In the case of measurements made for the TNT 30/B along the transversal direction of the fibres, the values collected were too small to permit to draw some conclusion, with values included between $0.28 \mathrm{MPa}$ and $0.88 \mathrm{MPa}$.
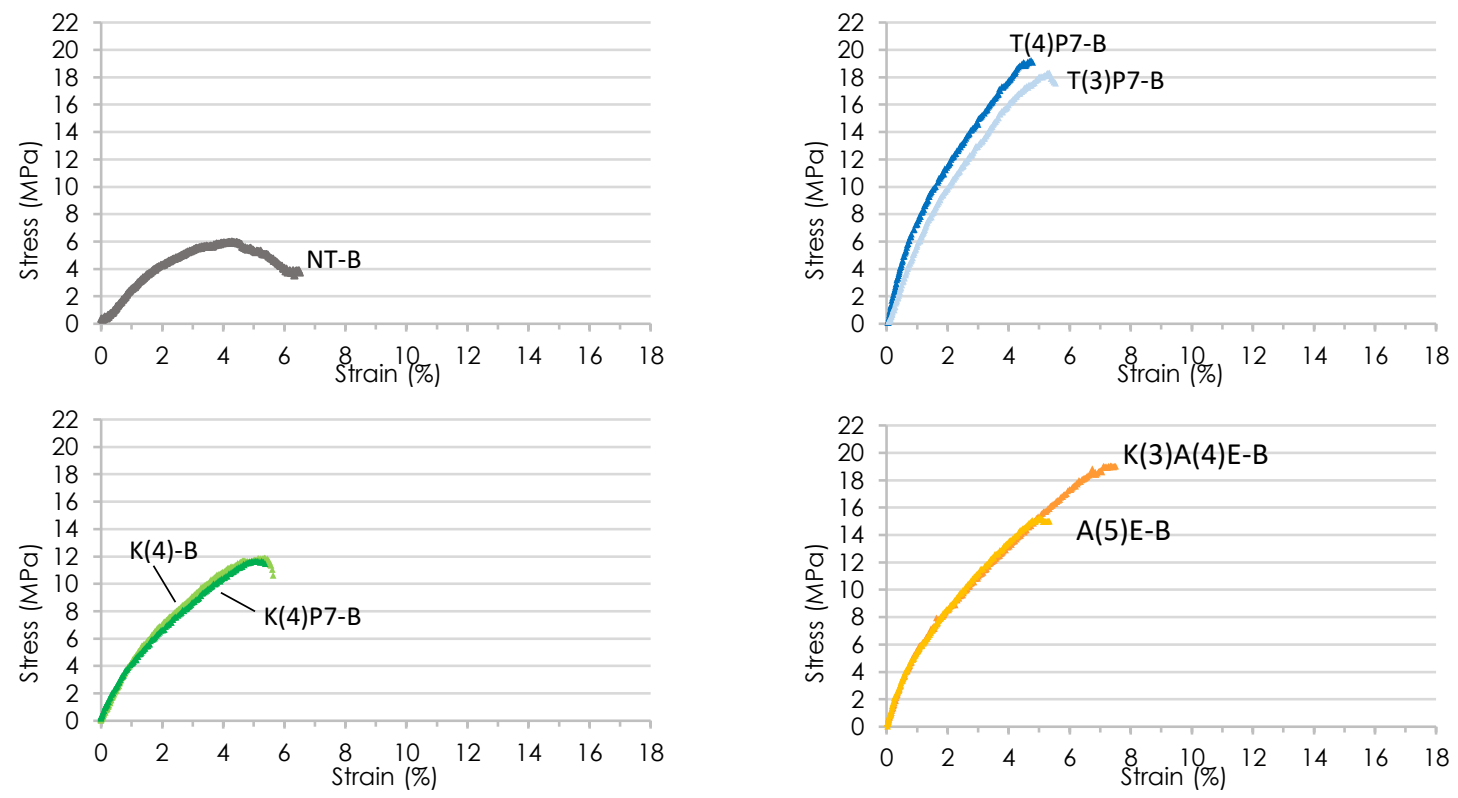

Figure 4.5.9. Stress-strain graphics of RTS prepared with Bib. Tengujo 240. 

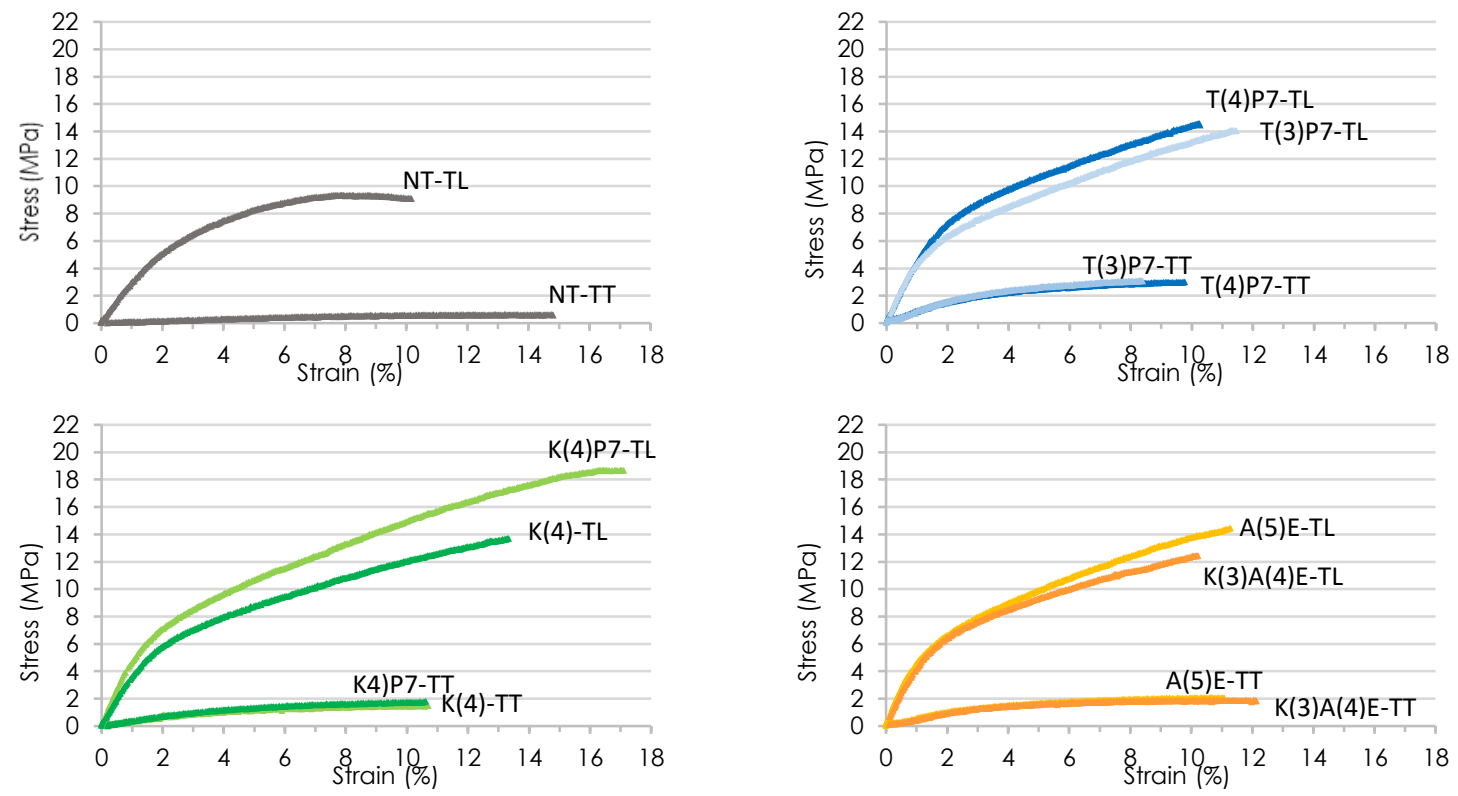

Figure 4.5.10. Stress-strain graphics of RTS prepared with TNT 30/B.

The differences in the EM found among the RTS prepared with the English tissue (Fig. 4.5.1 1) were smaller than those recorded for RTS of Bib Tengujo and TNT 30/B. This was probably due to the mechanical characteristics of the tissue, that was found to be the least elastic of all those tested, with an EM of 7.2 MPa. Anyway, despite of its high EM, the English tissue could not be considered dangerous for the preservation of the painting, since the proportional limit (6.3 MPa) and the OYP (9.0MPa) recorded were not too high. A part of T(3)P7 specimen whose values were affected by a considerable dispersion (ie E $7 \pm 3 \mathrm{MPa}$ ), in this series the behaviour of the RTS systems seemed mostly determined by the mechanical properties of the temporary support, although the adhesive mixtures impregnated the tissue. The use of T(4)P7 for the preparation of RTS slightly increased the elasticity of the support, but increased also its proportional limit and offset Yield strength. For RTS of T(4)P7 the EM recorded was of 5.7 MPa, while the proportional limit and offset yield strength were respectively of 11 $\mathrm{MPa}$ and $14 \mathrm{MPa}$.

With regard to RTS prepared with $\mathrm{K}(4)$ and $\mathrm{K}(4) \mathrm{P} 7$, these mixtures respectively slightly increased and decreased the EM of the support (K(4): 7.8MPa; K(4)P7: 6.0 $\mathrm{MPa}$ ), while left unchanged the proportional limit (K(4): 5.51 MPa; K(4)P7: 6.4 MPa) and the offset yield strength (K(4): 8.8 MPa: K(4)P7: $9 \mathrm{MPa}$ ) recorded for the support.

The use of $A(5) E$ and $K(3) A(4) E$ led respectively to a slight increase and decrease of the $\mathrm{EM}(\mathrm{A}(5) \mathrm{E}: 7.5 \mathrm{MPa} ; \mathrm{K}(3) \mathrm{A}(4) \mathrm{E}$ : 6.0), but also to an increase of the proportional limit (A(5)E: 7.96 MPa; K(3)A(4)E: 8.4 MPa) and the offset yield strength (A(5)E: 11.9 MPa; K(3)A(4)E: $12 \mathrm{MPa})$. 

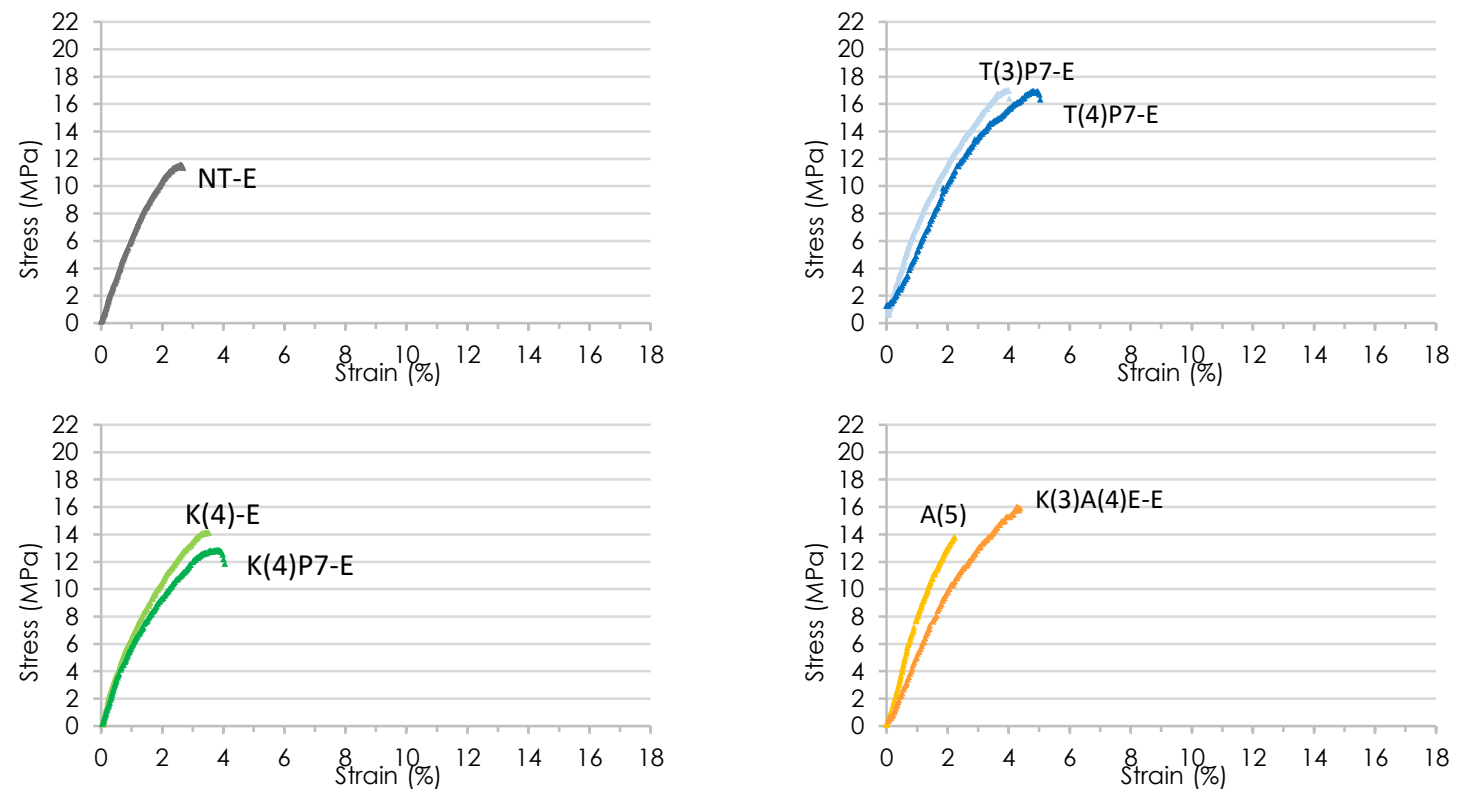

Figure 4.5.1 1. Stress-strain graphics of RTS prepared with English tissue.

In the case of Holytex (Fig. 4.5.12), it was observed that the mechanical behaviour of the system support/adhesive mixture was determined by the mechanical properties of the support. This led to assume that the support had not been impregnated by the adhesive mixtures, which during application settled rather at the interface with the Mylar foil. In this way, the adhesive did not soak and 'cement' the support fibres and the film formed during the preparation of the RTS was too thin to change the behaviour of the support, which remains fundamentally unchanged.

In fact, even if the support proved to be the most elastic (EM: 1.6 MPa; proportional limit: $3 \mathrm{MPa}$; offset yield strength: $3.58 \mathrm{MPa}$ ), the recorded values did not increase so much for the RTS prepared with the different adhesives. The greatest differences were found for the RTS prepared with T(4)P7 with and EMEM of $2.6 \mathrm{MPa}$ (T(4)P7), a proportional limit of 4.7 MPa, and a offset yield strength of 5.6 MPa. Instead, the values recorded for T(3)P7 were more similar to the ones of the not-treated tissue (EM: 1.8 MPa; Proportional limit: 2.6 MPa, offset yield strength 3.1 MPa).

The RTS prepared with K(4) and with K(4)P7 were almost identical, with an EM respectively of 1.4 MPa and 1.5 MPa, a proportional limit of $0.4 \mathrm{MPa}$ and $0.6 \mathrm{MPa}$, and an offset yield strength of $3.40 \mathrm{MPa}$ and 3.1 MPa.

The RTS prepared with $A(5) E$ and $K(3) A(4) E$ had a high discrepancy with regard to the $\mathrm{EM}(\mathrm{A}(5) \mathrm{E}: 2.12 \mathrm{MPa} ; \mathrm{K}(3) \mathrm{A}(4) \mathrm{E}: 1.1 \mathrm{MPa})$, but similar proportional limit (A(5)E: 2.5 MPa; K(3)A(4)E: 1.73 MPa) and offset yield strength (A(5)E: 1.9 $\mathrm{MPa}$; $\mathrm{K}(3) \mathrm{A}(4) \mathrm{E}: 2.10 \mathrm{MPa}$ ). 

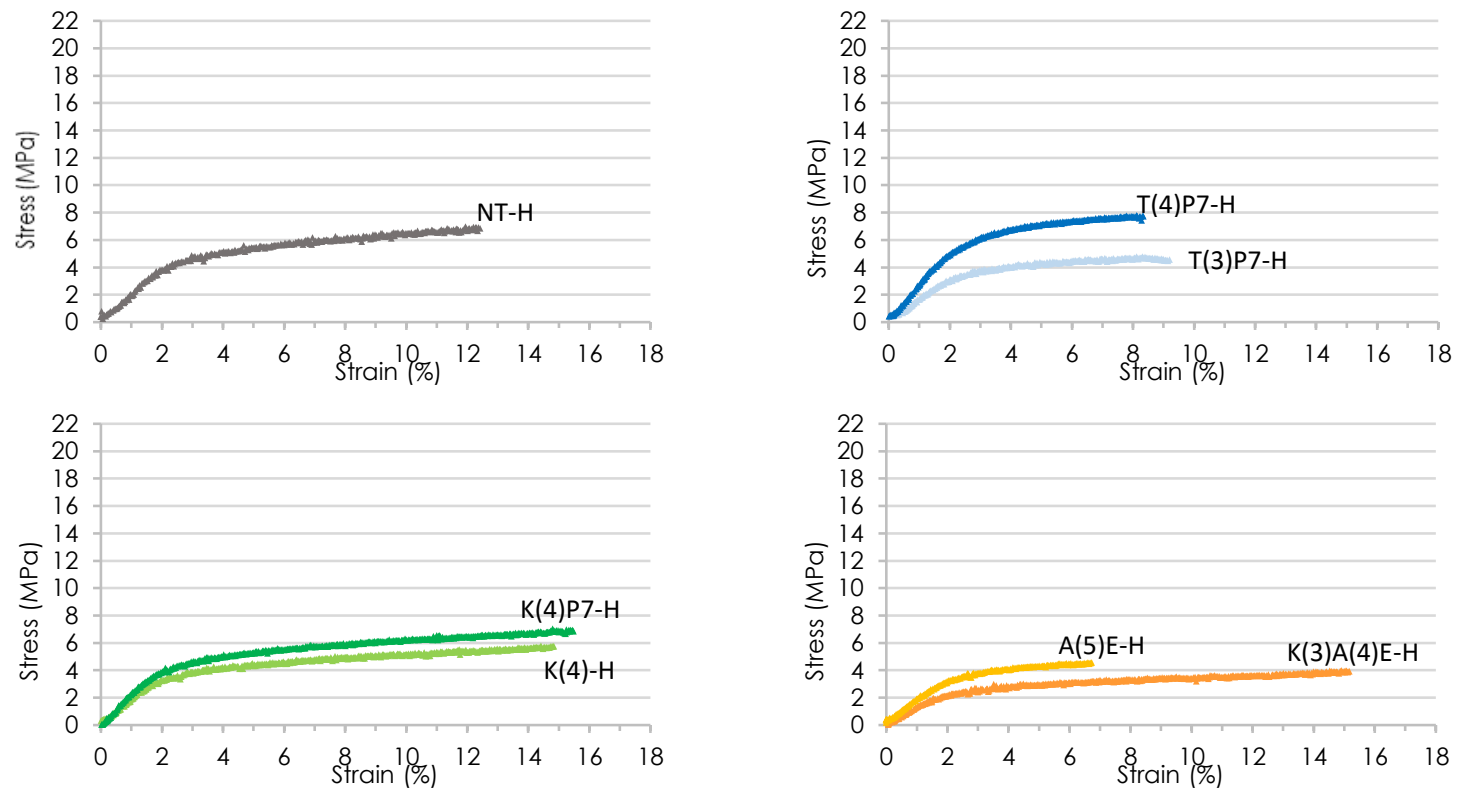

Figure 4.5.12. Stress-strain graphics of RTS prepared with Holytex.

\subsubsection{Conclusions}

As told before, the high accuracy and precision of the analytical method was not sufficient to obtain clarifying results which permitted to detect the mechanical characteristics of every type of RTS. Nevertheless, it was possible to make some hypothesis on the behaviour of the different class of RTS relating them to the interaction between the support and the dispersions.

Bib Tengujo revealed to be an elastic but fragile tissue. Nevertheless, probably because of its chemical constitution and its physical characteristics, it seems to have a good affinity with the water-based adhesives employed for the preparation of RTS. As demonstrated with the previous analyses on the evaporation rate, it is an absorbing material. According to these characteristics, it is possible to assume that once applied on the support, a part of the adhesive films at the interface with the Mylar foil, while the rest diffuses in the fibres of the support 'cementing' them, thus increasing its mechanical properties.

The TNT 30/B is a support with a clear different mechanical behaviour in the two principal directions of its fibres. If tensioned following the parallel direction of the fibres, it has good elastic properties and its EM is not too high. On the contrary, if tensioned perpendicularly to the direction of the fibres it has almost no strength and is highly plastic. Anyway, as it happens in the case of Bib Tengujo RTS, the EM of the support increase after the application of the adhesives. Also in this 
case, it is plausible to assume that a part of the adhesive penetrate among the fibres of the support increasing the stiffness of the system, thanks to the good affinity with the employed adhesives.

It is curious to notice the opposite behaviour of the RTS prepared with the English tissue. The discrepancy of the obtained result could be attributed to the heterogeneity of the support, but also to an uneven distribution of the adhesive in the support, as well as to possible defects in the adhesive layer. It could be that the variability in the results obtained for the corresponding RTS could be addressed to the higher EM of the English tissue. In fact, the English tissue is notably stiffer than Bib Tengujo. This is probably due to the presence of the polyamide additive present in the fibres (see chapter 3), that bulk the fibres and increase is EM. Considering the obtained results, it is possible to assume that the adhesives applied during the preparation of the RTS distributes at the interface with the Mylar foil, but also penetrate in the fibres, leading to a plasticising effect on the entire system.

The results obtained for the RTS made with Holytex could be explained assuming a scarce affinity of the support with the adhesives selected for the experimentation. Referring to the previous analyses that demonstrated the scarce absorbance rate of the Holytex, it is possible to assume that after the application the adhesives did not soaked the fibres of the support. On the contrary, the adhesive probably pass across the support creating a film at the interface with the Mylar foil without diffusing in the fibres. This would explain why the results obtained for the RTS made with Holytex do not differ from that obtained for the not-treated support.

In conclusion, even if the tensile tests made on temporary supports and corresponding RTS did not permit to obtain specific results, this analysis permitted to determine the importance of the interaction and the affinity of the temporary support with the adhesive mixture employed for the preparation of the RTS. Furthermore, this analysis led to assume that with the RTS system, the small quantity of adhesive employed for the preparation of the RTS do not permit to create an adhesive film strong enough to change the mechanical characteristics of the support. Instead, the adhesive that penetrate among the fibres seems to condition the mechanical behaviour of the tissue.

However, considering the scarce accuracy of the obtained results, it was decided to not discard any adhesive or support in view of the next step of the investigation. 


\section{Second experimental stage: evaluation of the efficiency of remoistenable tissues}

\subsection{SUMMARY OF ANALYTICAL METHODS}

The second step of the investigation was focused on the evaluation of the application of remoistenable temporary supports on mock-ups reproducing a canvas painting. In particular, the project was meant to underline those that were considered the most relevant factors. Adequate analyses and tests for the evaluation of each issue were selected (Table 5.1.1).

Table 5.1.1. Summary of efficiency parameters of RTS, analytical methods used for their evaluation and specimens and mock-ups used for each experimental analysis/examination.

\begin{tabular}{|c|c|c|}
\hline RTS efficiency parameters & Analytical method & Specimen/Mock-ups \\
\hline \multirow[t]{2}{*}{$\begin{array}{l}\text { Permanence of residues } \\
\text { and state of the substrate } \\
\text { after the removing of facing }\end{array}$} & UV/vis microscopy & $\begin{array}{l}\text { De-faced mock-ups prepared } \\
\text { with different paint layers (Raw } \\
\text { Siena, Iron oxide red, Titanium } \\
\text { White, Cobalt Blue) before and } \\
\text { after surface cleaning }\end{array}$ \\
\hline & FESEM & $\begin{array}{l}\text { De-faced mock-ups prepared } \\
\text { with Iron oxide red before and } \\
\text { after surface cleaning }\end{array}$ \\
\hline Penetration in the substrate & $\begin{array}{l}\text { - Micro Raman } \\
\text { spectroscopy } \\
\text { - High-resolution } \\
\text { optical microscopy }\end{array}$ & $\begin{array}{l}\text { Reference specimens mimic the } \\
\text { different layers of the mock-ups } \\
\text { prepared with Iron oxide red } \\
\text { Cross-sections obtained from } \\
\text { faced mock-ups prepared with } \\
\text { Iron oxide red }\end{array}$ \\
\hline Adhesive bond properties & - Peeling test & $\begin{array}{l}\text { Faced mock-ups prepared with } \\
\text { iron oxide red, previously } \\
\text { conditioned at different T/UR } \\
\text { values. }\end{array}$ \\
\hline
\end{tabular}




\subsection{MOCK-UPS DESIGN}

For this experimental stage, a long reflection was made for the preparation of the mock-ups that would have been used for all the analyses. The same kind of mock-ups were designed for all the projected analyses, because the respect of the principles of uniformity and reproducibility was considered of fundamental importance to facilitate the comparison among the tests results of this investigation, but also in view of a hypothetical comparison with further researches.

Nevertheless, because of the heterogeneous requirements of each test, it was necessary to make some further elaboration to the basic mock-ups. Therefore, in these under sections, the design of the basic painting mock-ups will be described. Additional details on the specific preparation of the mock-ups prepared for each test will be further given.

\subsubsection{Theoretical assumptions on mock-ups}

The issue of the mock-ups design is a fundamental step of any research and it has always been well-reasoned and selected case-by-case.

As illustrated in Chapter 2, the thin thickness of canvas painting presents such a variety of combination of layers and materials, which made every painting unique and unrepeatable. Furthermore, every artwork has a peculiar history, which marks its personal conservative state and strengthens its distinctiveness.

Test specimens can be designed with different systems, selected on the basis of the pursued degree of representation of the mock-ups. Solutions are usually of three kinds: in some circumstances, a real artwork is selected; other times, the choice falls on the reproduction of a specific technique, relying on ancient restoration handbooks or on the analysis of the stratigraphy of a real painting; in other cases, different degrees of simplification are employed, using painting mock-ups reproducing the most important characteristics of a painting and excluding the variables which are not determining for the investigation.

These options might be compared to different levels of magnification: the more the painting mock-up is distant to a specific reality, the less it is detailed in the sharpness, but in return, it allows a more general overview.

Using a real art piece leads the investigation to an extremely specific degree. It is true that a real paint is the one whit a natural degradation and that it is quite impossible to reproduce a specific damage with artificial ageing. Nevertheless, 
using real mock-ups excludes some of the fundamental requirements for data comparison, such as uniformity and reproducibility. In fact, it is difficult to find an extended and uniform surface. Ground layers could have been applied following the depicted figuration. The possibility of having a constant surface with uniform chemical-physical and mechanical behaviour is complicated by the same existence of a depiction, which involves the presence of different colour fields, of brushstroke with different thicknesses or colours superposition, or even the presence of final glazing. Furthermore, the state of conservation varies not only depending on different paintings, but also in the same artwork. For example, the phenomenon of cracking and flaking of the superficial layers could be present only on some specific colours, such as the more sensitives to thermo-hygrometric changes, or in the canvas corners which are subjected to higher stresses and strains. Thus, the use of a real canvas painting is legitimate when an investigation on a certain executive technique or a specific degradation phenomenon is needed, but it is anyway essential to have a homogeneous surface, extended enough for the required analyses.

A copy-mock-up of a real painting, prepared with a certain executive technique with a specific sequence of constitutive layers (glue size, gesso ground, toned oilgrounds, etc.), is useful for testing on little broader categories. For example, this system might be useful to examine paintings prepared by a single artist or by different artists of the same school, which are often described in ancient handbooks, such as the clay priming layers described by Pacheco in the $17^{\text {th }}$ century or the venetian red grounds of the $18^{\text {th }}$ century depicted by Volpato. Nevertheless, it would not be representative of other types of paintings.

On the contrary, a simplified mock-up reproducing the elementary stratigraphy or even just a part of a painting, will never be the identical copy of a real painting. However, such a mock-up can be descriptive of a huge class of paintings, making it representation and not copy of that category. Sometimes mock-ups reproducing a simplified stratigraphy are designed, avoiding all that variables which would overcomplicate the interpretation of the results. For example, in order to evaluate the mechanical behaviour of ground layers prepared with different kinds of animal glues, it could be good to make mock-ups with the only canvas and ground layer, preparing this last one using only glues and fillers, without adding some plasticizer (honey, molasses, oil) mentioned in ancient literature (Mecklenburg 2008). In other cases, simplification could reach a very high degree, reproducing only those characteristics useful for the purpose of the investigation. For instance, the comparison of different consolidants could be achieved using pressed pills of a porous and absorbent material like gesso, bound with a very low quantity of medium. In fact, the imitation of the medium porosity of a deteriorated painting makes it easier to visualize the penetration of the polymer (Buzzegoli, Landi, and 
Minotti 2008; Roche, Ottolini, and Riggiardi 2009). The use of these mock-ups helps to minimize the 'interferences', which make more difficult the understanding of a phenomenon. The exclusion of the non-essential variables allows achieving objective data and comparing results.

This brief overview shows the 'ethical' complexity of the choice of the correct mock-ups. In fact, each of these solutions has pros and cons: there is not a perfect solution. Every time it is necessary to start with the identification of the special needs of the single case, and to select the most appropriate kind of mock-ups.

This research deals with an innovative technique, which had never been tested before. Indeed, the principal aim was the design of mock-ups representative of a wide variety of oil paintings on canvas, pursuing the highest possible level of simplification. Furthermore, it was fundamental to use the same mock-ups for all the projected analyses, in order to compare results. The specific necessities related to each test were therefore taken into account, first and foremost the common basic principles of uniformity and reproducibility.

At first, it was thought to recover to a drastic simplification, as the examples mentioned above. For the peeling test, it would not have been necessary to reproduce the entire stratigraphy, so the realization of mock-ups reproducing only the last layer, the coating, could have had been a good choice (Alba and laccarino-Idelson 2016). In fact, all the adhesion theories agree on the importance of the forces acting at the interface of the bond, which depends on the liquid superficial tension and the solid potential energy at the surface (Roche, Ottolini, and Riggiardi 2009). In the case of facing, the force is exerted at the interface between the temporary support and the painting surface bonded by the adhesive, and it depends on the same parameters that condition adhesion mechanisms. Nevertheless, this solution was not certainly suitable for other tests.

For the tests on the assessment of the adhesives penetration in the substrate, it was also thought to prepare pressed pills, like the ones described before, modifying some details. This solution would have been useful especially for Raman microspectroscopy analyses. In fact, spectra of organic materials are quite complex, so that a Raman measurement on a mock-up prepared with organic materials could have been problematic. The possibility of using an inorganic substrate, prepared with a material with a simple Raman spectrum (with few and well-known peaks) would have made the analysis of the results easier. Nevertheless, such a simplification would not have been feasible, because facing is made on the front of the paint, so that the penetration and the permanence of the residues depends on the entire stratigraphy. 
It would have been necessary to reproduce, at least, the final coating, as well as the paint and the ground layers, outlining a system to recreate the cracking patterns. Furthermore, this system would have not prevented the use of organic materials for the preparation of the mock-ups and hence it would have not facilitated the interpretation of the Raman spectra. It was a cumbersome and useless solution and it could had led far away from reality.

\subsubsection{Practical design of basic painting mock-ups}

\subsubsection{Preparation}

The line of reasoning led to the awareness that it was necessary to design mockups reproducing a simplified version of the entire stratigraphy of an oil canvas painting. Basic materials were therefore combined to prepare the constitutive layers, in order to reduce the variables.

To prepare the mock-ups, two linen canvases 105 of the weight of $115 \mathrm{~g} \cdot \mathrm{m}^{-2}$ and a count ( $n^{\circ}$ of weft and warp yarns $/ \mathrm{cm}$ ) of $13 \times 13$ were used. The canvases were previously washed, tensioned on a temporary stretcher and then wetted again, in order to 'stress' them and to reduce their movements during the latter operations ${ }^{106}$.

After a second stretching, the canvases were sized with two layers of technical gelatine of pure skin ${ }^{107}$ dissolved in the proportion of 1:10 (W/W) in water (Fig. 5.2.1). The choice of the glue was not random. In fact, the generic term 'hide glue' or 'skin glve' refers to a wide range of animal glves prepared with diverse source materials and production processes (Schellmann 2007), so that the characteristics of two hide or skin glues from different suppliers could be very dissimilar. It is least likely with technical gelatine of pure skin, which is produced with a more standardized source material and is composed almost exclusively of collagen, facilitating the reproducibility. Furthermore, the low proportion of impurities is an advantage for Raman microspectroscopy used for assessing the permanence of residues (see section 5.4).

\footnotetext{
105 CTS Canvas 2139; manufacturer CTS Europe s.r.l.

106 When a canvas fixed on a stretcher is subjected to humidity increase, it tries to contract but its movement is impeded by the stretcher. In a first moment it reacts with a determined strength to the stretching, and weave reorganization consequently occur. But, when the humidity exceeds the $75-80 \% \mathrm{RH}$, the fibres of the canvas start slipping on each other and causing an irreversible increase in canvas dimensions. These behaviour decrease in intensity after the first cycling into high $\mathrm{RH}$. Wetting a canvas before using is necessary to reorganize the fibres and reduce the dimensional changes of the canvas (see chapter 2 for further information).

107 Technical gelatine of pure skin; manufacturer CTS Europe s.r.l.
} 


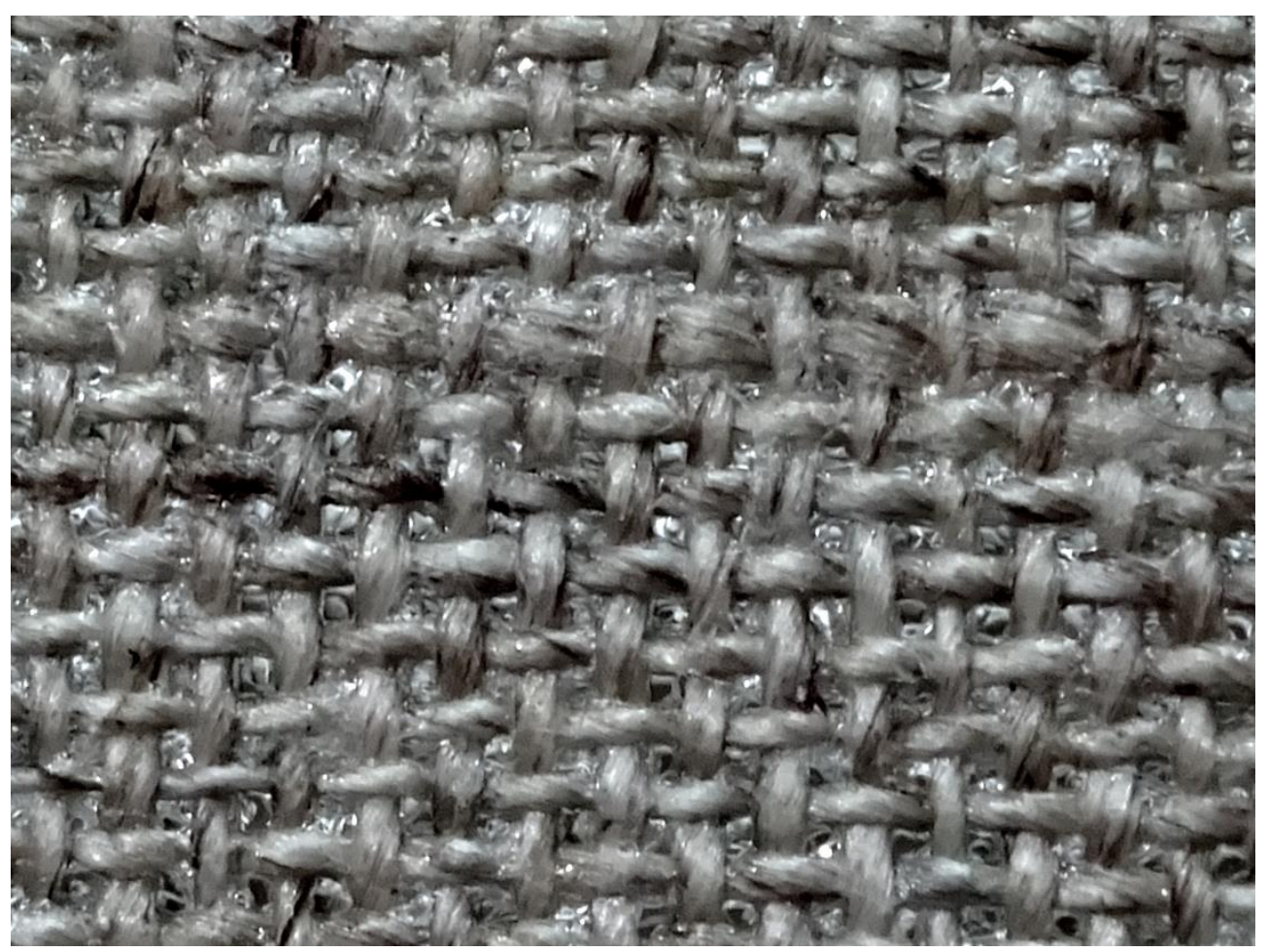

Figure 5.2.1. Canvas after sizing with technical gelatine of pure skin.

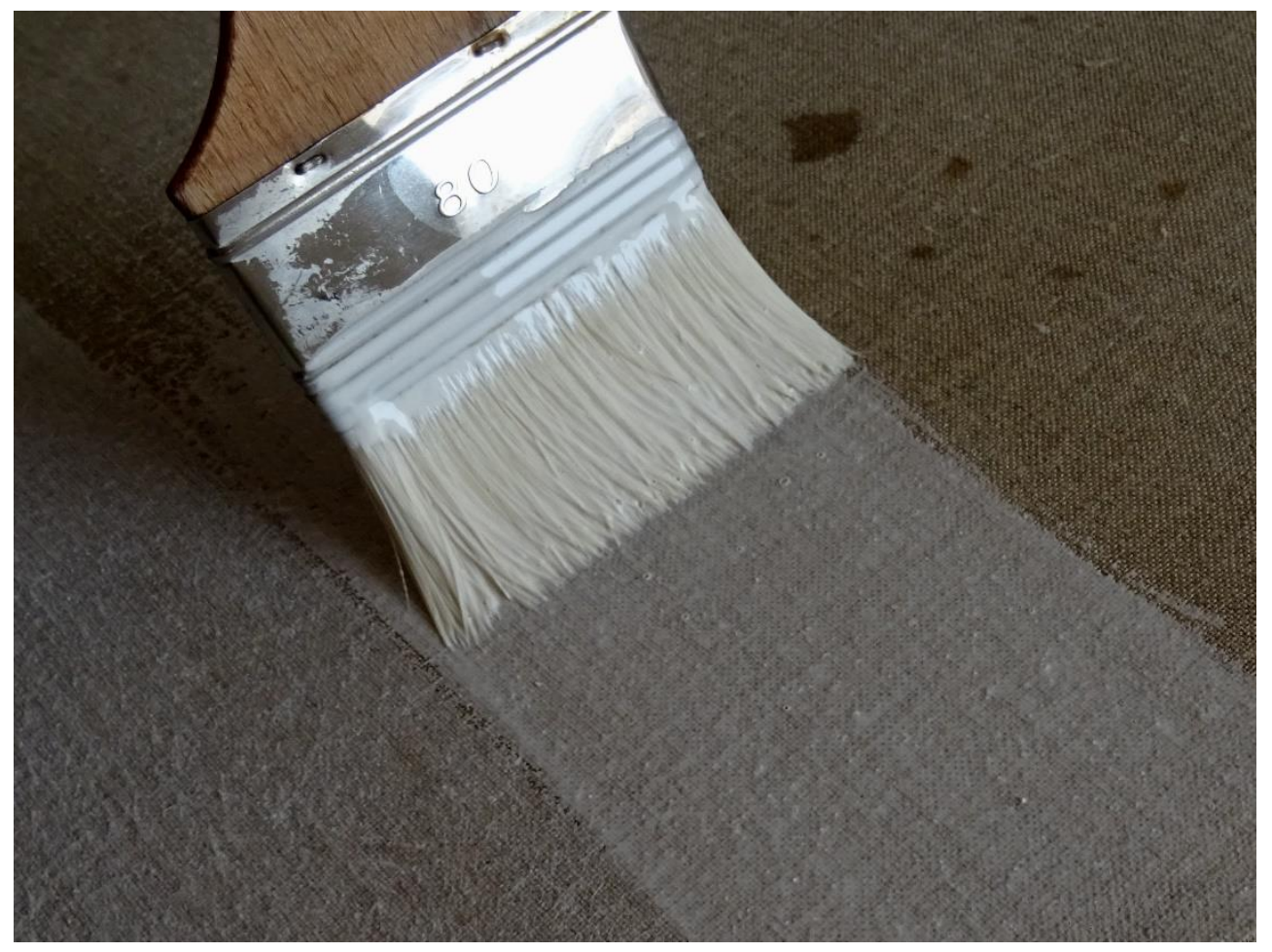

Figure 5.2.2. Application of the ground layer. 
Once the size was dried, three layers of ground were applied with brush (Fig. 5.2.2). The ground was prepared using the same technical gelatine (dissolved in the proportion of 1:14 (w/W) in water) and gesso di bologna ${ }^{108}$ in the proportion of 1:1 $(w / w)$.

It was thereafter applied the paint layer. The possibility of using ready-made colours was promptly discarded, because of the presence of undeclared additives which are not always easily identifiable with Raman analysis and which could have changed the chemical and mechanical behaviour of the paint layer. Colours were prepared using linseed oil and four kind of pigments: raw sienna ${ }^{109}$, iron oxide red ${ }^{110}$, titanium white ${ }^{111}$ and cobalt blue ${ }^{112}$.

The first two are natural pigments widespread used since ancient times, while the other two are synthetic pigments largely used since the $19^{\text {th }}$ century. This choice was made in order to have an idea of the efficiency of temporary remoistenable tissues on different classes of pigments. Each colour was prepared following the values of the pigment volume concentration (PVC) reported in literature (Matteini and Moles 2007; Kremer 2019).

The first canvas was divided into horizontal stripes where the four colour were applied (Fig. 5.2.3.), while on the second one, which was set aside for peeling tests, just a uniform layer of iron oxide red was applied. Colour were applied in a thin layer with a paint roller, to increase the uniformity of the surface.

The canvas were let dry for two months, then were varnished with Dammar Resin ${ }^{113}$ dissolved in White Spirit114 in the proportion of 1:3 (w/W). Dammar was selected because is one of the most employed coating materials since the $19^{\text {th }}$ century and it is still widely used in the restoration practice. Furthermore, there is a huge bibliography on this material and on its ageing, which would have facilitated its characterization during Raman analyses. Fig. 5.2.4 shows a scheme of the composition of the paint mock-ups prepared.

The mock-ups were let naturally dry for 4 months, with constant thermohygrometrical conditions $\left(45-55 \% \mathrm{RH}\right.$ and $\left.20-24{ }^{\circ} \mathrm{C}\right)$, before proceeding with artificial ageing.

\footnotetext{
108 Bologna gypsum; manufacturer CTS Europe s.r.l.

109 Raw sienna brownish (Order No: 40410); manufacturer Kremer Pigmente GmbH \& Co. KG

110 Iron oxide red, natural (Order No: 48600); manufacturer Kremer Pigmente GmbH \& Co. KG

111 Titanium white Rutile (Order No: 46200); manufacturer Kremer Pigmente GmbH \& Co. KG

112 Cobalt blue medium (Order No: 45710); manufacturer Kremer Pigmente GmbH \& Co. KG

113 Gum Dammar; manufacturer CTS Europe s.r.I.

114 Denatured white spirit D40; manufacturer CTS Europe s.r.l.
} 


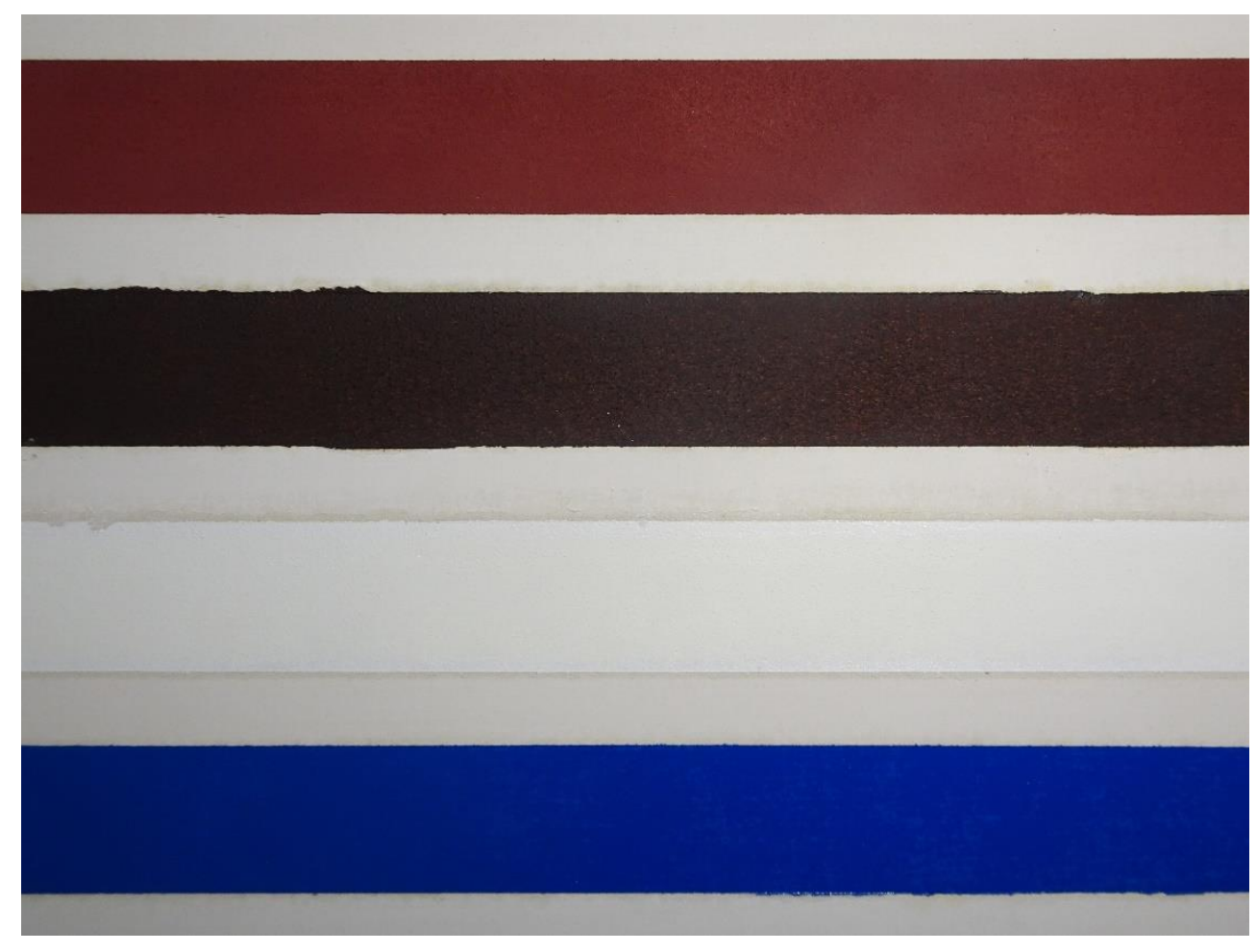

Figure 5.2.3. Application of the paint layer.

\begin{tabular}{|c|c|c|}
\hline Coating & Dammar & - Raw sienna \\
\hline Paint layer & & - Iron oxide red + + Linsed oil \\
\hline Ground & $\begin{array}{l}\text { Technical gelatine + } \\
\text { Bologna gypsum }\end{array}$ & - Cobalt blue \\
\hline Size & Technical gelatine & \\
\hline Support & Linen canvas & \\
\hline
\end{tabular}

Figure 5.2.4. Scheme of Paint mock-up and materials used. 


\subsubsection{UV accelerated ageing}

Artificial ageing represented another crucial step in the preparation of materials for analysis. It was considered necessary to 'pre-age' the mock-ups in some manner to reach a particular stage of deterioration, which had to mimic that due to natural age (Feller 1994). In fact, researches on aged varnishes indicated that oxidation, cross-linking and degradation processes take place during ageing (Doelen and Boon 2000) and this is true even for the paint layers. These processes change some characteristics, such as polarity, porosity and other mechanical properties. The artificial ageing was necessary in order to obtain a substrate similar to the one of a real painting for peeling tests, as well as a porous and fragile surface to observe the penetration of the polymers and evaluate the permanence of residues after facing removing.

Ageing with UV light was chosen, because light along with oxygen and water, is one of the three primary agents that induce slow degradation (aging) of many organic polymers (Hare 1992). It was decided to use a device equipped with fluorescent tubes (TL-D 18W BLB 1SL/25 - Philips), which emit UVA radiation with a wavelength range from approximately $410 \mathrm{~nm}$ down to 340 $\mathrm{nm}$, which peak at $365 \mathrm{~nm}$. Mock-ups were left in the chamber for $600 \mathrm{~h}$. UVA lamps use UV light to reproduce the damaging effects of sunlight but does not contain any short wavelengths below the normal solar cut-off, as the UVB lamps. Because the UV-A lamp produces only those wavelengths found in natural sunlight, it eliminates any unnatural results from short-wavelength UV (Brennan 2011 ). It was not considered necessary to use UV-A lamps for interior testing, since they are too weak for the desired result.

It was chosen not to proceed with other kinds of artificial ageing because they could have had compromised the uniformity of the mock-ups substrate, which was very important especially for peeling tests. A thermo-hygrometric ageing did not ensure a regular cracking. Anyway, also a regular craquelure could have had adversely affected peeling tests results, because of the interruption in the continuity of the substrate.

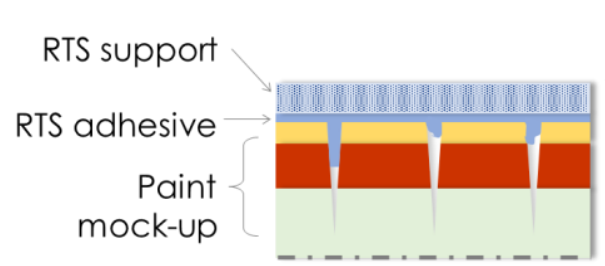

a)

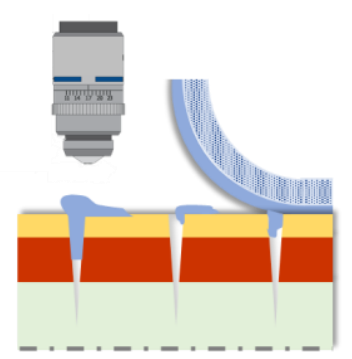

b)

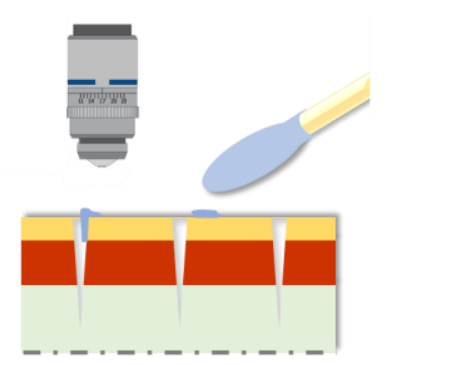

c)

Figure 5.2.5. Schematic description of the observation carried out on the mock-ups (a): after the removal of the RTS (b); after the surface cleaning with a cotton swab (c). 
5.2.3. Painting mock-ups: specific treatment for the evaluation of the permanence of residues and the state of the substrate after the removing of facing

For the observation with the optical microscope, two sets of samples were selected, using the canvas prepared with the four kind of paint layer (raw sienna, iron oxide red, titanium white and cobalt blue). The first set was prepared using the mock-ups as they were described in section 5.2.2. The surface of the second set mock-ups was mechanically cracked, in order to check the permanence of facing adhesives in painting cracks. For the observation with the FESEM microscope only the iron oxide red specimens were used.

All the mock-ups were faced with the RTS system described in chapter 3 and let dry for two weeks. Analyses were carried out after facing removal and after the surface cleaning with a cotton swab, as described in chapter 3 (Fig.5.2.5).

\subsubsection{Painting mock-ups: specific treatment for the evaluation of adhesive penetration in the substrate}

For the analyses with micro-Raman spectroscopy (coupled with a highresolution optical microscopy), it was prepared a set of cross sections from faced cracked mock-ups, in order to characterise adhesive penetration in cracks and porosities of the paint and ground layer. Because of the complexity and the long time required for this part of the experimental research, only the mock-ups prepared with iron oxide red paint layer were used. Cross-sections were prepared just cutting the faced mock-ups, without resorting to any kind of further elaborations. In fact, the use of grounding and polishing materials would have contaminated the mock-ups. Also the possibility of embed the specimens in epoxy resin had to be discarded because of its spectral similarity with facing materials.

For this step of the investigation, it was also necessary to prepare specimens of the reference materials that mimic the different layers of the mock-ups and of the adhesives used for facing. 
Three sets of reference specimens were prepared as follows:

- A set of specimens mimicking the different layers (varnish, paint layer and ground) of the mock-ups. The specimens were prepared applying the reference materials on microscope slides and let them dry two months under environmental conditions (Fig. 5.2.6).

- A second set of specimens with the same reference materials was aged with UV light.

- A third set of unaged specimens consisting of pure adhesives, thickeners and their mixtures applied on microscope slides was prepared and let dry for two months under environmental conditions.

a)

Dammar varnish

b)

Iron oxide red + linsed oil

c)

Technical gelatin + Bologna gypsum

Figure 5.2.6. Scheme of specimens prepared with reference materials as the separated layers composing a paint, applied on microscope slides: a) coating; b) Paint layer; c) ground.

\subsubsection{Painting mock-ups: specific treatment for the evaluation of RTS adhesive strength}

For the peeling test, only mock-ups with iron oxide red paint layer were employed. Two sets of mock-ups were faced and let dry for two weeks. Then, the first set was kept at environmental conditions of $23 \pm 1^{\circ} \mathrm{C}$ and $45 \pm 5 \% \mathrm{RH}$, while the second set was stored in climate chamber at $23 \pm 1^{\circ} \mathrm{C}$ and $80 \pm 5 \%$ $\mathrm{RH}$ for a minimum of $72 \mathrm{~h}$. Further information on the preparation of the mockups prepared for this test will be given in section 5.5. 


\subsection{Permanence of Residues and modification in test SPECIMENS SURFACE}

The evaluation of the permanence of the residues and the assessment of the possible modifications that can occur in the surface of a painting after the removing of a facing are two fundamental issues that have to be taken into account to evaluate the suitability of a specific kind of facing.

For this part of the investigation, microscopy techniques were chosen. First, the observation with optical microscope in visible and UV light was carried on. Then, control analyses with FESEM instrument were done. If compared to the analytical techniques selected for the evaluation of the penetration of the adhesive dispersions and for the assessment of the adhesion strength of the RTS, these two are relatively quick techniques. Furthermore, specimens of small dimensions are required for these tests. The easy of handling and the direct understanding of the results would have permitted the analysis of a wide variety of samples with a relatively easiness. For these reasons, it was decided to start with this part of the investigation, in order to gather the first useful information on selected RTS and to make further choices.

\subsubsection{Materials and methods}

Three sets of samples were prepared as described in section 5.2.3.

A first microscopic observation with visible light was made on the noncracked specimens, in order to make a first selection of the most suitable RTS. Subsequently, a second analysis was made with visible and UV light on the second set of cracked specimens faced with the selected RTS. The third specimens setoff was used for the observation with FESEM.

For the observation with optical microscope, it was used a ZEISS Axioskop $40 \mathrm{Pol}$ petrographic microscope, equipped with a lighting system EXFO X-Cite 120 - Vis/UV. Images were captured with a Nikon DS-Filc digital camera with $2 / 3$ " CCD, connected to the 'Lucia' software. The magnification at $x 2, \times 10$ and $20 x$ proved to be the best to observe the surfaces of the specimens without renounce to a general vision. 
Because of the roughness of the samples, it was not always possible to capture images depicting the entire cross-section in focus. In order to improve the legibility of the photos, a post-processing technique was used. Its name is focus blending. A series of photos gradually moving the focus plane through the subject from front to back were shot. Then, images where combined with Adobe Photoshop CC 2015 software using the focus stacking, bringing the entire image into sharp focus.

For the observation with FESEM it was used a ZEISS ULTRA 55 model, equipped with Secondary Electron Detector (SE2), Secondary Electron In-Lens Detector, Backscattered Electron Detector (AsB), Backscattered Electron Inlens Detector (EsB), and X-Ray Dispersive Energy Detector (EDS).

The FESEM is an instrument which works just like a conventional SEM, scanning the surface with an electron beam, but with higher resolution and a much greater energy range. The biggest difference between a FESEM and a SEM lies in the electron generation system. As a source of electrons, the FESEM uses a field emission gun that provides extremely focused high and low-energy electron beams, which greatly improves spatial resolution and enables work to be carried out at very low potentials $(0.02-5 \mathrm{kV})$. This helps to minimise the charging effect on non-conductive specimens and to avoid damage to electron beam sensitive samples (Electron Microscopy Service UPV 2020).

The observation with the optical microscope was carried out at the Earth and Geoenvironmental Sciences Departments of the Università degli Studi di Bari "Aldo Moro" - UniBA (Italy), while the FESEM analysis was carried out at the Electron Microscopy Service of the Universitat Politècnica de València (Spain).

\subsubsection{Results of the observation of the first set of specimens with visible light optical microscopy}

Results referring to T(3)P7 and T(4)P7 were similar. In general, on all the specimens, except the ones faced with RTS of Holytex, few residues were detectable with microscopic observation with visible light. The quantity of residues did not decrease a lot after the cleaning with the cotton swab. On the specimens faced with remoistenable tissues of Bib Tengujo (Fig. 5.3.1-5.3.5) there were very few residues of the adhesive dispersion and some residues of the temporary support. After the cleaning with the cotton swab some residues were removed. The observation of the specimens faced with RTS of English 
tissue (Fig. 5.3.2-5.3.6) revealed the presence of a smaller quantity of residues of temporary support compared to the ones faced with the Japanese paper. After the cleaning of the surface, the situation remained almost unchanged. Among the RTS prepared with T(3)P7 and T(4)P7, the remoistenable tissues of TNT (Fig. 5.3.3-5.3.7) gave the best results because almost no residues were found on the surface of the samples faced with the different paint layers, especially after the cleaning with the cotton swab. On the contrary, facing made with remoistenable tissues of Holytex (Fig. 5.3.4-5.3.8) left much more residues of adhesive. In some cases, adhesive's 'prints' with the shape of the texture of the temporary support were found on the surface. After the cleaning, the quantity of residues decreased but did not disappear.

The results concerning the specimens faced with remoistenable tissues of $\mathrm{K}(4)$ were not encouraging. There was observed a consistent quantity of residues in all the mock-ups. Even if after the cleaning with the cotton swab the greater part of the residues was removed, on some of the specimens faced with RTS of Japanese paper (Fig. 5.3.9), English tissue (Fig. 5.3.10) and TNT (Fig. 5.3.11) it was visible the mark of the support on the paint layer. In particular, on the surface of the specimens faced with RTS of Japanese paper and English tissue point-like and filamentous residues of adhesive were found, while on some specimens of cobalt paint layer there were residues of adhesive with the shape of the texture of the support. This was probably due to the smooth surface of the paint layer. On the mock-ups faced with Japanese paper fibres of the temporary support were found also. As told before, in some cases the footprint of the Japanese paper was marked on the surface of the painting. The observation of the surfaces faced with RTS of TNT a greater quantity of residues was observed. Also in this case the footprint of the support was visible on the surface after the cleaning with the cotton swab. Also in this case, the greater quantity of residues was found on the specimens faced with Holytex (Fig. 5.3.12). In some cases, it seemed that the entire adhesive layer present on the surfaced of the temporary support transferred to the surface of the painting. However, after the cleaning almost all the residues were removed and no marks of the support were found.

The visual analysis carried out on the mock-ups faced with K(4)P7 gave interesting results, especially for RTS of English tissue and TNT. Going into the specific, the remoistenable tissues of Japanese paper (Fig. 5.3.13) gave intermediate results, because on some mock-up residues of adhesive and fibres of the support were found. Especially on Titanium white paint layer, residue of adhesive in the form of plaques were found. After the cleaning, only a part of the residues was removed. The results referring to the RTS of English tissue (Fig. 5.3.14) were encouraging, since the few residues that were found 
were easy removed after cleaning. The same for TNT tissue (Fig.5.3.15). Even then, the RTS of Holytex (Fig. 5.3.16) left a great quantity of adhesive residues. Even if they were almost totally removed after facing, on some point of cobalt paint layer was found the mark of the support.

According to the observation with the optical microscope, RTS of A(5)E seemed to be the ones which left the greatest quantity of residues among all the tested adhesives. On the specimens faced with Bib Tengujo (Fig. 5.3.17), English tissue (Fig. 5.3.18) and TNT tissue (Fig. 5.3.19) the situation was similar. There were found considerable filamentous residues and in some cases residues with the shape of plaques. In addition, on the mock-ups faced with Japanese paper there were found fibres of the temporary support. Concerning the surfaces faced with Holytex remoistenable tissue (Fig. 5.3.20), it seemed that the entire adhesive layer was transferred to the substrate. After the cleaning of all the specimens, almost all the superficial residues were removed. However, the high water reactivity of the Aquazol and the low viscosity of the adhesive made suspicious of the penetration of the adhesive.

The examination of the surface of the mock-ups after the removal of the remoistenable tissues of K(3)A(4)E gave encouraging results. In fact, even if the quantity of the residues was a bit higher than that of RTS of T(3)P7 and K(4)P7, almost all the residues were removed by the cleaning with the cotton swab. Furthermore, if the RTS of the adhesive mixtures prepared with the cellulose ethers and Plextol left a smaller quantity of residues in association with the synthetic TNT, the adhesive in question left less residues in association with cellulose supports. Going into detail, Bib Tengujo remoistenable tissues (Fig.5.3.21) left a very small quantity of adhesive on the paint layers with a high roughness, and a bit more on the smoother paint layers. The remoistenable tissues of English tissue (Fig.5.3.22) gave better results than Japanese paper, since there were found less residues on the surface of the mock-ups. On the surfaces faced with TNT (Fig.5.3.23) a slightly bigger amount of adhesive was found on all the specimens. The situation after the removal of the RTS of Holytex (Fig. 5.3.24) was not positive, since a huge quantity of residues was found on the surface of the specimens. 

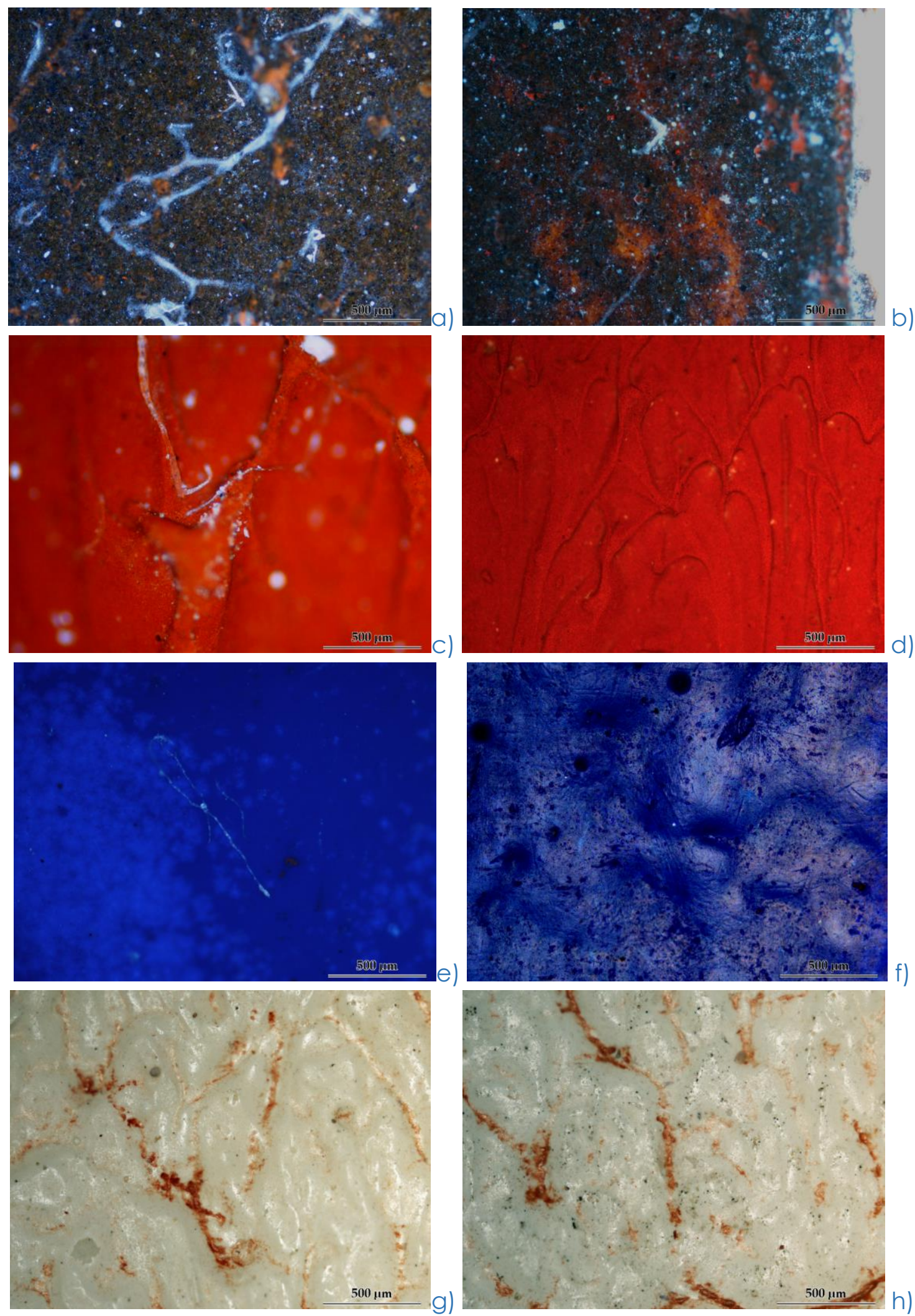

Figure 5.3.1. RTS of T(3)P7 and Bib Tengujo 240. Surfaces after the RTS removal (a, c, e, g) and after cleaning process $(b, d, f, h)$. 

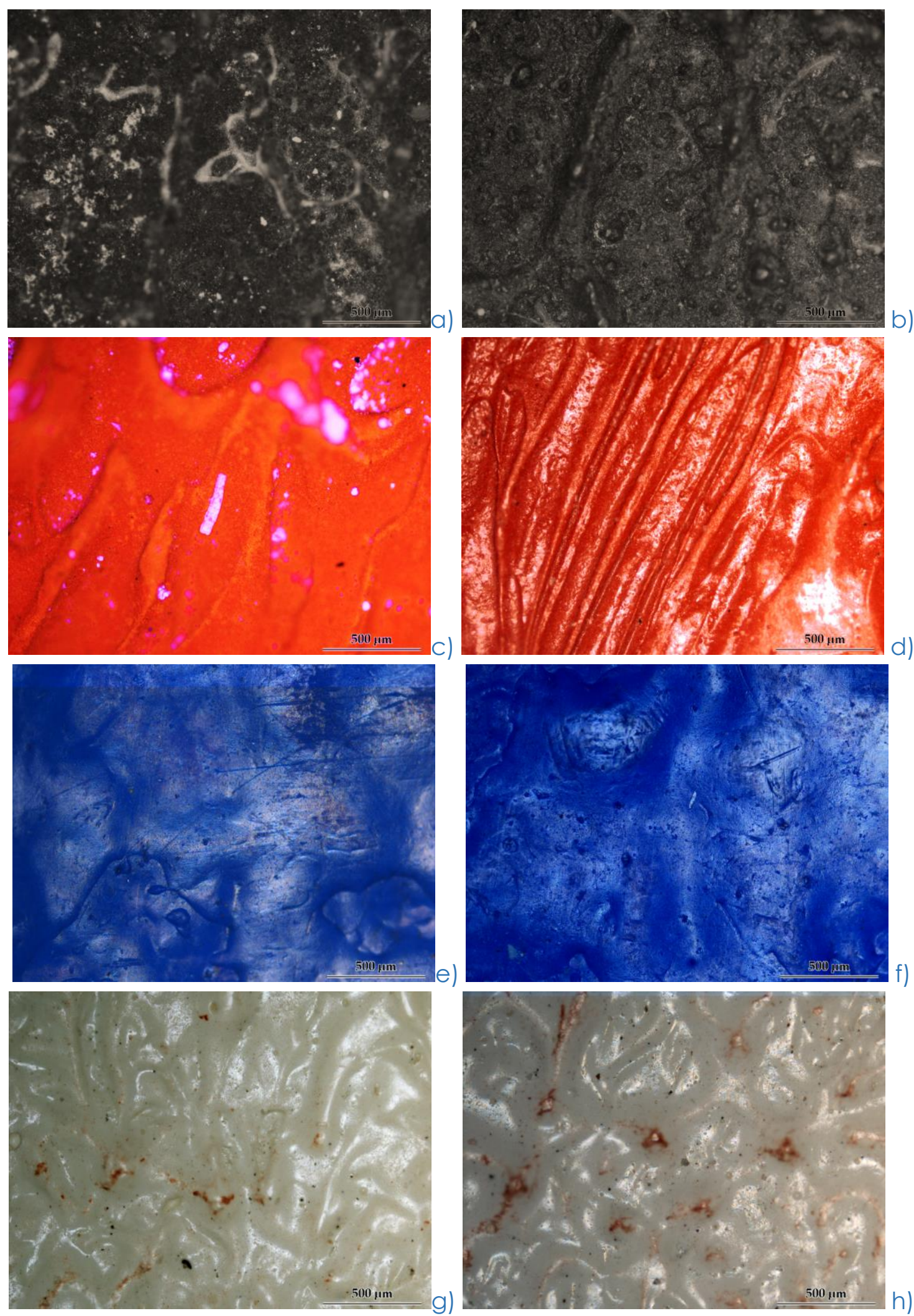

Figure 5.3.2. RTS of T(3)P7 and English tissue. Surfaces after the RTS removal (a, c, e, g) and after cleaning process $(b, d, f, h)$. 

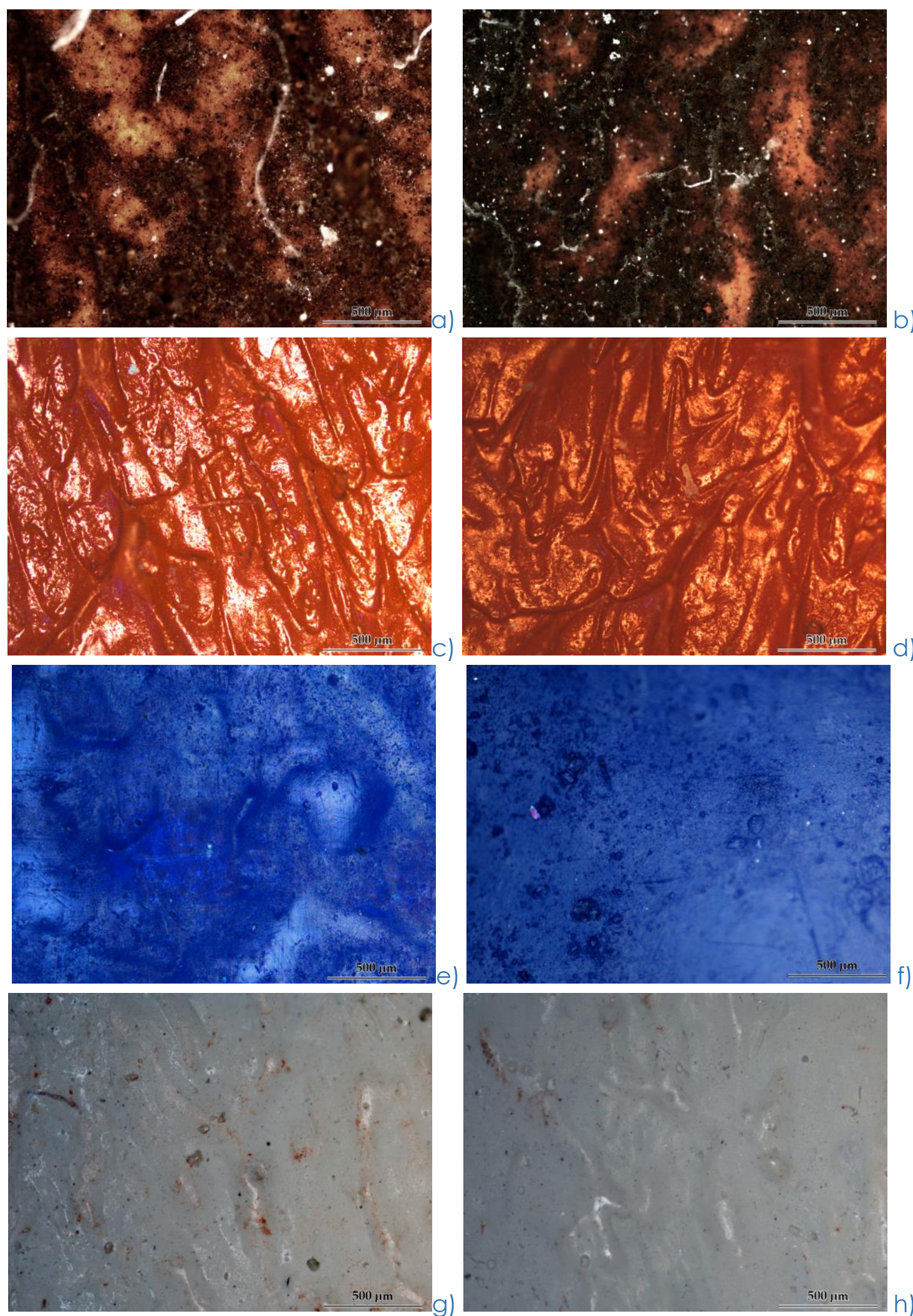

Figure 5.3.3. RTS of T(3)P7 and TNT30/B. Surfaces after the RTS removal (a, c, e, g) and after cleaning process $(b, d, f, h)$. 

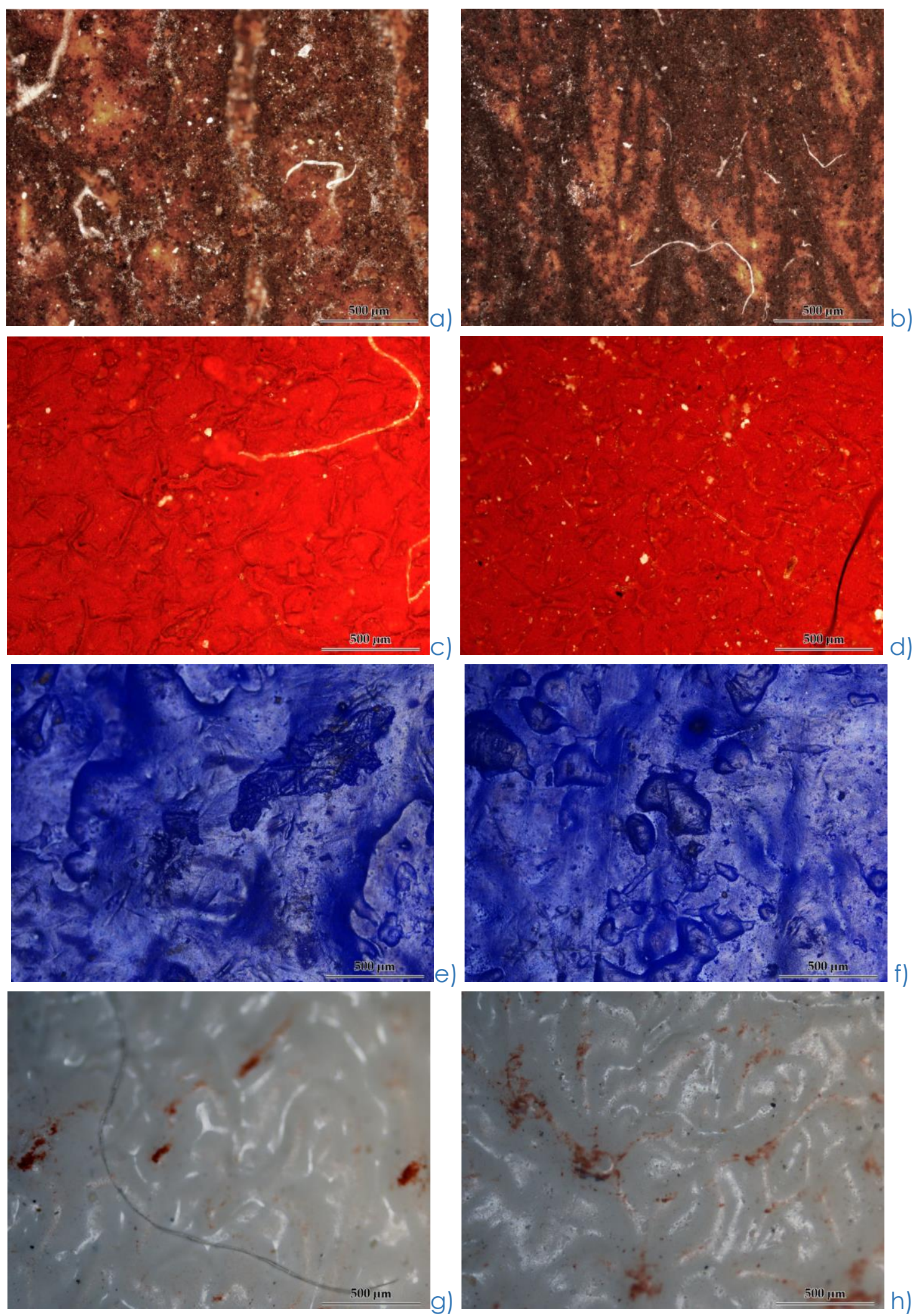

Figure 5.3.4. RTS of T(3)P7 and Holytex. Surfaces after the RTS removal (a, c, e, g) and after cleaning process $(b, d, f, h)$. 

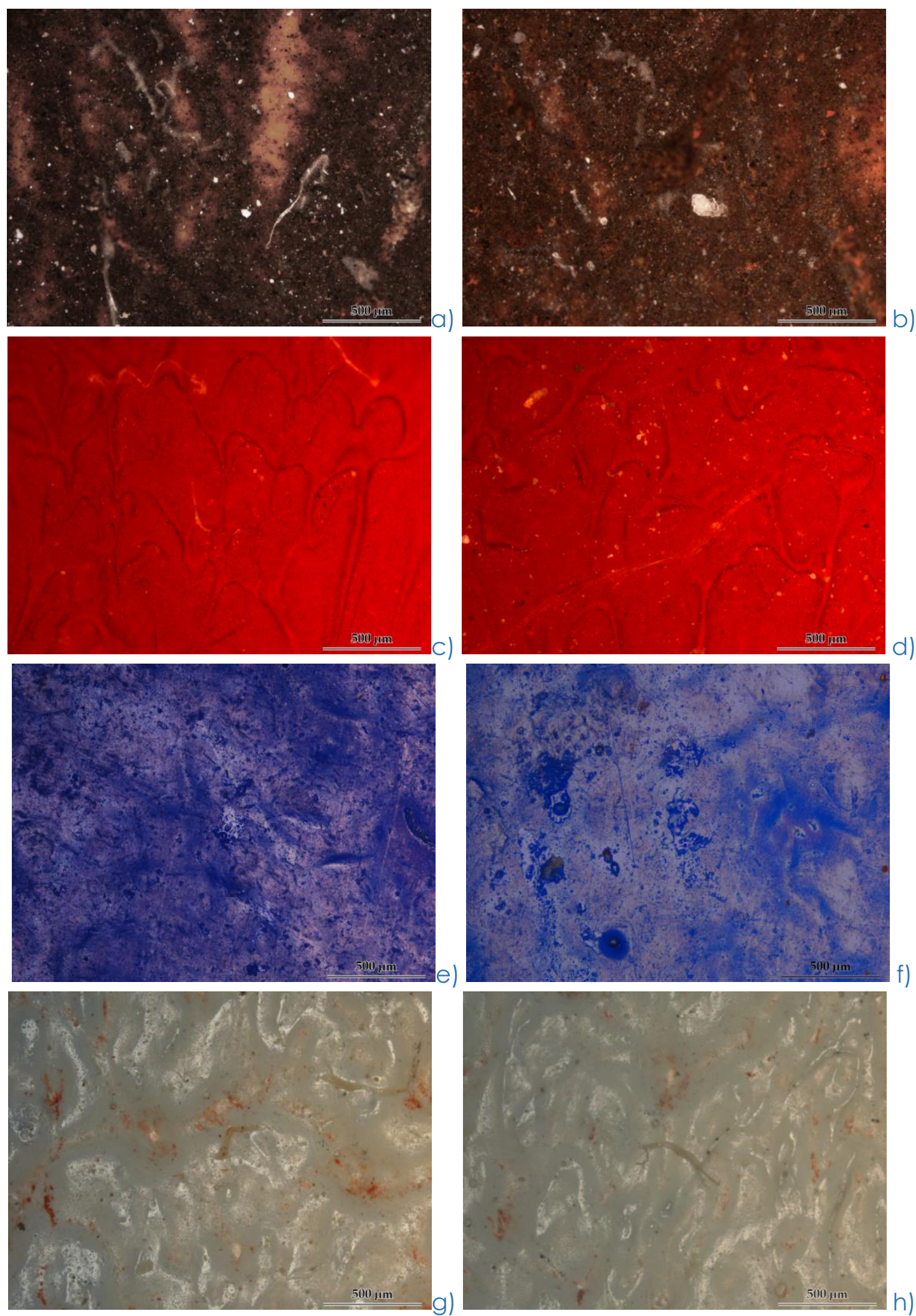

Figure 5.3.5. RTS of T(4)P7 and Bib Tengujo 240. Surfaces after the RTS removal (a, c, e, g) and after cleaning process $(b, d, f, h)$. 

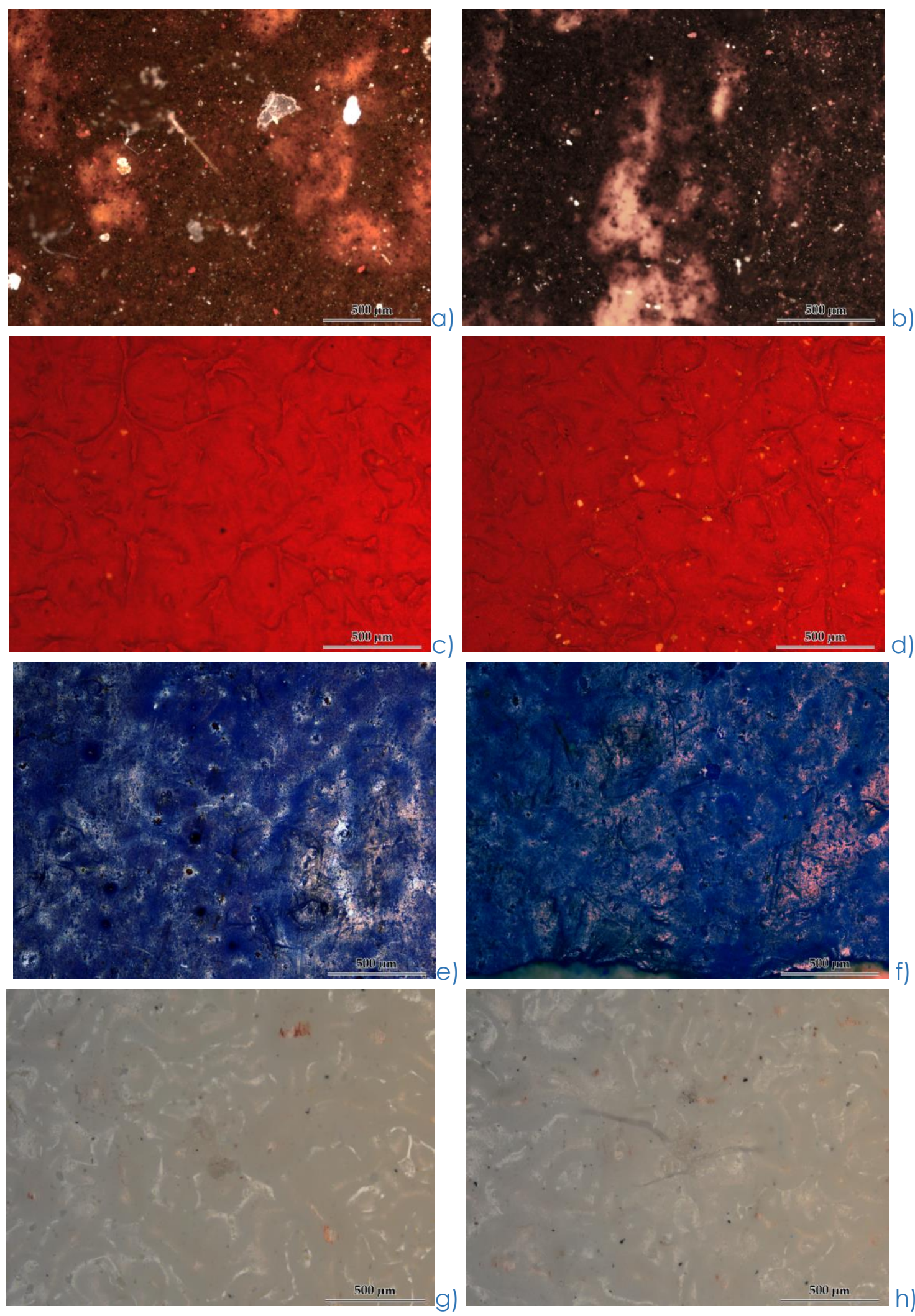

Figure 5.3.6. RTS of T(4)P7 and English tissue. Surfaces after the RTS removal (a, c, e, g) and after cleaning process $(b, d, f, h)$. 

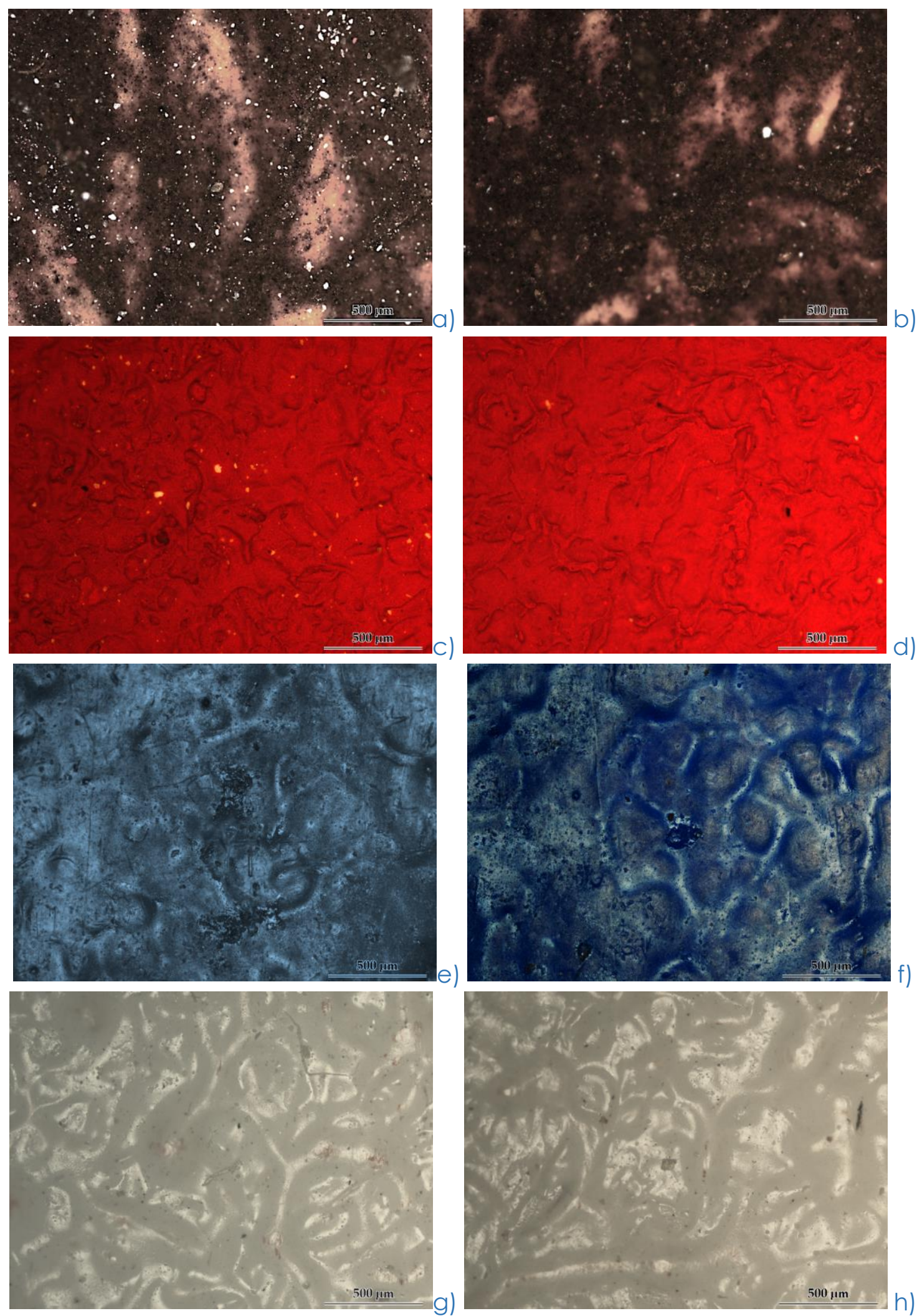

Figure 5.3.7. RTS of T(4)P7 and TNT30/B. Surfaces after the RTS removal (a, c, e, g) and after cleaning process $(b, d, f, h)$. 

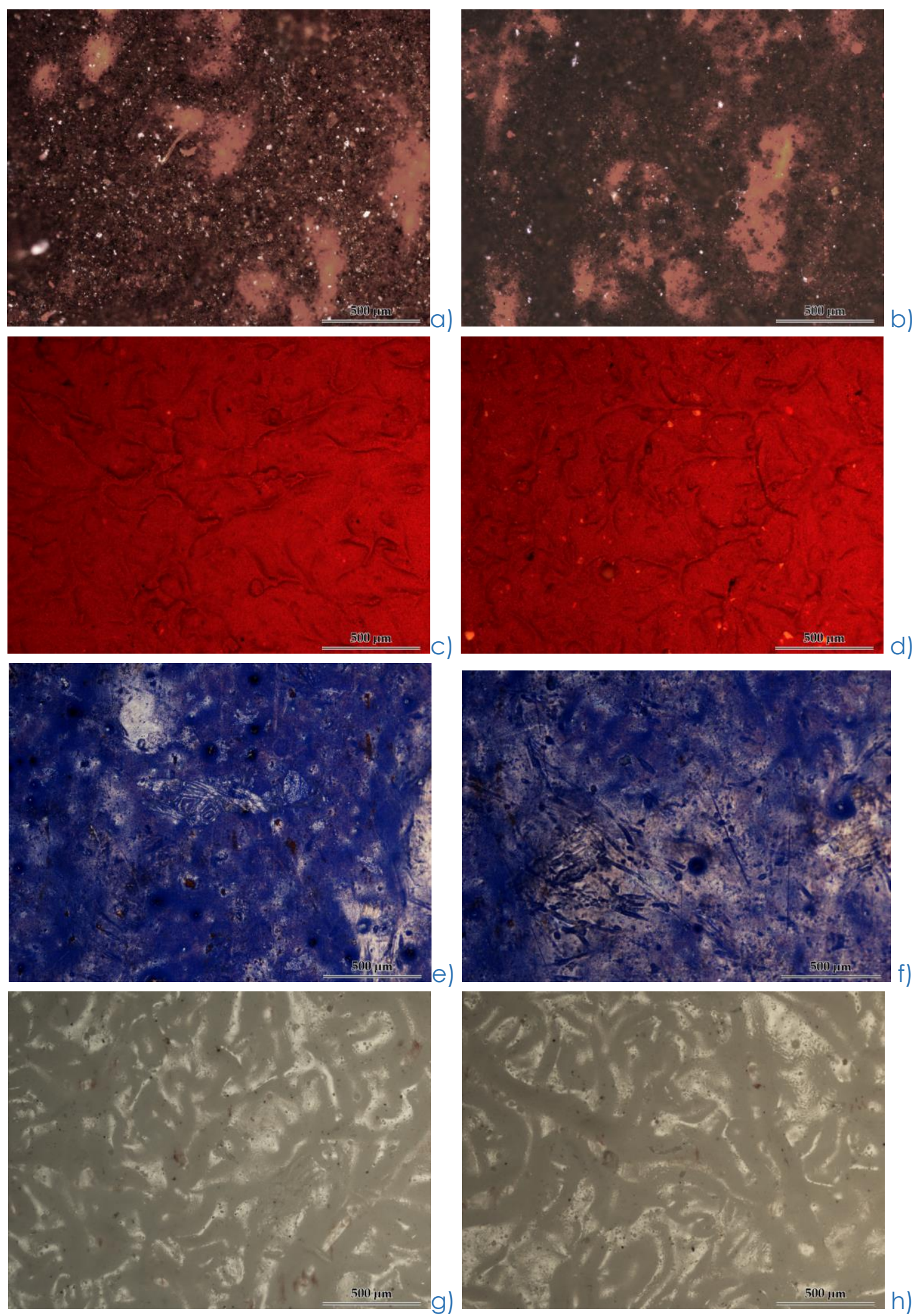

Figure 5.3.8. RTS of T(4)P7and Holytex. Surfaces after the RTS removal (a, c, e, g) and after cleaning process $(b, d, f, h)$. 

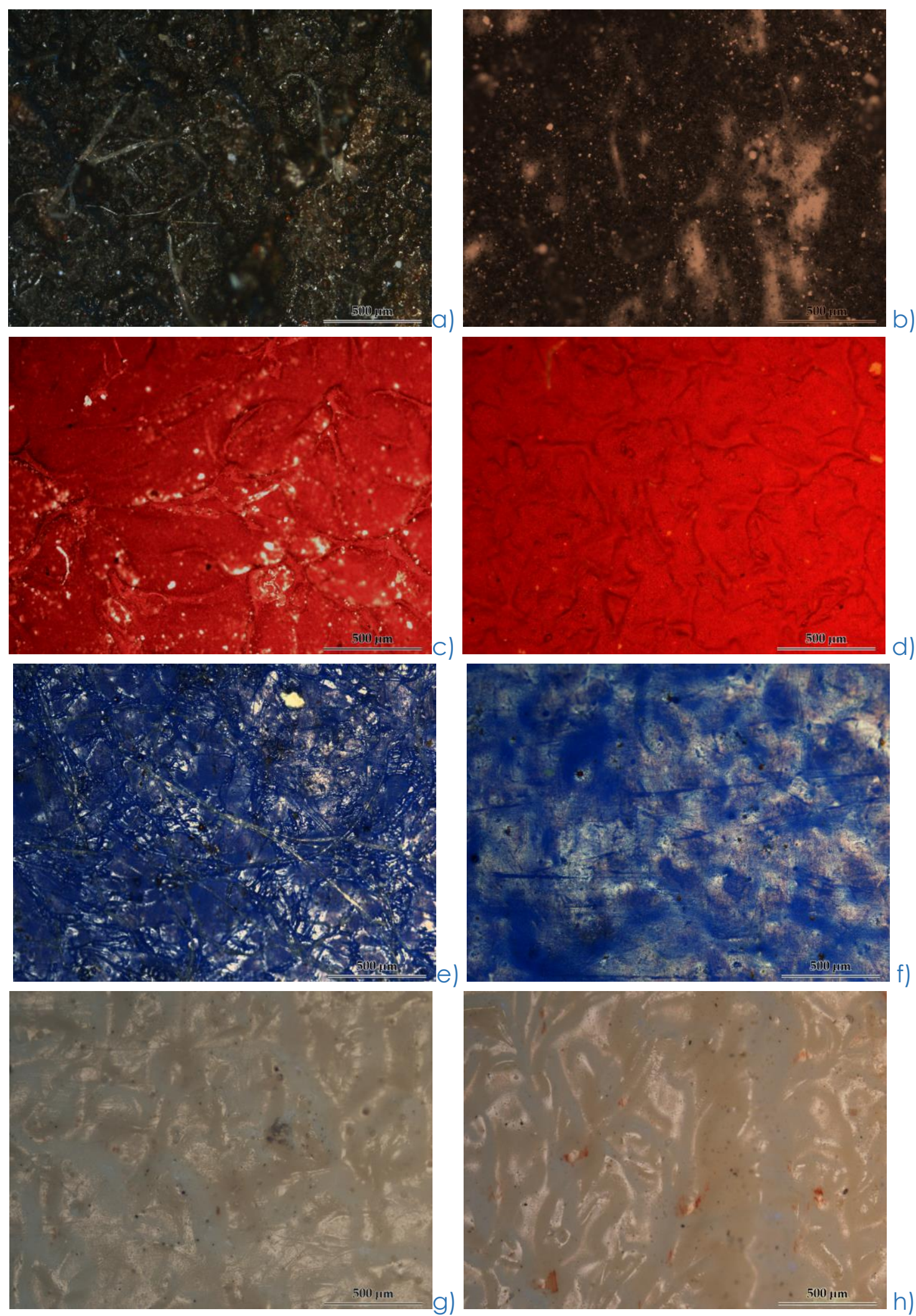

Figure 5.3.9. RTS of $K(4)$ and Bib Tengujo 240. Surfaces after the RTS removal (a, c, e, g) and after cleaning process $(b, d, f, h)$. 

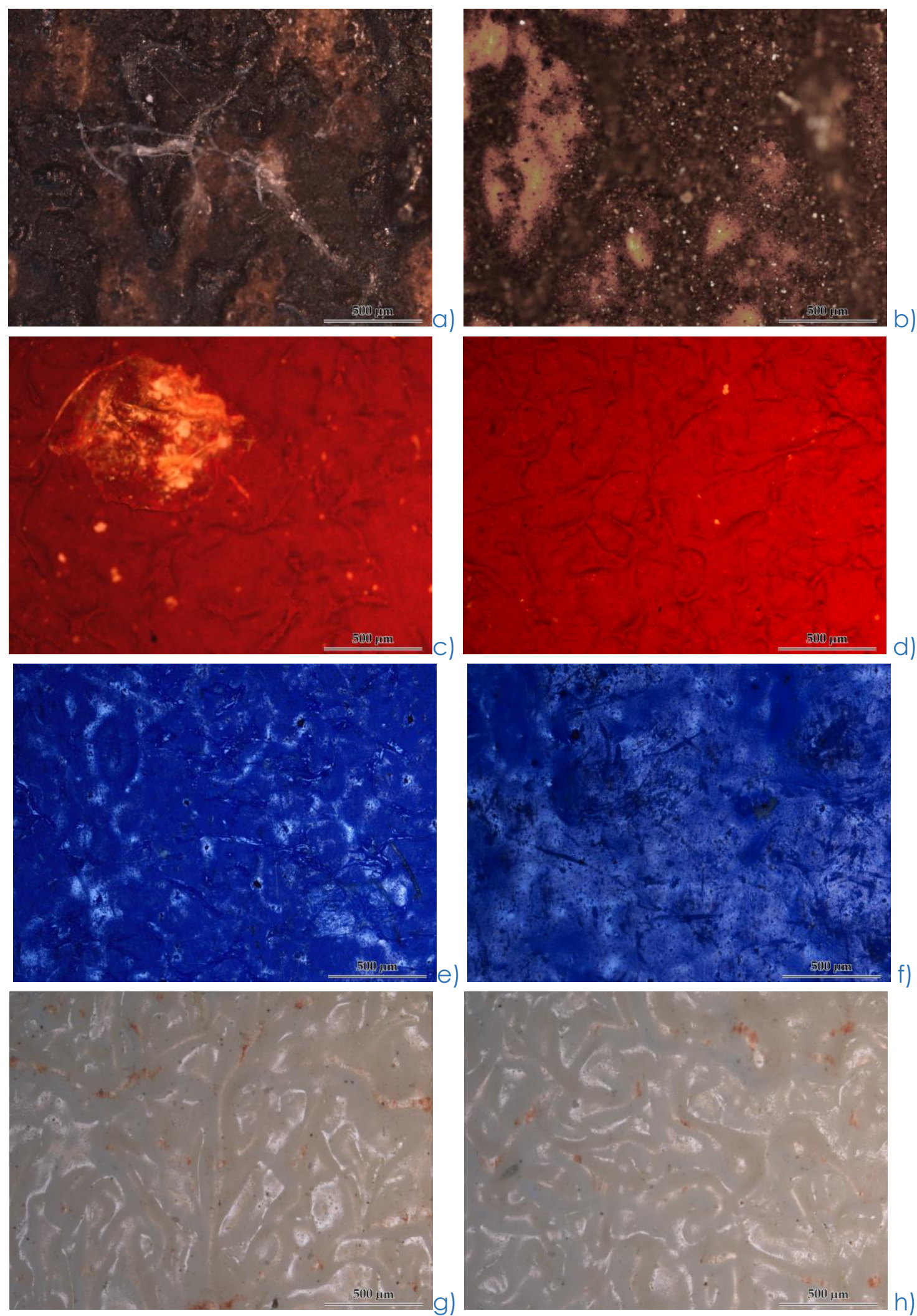

Figure 5.3.10. RTS of K(4) and English tissue. Surfaces after the RTS removal $(a, c, e, g)$ and after cleaning process $(b, d, f, h)$. 

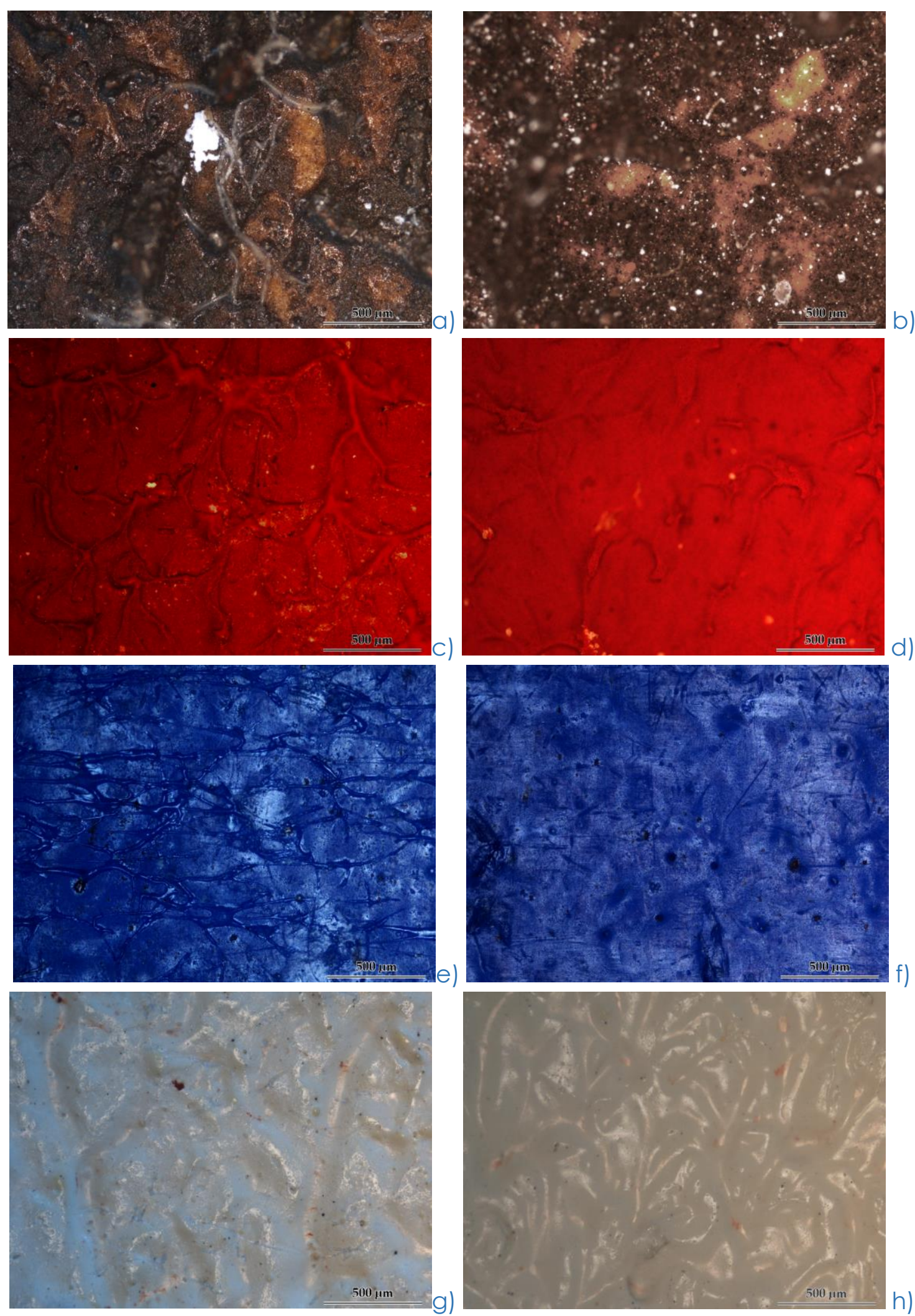

Figure 5.3.11. RTS of $K(4)$ and TNT30/B. Surfaces after the RTS removal (a, c, e, g) and after cleaning process $(b, d, f, h)$. 

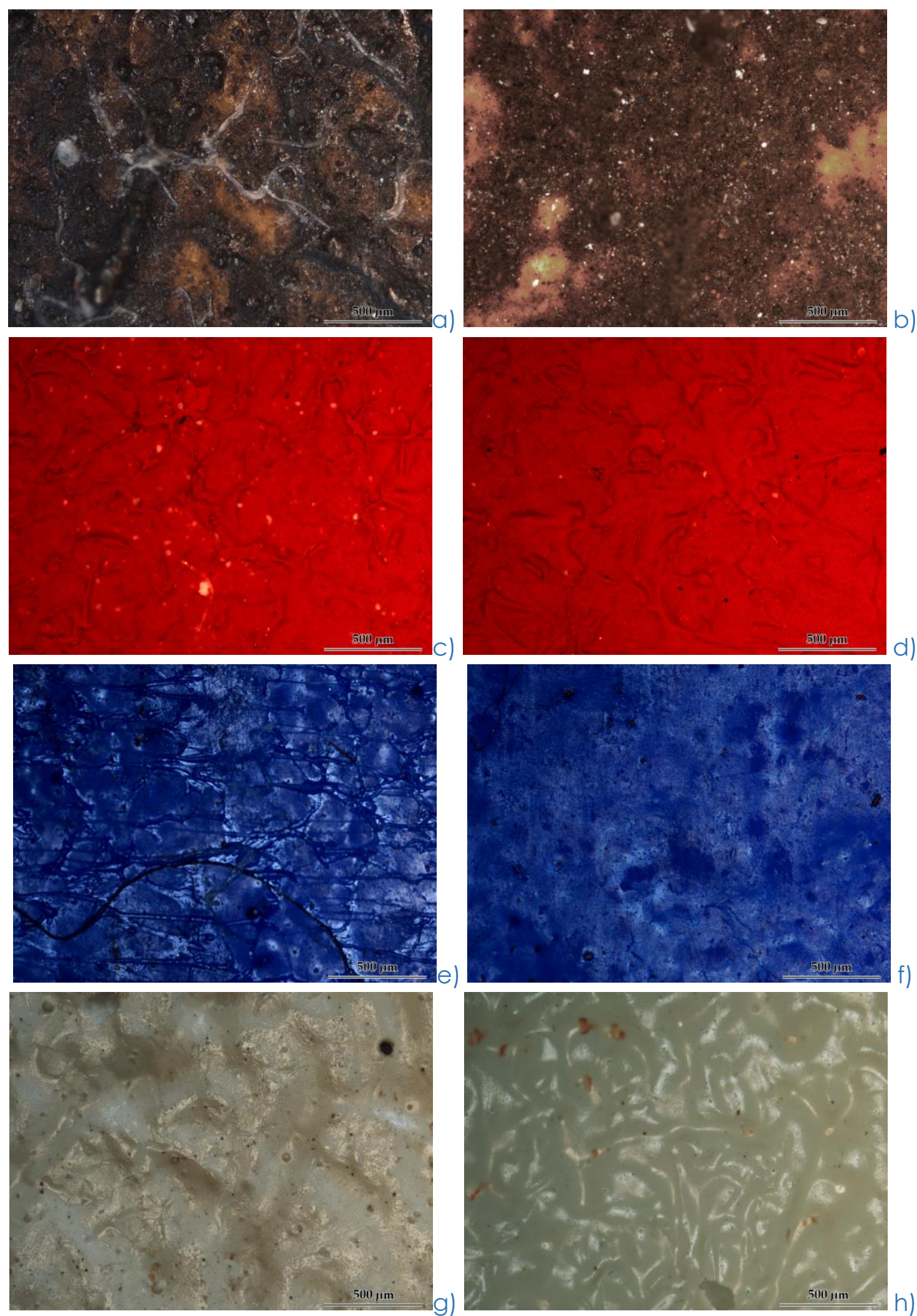

Figure 5.3.12. RTS of $K(4)$ and Holytex. Surfaces after the RTS removal (a, c, e, g) and after cleaning process $(b, d, f, h)$. 

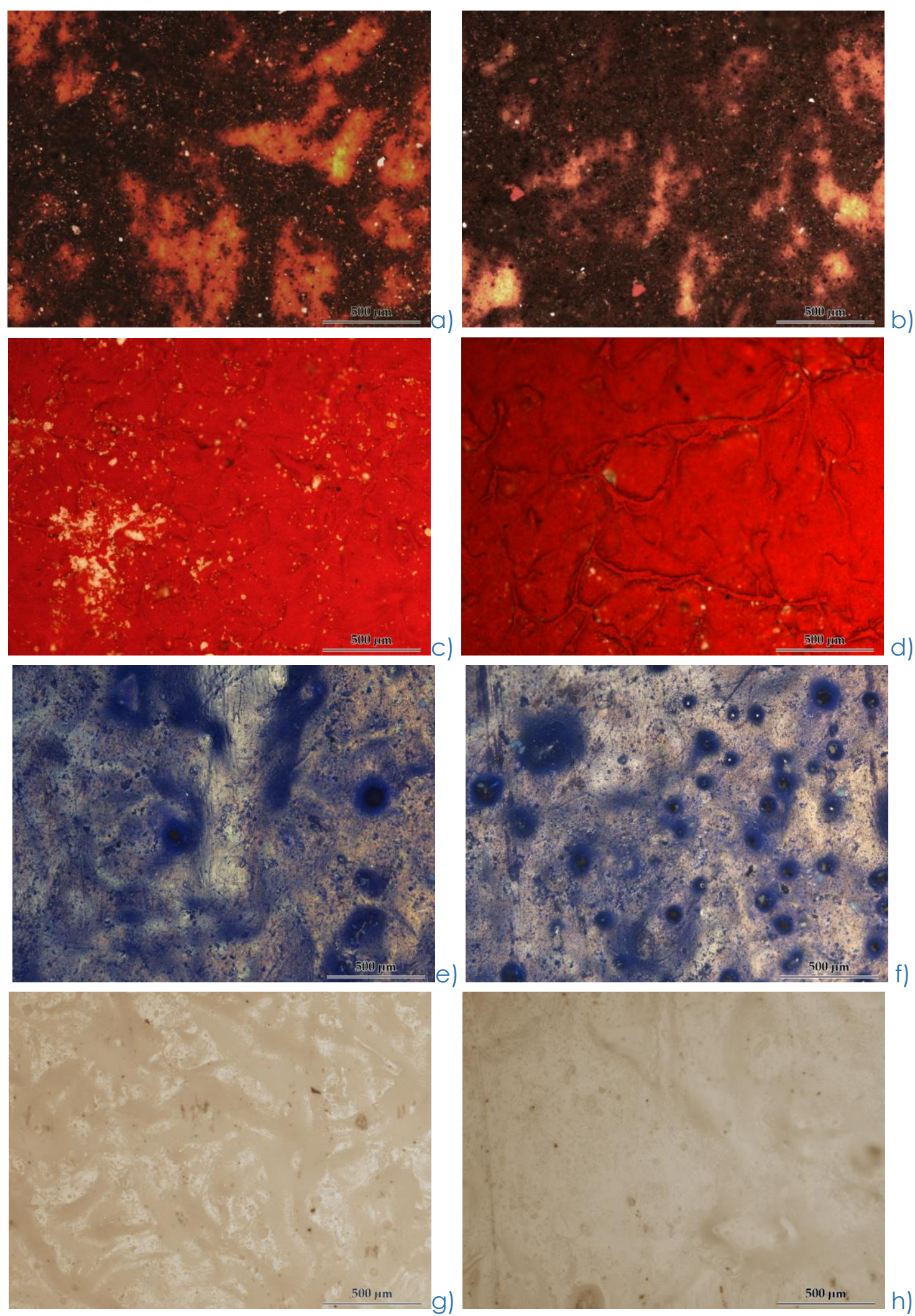

Figure 5.3.13. RTS of K(4)P7 and Bib Tengujo 240. Surfaces after the RTS removal (a, c, e, g) and after cleaning process (b, $d, f, h)$. 

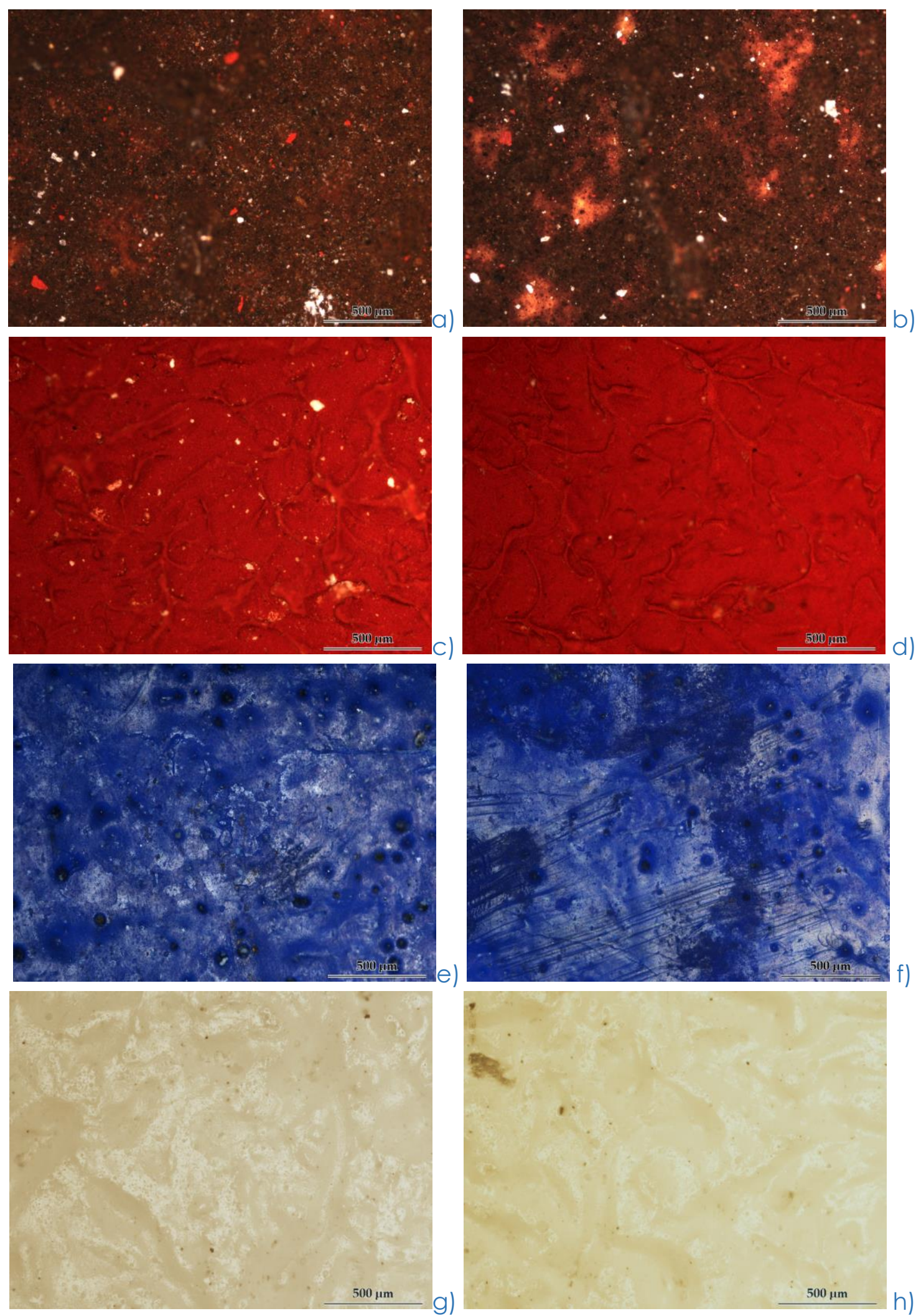

Figure 5.3.14. RTS of K(4)P7 and English tissue. Surfaces after the RTS removal (a, c, e, g) and after cleaning process $(b, d, f, h)$. 

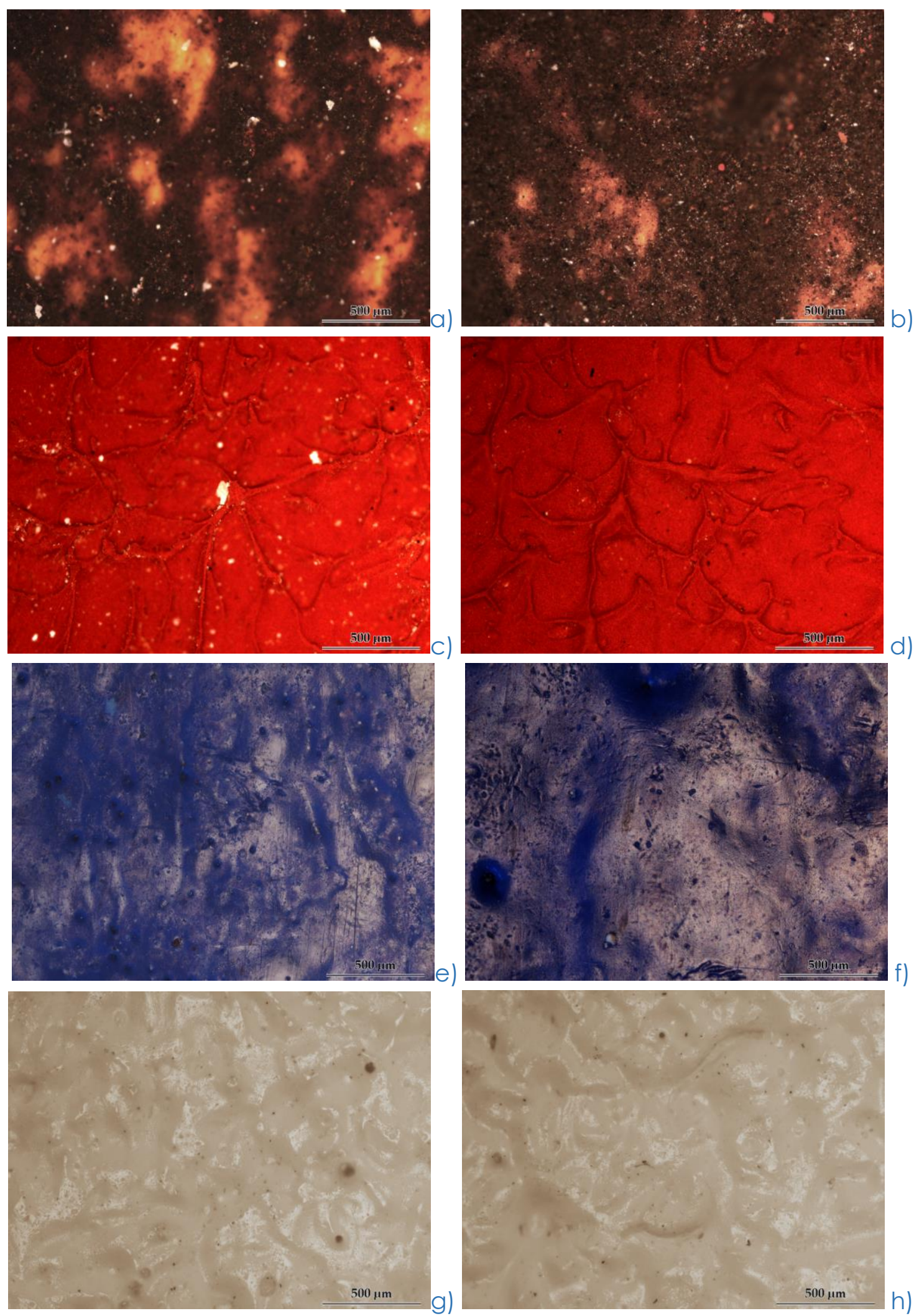

Figure 5.3.15. RTS of K(4)P7 and TNT30/B. Surfaces after the RTS removal (a, c, e, g) and after cleaning process $(b, d, f, h)$. 

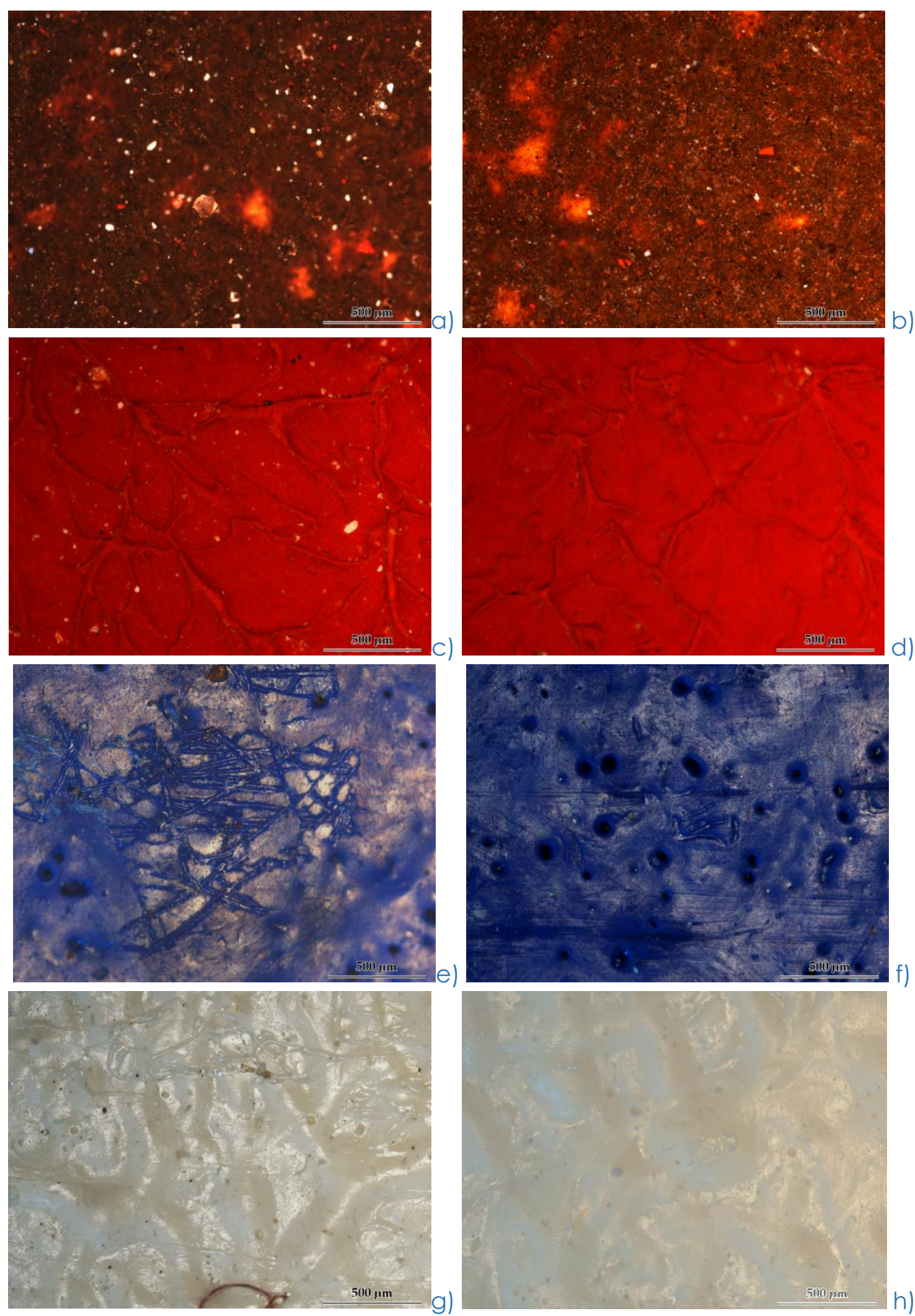

Figure 5.3.16. RTS of K(4)P7 and Holytex. Surfaces after the RTS removal (a, c, e, g) and after cleaning process $(b, d, f, h)$. 

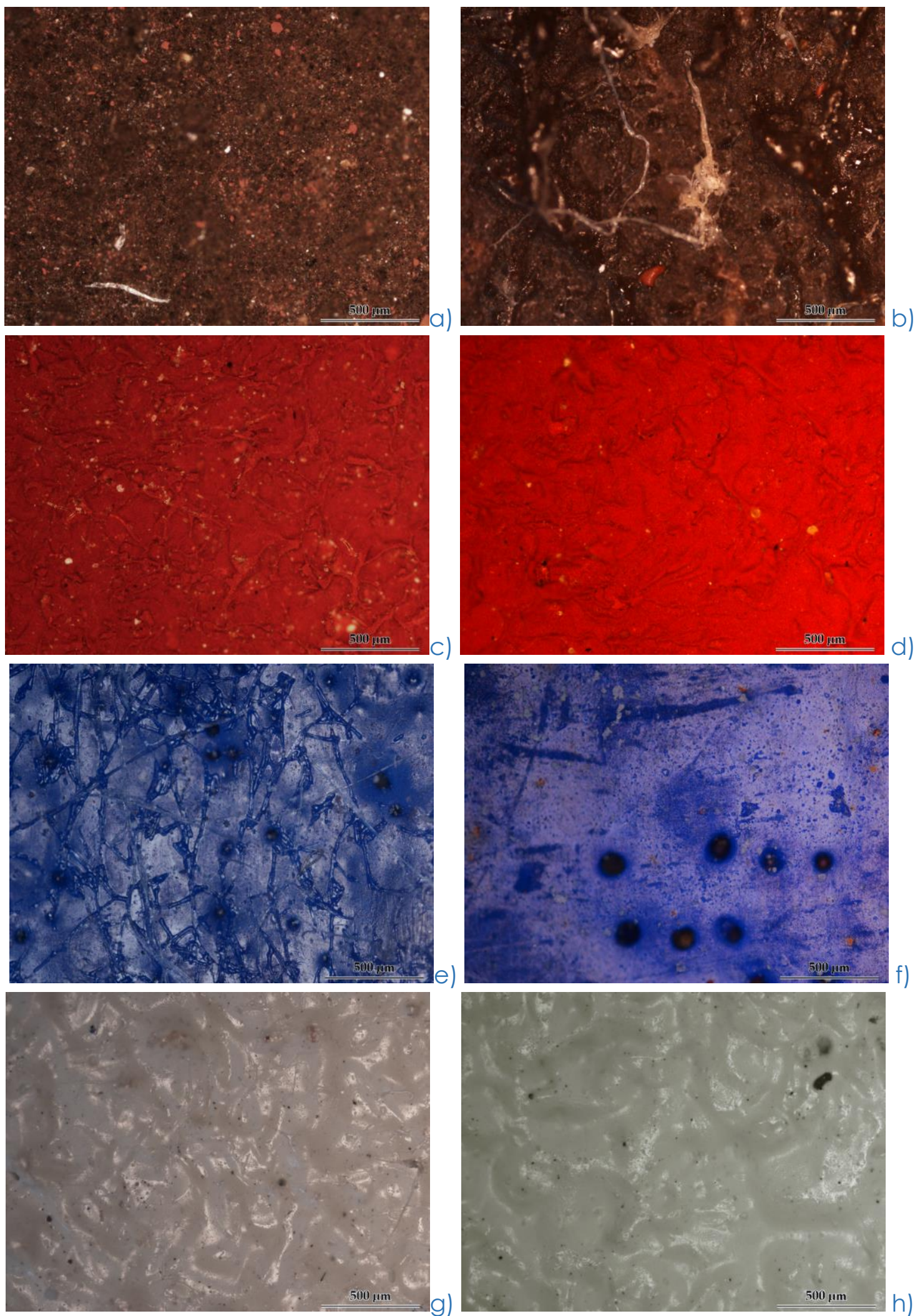

Figure 5.3.17. RTS of A(5)E and Bib Tengujo 240. Surfaces after the RTS removal (a, c, e, g) and after cleaning process $(b, d, f, h)$. 

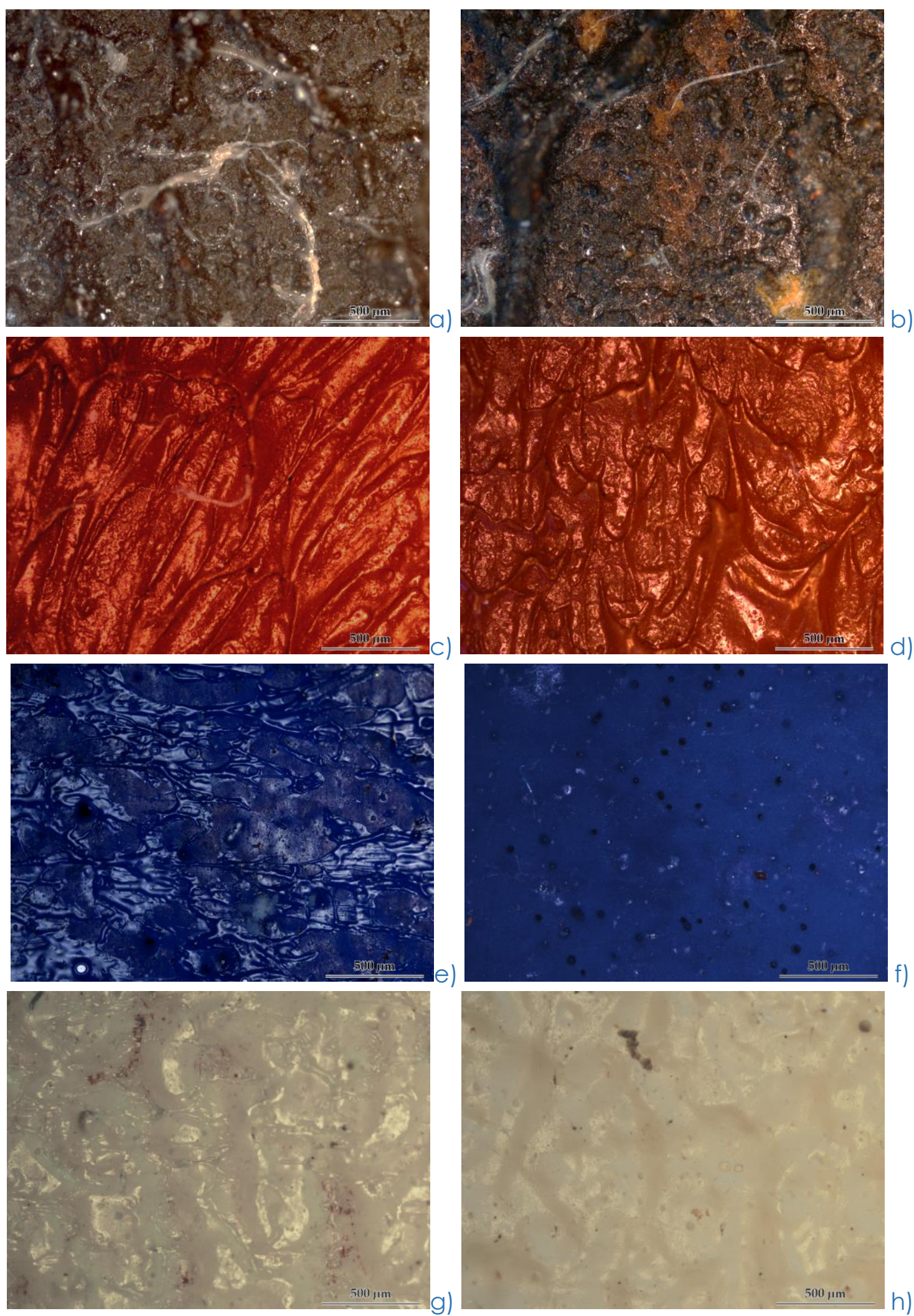

Figure 5.3.18. RTS of A(5)E and English tissue. Surfaces after the RTS removal $(a, c, e, g)$ and after cleaning process (b, d, f, h). 

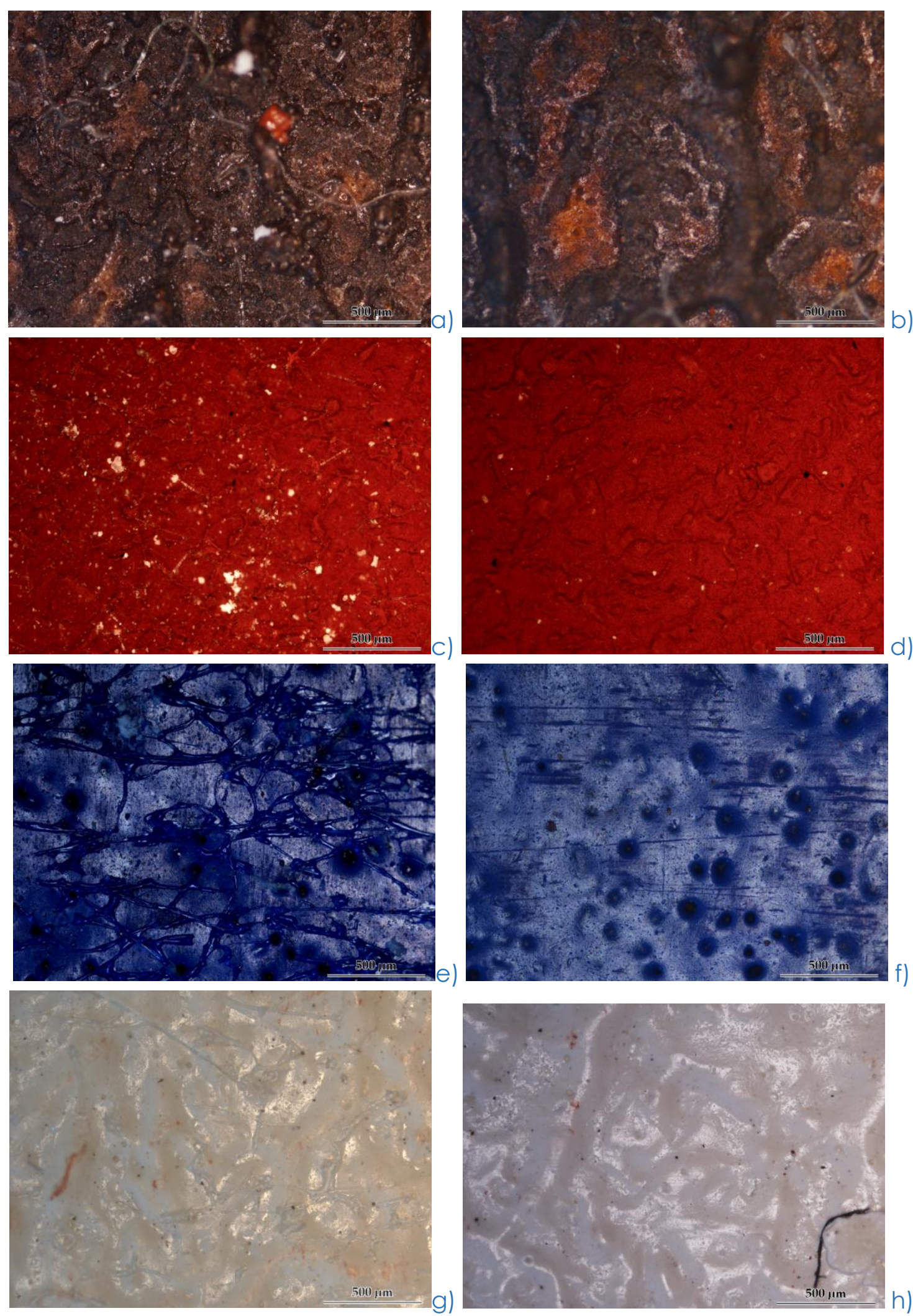

Figure 5.3.19. RTS of A(5)E and TNT30/B. Surfaces after the RTS removal (a, c, e, g) and after cleaning process $(b, d, f, h)$. 

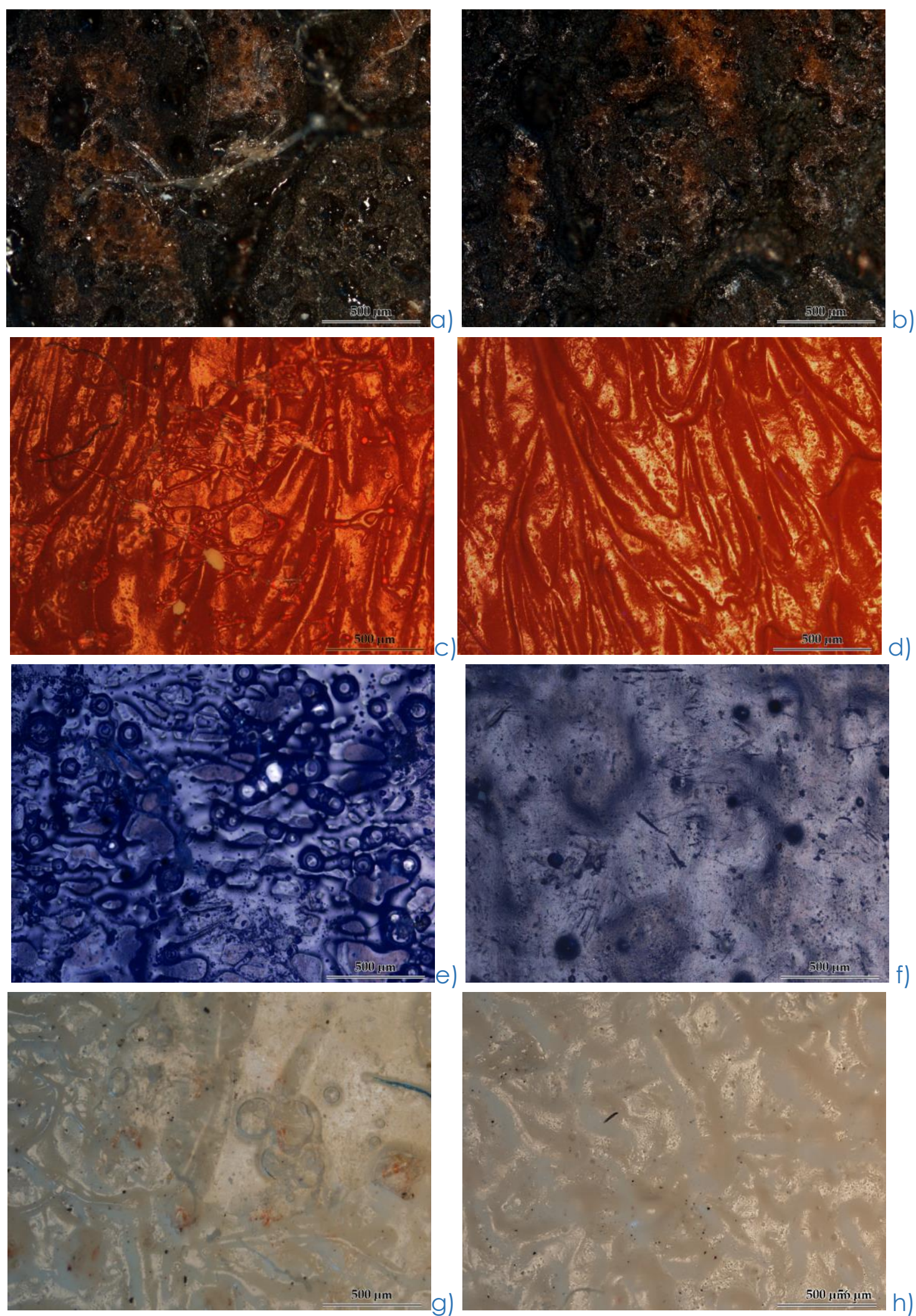

Figure 5.3.20. RTS of A(5)E and Holytex. Surfaces after the RTS removal (a, c, e, g) and after cleaning process $(b, d, f, h)$. 

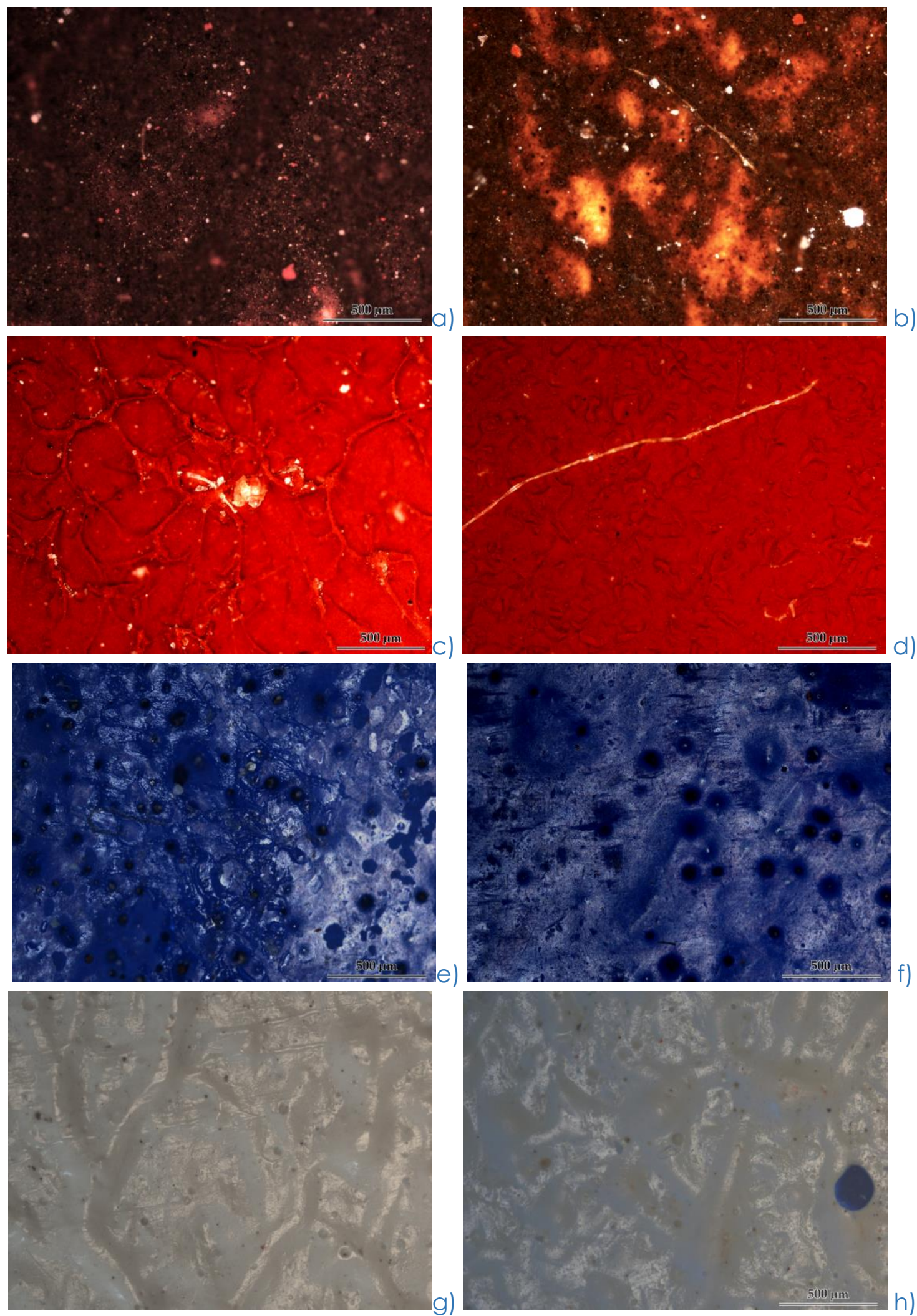

Figure 5.3.21. RTS of K(3)A(4)E and Bib Tengujo 240. Surfaces after the RTS removal $(a, c, e, g)$ and after cleaning process $(b, d, f, h)$. 

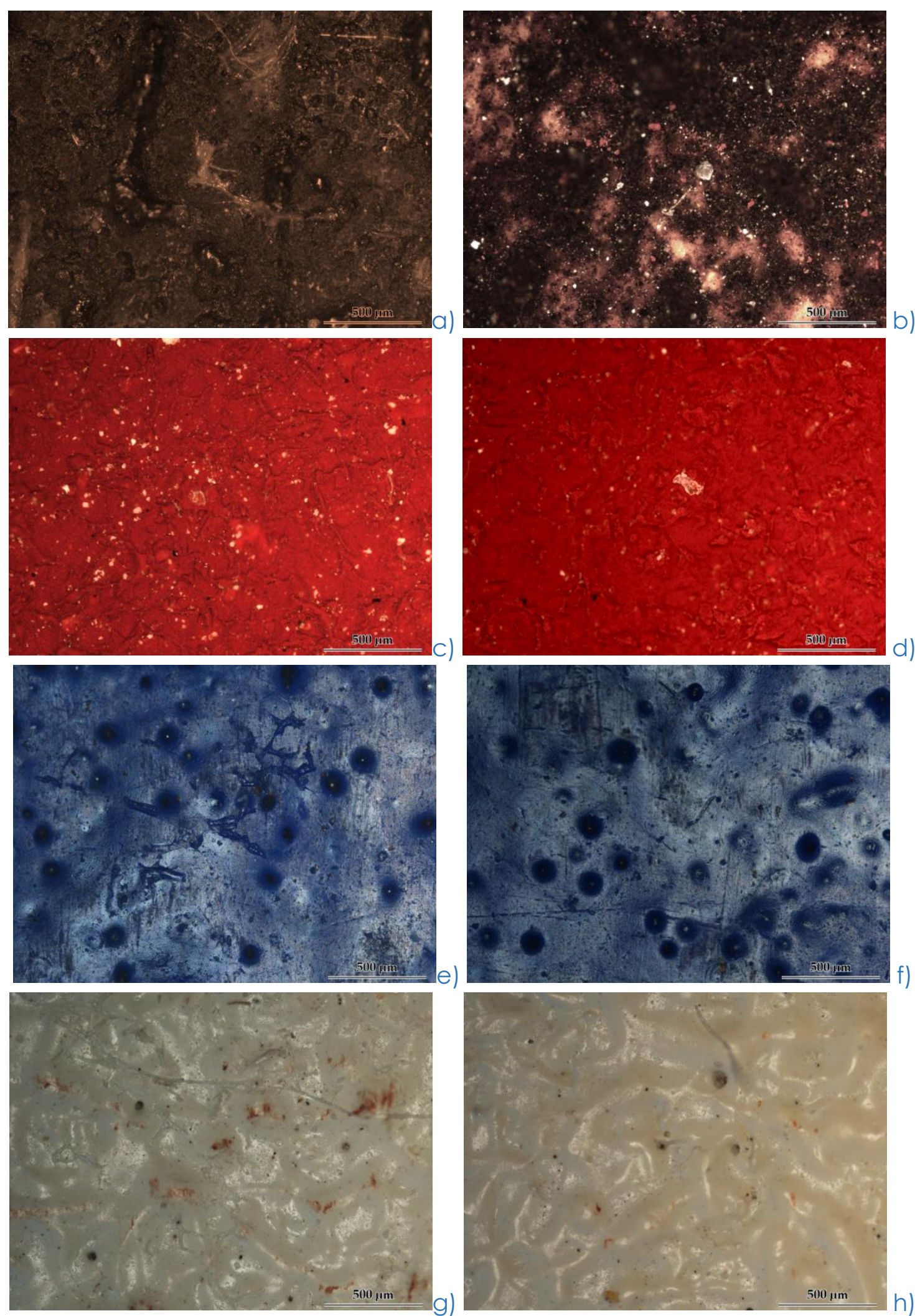

Figure 5.3.22. RTS of K(3)A(4)E and English tissue. Surfaces after the RTS removal (a, c, e, g) and after cleaning process $(b, d, f, h)$. 

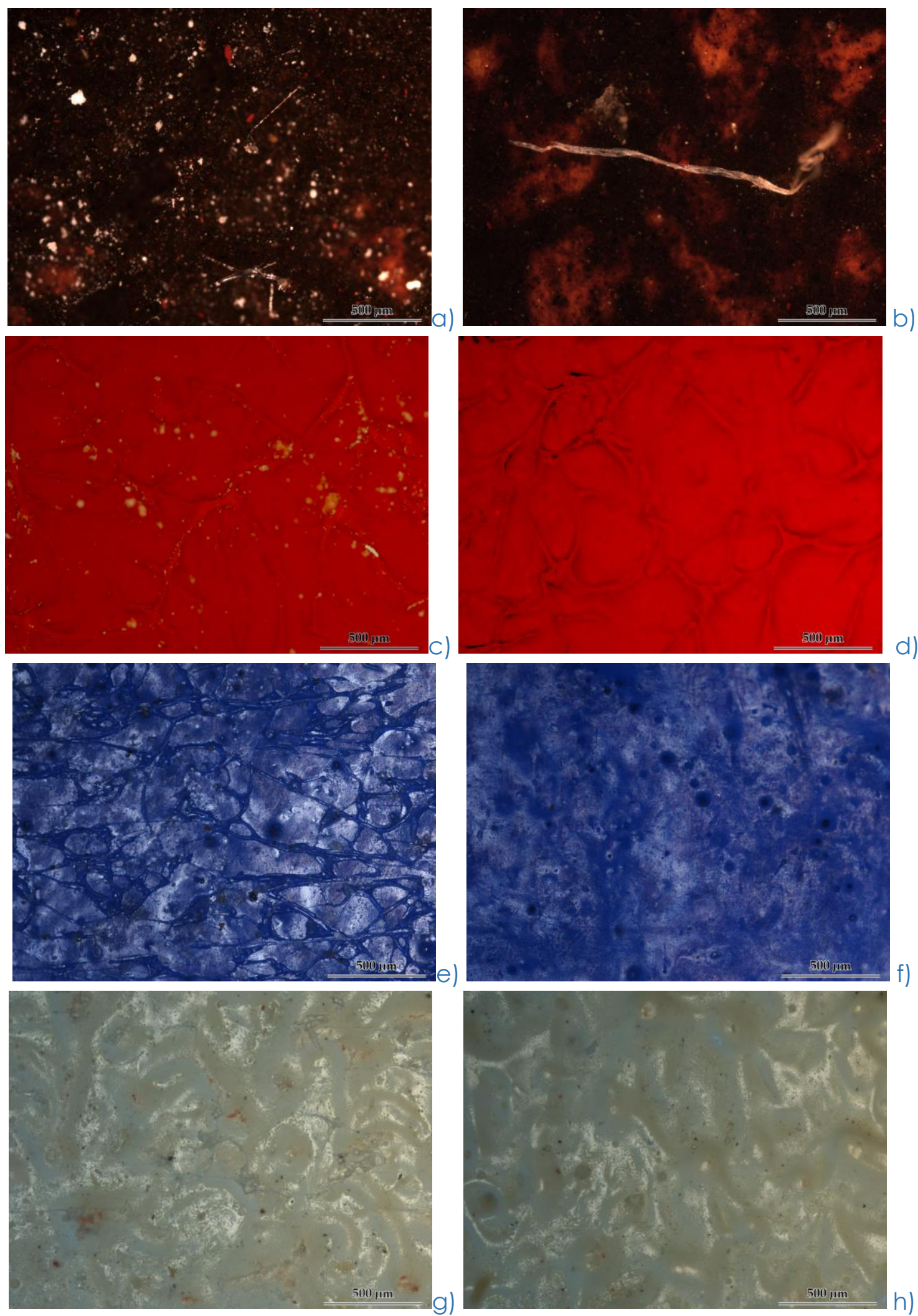

Figure 5.3.23. RTS of $K(3) A(4) E$ and TNT30/B. Surfaces after the RTS removal $(a, c, e, g)$ and after cleaning process $(b, d, f, h)$. 

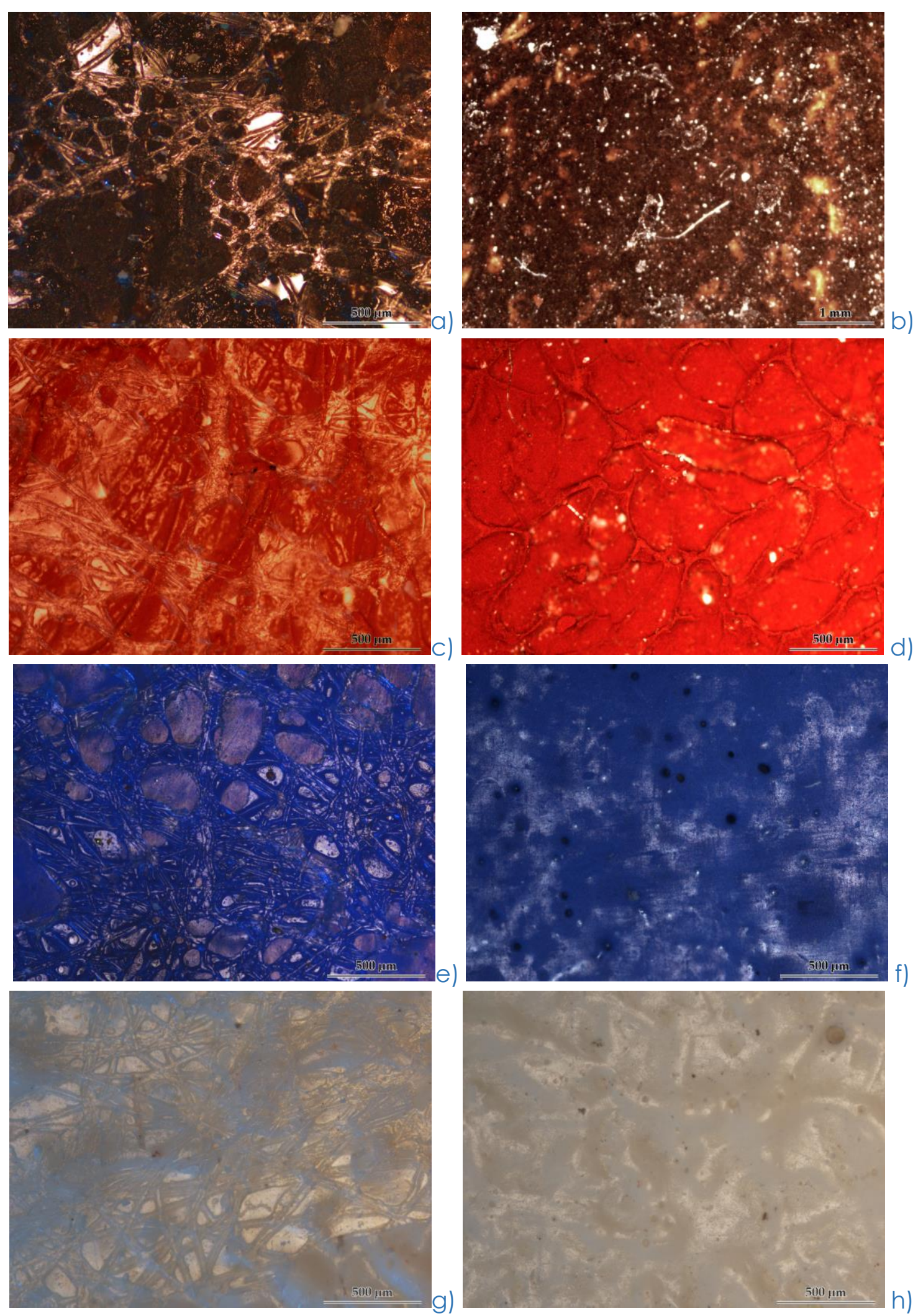

Figure 5.3.24. RTS of K(3)A(4)E and Holytex. Surfaces after the RTS removal (a, c, e, g) and after cleaning process $(b, d, f, h)$. 


\subsubsection{Results of the observation of the second set of specimens with UV/visible light optical microscopy}

Considering all the above mentioned discussion, it was decided to select T(3)P7, $\mathrm{K}(4) \mathrm{P7}$ and $\mathrm{K}(3) \mathrm{A}(4) \mathrm{E}$ as adhesive dispersions, and English tissue and TNT B/30 as temporary supports for the next step of the investigation.

The cracked specimens were observed at optical microscope with UV/visible light after the RTS removal and after the cleaning with the buffer solution. The analysis was focused to the identification of the presence of residues of the adhesives and the fibres of the temporary supports in the cracks of the paint layer. The use of the UV light was a useful instrument for this purpose. However, it was associated to the observation with visible light, since the fluorescence of the adhesives was not too high and it could be confused with the coating layer.

The results of this second step of specimens confirmed in broad terms the results obtained from the first observation with optical microscope in visible light. On the specimen faced with the RTS made with T(3)P7 (Fig. 5.3.25/28) and with both English tissue and TNT B/30 few adhesive residues were found.in some rare exceptions, as it is possible to see in the picture taken from the raw sienna specimens faced with English tissue, there were found residues of the temporary support. A very small amount of adhesive penetrated in the cracks, and just in some spotted areas. However, as already detected with the first observation, only a part of this few residues was removed after the cleaning with the buffer solution.

In the case of the RTS of K(4)P7 (Fig. 5.3.29/32), a lower quantity of adhesive was found on the specimens faced with TNT 30/B . In general, a slightly higher amount of residues with respect to specimens faced with T(3)P7 was found. The adhesive penetrated in some cracks, but just in some points. In some cases, filamentous bridges of adhesive were found in cracks cavity. However, the residues on the surface of the specimens seemed to be efficiently removed after the cleaning process, while the adhesive in the cracks was only partially removed.

As observed for the first set of specimens, the quantity of adhesive residues left by the RTS of K(3)A(4)E (Fig. 5.3.33/36) made with English tissue was lower than that left by those of TNT30/B. However, the residues left on the surface are clearly more than that left by the other two adhesive, even if their amount was still considered acceptable. As for K(4)P7 RTS, in the cracks there were found few residves in form of filamentous bridges. On some few specimens, especially on those of cobalt blue and titanium white which had a smother surface, there were found some adhesive agglomerations with the shape of small plates. However, these agglomerations were only superficial. After the cleaning process they were totally removed in almost all cases, without penetrating in the cracks. In general, the adhesive was found to be highly reversible.

For all the RTS tested, it was noticed that those prepared with English tissue left a higher amount of fibres on the specimens compared to TNT 30/B. 

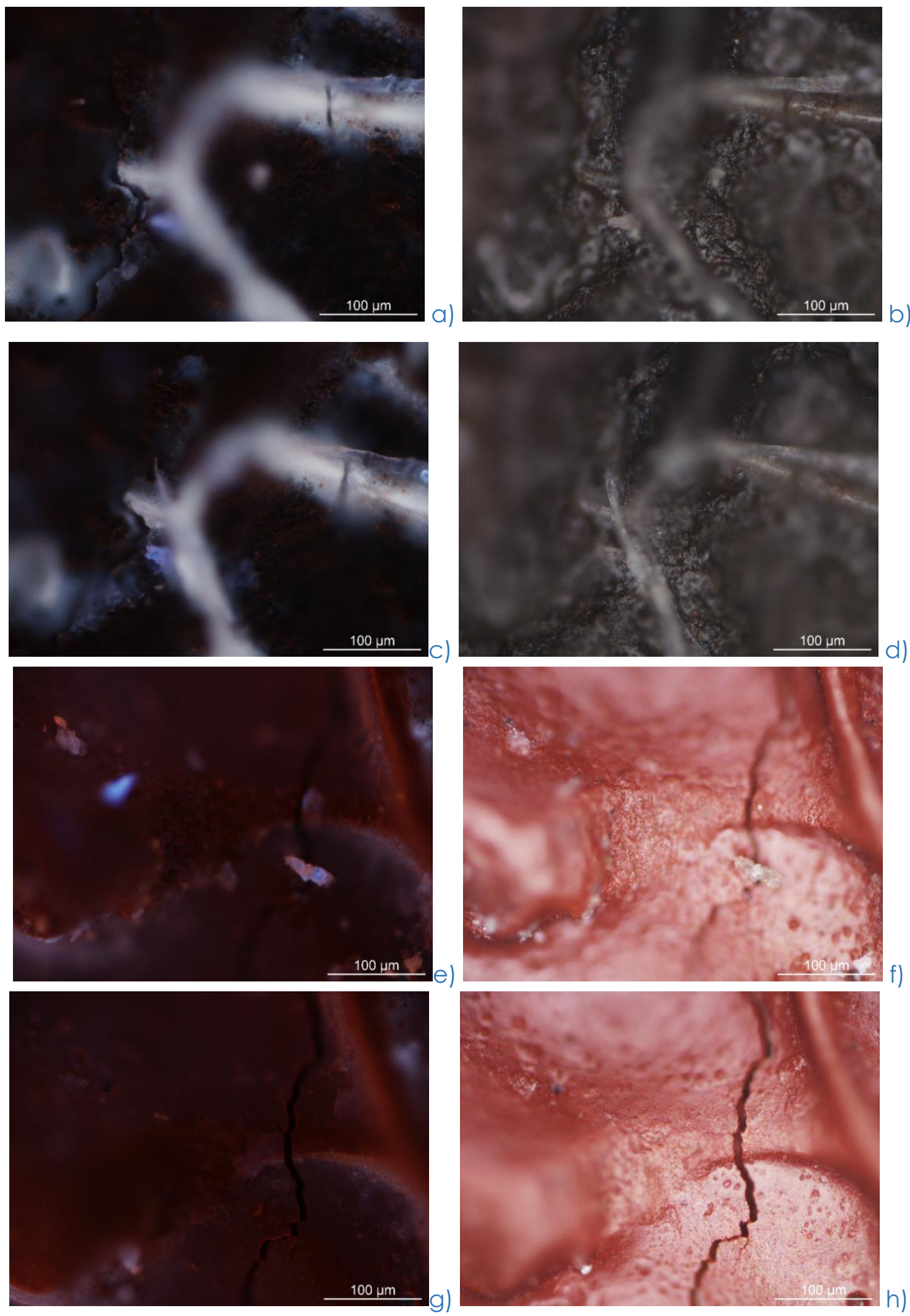

Figure 5.3.25. RTS of T(3)P7 and English tissue applied on Raw Sienna and Iron oxide red. Surfaces after the RTS removal: UV light $(a, e)$, visible light $(b, f)$; surfaces after cleaning process: UV light $(c, g)$, visible light $(d, h)$. 

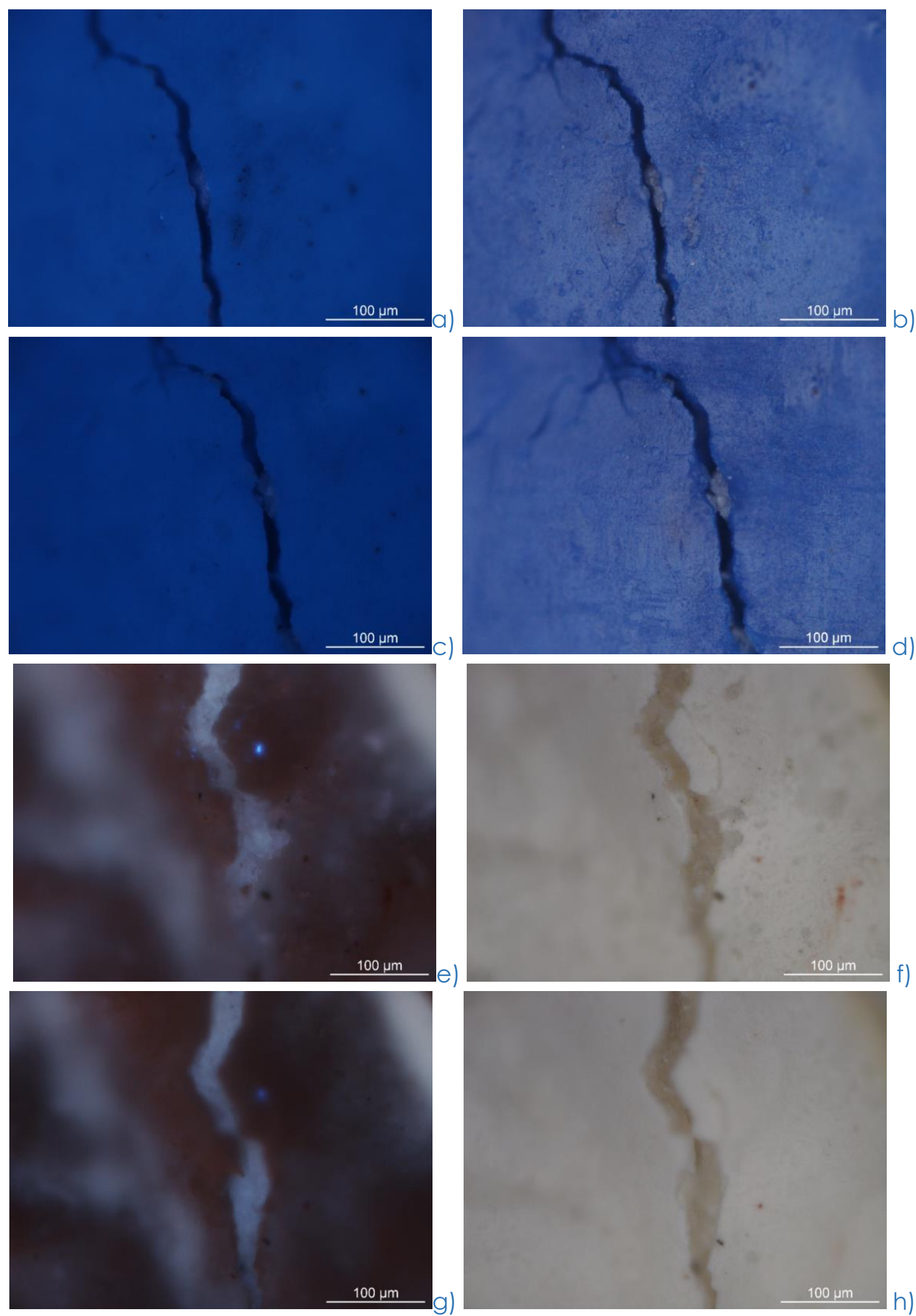

Figure 5.3.26. RTS of T(3)P7 and English tissue applied on Cobalt Blue and Titanium White. Surfaces after the RTS removal: UV light $(a, e)$, visible light $(b, f)$; surfaces after cleaning process: UV light (c, g), visible light $(d, h)$. 

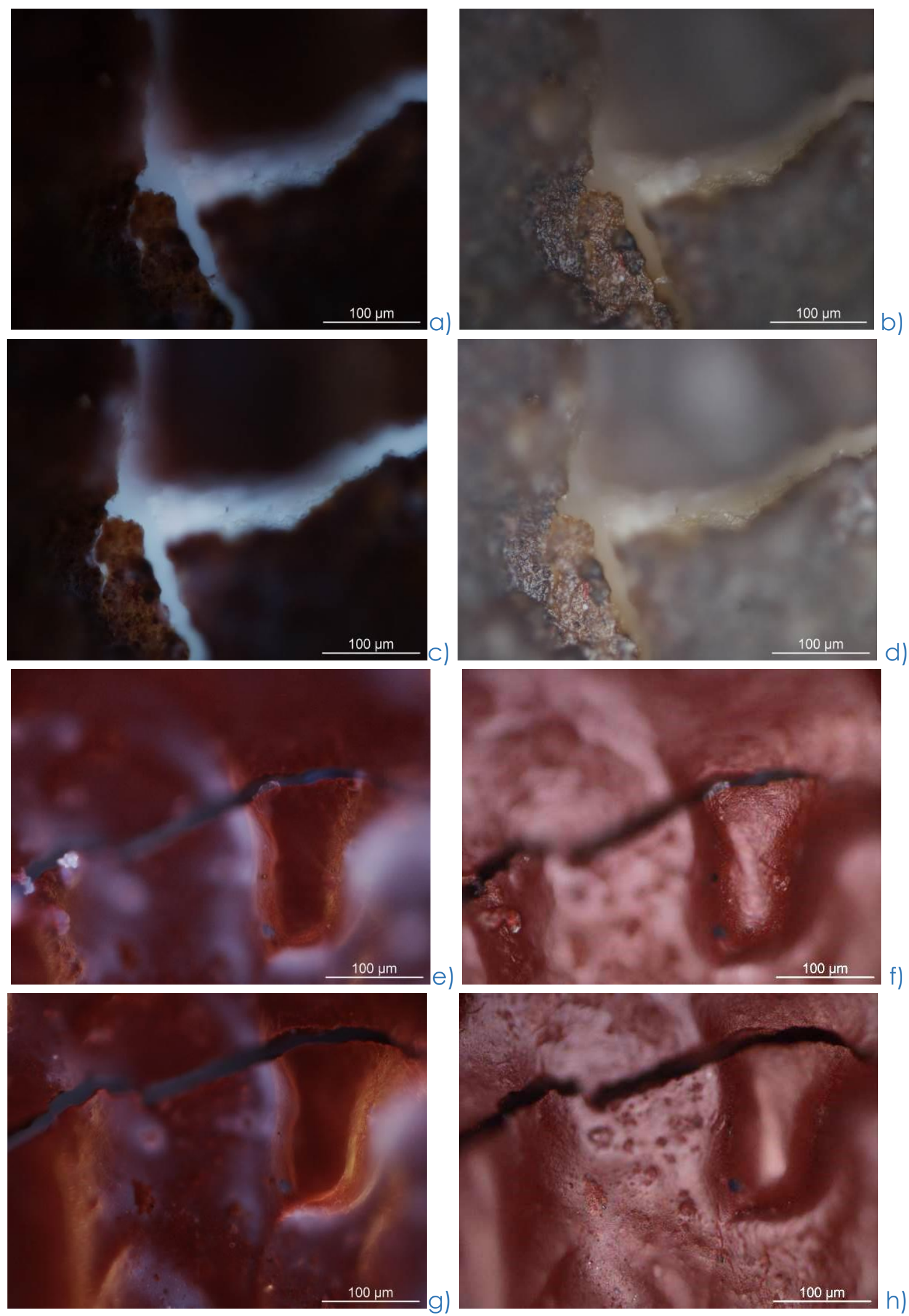

Figure 5.3.27. RTS of T(3)P7 and TNT 30/B applied on Raw Sienna and Iron oxide red. Surfaces after the RTS removal: UV light $(a, e)$, visible light $(b, f)$; surfaces after cleaning process: UV light (c, a), visible light $(d, h)$. 

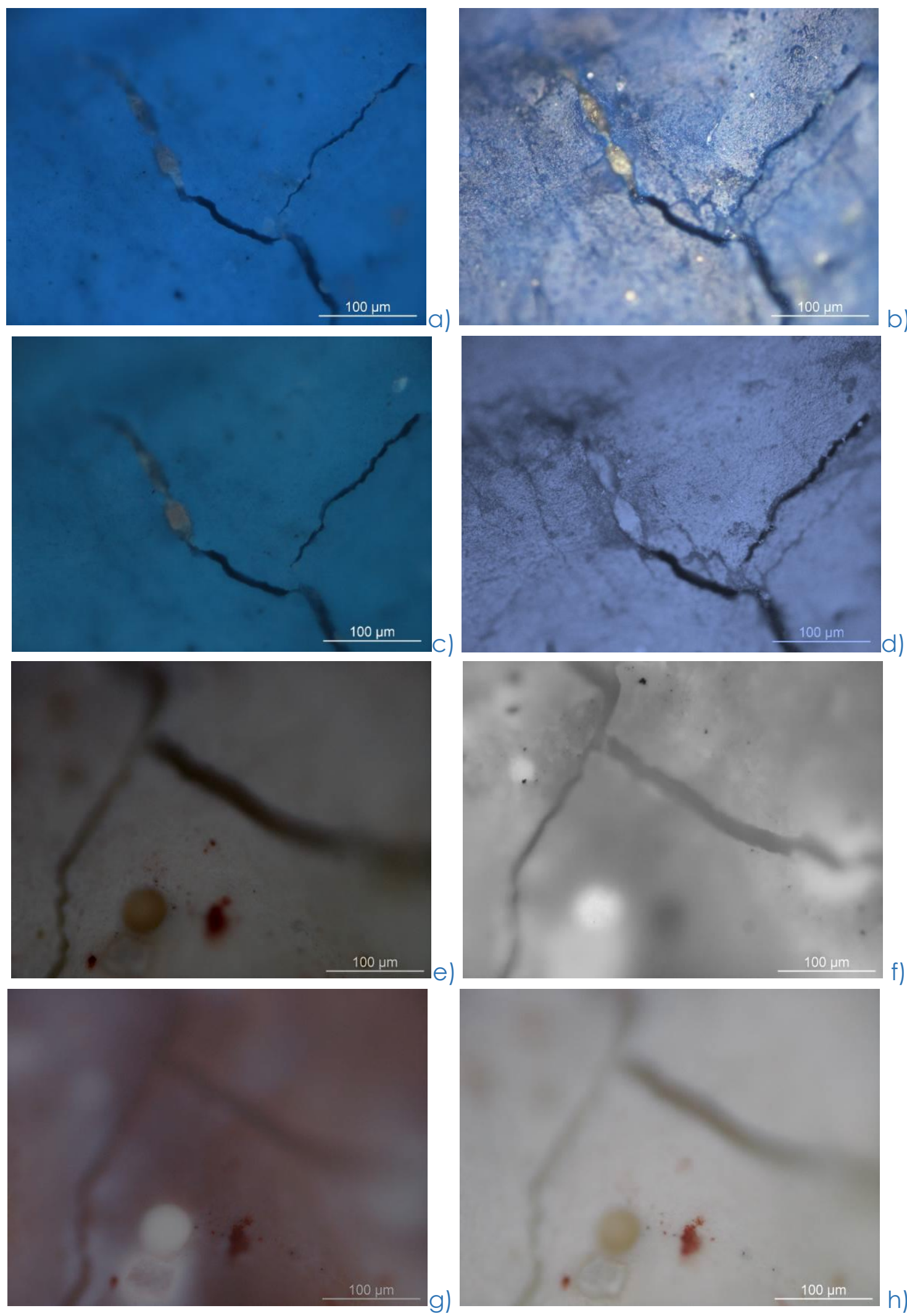

Figure 5.3.28. RTS of T(3)P7 and TNT 30/B applied on Cobalt Blue and Titanium White. Surfaces after the RTS removal: UV light $(a, e)$, visible light $(b, f)$; surfaces after cleaning process: UV light (c, g), visible light $(d, h)$. 

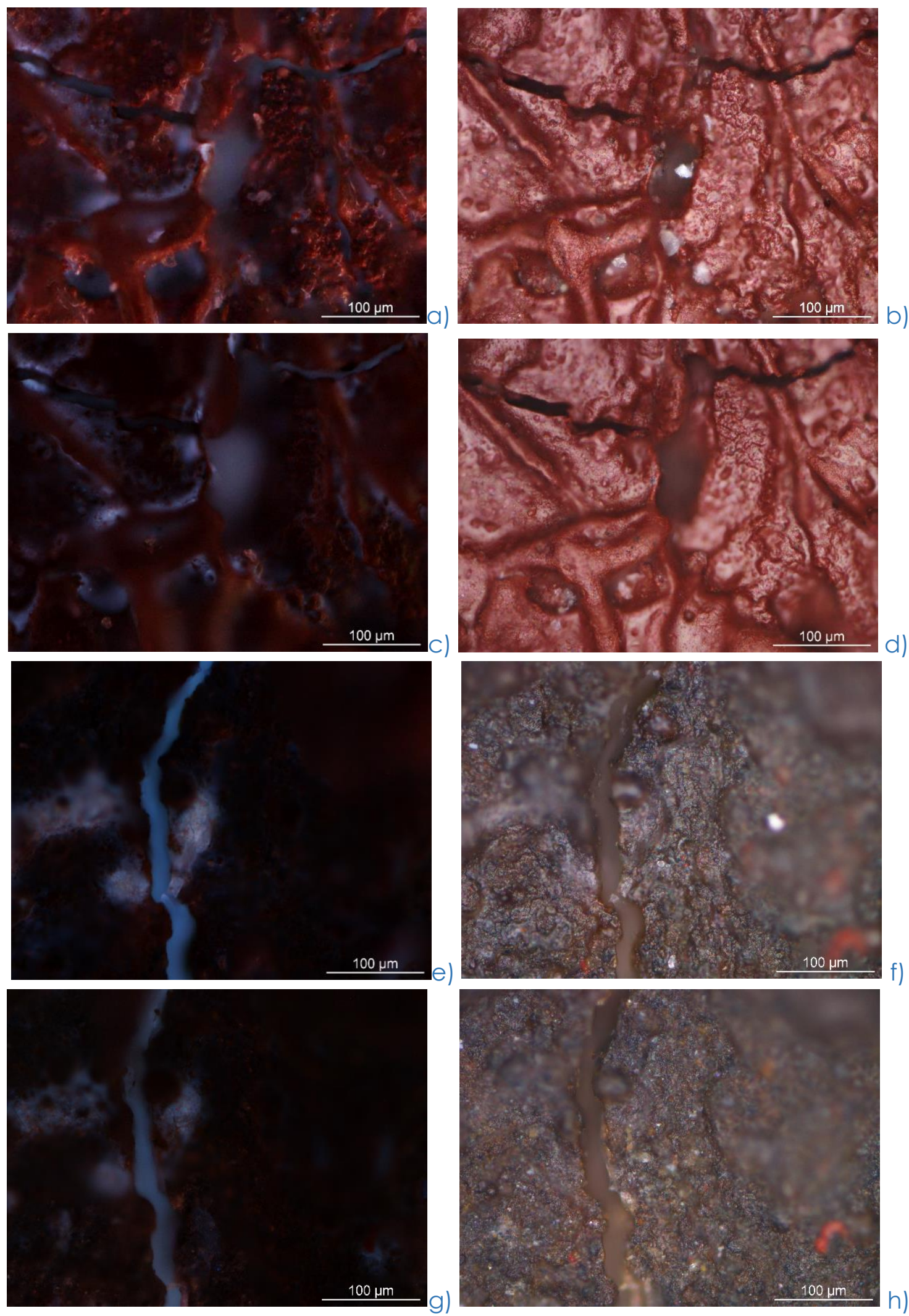

Figure 5.3.29. RTS of K(4)P7 and English tissue applied on Raw Sienna and Iron oxide red. Surfaces after the RTS removal: UV light $(a, e)$, visible light $(b, f)$; surfaces after cleaning process: UV light $(c, g)$, visible light $(d, h)$. 

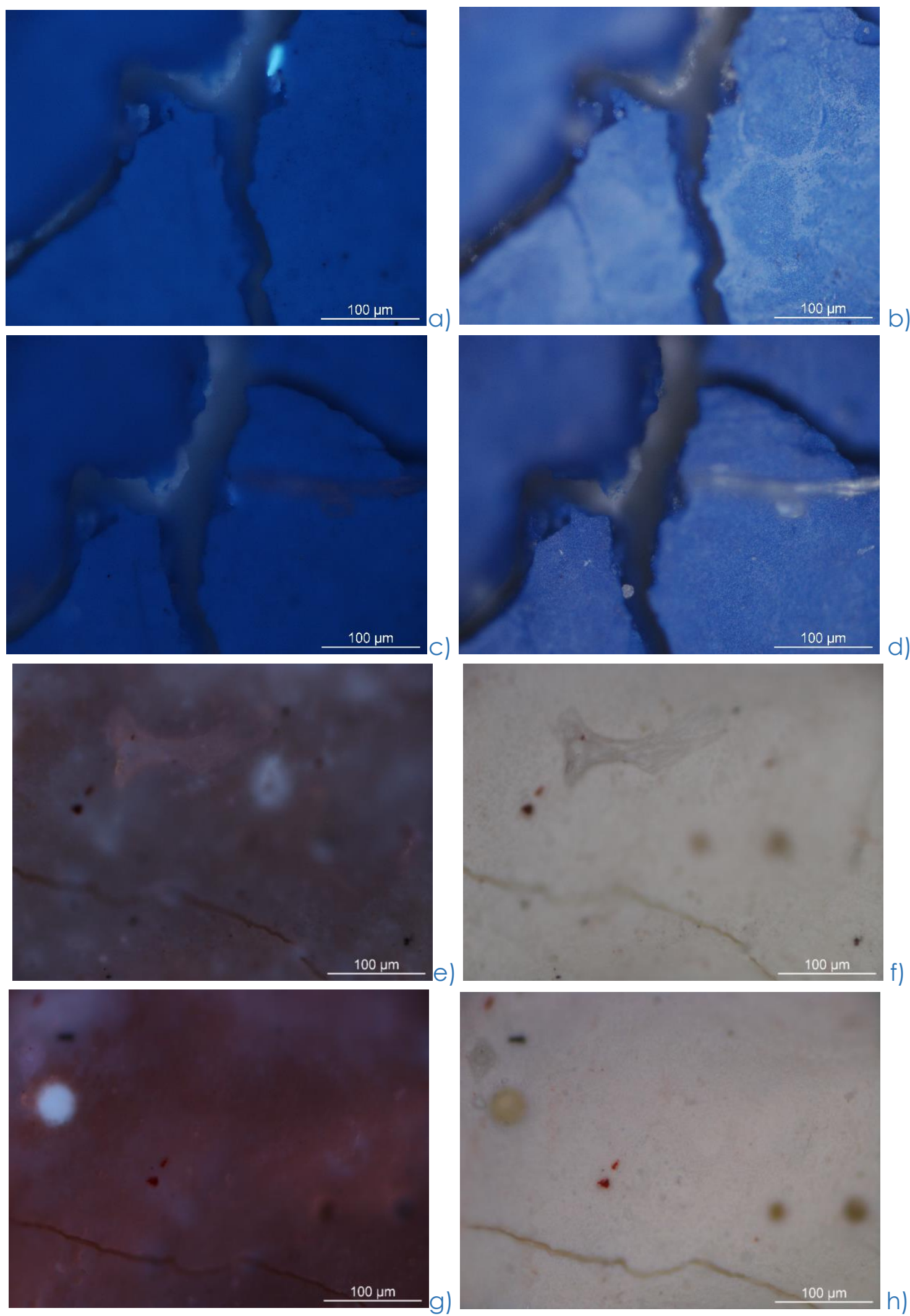

Figure 5.3.30. RTS of K(4)P7 and English tissue applied on Cobalt Blue and Titanium White. Surfaces after the RTS removal: UV light $(a, e)$, visible light $(b, f)$; surfaces after cleaning process: UV light $(c, g)$, visible light $(d, h)$. 

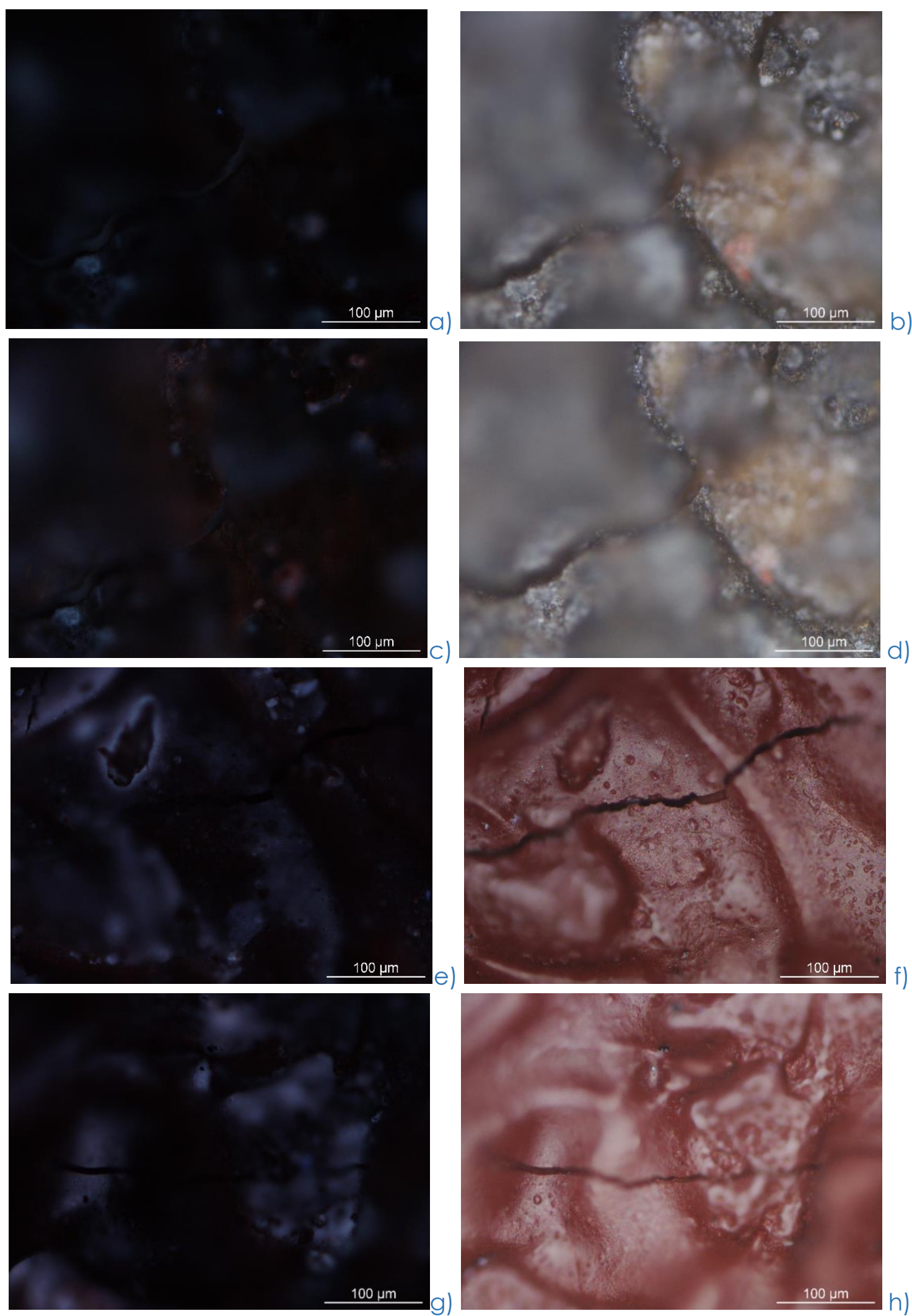

Figure 5.3.31. RTS of K(4)P7 and TNT 30/B applied on Raw Sienna and Iron oxide red. Surfaces after the RTS removal: UV light $(a, e)$, visible light $(b, f)$; surfaces after cleaning process: UV light $(c, g)$, visible light $(d, h)$. 

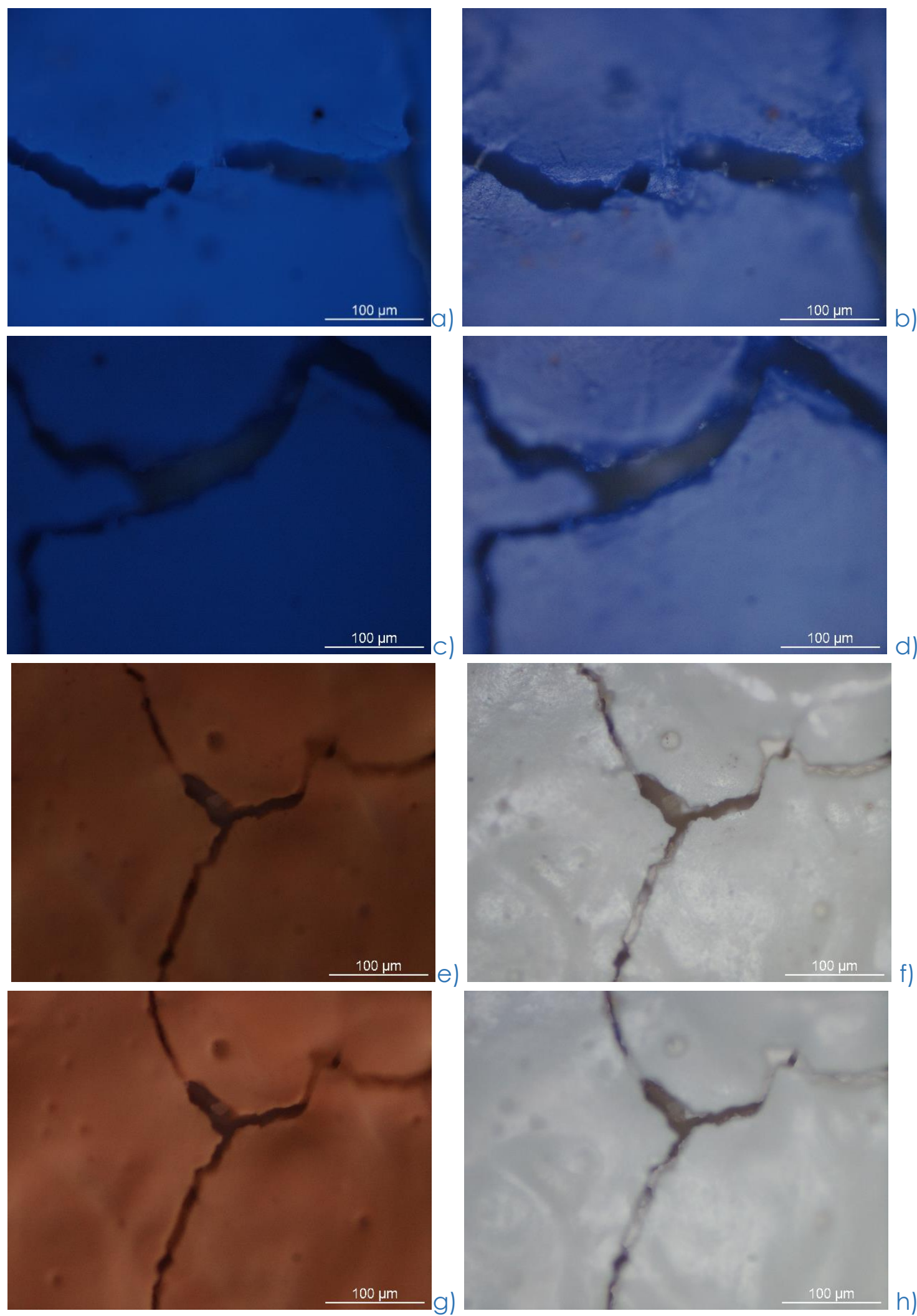

Figure 5.3.32. RTS of K(4)P7 and TNT 30/B applied on Cobalt Blue and Titanium White. Surfaces after the RTS removal: UV light $(a, e)$, visible light $(b, f)$; surfaces after cleaning process: UV light (c, g), visible light (d, h). 

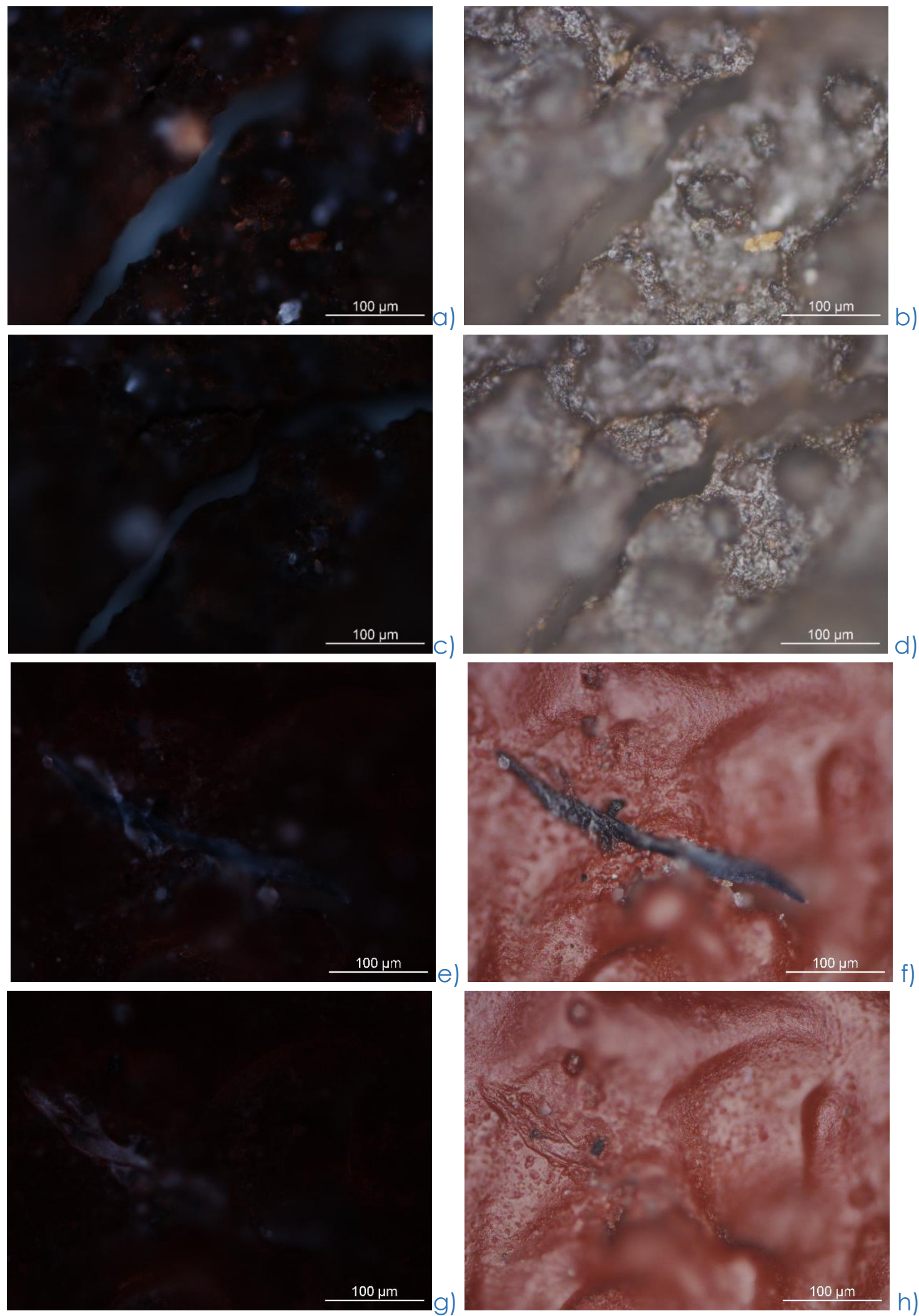

Figure 5.3.33. RTS of K(3) A(4)E and English tissue applied on Raw Sienna and Iron oxide red. Surfaces after the RTS removal: UV light $(a, e)$, visible light $(b, f)$; surfaces after cleaning process: UV light (c, g), visible light $(d, h)$. 

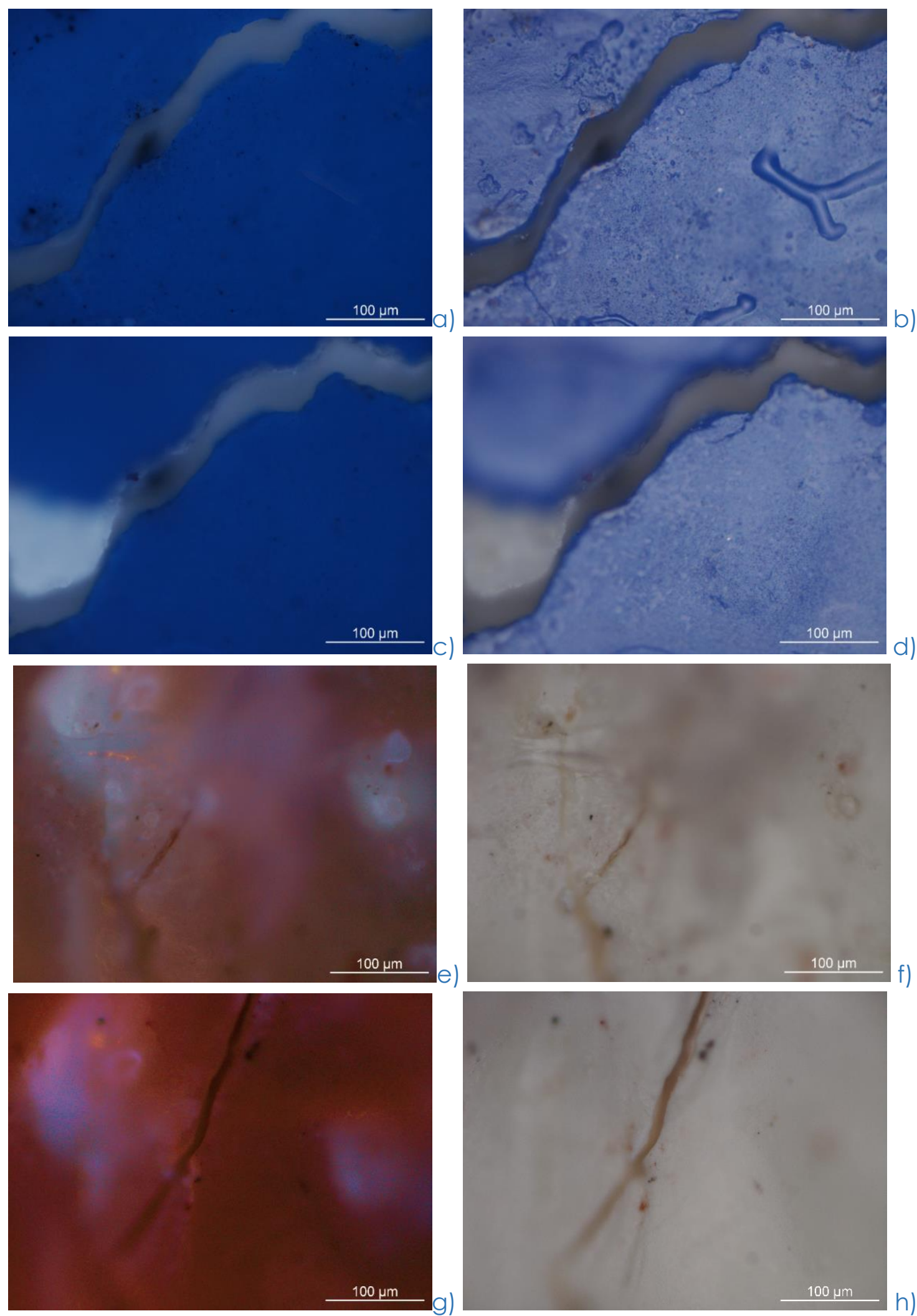

Figure 5.3.34. RTS of K(3) A(4)E and English tissue applied on Cobalt Blue and Titanium White. Surfaces after the RTS removal: UV light $(a, e)$, visible light $(b, f)$; surfaces after cleaning process: UV light (c, g), visible light $(d, h)$. 

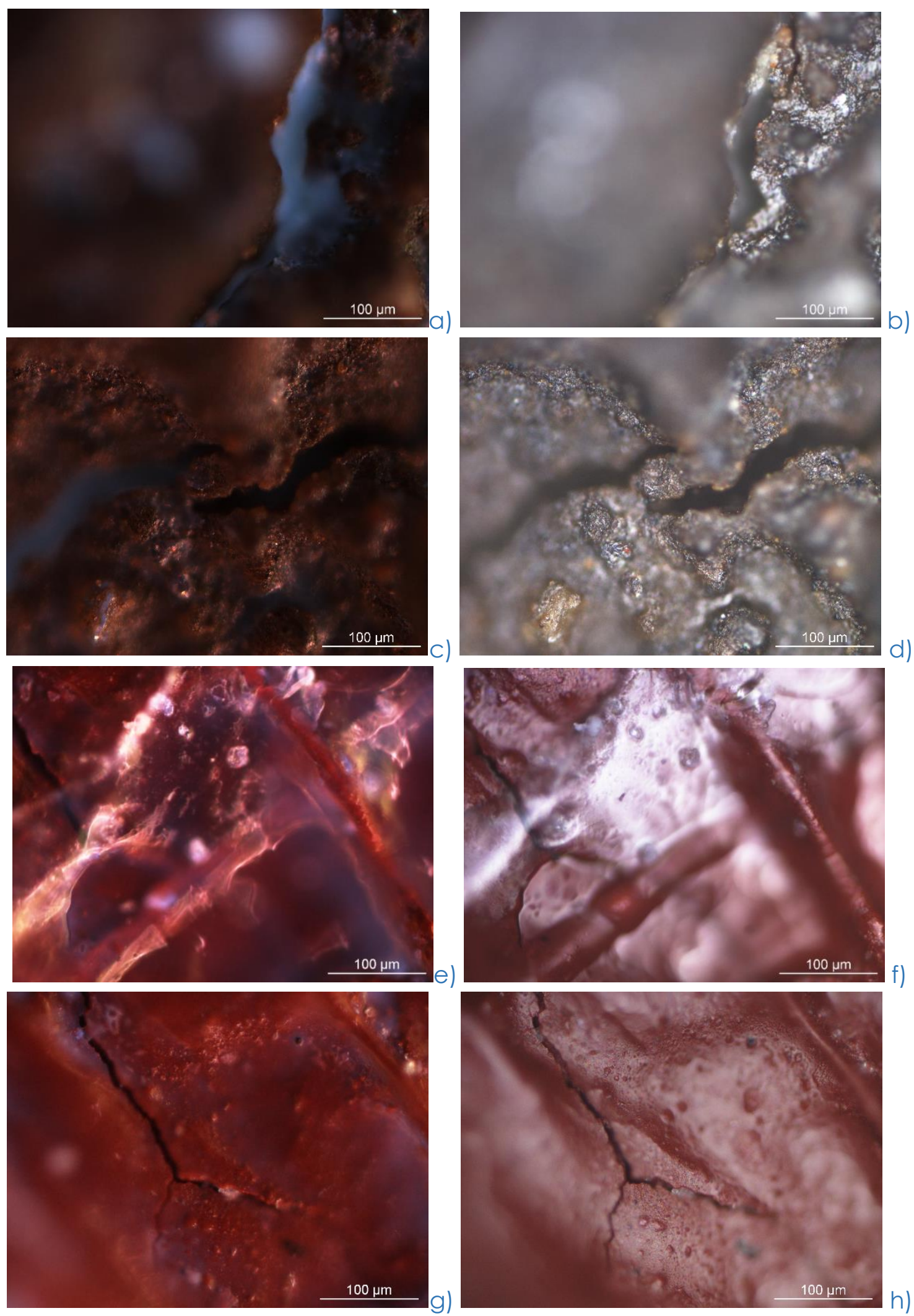

Figure 5.3.35. RTS of K(3) A(4)E and TNT 30/B applied on Raw Sienna and Iron oxide red. Surfaces after the RTS removal: UV light $(a, e)$, visible light $(b, f)$; surfaces after cleaning process: UV light $(c, g)$, visible light $(d, h)$. 

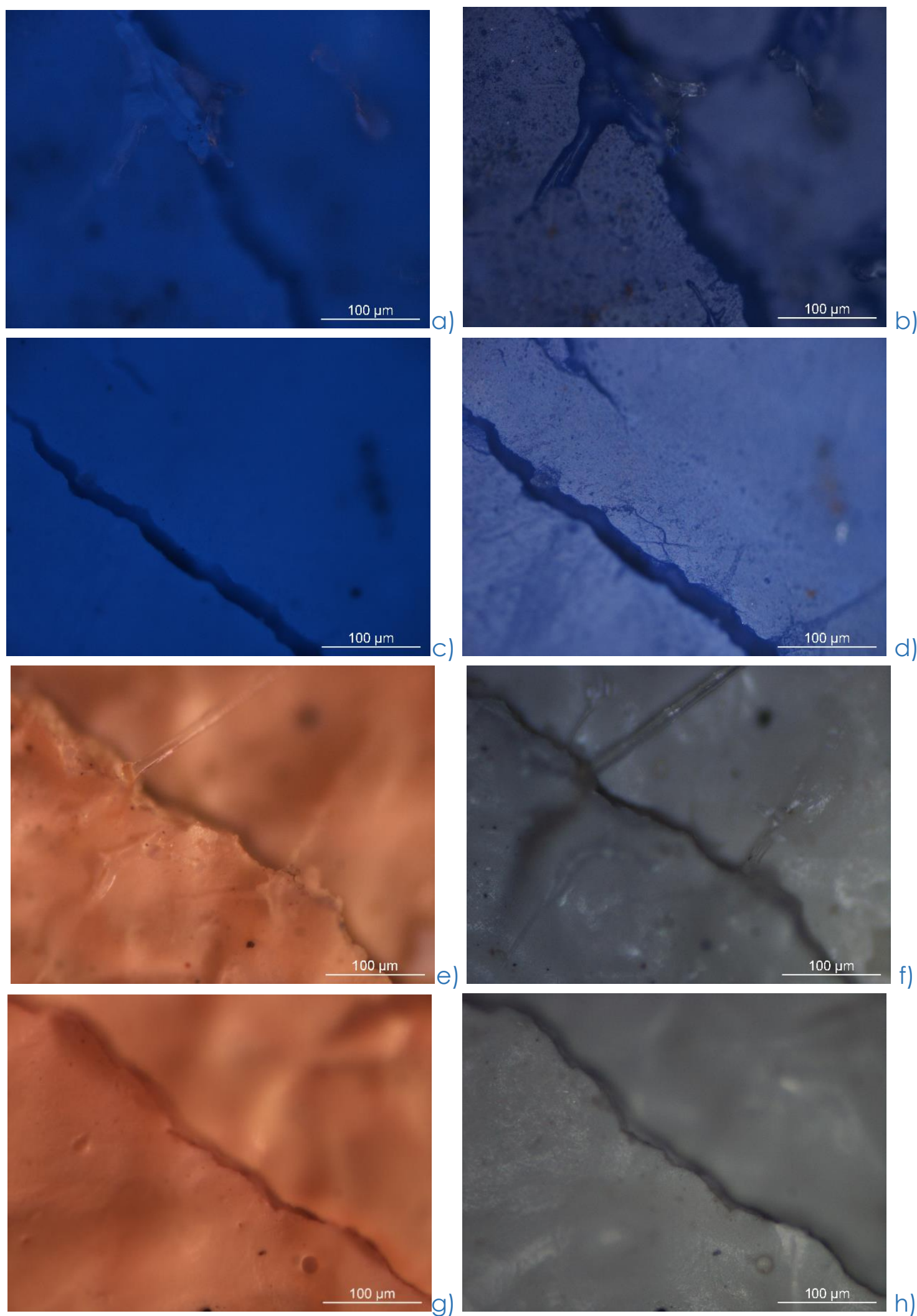

Figure 5.3.36. RTS of K(3) A(4)E and TNT 30/B applied on Cobalt Blue and Titanium White. Surfaces after the RTS removal: UV light $(a, e)$, visible light $(b, f)$; surfaces after cleaning process: UV light $(c, g)$, visible light $(d, h)$. 


\subsubsection{Results of the observation of the first set of specimens with FESEM}

Since the residues found on the specimens faced with RTS of English tissue were those that gave the most uncertain results, they were subjected to a last observation with FESEM, to prove the correctness of what observed with the optical microscope. For this part of the investigation only the specimens of iron oxide red were used.

The higher resolution of the images with the FESEM permitted a deepened observation of the residues left on the surface. The amount of residues of T(3)P7 was confirmed to be quite small (Fig.5.3.37). The punctiform shape of the residues of adhesive was a consequence of the medium-high rigidity of the adhesive and seemed to hint a medium-low reactivation degree, which led to a clear break in the adhesive layer. Very few residues of support fibres were found on the surface. After the cleaning with the buffer solution, the few residues were only partially removed, confirming the scarce reactivation speed of the adhesive.

On the specimens faced with RTS of K(4)P7 (Fig. 5.3.38), there were found more residues of both adhesive and support fibres. Differently from T(3)P7, adhesive residues had a filamentous shape, and in some rare cases small agglomerations of adhesive were found. This could be a clue of the higher reactivation speed of the adhesive mixture and of its plasticity. However, the observation with FESEM confirmed that almost all the residues were removed after the cleaning with buffer solution.

The RTS of K(3)A(4)E (Fig.5.3.39) confirmed be those that left the higher quantity of residues compared to the other two adhesives. The observation with FESEM revealed the presence of some residues of adhesive in form of filamentous bridges anchored to the roughness of the paint layer, probably due to the high reactivation degree of the adhesive. Very few agglomeration of adhesive in form of plates were also found, and very few residues of support fibres. This last analysis confirmed also the efficiency of the cleaning process, since almost no residues were found on the cleaned surfaces. 

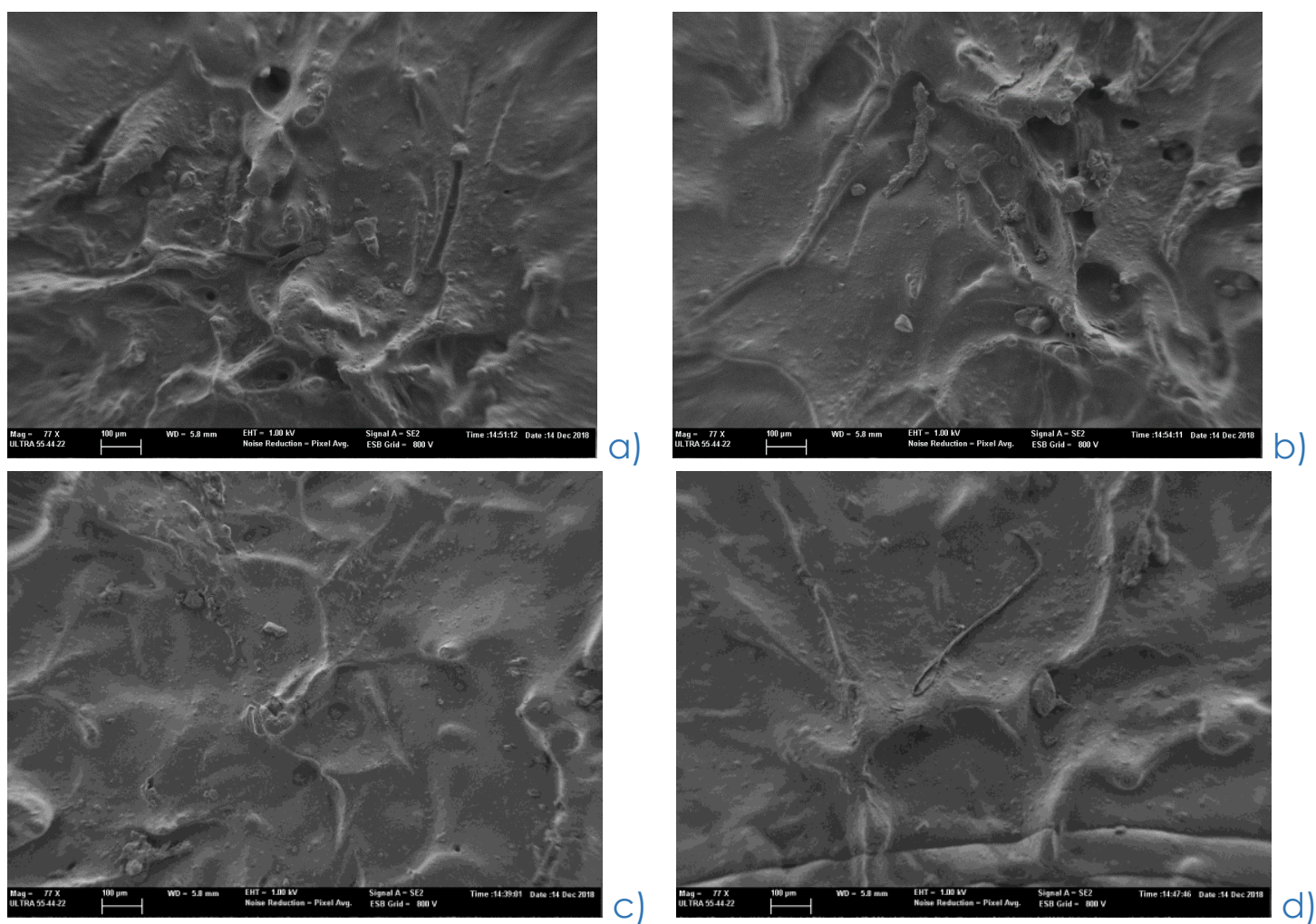

Figure 5.3.37. RTS of T(3)P7 and English tissue applied on Iron oxide red. Observation of the surfaces with FE-SEM after the RTS removal $(a, b)$ and after cleaning process $(c, d)$.

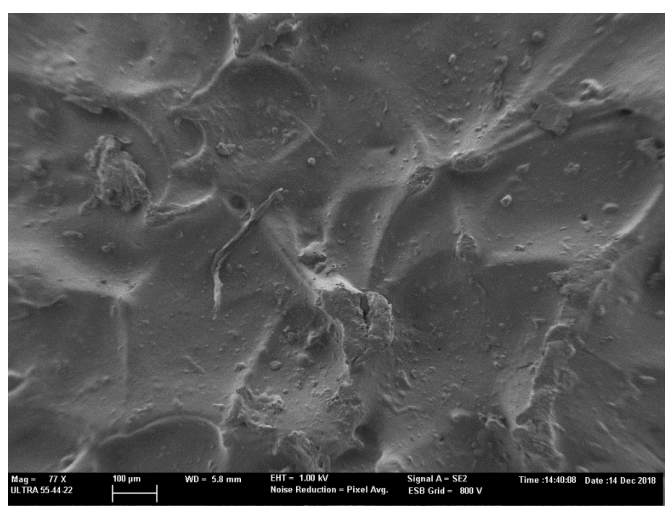

a)
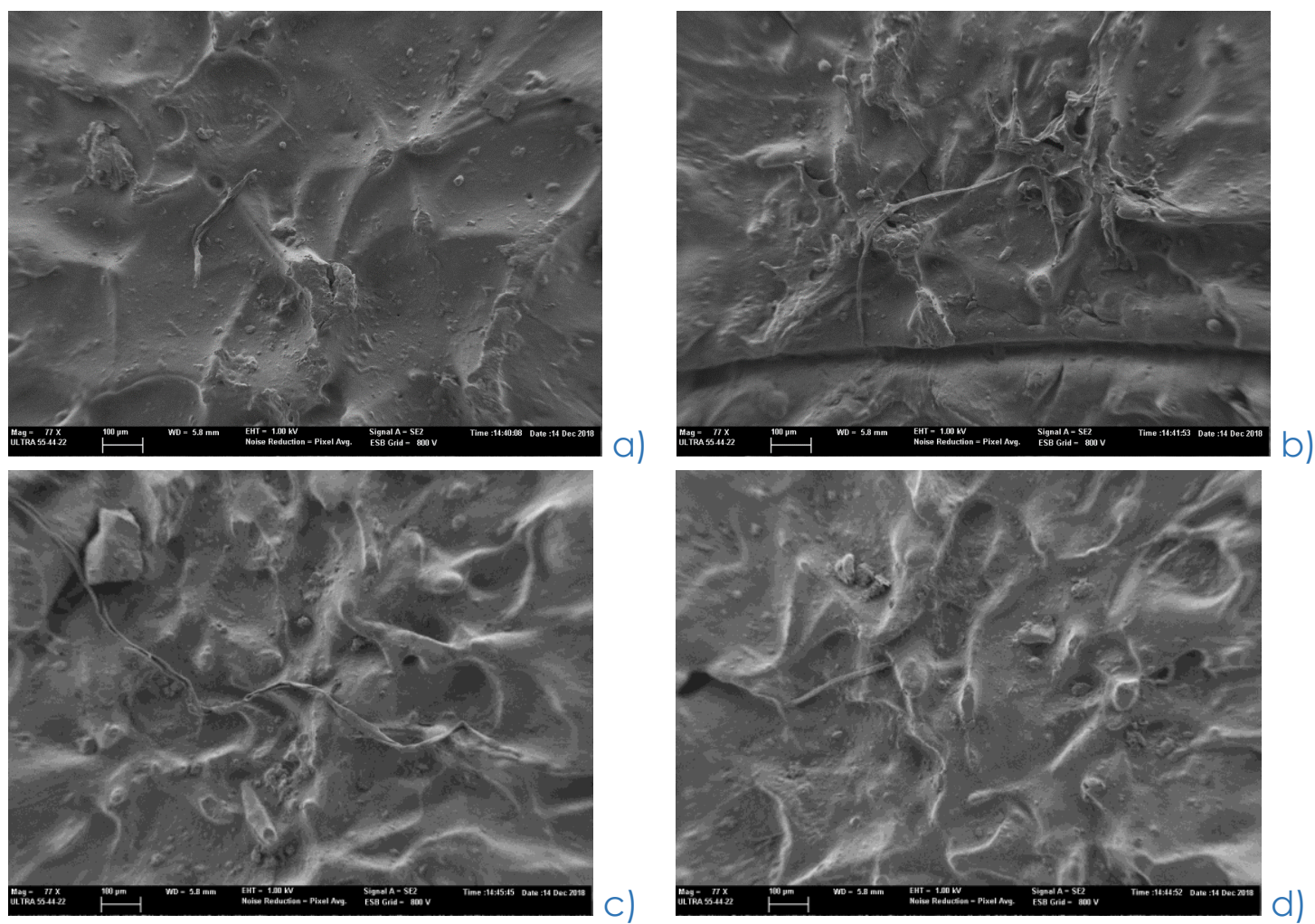

b)

Figure 5.3.38. RTS of K(4)P7 and English tissue applied on Iron oxide red. Observation of the surfaces with FE-SEM after the RTS removal $(a, b)$ and after cleaning process $(c, d)$. 

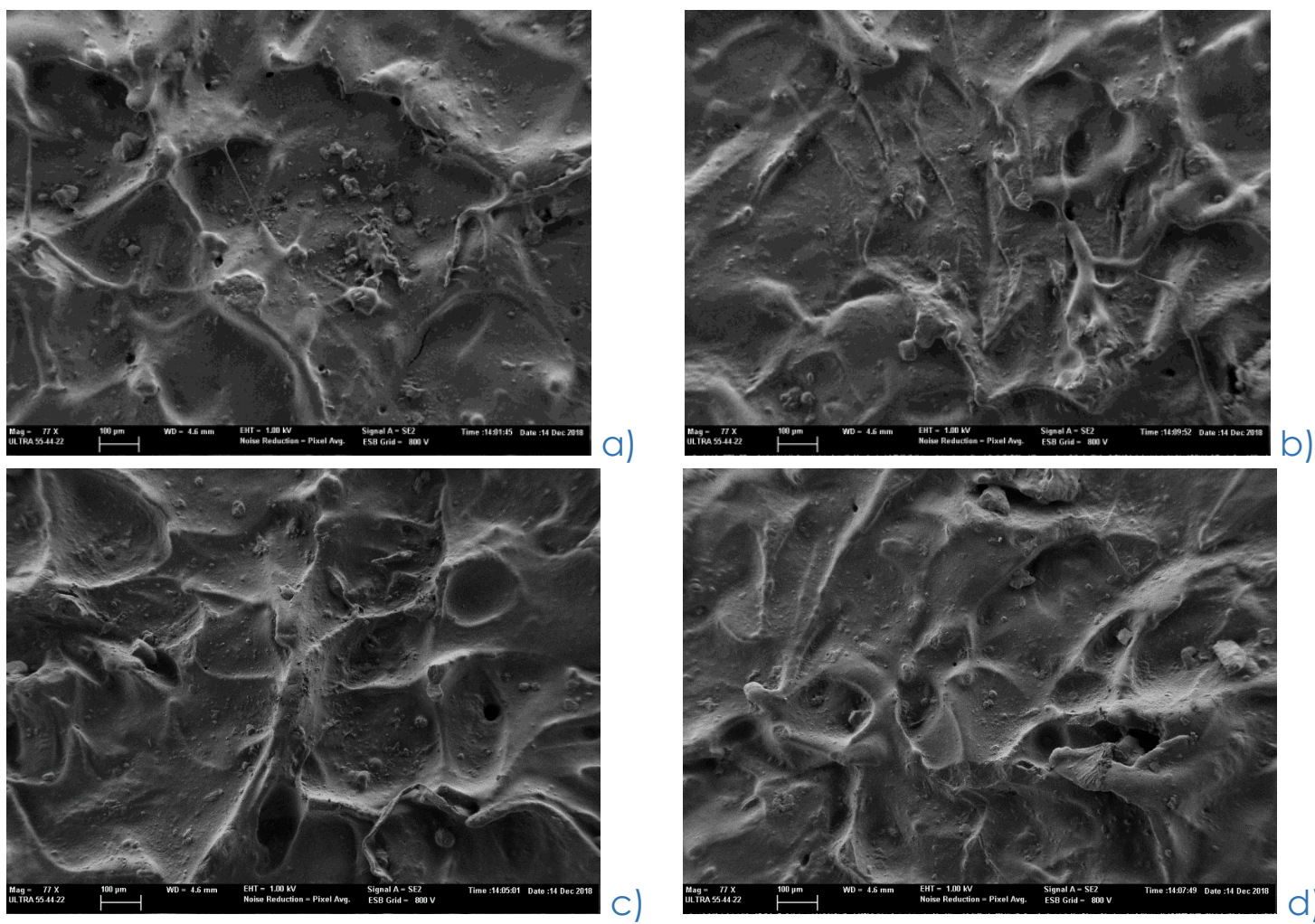

Figure 5.3.39. RTS of K(3) A(4)E and English tissue applied on Iron oxide red. Observation of the surfaces with FE-SEM after the RTS removal $(a, b)$ and after cleaning process (c, d).

\subsubsection{Conclusions}

The observation with the different microscopy techniques permitted to make a further selection regarding the materials employed for the preparation of the RTS. Thanks to these analyses, it was possible to make a qualitative characterisation of the residues left on the surface of the specimens.

The microscopic observation did not permit to establish a connection between the quantity of residues left on the surface of the paint layers and the kind of pigment employed. Only a slight difference in the amount of residues was noticed when using certain adhesive dispersions, but it probably depends on the different roughness of the surface, rather than on the kind of pigment. 
The analysis of the first set of specimens with optical microscope in visible light permitted to discard some adhesives and temporary supports, while the observation of the other two set of specimens with the optical microscope with UV/Visible light permitted to confirm the suitability of the selected materials.

As regards adhesive dispersions, two of them gave negative results: $K(4)$ and $A(5) E$. Actually, in both cases a great quantity of adhesive residues was found on the surface of many specimens. In particular, residues with the shape of plates were found, meaning that a direct transfer of the adhesive from the support to the paint layer occurred. After the cleaning, the traces of both adhesives were almost totally removed. However, in the case of K(4) a mark of the support was found on the paint layer. As regards $A(5) E$, the quick reactivation speed of the adhesive and its low viscosity previously tested allows the suspicion that during the cleaning process a certain quantity of adhesive, present in a great amount on the surface, could penetrate in the substrate without being removed. For these reasons, it was deemed appropriate to discard these two adhesives.

Both T(3)P7 and T(4)P7 gave positive results, thus the almost total absence of residues found on the surface of the mock-ups. However, it has to be taken into account that they were not easily removable. Anyway, considering their small amount, the results were acceptable. Due to the small differences in the results obtained for these two adhesives, it was decided to select just one of them. The choice fell on T(3)P7, since the high viscosity of T(4)P7 dispersion was considered as threshold value for the preparation of remoistenable tissues.

Results on the other adhesives were considered appropriate. The amount of residues left by the RTS made with K(4)P7 and especially with K(3)A(4)E was undoubtedly higher than that of T(3)P7, but their reversibility was higher too. The result was that the amount of residues present on the surfaces of the specimens after cleaning with buffer solution was even lower than that of T(3)P7. In particular, the performance of K(4)P7 was good, especially in the case of the RTS prepared with the English tissue and the TNT tissue. The amount of adhesive remaining on the substrates was a bit higher than the one left by Tylose mixtures, being the residues easily removable though. The amount of adhesive found in the specimens faced with K(3)A(4)E was higher than the other ones, but after the cleaning process almost all residues were efficiently removed.

Considering the high viscosity of the selected adhesives (see chapter 4), it was not hard to assume that the grade of adhesive penetration during the cleaning process could be very low. This seemed to be confirmed by the 
observation of the second set of specimens, since a very small amount of adhesive was detected in the cracks of the paint layer. Even in the case of a mock-up faced with K(3)A(4)E and English tissue, where an agglomeration of adhesive was found in correspondence with a crack, the adhesive was almost completely removed during the cleaning process without apparently penetrate in the fissure.

Regarding the temporary supports, the observation with microscope highlighted that it was no longer possible to consider Holytex as a good temporary support for the preparation of remoistenable tissues. In fact, the adhesive layer of the RTS transferred from the temporary support to the paint layer during the removal process of the remoistenable tissue. This phenomenon could be ascribed to the low absorption power of the temporary support, already tested in the first step on the investigation. The adhesive applied during the preparation of the remoistenable support created a uniform layer at the interface with the foil of Mylar, but it did not soak the fibres of the support, so during the reactivation of the RTS for the removal the adhesive got stuck to the paint and it was not removed. These results confirmed the importance of the absorption power of the temporary support.

Results on RTS prepared with TNT were positive, since in the majority of cases few residues were found on the surfaces previously faced with remoistenable tissue of TNT.

Results related to RTS made of Japanese paper were intermediate. In fact, in some cases the amount of residues left by these kind of remoistenable tissue was higher than those from remoistenable tissues of the other cellulosic support and from the synthetic TNT. In particular, residues of paper fibres were found in several specimens.

On the contrary, results related to English tissue were encouraging. In fact, in the majority of cases the quantity of residues was quite low. Furthermore, no residues of the support fibres were visible on the analysed substrates. This phenomenon was due to the high wet-strength given by the amide type wet additive (for more information, see Chapter 3). The observation with FESEM confirmed the presence of a small quantity of fibres residues, which were partially removed after cleaning. 


\subsection{Penetration Of the adhesive in the substrate}

An important issue to understand the efficiency of the selected remoistenable temporary supports (RTS) was the assessment of the penetration of the adhesive in the substrate.

The evaluation of the penetration of an organic material in a heterogeneous substrate such as a paint layer is extremely complex. In fact, probably this was the most difficult step of this research. To have clear answers, micro-Raman spectroscopy ( $\mu$ Raman spectroscopy) associated with a high-resolution microscope was chosen to analyse the cross-section of the mock-ups subjected to the application of a RTS. In fact, there were several advantages in the use of $\mu$ Raman spectroscopy, for example: the relative simplicity of the Raman spectra of organic materials compared to that obtained with FTIR spectroscopes; or the small scattering intensity of water and hydroxyl groups, useful for the analysis of hydrated materials as the tested ones; the accessibility of the low wavenumber region of the vibrational spectrum that was very important to distinguish materials composing the mock-ups (Edwards 2005). Furthermore, $\mu$ Raman spectroscopy permitted to analyse specified single points of the mock-ups.

\subsubsection{Basic principles of micro-Raman spectroscopy}

Raman spectroscopy is a powerful technique for the study of the properties and characteristics of molecules. It provides information about molecular composition, chemical bonds, chemical environment, crystalline and structural phase of tested specimens. It is apt to the analysis and identification of materials in any physical form: gases, liquids, solutions and crystalline and amorphous solids.

Today, Raman spectroscopy is a well-established technique for the molecular investigation of cultural heritage materials because it is extremely versatile. In fact, Raman spectroscopy permits to analyse different materials, such as spanning minerals, gems, organic and inorganic pigments and their degradation products, binding media, varnishes, plastics, glasses, ceramics, and conservation treatments (Casadio, Daher, and Bellot-Gurlet 2016). Raman spectroscopy can be considered non-destructive, because neither sampling nor contact or pre-treatment is required (Wehling et al. 1999). The only potential risk is due to the exciting radiation, because the heat generated by the laser can damage the sample or also induce transformations in the structure of the material, giving rise to spectra that are not representative of the original material (Daher 2012). 


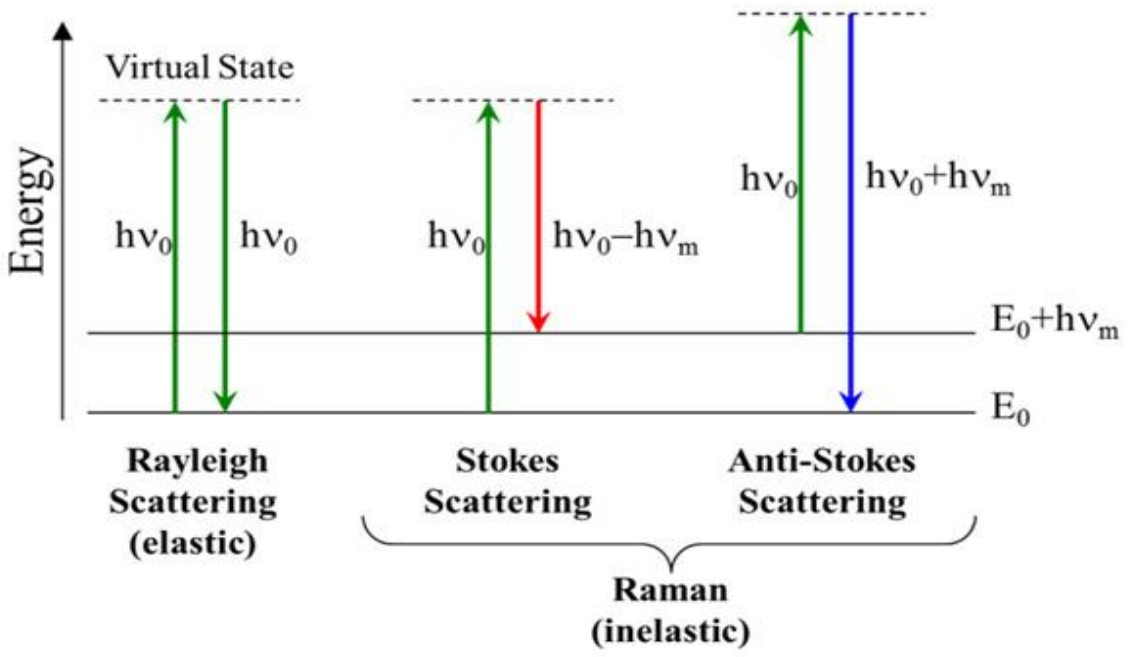

Figure 5.4.1. Schematic representation of the different possible energy transitions.

Raman spectroscopy is based on anelastic scattering as a consequence of the interaction with electromagnetic radiation, known as Raman Effect.

When a photon hits an object, it can cause a transition from the ground state into a "virtual state" of the object molecules. In most cases, the scattered photon has the same frequency of the original incident radiation (Rayleigh Scattering). Nevertheless, a small fraction of scattered radiation has a frequency different from frequency of incident radiation and it constitutes Raman scattering. In this last case, photons can be emitted at a lower (Stokes Raman photons) or higher (anti-stokes Raman photons) frequency with respect to the Rayleigh one (Fig. 5.4.1).

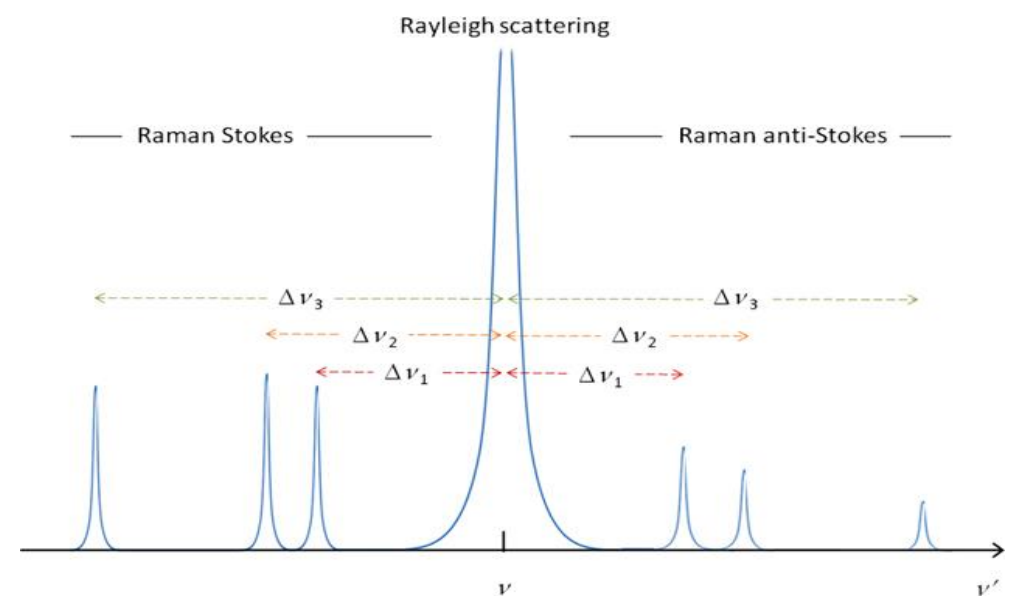

Figure 5.4.2. Schematic representation of a Raman spectrum. 
Since Stokes scattering is more intense than the anti-Stokes one, Stokes bands are used in conventional Raman spectroscopy to construct the Raman spectrum (Fig. 5.4.2). The obtained vibrational spectrum is highly characteristic of the molecules under study and it does not depend on the wavelength of the incident radiation (even if some materials are more or less susceptible to different wavelengths).

The problem of fluorescence can occur during the analysis of organic materials. When the incident radiation frequency allows reaching an excited electronic level of the molecule, the disexcitation in form of light emission can mask the Raman signal. In order to overcome this problem, different solutions can be founded. The first one is of course to use a lower energy wavelength (Barbillat et al. 1999, cit. in Caggiani 2014). It is possible also to variate the time of acquisition and use different gratings, which can implement the resolution of the spectrum.

In Raman microspectroscopy, the spectrophotometer is interfaced to an optical microscope, which permits to have both visual and spectroscopic examination as either single point, mapping or imaging measurements. Microscope is used to focus the laser beam onto the specimen. This permits to easily investigate complex samples analysing very small areas with a precision of about $1 \mu \mathrm{m})$.

\subsubsection{Instrumentation}

Every reference material specimen and cross-sections of faced paint mockups of iron oxide red described in section 5.2.4 was analysed with light microscopy and $\mu$ Raman spectroscope.

\subsubsection{Micro-Raman Spectroscopy}

Acquisition parameters were adjusted to obtain good quality spectra and to identify the characteristic peaks of each reference material of both mock-ups and RTS tested on the mock-ups. Then, common acquisition parameters were sought, to permit the latter identification of traces of the adhesive mixtures in the paint-specimens.

The most critical regions of the cross-sections of faced paint mock-up specimens, where a prior light microscope examination indicated possible presence of rests of adhesive, were selected for analysis with $\mu$ Raman spectroscopy. For each 
region, two to four micro-areas were analysed. The possibility of doing mapping analysis had to be discarded because of the roughness of the samples ${ }^{115}$.

For Raman analyses, Horiba HR Evolution spectrometer, at the Chemistry Department of the Università degli Studi di Bari "Aldo Moro" - UniBA (Italy), equipped with a Peltier-cooled charge-coupled device detector (CCD), $\mathrm{Ar}^{+} 514$ $\mathrm{nm}$ and $488 \mathrm{~nm}$ and He-Ne $633 \mathrm{~nm}$ lasers (spectral resolution of about $\pm 1 \mathrm{~cm}^{-1}$ ) was used. The spectrometer is coupled with a $\mathrm{BH} 2$ Olympus microscope provided with $\times 10, \times 50, \times 100$ and long working distance $x 50$ objectives. The spatial resolution is about $1 \mu \mathrm{m}$. The apparatus was equipped with the Ultra Low Frequency (ULF) module, which allows Raman spectroscopic information in the sub-100 $\mathrm{cm}^{-1}$ region, increasing the resolution of the spectra in the region included among 100 and $600 \mathrm{~cm}^{-1}$.

The better results were obtained with the following parameters: $x 100$ objective, $633 \mathrm{~nm}$ laser, laser power lower than $12 \mathrm{~mW}, 600 \mathrm{~g} / \mathrm{mm}$ grating, 40s measurement time, 5-10 accumulations spectra were acquired following instrumental calibration with Si at $520 \mathrm{~cm}^{-1}$ as a reference. Spectra were acquired in the region 100-3800 cm-1, 2500-3500 cm-1 and 100-1800 cm-1. Three spectra for each analysed area in reference specimens and cross-sections of faced mock-ups were acquired. A linear baseline was subtracted from the raw spectra and intensities were normalized to a fixed band using the incorporated software Labspec6.

\subsubsection{Optical microscopy}

The optical microscopy observation of cross-sections was carried out at the at the Earth and Geoenvironmental Sciences Departments of the Universita degli Studi di Bari "Aldo Moro" - UniBA (Italy), and a Nikon "Eclipse80i" reflected/transmitted light microscope, with six objectives $(2 x, 5 x, 10 x, 20 x, 50 x$, 100x) was used. Images were captured with a Nikon DS-5M camera equipped with Nikon DS-L1 controller, connected to the 'Lucia' software.

The magnification at $x 20$ and $x 50$ with cross polarized light (XPL) proved to be the best to observe the cross section in detail together with a more general view of the mock-up.

The same focus blending post-processing technique described in section 5.3.1. was used to improve images resolution.

115 The use of grounding and polishing materials would have contaminated the mock-ups. Also the possibility of embed the specimens in epoxy resin had to be discarded because of its spectral similarity with facing materials (see section 5.1). 


\subsubsection{Results and discussion}

\subsubsection{Characterization of Raman spectra of specimens prepared with reference materials}

A part from the different sensitivity to the different lasers, one of the principal problems related with Raman analyses was that spectra of all materials presented their characteristic peaks in the same regions (about 150-1800 $\mathrm{cm}^{-1}$ and 2500-3500 $\mathrm{cm}^{-1}$ ). It was therefore difficult to individuate distinctive peaks and a great resolution was needed to be sure of the presence/absence of the adhesive in the cross section of the specimens. In next sections are presented the results corresponding to the separate analyses of each specimen prepared with reference materials mimicking the different layers of the paint mock-ups. Then the spectra of all materials will be compared, in order to identify the differences among them, with the aim of selecting marker peaks specific of each material.

\subsubsection{Characterization of Raman spectra of materials used in the mock-} ups

\section{Dammar coating}

Among the natural resins, Dammar has become one of the most commonly used for varnish production since the 19th century. Dammar is obtained from various species of the Diptocarpaceae. It is composed of a mixture of similar molecules whose proportions vary from specimen to specimen. Typical samples contain upwards of nine triterpenoid molecular species, plus some higher molecular-mass compounds up to 850 (Horie 2010). One of the main components is dammarolic acid $\left(\mathrm{C}_{54} \mathrm{H}_{77} \mathrm{O}_{3}(\mathrm{COOH})_{2}\right)$. Many components are terpenoid resins, but also alcohols, carboxylic acids, ketones, polycyclic hydrocarbon structures and aromatic components are present (Vandenabeele et al. 2000). Autoxidative degradation of Dammar films causes changes as cracking, hazing, loss of gloss, yellowing (De la Rie 1988). The influence of many factors (e.g. environmental effects, reactions with other constitutive materials) on the molecular ageing process of triterpenoid varnishes is largely unknown. Furthermore, unaged triterpenoid resins are already complex mixtures, but with ageing appear an even larger number of compounds, so aged triterpenoid varnishes are difficult to analyse by Raman (Doelen 2000). 
For this study, spectra of both unaged Dammar and UV-aged Dammar were acquired. The most important wavenumber regions for the identification of the resin are the regions between 280 and $1750 \mathrm{~cm}^{-1}$ and between 2600 and $3200 \mathrm{~cm}^{-1}$. The latter region was mainly inspected for the C-H stretching vibrations of organic components.

In both unaged and aged Dammar (Fig. 5.4.3-4), the most prominent bands in the Raman spectra are those of aliphatic $v(\mathrm{CH})$ stretching in high frequency region, which refers to $\mathrm{CH}, \mathrm{CH}_{2}$ and $\mathrm{CH}_{3}$ bonds. In particular, the peak at $2932 \mathrm{~cm}^{-1}$ (Edwards, Farwell, and Villar 2007; Winkler et al. 2003, cit. in Caggiani 2014) is characteristic of many natural and fossil resins.

The region which gives interesting information for the identification of Dammar is represented by the bands between 700 and $1500 \mathrm{~cm}^{-1}$, where the most characteristic peaks are the ones at $1449 \mathrm{~cm}^{-1}(\delta(\mathrm{CH})$ deformation), at $1655 \mathrm{~cm}^{-1}$ ( $\mathrm{V}(\mathrm{C}=\mathrm{C})$ mode) and at about $1704 \mathrm{~cm}^{-1}$ ( $\mathrm{V}(\mathrm{C}=\mathrm{O})$ vibration). In the same region, the peak at $713 \mathrm{~cm}^{-1}$ can be ascribed to the simple bonds $\vee(C-$ $\mathrm{C})$, the one at $804 \mathrm{~cm}^{-1}$ to $\delta\left(\mathrm{C}-\mathrm{C}^{\prime}-\mathrm{OH}\right)$ distortion, the other at $1179 \mathrm{~cm}^{-1}$ to $\checkmark(C-C)$ vibration, while the peak at $1201 \mathrm{~cm}^{-1}$ to the $\delta(C-H)$ mode. The peak at $950 \mathrm{~cm}^{-1}$ corresponds to the ring mode $(\delta(C-C)$ aromatic), while the one at $1026 \mathrm{~cm}^{-1}$ is related to the $\mathrm{v}(\mathrm{C}-\mathrm{C}$ ) ring mode (Edwards, Farwell, and Daffner 1996; Vandenabeele et al. 2000; Nevin et al. 2009; Daher et al. 2010; Caggiani 2014).

Raman spectrum of aged Dammar (Fig. 5.4.3-4) indicates that the changes observed in the fluorescence of dammar are the result of molecular changes in the varnish which occur with ageing (Nevin et al. 2009) This may lead to the disappearance of the peaks at 316 and $415 \mathrm{~cm}^{-1}$ and the appearance of the peaks at 2673 and $2766 \mathrm{~cm}^{-1}$. 


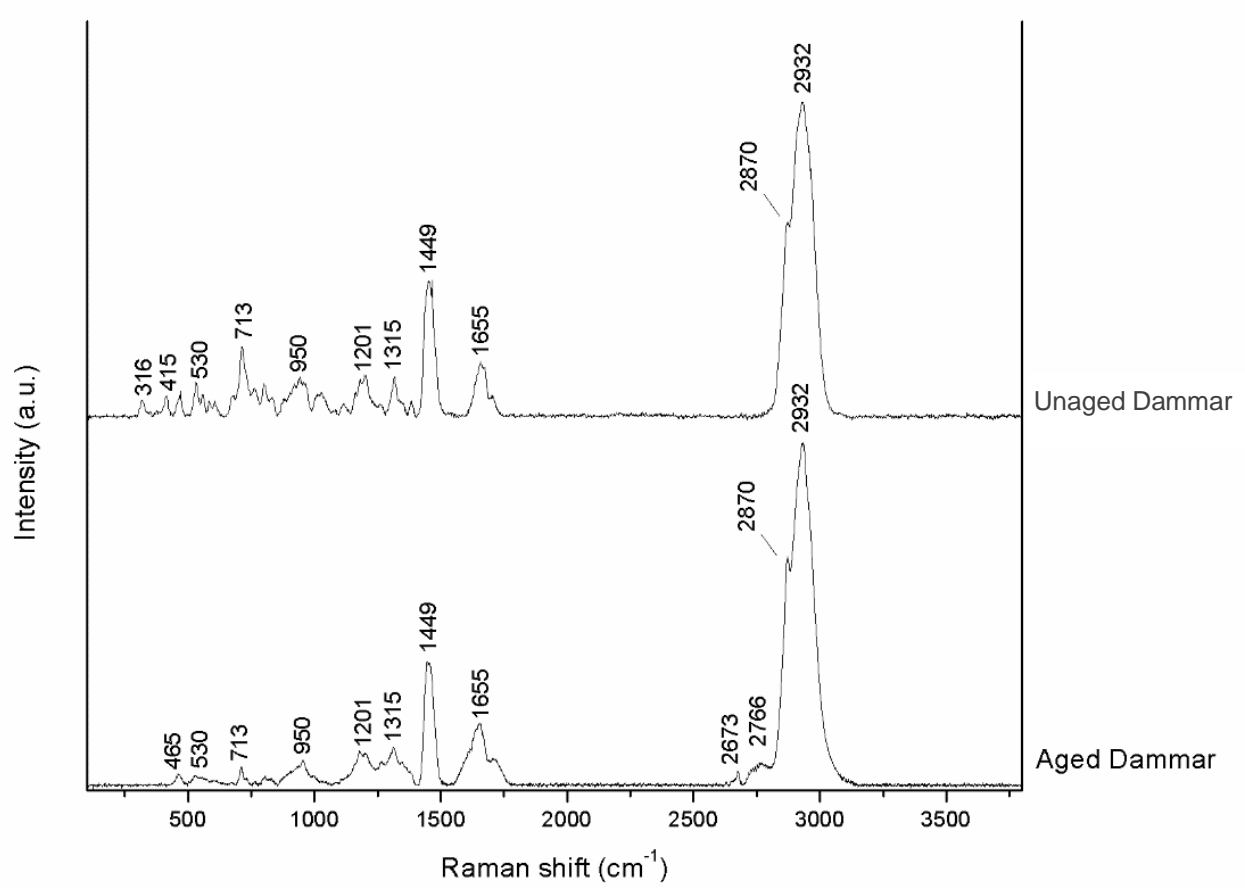

Figure 5.4.3. Representative baseline-subtracted Raman spectra of unaged and aged Dammar resin in the region $100-3800 \mathrm{~cm}-1$.

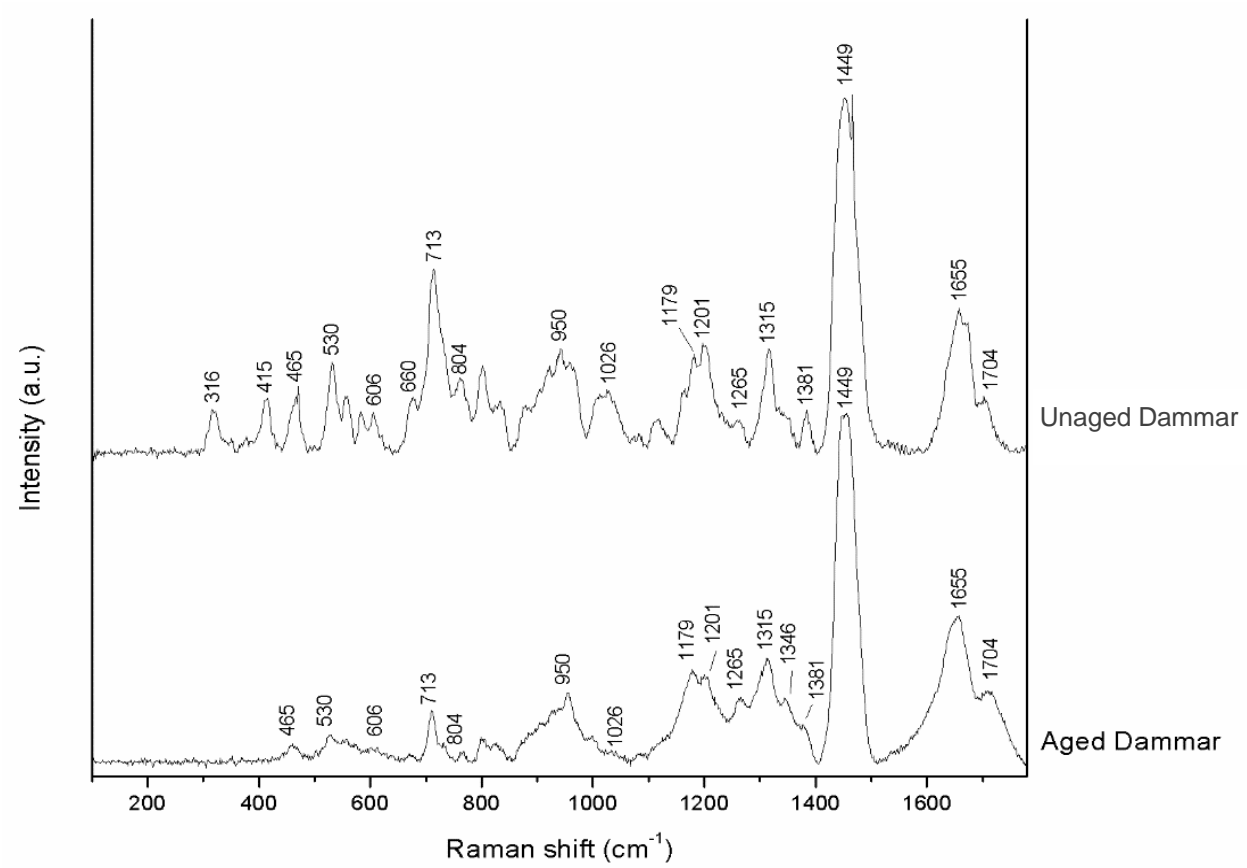

Figure 5.4.4. Representative baseline-subtracted Raman spectra of unaged and aged Dammar resin in the region $100-1780 \mathrm{~cm}^{-1}$. 


\section{Paint layer of iron oxide red}

Iron oxide red $\left(\mathrm{Fe}_{2} \mathrm{O}_{3}\right)$, known also as haematite in its natural mineral source, is a red pigment used since ancient times. As for other mineral pigments, it is not difficult to find a reference in online databases of Raman spectra (Bell, Clark, and Gibbs 1997).

In our case, the unaged pigment, and the unaged and aged paint layer section were analysed, in order to understand the influences of both the medium and the ageing on the spectra of the paint.

As is it possible to see in the Figure 5.4.5-6, all the characteristic peaks of Iron (III) oxide, as it happens for almost all the inorganic pigments, are in the region between 190 and $950 \mathrm{~cm}^{-1}\left(224,243,292,409,497,612,660,814 \mathrm{~cm}^{-1}\right)$, with another characteristic band at about $1314 \mathrm{~cm}^{-1}$. In general, the presence of the medium in the unaged paint layer (Fig. 5.4.5-6) is visible in the band at $2930 \mathrm{~cm}^{-1}$. No significant variation is detectable between the unaged and the artificially aged paint layer (Fig. 5.4.5-6).

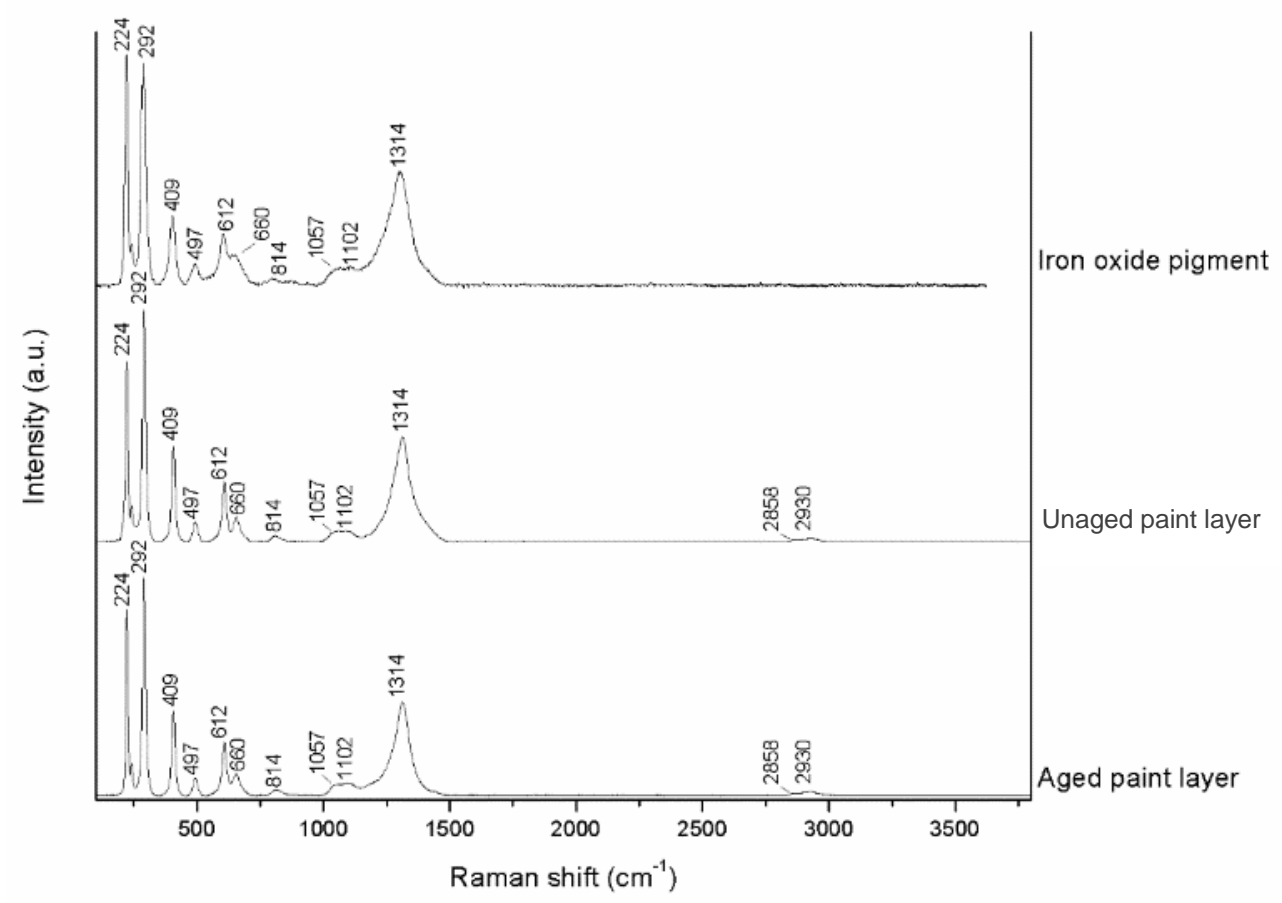

Figure 5.4.5. Representative baseline-subtracted Raman spectra of Haematite pigment, unaged paint layer and aged paint layer in the region $100-3800 \mathrm{~cm}-1$. 


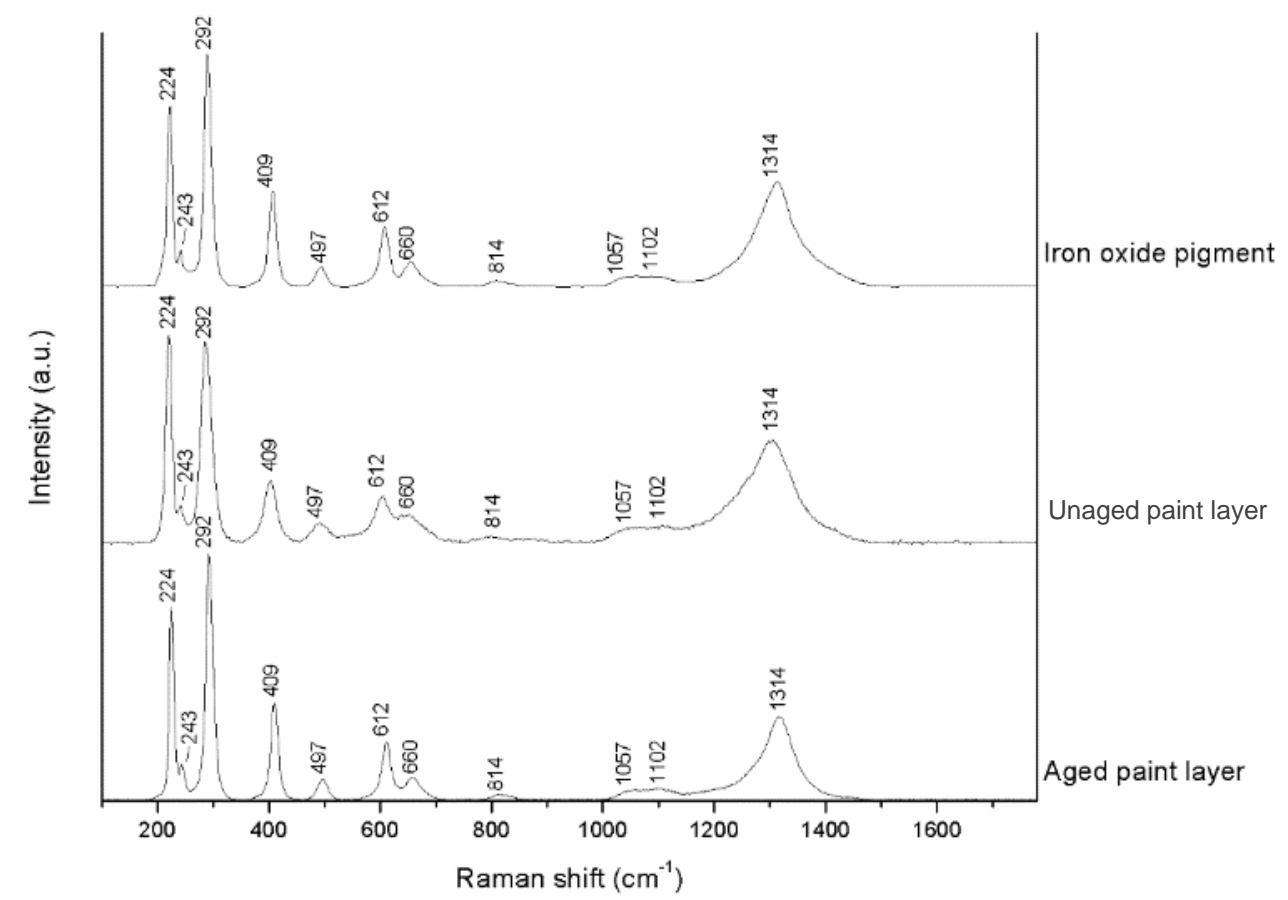

Figure 5.4.6. Representative baseline-subtracted Raman spectra of Haematite pigment, unaged and aged paint layer in the region 100-1780 $\mathrm{cm}^{-1}$.

\section{Ground layer}

The ground layer was prepared with technical gelatine and Bologna gypsum. The technical gelatine is a natural polymer derived from the denaturation of mammalian collagen. In general, animal glues may exhibit extremely diverse physical, chemical and mechanical properties depending on the source materials (bones, rabbit skin, pork or cow hide), and on the extraction process (for example acid or basic pre-treatment, extraction temperature and duration). In fact, these factors strongly influence the chemical composition (Proline and Hydroxiproline content), average molecular weight (AMW), the degree of renaturation and network structure, which are crucial for the most important technological characteristics (Matteini and Moles 2007; Schellmann 2007; Horie 2010; Soppa et al. 2014). The Raman spectra of different animal glues are therefore different, even if common characteristics can be found. Bologna gypsum, widely used for the preparation of ground layers in the Mediterranean Europe, is a mineral composed of calcium sulphate dehydrate $\left(\mathrm{CaSO}_{4} \cdot 2 \mathrm{H}_{2} \mathrm{O}\right)$. 
For this study, unaged specimens of animal glue and Bologna gypsum, and unaged and aged specimen of the ground layer were analysed.

In general, the Raman spectra of technical gelatine (Fig. 5.4.7-8) showed a high fluorescence continuum, which has been subtracted. Technical gelatine has its characteristics peak in the two characteristic regions of many organic materials. The first goes from 180 to $1740 \mathrm{~cm}^{-1}$, where it is possible to recognize one weak peak at $200 \mathrm{~cm}^{-1}$, another broad band going from 246 to $490 \mathrm{~cm}^{-1}$, to continue with another peak at $559 \mathrm{~cm}^{-1}$. Between 700 and $1000 \mathrm{~cm}^{-1}$ the characteristic bands of tyrosine amino acid residues appear (Vandenabeele et al. 2000).

At $1003 \mathrm{~cm}^{-1}$, the sharp peak corresponding to the aromatic ring breathing arises probably from phenylalanine amino acid residues. The gelatine shows also amide III band at $1240 \mathrm{~cm}^{-1}, \delta\left(\mathrm{CH}_{3}\right)$ vibration at $1449 \mathrm{~cm}^{-1}$ and amide I band at $1668 \mathrm{~cm}^{-1}$.

The second characteristic region is the region $2600-3600 \mathrm{~cm}^{-1}$, where it is possible to recognize a weak peak at $2670 \mathrm{~cm}^{-1}$ and the band at $2938 \mathrm{~cm}^{-1}$ corresponding to $\vee(\mathrm{CH}$ ) modes (Frushour and Koenig 1975; Vandenabeele et al. 2000), with two shoulder at 2881 and $2984 \mathrm{~cm}^{-1}$ and a weak peak at 3060 $\mathrm{cm}^{-1}$. It is visible a broad band at $3339 \mathrm{~cm}^{-1}$. Here too, the observed variation in the ratio among some peaks can be ascribed to the variability of the natural material.

Gypsum, as many inorganic materials, shows a spectrum characterised from few bands (Fig. 5.4.9-10). The spectrum presents peaks at 179, 415, 493, 619, 670, 1011, 1139, 3403, and $3491 \mathrm{~cm}^{-1}$ (Bell, Clark, and Gibbs 1997; Burgio and Clarck 2001). In spectra analysed with ULF it is possible to recognize also a weak peak at $136 \mathrm{~cm}^{-1}$.

The spectra of the unaged ground layer (Fig. 5.4.11-12) shows all the peaks of gypsum, but only the strongest bands of glve are visible slightly shifted, at $1449,1668,2674,2881$ and $2938 \mathrm{~cm}^{-1}$. The difference in the intensity ratio of the bands of glue and gypsum can depends on the very low proportion of glue present in the preparation. In fact, the glue used for the ground was dissolved in water in the proportion of 1:14 (w/w) and mixed with gypsum in the proportion of 1:1 (w/w). There are few differences between the unaged and the aged specimen (Fig. 5.4.11-12). 


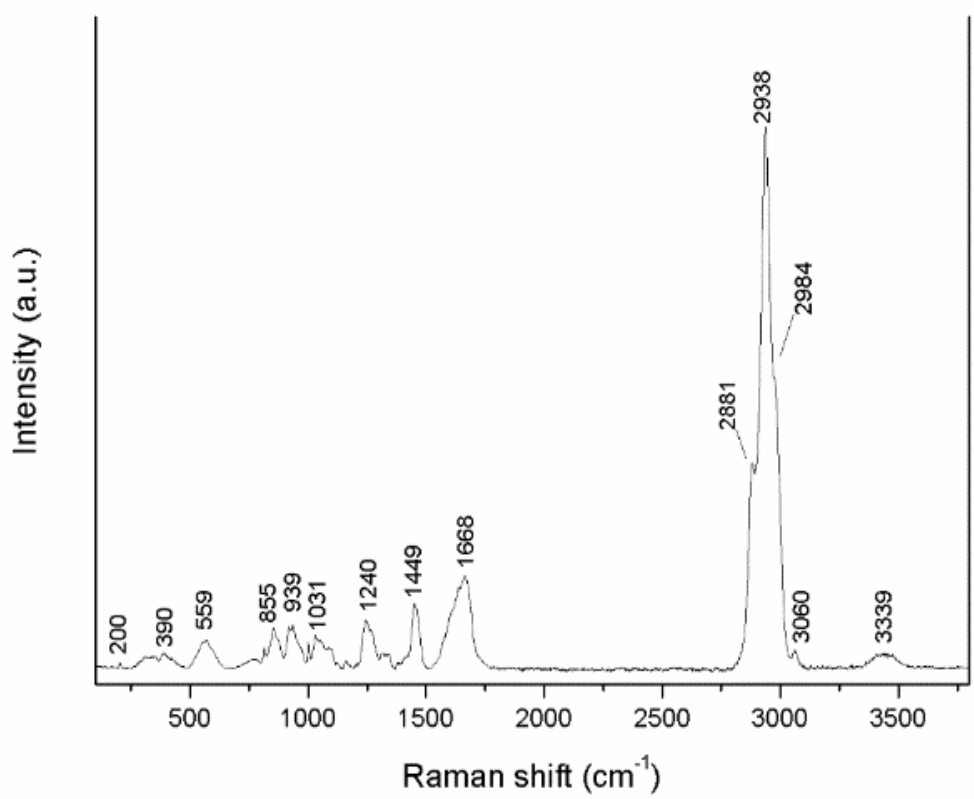

Figure 5.4.7. Representative baseline-subtracted Raman spectra of unaged technical gelatine in the region $100-3800 \mathrm{~cm}-1$.

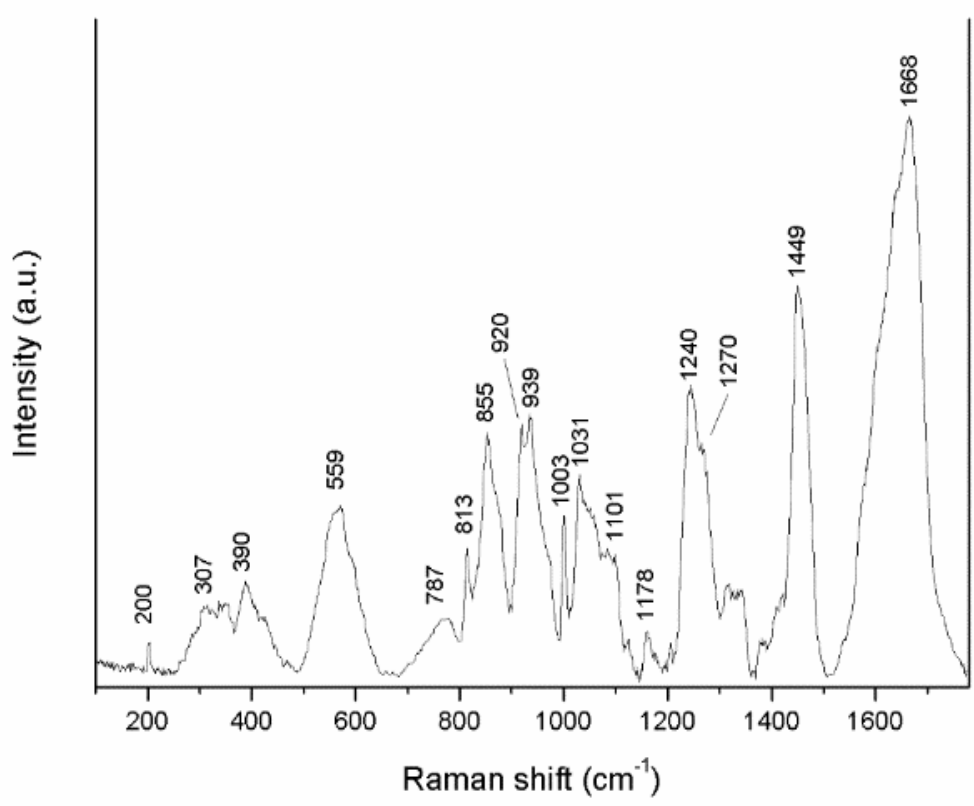

Figure 5.4.8. Representative baseline-subtracted Raman spectra of unaged technical gelatine in the region 100-1780 cm-1. 


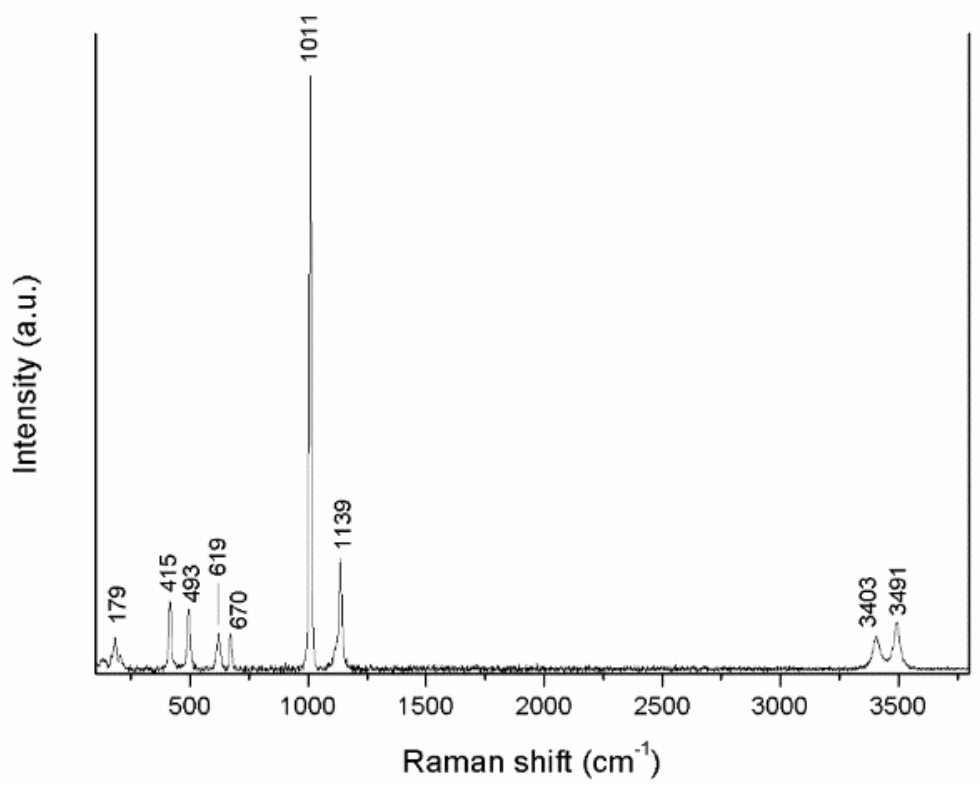

Figure 5.4.9. Representative baseline-subtracted Raman spectra of unaged Bologna gypsum in the region $100-3800 \mathrm{~cm}^{-1}$.

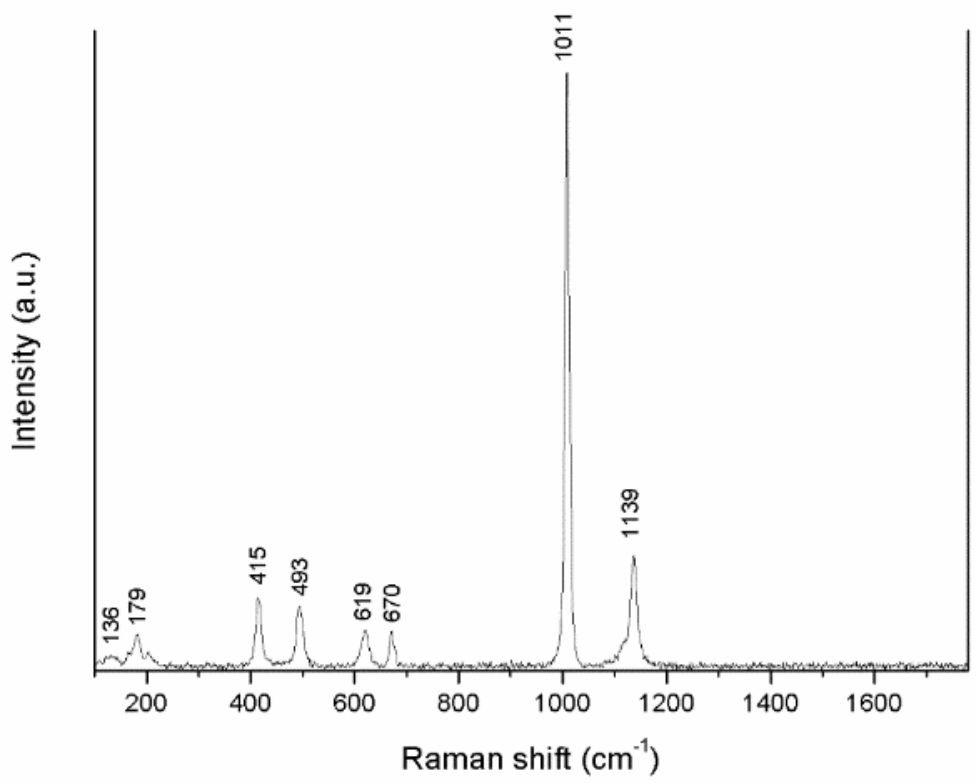

Figure 5.4.10. Representative baseline-subtracted Raman spectra of unaged Bologna gypsum in the region $100-1780 \mathrm{~cm}^{-1}$. 


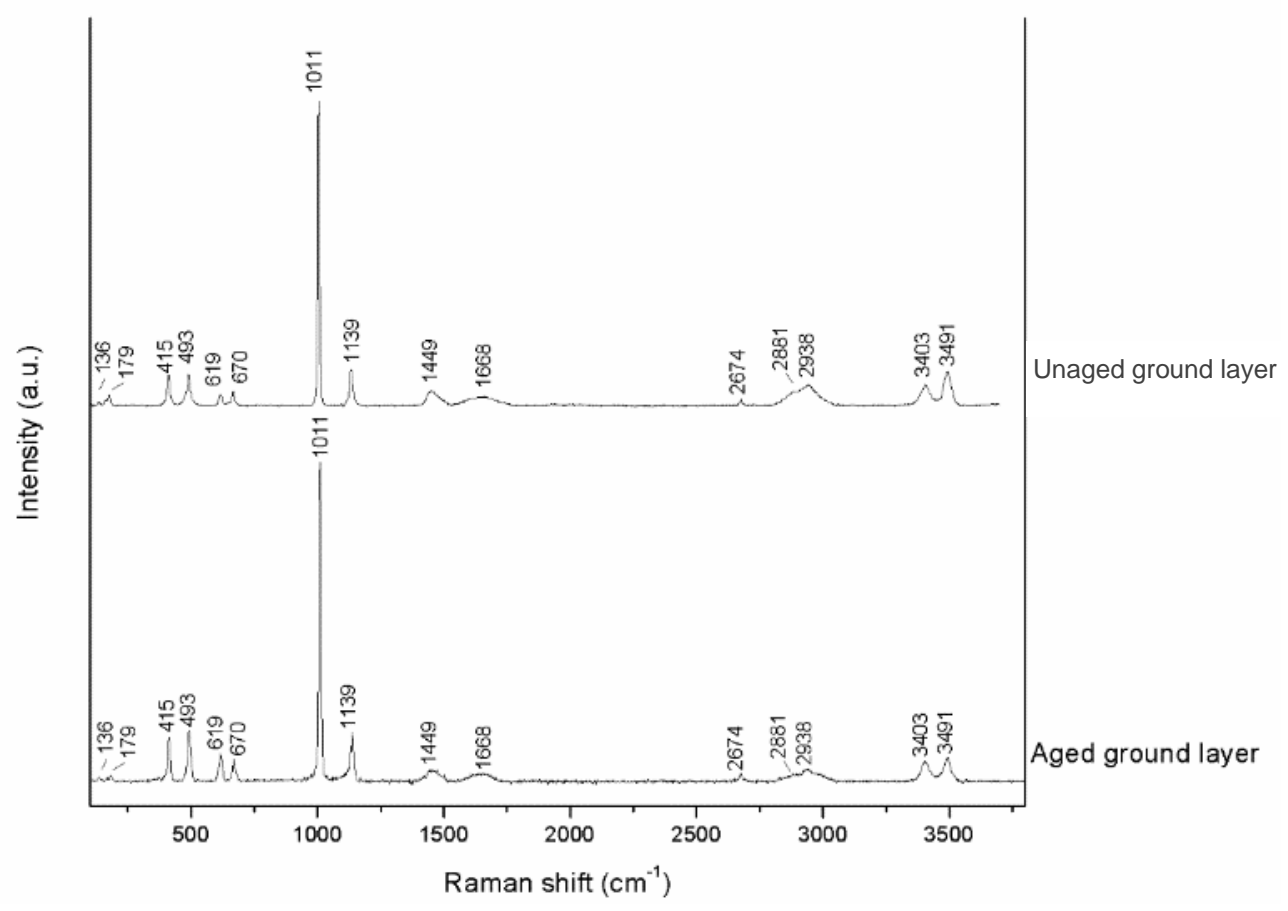

Figure 5.4.11. Representative baseline-subtracted Raman spectra of unaged and aged ground layer in the region $100-3800 \mathrm{~cm}$ -

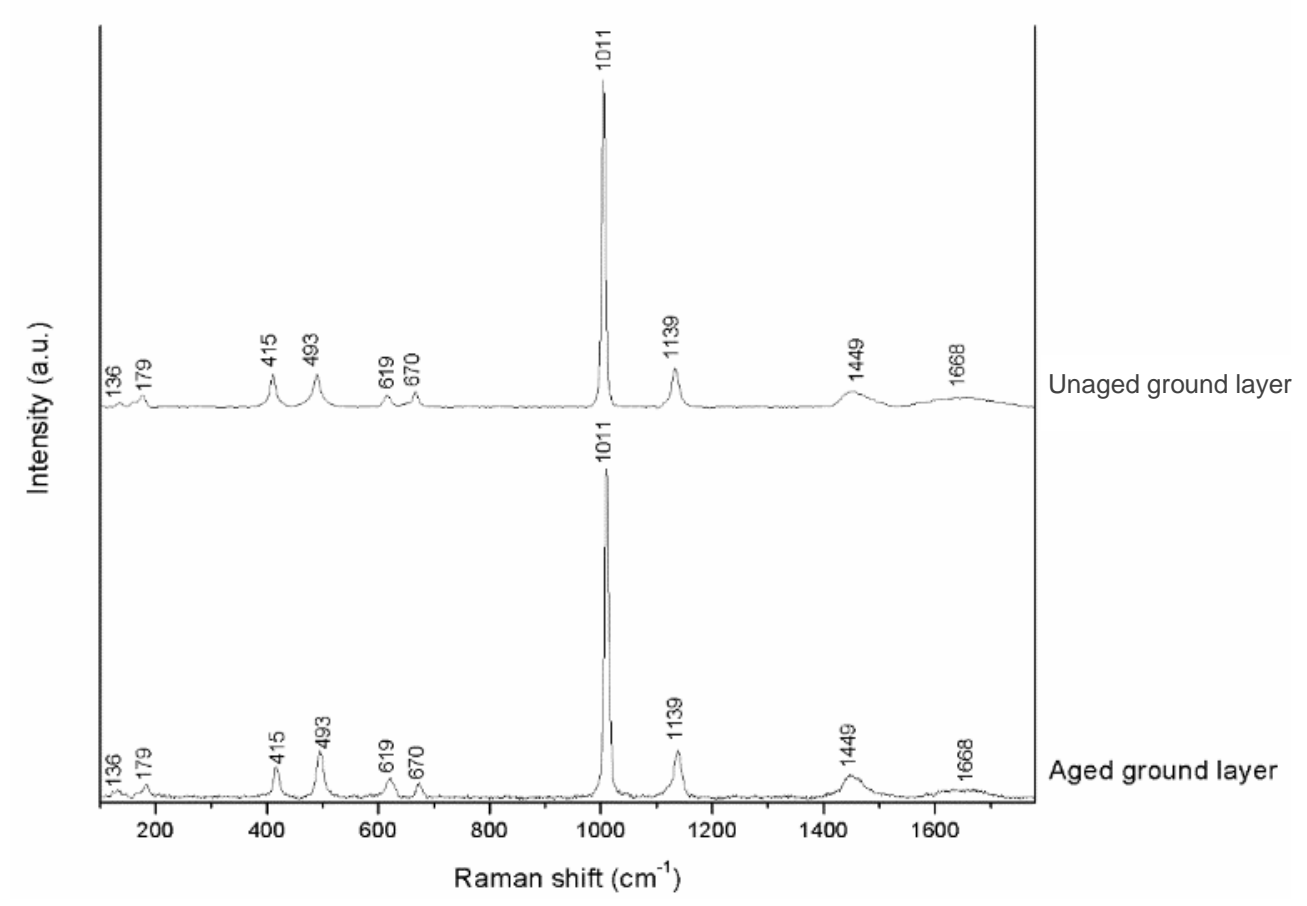

Figure 5.4.12. Representative baseline-subtracted Raman spectra of unaged and aged ground layer in the region 100-1780 cm-1. 


\subsubsection{Characterization of Raman spectra of materials used in facing}

For the characterization of the spectra of the adhesives were analysed separately the specimens prepared with single thickeners and adhesives. After this, their combinations were examined.

\section{Adhesives and thickeners}

\section{Tylose MH 300 and Klucel G}

Both Klucel G and Tylose MH 300 are cellulose ethers. Cellulose ethers were produced in the twenties in Germany, but their use in conservation started in the seventies. These polymers have good thickening and wetting and they have surfactant properties, which means they have poor penetration. They are alkyl derivatives, produced by modifying the molecular structure of cellulose. Methyl, ethyl-, hydroxypropyl-, methylmydroxyethyl-celluloses are the most used derivatives. Tylose MH 300 is a methylhydroxyethyl cellulose (MHEC). Even if exist many types of Tylose (e.g.: MH 20, MH 50), the most used is Tylose MH 300. The number following $\mathrm{MH}$ refers to the viscosity of an aqueous solution at $2 \%(\mathrm{w} / \mathrm{W})$. Klucel $\mathrm{G}$ is a hydroxypropyl Cellulose (HPC), with a molecular weight from 80.00095.000 uma (Klucel G E, L) to 1.000 .000 uma (Klucel G H, M). Klucel G, the most used in restoration of easel paintings, has a molecular weight of 370.000 uma (Borgioli, and Cremonesi 2005; Horie 2010).

Comparing the Raman spectra of these two cellulose ethers, differences in the bands position and in the ratio of bands intensities can be observed, due to the different substituents.

Tylose MH 300 (Fig. 5.4.13-14) spectrum shows peaks at 200, 293 and $459 \mathrm{~cm}^{-1}$, Klucel G (Fig. 5.4.15-16) at 200, 289,438, 472 and $499 \mathrm{~cm}^{-1}$. Some differences can be found in the region $750-850 \mathrm{~cm}^{-1}$, assigned to the ether $\mathrm{v}(\mathrm{C}-\mathrm{O}-\mathrm{C})$ modes and to the $\mathrm{v}(\mathrm{C}-\mathrm{C})$ modes of branched alkanes constituting the substituents in the cellulose chains. Tylose MH 300 presents two characteristic peaks at 847 and 888 $\mathrm{cm}^{-1}$ while Klucel $\mathrm{G}$ has a stronger single one at $851 \mathrm{~cm}^{-1}$.

The region from 850 to $1000 \mathrm{~cm}^{-1}$ corresponds to $\mathrm{v}(\mathrm{C}-\mathrm{C})$ stretching of unsubstituted cellulose and $\mathrm{V}(\mathrm{C}-\mathrm{C}-\mathrm{O})$ vibration mode. In this region, Tylose $\mathrm{MH}$ 300 shows a peak at $943 \mathrm{~cm}^{-1}$, Klucel $G$ at $925 \mathrm{~cm}^{-1}$. The $1000-1200 \mathrm{~cm}^{-1}$ region also have contributions from $\mathrm{C}-\mathrm{C}$ and $\mathrm{C}-\mathrm{O}$ stretches, with peaks at 1026, 1093, 1120 and $1150 \mathrm{~cm}^{-1}$ for Tylose $\mathrm{MH} 300$ and 1016, 1086, 1126 and $1152 \mathrm{~cm}^{-1}$ for Klucel $\mathrm{G}$. The region $1200-1500 \mathrm{~cm}^{-1}$ is typical for $\mathrm{CH}$ bends, many of which have strong Raman intensity. Bands in this region are at 1262, 1301, 1404 and $1452 \mathrm{~cm}^{-1}$ 
for Tylose MH 300 and at 1263, 1297, 1301, 1363, 1403 and $1454 \mathrm{~cm}^{-1}$ for Klucel G. These last one are characteristic for the alkane parts in the substituted celluloses.

A weak peak at $2675 \mathrm{~cm}^{-1}$ is present in the spectra of both Tylose $\mathrm{MH} 300$ and Klucel $G$, while there are differences in the bands of the stretching modes of the $\mathrm{CH}, \mathrm{CH}_{2}$ and $\mathrm{CH}_{3}$ groups. In fact, the band of Tylose $\mathrm{MH} 300$ shows a medium peak at $2843 \mathrm{~cm}^{-1}$ and another strong one at $2894 \mathrm{~cm}^{-1}$, with a shoulder at $2933 \mathrm{~cm}^{-1}$. On the contrary, in Klucel $\mathrm{G}$ spectrum, there is a band with peaks at 2879, 2934 and $2974 \mathrm{~cm}^{-1}$ (Langkilde and Svantesson 1995; Alvarez et al. 1999; Fechner et al. 2005; Deveij et I. 2009; Sievens-Figueroa et al. 2012; Casanova et al. 2016). Both the cellulose ethers present a broad band at $3432 \mathrm{~cm}^{-1}$.

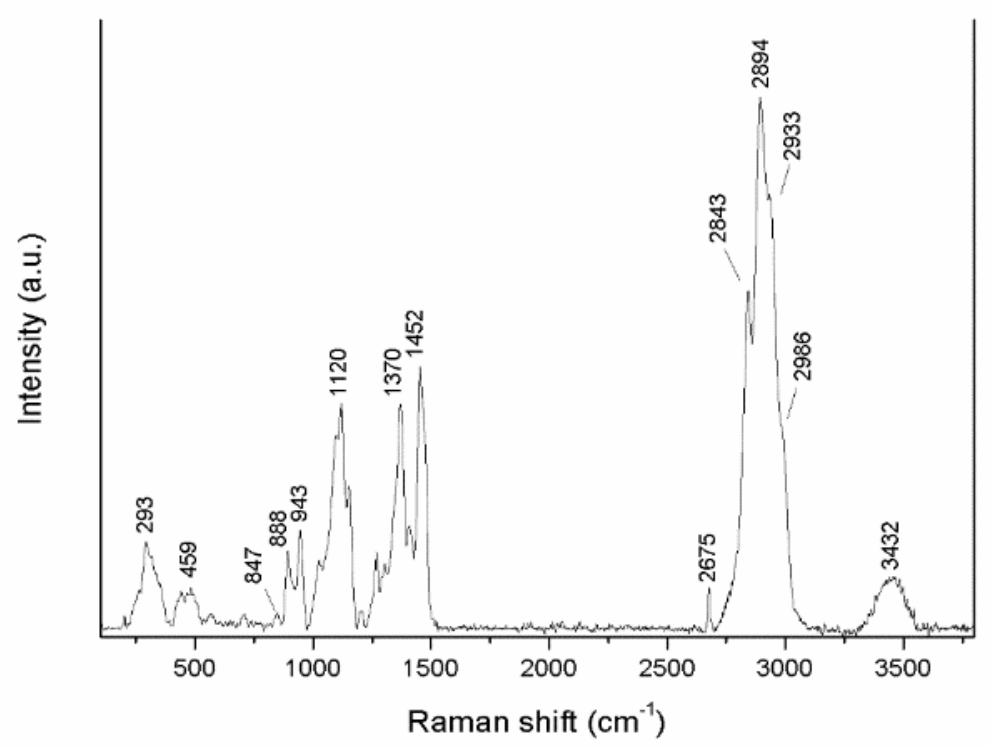

Figure 5.4.13. Representative baseline-subtracted Raman spectra of Tylose $\mathrm{MH}$ 300 in the region $100-3800 \mathrm{~cm}^{-1}$. 


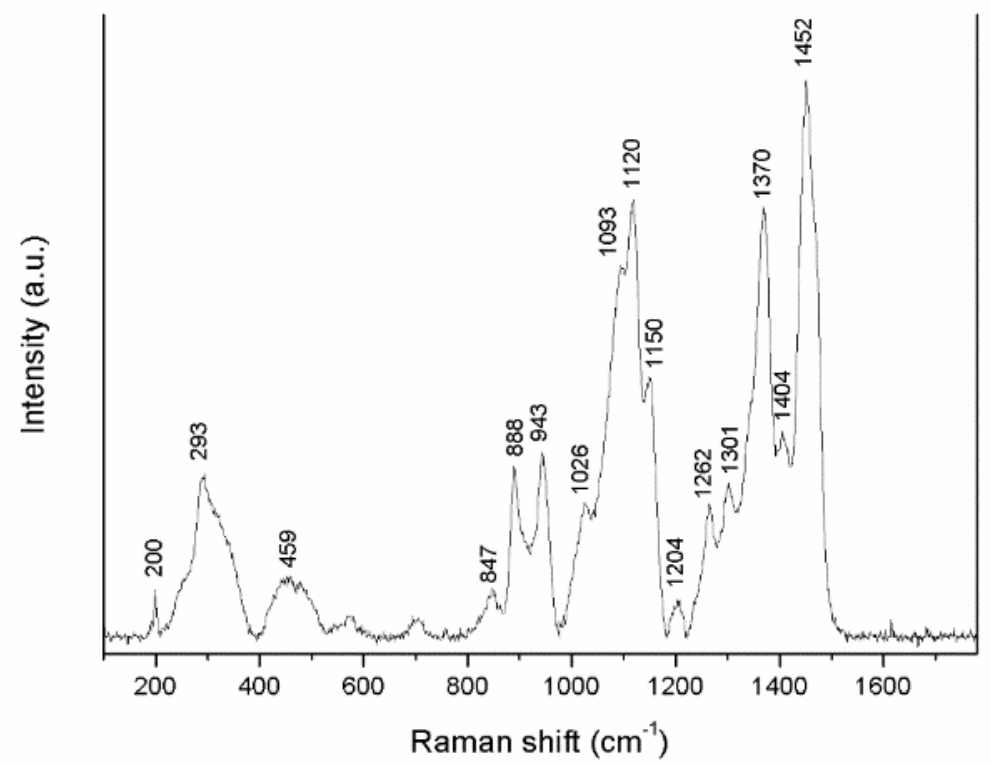

Figure 5.4.14. Representative baseline-subtracted Raman spectra of Tylose MH 300 in the region 100-1780 $\mathrm{cm}^{-1}$.

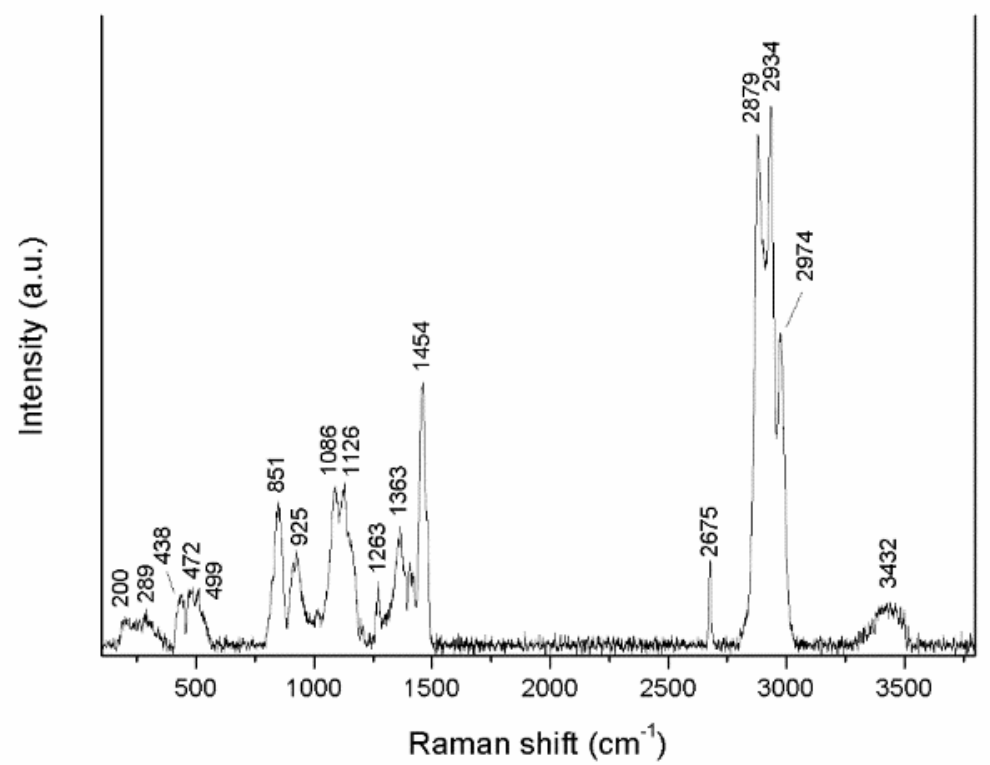

Figure 5.4.3.15. Representative baseline-subtracted Raman spectra of Klucel G in the region $100-3800 \mathrm{~cm}^{-1}$. 


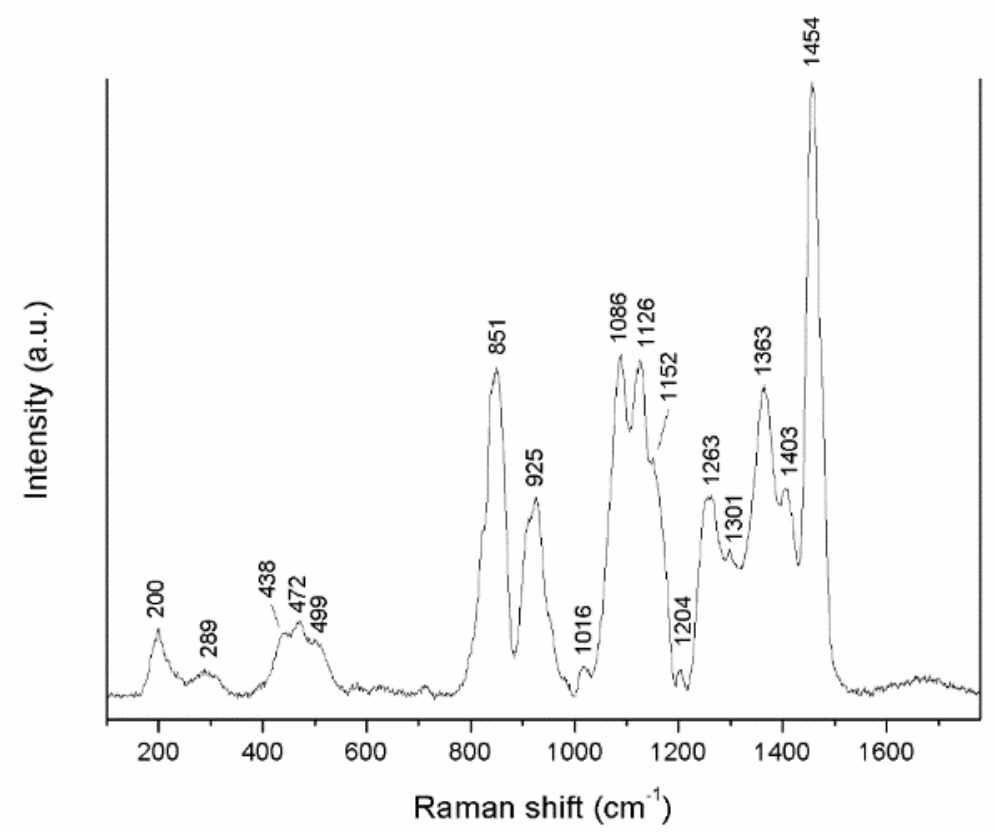

Figure 5.4.16. Representative baseline-subtracted Raman spectra of Klucel G in the region $100-1780 \mathrm{~cm}^{-1}$.

\section{Plextol B500}

Plextol B500, nowadays solds as Degalan B500, is an acrylic emulsion (solid content: $50 \pm 1 \%$ ) containing $60 \%$ of ethyl acrylate (PEA) and $40 \%$ of methyl methacrylate (PMMA) with with polymer microdrops of 0.1-0.2 $\mu \mathrm{m}$. (Borgioli, and Cremonesi 2005; Horie 2010).

The spectra of Plextol (Fig. 5.4.17-18) were compared with the ones of ethyl acrylate and methyl methacrylate found in bibliography, in order to have some information on their functional groups. As all the analysed materials, the spectrum of Plextol has characteristic peaks in the regions $250-1800 \mathrm{~cm}^{-1}$ and $2400-3150 \mathrm{~cm}^{-1}$.

The most prominent bands in the Raman spectra are those of aliphatic $v(\mathrm{CH})$ stretching in high frequency region, which refers to $\mathrm{CH}, \mathrm{CH}_{2}$ and $\mathrm{CH}_{3}$ bonds. In particular, in the spectrum of Plextol a peak at $2934 \mathrm{~cm}^{-1}$ with three shoulders at 2843 , 2873 and $2978 \mathrm{~cm}^{-1}$ is present.

The most interesting peaks are that at 1454 and $1729 \mathrm{~cm}^{-1}$. The peak at $1454 \mathrm{~cm}^{-1}$ is supposed to correspond to methyl deformations of $\mathrm{CH}, \mathrm{CH}_{2}$ and $\mathrm{CH}_{3}$ groups of PEA 
(Neppel, Butler, and Eisenberg 1979) and PMMA (Willis, Zichy, and Hendra 1969). The band at $1729 \mathrm{~cm}^{-1}$ correspond to the $\mathrm{C}=\mathrm{O}$ stretching frequency of the methyl and ethyl esters (Bowles 1970).

The other two visible peaks at 857 and $1116 \mathrm{~cm}^{-1}$, as the one at $857 \mathrm{~cm}^{-1}$, correspond to $\vee(C-C)$ modes of PEA (Bowels 1970; Neppel, Butler, and Eisenberg 1979).

The more prominent low frequency bands of Plextol B500, at 366, 484, 533 and 600 $\mathrm{cm}^{-1}$, are probably due to $\mathrm{v}(\mathrm{C}-\mathrm{CO}-\mathrm{C})$ and $\mathrm{v}(\mathrm{C}-\mathrm{CO}-\mathrm{O})$ vibrational modes of PMMA. The weak Raman band at $1161 \mathrm{~cm}^{-1}$ correspond to $\mathrm{V}(\mathrm{C}-\mathrm{O}-\mathrm{C})$ modes of PMMA, while the other two peaks at 1236 and $1277 \mathrm{~cm}^{-1}$ are due to $\mathrm{v}(\mathrm{C}-\mathrm{C}-\mathrm{O}$ ) vibration (Willis, Zichy, and Hendra 1969).

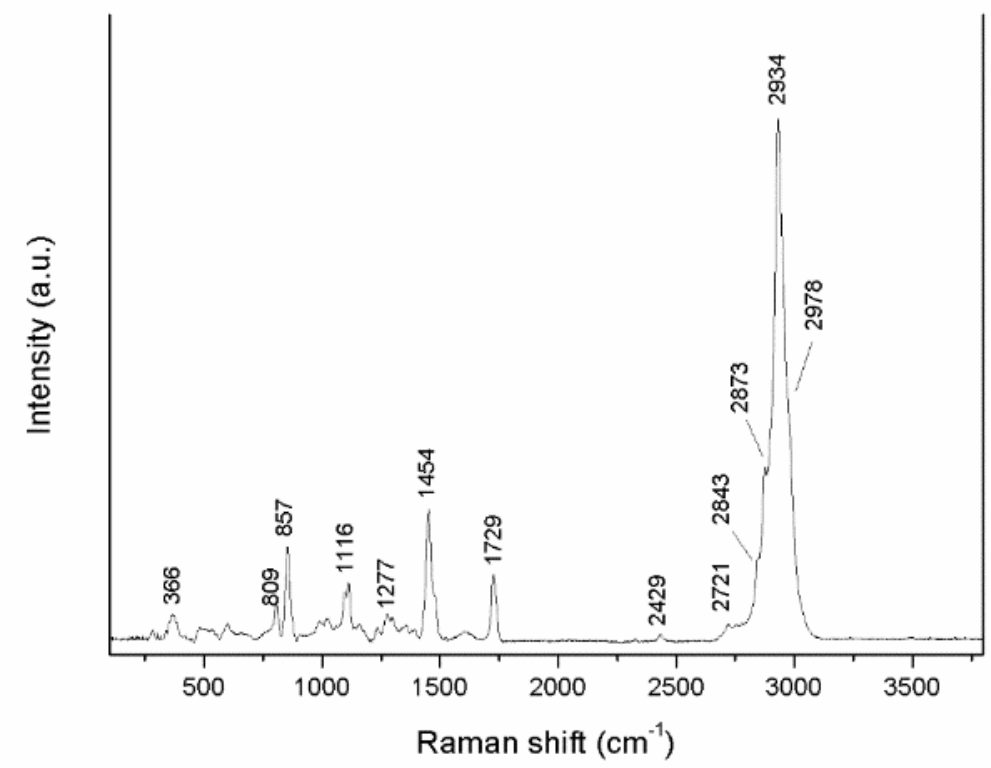

Figure 5.4.17. Representative baseline-subtracted Raman spectra of Plextol B500 in the region $100-3800 \mathrm{~cm}^{-1}$. 


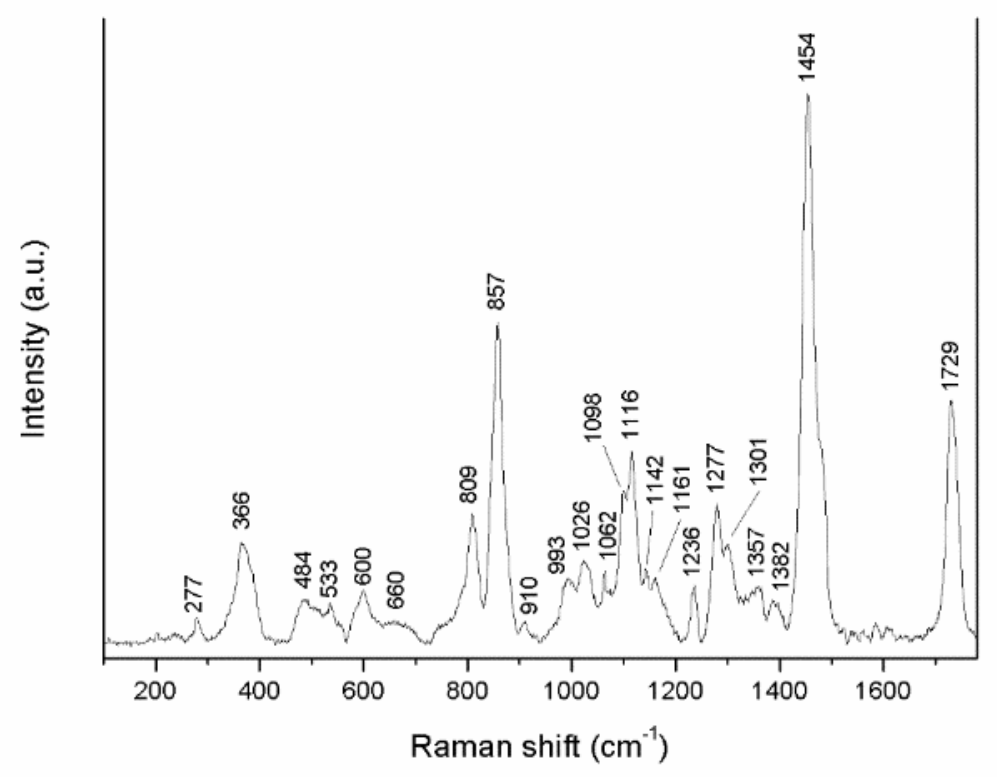

Figure 5.4.18. Representative baseline-subtracted Raman spectra of Plextol B500 in the region 100-1780 $\mathrm{cm}^{-1}$.

\section{Aquazol 500}

Aquazol is a relatively new polymer, manufactured by Polymer Chemistry Innovations, introduced in the conservation practice by Richard Wolbers at the end of the past century. It is constituted by polyalkylenimine chains formed from 2-ethyl-2oxazoline. Its chemical formula is $-\left(\mathrm{C}_{5} \mathrm{H}_{9} \mathrm{NO}\right)_{n^{-}}$. The chains are usually synthesized by cationic ring-opening polymerization initiated by an electrophilic initiator (ex. methyl tosylate) and terminated by nucleophiles. The different chemical nature of initiators and terminations produces 2-oxazoline polymers with several proprieties and uses.

The most evident band of the Aquazol (Fig. 5.4.19-20) spectrum is at $2941 \mathrm{~cm}^{-1}$, with three shoulder at 2738, 2886 and $2978 \mathrm{~cm}^{-1}$, all referred to $\mathrm{CH}_{2}$ and $\mathrm{CH}_{3}$ bonds. The same is for the weak peak at $2677 \mathrm{~cm}^{-1}$.

The most informative region for Aquazol is $200-1700 \mathrm{~cm}^{-1}$. Here, the peak at 1635 is supposed to correspond to $\mathrm{V}(\mathrm{C}=\mathrm{O})$ modes (Sun, and $\mathrm{Wu}$ 2015). The region included between 1390 and $1530 \mathrm{~cm}^{-1}$, with peaks at 1429, 1460 and $1482 \mathrm{~cm}^{-1}$, corresponds to $\delta\left(\mathrm{CH}_{2}\right)$ modes (Durig, Riethmiller, and Li 1974).

It has been suggested that bands between 250 and $560 \mathrm{~cm}^{-1}$ could are due to vibration about the C-C-N bond (Socrates 2001), while the others included in the region $930-1300 \mathrm{~cm}^{-1}$ are overtones of different vibrational mode of $\mathrm{CH}_{2}$ bonds (Durig, Riethmiller, and Li 1974). 


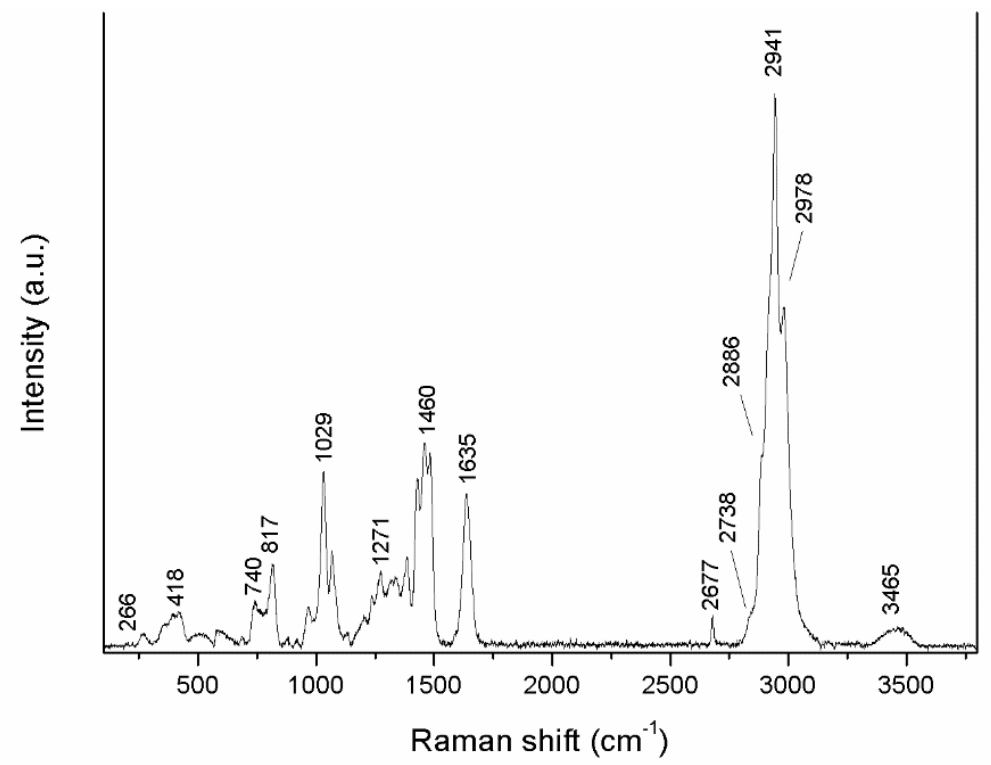

Figure 5.4.19. Representative baseline-subtracted Raman spectra of Aquazol 500 in the region $100-3800 \mathrm{~cm}^{-1}$ and in the region $100-3800 \mathrm{~cm}^{-1}$.

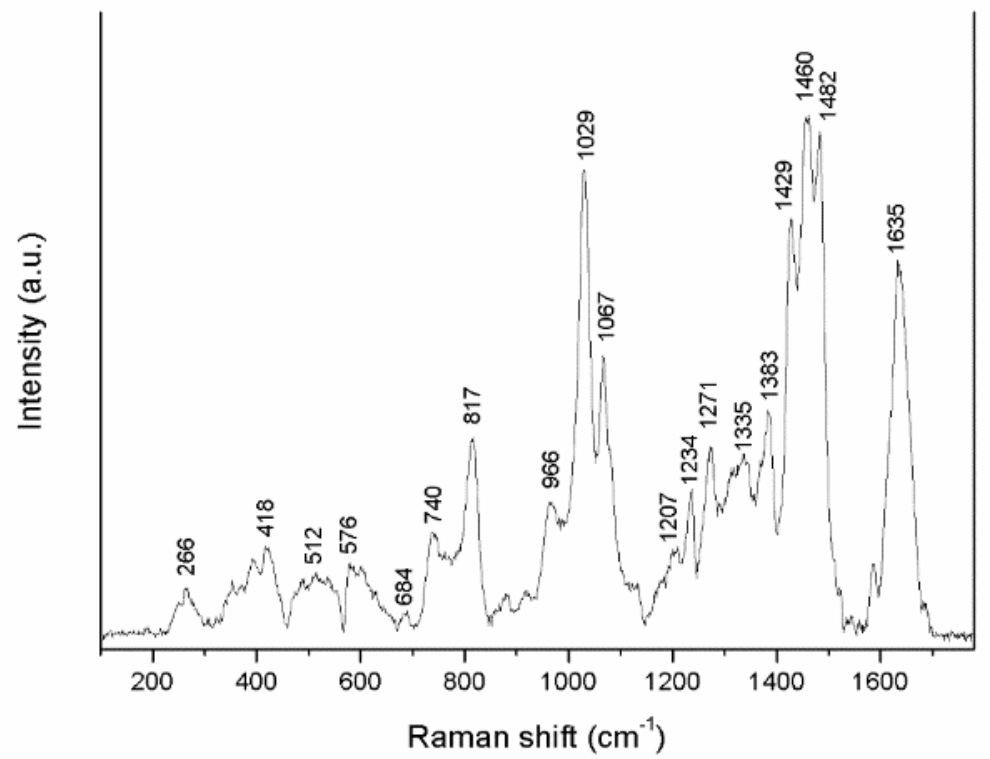

Figure 5.4.20. Representative baseline-subtracted Raman spectra of Aquazol 500 in the region 100-1780 $\mathrm{cm}^{-1}$. 


\section{Facing adhesives: mixtures}

\section{$T(3) P 7$}

Spectra of the adhesive mixture T(3)P7 (Fig. 5.4.21-22) present both characteristics of Tylose MH 300 and Plextol B500, even if some peaks are slightly shifted compared to the spectra of source polymers. The low frequency peak at $200 \mathrm{~cm}^{-1}$ it is supposed to be of Tylose, while the band at $370 \mathrm{~cm}^{-1}$ (as Plextol) present a shoulder corresponding to $297 \mathrm{~cm}^{-1}$ (as Tylose). The region between 400 and $720 \mathrm{~cm}^{-1}$ is similar to the spectrum of Plextol, as the two peaks at 809 and $857 \mathrm{~cm}^{-1}$. The band between 970 and $1200 \mathrm{~cm}^{-1}$ presents characteristics of the two polymers, with a principal peak at $1118 \mathrm{~cm}^{-1}$. The band included among 1220 and $1520 \mathrm{~cm}^{-1}$ shows a weak but distinct peak at $1370 \mathrm{~cm}^{-1}$, characteristic of Tylose, and a higher peak at $1454 \mathrm{~cm}^{-1}$, which can be ascribed to the contributions of the functional groups of source polymers. The detached peak at $1729 \mathrm{~cm}^{-1}$ corresponds to Plextol. In the region between 2500 and $3500 \mathrm{~cm}^{-1}$, the peak at $2675 \mathrm{~cm}^{-1}$ and the broad band at $3432 \mathrm{~cm}^{-1}$ are due to the presence of Tylose, while the band $2690-3090 \mathrm{~cm}^{-1}$ seems to be the result of polymers mixture. In this region, the principal peak is at $2934 \mathrm{~cm}^{-1}$, with other visible shoulders at 2843, 2881 and $2986 \mathrm{~cm}^{-1}$.

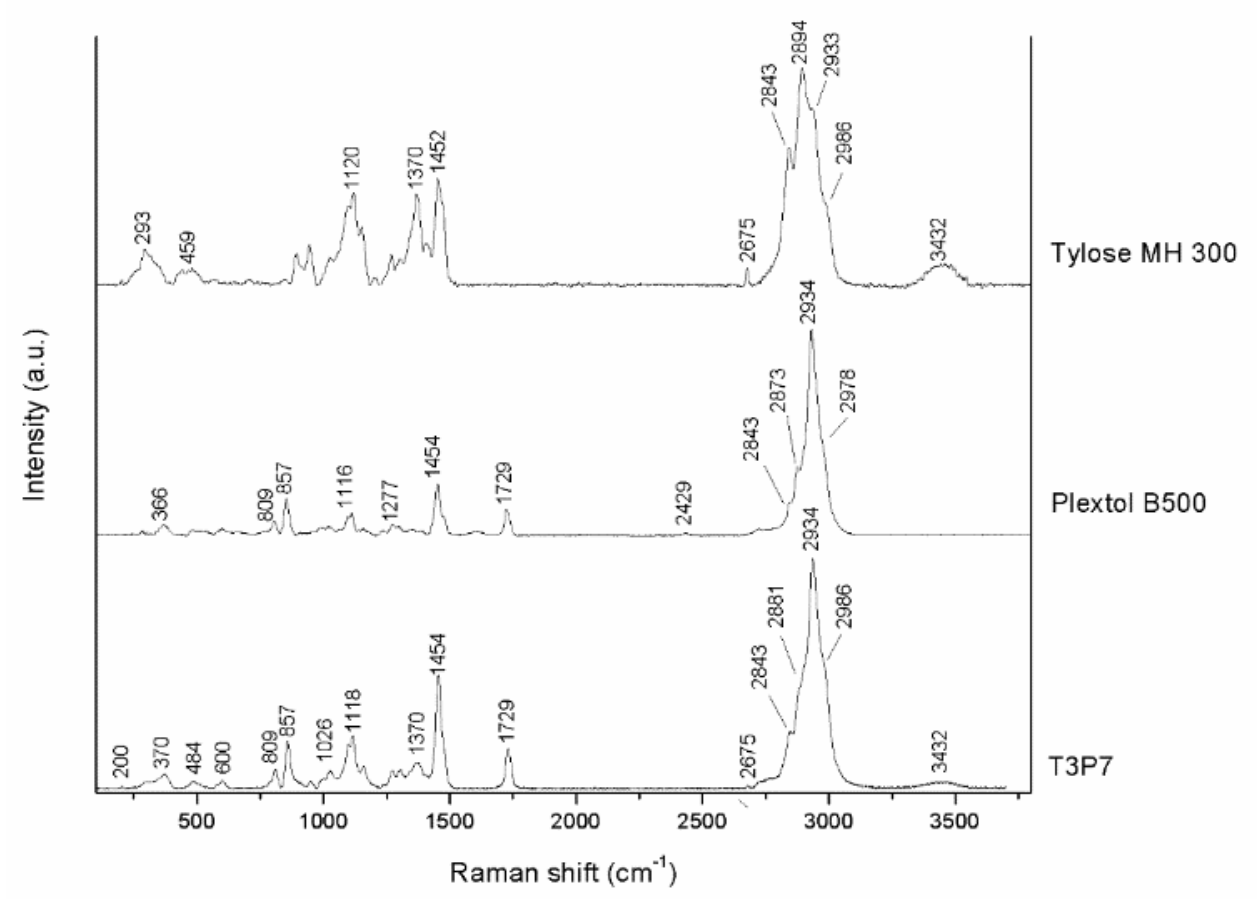

Figure 5.4.21. Representative baseline-subtracted Raman spectra of T(3)P7 in the region 100-3800 $\mathrm{cm}^{-1}$ and in the region $100-1780 \mathrm{~cm}^{-1}$. 


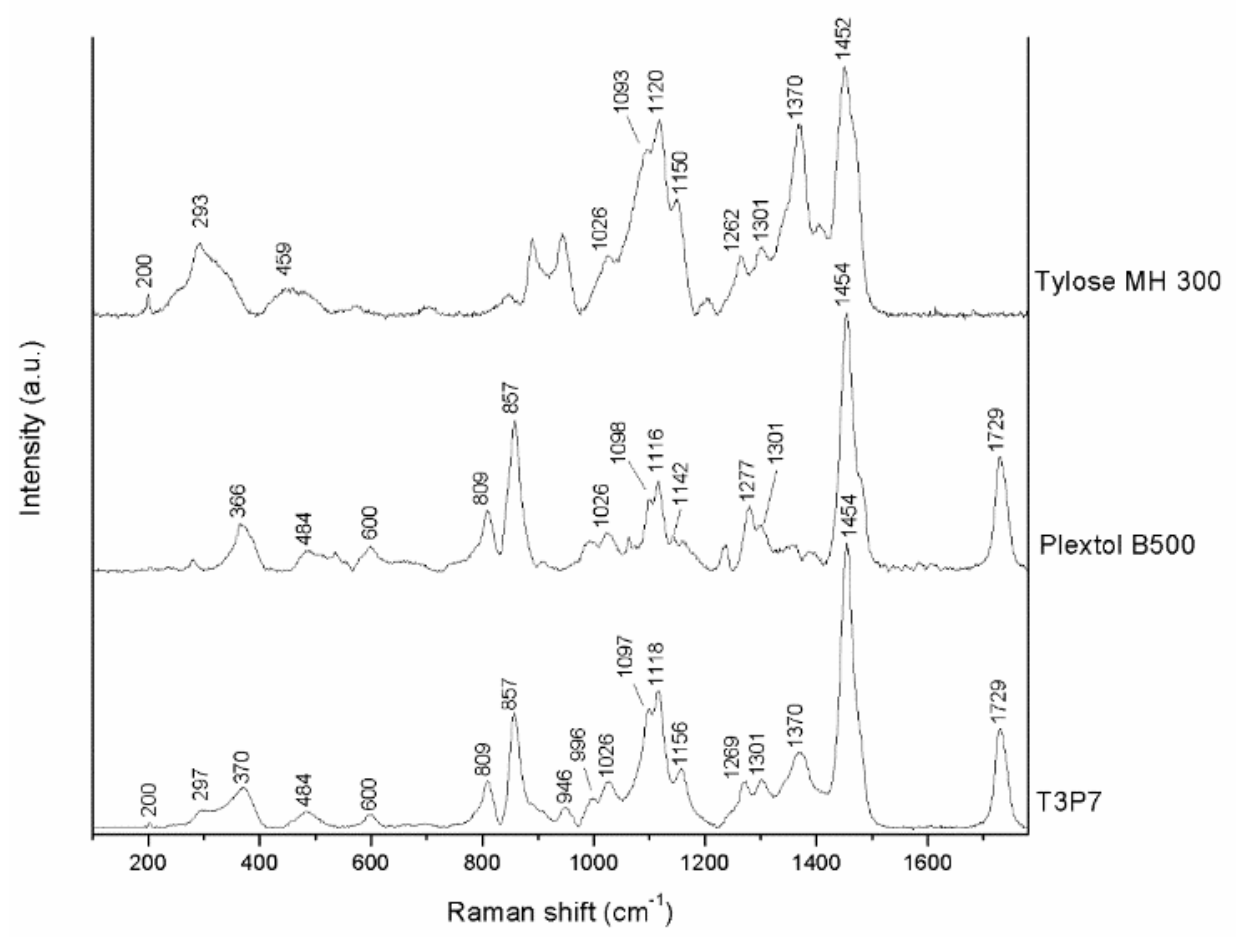

Figure 5.4.22. Representative baseline-subtracted Raman spectra of T(3)P7 in the region $100-3800 \mathrm{~cm}^{-1}$ and in the region $100-1780 \mathrm{~cm}^{-1}$.

\section{K(4)P7}

In the spectra of K(4)P7 (Fig. 5.4.23-24) it is possible to individuate the characteristic peaks of the two source polymers, with some shifting due to their conjunction in the mixture. There is a weak band at $200 \mathrm{~cm}^{-1}$, corresponding to Klucel. The bands between 320 and $720 \mathrm{~cm}^{-1}$ coincide with the Plextol ones, as the peak at $809 \mathrm{~cm}^{-1}$. The peak at $855 \mathrm{~cm}^{-1}$ and the weaker band included among $880-980 \mathrm{~cm}^{-1}$ are the result of the contribution of both Klucel and Plextol. Also the band in the region $980-1215 \mathrm{~cm}^{-1}$ and $1215-1550 \mathrm{~cm}^{-1}$ presents characteristics of the source polymers. The most detached peaks in this region are at 1096, 1116, 1301 and $1454 \mathrm{~cm}^{-1}$. It stands out the peak at $1729 \mathrm{~cm}^{-1}$ of Pextol. In the region 2500-3500 $\mathrm{cm}^{-1}$ it is possible to see the weak peak of Klucel at $2675 \mathrm{~cm}^{-1}$, as the broad band at $3432 \mathrm{~cm}^{-1}$. Here again, the band 2690-3090 $\mathrm{cm}^{-1}$ appears as a conjunction of the two source polymers, with the principal peak at $2974 \mathrm{~cm}^{-1}$ and other two at 2879 and $2974 \mathrm{~cm}^{-1}$. 


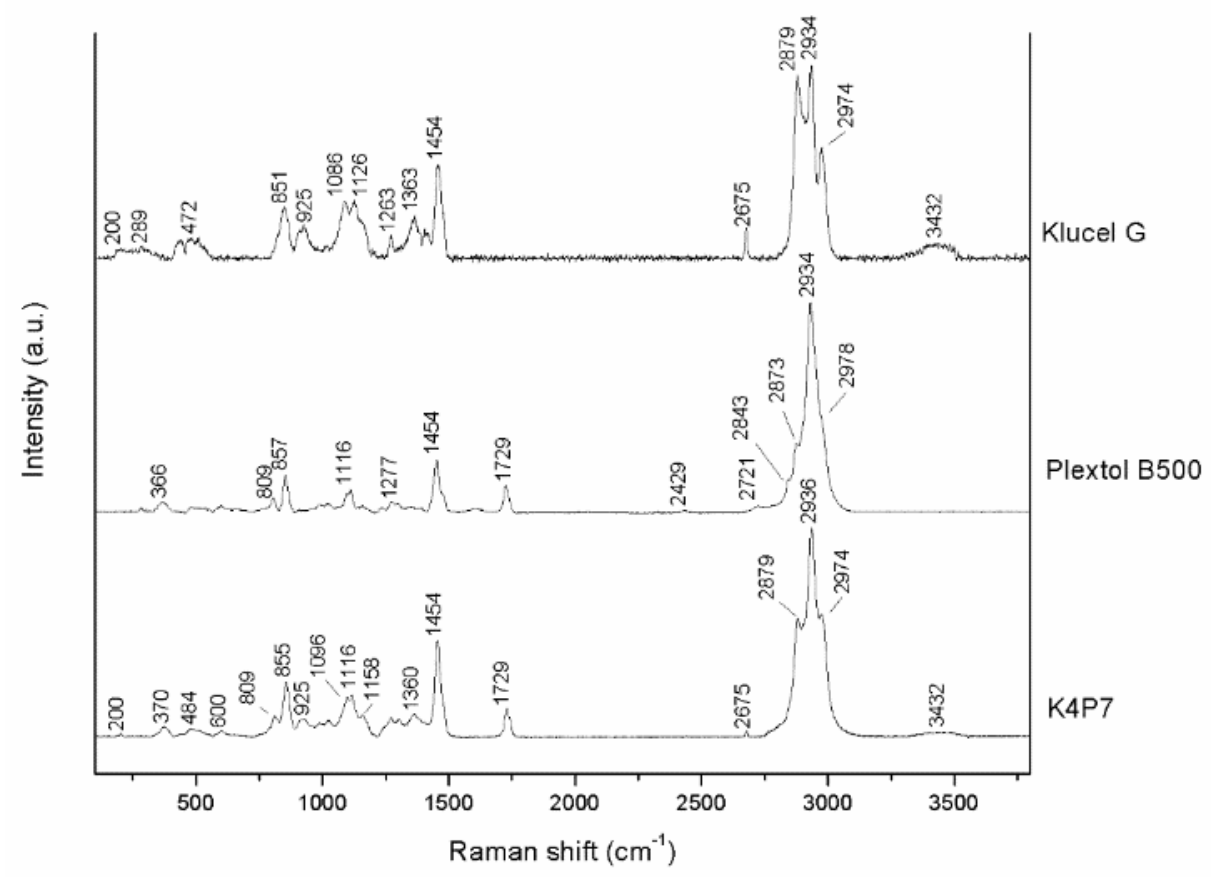

Figure 5.4.23. Representative baseline-subtracted Raman spectra of K(4)P7 in the region $100-3800 \mathrm{~cm}^{-1}$ and in the region $100-1780 \mathrm{~cm}^{-1}$.

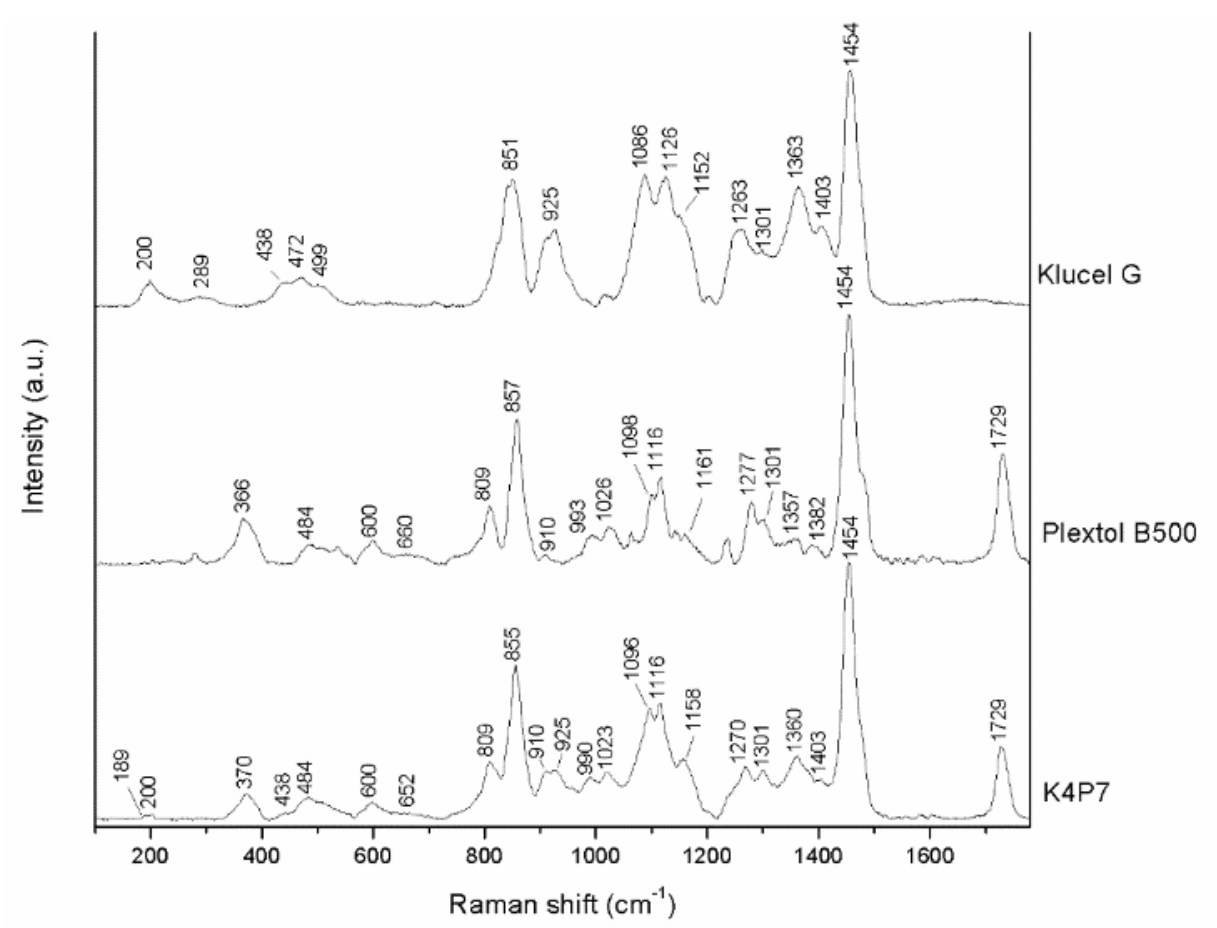

Figure 5.4.24. Representative baseline-subtracted Raman spectra of K(4)P7 in the region 100-3800 $\mathrm{cm}^{-1}$ and in the region $100-1780 \mathrm{~cm}^{-1}$. 


\section{$K(3) A(4) E$}

In the case of the spectra of K(3)A(4)E (Fig. 5.4.25-26) more shifted peaks were found. In the region of low frequency is present a weak band which peaks at $204 \mathrm{~cm}^{-1}$, with a shoulder at $194 \mathrm{~cm}^{-1}$. The bands included among 210 and $700 \mathrm{~cm}^{-1}$ can be ascribed principally to Aquazol, except peak at $478 \mathrm{~cm}^{-1}$, which probably convey the influence of Klucel.

The bands included among 700 and $1550 \mathrm{~cm}^{-1}$ are the result of the contribution of both polymers. Particularly, the region $700-885 \mathrm{~cm}^{-1}$ shows peaks at 740 and $817 \mathrm{~cm}^{-1}$, corresponding to Aquazol, and another one at $850 \mathrm{~cm}^{-1}$, referred to Klucel. The other band at $890-990 \mathrm{~cm}^{-1}$ present the Klucel peak at $925 \mathrm{~cm}^{-1}$ and the Aquazol one at $965 \mathrm{~cm}^{-1}$.

The band in the region $990-1220 \mathrm{~cm}^{-1}$ has a higher peak at $1029 \mathrm{~cm}^{-1}$, and another at $1067 \mathrm{~cm}^{-1}$ corresponding to Aquazol, while the others at 1083 and $1129 \mathrm{~cm}^{-1}$ are characteristic of Klucel. In the band $1220-1550 \mathrm{~cm}^{-1}$, a part from the peaks at 1269 and $1381 \mathrm{~cm}^{-1}$, it worth emphasize the presence of a high peak at $1460 \mathrm{~cm}^{-1}$, that is the result of the contribution of the two polymers, which shows two shoulders at 1428 and $1480 \mathrm{~cm}^{-1}$, characteristic of the corresponding band of Aquazol. The other distinctive peak of Aquazol is visible at $1635 \mathrm{~cm}^{-1}$.

In the high frequency region is present a peak at $2677 \mathrm{~cm}^{-1}$, conveying the contribution of the two polymers. The very strong band that appears in the region 2750-3100 $\mathrm{cm}^{-1}$ is the result of the overlapping of the principal peaks of the spectra of source polymers. Particularly, the higher peak is at $2941 \mathrm{~cm}^{-1}$, which is accompanied by lateral peaks at 2882 and $2977 \mathrm{~cm}^{-1}$. Finally, in the region $3100-3550 \mathrm{~cm}^{-1}$ is present a broad band at $3340 \mathrm{~cm}^{-1}$. 


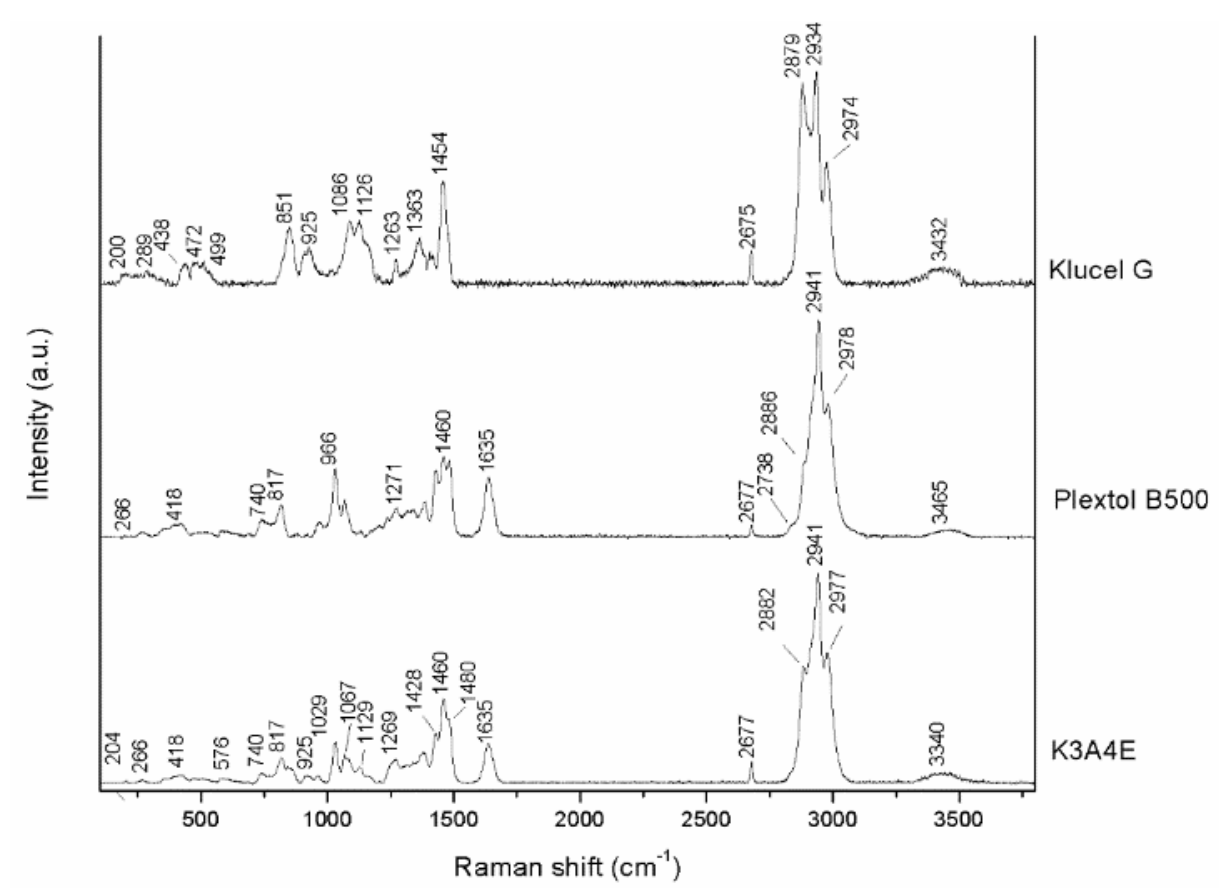

Figure 5.4.25. Representative baseline-subtracted Raman spectra of K(3)A(4)E in the region $100-3800 \mathrm{~cm}^{-1}$ and in the region $100-1780 \mathrm{~cm}^{-1}$.

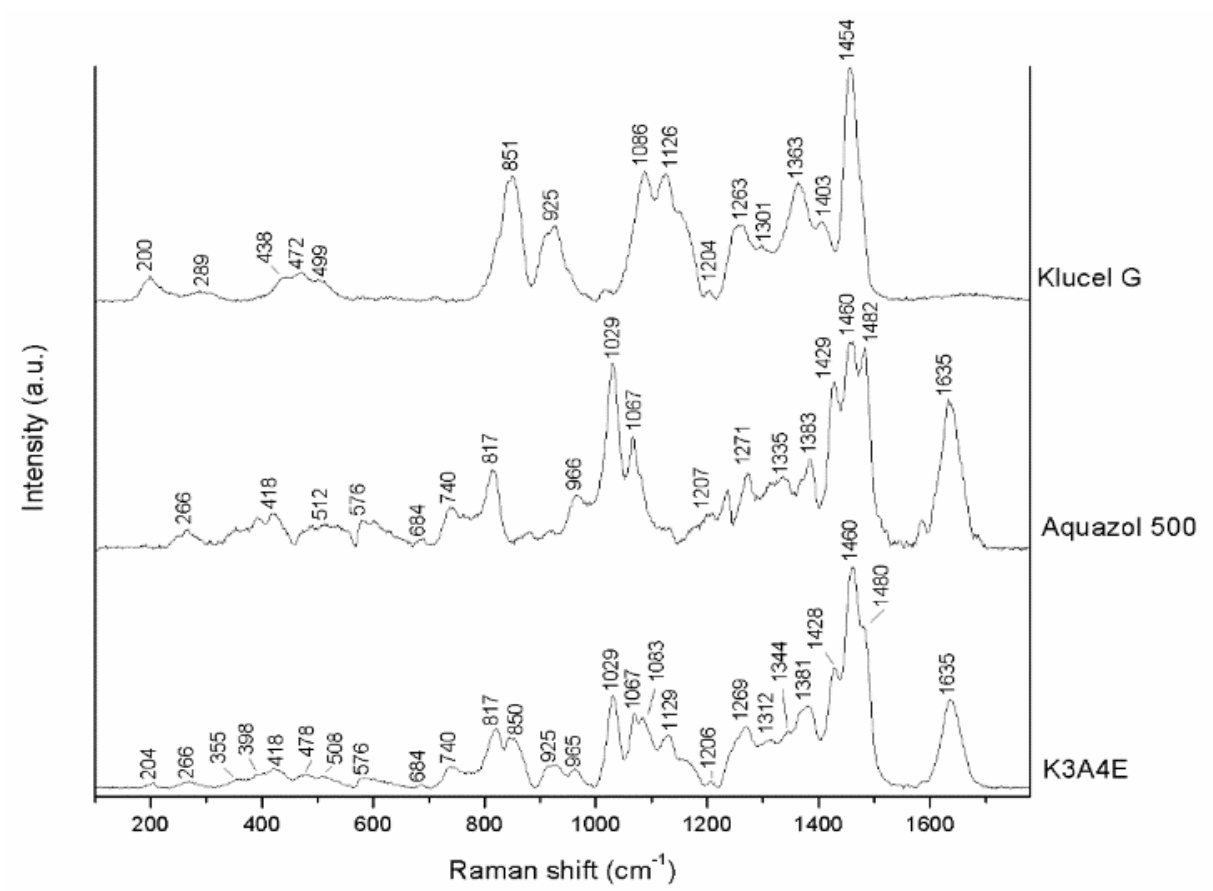

Figure 5.4.26. Representative baseline-subtracted Raman spectra of K(3)A(4)E in the region 100-3800 $\mathrm{cm}^{-1}$ and in the region $100-1780 \mathrm{~cm}^{-1}$. 
Table 5.4.1. Materials analysed with Horiba HR Evolution spectrometer $\left(\lambda_{0}=633 \mathrm{~nm}\right)$.

\begin{tabular}{|c|c|c|c|}
\hline & Name & Raman wavenumber $\mathrm{cm}^{-1}(+/-1)$ & Figure \\
\hline \multirow{9}{*}{ 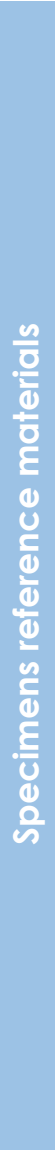 } & Unaged Dammar & $\begin{array}{l}316,415,465,530,557,583,606,713,760,804,950,1026, \\
1119,1179,1201,1265,1315,1346,1381,1449,1655 \\
1704,2870,2932\end{array}$ & 5.4.3-4 \\
\hline & Aged Dammar & $\begin{array}{l}465,530,557,606,713,760,804,950,1179,1201,1265 \\
1315,1346,1381,1449,1655,1704,2673,2766,2870,2932\end{array}$ & 5.4.3-4 \\
\hline & Iron oxide (III) red & $224,243,292,409,497,612,660,814,1057,1102,1314$ & $5.4 .5-6$ \\
\hline & $\begin{array}{l}\text { Unaged paint } \\
\text { layer }\end{array}$ & $\begin{array}{l}224,243,292,409,497,612,660,814,1057,1102,1314, \\
2858,2930\end{array}$ & $5.4 .5-6$ \\
\hline & Aged paint layer & $\begin{array}{l}224,243,292,409,497,612,660,814,1057,1102,1314, \\
2858,2930\end{array}$ & $5.4 .5-6$ \\
\hline & $\begin{array}{l}\text { Technical } \\
\text { gelatine }\end{array}$ & $\begin{array}{l}200,307,390,559,787,813,855,920,939,1003,1031 \\
1062,1101,1161,1178,1240,1270,1449,1668,2881 \\
2938,2984,3060,3339\end{array}$ & 5.4.7-8 \\
\hline & Bologna gypsum & $136,179,415,493,619,670,1011,1139,3403,3491$ & $5.4 .9-10$ \\
\hline & $\begin{array}{l}\text { Unaged ground } \\
\text { layer }\end{array}$ & $\begin{array}{l}136,179,415,493,619,670,1011,1139,1449,1668 \\
2674,2881,2938,3403,3491\end{array}$ & 5.4.11-12 \\
\hline & $\begin{array}{l}\text { Aged ground } \\
\text { layer }\end{array}$ & $\begin{array}{l}136,179,415,493,619,670,1011,1139,1449,1668 \\
2674,2881,2938,3403,3491\end{array}$ & $5.4 .11-12$ \\
\hline \multirow{4}{*}{ 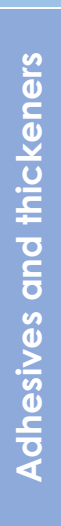 } & Tylose MH 300 & $\begin{array}{l}200,293,459,847,888,943,1026,1093,1120,1150,1262 \\
1301,1370,1404,1452,2675,2843,2894,2933,2986 \\
3432\end{array}$ & $5.4 .13-14$ \\
\hline & Klucel G & $\begin{array}{l}200,289,438,472,499,851,925,1016,1086,1126 \\
1152,1204,1263,1297,1301,1363,1403,1454,2675 \\
2879,2934,2974,3432\end{array}$ & $5.4 .15-16$ \\
\hline & Plextol B500 & $\begin{array}{l}277,366,484,533,600,660,809,857,910,993,1026 \\
1062,1098,1116,1142,1161,1236,1277,1301,1357 \\
1382,1454,1729,2429,2721,2843,2873,2934,2978\end{array}$ & 5.4.17-18 \\
\hline & Aquazol 500 & $\begin{array}{l}266,355,398,418,512,576,684,740,817,966,1029 \\
1067,1207,1234,1271,1314,1335,1383,1429,1460 \\
1482,1635,2677,2738,2886,2941,2978,3465\end{array}$ & 5.4.19-20 \\
\hline \multirow{3}{*}{ 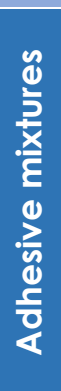 } & $\mathrm{T}(3) \mathrm{P} 7$ & $\begin{array}{l}200,297,370,484,600,809,857,946,996,1026,1097, \\
1118,1156,1269,1301,1370,1454,1729,2675,2843 \\
2881,2934,2986,3432\end{array}$ & $5.4 .21-22$ \\
\hline & $\mathrm{K}(4) \mathrm{P} 7$ & $\begin{array}{l}189,200,370,438,484,600,652,809,855,910,925,990 \\
1023,1096,1116,1158,1270,1301,1360,1403,1454 \\
1729,2675,2879,2936,2974,3432\end{array}$ & $5.4 .23-24$ \\
\hline & $K(3) A(4) E$ & $\begin{array}{l}204,266,355,398,418,478,508,576,684,740,817,850 \\
925,965,1029,1067,1083,1129,1206,1269,1312,1344 \\
1381,1428,1460,1480,1635,2677,2882,2941,2977,3340\end{array}$ & $5.4 .25-26$ \\
\hline
\end{tabular}




\subsubsection{Selection of marker peaks}

Once all the spectra of single materials were obtained, it was possible to compare them to identify the distinctive peaks of the adhesives.

Spectra of all materials presented bands in the same regions (about 150-1800 $\mathrm{cm}^{-1}$ and $2500-3500 \mathrm{~cm}^{-1}$ ) and this made difficult to state for sure the presence of the adhesive mixture in the specimens.

Since every material presented a peak with a characteristic morphology in the region 2500-3500 $\mathrm{cm}^{-1}$, this area was firstly investigate. Unfortunately, the overlapping of the peaks of the different materials made it impossible to distinguish facing adhesives among all the substances.

It was thought to focus on the little peaks and bands visible in this same region. Nonetheless, the weak peaks at $2675 \mathrm{~cm}^{-1}$ (T(3)P7, K(4)P7) and $2677 \mathrm{~cm}^{-1}$ $(\mathrm{K}(3) \mathrm{A}(4) \mathrm{E})$ could have been confused with the peak at 2673 of Dammar and the one at $2674 \mathrm{~cm}^{-1}$ of the glve of the ground layer. Neither the broad band overlapping peaks at $3340 \mathrm{~cm}^{-1}$ (K(3)A(4)E) and $3432 \mathrm{~cm}^{-1}$ (T(3)P7, K(4)P7) could be chosen, because of the presence in the same region of the peaks of gypsum of the ground layer (3403 and $3491 \mathrm{~cm}^{-1}$ ).

It was therefore decided to investigate the region 100-1800 $\mathrm{cm}^{-1}$, which gives most information on all the analysed materials. This actually permitted to have more marker peaks. 


\section{$\underline{T(3) P 7}$}

The peak at $200 \mathrm{~cm}^{-1}$ of T(3)P7 mixture (Fig. 5.4.27) could have been an evidence of the presence of the adhesive. In the region $210-720 \mathrm{~cm}^{-1}$ it was not possible to distinguish the peaks of T(3)P7 due to the presence of the very intense peaks of both the paint and the ground layers. It would have been possible to distinguish the peak at $809 \mathrm{~cm}^{-1}$ of T(3)P7, despite the presence of the peak at $814 \mathrm{~cm}^{-1}$ of the paint layer. The peak at $857 \mathrm{~cm}^{-1}$, which was the only one in this region, would have been recognizable. Another identifying band was the one between 975 and $1220 \mathrm{~cm}^{-1}$. It would have been possible to identify the peaks at 1269 and $1370 \mathrm{~cm}^{-1}$ as shoulders of the band at $1314 \mathrm{~cm}^{-1}$ of the paint layer. It would have been possible to distinguish also the peak of T(3)P7 at $1454 \mathrm{~cm}^{-1}$ from the one at $1449 \mathrm{~cm}^{-1}$ of Dammar and ground layer. The analysis of the entire region could ensure the detection of adhesive traces, but the identifying peak at $1729 \mathrm{~cm}^{-1}$, corresponding to the Plextol presents in the adhesive mixture, would have assessed the presence of T(3)P7.

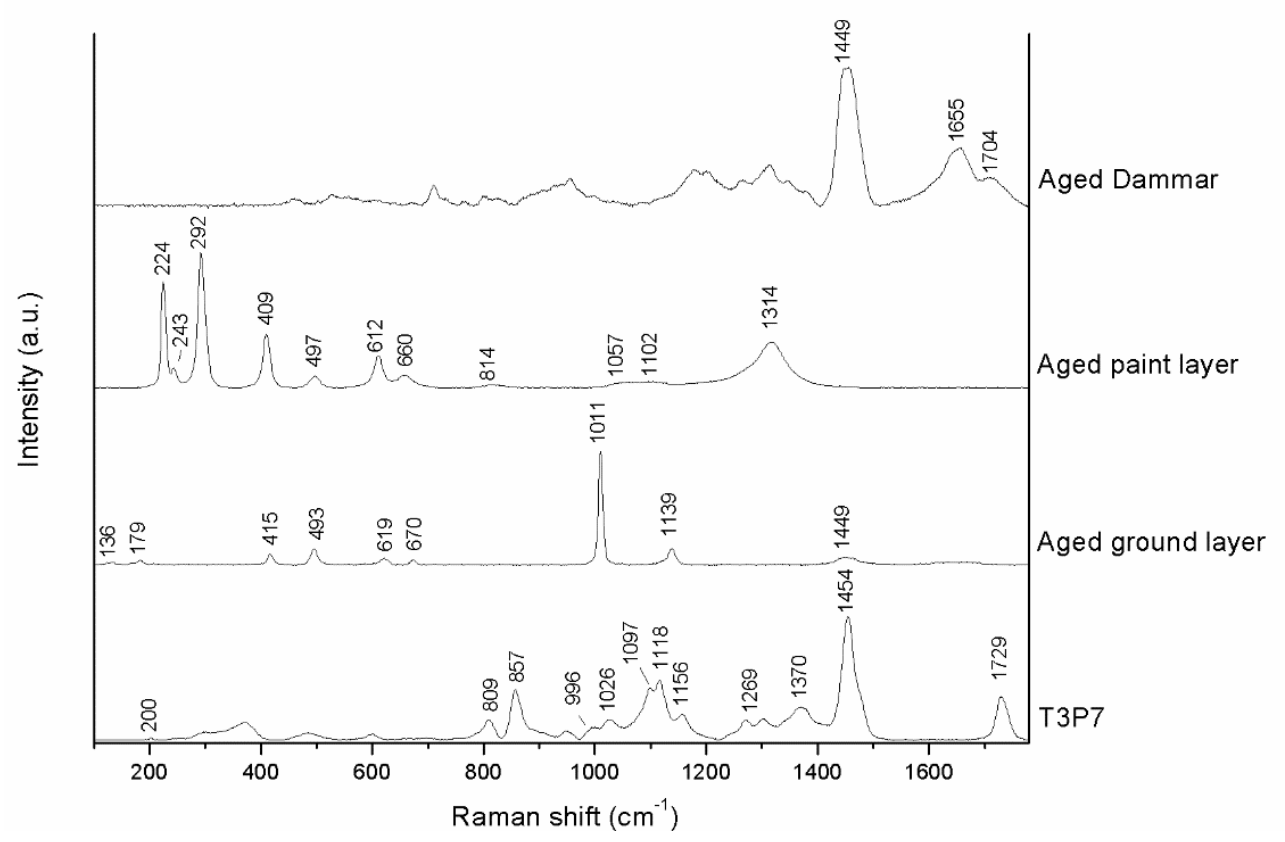

Figure 5.4.27. Comparison of spectra of aged dammar, paint layer, ground layer and T(3)P7, useful to the assessment of adhesive mixture identifying peaks. 


\section{$\underline{\mathrm{K}(4) \mathrm{P} 7}$}

The distinctive bands of K(4)P7 (Fig. 5.4.28) were similar to that of T(3)P7. The peak in the low frequency region at $200 \mathrm{~cm}^{-1}$ would have been useful to reveal the presence of the adhesive. Here too, the region between 210 and $720 \mathrm{~cm}^{-1}$ could not be representative, because the peaks of the paint and the ground layer. Nevertheless, the peaks at 809 and $855 \mathrm{~cm}^{-1}$ would have been useful to determinate the presence of the adhesive. Other identifying bands are at 1066, 1116 and $1158 \mathrm{~cm}^{-1}$, while the peaks at 1270 and $1360 \mathrm{~cm}^{-1}$ could be visible also in the case of the presence of the paint layer and shoulder of the peak at 1314 $\mathrm{cm}^{-1}$. As for T(3) P7, the peak at $1454 \mathrm{~cm}^{-1}$ could have been discernible from the one at $1449 \mathrm{~cm}^{-1}$ of Dammar and ground layer. Even if the analysis of the entire region can be useful to assess the presence of the adhesive, the identifying peak of Plextol $\left(1729 \mathrm{~cm}^{-1}\right)$ would have assessed the presence of T(3)P7.

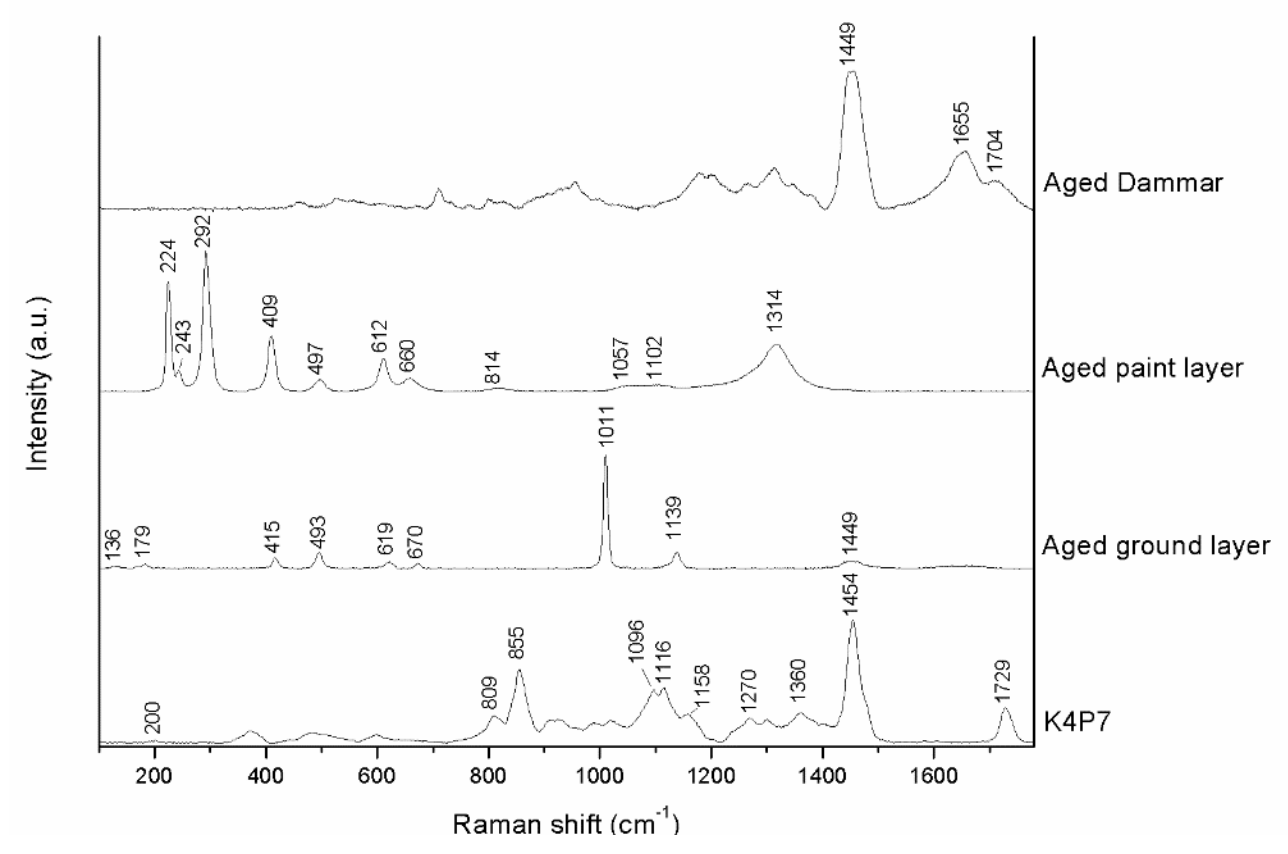

Figure 5.4.28. Comparison of spectra of aged dammar, paint layer, ground layer and K(4)P7, useful to the assessment of adhesive mixture identifying peaks. 


\section{$\underline{K}(3) A(4) E$}

To distinguish the spectrum of the K(3)A(4)E (Fig. 5.4.29) in the mock-ups would have been more difficult. The presence of the adhesive could be detected by the presence in the spectrum of the peak at $204 \mathrm{~cm}^{-1}$. As for the other two facing adhesives, it would have been difficult to recognize peaks in the region between 210 and $720 \mathrm{~cm}^{-1}$. Nevertheless, the bands at 817 and $850 \mathrm{~cm}^{-1}$, as the ones at 925 and $965 \mathrm{~cm}^{-1}$ might have been recognizable. In the region between 990 and $1220 \mathrm{~cm}^{-1}$ peaks at 1029 and $1067 \mathrm{~cm}^{-1}$, could have been detected. In this case, it could be useful to analyse the shape of the peak at $1460 \mathrm{~cm}^{-1}$ that could give a hint. On the contrary, the region between 1600 and $1700 \mathrm{~cm}^{-1}$ would have been analysed with accuracy to identify the peak at $1635 \mathrm{~cm}^{-1}$ and distinguish it from the one at $1655 \mathrm{~cm}^{-1}$ of Dammar.

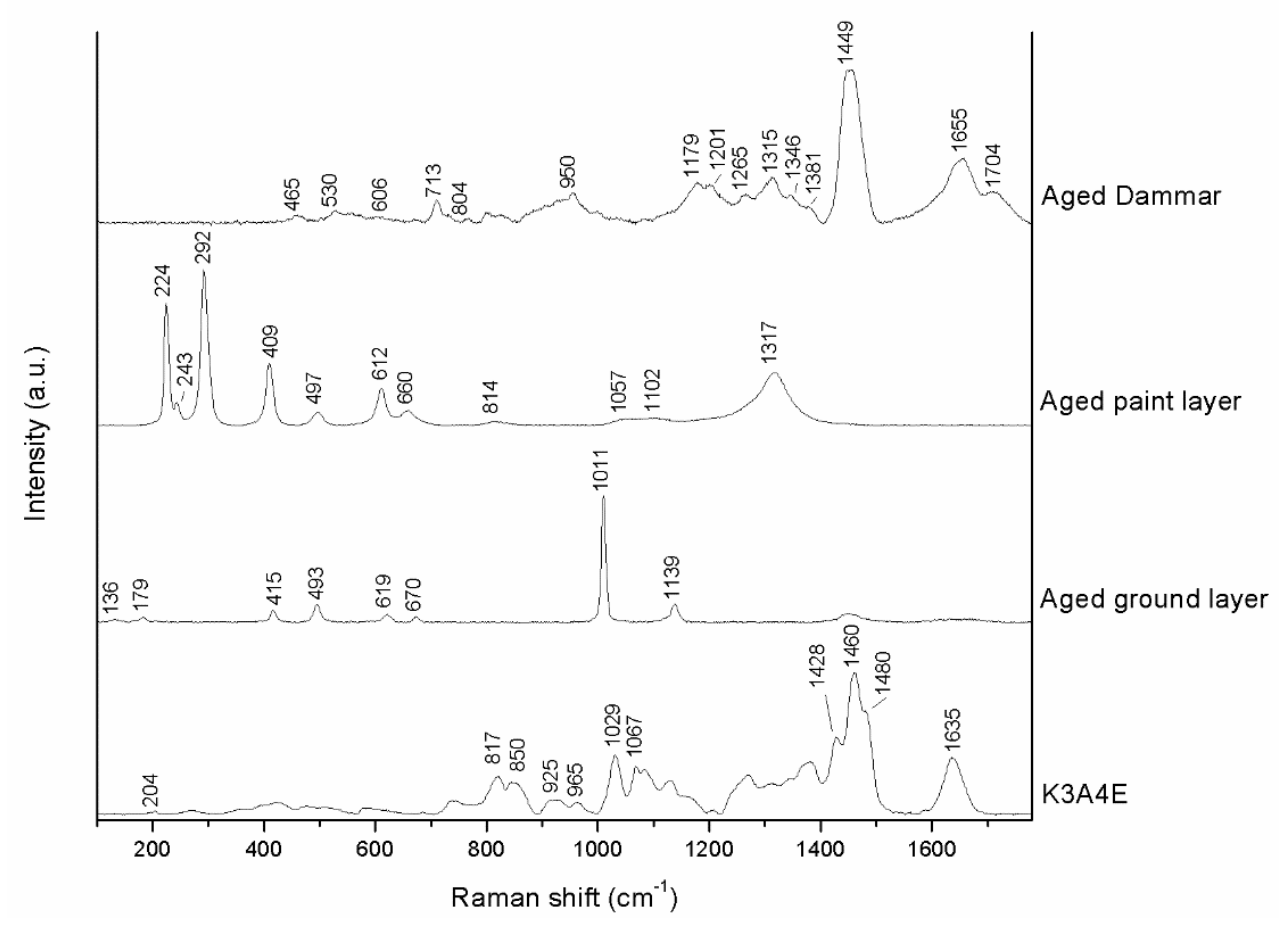

Figure 5.4.29. Comparison of spectra of aged dammar, paint layer, ground layer and $\mathrm{K}(3) \mathrm{A}(4) \mathrm{E}$, useful to the assessment of adhesive mixture identifying peaks. 


\subsubsection{Analyses on the faced specimens}

Once the reference materials were analysed and the marker peaks were identified, it was possible to carry out the Raman analyses on the specimens cross-sections of iron oxide red cracked mock-ups $(1 \times 3 \mathrm{~cm})$, previously faced with the selected RTS. The light microscope observation permitted to examine the porosities and the cracks were it seems there was adhesive penetration. Then, the most critical areas were analysed with micro-Raman spectroscope.

\section{T(3)P7 - English tissue}

In the specimens faced with RTS prepared with English tissue and T(3)P7 mixture, the penetration in the substrate seemed to be limited to the most superficial part of it. Furthermore, the adhesive was present only on the edges of the cracks, without filling the gaps.

This condition was found in the area $n^{\circ} 1$ (Fig. 5.4.30), where the adhesive was detected just in the point $a$ ) and b), which were the most superficial of the crack. In fact, in the spectrum acquired in the point a) it was possible to recognize the peaks at 200 and $1729 \mathrm{~cm}^{-1}$. In the spectra b) it was also observed a shoulder at $1269 \mathrm{~cm}^{-1}$. The spectra acquired in the deeper parts of the crack, c) and d), showed the characteristic peaks of both ground and paint layer.

In the area $\mathrm{n}^{\circ} 2$ (Fig. 5.4.31), it was not possible to exclude the penetration of the adhesive. In the spectrum of the translucent material in the point a) it was not possible to identify the peak at $1729 \mathrm{~cm}^{-1}$, but it might be hidden by the Dammar one at $1655 \mathrm{~cm}^{-1}$. Furthermore, the band at $1449 \mathrm{~cm}^{-1}$ presented a shoulder about $1729 \mathrm{~cm}^{-1}$, typical of T(3)P7.

The zones $n^{\circ} 3$ (Fig. 5.4.32) and $n^{\circ} 4$ (Fig. 5.4.33) presented a porous morphology in the paint and ground layer. In the first one, the adhesive has penetrated filling the gaps of the paint layer, while in the second one the white and brilliant material revealed to be Dammar varnish.

As state before, the adhesive does not fill all the gap of the cracks, neither in the case of the broad crack in the area n5 (Fig. 5.4.34), where the adhesive is present just in the very superficial part. 

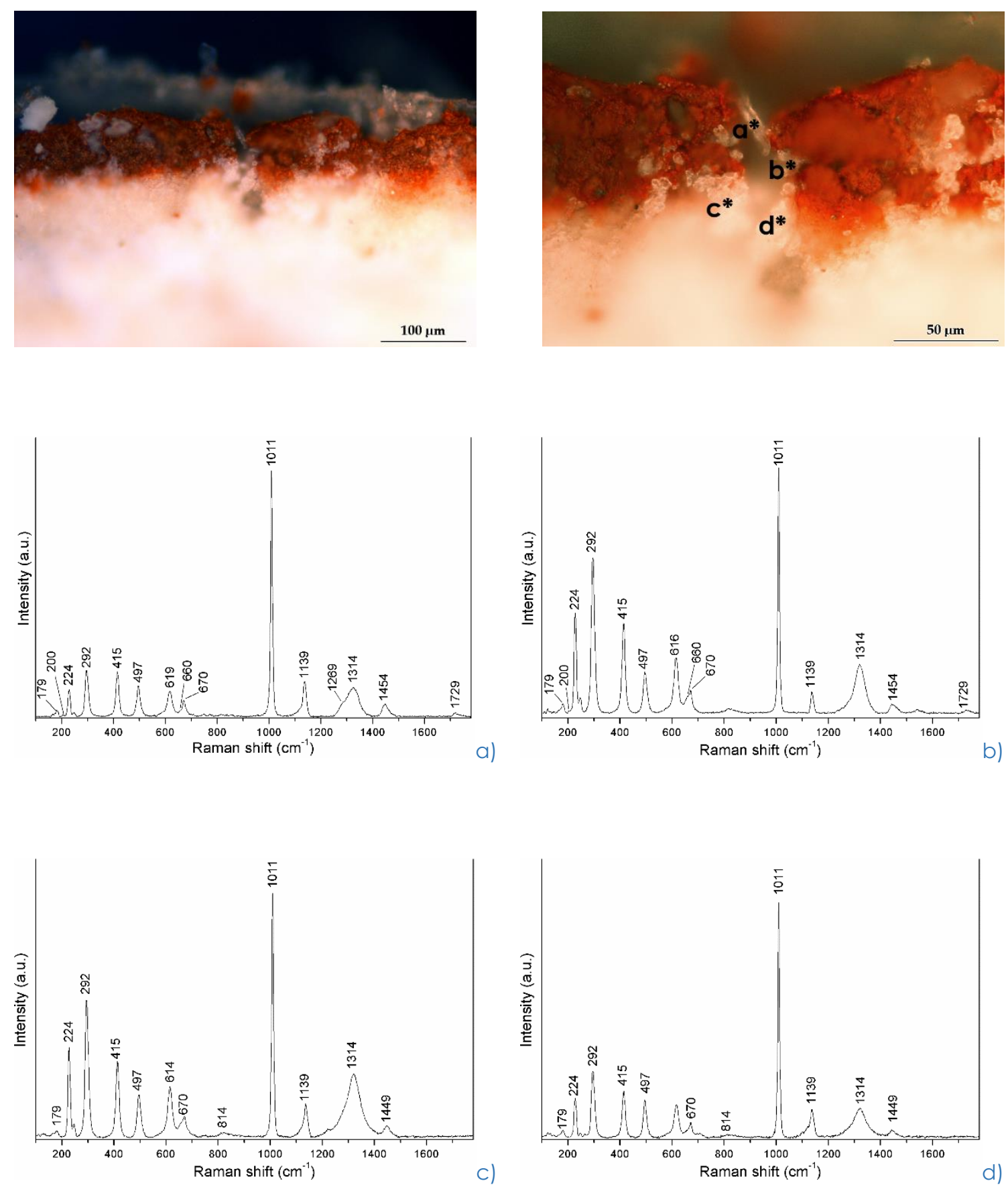

Figure 5.4.30. T(3)P7-English tissue $\mathrm{n}^{\circ} 1$ : Reflected light optical microscope image of the cross-sections obtained from the faced mock-ups and relative baselinesubtracted Raman spectra of analysed areas. 

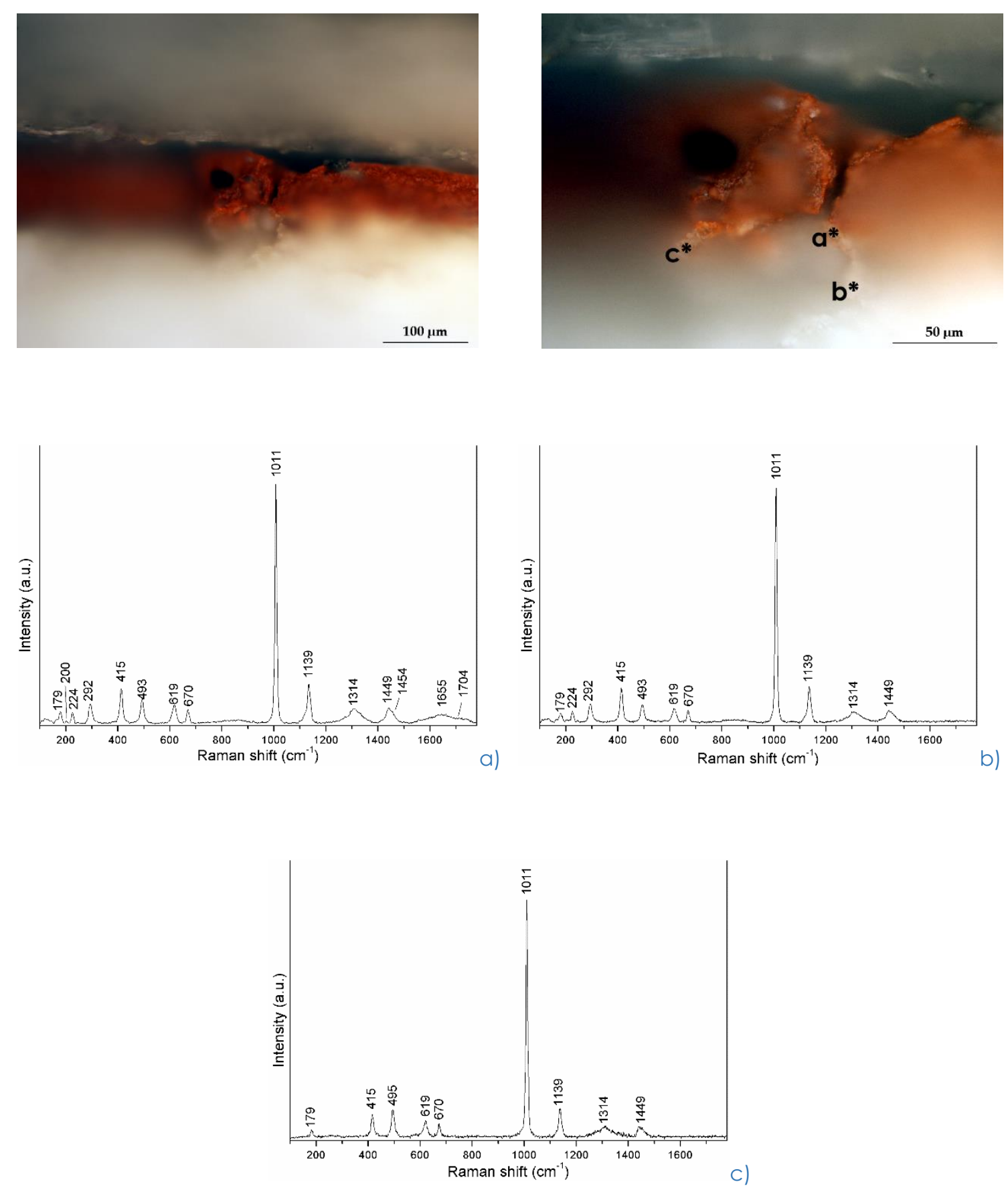

Figure 5.4.31. T(3)P7-English tissue $n^{\circ} 2$ : Reflected light optical microscope image of the cross-sections obtained from the faced mock-ups and relative baselinesubtracted Raman spectra of analysed areas. 

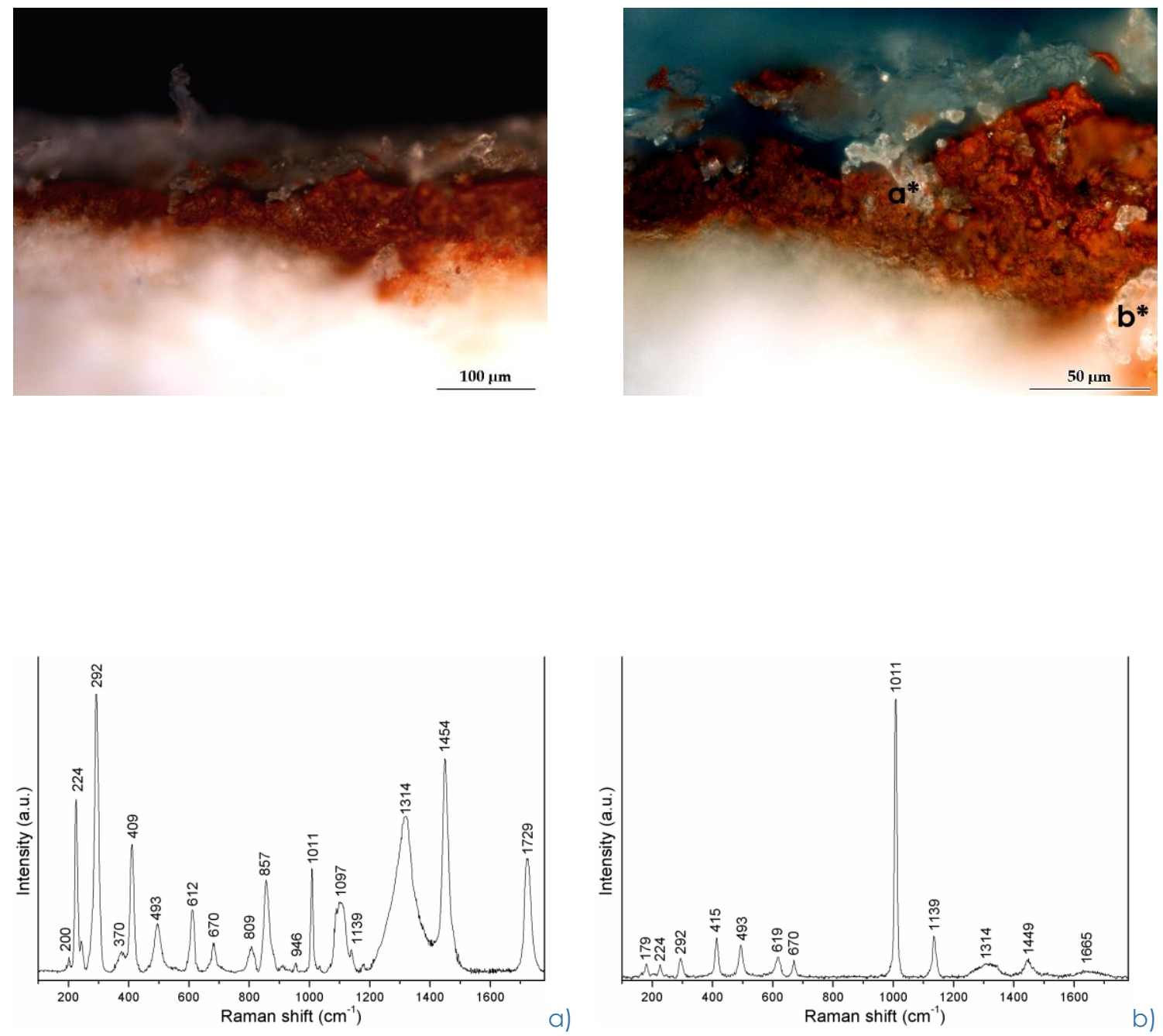

Figure 5.4.32. T(3)P7-English tissue $n^{\circ} 3$ : Reflected light optical microscope image of the cross-sections obtained from the faced mock-ups and relative baselinesubtracted Raman spectra of analysed areas. 

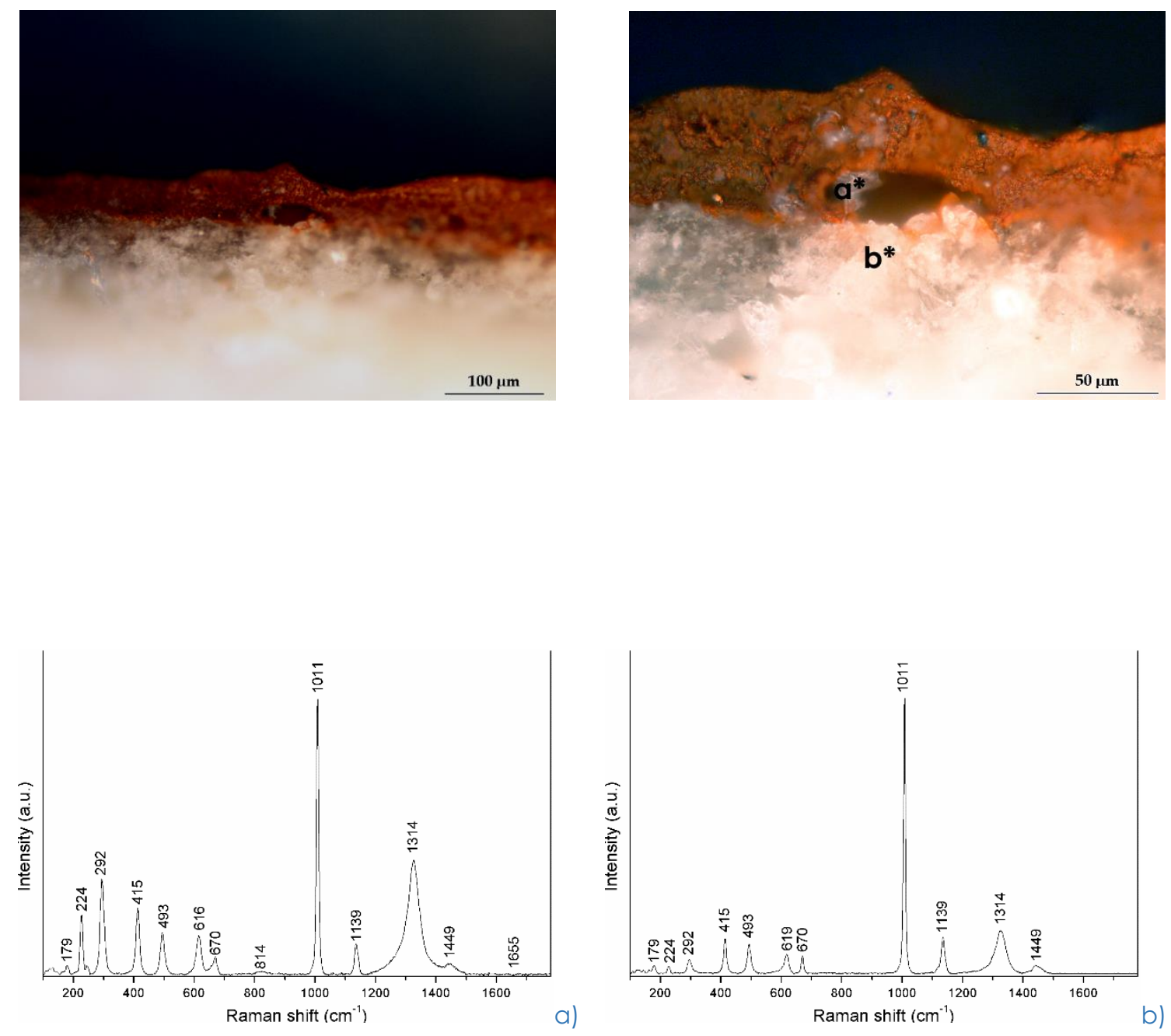

Figure 5.4.33. T(3)P7-English tissue $n^{\circ} 4$ : Reflected light optical microscope image of the cross-sections obtained from the faced mock-ups and relative baselinesubtracted Raman spectra of analysed areas. 

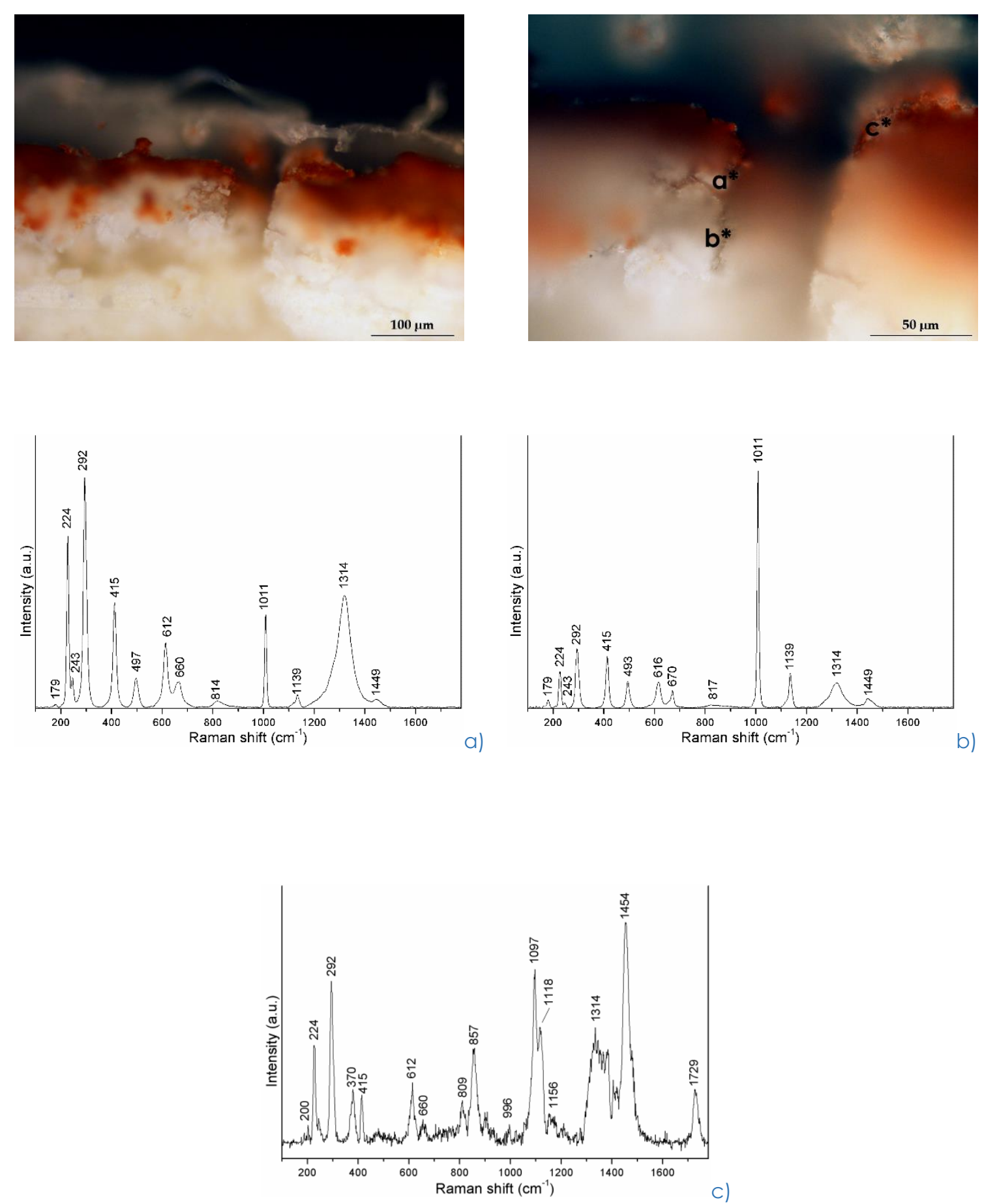

Figure 5.4.34. T(3)P7-English tissue $n^{\circ}$ 5: Reflected light optical microscope image of the cross-sections obtained from the faced mock-ups and relative baselinesubtracted Raman spectra of analysed areas. 


\section{T(3)P7 - TNT 30/B Tissue}

Specimens faced with the TNT tissue and T(3)P7 mixture showed a slightly higher penetration of the adhesive, although the adhesive settled only on the edges of the cracks without filling all its volume.

In the area $\mathrm{n}^{\circ} 1$ (Fig. 5.4.35), residues of adhesive and traces of varnish can be recognized in the superficial part of the crack a). The mixture penetrated also in the deeper point b). In fact, in the corresponding spectrum the characteristic peaks at $809,857,1026,1097,1454$ and $1729 \mathrm{~cm}^{-1}$ were visible. The adhesive did not penetrate up to the bottom of the crack, as revealed the spectrum acquired in the point $c$ ), where it was possible to see the characteristic peaks of the ground layer and the paint layer.

Areas $n^{\circ} 2$ (Fig. 5.4.36) and $n^{\circ} 3$ (Fig. 5.4.37) where analysed because a prior examination with low magnification microscope suggested the presence of the adhesive. That was confirmed in the case of the area $n^{\circ} 2$, where the Raman analysis revealed the presence of the adhesive. On the contrary, in the area $n^{\circ} 3$ no adhesive hints were found.

In the crack of the area $n^{\circ} 4$ (Fig. 5.4.38), the adhesive penetrated in the most superficial part, as confirmed by the observation of the spectrum acquired in the point a), but no traces were found in the points b) and c).

In the zone $\mathrm{n}^{\circ} 5$ (Fig. 5.4.39) the adhesive was present just in the very superficial part of the crack. The translucent parts in the deeper region of the crack revealed to be constituted by Dammar resin -points b) and c)- and ground layer -point d). 

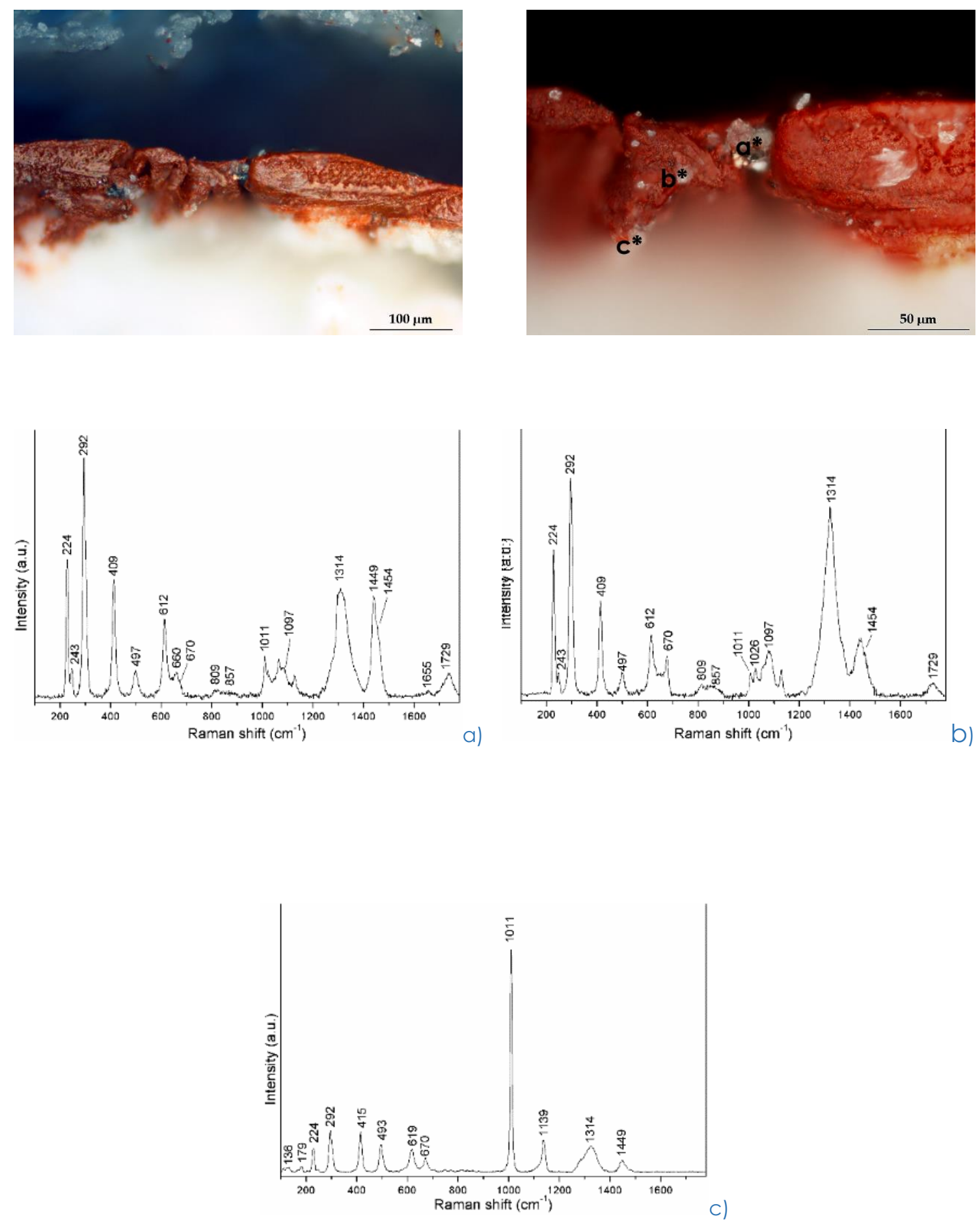

Figure 5.4.35. T(3)P7-TNT tissue $n^{\circ} 1$ : Reflected light optical microscope image of the cross-sections obtained from the faced mock-ups and relative baselinesubtracted Raman spectra of analysed areas. 

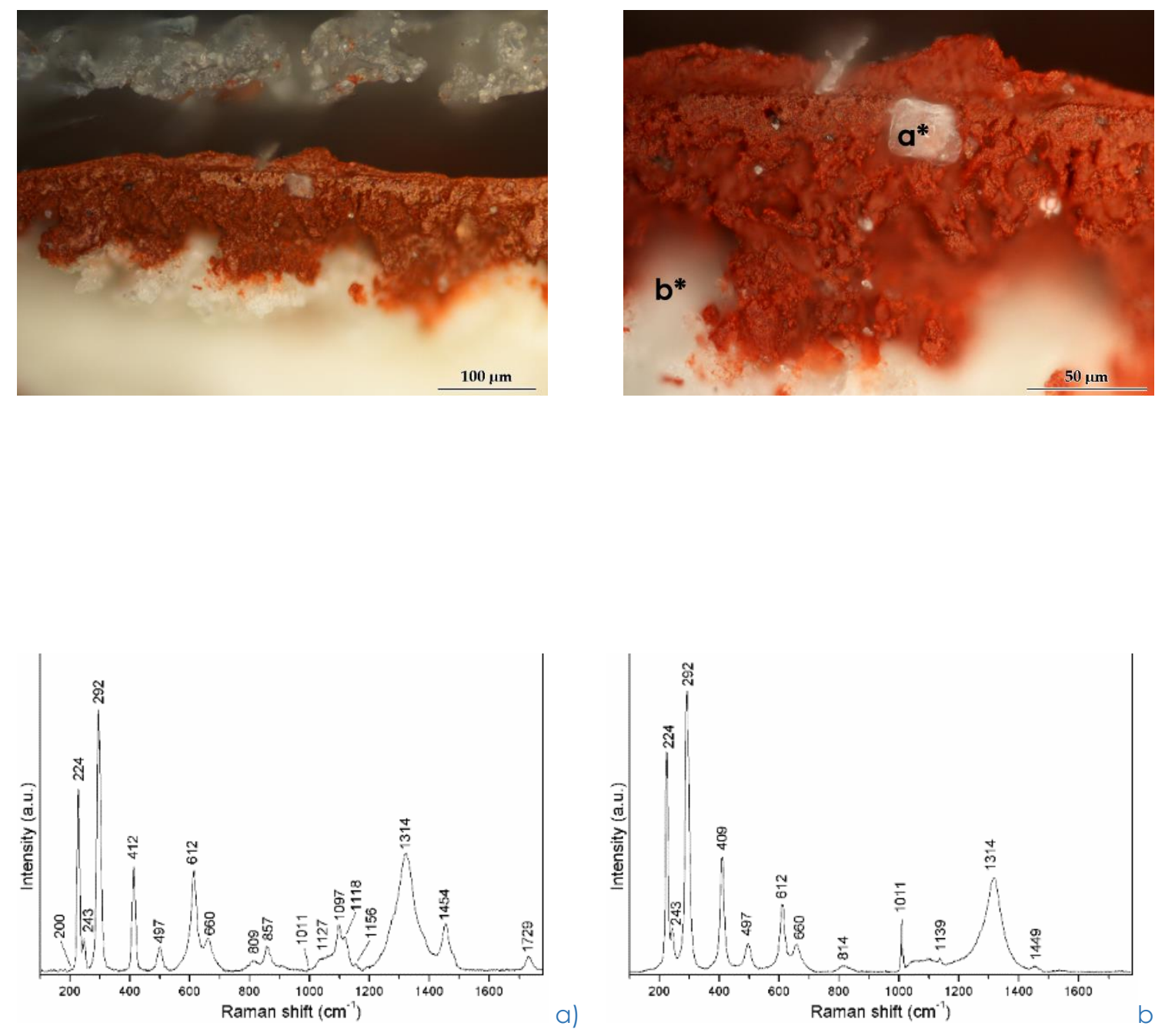

Figure 5.4.36. T(3)P7-TNT tissue $n^{\circ} 2$ : Reflected light optical microscope image of the cross-sections obtained from the faced mock-ups and relative baselinesubtracted Raman spectra of analysed areas. 

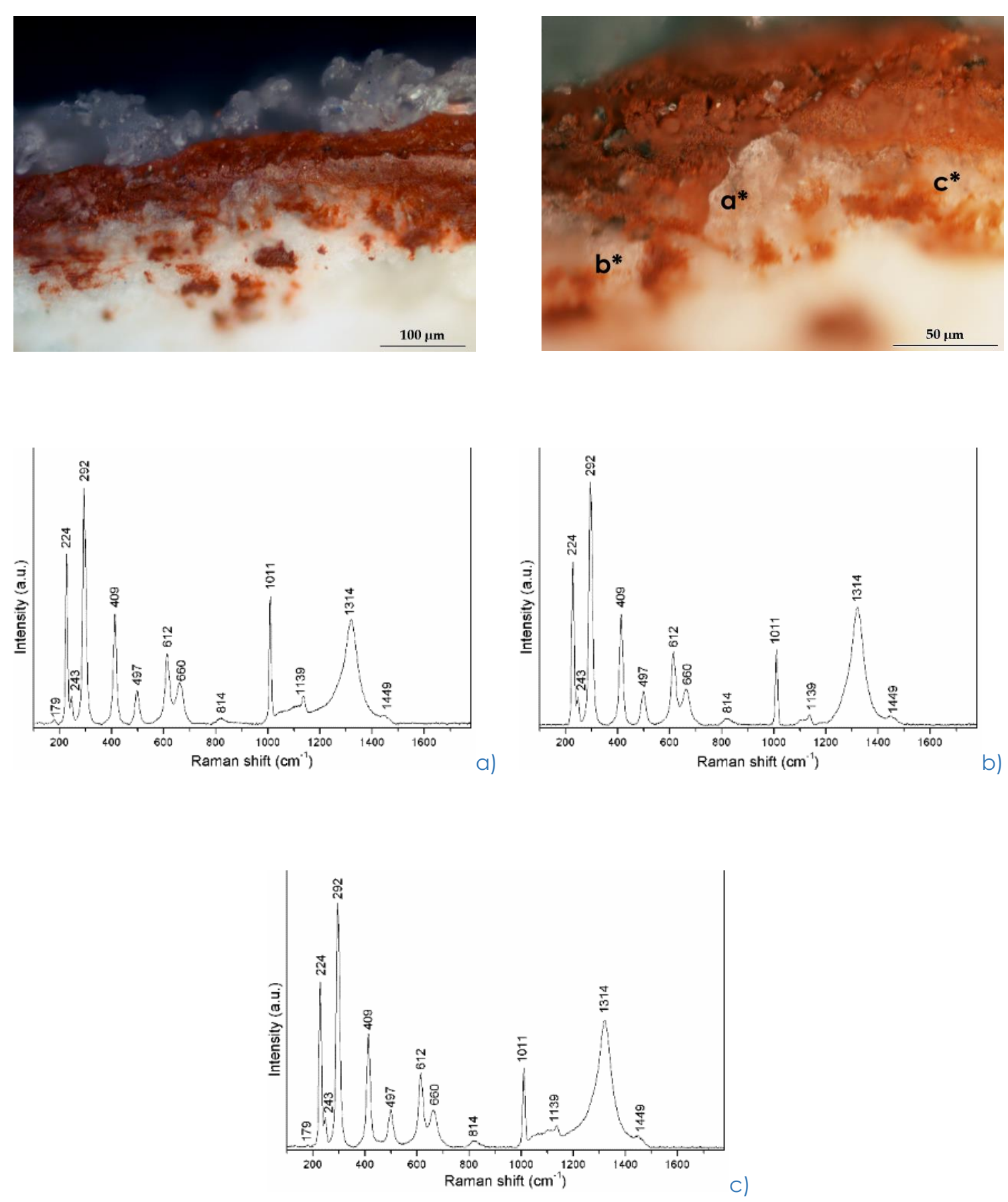

Figure 5.4.37. T(3)P7-TNT tissue n³: Reflected light optical microscope image of the cross-sections obtained from the faced mock-ups and relative baselinesubtracted Raman spectra of analysed areas. 

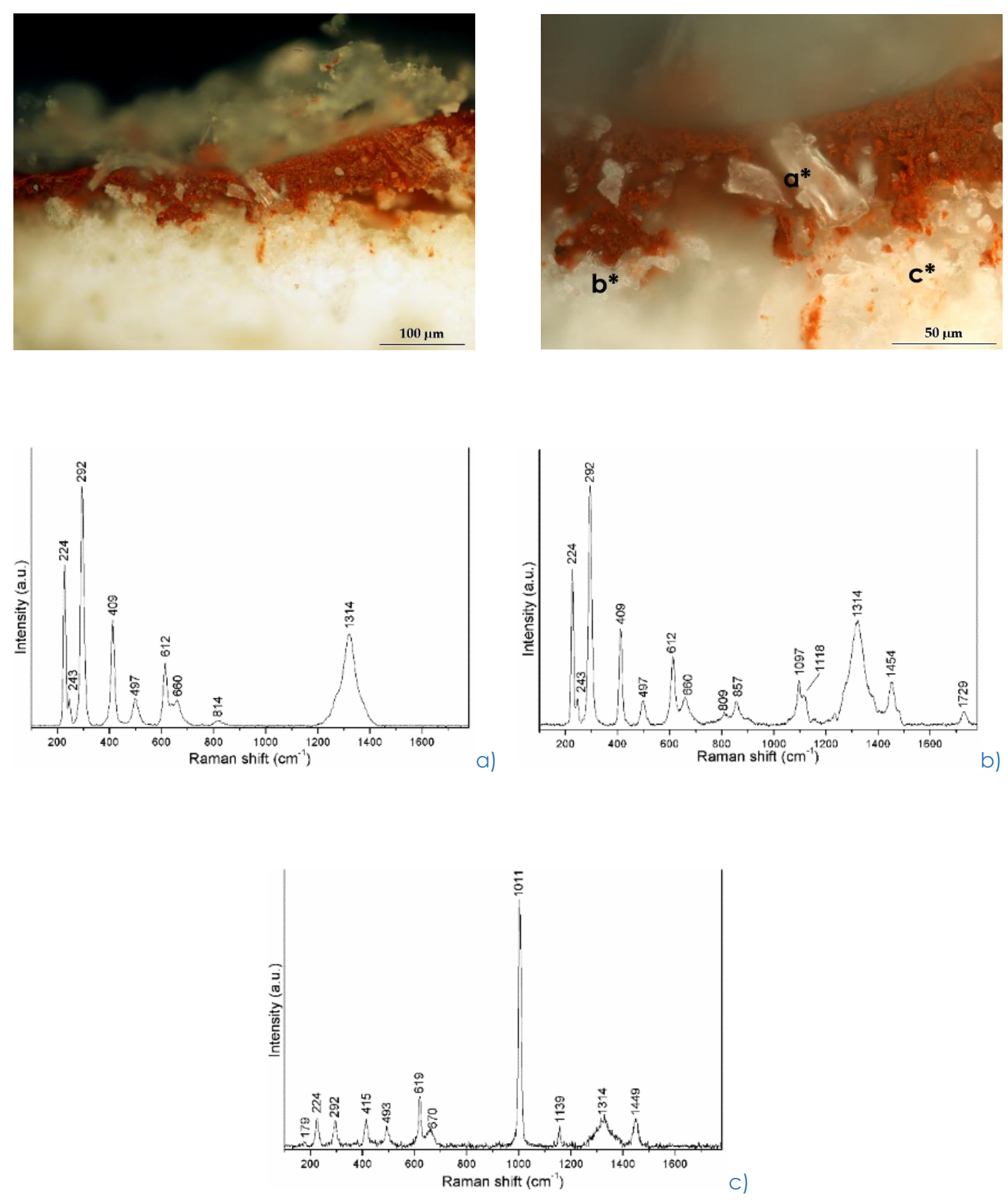

Figure 5.4.38. T(3)P7-TNT tissue $n^{\circ} 4$ : Reflected light optical microscope image of the cross-sections obtained from the faced mock-ups and relative baselinesubtracted Raman spectra of analysed areas. 

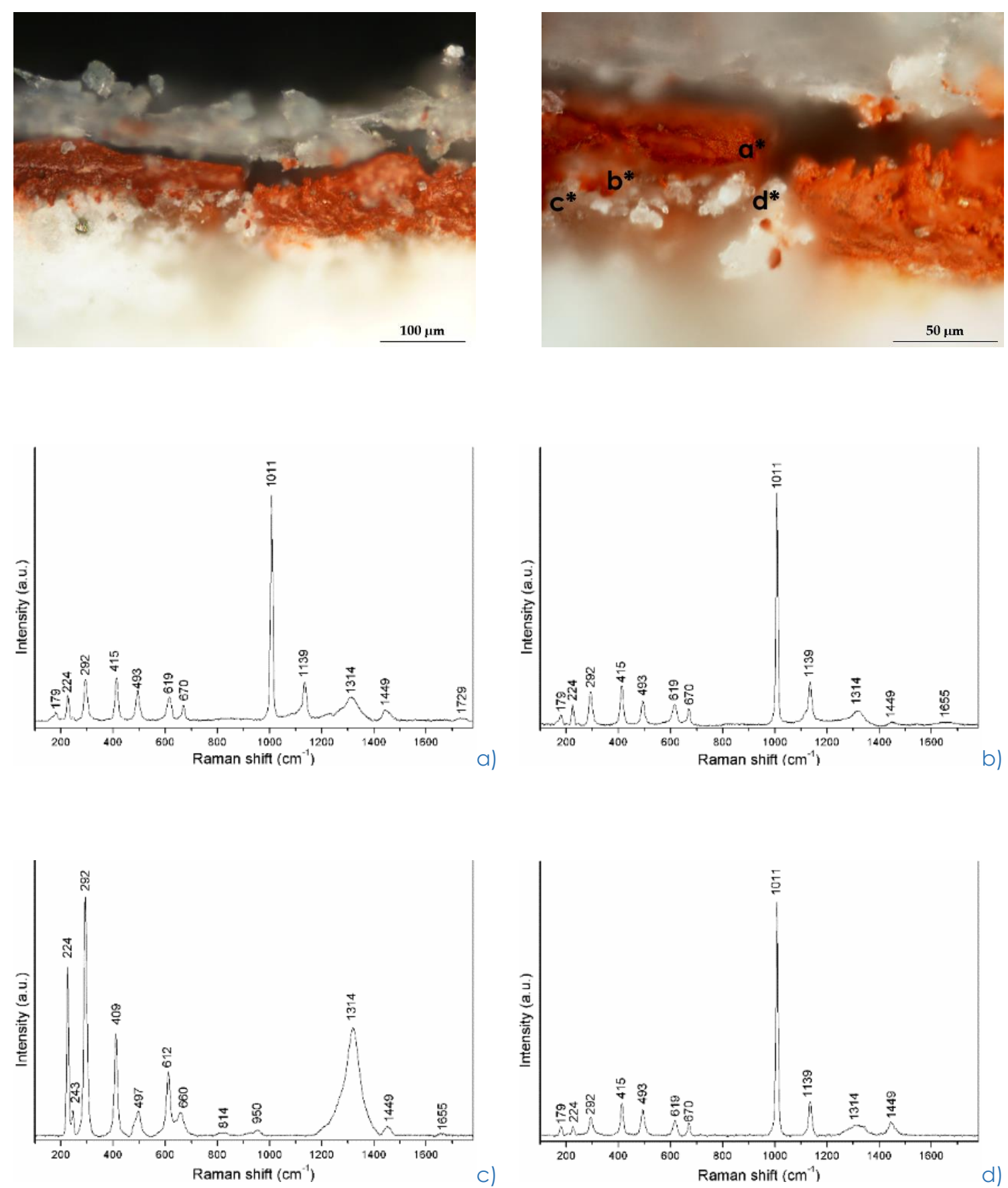

Figure 5.4.39. T(3)P7-TNT tissue $n^{\circ} 5$ : Reflected light optical microscope image of the cross-sections obtained from the faced mock-ups and relative baselinesubtracted Raman spectra of analysed areas. 


\subsection{K(4)P7- English tissue}

Facings prepared with RTS made with English tissue and K(4)P7 mixture gave interesting results. In fact, it seemed there was almost no penetration and the few traces that were found, were barely superficial.

The spectra acquired in the area $n^{\circ} 1$ (Fig. 5.4.40) revealed the presence of some traces of varnish, clearly recognisable in the spectrum acquired in the point a), by the peaks at 1449 and $1655 \mathrm{~cm}^{-1}$. No traces of the mixture where found in the other points.

In the area n² (Fig. 5.4.41) the analyses revealed the presence of Dammar varnish, that had probably penetrated during the preparation of the mock-ups.

The same applies to the crack in the area $n^{\circ} 3$ (Fig. 5.4.42), where the analysed points revealed the presence of varnish and ground layer.

On the contrary, in the area $n^{\circ} 4$ (Fig. 5.4.43) there was a little penetration of the adhesive, confined to the most superficial part of the crack. In fact, in the spectrum acquired in point a) it was possible to recognize the peak at $1729 \mathrm{~cm}^{-1}$ of the facing mixture, while the spectra of the points b) and c) showed the peaks of the ground and paint layer.

In the image of the area $n^{\circ} 5$ (Fig. 5.4.44) it was visible a transparent material in the point a), identified as K(4)P7 thanks to the analysis of the Raman spectrum, which showed all the characteristic peaks of the adhesive. 

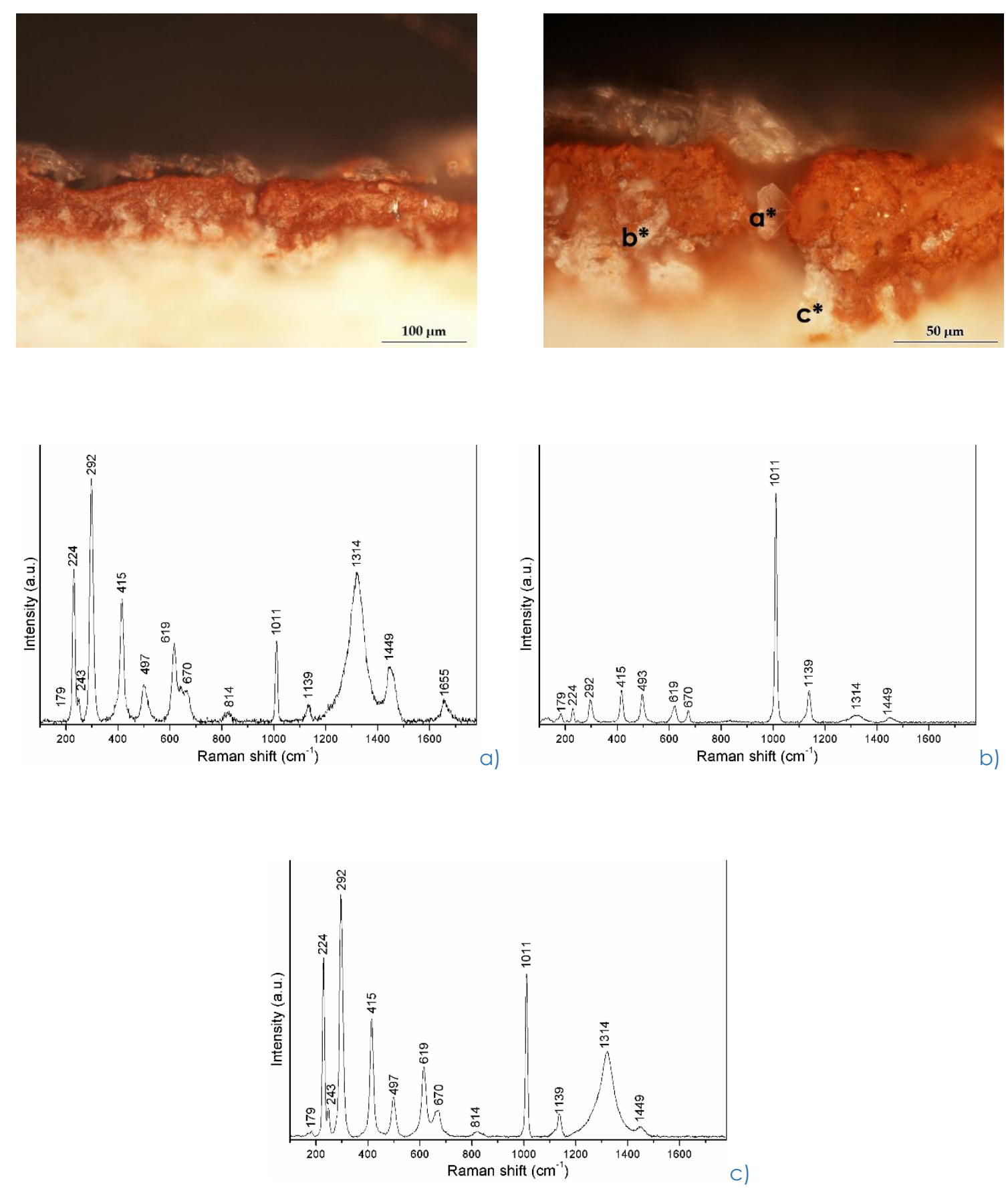

Figure 5.4.40. K(4)P7-English tissue $\mathrm{n}^{\circ} 1$ : Reflected light optical microscope image of the cross-sections obtained from the faced mock-ups and relative baselinesubtracted Raman spectra of analysed areas. 

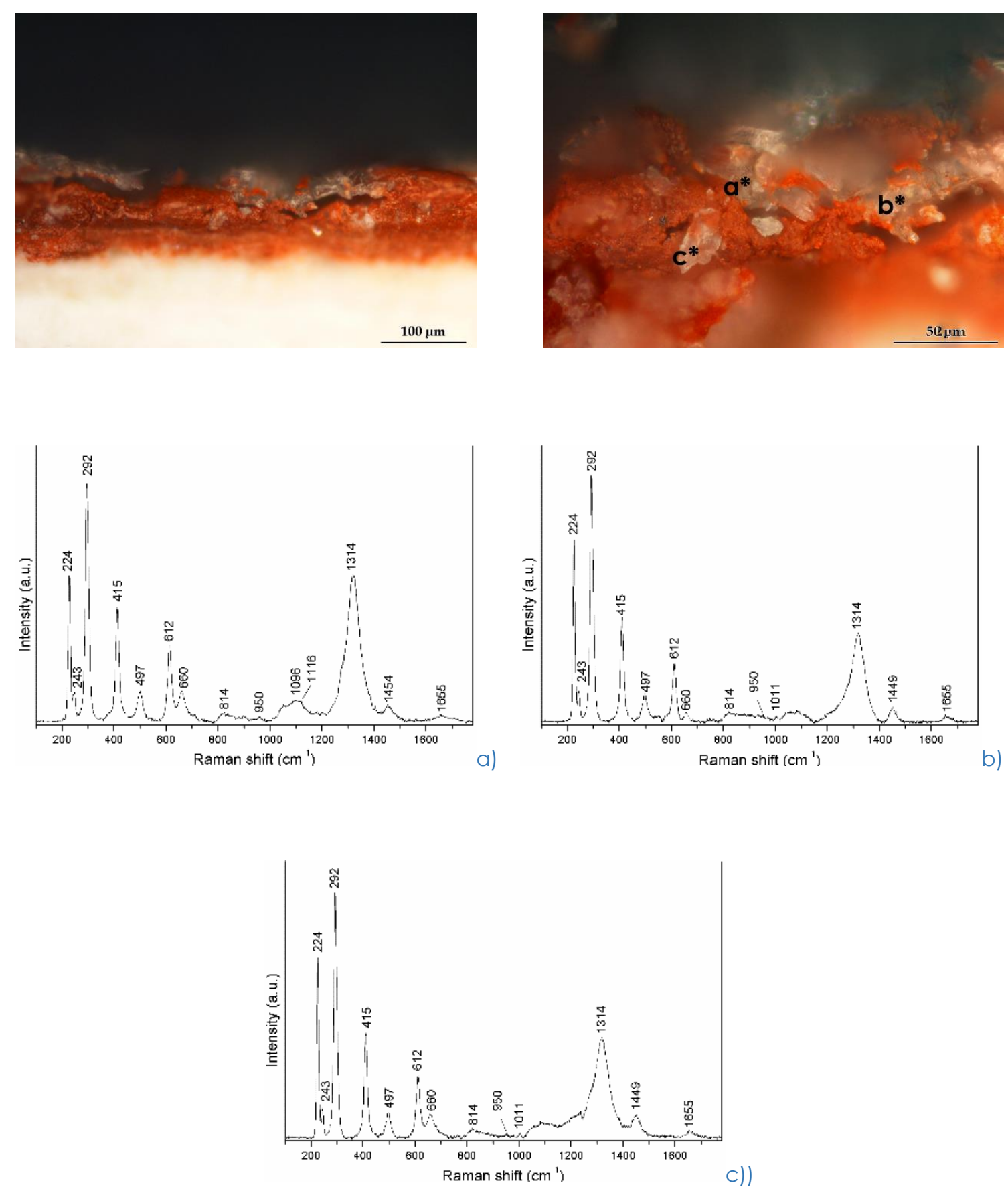

Figure 5.4.41. K(4)P7-English tissue $n^{\circ} 2$ : Reflected light optical microscope image of the cross-sections obtained from the faced mock-ups and relative baselinesubtracted Raman spectra of analysed areas. 

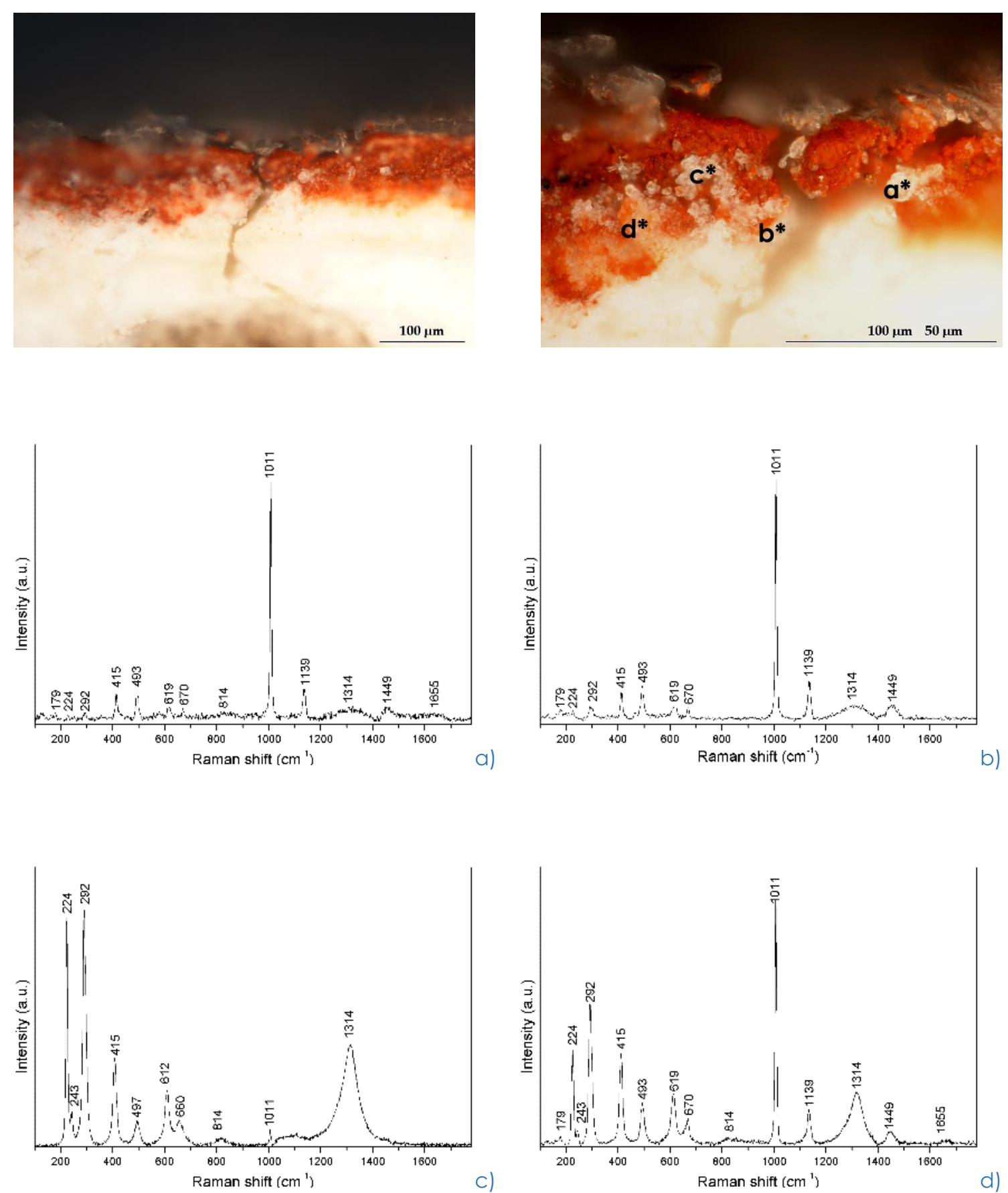

Figure 5.4.42. K(4)P7-English tissue $n^{\circ} 3$ : Reflected light optical microscope image of the cross-sections obtained from the faced mock-ups and relative baselinesubtracted Raman spectra of analysed areas. 

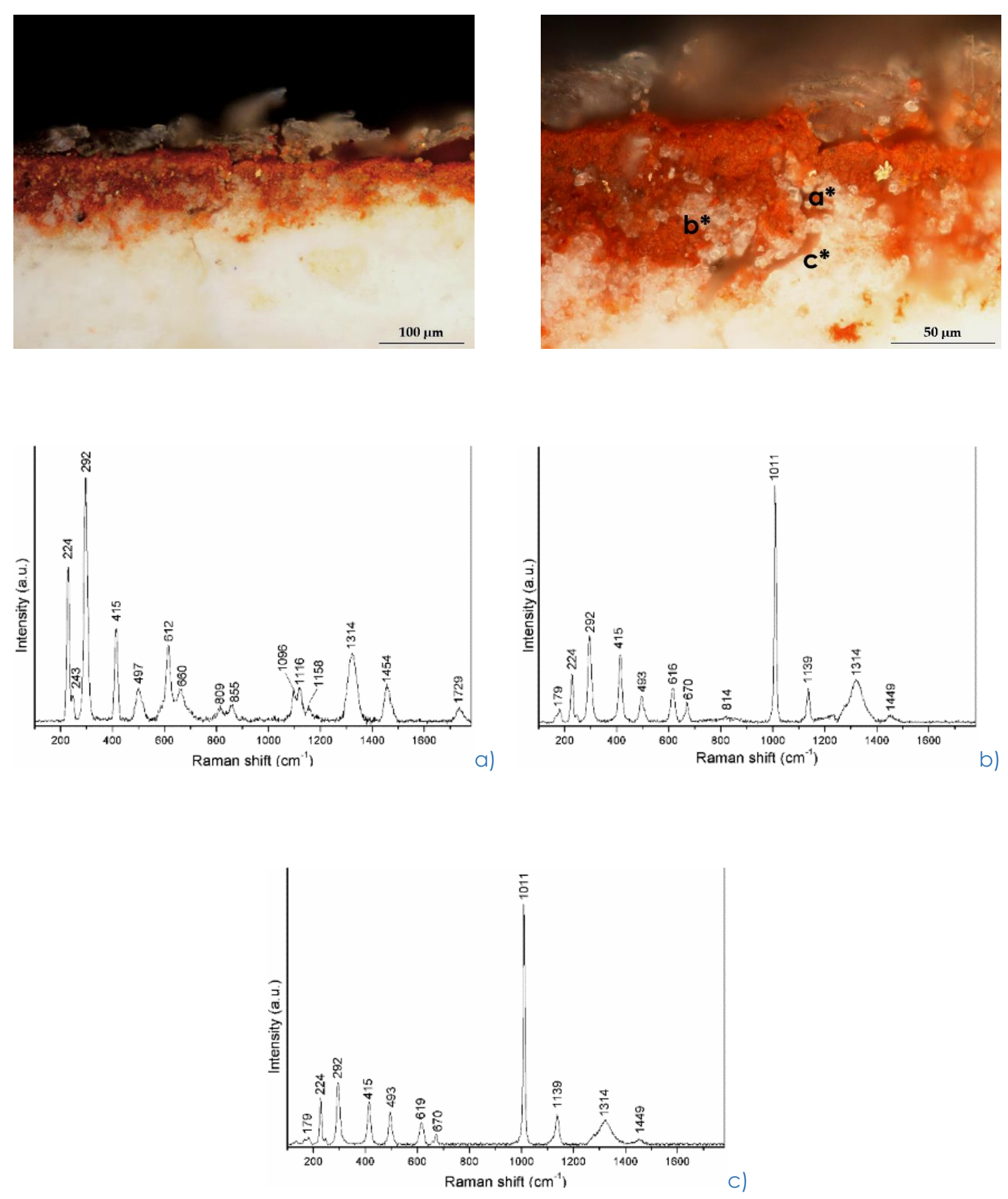

Figure 5.4.43. K(4)P7-English tissue $n^{\circ} 4$ : Reflected light optical microscope image of the cross-sections obtained from the faced mock-ups and relative baselinesubtracted Raman spectra of analysed areas. 

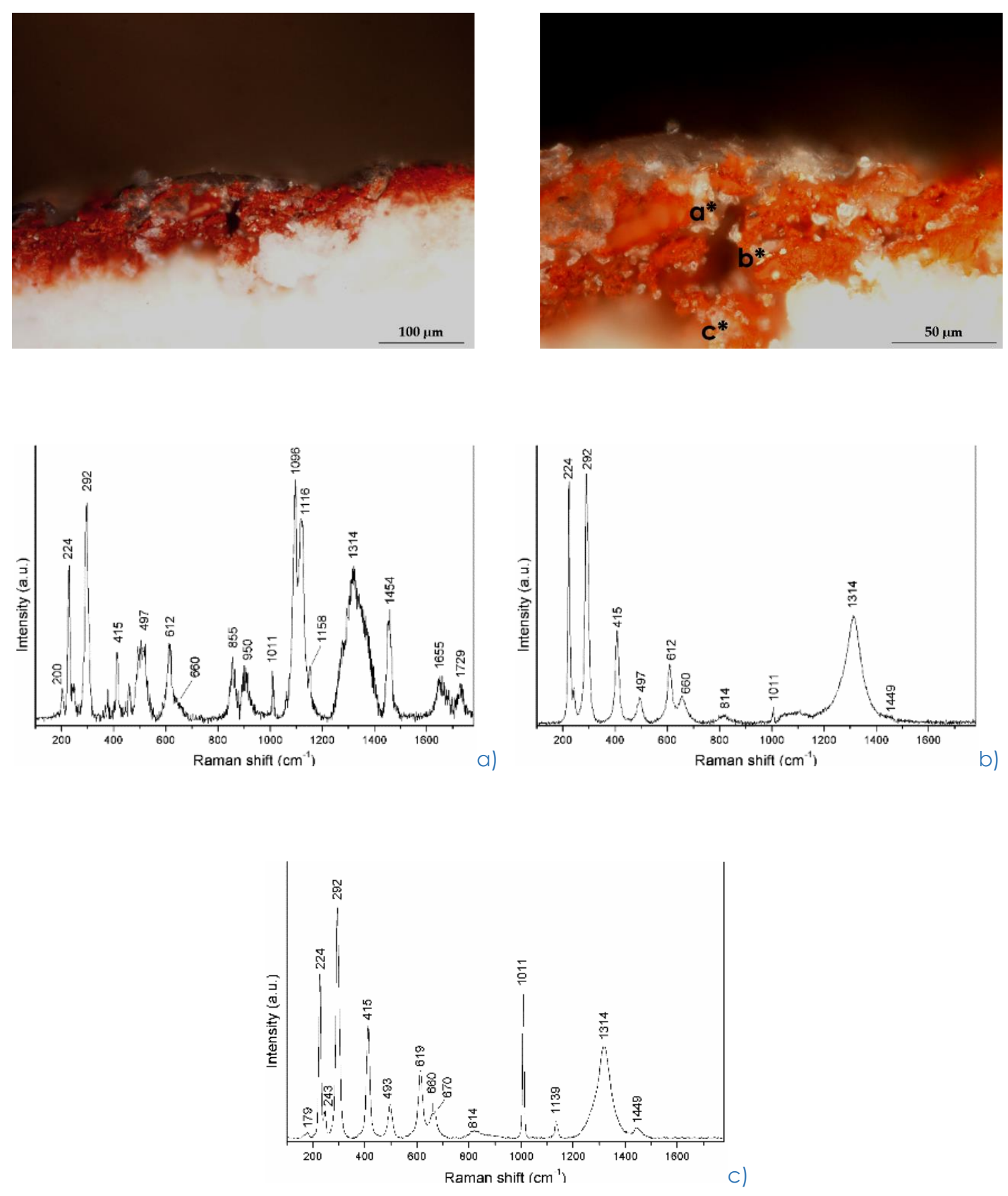

Figure 5.4.44. K(4)P7-English tissue n5: Reflected light optical microscope image of the cross-sections obtained from the faced mock-ups and relative baselinesubtracted Raman spectra of analysed areas. 


\section{$\underline{\text { K(4)P7 - TNT 30/B tissue }}$}

Facings made with TNT tissue and K(4)P7 adhesive mixture showed good superficial properties. In fact, in most cases, there was no penetration or it was anyway limited to the most superficial part of cracks or porosities.

In the images of area $n^{\circ}$ (Fig. 5.4.45), it was visible a string of adhesive in the most superficial part of the crack, confirmed by Raman acquisition. Nevertheless, no traces of adhesive where found at the bottom of the crack.

In the area $n^{\circ} 2$ (Fig. 5.4.46), the white residue at the middle of the crack was a piece of ground layer probably detached during the preparation of the specimens. However, in point a), corresponding to the upper part of the fragment of ground layer, a trace of K(4)P7 was found. On the contrary, the spectrum acquired in the point $c$ ) revealed the penetration of the varnish during the preparation of the mock-ups.

The white fragment in the porosity of the paint layer in area $n^{\circ} 3$ (Fig. 5.4.47) was of ground layer, which h ad been probably mixed with the paint layer during the preparation phase.

Raman acquisitions in area $\mathrm{n}^{\circ} 4$ (Fig. 5.4.48) excluded the presence of adhesive in the crack, revealing on the contrary the presence of traces of Dammar resin.

The crack in area $n^{\circ} 5$ (Fig. 5.4.49) surprisingly present different results. In fact, traces of adhesive where revealed with Raman analysis. In the spectrum acquired at the bottom of the crack is visible the weak peak at $200 \mathrm{~cm}^{-1}$ and the other one at $1729 \mathrm{~cm}^{-1}$. 

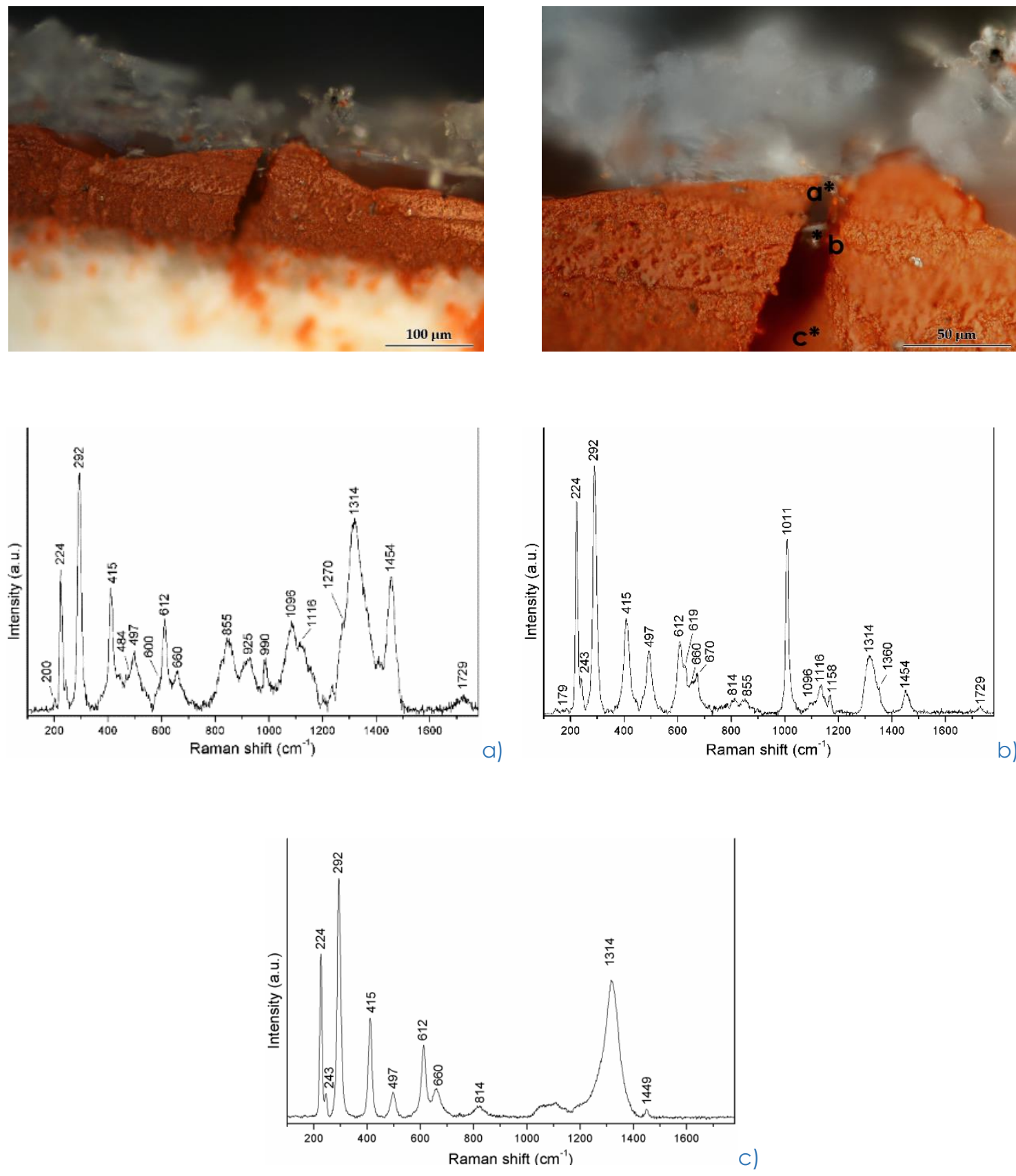

Figure 5.4.45. K(4)P7-TNT tissue $\mathrm{n}^{\circ} 1$ : Reflected light optical microscope image of the cross-sections obtained from the faced mock-ups and relative baselinesubtracted Raman spectra of analysed areas. 

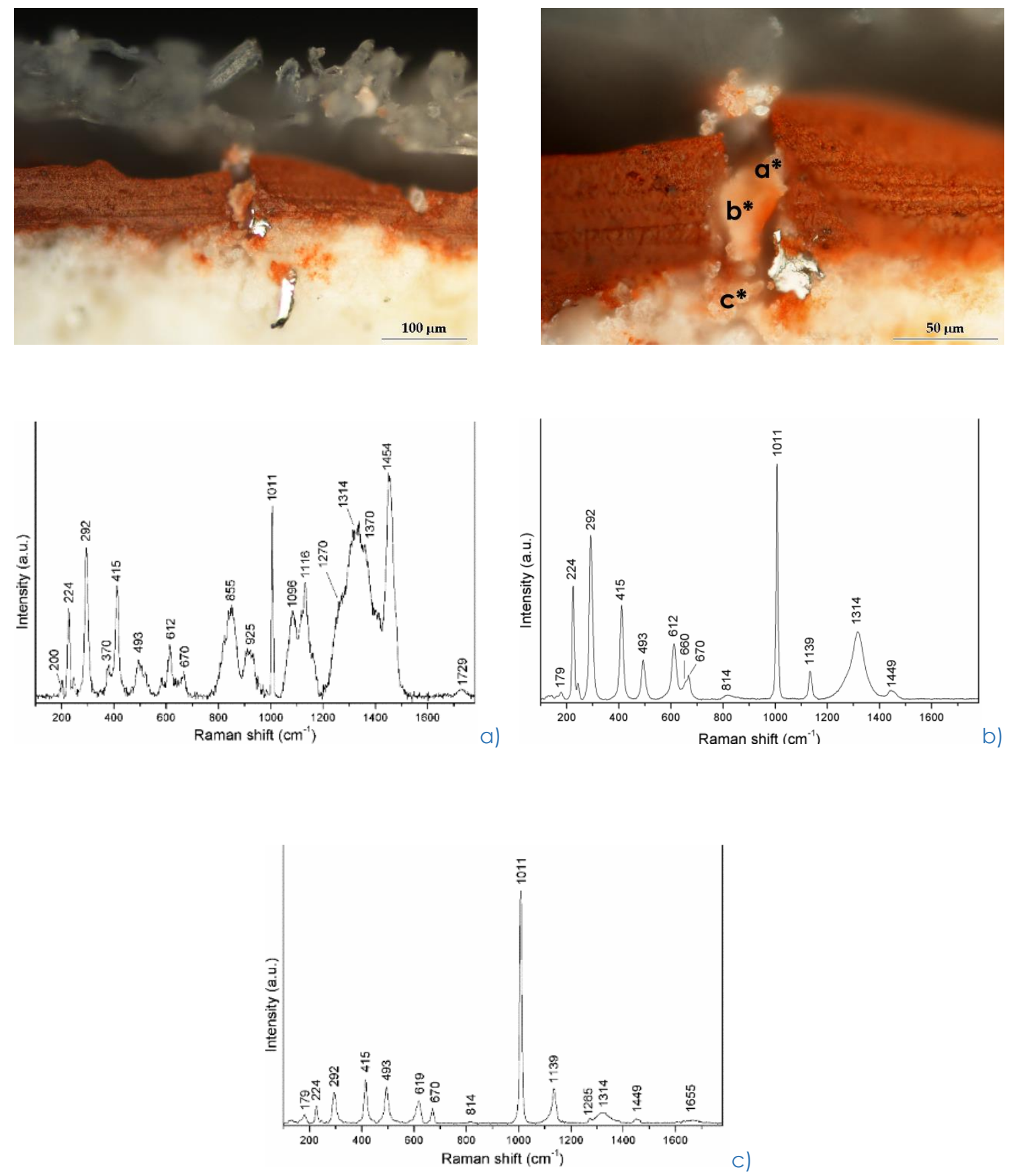

Figure 5.4.46. K(4)P7-TNT tissue $\mathrm{n}^{\circ} 2$ : Reflected light optical microscope image of the cross-sections obtained from the faced mock-ups and relative baselinesubtracted Raman spectra of analysed areas. 

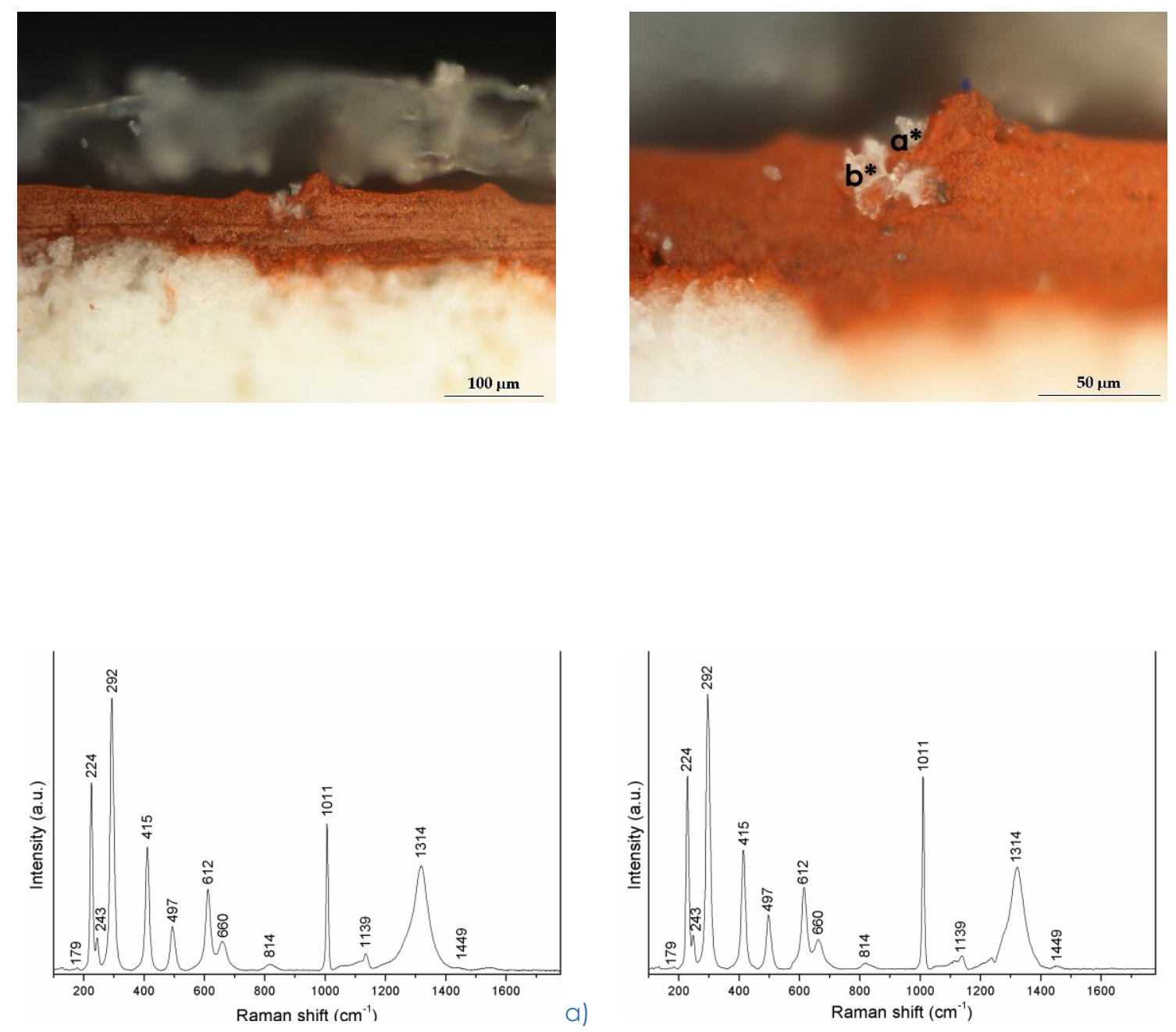

b)

Figure 5.4.47. K(4)P7-TNT tissue $\mathrm{n}^{\circ} 3$ : Reflected light optical microscope image of the cross-sections obtained from the faced mock-ups and relative baselinesubtracted Raman spectra of analysed areas. 

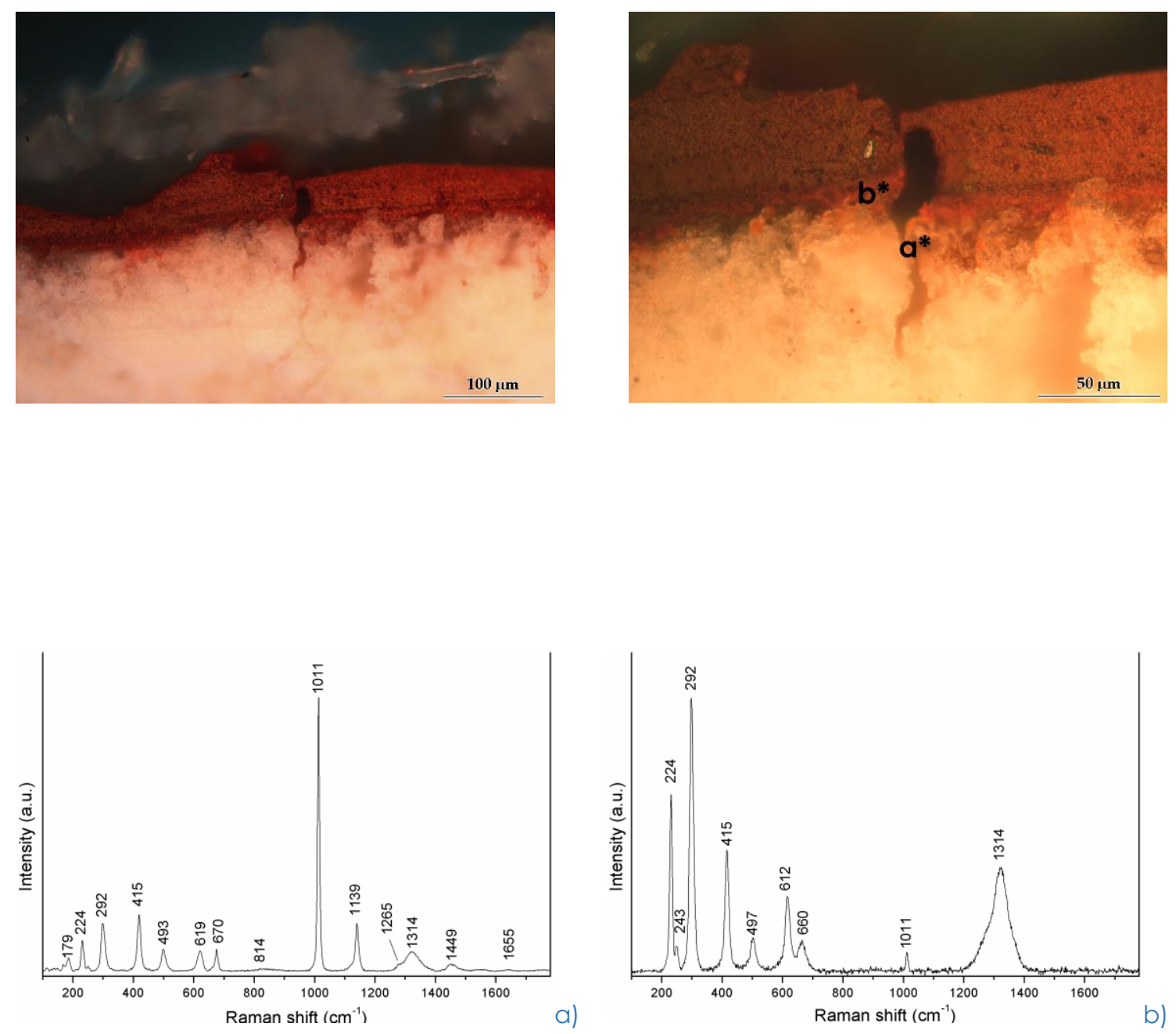

Figure 5.4.48. K(4)P7-TNT tissue $n^{\circ} 4$ : Reflected light optical microscope image of the cross-sections obtained from the faced mock-ups and relative baselinesubtracted Raman spectra of analysed areas. 

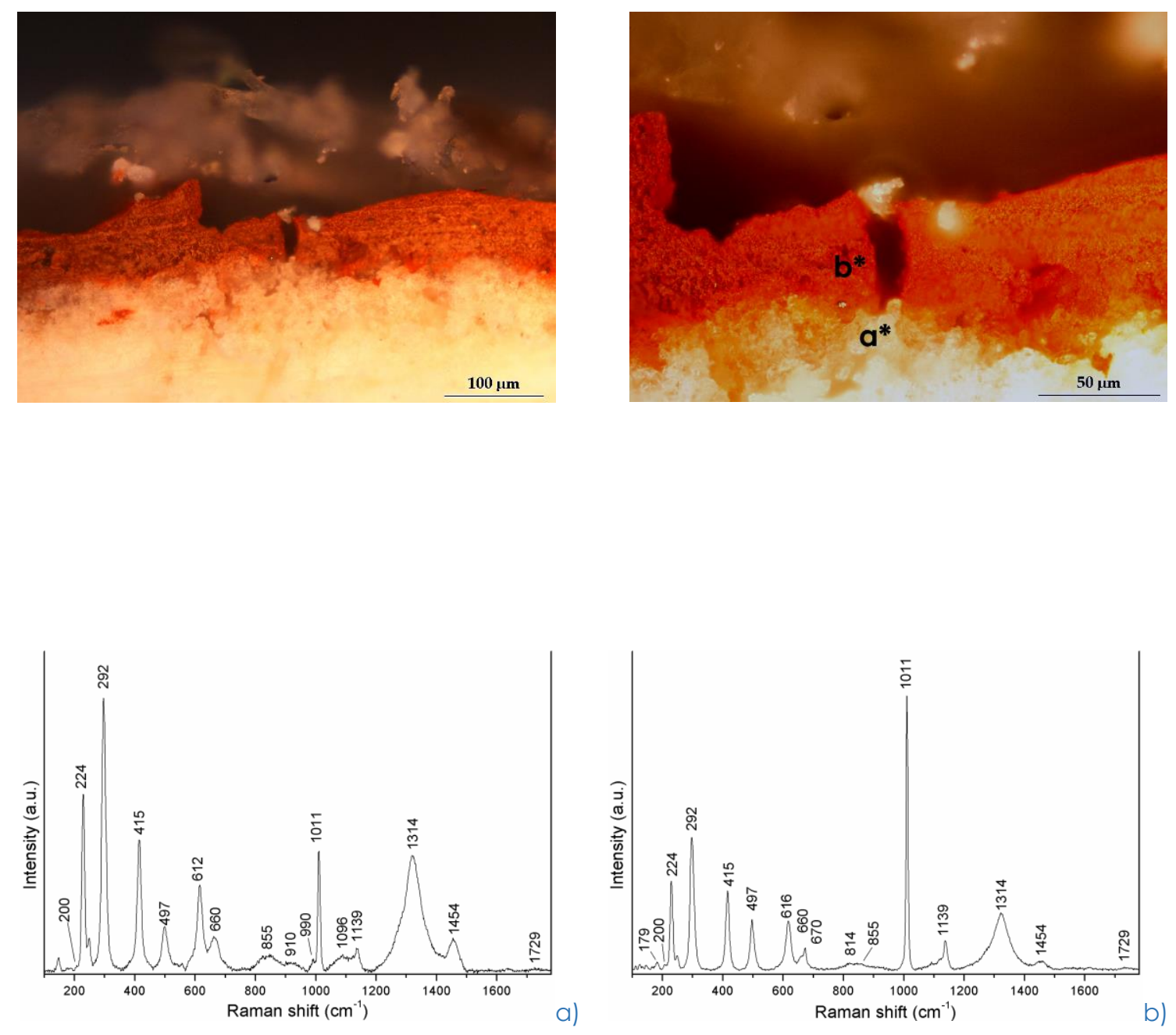

Figure 5.4.49. K(4)P7-TNT tissue $\mathrm{n}^{\circ}$ 5: Reflected light optical microscope image of the cross-sections obtained from the faced mock-ups and relative baselinesubtracted Raman spectra of analysed areas. 


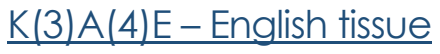

As already written, the identification of $\mathrm{K}(3) \mathrm{A}(4) \mathrm{E}$ mixture was more complex. For this kind of RTS a higher penetration was discovered. In some cases, only little traces were found, but, in two cases, more significant residues were visible in the most superficial part of the analysed cracks.

In the images of area $n^{\circ} 1$ (Fig. 5.4.50) were visible some dubious transparent points, analysed with micro Raman. Unfortunately, in this case was not possible to determine for sure the presence of the adhesive. The analysed area seemed constituted by a mixture of Dammar resin and K(3)A(4)E. In fact, all the three spectra acquired in this area showed a peak at $1449 \mathrm{~cm}^{-1}$. The weak peak at $1635 \mathrm{~cm}^{-1}$ of $\mathrm{K}(3) \mathrm{A}(4) \mathrm{E}$ is also visible.

In area $n^{\circ} 2$ (Fig. 5.4.51) the adhesive penetrated up to the ground layer (approx. $100 \mu \mathrm{m}$ ), but it did not reach the bottom of the crack. Anyway, only some traces of adhesive on the lonely edges of the crack were found.

In the case of area $\mathrm{n}^{\circ} 3$ (Fig. 5.4.52), the adhesive penetrated just in the most superficial part of the crack, since in the spectrum of the point a) it was possible to see a peak at $1635 \mathrm{~cm}^{-1}$. The same applied to the area $\mathrm{n}^{\circ} 4$ (Fig. 5.4.53).

In the crack of zone n ${ }^{\circ} 5$ (Fig. 5.4.54), the adhesive seemed to reach the depth of about $50 \mu \mathrm{m}$. 

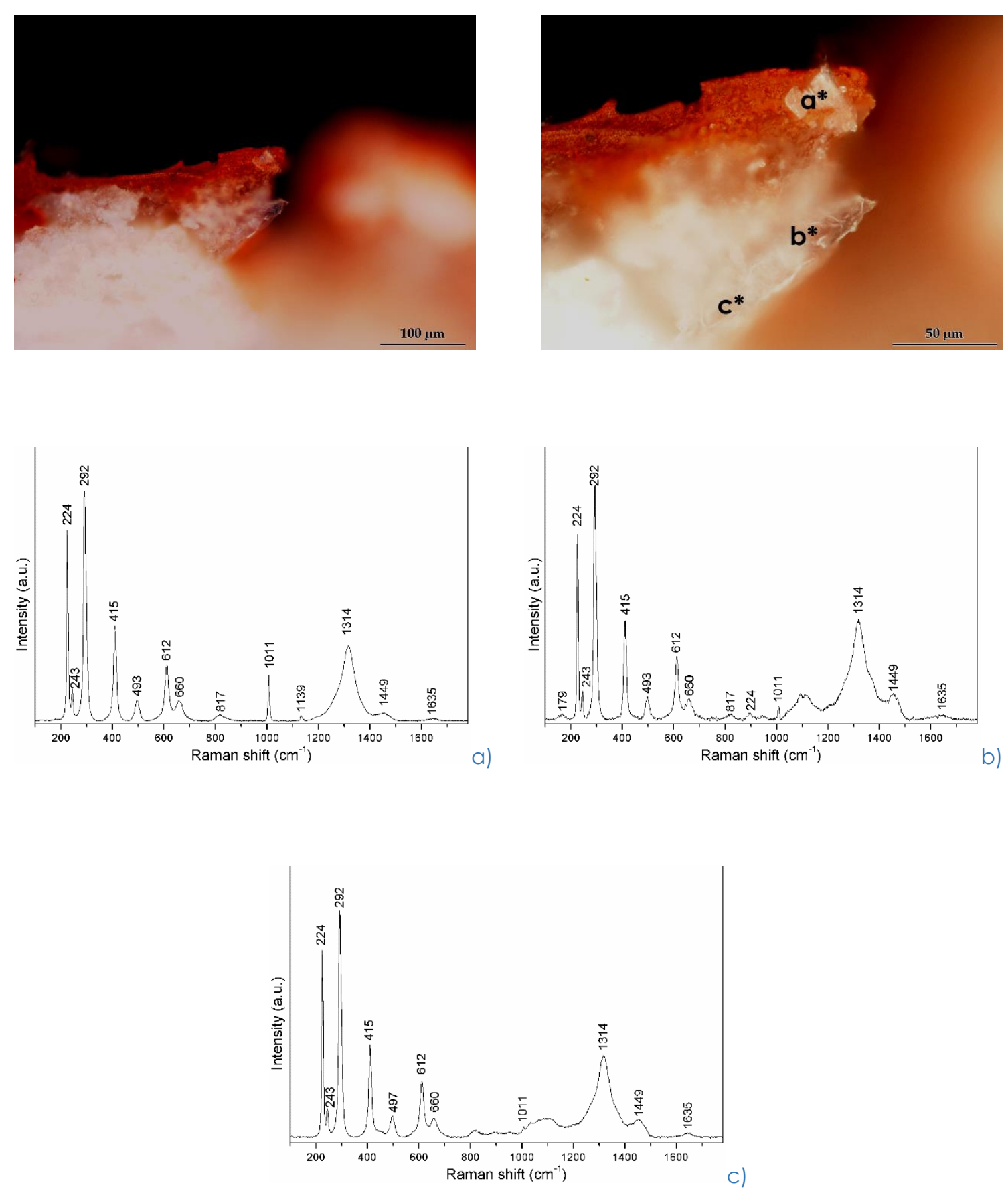

Figure 5.4.50. K(3)A(4)E-English tissue $n^{\circ} 1$ : Reflected light optical microscope image of the cross-sections obtained from the faced mock-ups and relative baseline-subtracted Raman spectra of analysed areas. 

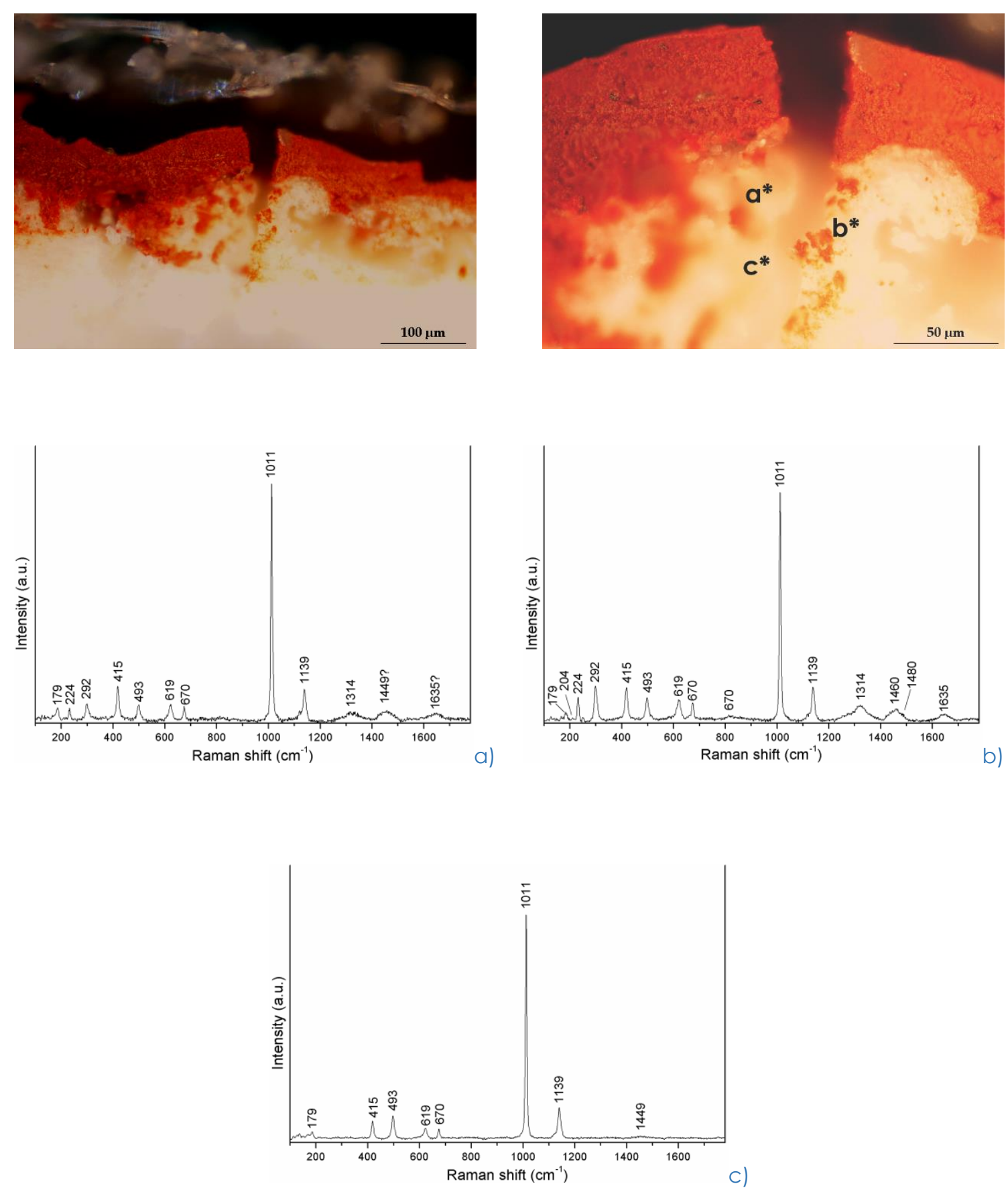

Figure 5.4.51. K(3)A(4)E-English tissue $n^{\circ} 2$ : Reflected light optical microscope image of the cross-sections obtained from the faced mock-ups and relative baseline-subtracted Raman spectra of analysed areas. 

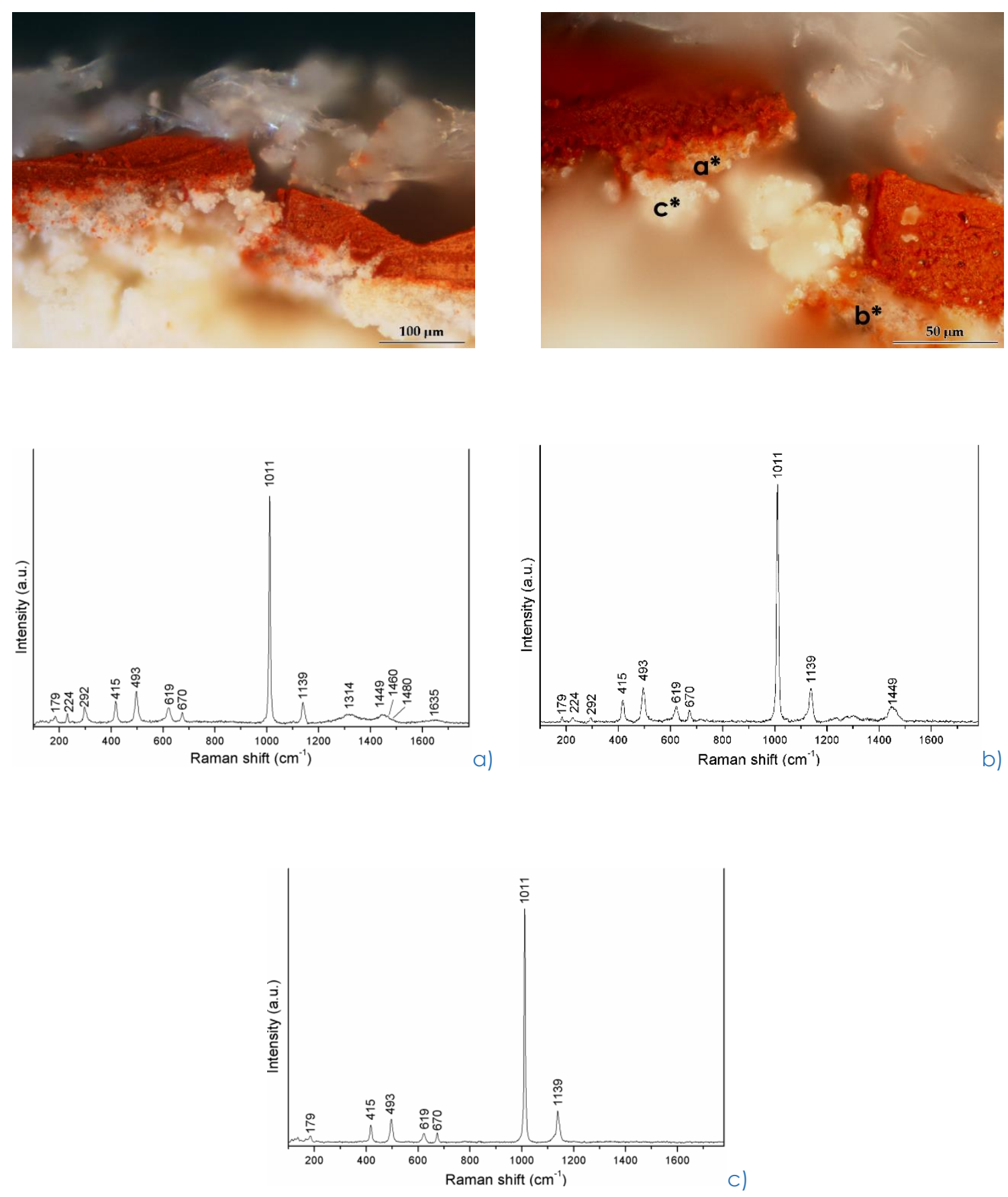

Figure 5.4.52. K(3)A(4)E-English tissue $\mathrm{n}^{\circ} 3$ : Reflected light optical microscope image of the cross-sections obtained from the faced mock-ups and relative baseline-subtracted Raman spectra of analysed areas. 

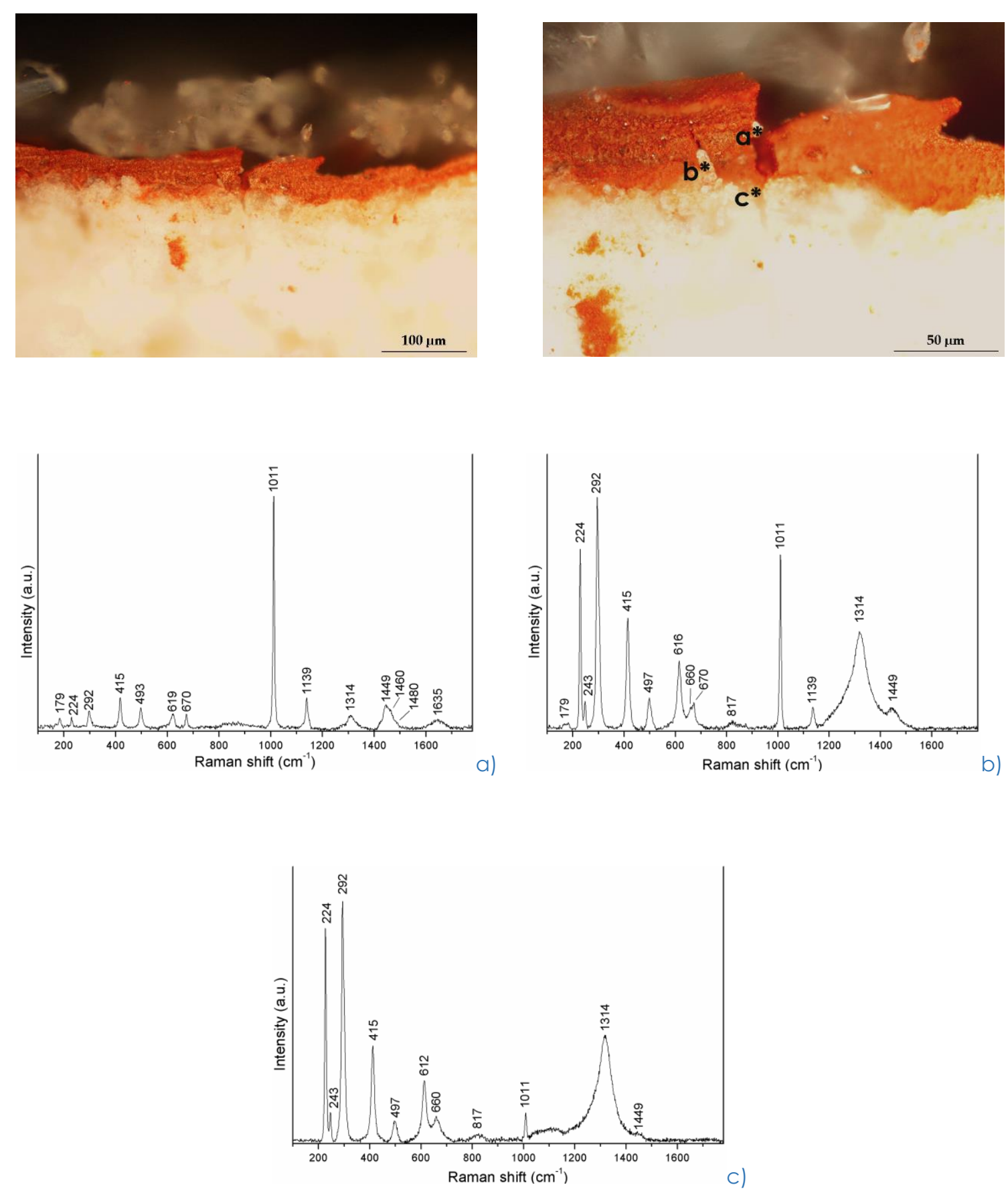

Figure 5.4.53. K(3)A(4)E-English tissue $n^{\circ} 4$ : Reflected light optical microscope image of the cross-sections obtained from the faced mock-ups and relative baseline-subtracted Raman spectra of analysed areas. 

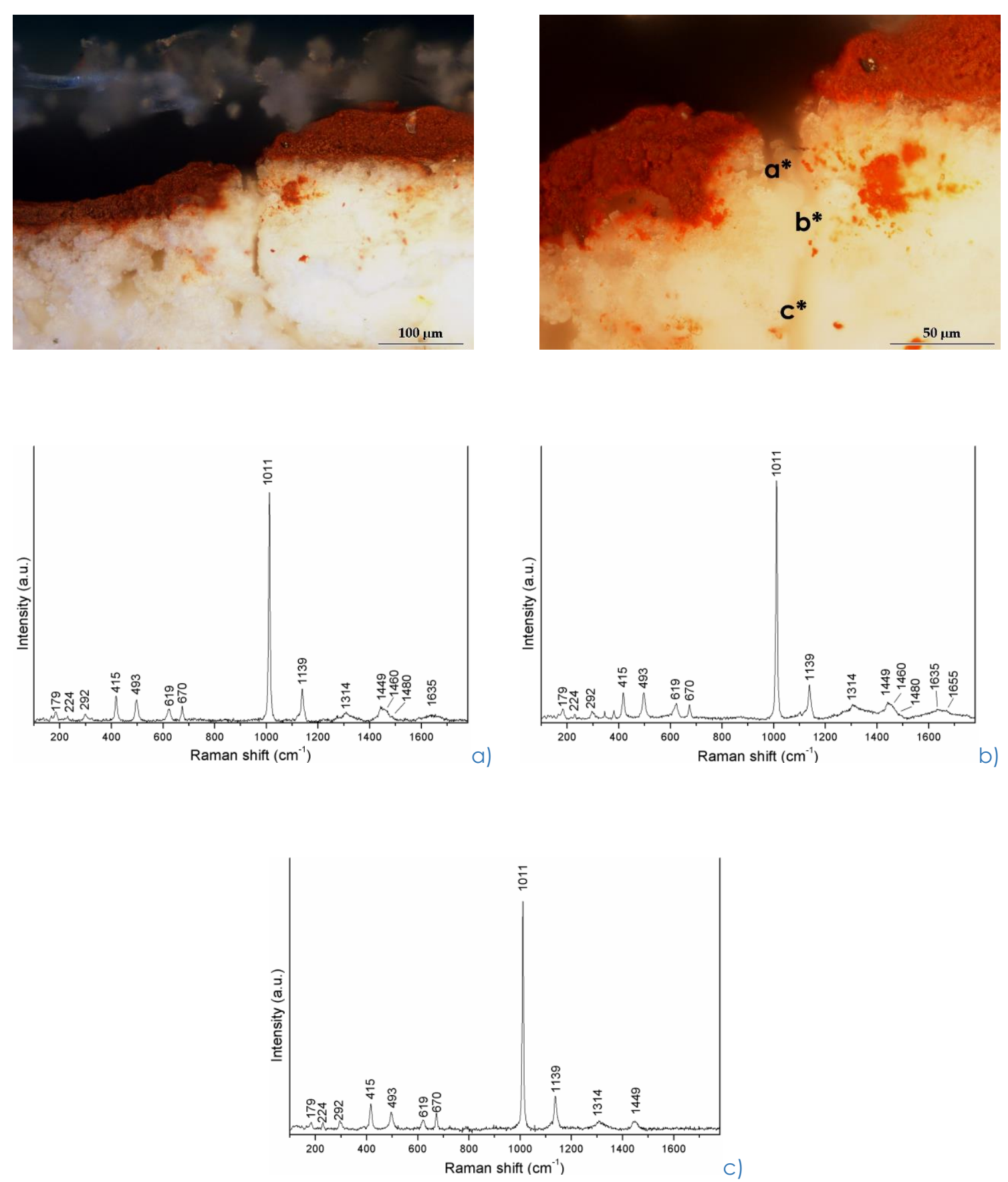

c)

Figure 5.4.54. K(3)A(4)E-English tissue $n^{\circ}$ 5: Reflected light optical microscope image of the cross-sections obtained from the faced mock-ups and relative baseline-subtracted Raman spectra of analysed areas. 


\section{$\underline{K}(3) \mathrm{A}(4) \mathrm{E}-\mathrm{TNT} 30 / \mathrm{B}$ tissue}

Facing prepared with $\mathrm{K}(3) \mathrm{A}(4) \mathrm{E}$ and TNT tissue seemed to have a very lower penetration than the corresponding ones prepared with English tissue. In fact, very little penetration was observed, which suggested that there was a good compatibility between the adhesive mixture and the temporary support.

Some traces of the adhesive were found in areas $n^{\circ} 2$ (Fig. 5.4.55) and $n^{\circ} 5$ (Fig. 5.4.56). In area $n^{\circ} 2$, traces of adhesive mixed to Dammar resin were found. The presence of the adhesive was confirmed by the presence of the very weak peak at $204 \mathrm{~cm}^{-1}$ and of a shoulder at $1460 \mathrm{~cm}^{-1}$ in the peak at $1449 \mathrm{~cm}^{-1}$ of the varnish. No traces were found in the deeper regions of the crack. Also in area $n^{\circ} 5$ the adhesive was found only in the most superficial part of the crack.

On the contrary, in the areas $n^{\circ} 1$ (Fig. 5.4.57), $n^{\circ} 3$ (Fig. 5.4.58) and $n^{\circ} 4$ (Fig. 5.4.59) no adhesive residues were found. 

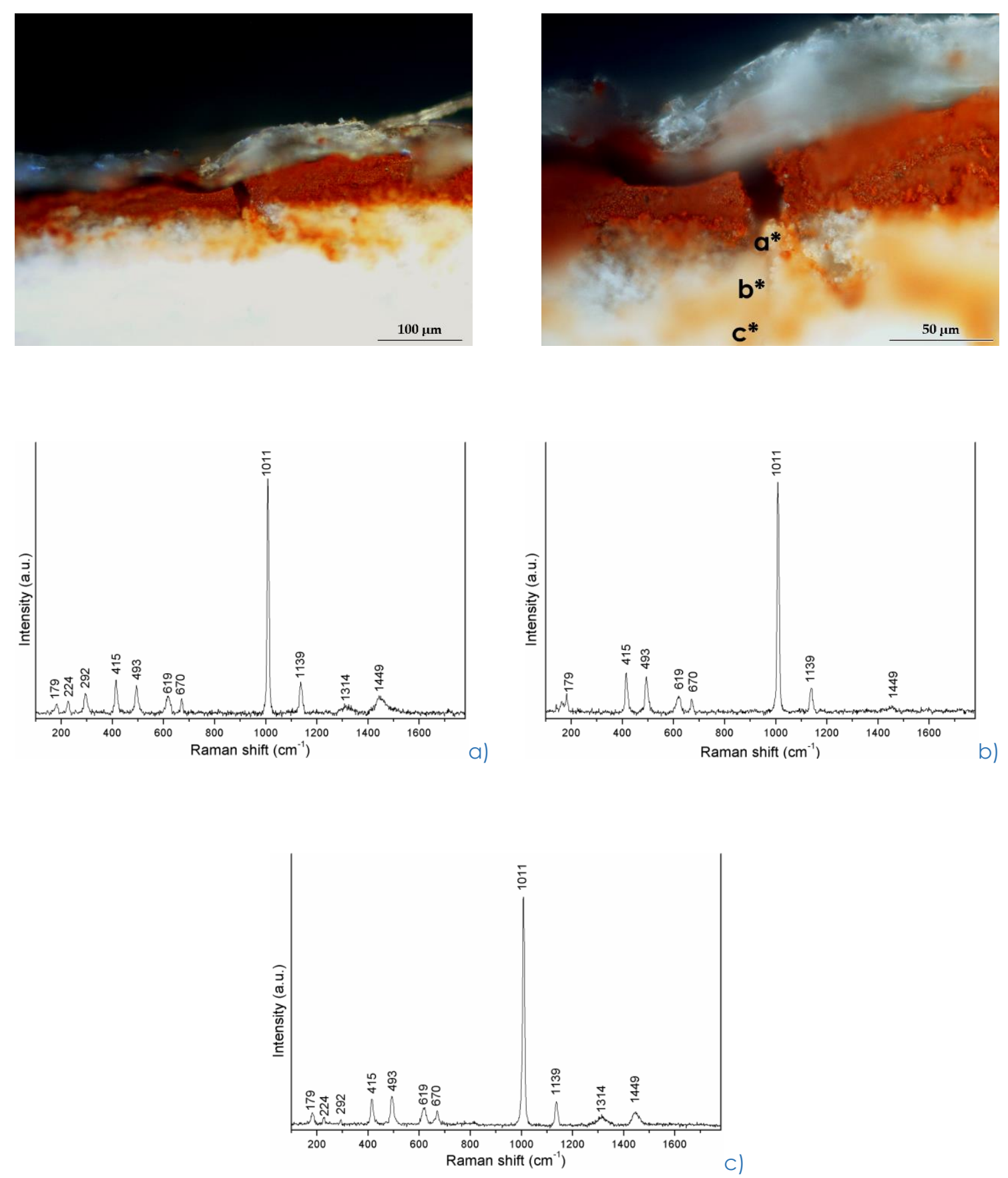

C)

Figure 5.4.55. $\mathrm{K}(3) \mathrm{A}(4) \mathrm{E}-\mathrm{TNT}$ tissue $\mathrm{n}^{\circ} 1$ : Reflected light optical microscope image of the cross-sections obtained from the faced mock-ups and relative baselinesubtracted Raman spectra of analysed areas. 

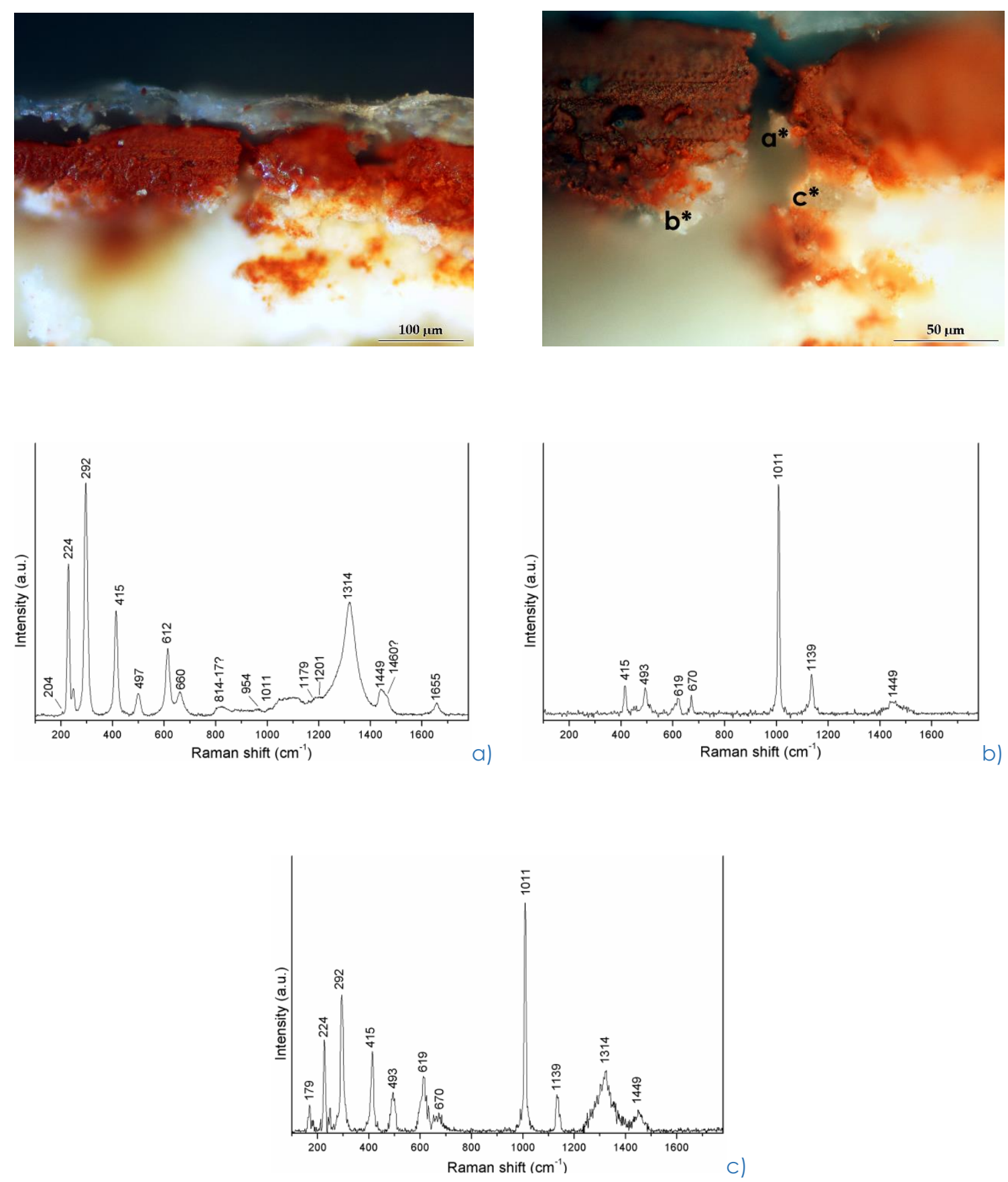

Figure 5.4.56. K(3)A(4)E-TNT tissue $n^{\circ} 2$ : Reflected light optical microscope image of the cross-sections obtained from the faced mock-ups and relative baselinesubtracted Raman spectra of analysed areas. 

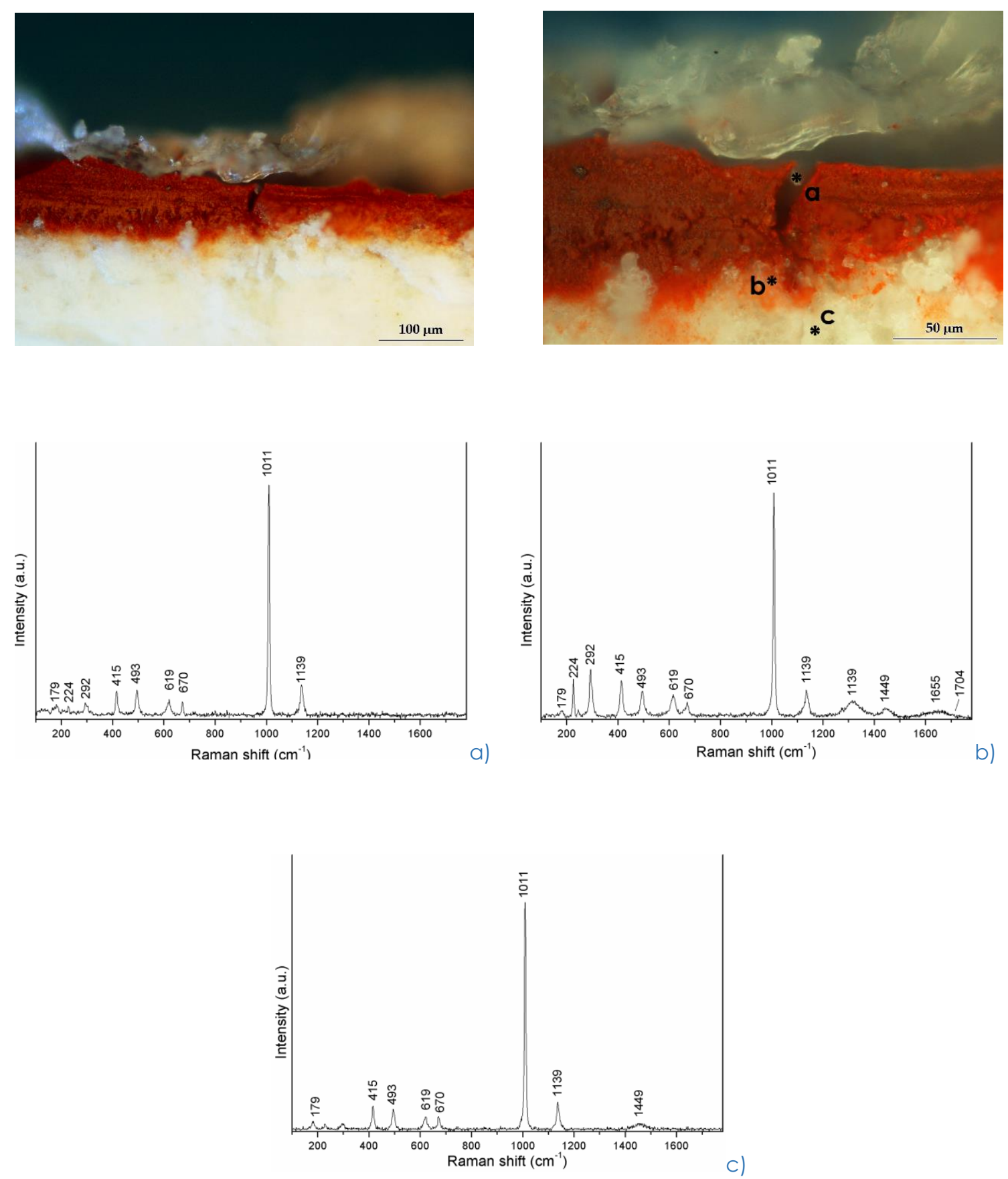

c)

Figure 5.4.57. K(3)A(4)E-TNT tissue $n^{\circ} 3$ : Reflected light optical microscope image of the cross-sections obtained from the faced mock-ups and relative baselinesubtracted Raman spectra of analysed areas. 

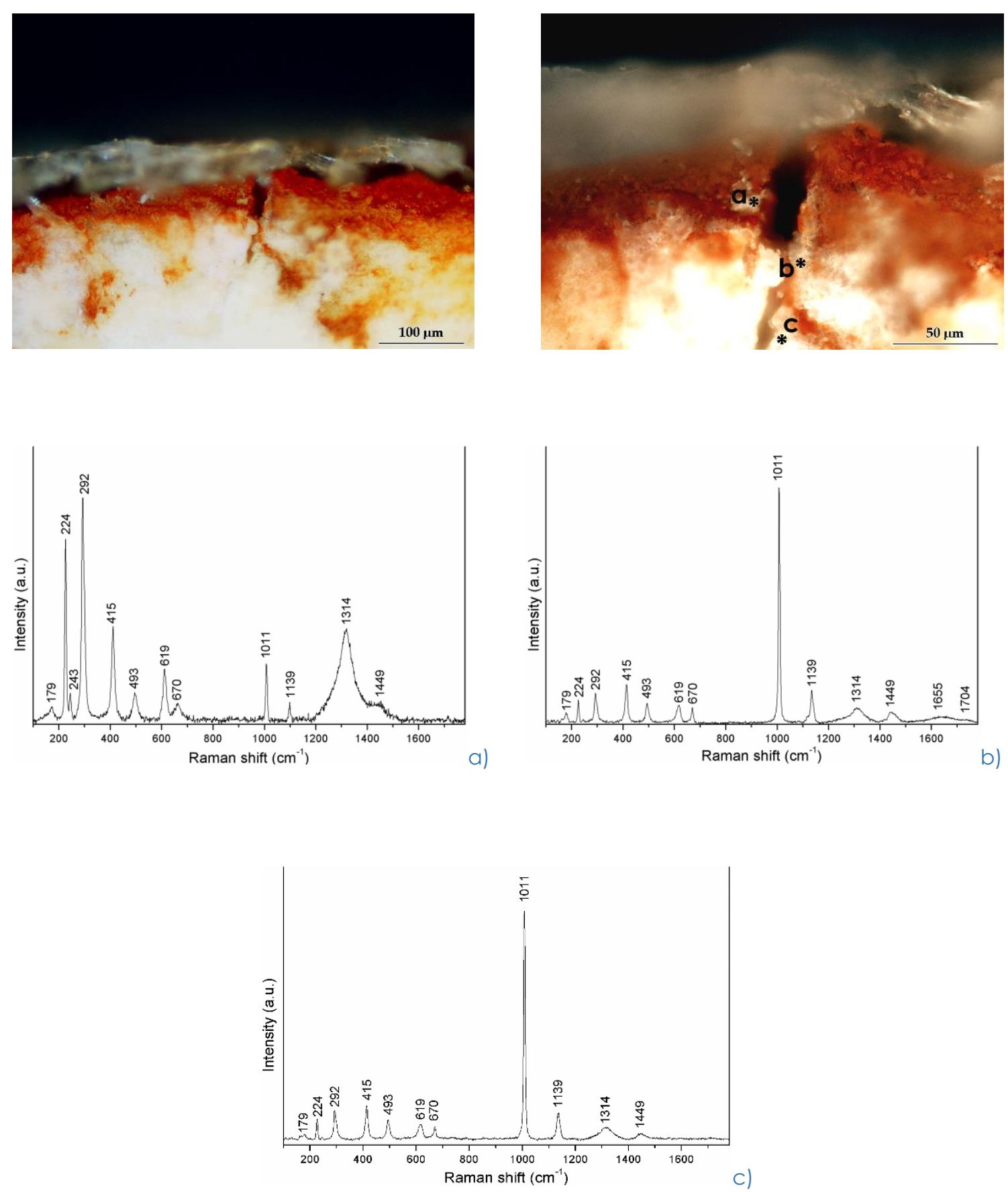

Figure 5.4.58. K(3)A(4)E-TNT tissue $n^{\circ} 4$ : Reflected light optical microscope image of the cross-sections obtained from the faced mock-ups and relative baselinesubtracted Raman spectra of analysed areas. 

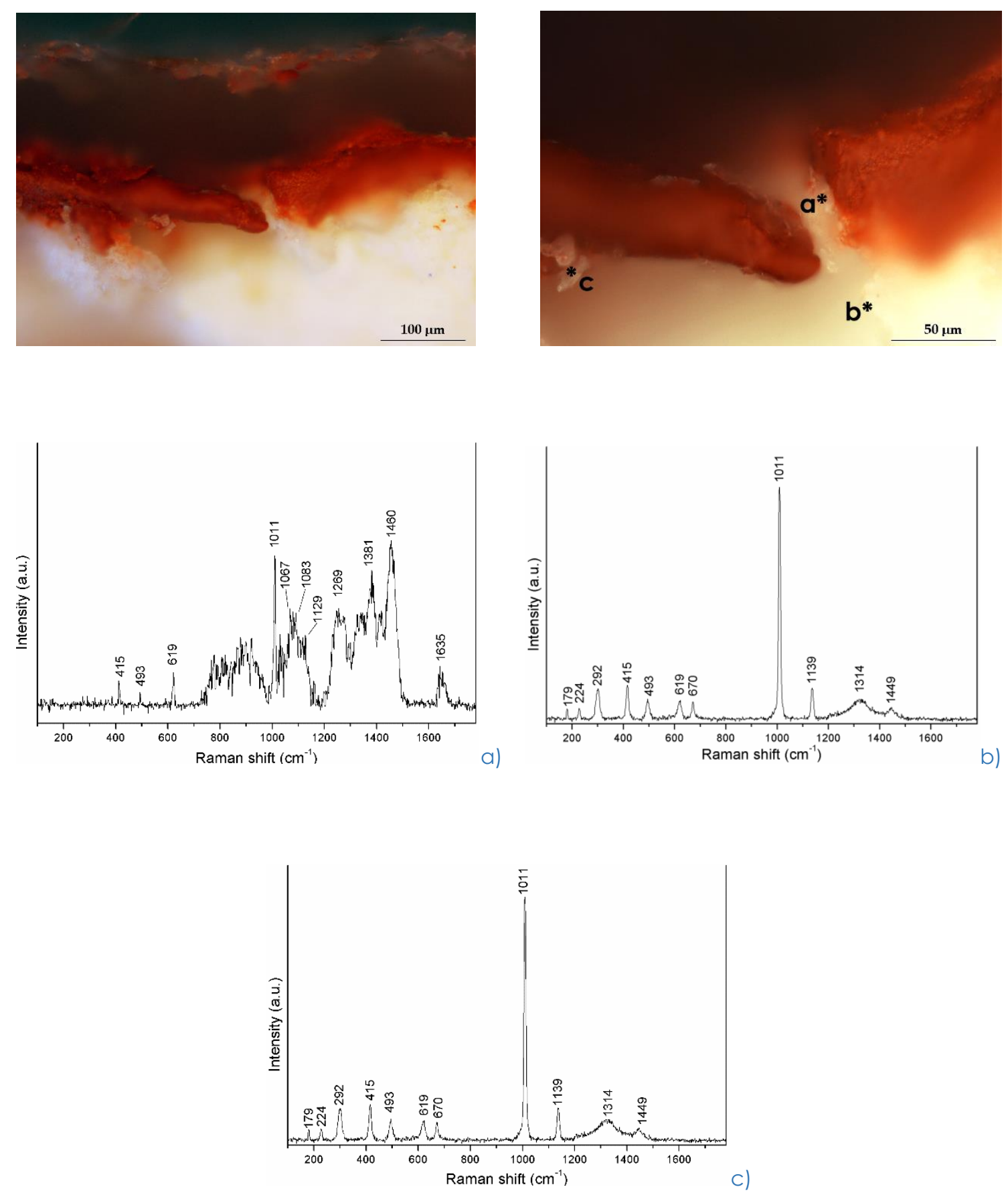

Figure 5.4.59. K(3)A(4)E-TNT tissue $n^{\circ}$ 5: Reflected light optical microscope image of the cross-sections obtained from the faced mock-ups and relative baselinesubtracted Raman spectra of analysed areas. 


\section{$\underline{\text { K(4)P7 - English tissue (brush) }}$}

The observation of specimens faced with English tissue and K(4)P7 applied with brush revealed there is a greater penetration with the traditional system than with the RTS method. In fact, the penetration of the adhesive in the cracks is significantly high: the adhesive penetrate not only in the most superficial part, but it spread along all the detached part between the paint and the ground layers. On the contrary, the penetration in the porosity of the constitutive layers of the paint is quite low.

In area $n^{\circ} 1$ (Fig. 5.4.60), traces of K(4)P7 were present in all the analysed points. The liquid adhesive penetrated through the crack and spread across all the gap between the layers.

In the porosity present in area $n^{\circ} 2$ (Fig. 5.4.61), the adhesive did not penetrate, as all the spectra presented only the characteristic peaks of the paint and ground layers.

In area $n^{\circ} 3$ (Fig. 5.4.62), the adhesive penetrated in all the crack and along all the detached part between the layers. The adhesive filled all the crack.

In the case of area $n^{\circ} 4$ (Fig. 5.4.63), Raman analyses revealed the presence of the adhesive just in the most superficial part. The spectra acquired in the deepest points show the presence of the ground layer.

In the crack of area n`5 (Fig. 5.4.64), the adhesive penetrated up to the bottom of the crack and in the ground layer. 

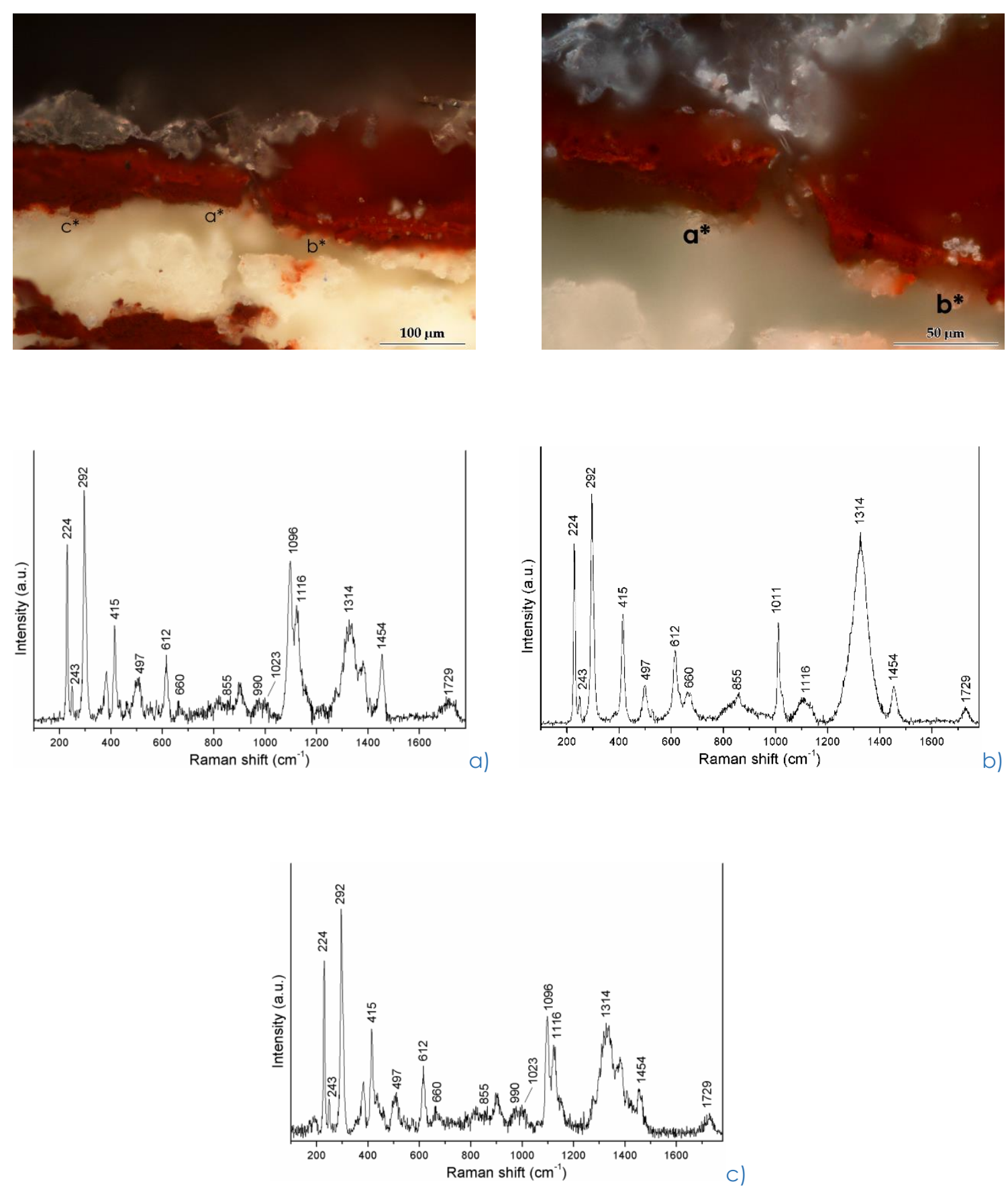

Figure 5.4.60. K(4)P7-English tissue (brush) $n^{\circ} 1$ : Reflected light optical microscope image of the cross-sections obtained from the faced mock-ups and relative baseline-subtracted Raman spectra of analysed areas. 

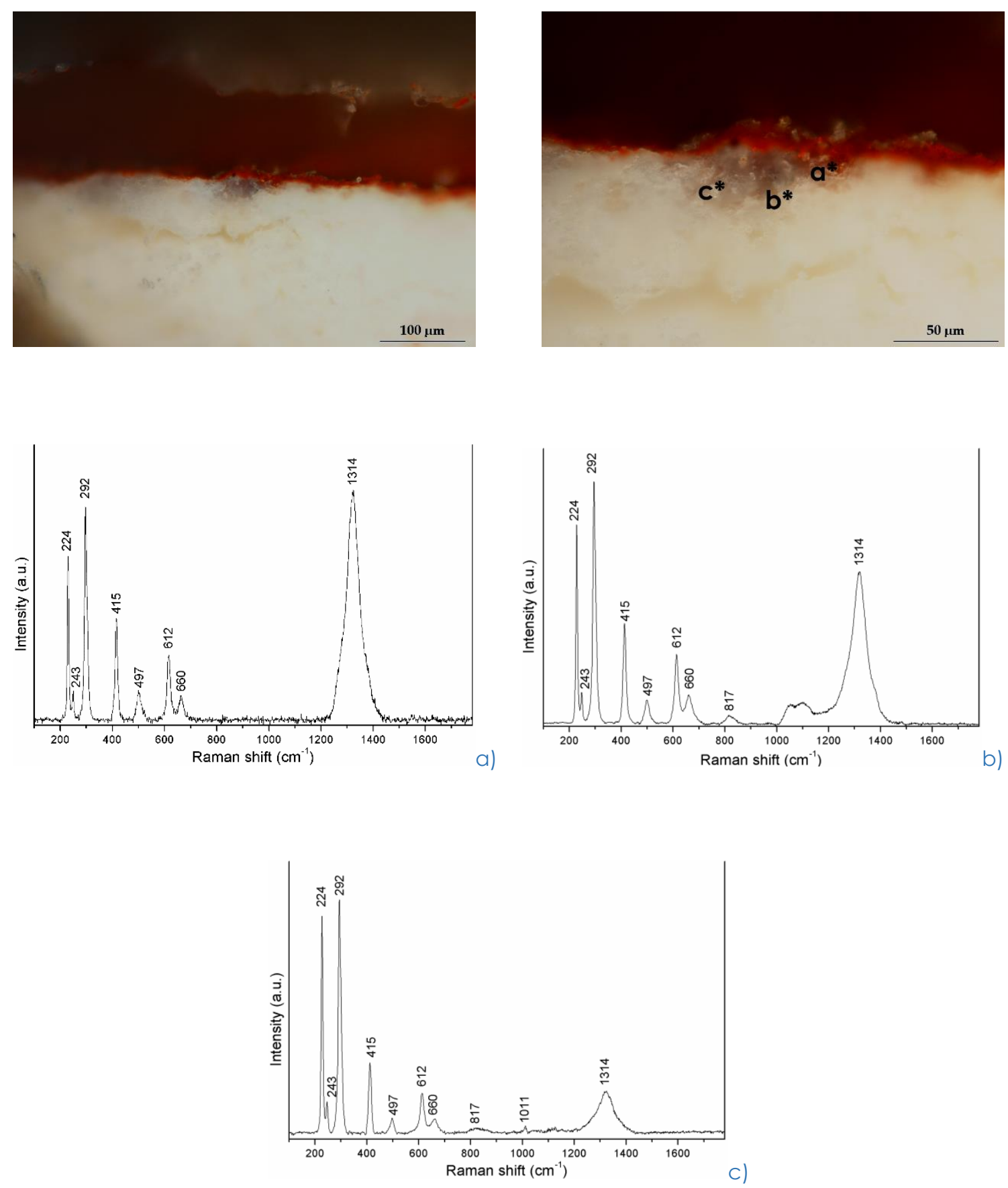

Figure 5.4.61. K(4)P7-English tissue (brush) $n^{\circ} 2$ : Reflected light optical microscope image of the cross-sections obtained from the faced mock-ups and relative baseline-subtracted Raman spectra of analysed areas. 

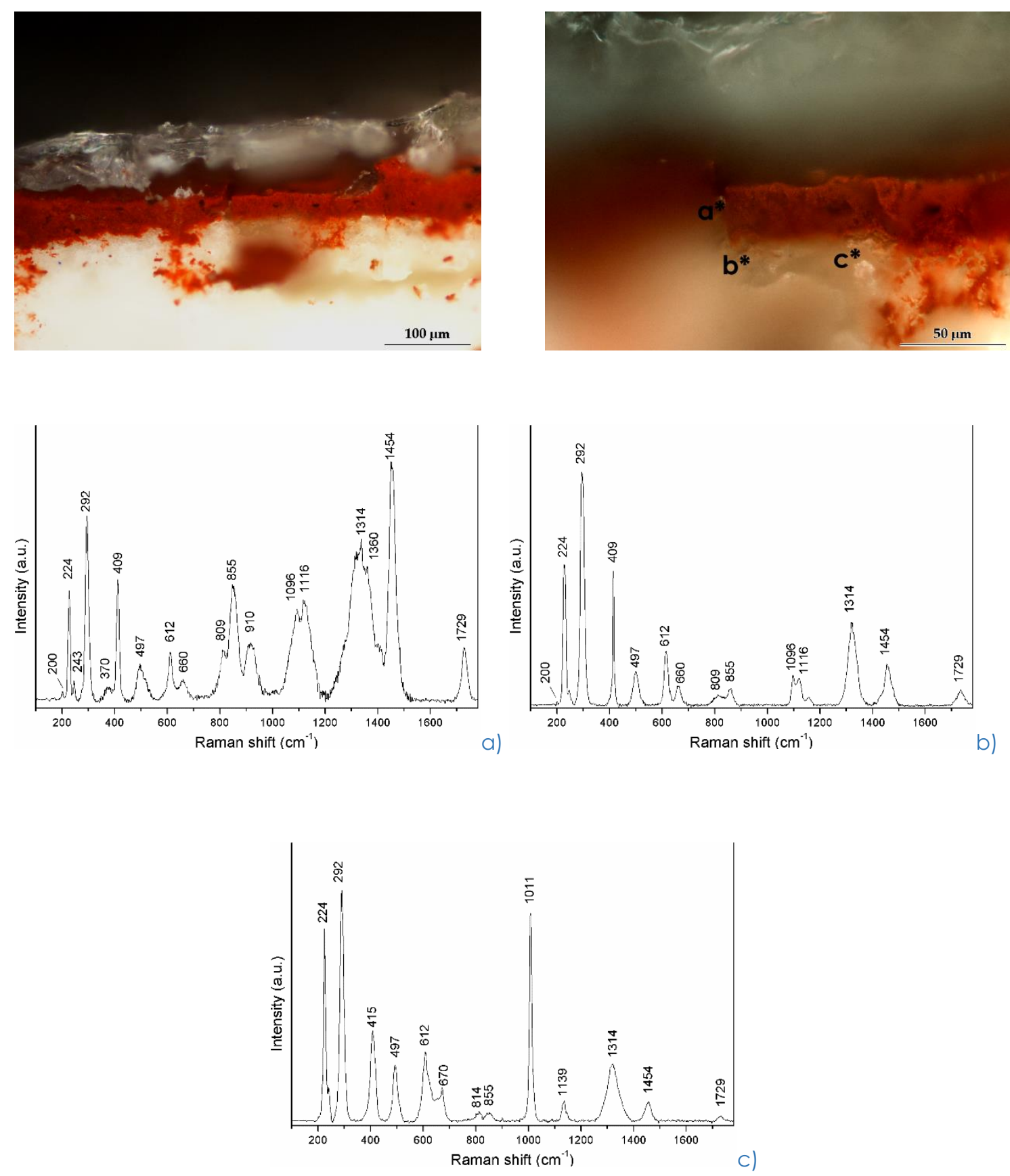

Figure 5.4.62. K(4)P7-English tissue (brush) n³: Reflected light optical microscope image of the cross-sections obtained from the faced mock-ups and relative baseline-subtracted Raman spectra of analysed areas. 

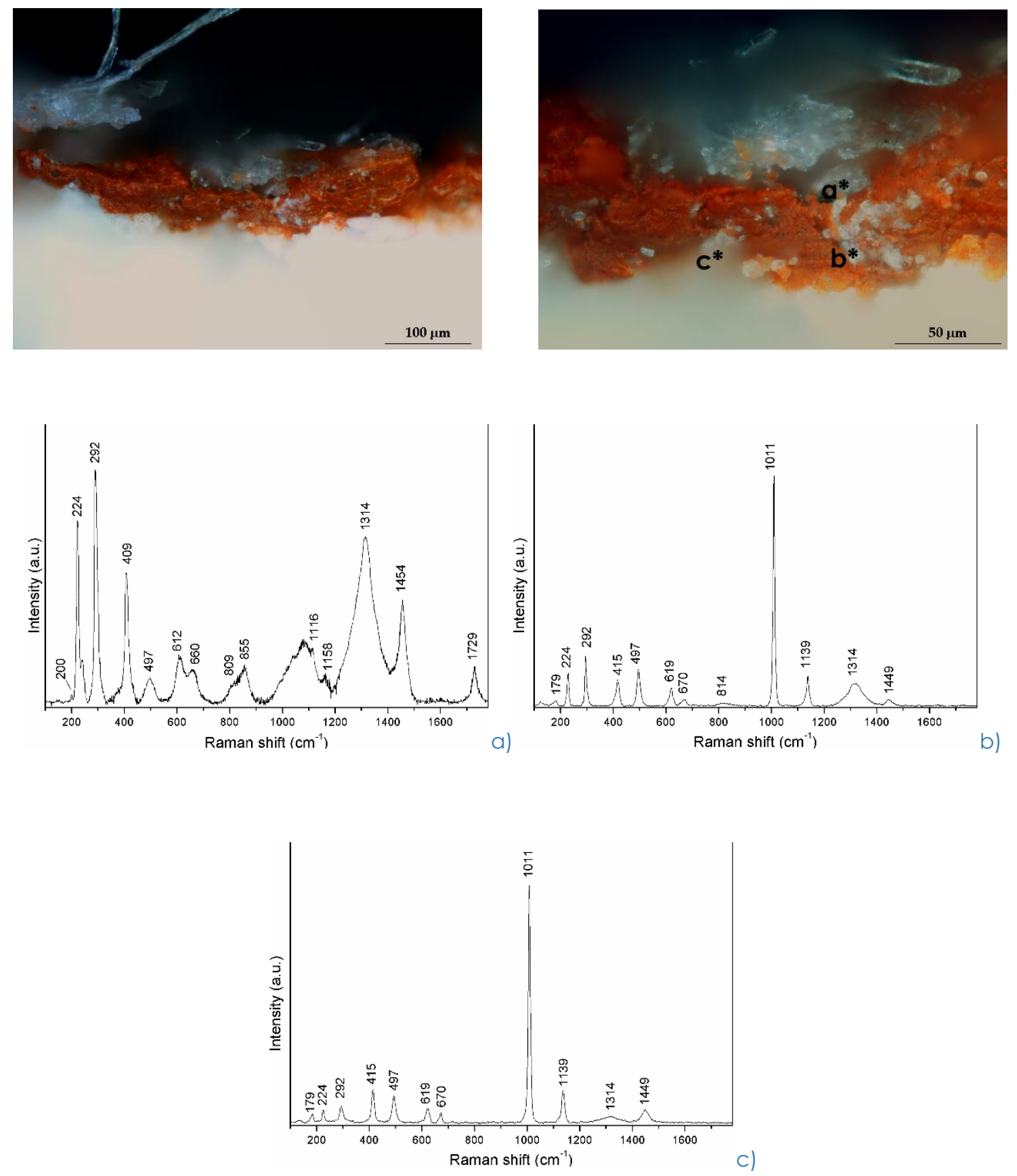

Figure 5.4.63. K(4)P7-English tissue (brush) $n^{\circ} 4$ : Reflected light optical microscope image of the cross-sections obtained from the faced mock-ups and relative baseline-subtracted Raman spectra of analysed areas. 

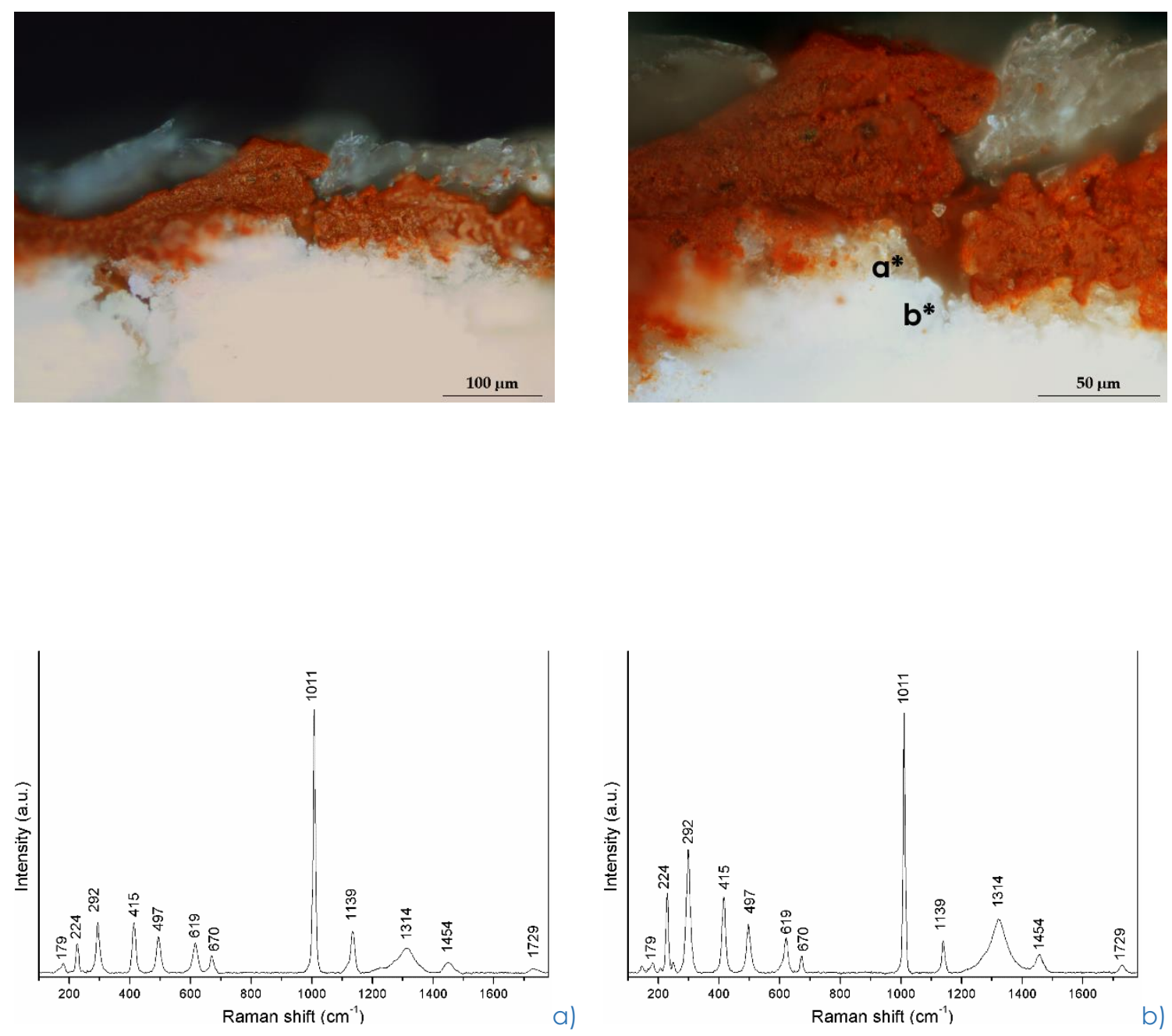

Figure 5.4.64. K(4)P7-English tissue (brush) n5: Reflected light optical microscope image of the cross-sections obtained from the faced mock-ups and relative baseline-subtracted Raman spectra of analysed areas. 


\section{K(4)P7 - TNT 30/B tissue (brush)}

Also in the case of facing prepared with TNT tissue and K(4)P7 applied with brush the penetration was higher than that observed in the corresponding ones prepared with RTS system. In fact, traces of adhesive were found in all the analysed areas. Furthermore, in some cases the adhesive spread all over the detached parts, filling all the volume of the cracks.

In area $n^{\circ} 1$ (Fig. 5.4.65), the adhesive did not penetrate too much, but it was detected only in the most superficial part, corresponding to point a).

On the contrary, in area $n^{\circ} 2$ (Fig. 5.4.66) the adhesive penetrated in the porosity of the ground layer and spread across the gap. In fact, spectrum acquired in point b) revealed the presence of the adhesive and presented all the characteristic peaks of K(4)P7.

The same applied to area $n^{\circ} 3$ (Fig. 5.4.67) and area $n^{\circ} 4$ (Fig. 5.4.68), where the adhesive was present along all the detachment. Only in area $n^{\circ} 4$ the adhesive did not reach the deepest part of the crack.

Also in the crack of area $n^{\circ} 5$ (Fig. 5.4.69) the adhesive spread all over the gap and penetrated up to the bottom of the crack. 

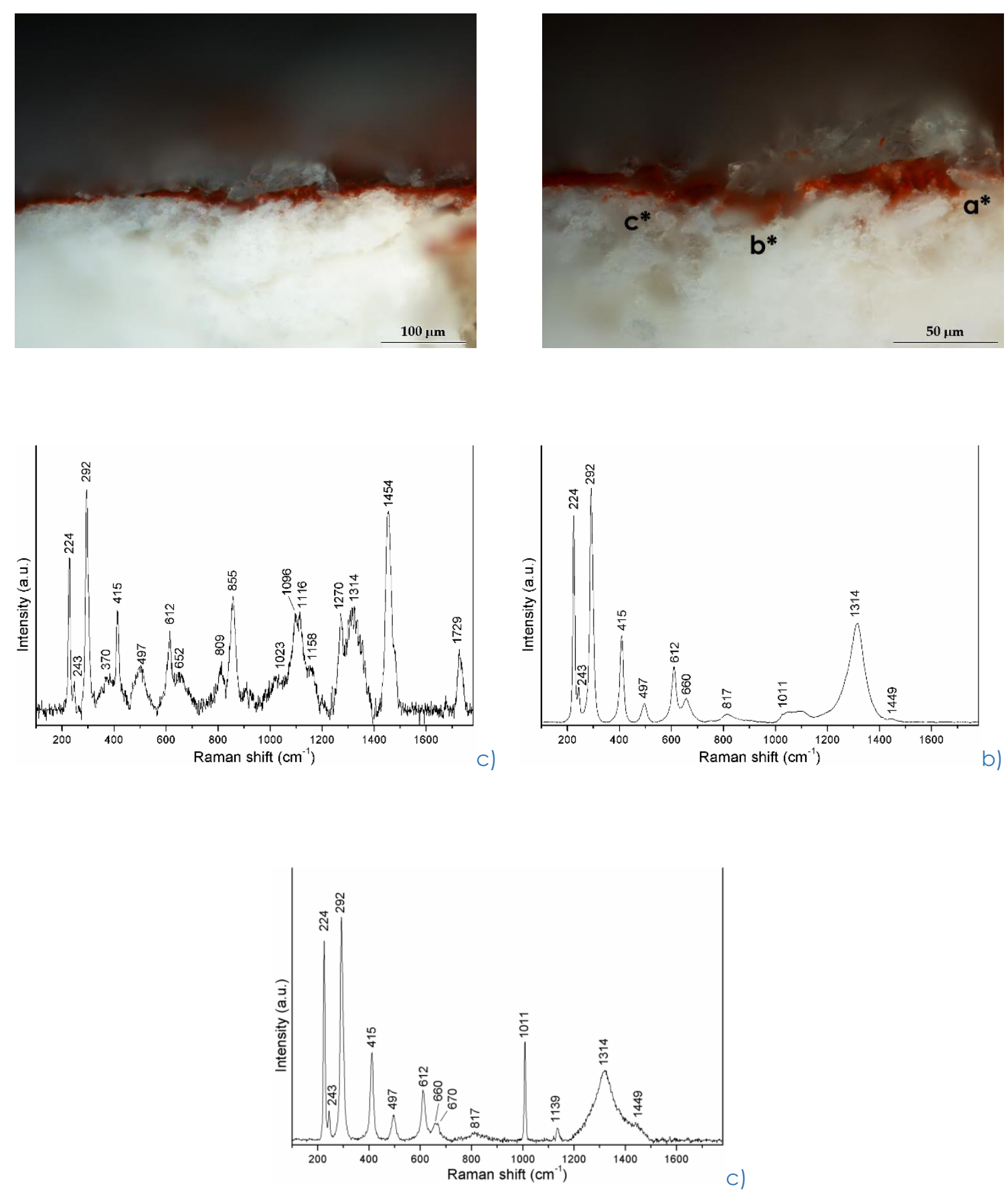

Figure 5.4.65. K(4)P7-TNT tissue (brush) $n^{\circ} 1$ : Reflected light optical microscope image of the cross-sections obtained from the faced mock-ups and relative baseline-subtracted Raman spectra of analysed areas. 

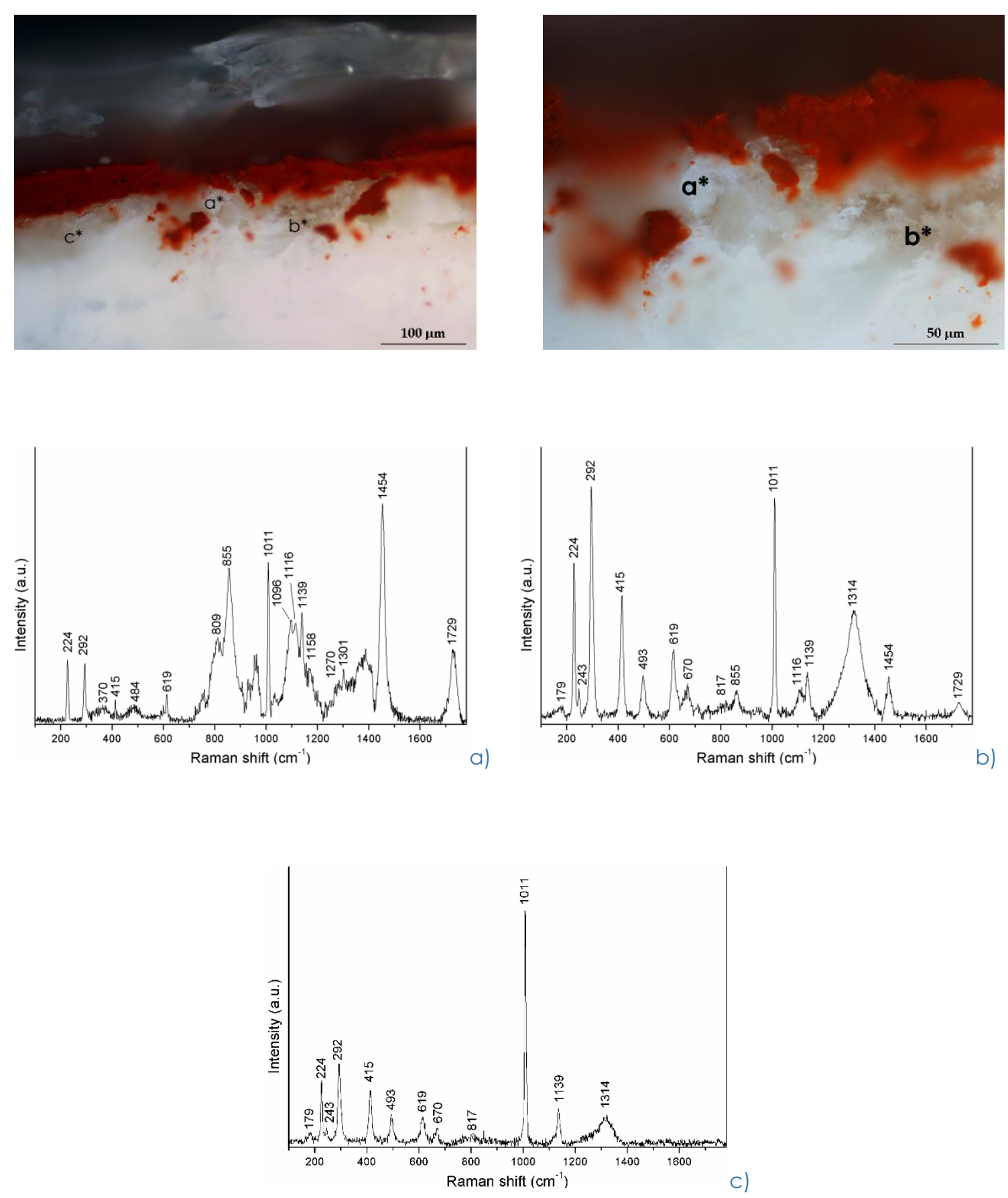

Figure 5.4.66. K(4)P7-TNT tissue (brush) $n^{\circ} 2$ : Reflected light optical microscope image of the cross-sections obtained from the faced mock-ups and relative baseline-subtracted Raman spectra of analysed areas. 

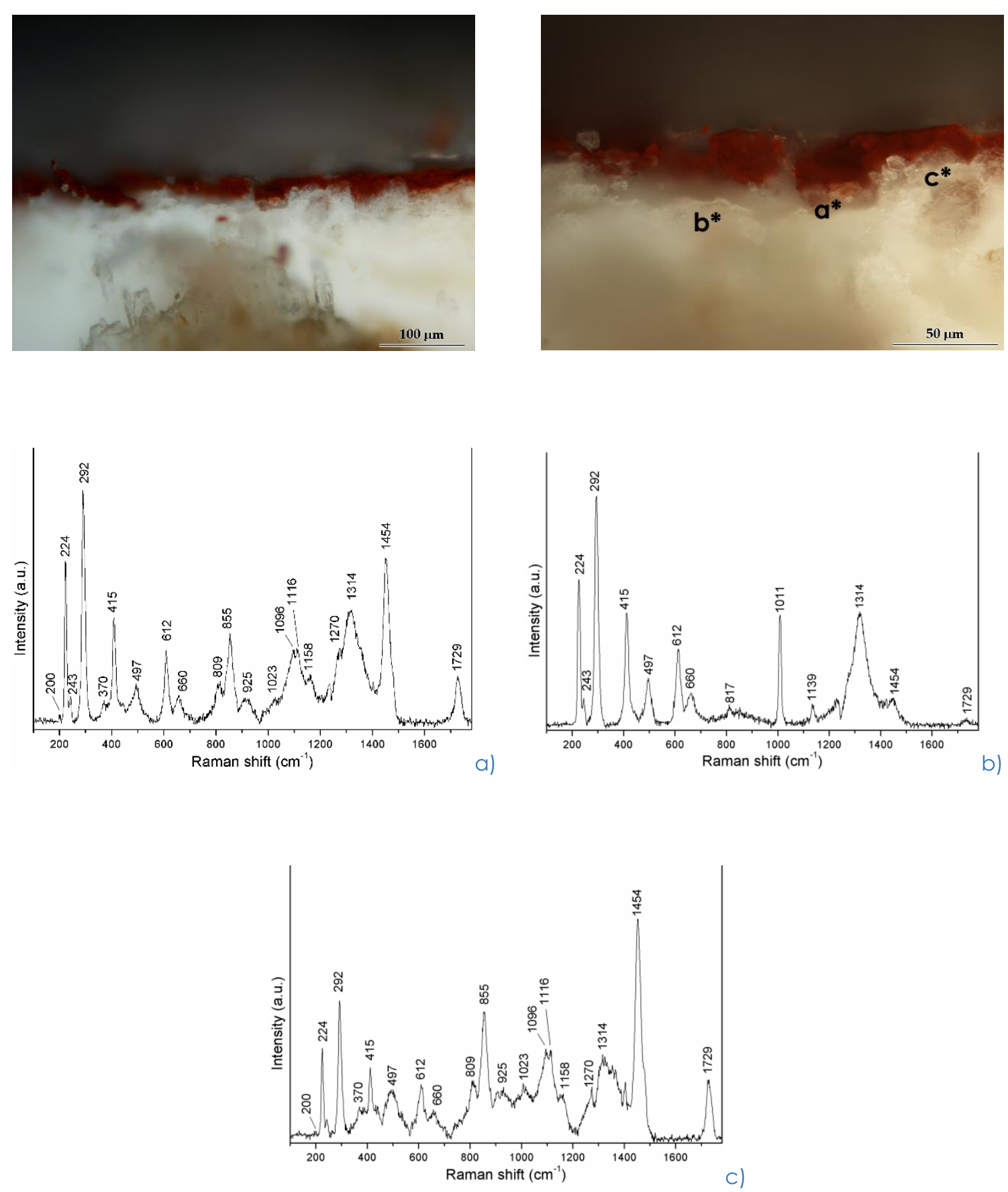

Figure 5.4.67. K(4)P7-TNT tissue (brush) n³: Reflected light optical microscope image of the cross-sections obtained from the faced mock-ups and relative baseline-subtracted Raman spectra of analysed areas. 

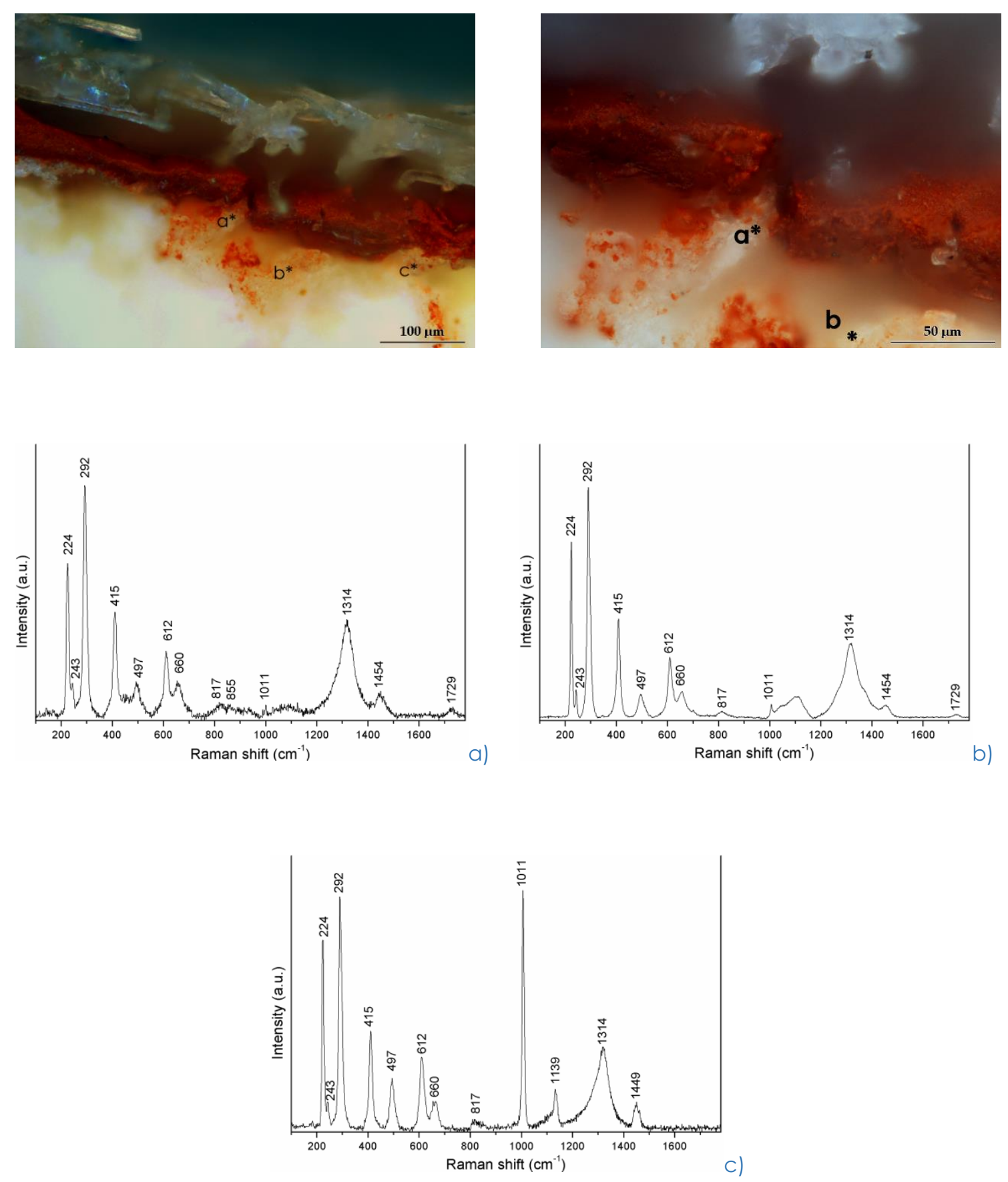

Figure 5.4.68. K(4)P7-TNT tissue (brush) $n^{\circ} 4$ : Reflected light optical microscope image of the cross-sections obtained from the faced mock-ups and relative baseline-subtracted Raman spectra of analysed areas. 

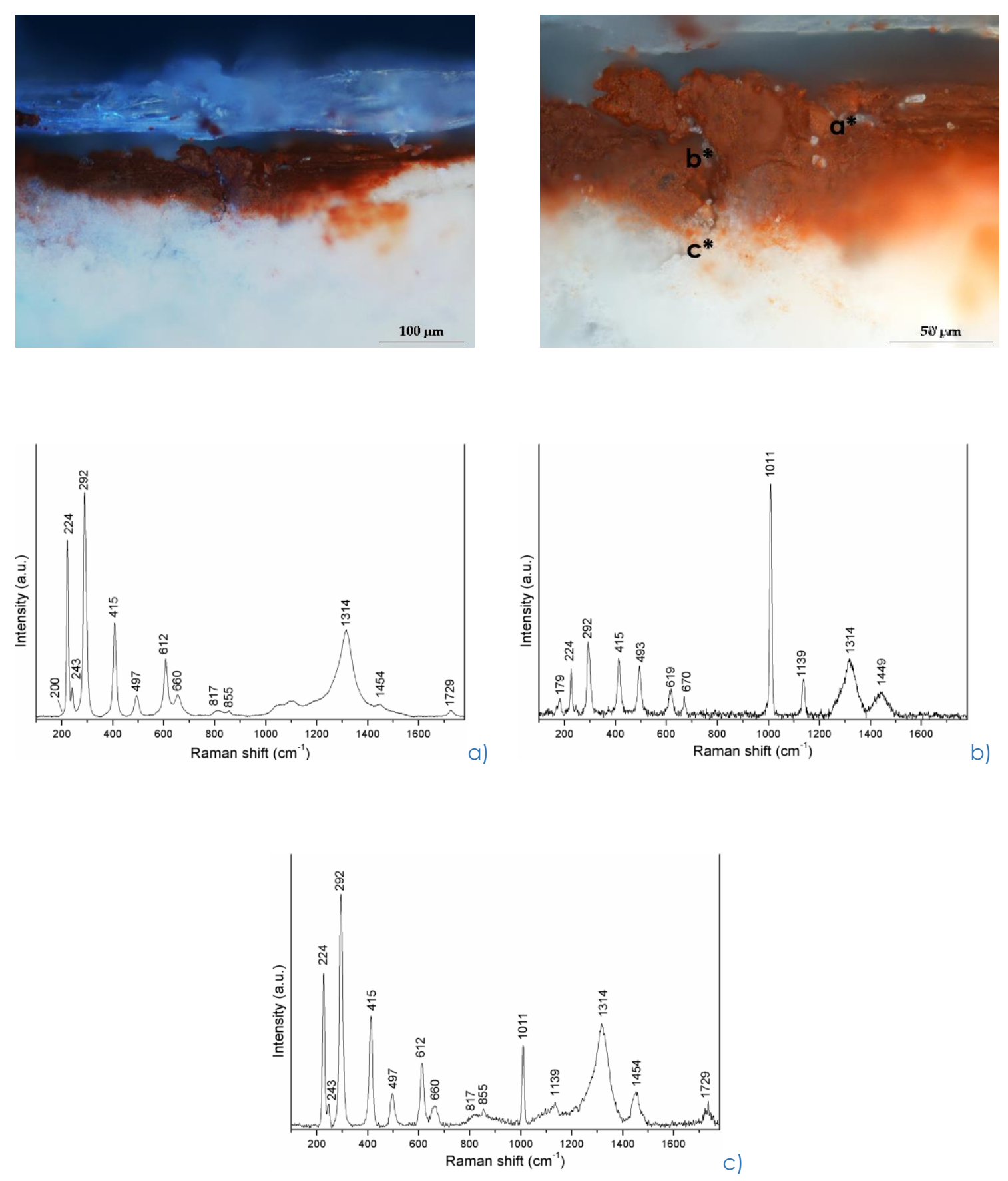

c)

Figure 5.4.69. K(4)P7-TNT tissue (brush) n5: Reflected light optical microscope image of the cross-sections obtained from the faced mock-ups and relative baseline-subtracted Raman spectra of analysed areas. 


\subsubsection{Conclusions}

The complementary use of $\mu$ Raman spectroscopy and optical microscopy permitted to assess the grade of penetration of the adhesives used to face artificially aged mock-ups reproducing the stratigraphy of an oil painting.

The reference spectra of the dried adhesive dispersions and the constitutive layers of the mock-ups were acquired. Then, the distinctive peaks of every analysed material were identified, in order to find marker peaks of every material, which would have permitted to identify traces of the adhesive dispersions in the cross-section of the faced specimens.

The Remoistenable Temporary Supports used for this step of the investigation were prepared with the previously selected combination of adhesive dispersions (T(3)P7, K(4)P7, K(3)A(4)E) and selected temporary supports (English tissue, TNT Tissue). In order to compare the penetration of the adhesive applied with the RTS method and with the traditional brush application, two sets of mock-ups were faced using K(4)P7 prepared as both the RTS and applied with a brush.

The results show that there is a minimal penetration (limited to the edges of the most superficial part of the cracks) of the adhesive dispersion in the case of RTS prepared with T(3)P7 and English tissue. The results relative to RTS prepared with T(3)P7 and TNT Tissue show a slightly higher penetration.

All the RTS prepared with K(4)P7 and with both English and TNT tissues show a very little penetration, limited to the most superficial part of the cracks edges.

It is noticeable the higher penetration of $K(3) A(4) E$ used for English tissue RTS, because of the high viscosity of the dispersion. This does not happen with K(3)A(4)E coupled with TNT tissue, where the adhesion appears almost exclusively superficial. The first phenomenon probably depends on the high sensitivity of Aquazol 500 to water; the latter could be due to a good affinity between the adhesive and the temporary support.

The results found for mock-ups faced with the brush revealed a much higher penetration. In fact, in the mock-ups faced with K(4)P7 applied with brush, traces of adhesive dispersion were found in the deepest part of the analysed cracks. Furthermore, the applied polymer filled all the volume of the cracks.

In general, RTS prepared with K(4)P7 with any temporary support and the one prepared with K(3)A(4)E and TNT tissue, are the ones with the lowest penetration.

This step of the investigation confirmed the previous hypotheses on the little penetration of the adhesive using the remoistenable temporary support system. 
Furthermore, it was demonstrated that the use of the traditional method with a brush involves a higher penetration, even when a high viscosity adhesive is used.

The development of the analytical method itself is an important achievement, because it proved to be successful for the identification of traces of adhesive polymers in the cross-section of complex specimens reproducing an oil painting. This means that it could be used in the future for other investigation on facing techniques. For example, it could be used for the assessment of changes in penetration according to environmental changes, or after facing removal. Furthermore, the same analytical method could be a successful strategy for the assessment of the penetration of the polymers employed for other interventions, for example consolidation.

\subsection{ASSESSMENT OF the ADHESIVE StRENGTH OF SELECTED RTS (PEeling Test)}

The evaluation of the mechanical characteristics of selected RTS was important to understand their suitability for facing. A first test of mechanical properties of selected materials was made in the first step of the investigation, when tensile tests were performed. However, in order to define the eligibility of RTS for facings, it was necessary to determine their adhesive strength, which is one of the most important requirement to determine the efficiency of selected remoistenable tissues.

In fact, even if the understanding of the mechanical behaviour of an adhesive is fundamental to its characterisation, it is equally important to understand the characteristic of the joint it creates with its adherends. The kind of adhesive joint under discussion was quite complex, because it was constituted by two different adherends (temporary support and paint layer) bonded together by an adhesive. Since the adhesive joint strength is expressed in terms of stresses required to break the joint, it is determined by the mechanical response of all the involved materials. 


\subsubsection{Basic principles of Peeling test}

As explained in Chapter 3, there are different theories that try to explain adhesion mechanisms and to calculate the basic adhesion, which is the summation of mechanical, physical and chemical interactions at the interface. Since it is not possible to calculate basic adhesion, it makes sense to study the influence of the changes in parameters on the adhesive bond strength and its failure mechanisms. There are a number of tests for evaluating practical adhesion, which have been formalised and standardised. The ASTM and ISO have compiled the most complete description of these tests (Dillard and Pocius 2002). The three most common adhesion tests are probably the lap shear, butt tensile and peeling tests.

For this investigation, the peeling test was chosen to evaluate the adhesion strength of remoistenable tissues.

The peel test is the most indicative test to observe the quality of one bonded substrate to the other. In this kind of test, the load needed to pull the adherends apart is transmitted to the peel front of the area that is peeled apart at a constant velocity, and it permits a direct and quantitative measurement of the peeling force (Gent and Hamed 1977). Furthermore, it permits to discriminate between different adhesives or surface pretreatments in a much more sensitive manner than could be achieved by lap shear testing (Adams, Crocombe and Harris 1977).

However, the data of the results of the peel tests show less importance as absolute values, but should be interpretated as very good indication of the quality of the adhesive bond. Because of the large standard deviation, it is necessary to collect a sufficient number of data, in order to be able to compare the results with determined criteria (Young 2006). In fact, the peel strength changes conforming to the peel angle and the peel velocity among other factors. As Dillard and Pocius state:

"The peel strength is not a fundamental property for an adhesive. The value of force per unit width required to initiate or sustain peel is not only a function of the adhesive type, but also depends on the particular test method, rate of loading, thickness and stiffness of adherends and adhesive as well as other factors. Thus, peel tests generally do not yield results that may be used in quantitative design. This does not imply, however, that peel test is not a useful test. Peel test provide quantitative comparisons between different adhesive systems, insight into rate and temperature effects, etc." (Dillard and Pocius 2002). 
American Society for Testing and Materials (ASTM) or ASTM International has formalized different peel tests, which differ in the flexibility required for one or both on the adherends and the peel angle maintained during debonding. The most common peel tests are T-peel test (ASTM D1876), roller peel test (ASTM D3167), climbing drum peel test (ASTM D 1781) and $180^{\circ}$ peel test (ASTM D903). All these are variation of the most simple scheme reported in Fig. 5.5.1, where a strip is peeled away from a substrate at an angle $\Theta$ by a force $P$.

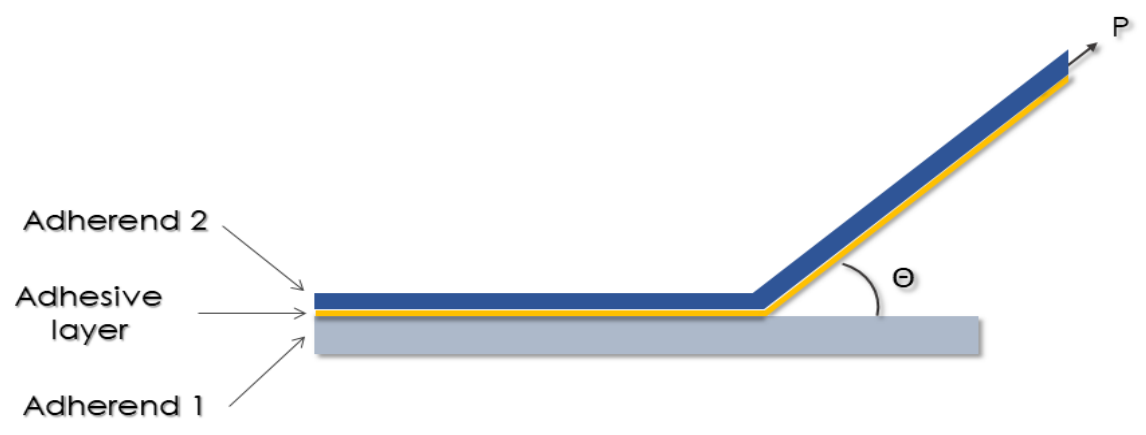

Figure 5.5.1. Schematic representation of generic peel test.

For this investigation, T-peel was chosen since the specimens were composed by two flexible adherends (RTS and canvas painting). T-peel specimens consist in strips constituted by the two flexible adherends properly prepared and bonded together along the majority of their length. The not bonded portions of the substrates are clamped in the grips of a dynamometer and pulled apart on a vertical axis and at a constant selected speed.

Theoretically, the angle of the bonded 'tail' should form a $90^{\circ}$ angle. In the practice, even if the forces are the same on each arm, when the two adherends present different thicknesses ad elasticity, the bonded part finds a specific equilibrium angle, as shown in Fig. 5.5.2, where the bonded tail rotates towards the less stiff adherend, as the peel failure (Dillard and Pocius 2002). The equilibrium angle depends also on the strength of the bond in relation to the weight of the still bonded part of the tail.

Considering all the possible variables which can affect the results, it is important to report all the details of the settings used for the peel test, such as information on specimens and the bonding process, conditioning procedures, type of test machine, separation rate, average, maximum and minimum peeling load values, type of failure (ASTM D1876). 
In particular, the indication of the type of joint failure is important to understand the danger that resides in the use of some materials. Application of stress may cause the joint to fail either 'adhesively' or 'cohesively'. Adhesive failure ideally corresponds to a perfect separation of the two phases meeting at the interface. However, this theoretical 'adhesive' or 'interfacial' failure hardly ever occurs. In fact, the geometric complexity of real interfaces at microscopic level, unlikely entails a precise disjoint along the system contours. There is generally a transition zone of finite thickness separating the bulk phases, called 'interface', which has a structure, and possibly a composition, distinct from that of either of the bulk phases. When the failure occurs within or immediately adjacent to the interphase zone, it will be called 'adhesive' or 'interfacial' failure. When failure of the joint occurs in material outside the interphase it will be designated as 'cohesive' failure instead. However, some cases involve a mixture of adhesive and cohesive failures. For this reason, the separated surfaces should be examined thoroughly to gain knowledge about the locus and mechanism of failure (Berg 2002).

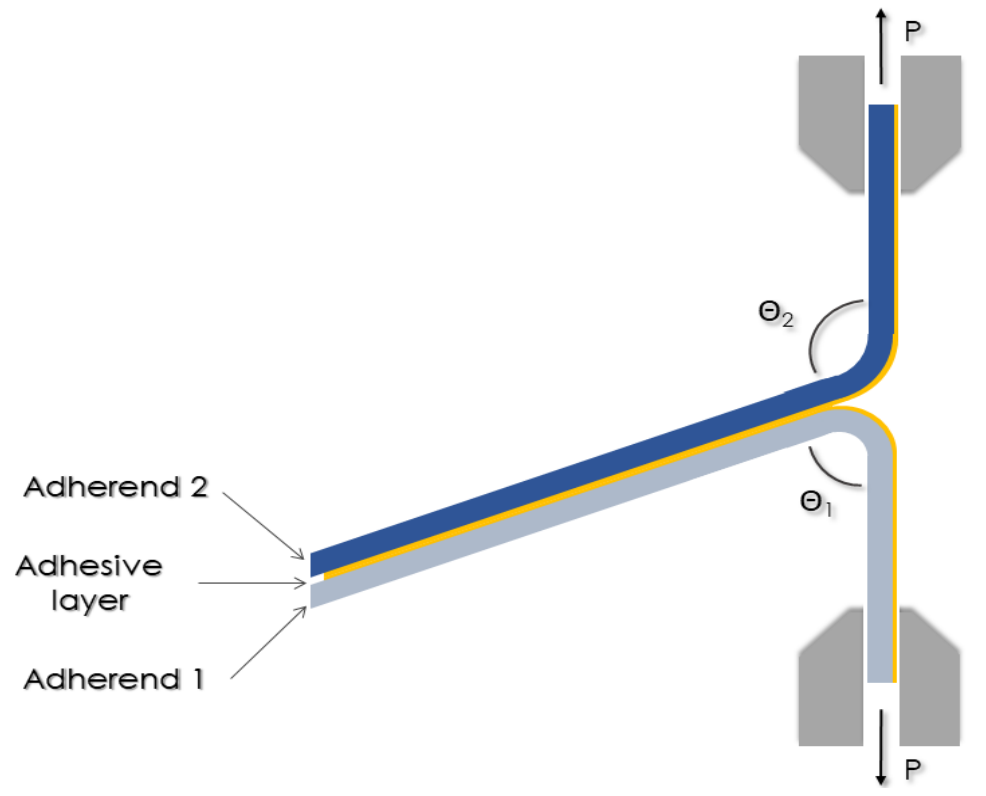

Figure 5.5.2. Schematic representation of T-peel test.

\subsubsection{Methodology}

For this investigation, peel tests were carried out mainly in accordance with the D1876 ASTM standard test. Nevertheless, as it often happens in the case of tests made for conservation purposes, it was necessary to make some changes.

The principal problem for carrying out peel test was the fragility of the RTS. The risk of the rupture of the temporary support during the test was quite high and, for this reason, it was necessary to have a sufficient number of samples of 
significant dimension, reducing the standard deviation of the average peel force for each test. Six specimens for every kind of selected RTS were prepared (selected adhesives: T(3)P7, K(4)P7, K(3)A(4)E; selected temporary supports: English tissue, TNT tissue), as required by the ASTM standard test. The recommended dimension of the specimens was reduced to $(20 \times 2.5) \mathrm{cm}$, bonded over $16 \mathrm{~cm}$ of their length (the unbounded $4 \mathrm{~cm}$ were necessary to clamp the strips to the grips of the dynamometer). For the TNT two set of samples, one for every fibre direction were prepared.

It was necessary to make a further change to reduce the risks connected with the fragility of the RTS. In fact, it was decided to take inspiration from the indications given for weak materials in the 8510-2 UNI EN ISO standard test. The strips of remoistenable tissue were prepared $0.8 \mathrm{~cm}$ wider than the ones of painting specimens. Furthermore, the last $5 \mathrm{~mm}$ of each lengthwise edge of the RTS strips was pre-treated with liquid silicon before the adhesion to the canvas specimens. In addition, before conducing the test, a layer of paper tape was applied on the surface. In this way, it was possible to reduce the failure of the remoistenable tissue during peeling test. The use of adhesive tape permitted also to reduce the elasticity of the TNT in the transversal direction, avoiding the need of doing further correction during the analysis and calculation of the results (Dillard and Pocius 2002). It was also necessary to reduce the speed of delamination from the standard one of $254 \mathrm{~mm} \cdot \mathrm{min}^{-1}$ to $100 \mathrm{~mm} \cdot \mathrm{min}^{-1}$.

The decision of making these changes was well reasoned, because modifications to the standard parameters meant a renounce to the direct confrontation with other tests conducted following the same standard test. Nevertheless, they were necessary to improve the reliability of the results.

For each kind of remoistenable tissue, two sets of six samples were prepared and left to dry for two weeks. Then, the first set was kept at environmental conditions of $23 \pm 1{ }^{\circ} \mathrm{C}$ and $45 \pm 5 \% \mathrm{RH}$, while the second set was stored in climate chamber at $23 \pm 1^{\circ} \mathrm{C}$ and $80 \pm 5 \% \mathrm{RH}$ for a minimum of $72 \mathrm{~h}$ (Fig.5.5.4). The test environment was $23 \pm 1^{\circ} \mathrm{C}$ and $45 \pm 5 \% \mathrm{RH}$.

For the conditioning of the second set of specimens, a climate chamber (Contoltecnica-CTS) series C-40/1000 was used. Peeling tests were carried out by a Zwick-Roell 10kN, equipped with a $1 \mathrm{kN}$ load cell.

This part of the research was carried out at the Adhesion Institute, in the Aerospace Engineering Department of the Delft University of Technology, with the authorization and the precious advice of Dr. J.A. Poulis, director of the institute, and the help of the expert technicians of the department. 


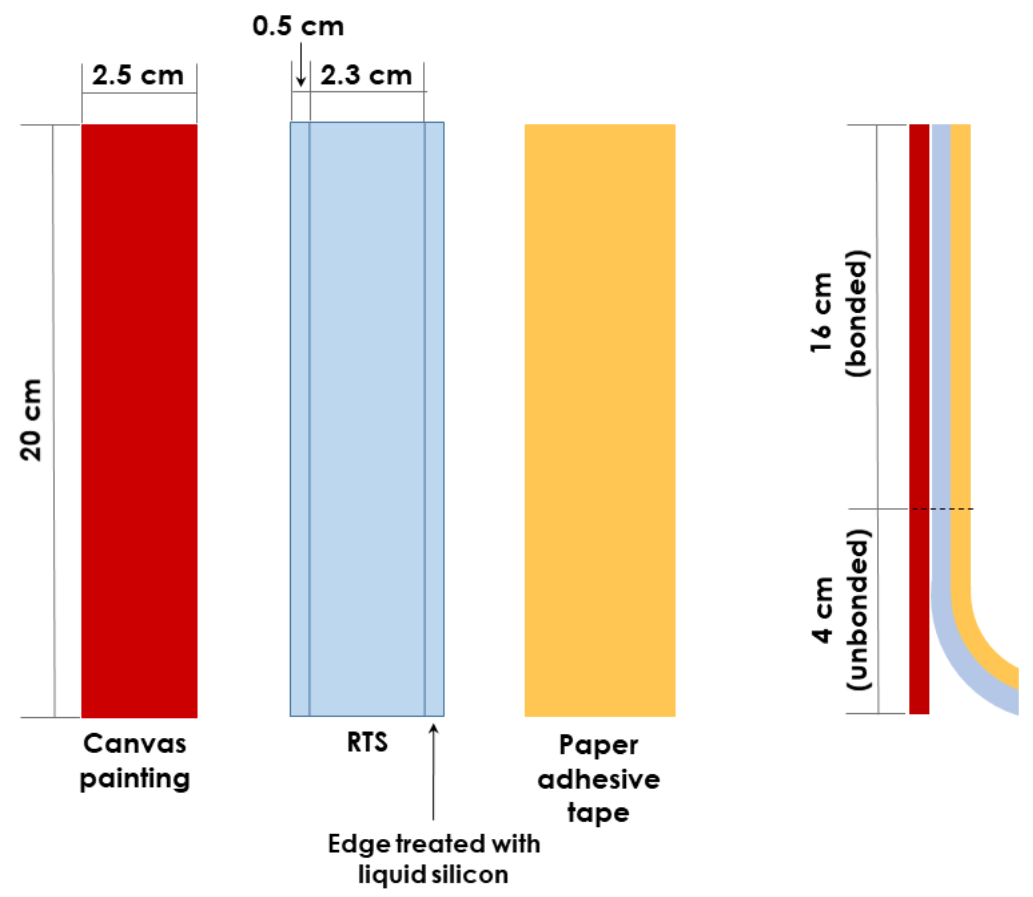

Figure 5.5.3. Schematic representation of the peel test specimens and changes introduced for specific needs.

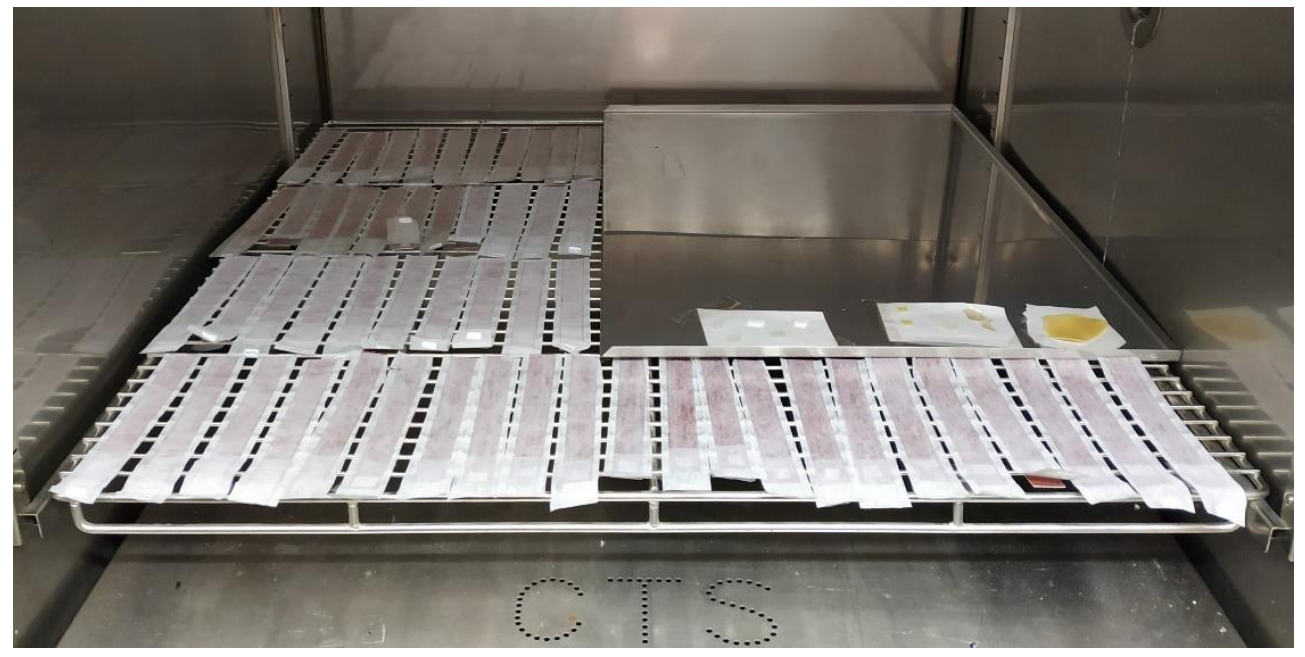

Figure 5.5.4. Specimens stored in the climate chamber at $23 \pm 1{ }^{\circ} \mathrm{C}$ and $80 \pm 5 \%$ $\mathrm{RH}$ for a minimum of $72 \mathrm{~h}$. 


\subsubsection{Results and discussion}

For each individual specimen, maximum, minimum and average peeling load were recorded and subsequently the average values for each combination of materials were calculated. After the test, the type of failure of each specimen was observed and recorded.

The reported values refer to a steady-state peel of $130 \mathrm{~mm}(50-180 \mathrm{~mm})$. In the case of the specimens faced with the RTS prepared with K(3)A(4)E and TNT positioned in the transversal direction (stored at $80 \% \mathrm{RH}$ ), it was necessary to take these values from the range of steady-state peel between 20 and $50 \mathrm{~mm}$. In fact, the adhesion of the RTS to the substrate was too high and the TNT broke before finishing the test.

Results are summarised in Table 5.5.1, where maximum, minimum and average peeling force of each class of tested mock-ups are listed. Fig. 5.5.6. shows the average load required to pull apart each class of RTS.

In general, a higher adhesive bond strength for the remoistenable tissue prepared with the TNT was recorded. Furthermore, for almost all the tested RTS, the peel strength is higher in the transversal direction than in the longitudinal one. This is probably due to the high deformability of the adgesuve, and of the tissue in this direction, which was already proven by tensile tests. It is also likely that the adhesive strength experienced is higher because of the higher surface contact of the tissue with the paint layer in this fibre direction.
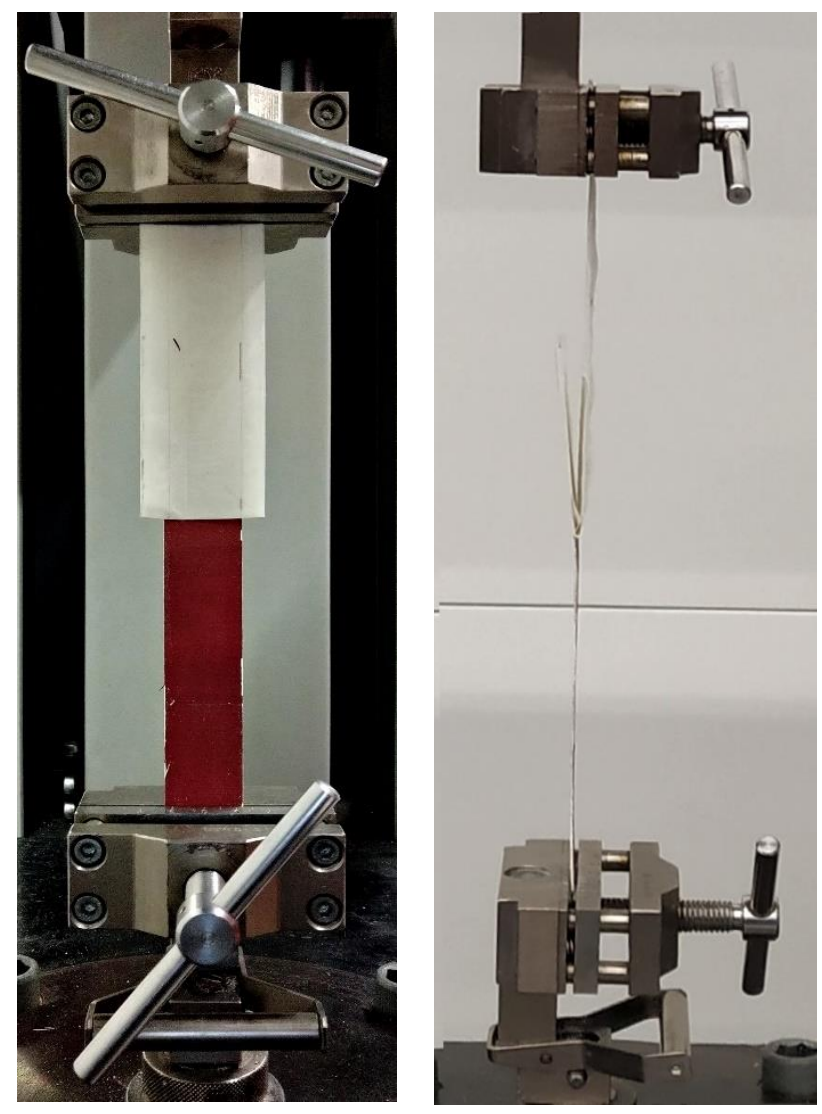

Figure 5.5.5. Peel test of a specimen faced with RTS of T(3)P7 and English tissue. 

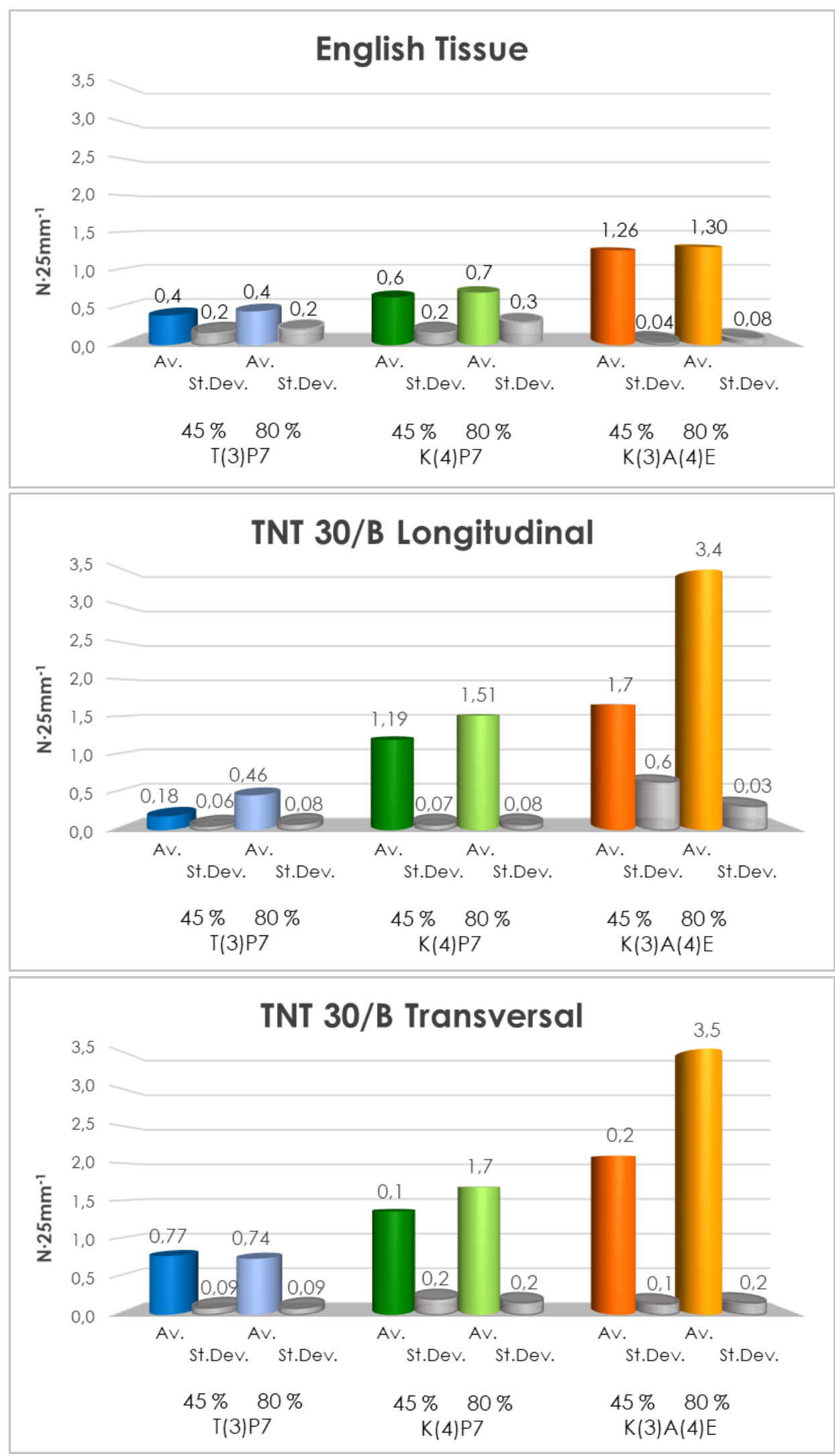

Figure 5.5.6. Results of the average peel force needed to separate the RTS from the painting mock-ups. 
Table 5.5.1. Results of the peel test.

\begin{tabular}{|c|c|c|c|c|c|c|c|c|c|c|c|c|c|}
\hline \multicolumn{14}{|c|}{ ENGLISH TISSUE } \\
\hline & \multicolumn{6}{|c|}{$45 \% R H-23^{\circ} \mathrm{C}$} & \multicolumn{6}{|c|}{$80 \% R H-23^{\circ} \mathrm{C}$} & \multirow{4}{*}{$\begin{array}{c}\text { Diff } F_{a v} \\
45-80 \% \text { RH }\end{array}$} \\
\hline & \multicolumn{2}{|c|}{$F_{\max }$} & \multicolumn{2}{|c|}{$F_{\min }$} & \multicolumn{2}{|c|}{$F_{\mathrm{av}}$} & \multicolumn{2}{|c|}{$F_{\max }$} & \multicolumn{2}{|c|}{$\mathbf{F}_{\min }$} & \multicolumn{2}{|c|}{$F_{a v}$} & \\
\hline & Av. & St.Dev. & Av. & St.Dev. & Av. & St.Dev. & Av. & St.Dev. & Av. & St.Dev. & & St.Dev. & \\
\hline & \multicolumn{2}{|c|}{$\left(\mathrm{N} \cdot 25 \mathrm{~mm}^{-1}\right)$} & \multicolumn{2}{|c|}{$\left(\mathrm{N} \cdot 25 \mathrm{~mm}^{-1}\right)$} & \multicolumn{2}{|c|}{$\left(\mathrm{N} \cdot 25 \mathrm{~mm}^{-1}\right)$} & \multicolumn{2}{|c|}{$\left(\mathrm{N} \cdot 25 \mathrm{~mm}^{-1}\right)$} & \multicolumn{2}{|c|}{$\left(\mathrm{N} \cdot 25 \mathrm{~mm}^{-1}\right)$} & \multicolumn{2}{|c|}{$\left(\mathrm{N} \cdot 25 \mathrm{~mm}^{-1}\right)$} & \\
\hline $\mathrm{T}(3) \mathrm{P7}$ & 1,2 & 0,4 & 0,12 & 0,06 & 0,4 & 0,2 & 1,2 & 0,4 & 0,14 & 0,09 & 0,4 & 0,2 & 0,1 \\
\hline$K(4) P 7$ & 1,6 & 0,2 & 0,17 & 0,05 & 0,6 & 0,2 & 1,6 & 0,4 & 0,3 & 0,1 & 0,7 & 0,3 & 0,1 \\
\hline $\mathrm{K}(3) \mathrm{A}(4) \mathrm{E}$ & 2,5 & 0,4 & 0,219 & 0,003 & 1,26 & 0,04 & 2,3 & 0,6 & 0,7 & 0,2 & 1,30 & 0,08 & 0,04 \\
\hline
\end{tabular}

\section{TNT TISSUE (LONGITUDINAL FIBRES)}

\begin{tabular}{|c|c|c|c|c|c|c|c|c|c|c|c|c|c|}
\hline & \multicolumn{6}{|c|}{$45 \% R H-23^{\circ} \mathrm{C}$} & \multicolumn{6}{|c|}{$80 \% R H-23^{\circ} \mathrm{C}$} & \multirow{4}{*}{$\begin{array}{c}\text { Diff } F_{\mathrm{av}} \\
45-80 \% \text { RH }\end{array}$} \\
\hline & \multicolumn{2}{|c|}{$F_{\max }$} & \multicolumn{2}{|c|}{$F_{\min }$} & \multicolumn{2}{|c|}{$F_{a v}$} & \multicolumn{2}{|c|}{$F_{\max }$} & \multicolumn{2}{|c|}{$F_{\min }$} & \multicolumn{2}{|c|}{$F_{\mathrm{av}}$} & \\
\hline & Av. & St.Dev. & Av. & St.Dev. & Av. & St.Dev. & Av. & St.Dev. & Av. & St.Dev. & Av. & St.Dev. & \\
\hline & \multicolumn{2}{|c|}{$\left(\mathrm{N} \cdot 25 \mathrm{~mm}^{-1}\right)$} & \multicolumn{2}{|c|}{$\left(\mathrm{N} \cdot 25 \mathrm{~mm}^{-1}\right)$} & \multicolumn{2}{|c|}{$\left(\mathrm{N} \cdot 25 \mathrm{~mm}^{-1}\right)$} & \multicolumn{2}{|c|}{$\left(\mathrm{N} \cdot 25 \mathrm{~mm}^{-1}\right)$} & \multicolumn{2}{|c|}{$\left(\mathrm{N} \cdot 25 \mathrm{~mm}^{-1}\right)$} & \multicolumn{2}{|c|}{$\left(\mathrm{N} \cdot 25 \mathrm{~mm}^{-1}\right)$} & \\
\hline $\mathrm{T}(3) \mathrm{P7}$ & 0,6 & 0,3 & 0,07 & 0,04 & 0,18 & 0,06 & 1,4 & 0,2 & 0,12 & 0,03 & 0,46 & 0,08 & 0,28 \\
\hline K(4)P7 & 2,50 & 0,07 & 0,5 & 0,2 & 1,19 & 0,07 & 2,8 & 0,1 & 0,73 & 0,06 & 1,51 & 0,08 & 0,32 \\
\hline$K(3) A(4) E$ & 3,1 & 0,8 & 0,8 & 0,4 & 1,7 & 0,6 & 4,6 & 0,3 & 2,27 & 0,33 & 3,4 & 0,3 & 1,8 \\
\hline
\end{tabular}

TNT TISSUE (TRANSVERSAL FIBRES)

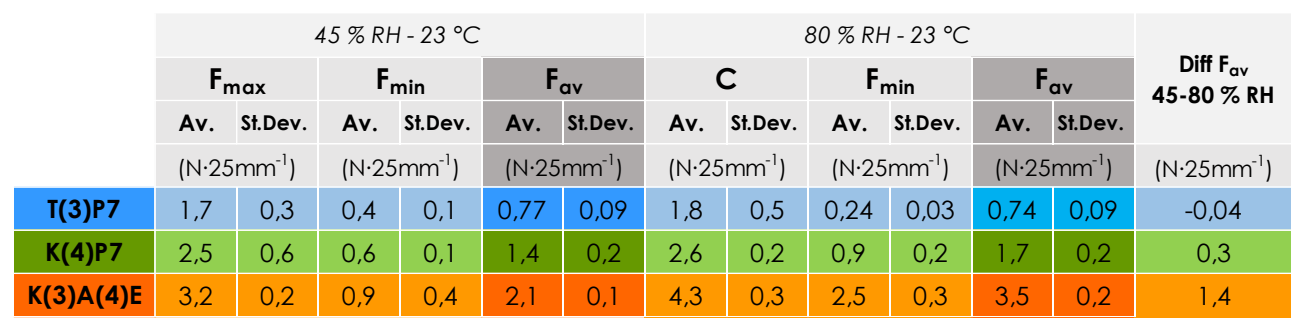

\subsubsection{Peeling at $45 \% \mathrm{RH}$}

As shown in above mentioned table and graph, RTS embedded with T(3)P7 (Fig. 5.5.7-8) were found to be the ones with the lowest peel strength, both for remoistenable tissues of English tissue and of TNT tissue. In general, the data reported for these mock-ups were not enough precise, considering the high values recorded for the standard deviation. However, they give an impression of the mechanical behaviour of this kind of remoistenable tissue. Remoistenable tissues of T(3)P7 prepared with English tissue showed an average force of $0.4 \pm 0.4 \mathrm{~N} \cdot 25 \mathrm{~mm}^{-1}$. The ones prepared with TNT showed an even lower average force of $0.18 \pm 0.06 \mathrm{~N} \cdot 25 \mathrm{~mm}^{-1}$ in the longitudinal 
direction, while in the transversal direction it was higher $10.77 \pm 0.09 \mathrm{~N} \cdot 25 \mathrm{~mm}^{-}$ $1)$. The visual observation of the specimens after the peel test revealed that the failure of the adhesive joint was positioned almost entirely at the interface between the RTS and the substrate.

Remoistenable tissues prepared with K(4)P7 (Fig. 5.5.9-10) showed intermediate values among the selected adhesive dispersions. However, RTS prepared with English tissues had a quite low average peeling load of $0.6 \pm$ $0.2 \mathrm{~N} \cdot 25 \mathrm{~mm}^{-1}$. Also in this case, the standard deviation was high compared to the recorded force, but it gives an idea of the adhesive strength and mechanical performance of this kind of remoistenable tissue. As for the T(3)P7 RTS, the failure of the joint was at the interface with the substrate.

Results recorded for remoistenable tissues of K(4)P7 and TNT revealed an appreciably higher average strength of $1.19 \pm 0.07 \mathrm{~N} \cdot 25 \mathrm{~mm}^{-1}$ in the longitudinal direction, and of $1.4 \pm 0.2 \mathrm{~N} \cdot 25 \mathrm{~mm}^{-1}$ in the transversal one. In this case, the difference in the forces recorded for the two fibre directions was not too high if it is taken into account that the average value in longitudinal direction has an elevated level of dispersion as indicated by the high 0.2 value of standard deviation. The adhesive failure was situated mainly at the interface with the paint-specimen, even if some residues of adhesive were visible on its surface. The temporary support of one of the samples faced with RTS of TNT in the transversal direction broke at the end of the overlap.

Remoistenable tissues of K(3) A(4)E (Fig. 5.5.11-12) revealed to be the ones with the higher values of peel force. In the case of the RTS prepared with English tissue, the average strength was of $1.3 \pm 0.2 \mathrm{~N} \cdot 25 \mathrm{~mm}^{-1}$. The value of the average peel force increased in the case of RTS prepared with TNT tissue. In fact, the peel force in the longitudinal direction was of $1.7 \pm 0.6 \mathrm{~N} \cdot 25 \mathrm{~mm}^{-}$ 1 , while in the transversal direction it was of $2.1 \pm 0.12 \mathrm{~N} \cdot 25 \mathrm{~mm}^{-1}$. Nevertheless these considerations must be taken cautiously due to the high values of standard deviation reported for this series of specimens. The observation of the samples after the peel test revealed the presence of residues of adhesive on the surface. In the case of some mock-ups faced with RTS of English tissue, the temporary support broke at the end of the test. Instead, in the case of mock-ups faced with TNT tissue, there were residues of some fibres of the temporary support that revealed the cohesive rupture of the TNT. 

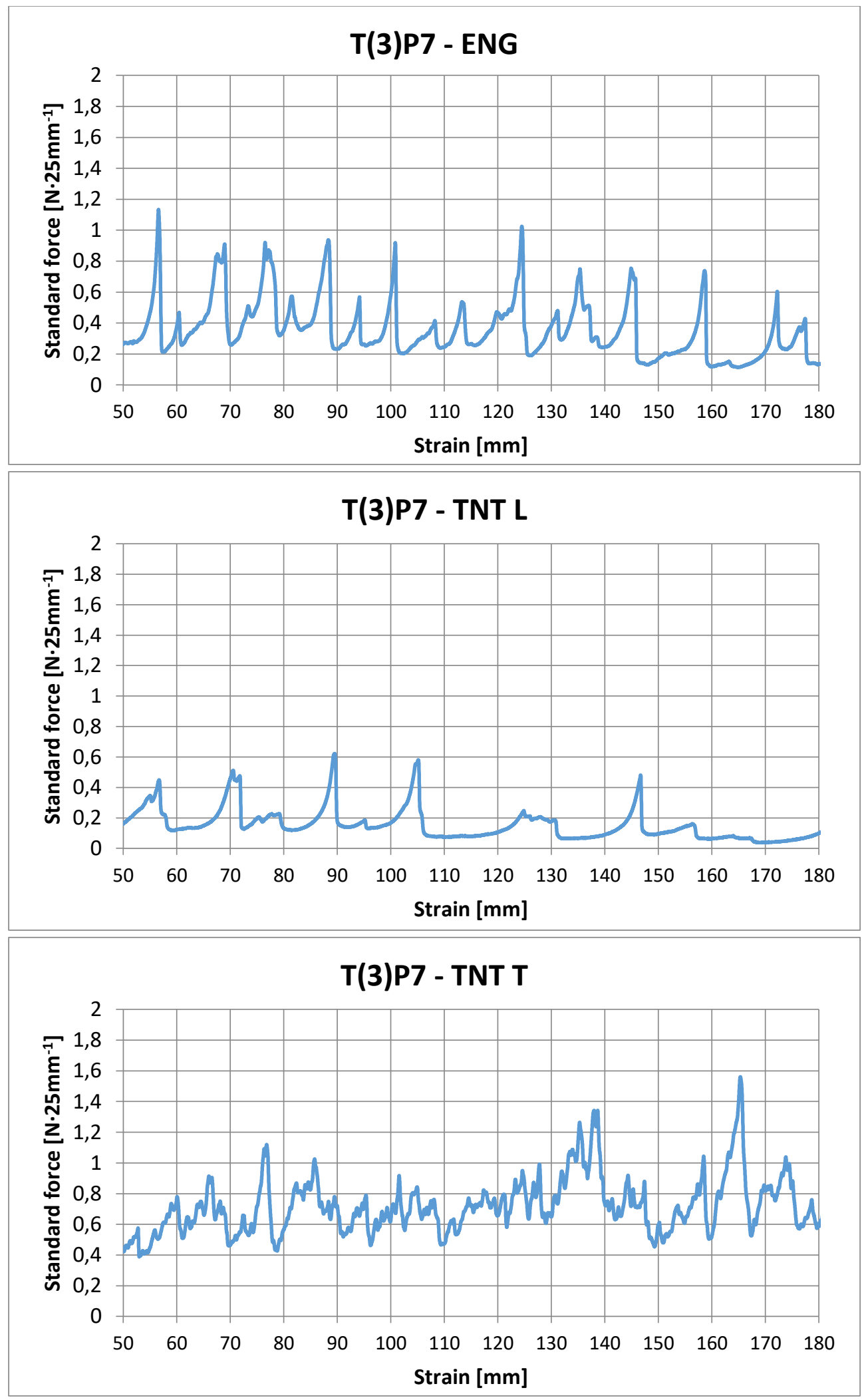

Figure 5.5.7. Typical stress-strain graphs of the peel test made on RTS prepared with T(3)P7 and stored at $45 \% \mathrm{RH}$. 

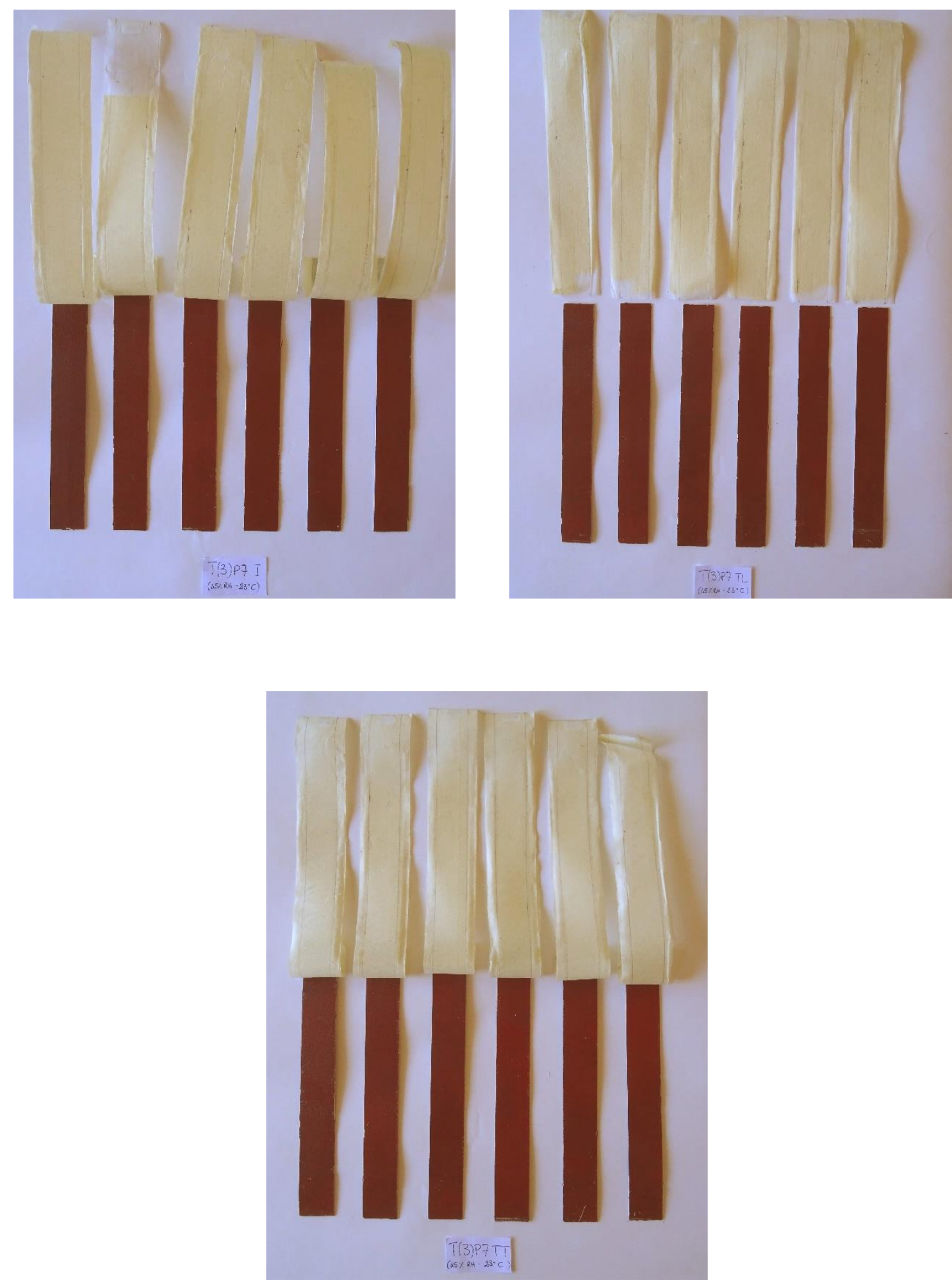

Fig. 5.5.8. Specimens faced with RTS of T(3)P7 and stored at $45 \%$ RH after the RTS (white strips) were peeled apart from the paint-mock-ups (red strips). 

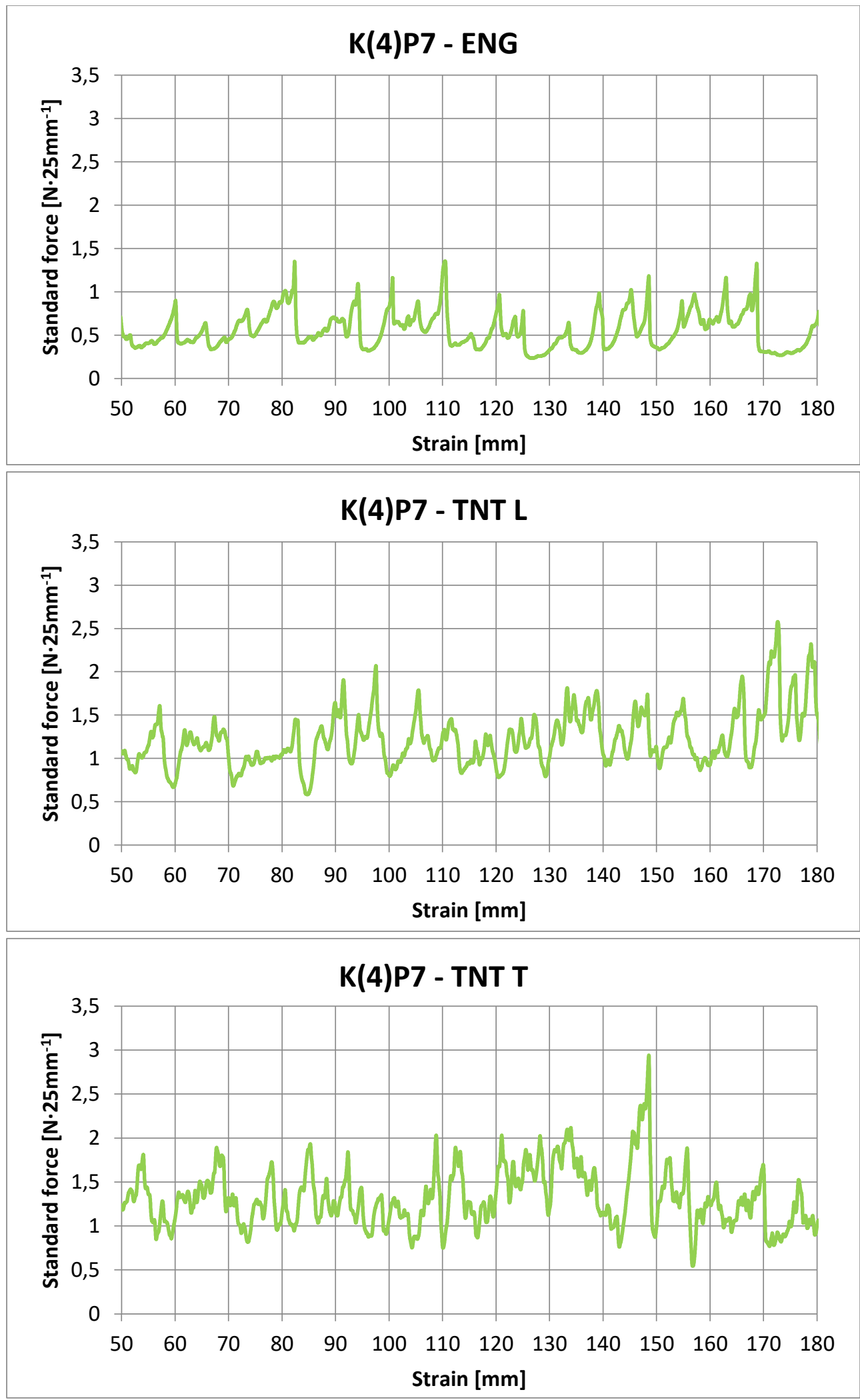

Figure 5.5.9. Typical stress-strain graphs of the peel test made on RTS prepared with K(4)P7 and stored at $45 \% \mathrm{RH}$. 

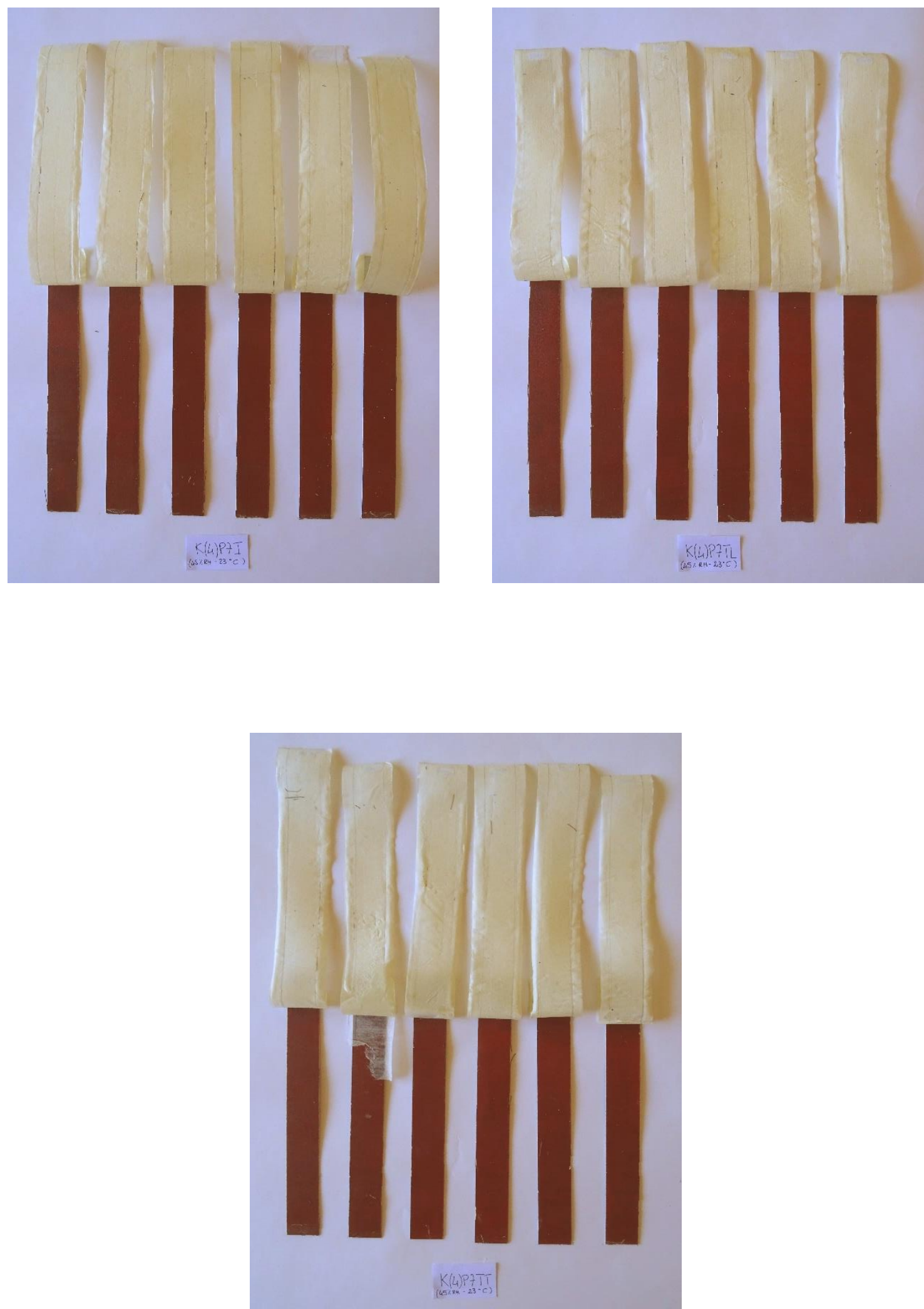

Fig. 5.5.10. Specimens faced with RTS of K(4)P7 and stored at $45 \%$ RH after the RTS (white strips) were peeled apart from the paint-mock-ups (red strips). 

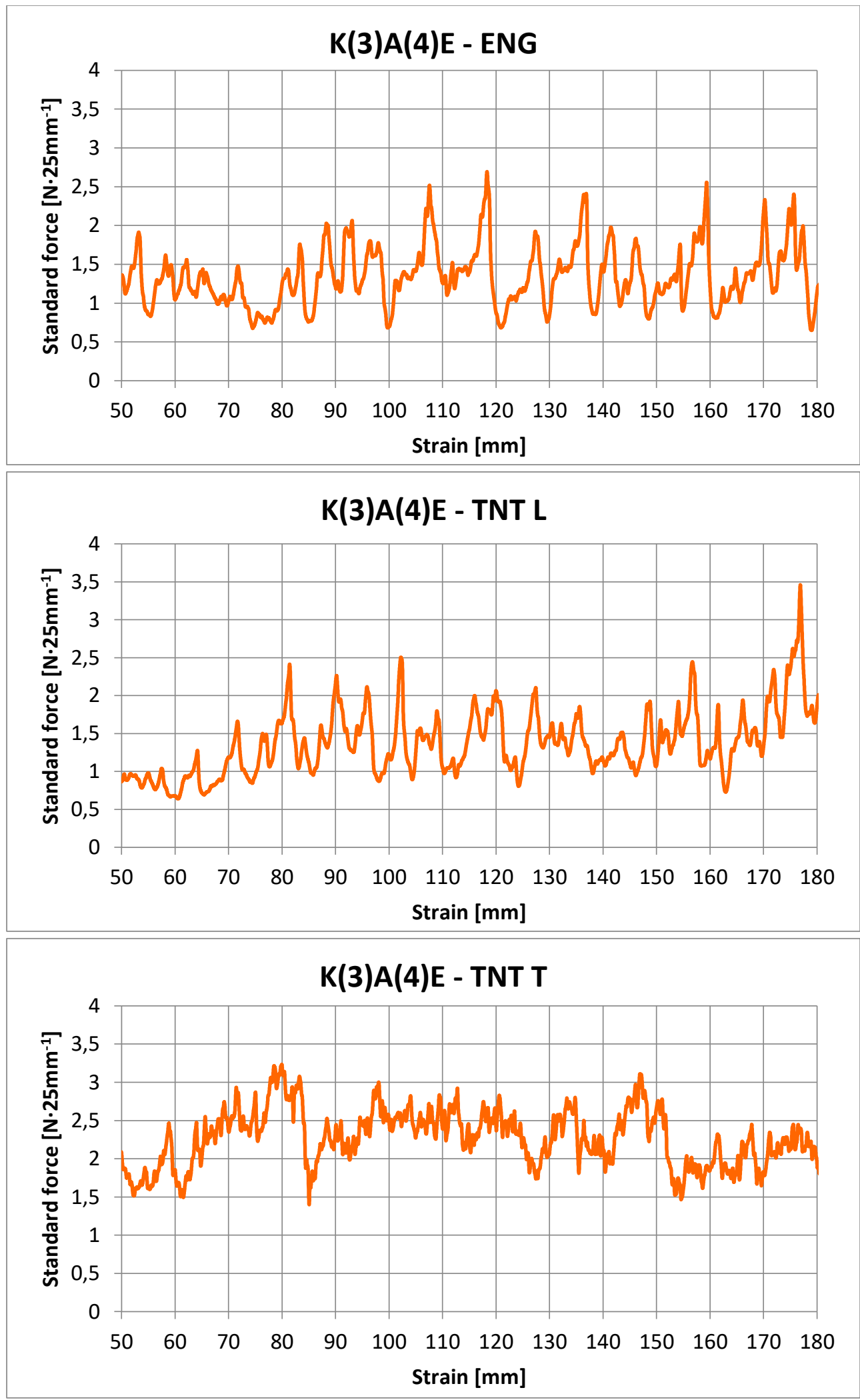

Figure 5.5.11. Typical stress-strain graphs of the peel test made on RTS prepared with $\mathrm{K}(3) \mathrm{A}(4) \mathrm{E}$ and stored at $45 \% \mathrm{RH}$. 

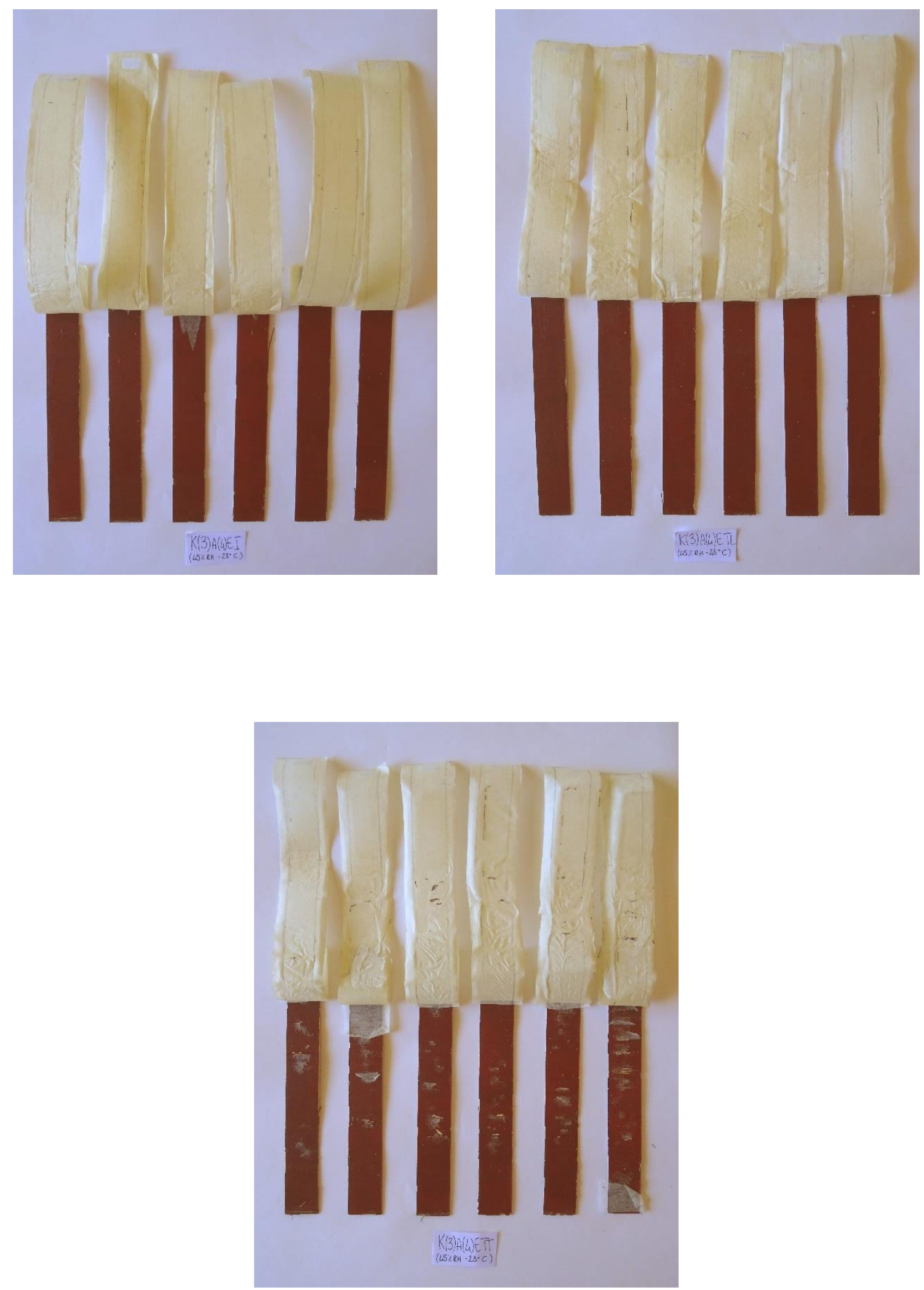

Figure 5.5.12. Specimens faced with RTS of K(3)A(4)E and stored at $45 \%$ RH after the RTS (white strips) were peeled apart from the paint-mock-ups (red strips). 


\subsubsection{Peeling at $80 \% \mathrm{RH}$}

The aim ofthis part of the test was to understand the variation in the adhesive strength of tested remoistenable tissues in unfavourable conservation environment. In fact, the thermo-hygrometrical changes affect dimensional properties, stiffness and mechanical performance of restoration materials. It is known that high levels of relative humidity are the most dangerous for a painting. Nevertheless, too many times faced paintings are left in spaces with uncontrolled climate conditions. For this reason, it was decided to test the adhesion of the tested specimens also at high levels of RH. This would have also permitted to ensure the good adhesion of RTS on a painting also during other restoration treatments that imply the use of moisture.

Contrary to the initial assumptions, the values of adhesive strength measured for all the mock-ups stored in the climate chamber at $80 \% \mathrm{RH}$ were higher than the ones recorded for the specimens stored at $45 \% \mathrm{RH}$. In fact, it was thought that the permanence of the faced mock-ups in a highhumidity environment would have reduced the strength of the adhesive joint. The obtained results were therefore unexpected. It is thought that the increase in the adhesive force could be explained by different factors. In fact, it is plausible to assume that the stay in a moist environment led the adhesive to a more plastic state. In this way, adhesive obtained a higher plasticity and as a result, the stresses during testing decreased, thus changing the apparent mechanical properties of RTS materials. In fact, the increase in the recorded force could be very well due to an increase of the elastic properties of the adhesives and the temporary supports.

The changes on the adhesive bond strength are very little for RTS prepared with English tissue, while they are clearly appreciable for RTS prepared with TNT tissue, especially for the ones embedded with K(3)A(4)E.

The adhesive peel strength of the remoistenable tissues prepared with T(3)P7 (Fig. 5.5.113-14) remained quite low. The average peel force recorded for RTS of English tissue was of $0.4 \pm 0.2 \mathrm{~N} \cdot 25 \mathrm{~mm}^{-1}$ at $80 \% \mathrm{RH}$. Difference of this value with that obtained at $45 \% \mathrm{RH}$ is difficult to establish due to the higher uncertainty of these measurements as indicated by the high standard deviation of 0.2 reported for both measurements. Difference with $\mathrm{RH}$ was observed for the RTS prepared with TNT tissue, where the average peel strength measured in the longitudinal direction was of $0.46 \pm 0.0,08 \mathrm{~N} \cdot 25 \mathrm{~mm}^{-}$ 1 , with an increase of $0.28 \mathrm{~N} \cdot 25 \mathrm{~mm}^{-1}$. In the transversal direction, the peel force remained quite unchanged $\left(-0,04 \mathrm{~N} \cdot 25 \mathrm{~mm}^{-1}\right)$, passing from the $0.77 \pm$ $0.09 \mathrm{~N} \cdot 25 \mathrm{~mm}^{-1}$ of the specimens stored at $45 \% \mathrm{RH}$ to the $0.74 \pm 0.09 \mathrm{~N} \cdot 25 \mathrm{~mm}^{-}$ 1 of the ones stored at $80 \% \mathrm{RH}$. Anyway, the variation in the peel force recorded for RTS of T(3)P7 were very small and the standard deviation 
recorded was comparatively high, which makes these values purely indicative. As for the observation of the corresponding specimens stored at $45 \% \mathrm{RH}$, an adhesive rupture at the interface with the paint layer was noted.

The average peel force of RTS of K(4)P7 and English tissue remained almost unchanged $\left(0.7 \pm 0.3 \mathrm{~N} \cdot 25 \mathrm{~mm}^{-1}\right)$, with a difference of $0.1 \mathrm{~N} \cdot 25 \mathrm{~mm}^{-1}$. However, also in this case the results were not precise enough. On the contrary, to the case of TNT tissue, the change in the peel strength for the longitudinal direction was evident. The recorded average peeling force was of $1.51 \pm$ $0.08 \mathrm{~N} \cdot 25 \mathrm{~mm}^{-1}$, with a difference of $0.32 \mathrm{~N} \cdot 25 \mathrm{~mm}^{-1}$. In the transversal direction, average peeling force $\left(1.7 \pm 0.2 \mathrm{~N} \cdot 25 \mathrm{~mm}^{-1}\right)$ increased equally of $0.3 \mathrm{~N} \cdot 25 \mathrm{~mm}^{-1}$. The visual inspection after the peel test revealed the presence of some residues of adhesive on the surface of all the specimens. In the case of mock-ups faced with remoistenable tissues of TNT tissue and pulled in the transversal direction, also some residues of TNT fibres were found (Fig. 5.5.15-16).

As mentioned before, the most evident changes in the peel force were recorded for the RTS prepared with K(3)A(4)E (Fig. 5.5.17-18). While for RTS of English tissue the increase in the peel strength $\left(1.30 \pm 0.08 \mathrm{~N} \cdot 25 \mathrm{~mm}^{-1}\right)$ was of only $0.04 \mathrm{~N} \cdot 25 \mathrm{~mm}^{-1}$, in the case of RTS prepared with TNT the change was undeniable. The recorded average load was of $3.4 \pm 0.3 \mathrm{~N} \cdot 25 \mathrm{~mm}^{-1}$ for the longitudinal direction and of $3.5 \pm 0.2 \mathrm{~N} \cdot 25 \mathrm{~mm}^{-1}$ for the transversal direction, with a change that was respectively of $1.8 \mathrm{~N} \cdot 25 \mathrm{~mm}^{-1}$ and of $1.4 \mathrm{~N} \cdot 25 \mathrm{~mm}^{-1}$. However, it should be recalled that the specimens faced with TNT remoistenable tissues in the transversal direction the peel force was actually too strong to be calculated along all the length of the samples because the temporary support of all the mock-ups broke rapidly. It was tried also to use a stronger adhesive tape, the marine cloth tape, which is also moist resistant, but it was worthless. It was therefore necessary to calculate the peel force along the range between 20 and $50 \mathrm{~mm}$.

Examining the mock-ups faced with English tissue through visually observation, it seemed as if the rupture was almost at the interface with the paint layer, since no residues of adhesive were visible on the surface of the specimens. On the contrary, on the surface of the mock-ups faced with TNT in the longitudinal direction, several residues of TNT fibres were observed. Furthermore, the RTS of one mock-up broke at the end of the test, and some residues of paint layer were found on the remoistenable tissue of another specimen. As shown above, the adhesion of the RTS in the transversal direction was higher. This was proven by the presence of several residues of TNT fibres on the paint layer of the mock-ups before the ailure of the RTS. 

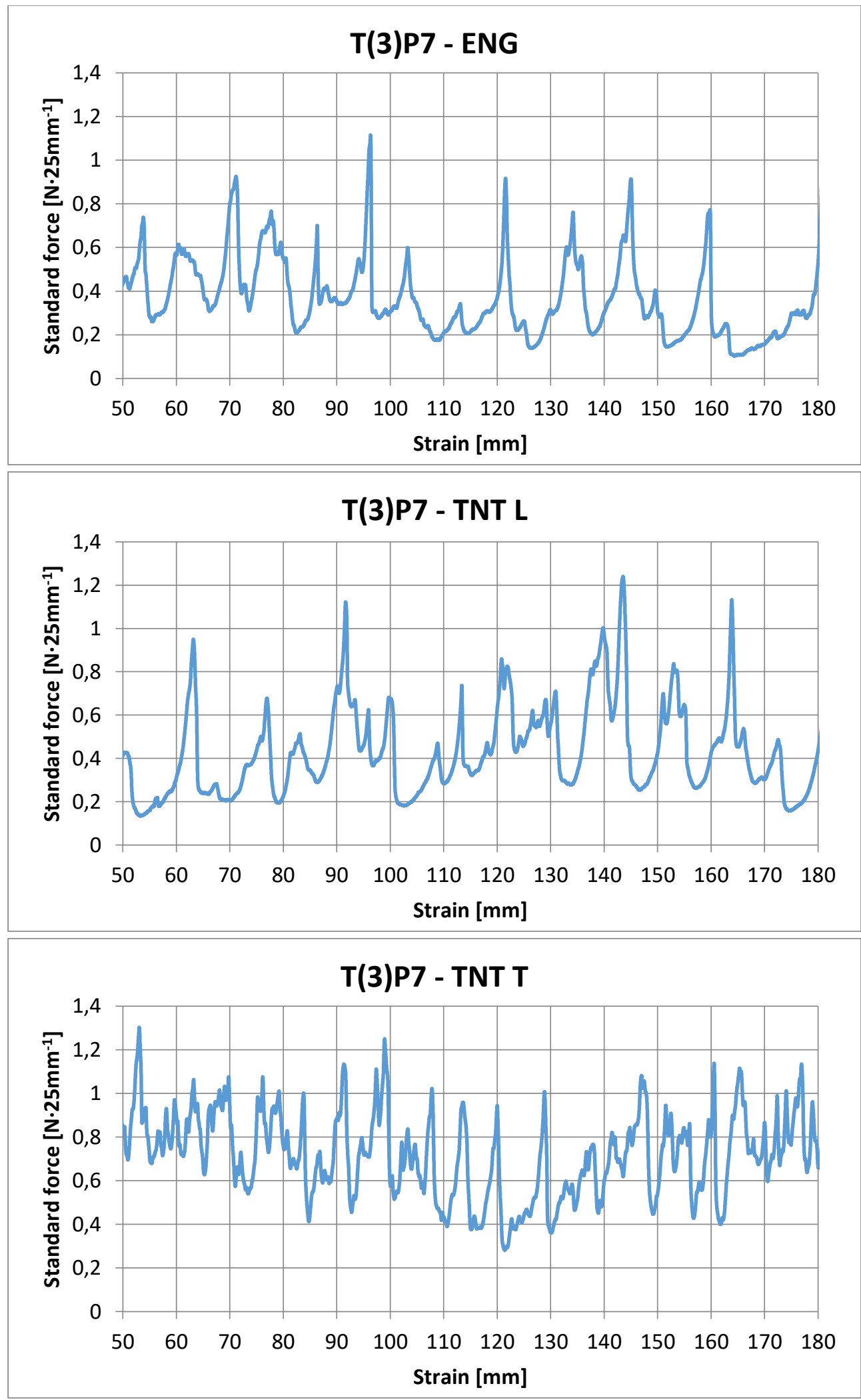

Figure 5.5.13. Typical stress-strain graphs of the peel test made on RTS prepared with T(3)P7 and stored at $80 \% \mathrm{RH}$. 

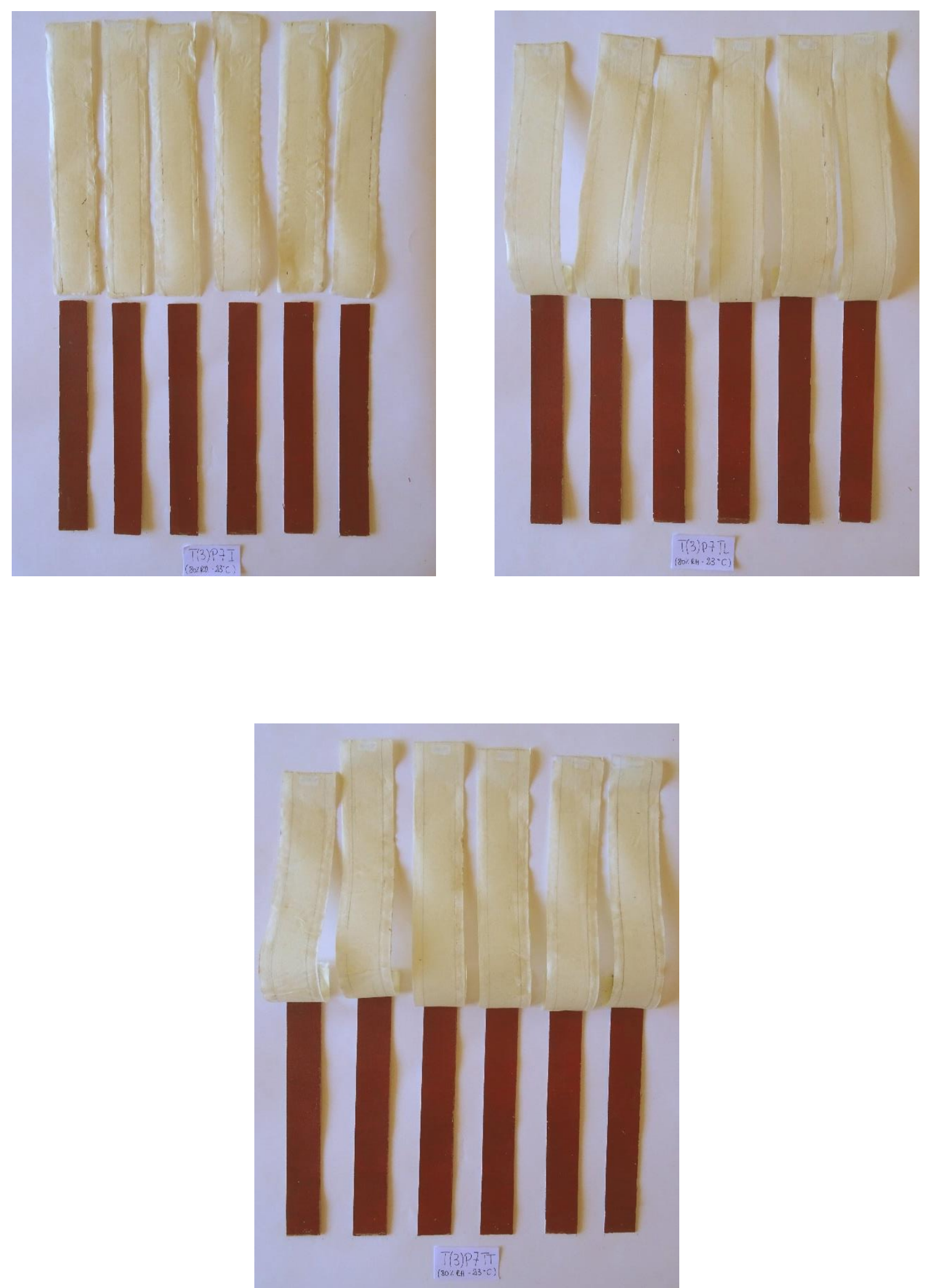

Fig. 5.5.14. Specimens faced with RTS of T(3)P7 and stored at $80 \%$ RH after the RTS (white strips) were peeled apart from the paint-mock-ups (red strips). 

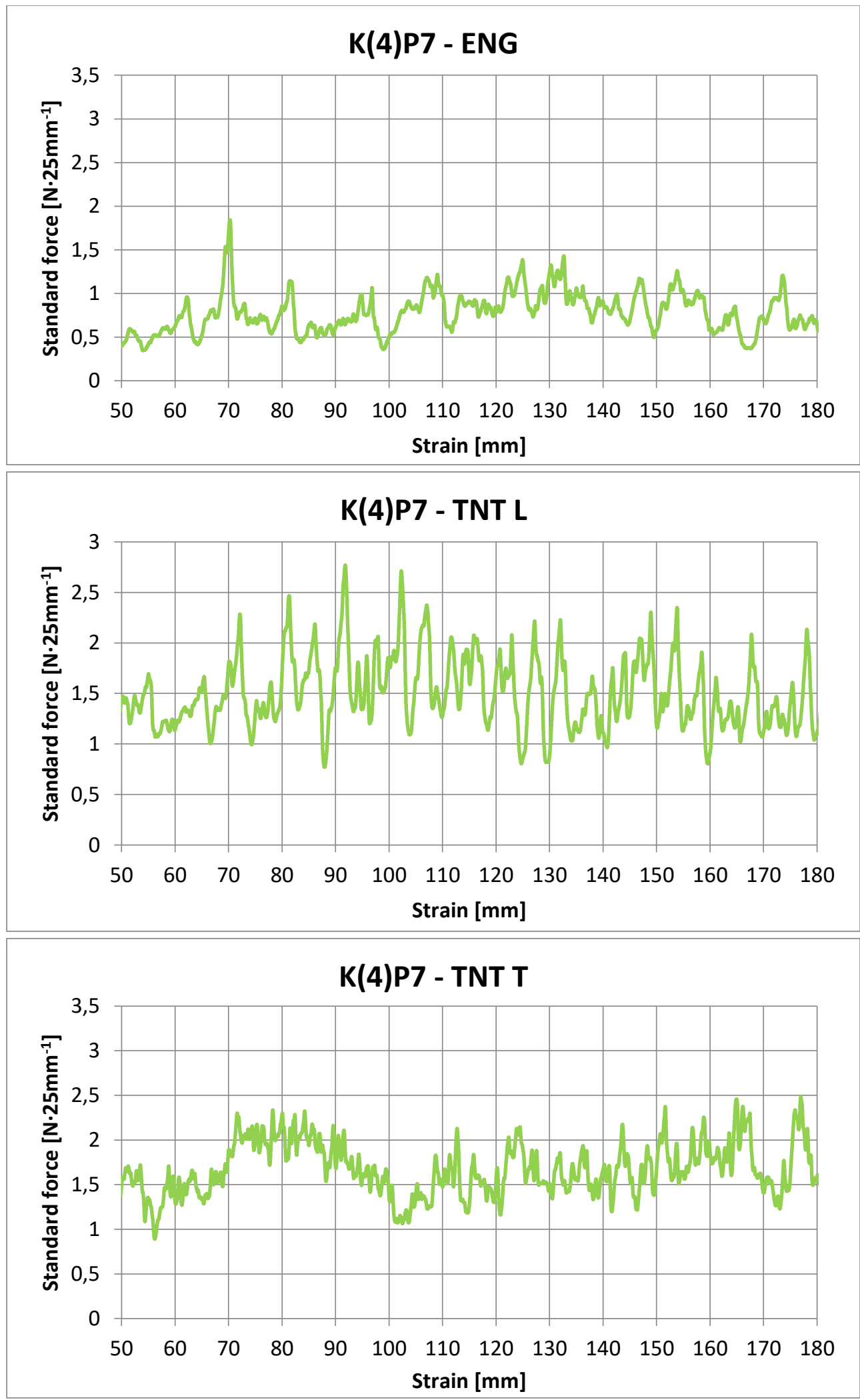

Figure 5.5.15. Typical stress-strain graphs of the peel test made on RTS prepared with K(4)P7 and stored at $80 \% \mathrm{RH}$. 

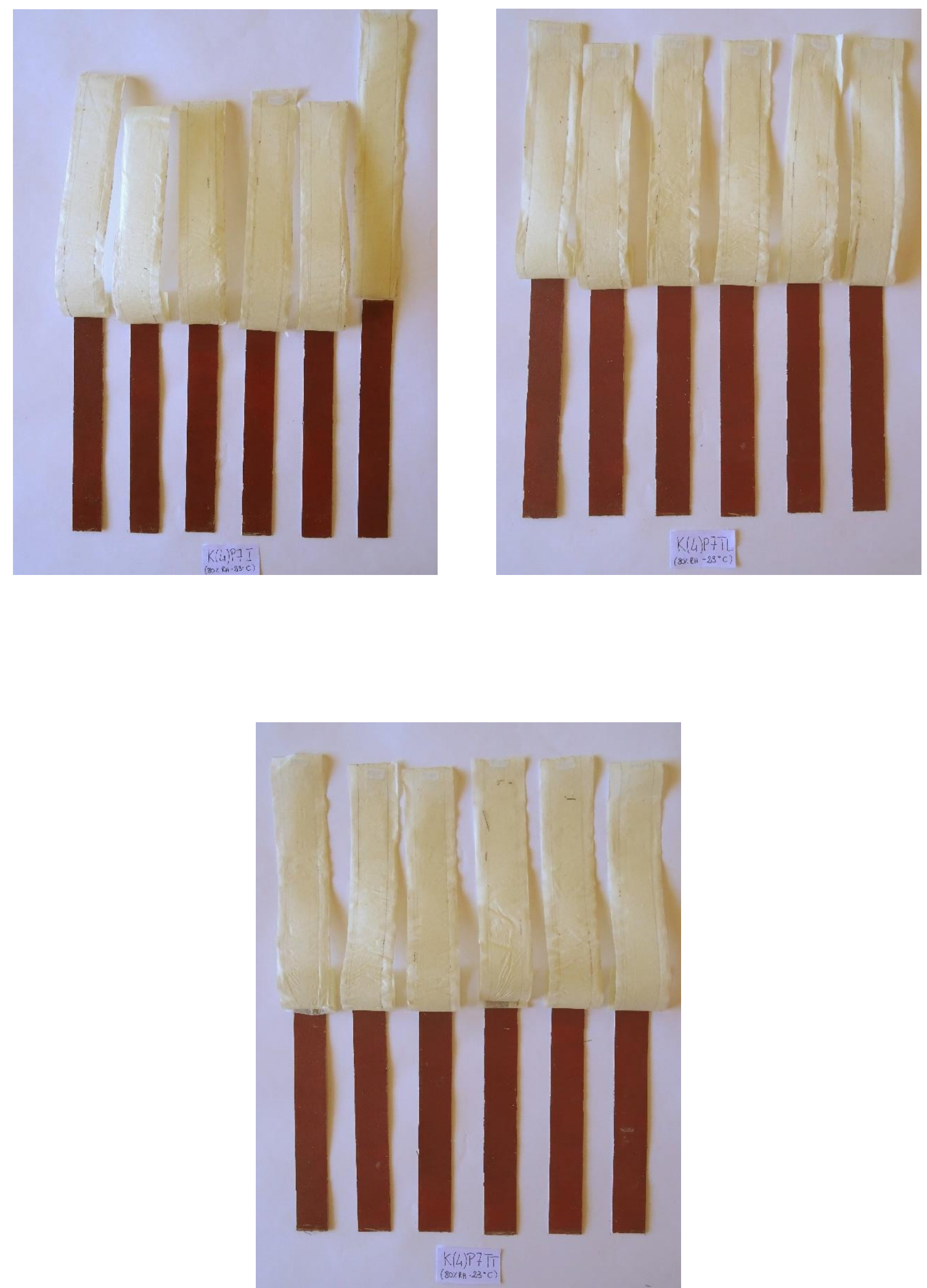

Figure 5.5.16. Specimens faced with RTS of K(4)P7 and stored at $80 \%$ RH after the RTS (white strips) were peeled apart from the paint-mock-ups (red strips). 


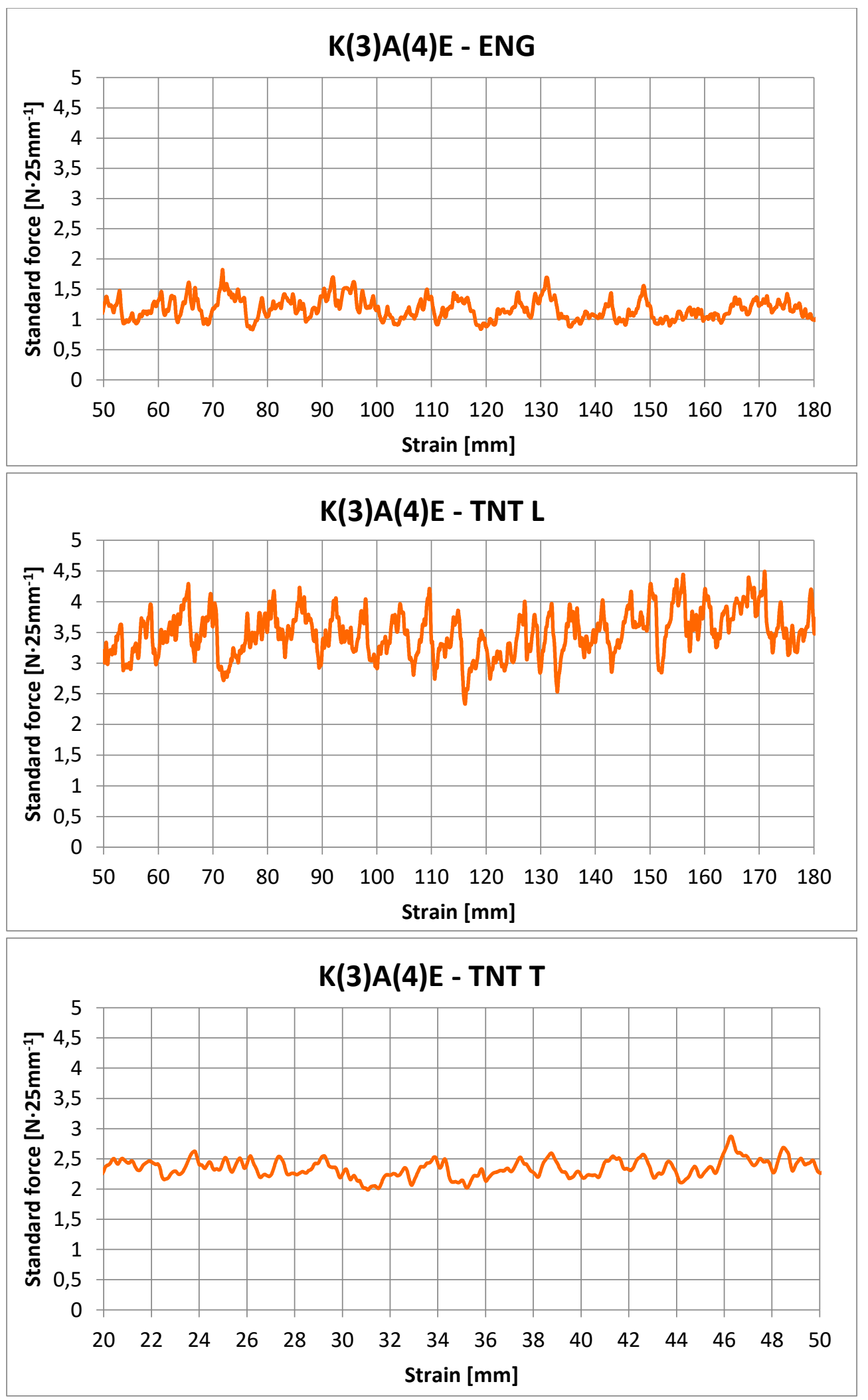

Figure 5.5.17. Typical stress-strain graphs of the peel test made on RTS prepared with $\mathrm{K}(3) \mathrm{A}(4) \mathrm{E}$ and stored at $80 \% \mathrm{RH}$. 

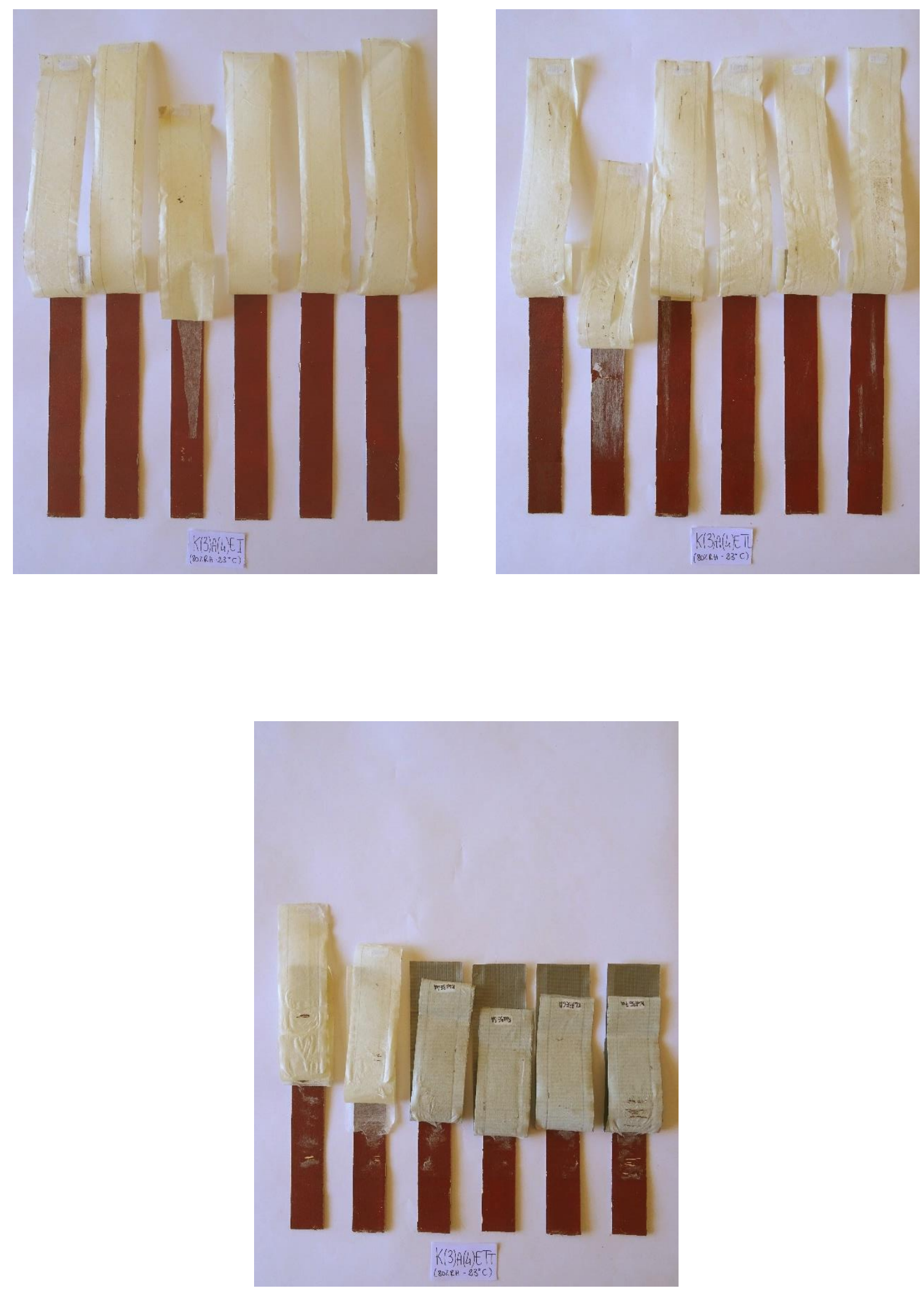

Figure 5.5.18. Specimens faced with RTS of K(3)A(4)E and stored at $80 \%$ RH after the RTS (white strips) were peeled apart from the paint-mockups (red strips). 


\subsubsection{Conclusions}

The determination of the adhesive strength of a facing is one of the most important requirements to determine the efficiency of selected remoistenable tissues. For this reason T-peel test was carried out which is the most indicative among the most common adhesion test. In fact, it permits a direct and quantitative measurement of the force needed to pull apart two bonded adherends.

For this part of the investigation, D1876 ASTM standard test was used as a guideline. Remoistenable temporary supports used to face the canvasspecimens were prepared with the previously selected combination of adhesive dispersions (T(3)P7, K(4)P7, K(3)A(4)E) and selected temporary supports (English tissue, TNT tissue). Peel tests were carried out on two different sets of mock-ups, previously conditioned at two different levels of Relative Humidity (45 and $80 \%$ $\mathrm{RH}$ ), in order to mimic the variation in the adhesive performance in unfavourable conservation environment, and during restoration treatments that include the use of moisture.

In general, the test performed revealed that the facings made with RTS of English tissue had a lower peel force than the one measured for RTS of TNT. Furthermore, the peel strength in the transversal direction of the TNT fibres was higher than that in the longitudinal one. In contrary to the common beliefs reported from different interviews with reputed conservators and restorers, the results revealed that the staying in a high humidity environment increase the peel strength. This growth is almost unappreciable in RTS of English tissues, while is distinctly noticeable in RTS made with TNT.

Regarding to the RTS prepared with the different adhesive dispersions, remoistenable temporary tissues of T(3)P7 showed a very low peel strength at $45 \% \mathrm{RH}$. The variations in the peel force recorded for the mock-ups stored at $80 \%$ RH were very small and the standard deviation recorded was comparatively high, which makes these values purely indicative. However, the results obtained for these kind of RTS demonstrated that the strength of remoistenable tissues of T(3)P7 cannot be considered be sufficient to guarantee a safe facing in any case.

RTS prepared with K(4)P7 exhibited an intermediate peel force among all the tested remoistenable tissues. In relation to RTS of English tissue, a quite low load was observed, and the increase in the strength of the mock-ups stored at $80 \%$ $\mathrm{RH}$ was not significant. IThus, it could be good for protective facings applied for the transportation of the painting or also small structural interventions that do not involve the use of high stresses. The strength of the RTS prepared with TNT tissue 
was higher.The mock-ups stored at $80 \% \mathrm{RH}$ showed the same increase of peel force in the two fibre directions. Therefore, this kind of RTS could be considered suitable for facing applied to protect the paint layer during structural interventions on the back of the paintings.

Remoistenable tissues prepared with K(3)A(4)E exhibited the highest values of peel strength. The average force of the specimens faced with RTS of English tissue showed suitable values for facing applied in view of structural interventions on the back of the painting. This strength remained almost unchanged for the mock-ups stored at $80 \%$ RH. RTS made with TNT presented a relevant peel load in the longitudinal direction, but even more in the transversal one. In this case, the permanence of the mock-ups in a high humidity environment led to a remarkable increase in the average peel force. This force is lower than that measured for facings prepared with rabbit skin glve or for Roman colletta in previous researches (Alba 2015) (for more information, see Chapter 3). This kind of RTS could be probably used when dangerous interventions on the back of the painting are projected or for big canvas paintings.

There has been discussions about the danger of faced painted surfaces exposed to high levels of $\mathrm{RH}$, thinking it can affect the adhesive strength of the facing. There are also contradictory ideas on the selection of restoration materials used in the subsequent operations during a restoration. For example, someone uses materials with similar solubility for facing and for lining (e.g.: traditional flour-paste linings), while other restorers strictly respect the concept of opposite polarity (e.g.: facing of Aquazol, lining of Plexisol). The latter, especially in the case of facing applied before the removing of residues of flour-paste on the back with the use of supported water solutions, recommend to use facing materials which are not soluble in water. These advices (Borgioli, Boschetti and Tortato 2016) are given also to avoid the detachment of the facing during the different interventions. What emerged in this research was therefore unexpected, and it could be worth to consider whether this strict indications should be followed, since in case of applying moisture (and not liquid water) the facing adhesion should not be affected.

With the available information, it is possible to assume that these changes are related both to the temporary support and to the adhesive dispersion. In fact, the increase in the peel force is clearly detectable only in the RTS prepared with TNT tissue and not in the ones prepared with English tissue. It is possible to suppose that the humidification of TNT leads to some change in its mechanical properties, making it more elastic and flexible, thus increasing the measured force.

The increase in the peel force is due also to the employed adhesive. It is conceivable that this factor is related to the affinity of the adhesive with moisture 
and water. The hydrated adhesive becomes more plastic and it adjust to the roughness of the surface of the painting, increasing the contact surface and consequently the adhesive bond strength. Its penetration in the substrate could also increase this phenomenon. Furthermore, the changes of the same mechanical properties could probably influence the measured peel load. This would explain the higher increase in the RTS of K(3)A(4)E, compared to the other two adhesive dispersions. In fact, the dispersion of $K(3) A(4) E$ is made by two polymers which are reactive to water. While the speed of solubilisation of Klucel is not too high, it is known that Aquazol is highly reactive to water. Instead, the other two adhesive dispersions are made by a cellulose ether (Klucel and Tylose) with intermediate reactivity and an acrylic polymer that is not too much responsive to water.

In this regard, it would be better to check the penetration of the adhesives in the substrate of specimens stored at different thermo-hygrometrical conditions. It would be very important to check this aspect, because it could invalidate the concepts of superficiality and reversibility required for this kind of facings. This means that the removability of the RTS should be verified after the permanence in unfavourable environmental conditions. It would also be worth to make further tensile tests at different thermo-hygrometrical conditions. This would permit to assess the changes in the mechanical properties of the different materials used. Some tests could be done to understand the connection between the response of the different materials to water and the increase/decrease in the adhesion.

Finally, in order to deepen the understanding of the adhesion of the selected remoistenable tissue, it would be useful to find an effective system to make shear tests, overcoming the technical problems related to the fragility of the temporary supports. 



\section{General conclusions and further developments}

The dual goal of this PhD was (1) to shed light on the limitations and complications regarding the application of facing, an operation which risks have always been underestimated, and (2) to open the way to other possibilities by providing restorers with a practical and real alternative, based on the use of the application system of the Remoistenable temporary supports.

The preliminary bibliographic study was fundamental to frame the topic and highlight the problems related to the common approach to facing. Facing has often been neglected, considered accessory to other structural interventions, thought as harmless because it is removed at the end of each intervention. In addition, it was often used as a wildcard, to protect or consolidate the paintings without wondering the effects and the conservative issues it could cause. Too little space has always been given to facing in written texts, both in indirect sources from the 18th century and manuals from the 19th century, as well as in texts published by the scientific community in recent decades. The rare written witnesses and the often elusive citations made it necessary to weigh silences and omissions, which certainly cannot give indications on materials and techniques, but represent a testimony of the importance attributed (or not) to this operation over time.

Despite these difficulties, in some cases it was possible to link different facings used over the centuries. For example, it was possible to understand the connection between the very first documented facings made with starch or flour paste of the $18^{\text {th }}$ century used in the Edwards' Venetian laboratory and those described by Forni and Secco-Suardo in the two main Italian handbooks of the $19^{\text {th }}$ century. Then again, with those adopted as 'traditional' facings at the two main Italian restoration institutes - the ISCR and the OPD - that are still the most widely used facings in the peninsula.

The bibliographic research brought knowledge of some thrilling episodes, in which the preparation and sensitivity of highly qualified restorers made it possible 
to make wise choices based on in-depth knowledge of conservation issues and the implications related to restoration interventions, thus saving entire collections of art in extreme emergency conditions. An example was the sensitivity shown by restorers of the Prado Museum to face only some of the paintings of the Prado collection which were subjected to a real exodus during the civil war (1936-39), traveling to different countries for three years before being brought back to Spain and finally subjugated by Franco's dictatorship. Another significant event was the 1966 flood in Florence, which required the collaboration of restorers from many countries and represented one of the first cases in which a synthetic adhesive (the new Paraloid B72 arrived from America) was used for the creation of emergency facings carried out on a large scale and strongly criticised by some. However, the bibliographic research also led to several bitter findings. In fact, neither the theoretical and technical review of conservation materials and methods nor the awareness of the importance of concepts, such as reversibility and minimal intervention started in the seventies where enough to involve the study of facing techniques. Recently, more and more conservators have started to re-think the process by designing facings with specific characteristics for the needs of the painting's surface. Unfortunately, only few reflections and experiences have been published in conservation journals and congress proceedings, so that the debate remains connected with oral tradition.

The bibliographic research was addressed to the understanding of the theoretical conception of facing over time, and to identify the ideological gaps to be filled. On the other hand, the study illustrated in the second chapter of the thesis allowed to give a more objective and limited form to the topic, starting from the analysis of the chemical-physical causes that lead to the degradation phenomena of canvas paintings that are usually treated with facing. The logical and orderly analysis of the characteristics of the materials and of the application methodologies used for facing allowed identifying clearly the mechanisms that occurs when facing is applied, the variables that influence its performance, as well as the risks and conservative issues deriving from this operation. In particular, it was possible to highlight the tricky distinction between protective facings and consolidating facings, which is only theoretical, since the adhesive's application by brush and the use of a low-viscosity adhesive do not allow having a superficial, temporary and removable protection in any case.

The whole preliminary study was of fundamental importance to acquire the knowledge to develop an innovative facing system safer than those usually used, providing a practical and concrete alternative to restorers. The long designing process of the remoistenable tissues allowed the selection of some combinations of adhesive mixtures and interim supports for the creation of remoistenable tissues. The research project was divided in two main phases. The first part tackled 
the chemical, physical and mechanical characterisation of the different classes of materials (adhesives and temporary supports) and their combination for the preparation of RTS. The second part concerned the verification of the suitability of the RTS for their application on oil canvas paintings and the compliance with those that had been identified as the fundamental characteristics to be achieved, namely poor residues, poor penetration and adequate adhesive strength.

Starting from the identification of the ideal characteristics to be achieved, 25 adhesive mixtures were selected combining in different ways and percentages a thickener (Klucel $G$, Tylose MH300) and a polymer with good adhesive properties (Plextol B500, Aquazol 500). Four supports (Japanese paper Bib. Tengujo 240, English Tissue, TNT 30/B, Holytex) were chosen. Empirical tests were carried out to obtain a clear and standardised application methodology, with the aim of improving its reproducibility in a univocal way. The aim was to provide other restorers with the tools to perform the operation using the adequate amount of adhesive for the preparation of the RTS and buffer solution to be applied on a reactivation cloth used for the for their reactivation .

In the first experimental stage, the moisture content, hardness, viscosity, and $\mathrm{pH}$ of the adhesive dispersions were tested. The mechanical characteristics were evaluated as well through tensile tests with a micro tester. According to the results, almost all the adhesive dispersions seemed safe for their use in the preparation of remoistenable tissues. Furthermore, no evident differences were found between the dispersions prepared with different percentages of the same polymers. Nevertheless, a selection was required to proceed with the experimentation. Therefore, it was decided to make a selection not prejudging the gathering of information, which could have become precious in the next steps of the investigation. For each type of adhesive mixture, it was selected the one with intermediate percentage of adhesive, according to the class of viscosity. These adhesives were then submitted to tensile testing, to assess their mechanical characteristics, and six of them were selected for the next step: T(3)P7, T(4)P7, K(4), K(4)P7, A(5)E, K(3)A(4)E.

However, the most conclusive results of this part of the research were probably related to the influence of the supports (often neglected) in the $\mathrm{pH}$ of remoistenable tissues, the absorbance as well the evaporation speed of the water used for the reactivation, the dimensional changes and on the mechanical properties of the resulting RTS. Even if the analyses carried out in this step did not allow to make a selection, they provided useful information for the characterisation of supports. The two cellulosic supports revealed similar results, which were considered as suitable for RTS facing. They presented similar 
contraction after drying (it was slightly bigger in the English tissue). Both papers revealed to have an almost neutral $\mathrm{pH}$, good absorption and intermediate values of evaporation speed. TNT tissues seemed to be suitable as well. Its strong contraction along the transversal direction of fibres was compensated by the low tensile strength along the same direction. Even if the support was a bit acidic, $\mathrm{pH}$ values of the corresponding remoistenable tissues were quite neutral, especially when reactivated with the buffer solution. The absorbance of the tissue was higher than that of the cellulosic tissues. Nevertheless, the results obtained in this step cast doubt about the suitability of Holytex as temporary support for RTS. In fact, the pH of this support associated with selected adhesives was strongly basic, even if it was controllable by using a buffer solution. This support showed very low dimensional changes and absorption rate. These factors could represent a clue of a poor adaptability of the support to the substrate, as well as a low affinity with the adhesives and the solvent, leading to a poor adhesion strength of the facing and to a higher penetration of the adhesive in the substrate. However, it was decided not to discard this tissue and to postpone the decision until after the next step of the investigation.

The second step of the investigation allowed determining the suitability of the selected RTS for their application on oil canvas painting, in terms of permanence of the residues, penetration of the adhesive in the substrate and adequate adhesive strength. For this purpose, a great attention was drawn to the design of the mock-ups that were used for all the analyses, according to the principles of uniformity and reproducibility. This choice was fundamental not only to facilitate the comparison among the different analyses, but also to display a hypothetical comparison with further researches.

The evaluation of the permanence of residues and the assessment of the possible modifications that can occur in the surface of a painting after the removal of a facing are two key issues. The observation with optical microscope in visible and UV light and with FESEM instrumentation allowed to evaluate the removal of residues on a huge number of cracked and not cracked mock-ups, due to the easy handling of the techniques and the reduced dimension required for the specimens. The adhesive dispersions selected for the next step of the investigation were T(3)P7, K(4)P7 and K(3)A(4)E. The RTS prepared with T(3)P7 left the lowest quantity of residues, although they were not easily removable with the subsequent cleaning of the surface with the buffer solution. On the contrary, RTS made with K(4)P7 and K(3) A(4)E left a higher amount of adhesive residues, but after the cleaning process almost all residues were efficiently removed. As temporary supports, TNT 30/B and English tissues were selected to carry out the investigation. In the majority of mock-ups faced with TNT few residues were found. The same goes for those faced with English tissue, in which case almost 
no traces of support fibres were found - unlike in the case of Japanese RTS thanks to the high wet-strength given by the amide type wet additive. The observation with microscope definitively confirmed the previous doubt regarding the unsuitability of Holytex as a good temporary support for the preparation of remoistenable tissues, due to the very high amount of adhesive residues left on the surface.

The assessment of the grade of penetration of the adhesives in the substrate of mock-ups was probably the most challenging step of the $\mathrm{PhD}$. When analysing a complex organic system such as the one tested (a mock-up composed by different layers of organic constitutive materials and faced with an organic adhesive mixtures), both a powerful analytical instrument and an effective analytical methodology were needed. For this reason, the observation with a high-resolution optical microscope was coupled with micro-Raman spectroscopy, which is a well-established technique for the molecular investigation of cultural heritage materials. The mock-ups cross-sections were previously observed with optical microscope to individuate the most critical regions where the adhesive could have penetrated, and then investigated through micro-Raman spectroscopic technique. Detailed spectra of the analysed portion of the cross-sections were obtained equipping the Raman apparatus with an Ultra-Low Frequency (ULF) module, which allows Raman spectroscopic information in the sub-100 $\mathrm{cm}^{-1}$ region, and increases the resolution of the spectra in the region between 100 and $600 \mathrm{~cm}^{-1}$. The Remoistenable Temporary Supports used for this step of the investigation were prepared with the previously selected combination of adhesive dispersions (T(3)P7, K(4)P7, K(3)A(4)E) and selected temporary supports (English tissue, TNT Tissue). In order to compare the penetration of the adhesive applied with the RTS method and with the traditional brush application, two sets of mock-ups were faced using K(4)P7 applied with a brush. The employed methodology revealed to be effective and allowed to verify the scarce penetration of adhesive with all the tested Remoistenable Temporary Support, since in the worst cases a minimal penetration was detected, limited to the edges of the most superficial part of the cracks of the mock-ups. On the other hand, the results obtained for mockups faced with the brush revealed a much higher penetration. In fact, in the mock-ups faced with K(4)P7 applied with brush, traces of adhesive dispersion were found in the deepest part of the analysed cracks, even filling the whole volume of the cracks in some cases. These results were significant for the aim of the $\mathrm{PhD}$, since they allowed to demonstrate the correctness of the previous hypotheses on the small penetration of the adhesive with the Remoistenable Temporary Support System. Furthermore, it was demonstrated that the use of the traditional application method by brush involves a higher penetration, even when a high viscosity adhesive is used. 
The determination of the adhesive peel strength was the final and decisive step for the assessment of the suitability of the selected RTS for their use as a facing of canvas paintings. For this part of the investigation, the ASTM D1876 standard test was used as a guideline. Peel tests were carried out on two different sets of mock-ups, previously conditioned at two different levels of Relative Humidity ( 45 and $80 \% \mathrm{RH}$ ), in order to assess the variation in the adhesive strength in unfavourable conservation environment, and during restoration treatments that include the use of moisture.

Results obtained from the peel test revealed the unsuitability of T(3)P7 as RTS adhesive, because of its very low peel strength, which cannot be considered sufficient to guarantee a safe facing in any case. On the contrary, RTS prepared with K(4)P7 and K(3)A(4)E displayed different values of peel strength, which can be considered suitable for facings made with different purposes. Remoistenable tissues of K(4)P7 exhibited an intermediate peel force. The strength recorded for English tissue RTS was quite low and it could be good for protective facings applied for the transportation of the painting or even also small structural intervention that do not expect to apply high stresses. The strength of the RTS prepared with TNT tissue was higher, and it could be considered suitable for facings applied to protect the paint layer during structural interventions on the back of the paintings. Remoistenable tissues prepared with K(3)A(4)E presented the highest values of peel strength. The average force of specimens faced with RTS of English tissue showed suitable values for facing applied in view of structural interventions on the back of the painting. RTS made with TNT presented a relevant peel load. In this case, the permanence of the mock-ups in a high humidity environment led to a remarkable increase in the average peel force. This kind of RTS could probably be used when dangerous interventions on the back of the painting are projected or for big canvas paintings.

Another important information derived from the peel test is the increase in the peel strength recorded for the mock-ups stored at $80 \% \mathrm{RH}$. This growth is almost unappreciable in RTS of English tissues, while is distinctly noticeable in RTS made with TNT. This is an unexpected result that denies the common belief that the storage in very humid condition or the use of water for other interventions on a faced painting, can affect the adhesive strength of the facing for the worse, leading to the detachment of the facing when wet. It would be worth to reconsider this aspect, since in the case of the application of moisture (and not liquid water) the adhesion of the facing should not decrease, but become stronger (probably too strong).

In conclusion, this PhD has allowed validating an innovative facing system that enables to obtain an almost exclusively superficial adhesion and an easy and 
effective removal of residues. The long design process made it possible to select two high viscosity adhesive mixtures and two interim supports, to be combined in specific percentages for the preparation of RTS with different degrees of adhesion according to need. The proposed application method also allows to considerably reducing the water intake, using a reactivation cloth embedded with a specific quantity of buffer solution, to be used for the reactivation of RTS during both the application and removal of the facing.

The results reported here do not represent in any way a ready-made formula to be applied universally as a substitute for traditional facings. As always should be done in the field of conservation, the reported data provide a possibility to be evaluated case by case, with extreme care, paying attention to the compatibility of the proposed RTS with the characteristics of the painting to be restored and the objectives to be achieved. It is certain, however, that the analyses carried out with rigor and method during this $\mathrm{PhD}$ provide a certain degree of confidence regarding the characteristics and performance of the presented remoistenable tissues. In fact, this PhD represents one of the first cases in which a comprehensive research for the development of a facing system was conducted, by using cutting-edge techniques and sophisticated analytical systems.

In this regard, another achieved goal is the development of successfully investigation methodologies. For example, the method developed for assessing the penetration of adhesives through micro-Raman spectroscopy is an important achievement itself, since it proved to be successful for the identification of traces of adhesive polymers in the cross-section of complex specimens reproducing an oil painting. Therefore, it could be used in the future for other investigation on facing techniques, as well as for the assessment of the penetration of the polymers employed for other interventions, such as consolidation. The same applies to the changes made to the D1876 ASTM standard test for peeling tests, which made it possible to overcome the difficulties associated with the fragility of temporary supports, developing a methodology that could be effectively used for future analyses.

The obtained results highlight the need to deepen in the issue of the effects of environmental conditions with further analysis to determine the causes of the increase of peel force, and to assess the potential dangers for the painting. With the available information, it is possible to assume that these changes are related to the mechanical change occurring both in the temporary support and the adhesive dispersion, but it would be important to assess the influence of a possibly higher penetration of the adhesive. In this regard, it would be better to check the penetration of the adhesives in the substrate of specimens stored at 
different thermo-hygrometric conditions. It would be very important to check this aspect, because it could invalidate the concepts of superficiality and reversibility required for this kind of facings. This means that the removability of the RTS should be verified after the permanence in unfavourable environmental conditions as well. It would also be worth to make further tensile tests at different thermohygrometrical conditions, which would permit to assess the changes in the mechanical properties of the different materials used. Some tests could be done to understand the connection between the response of different materials to water and the increase in the adhesion. Finally, in order to deepen the understanding of the adhesion properties of the selected remoistenable tissue, it would be useful to find an effective system to make shear tests, overcoming the technical problems related to the fragility of temporary supports.

In any case, the large amount of work carried out for this $\mathrm{PhD}$ represents only the tip of the iceberg of what could and should be done in the field of facing research. Indeed, it would be of great use to investigate the performance of the selected facings under different stresses and conditions, typical of the intervention usually associated to facing (e.g.: movimentation, lining, de-lining, structural operation on the back of the painting). This would permit to define the field of action of the RTS in relation to the different interventions.

Furthermore, thanks to the boost given by the Getty's "Conserving Canvas" project in terms of interdisciplinary and international collaboration on linings and related issues, this could be the optimal time to kick-start a research based on the study of facings used in different European countries regarding lining/delining processes. The research should be performed in collaboration with professionals of different geographical contexts and expertizes. It should be aimed to share information, increase the awareness of the risks, and change the attitude and practice of facing, proposing an alternative approach that could represent a breakthrough itself. A deeper reflection on facing mechanisms should lead to a more careful evaluation on the use of facing, and to a greater awareness of the purposes addressed to the operation (consolidation/protection). A debate on this specific question could help to adopt an internationally harmonized terminology on the issue.

Facing is an actual issue and there is a need of carrying out well-structured researches addressed to the study of facing mechanisms and their effects on paintings. Practical answers are needed to choose the most suitable facings according to knowledge-based investigations, replicable experiences and scientifically proved data, rather than on intuitions or hypothetic reasoning. 


\section{References}

Ackroyd, Paul. 2002. "The structural conservation of canvas paintings: changes in attitude and practice since the early 1970s." In Studies in Conservation 47(sup 1): 3-14. DOI: 10.1179/sic.2002.47.Supplement-1.3.

Adams, Robert D., Andrew D. Crocombe, and J. A. Harris. 1977. "The mechanics of Peel." In Adhesion 7, 39-58. London: Applied Science Publishers.

Agostinelli, Giulia. 2013. "Il trasporto dei dipinti su tela: storia di una tecnica, attualizzazione e prospettive." Master's Thesis, Università degli Studi di Urbino "Carlo Bo".

Alba, Paola, and Antonio laccarino-ldelson. 2016. "Protezione o consolidamento? La velinatura tra tradizione e innovazione". Proceedings of the $32^{\text {nd }}$ Convegno di studi Scienza e Beni Culturali: Ereresia ed Ortodossia nel Restauro, Arcadia Ricerche, Bressanone, June 28 - July 1, Bressanone, 225-235. Marghera: Arcadia Ricerche.

Alba, Paola, Antonio laccarino-Idelson, and Susana Martín-Rey. 2017. "Riflessioni sulla velinatura: una ricerca in corso." Proceedings of XV Congresso Nazionale IGIIC. Lo stato dell'arte 15, October 12-14, Bari, 597-605. Firenze: Nardini.

Alba, Paola, Susana Martín-Rey, and María Teresa Doménech-Carbó, "Analysis of facing materials used as remoistenable temporary supports for facing on canvas paintings." In CeROArt [Online], 11. DOI: 10.4000/ceroart.6532. DOI: https://doi.org/10.4000/ceroart.6532.

Alba, Paola. 2015. "La velinatura. Riflessioni su un'operazione problematica." Master's Degree diss., Università degli Studi di Urbino "Carlo Bo".

Allegretti, Ottaviano, and Francesca Raffaelli. 2008. "Barrier Effect to Water Vapour of Early European Painting Materials on Wood Panels" in Studies in Conservation 53(3):187-197. DOI: 10.2307/27867037. 
Alonso-Alonso, Rafael. 2009. "La actuación del taller de restauración del Museo Nacional del Prado durante la guerra civil." In Arte protegido. Memoria de la Junta del Tesoro Artístico durante la guerra civil. Madrid: Museo Nacional del Prado-IPHE, 165-186.

Alvarez, Lorenzo, et al. 1999. "A comparison of gas-liquid chromatography, NMR spectroscopy and Raman spectroscopy for determination of the substituent content of general non-ionic cellulose ethers." Journal of Pharmaceutical and Biomedical Analysis, 20: 373-383. DOI: https://doi.org/10.1016/S0731-7085(99)00066-7.

Ansalone, Mario, et al. 1986. "La connotazione dei materiali impiegati nel restauro. Le carte giapponesi." Bollettino ICPAL 40: 12-19.

Arends, Thomas, et al. 2018. "Relating relative humidity fluctuations to damage in oak panel paintings by a simple experiment." In Studies in Conservation 64(2): 101-114. DOI: 10.1080/00393630.2018.1481351

Arslanoglu, Julie. 2003a. "Evaluation of the use of Aquazol as an adhesive in Painting Conservation". WAAC newsletter 25 (2): 12-18.

Arslanoglu, Julie. 2003b. "Aquazol as used in conservation practice". WAAC newsletter 26(1): 10-15.

ASTM Standard D1876. 2015. "Standard Test Method for Peel Resistance of Adhesives (T-Peel Test)." ASTM International, DOI: 10.1520/D187608R15E01, wWw.astm.org.

Awaja, Firas, et al. 2009. "Adhesion of polymers." Progress in Polymer Science 34 (9): 948-968. DOI: https://doi.org/10.1016/j.progpolymsci.2009.04.007.

Baldini, Umberto, and Paolo Dal Poggetto. 2013 (1972). Firenze Restaura. II laboratorio nel suo quarantennio. Firenze: Edifir.

Barbillat, Jacques, et al. 1999. Spectrométrie Raman. Saint-Denis: Techniques de l'Ingénieur.

Barrès, Frankline. 2005. Les peintures transposées du Musée du Louvre, étude des techniques de transposition en France, de 1750 jusqu'à la fin du XIX siècle. Proceedings from ICOM-CC 14th Triennial Meeting, 12-16 September, ICOM Committee for Conservation. The Hague.

Baruffaldi, Girolamo. 1740. Vite de' pittori e scultori ferraresi. Ferrara: Davide Passigli Tipografo Editore. 
Battle, Edward. 2018. "An initial investigation into de-lining BEVA 371 adhered polyester sailcloth from archival canvas and an evaluation of the affects facing may have on the procedure." Final Year Postgraduate Dissertation, The Cortauld Institute of Art.

Bedenikovic, Theresa, Sigris Eyb-Green, and Wolfgang Baatz. 2018. "NonAqueous Facing Methods in Paper Conservation - Part I: Testing Facing Materials". Restaurator. International Journal for the Preservation of Library and Archival Material 39(3): 185-214. DOI: https://doi.org/10.1515/res-2018-0009.

Bell, Ian M., Robin J.H. Clark, and Peter J. Gibbs.1997. "Raman spectroscopic library of natural and synthetic pigments (Pre 61850 AD)." Spectrochimica Acta Part A 53: 2159-2179.

Berg, Jhon C. 2002. Semi-empirical strategies for predicting adhesion. In "Adhesion Science and Engineering: Surfaces, Chemistry and Applications." Amsterdam: Elsevier Science.

Berger, Gustav A. 1972. "Testing adhesives for the consolidation of paintings. Studies in conservation. 17: 173-194. DOI: https://doi.org/10.1179/sic.1972.016

Berger, Gustav A., and William H. Russell. 1990. "Deterioration of Surfaces Exposed to Environmental Changes." In Journal of the American Institute for Conservation 29(1): 45-76. DOi: https://doi.org/10.1179/019713690806046145.

Berger, Gustav A., Harold I. Zeliger. 1984. The procedure of developing an adhesive for paintings: the importance of valid tests. 29: 13-17. DOI: https://doi.org/10.1179/sic.1984.29.Supplement-1.13.

Berger, Gustav, and William H. Russell. 2000. Conservation of Paintings. Research and Innovation. London: Archetype Publications.

Bonsanti, Giorgio and Marco Ciatti. 2004. Manuale del pittore restauratore. Studi per la nuova edizione. Firenze: Edifir.

Borgioli, Leonardo, and Paolo Cremonesi. 2005. Le resine sintetiche usate nel trattamento di opere policrome. Padova: II Prato.

Borgioli, Leonardo, Enrica Boschetti, and Arianna Splendore. 2009. "Preconsolidare e velinare: I'opzione ciclododecano." In Kermes 73: 67-75. 
Borgioli, Leonardo, Enrica Boschetti, and Claudia Tortato. 2016. "I cerotti di Aquazol 500. Una procedura alternativa per la velinatura dei dipinti". Progetto Restauro 73: 3-13.

Borrelli-Vlad, Licia. 1950. "Restauro e restauratori di dipinti in Francia dal 1750 al 1860." Bollettino dell'Istituto Centrale del Restauro 1: 71-84.

Bowles, A. J., W. O. George, and D.B. Cunliffe-Jones. 1970. "Conformations of some aß-unsaturated carbonyl compounds. Part II. Infrared and Raman spectra of methyl and ethyl acrylates and trans-crotonates." Journal of the Chemical Society B: Physical Organic, 0: 1070-1075. DOI: https://doi.org/10.1039/J29700001070.

Brennan, Patrick J. 2011. "Improved UV Light Source Enhances Correlation in Accelerated Weathering". Technical bulletin of Q-Lab Corporation LU-8003. URL: https://www.q-lab.com/resources/technicalbulletins.aspx.

Buckle, Irene. 1997. "Update: Remoistenable Lining with Methyl Cellulose Adhesive Preparation". Topics in Photographic Preservation 7: 88-90.

Burgio, Lucia, and Robin J.H.Clark. 2001. "Library of FT-Raman spectra of pigments, minerals, pigment media and varnishes, and supplement to existing library of Raman spectra of pigments with visible excitation". Spectrochimica Acta Part A 57: 1491-1521. DOI: https://doi.org/10.1016/S1386-1425(00)00495-9.

Buzzegoli, Ezio, Luisa Landi, and Debora Minotti. 2008. Fenomeni di diffusione, in supporto poroso, di materiali utilizzati per il consolidamento in opere di pittura. Proc. of the 3rd International Congress "Colore e Conservazione - materiali e metodi nel restauro delle opere policrome mobili", 10-11 of November 2006, CESMAR7. Saonara (PD): II Prato.

Caggiani, Maria Cristina. 2014. "Spectroscopic Techniques for the Study of Geological and Archaeological Materials." PhD, Università degli Studi di Bari "Aldo Moro".

Capriotti, Giorgio, and Antonio laccarino-Idelson. 2004. Tensionamento dei dipinti su tela. La ricerca del valore di tensionamento. Firenze: Nardini.

Carena, Giacinto. 1859. Nuovo vocabolario italiano domestico. Napoli: Giovanni Pedone. 
Casadio, Francesca, Céline Daher, and Ludovic Bellot-Gurlet.2016. "Raman Spectroscopy of cultural heritage Materials: Overview of Applications and New Frontiers in Instrumentation, Sampling Modalities, and Data Processing." Analytical Chemistry for Cultural Heritage, 61-211. Cham: Springer.

Casanova et al. 2016. "The use of vibrational spectroscopy techniques as a tool for the discrimination and identification of the natural and synthetic organic compounds used in conservation". Analytical Methods Royal Society of Chemistry.

Catell-Augustí, Maria, et al. 2010. "Factores de mejora en tratmientpos de protección y consolidación de pinturas sobre lienzo de gran formato." In Arché 4-5: 125-130.

Cecchini, Giovanni. 2009. "L'Annunciazione e la Beata Michelina di Federico Barocci nella Pinacoteca Vaticana: osservazioni in seguito agli ultimi restauri." In Bollettino dell'Istituto Centrale del Restauro 18-19: 85-151.

Chung, Frank H. 1991. "Unified theory and guidelines on adhesion." Journal of applied polymer science 42(5):1319-133. Doi: https://doi.org/10.1002/app.1991.070420515.

Ciatti, Marco, Ciro Castelli, and Andrea Santacesaria. 2006. Panel painting. Technique and Conservation of Wood Supports. Firenze: Edifir.

Ciatti, Marco. 1995. "Il trasporto del colore nei dipinti su tavola: analisi storica, tecnica esecutiva, attuali applicazioni." In OPD Restauro 7: 141-160.

Ciatti, Marco. 2009. Appunti per un manuale di storia e teoria del restauro. Dispense per gli studenti. Firenze: Edifir.

Conti, Alessandro. 1988. Storia del restauro e della conservazione delle opere d'arte. Milano: Mondadori Electa. (Glanville, Helen, ed. 2016. History of the restoration and conservation of works of art. London: Routledge).

Cremonesi, Paolo, Maria Fratelli, and Davide Riggiardi. 2006. "Opere senza veli: la criticità della velinatura dei dipinti e le alternative possibili", in Postprints: Lo stato dell'arte 4, IV congresso nazionale IGIIC, Siena, 2830 September, 173-178. Firenze: Nardini.

Cremonesi, Paolo. 2011. L'ambiente acquoso per la pulitura di opere policrome. Padova: II Prato. 
Daher, Céline, et al. 2010. "A joint use of Raman and infrared spectroscopies for the identification of natural organic media used in ancient varnishes". Journal of Raman Spectroscopy 41: 1494-1499. DOI: https://doi.org/10.1002/jrs.2693.

Daher, Céline. 2012. "Analyse par spectroscopies Raman etinfrarouge de matériaux naturels organiques issus d'objets du patrimoine: méthodologies et applications." PhD diss., Université Pierre et Marie Curie Paris. URL: https://tel.archives-ouvertes.fr/tel-00742851/.

De la Rie, Rene. 1988. "Photochemical and thermal degradation of films of dammar resin". Studies in Conservation 33:53-70. DOI: https://doi.org/10.1179/sic.1988.33.2.53.

Deveij, Marleen de, et al. 2009. "Reference database of Raman spectra of pharmaceutical excipients" Journal of Raman Spectroscopy 40: 297307. DOI: https://doi.org/10.1002/jrs.2125.

Dillard, David A., and Alphonus V. Pocius. 2002. The mechanics of adhesion. In "Adhesion Science and Engineering: Surfaces, Chemistry and Applications." Amsterdam: Elsevier Science.

Dizionario delle scienze naturali, nel quale si tratta metodicamente dei differenti esseri della natura. Firenze: V. Batelli e figli, 1837.

Doelen, Gisela A. Van der, and Jaap J. Boon. 2000. "Artificial ageing of varnish triterpenoids in solution". Journal of Photochemistry and Photobiology A: Chemistry 134 (1-2): 45-57. DOI: https://doi.org/10.1016/S10106030(00)00245-8.

Durig, James R., Steven Riethmiller, and Yu S. Li. 1974. "Spectra and structure of small ring compounds. XXXI Microwave, Raman and infrared spectra, conformation, dipole moment, and quadrupole coupling constants of 2-oxazoline". The Journal of chemical physics 61: 253-262.

Edwards, Howell G. M., Dennis W. Farwell, and Susana E. Jorge Villar. 2007. "Raman microspectroscopic studies of amber resins with insect inclusions" Spectrochimica Acta Part A: Molecular and Biomolecular Spectroscopy 68(4): 1089-1095. DOI: https://doi.org/10.1016/j.saa.2006.11.037.

Edwards, Howell G. M., Dougleas W. Farwell, and Lee A. Daffner. 1996. "Fouriertransform Raman spectroscopic study of natural waxes and resins." Spectrochimica Acta Part A 52: 1639-1648. 
Edwards, Howell G.M., and John M. Chalmers. 2005. Raman Spectroscopy in Archaeology and Art History. Cambridge: Royal Society of Chemistry.

Fechner, Patra M., et al. 2005. Interaction of water with different cellulose ethers: a Raman spectroscopy and environmental scanning electron microscopy study." Journal of Pharmacy and Pharmacology 57:689698.

Feller, Robert L. 1994. Accelerated Aging: Photochemical and Thermal Aspects. United States: Getty Conservation Institute, PDF e-book.

Fioravanti, Leonardo. 1596. Compendio de secreti rationali. V vols. Venezia: Altobello Salicato.

Frushour, Bruce G., and Jack L. Koenig. 1975. "Raman Scattering of Collagen, Gelatin, and Elastin." Biopolymers 14:379-391. DOI: https://doi.org/10.1002/bip.1975.360140211.

Ge, Liehui, et al. 2007. "Carbon nanotube-based synthetic gecko tapes". Proceedings of the National Academy of Sciences of the United States of America 104(26): 10792-10795. DOI: https://doi.org/10.1073/pnas.0703505104.

Gent, Alan N., and Gary R. Hamed. 1977. "Peel Mechanics of Adhesive Joints." Polymer Engineering and Science, 17 (7): 462-466. DOI: https://doi.org/10.1002/pen.760170708.

Grantham, Sandra. 2002. "Japanese handmade paper." Papier restaurierung 2(3): 30 .

Hackney, Stephen. 2020. On Canvas: Preserving the Structure of Paintings. Los Angeles, CA: The Getty Conservation Institute.

Hadavinia, Homayoun, et al. 2006. "A numerical analysis of the elastic-plastic peel test." Engineering Fracture Mechanics. 73 (16): 2324-2335. DOI: https://doi.org/10.1016/j.engfracmech.2006.04.022.

Hangleiter, Hans, and Leonie Saltzmann. 2008. "Un legante volatile: il Ciclododecano." In Postprints: The Care of Painted Surfaces. Materials and methods for consolidation, and scientific methods to evaluate their effectiveness. CESMAR7 International Conference, Milan, 10-11 November 2006, 109-113. Padova: II Prato. 
Hare, Clive H. 1992. "The Degradation of Coatings by Ultraviolet Light and Electromagnetic Radiation". Anatomy of Paint. Materials Technology Section.

Hedley, Gerry. 1981. The stiffness of lining fabrics: theoretical and practical considerations, Proceedings from ICOM-CC 6th Triennial Meeting, 21 25 September, ICOM Committee for Conservation. Ottawa.

Hedley, Gerry. 1988. "Relative humidity and the stress/strain response of canvas paintings: uniaxial measurements of naturally aged samples." In Studies in Conservation 33(3): 133-148. DOI: 10.1179/sic.1988.33.3.133.

Horie, Charles Velson. 2010. Materials for Conservation: Organic Consolidants, Adhesives and Coatings. Oxford: Butterworth Heinemann.

Horie, Charles Velson. 2012. "Setting the scene: considerations and decision making for planning and undertaking treatments." In Adhesives and Consolidants in Painting Conservation, 1-6. London: Archetype Publications.

Hunter, Dard. 1978. Papermaking: the history and technique of an ancient craft. New York: Dover.

laccarino-Idelson, Antonio, and Carlo Serino. 2012. "Le grandi tele nel soffitto della Galeria Dorada di Gandia (Spagna). Smontaggio e ricollocazione, restauro e rifunzionalizzazione elastica dei telai originali." Proceedings of VI Congresso Internazionale Colore e Conservazione. Prima, durante... invece del restauro, CESMAR7 International Conference, 16-17 November 2012, 277-292. Padova: ॥ Prato.

laccarino-Idelson, Antonio, and Carlo Serino. 2014. "L'intervento Strutturale". In Lungo la via degli Abruzzi, un restauro per Pescocostanzo, Massimo Stanzione e Giambattista Gamba nella chiesa di Gesù e Maria, 64-75. Foligno: Etgraphiae.

laccarino-Idelson, Antonio. 2007. Le tecniche tradizionali di foderatura. Lecture notes of the canvas paintings supports at the Universita degli studi di Urbino "Carlo Bo", A.A.2007/2008 (unpublished).

laccarino-Idelson, Antonio. 2011. "Reflections on the relation between conservation and science." CeROArt [Online]. DOI: http://journals.openedition.org/ceroart/2239. 
laccarino-Idelson, Antonio. 2012. "Aspetti strutturali della conservazione dei dipinti su tela", in Restaurid'arte. Opere dell'Abruzzo recuperate dopo il sisma, 164-169. Ancona: Gabbiano Editore.

Karpowicz, Adam. 1990. "A Study on Development of Cracks on Paintings." In Journal of the American Institute for Conservation 29(2): 169-180. DOI: https://doi.org/10.1179/019713690806046028.

Kawashita, Luiz F., D. Roy Moore, and Gordon J. Williams. 2006. "Protocols for the Measurement of Adhesive Fracture Toughness by Peel Tests." The Journal of Adhesion, 82: 973-995.

Kendall, Kevin. 1973. "Peel adhesion of solid films: the surface and bulk effect." The Journal of Adhesion. 5: 179-202. DOI: https://doi.org/10.1080/00218467308075019.

Kremer, David. Kremer Pigmente. Kremer Pigmente GmbH \& Co. KG. URL: https://www.kremer-pigmente.com/en/ (31/01/2019).

Langkilde, Frans W, and A. Svantesson. 1995. "Identification of celluloses with Fourier-Transform (FT) mid-infrared, FT-Raman and near-infrared spectrometry." Journal of Pharmaceutical and Biomedical Analysis 13(4-5): 409-414.

Laroche, Jacqueline, and Maria Vittoria Saccarello. 1996. "La foderatura dei dipinti, due teorie a confronto." In Kermes 25 (9): 11-24.

Lechuga, Katherine. 2011 . Aquazol-Coated Remoistenable Mending Tissues. Proc. of Symposium 2011: Adhesives and Consolidants for Conservation: Research and Applications, October 17-21, Canadian Conservation Institute. Ottawa.

Lee, Yu, et al. 2018. "Evaluation of a gelatin-based adhesive for historic paintings that incorporates citronella oil as an eco-friendly biocide." In Journal of adhesion science and technology 32(21): 2320-2349. DOI: https://doi.org/10.1080/01694243.2018.1477411.

Lorusso, Salvatore. 2006. Caratterizzazione, tecnologia e conservazione dei manufatti cartacei (I beni culturali e l'ambiente). Bologna: Pitagora.

Macarrón-Miguel, Ana. 2013. Historia de la conservación y la restauración: desde la Antigüedad hasta el siglo XX. Madrid: Tecnos. 
Macarron-Miguel, Ana. 2018. Vicente Polerò. Arte de la restauración y otros textos sobre conservación de cuadros. Madrid: Athenaica.

Maccarón-Serrano, Ángel, Ana María Macarrón-Miguel, and Mauricio Macarrón-Larrumbe. 2009. "Embalaje y transporte de las obras de arte durante la guerra civil española." In Arte protegido. Memoria de la Junta del Tesoro Artístico durante la guerra civil. Madrid: Museo Nacional del Prado-IPHE, 187-200.

Marinetti, Raffaella. 2007. La foderatura dei dipinti: documenti e protagonisti, in Restauri pittorici e allestimenti museali a Roma tra Settecento e Ottocento. Firenze: Edifir.

Martín-Rey, Susana, et al. 2012. "Requisiti e problemi delle velinature di protezione di grandi dipinti su tela: nuovi materiali utilizzati nelle opere del Palazzo Ducale di Gandia (Spagna)." Proceedings of VI Congresso Internazionale Colore e Conservazione. Prima, durante... invece del restauro, CESMAR7 International Conference, 16-17 November 2012, 293-306. Padova: II Prato.

Martín-Rey, Susana, Vicente Guerola-Blay, and Maria Catell-Augustí (Eds.). 2010. International congress on outsize paintings conservation. Valencia: Editorial Universitat Politècnica de València.

Martín-Rey, Susana. 2006. Investigación en el campo de las técnicas de reentelado conducente a la obtención de forraciones transparentes en pintura sobre lienzo: historia, materiales y métodos. Valencia: Editorial Universitat Politècnica de València.

Martín-Rey, Susana. 2012. "Mecanismos y handicaps de adhesión en el estrato pictórico e las pinturas sobre lienzo." Arché 6-7: 265-272.

Massing, Ann. 2012. Painting Restoration before 'La Restauration': The Origins of the Profession in France. Cambridge: Harvey Miller.

Matteini, Mauro, and Arcangelo Moles. 2007. La chimica nel Restauro: i materiali dell'arte pittorica. Firenze: Nardini Editore.

Mecklenburg, Marion F. 1982. "[Report] Some Aspects of the Mechanical Properties of Fabric-Supported Paintings." Smithsonian Libraries, Smithsonian research online. https://repository.si.edu/handle/10088/55639. 
Mecklenburg, Marion F. 2007. "Determining the Acceptable Ranges of Relative Humidity And Temperature in Museums and Galleries: Part 1, Structural Response to Relative Humidity." Smithsonian Libraries, Smithsonian research online, 1-29. DOI: http://sipddr.si.edu/dspace/handle/10088/7055.

Mecklenburg, Marion F. 2008. Failure mechanisms in canvas supported paintings: approaches for developing consolidation protocols. Padova: II Prato.

Mecklenburg, Marion F., and Laura Fuster-Lopez. 2008. "Failure Mechanisms in Canvas Supported Paintings: Approaches for Developing Consolidation Protocols." In Postprints: The Care of Painted Surfaces. Materials and methods for consolidation, and scientific methods to evaluate their effectiveness. CESMAR7 International Conference, Milan, 10-1 1 November 2006, 49-58. Padova: II Prato.

Mecklenburg, Marion F., Charles S. Tumosa, and W. David Erhardt. 1998. "Structural Response of Painted Wood Surfaces to Changes in Ambient Relative Humidity." in Painted Wood: History and Conservation, 464483. Los Angeles, CA: The Getty Conservation Institute.

Mecklenburg, Marion F., Laura Fuster-Lopez, and Silvia Ottolini. 2012. "A Look at the Structural Requirements of Consolidation Adhesives for Easel Paintings." in Adhesives and Consolidants in Painting Conservation, 723. London: Archetype Publications.

Mehera, Viswa Raj. 1972. "Comparative study of conventional relining methods and materials and research towards their improvement." Proceedings from ICOM-CC 3rd Triennial Meeting, 2-7 October, ICOM Committee for Conservation. Madrid.

Mehra, Viswa Raj. 1975." Further developments in cold-lining (nap-bond system)." Proceedings from ICOM-CC 4th Triennial Meeting, October 13-16, ICOM Committee for Conservation. Venezia.

Melià-Angulo, Ana, Laura Fuster-López, and Angel Vicente-Escuder. 2017. "Study of the mechanical properties of selected animal glues and their implication when designing conservation strategies." In CeROArt [Online]. DOI: http://journals.openedition.org/ceroart/5152.

Merrifield, Mary P. 1849. Original treatise on the arts of painting. vols II. London: J. Murray. 
Michalski, Stefan. 1993. Relative humidity: a discussion of correct/incorrect values. Proceedings from ICOM-CC 10th Triennial Meeting, 22-27 August, ICOM Committee for Conservation. Washington, DC.

Michalski, Stefan. 2007. The Ideal Climate, Risk Management, the ASHRAE Chapter, Proofed Fluctuations, and Toward a Full Risk Analysis Model, Contribution to the Experts' Roundtable on Sustainable Climate Management Strategies, April. Tenerife.

Michalski, Stefan. 2008. "A physical model of the consolidation process, particularly of paintings." In Postprints: The Care of Painted Surfaces. Materials and methods for consolidation, and scientific methods to evaluate their effectiveness. CESMAR7 International Conference, Milan, 10-11 November 2006, 27-47. Padova: II Prato.

Mittal, K. L. 1977. "The Role of the Interface in Adhesion Phenomena." Polymer Engineering and Science 17 (7): 467-473. DOI: https://doi.org/10.1002/pen.760170709.

Moore, D. Roy, and Gordon J. Williams. 2010. A protocol for determination of the adhesive fracture toughness of flexible laminates by peel testing: fixed arm and t-peel methods. ESIS Protocol. URL: https://www.imperial.ac.uk/media/imperial-college/researchcentres-and-groups/adhesion-and-adhesives-group/ESIS-peelprotocol-(June-07)-revised-Nov-2010.pdf.

Muñoz-Viñas, Salvador. Contemporary theory of conservation, Oxford 2005.

Murphy, Bernice L. 2016. Museums, Ethics and Cultural Heritage. London: Routledge.

Neppel, Anton, Ian S. Butler, and Adi Eisenberg. 1979. Vibrational Spectra of Polymers. 2. Variable-Temperature Raman Spectroscopy as a Probe for lon Clustering in lonomers." Macromolecules 12(5): 948-952. DOI: https://doi.org/10.1021/ma60071a032.

Nevin, Austin, et al. 2009. Assessment of the ageing of triterpenoid paint varnishes using fluorescence, Raman and FTIR spectroscopy." Analytical and Bioanalytical Chemistry 395(7): 2139-2149. DOI: https://doi.org/10.1007/s00216-009-3005-4.

Olender, Jacek, Christina Young, Ambrose Taylor. 2017. The applicability of geckoinspired dry adhesives to the conservation of photographic prints. Proceedings of ICOM-CC 18th Triennial Conference Modern Materials 
and Contemporary Art, September 4-8, International Council of Museums. Copenhagen: J. Bridgland.

Orlandi, Pellegrino A. 1704. L'abecedario Pittorico. Bologna: Pisarri.

Papini, Giulia, et al. 2018. "Evaluation of the effects of cyclododecane on oil paintings." In International Journal of Conservation Science 9(1): 105116.

Parodi, Valentina. 2008. Giovanni Bedotti. Il restauro dei dipinti. Firenze: Edifir.

Pasti, Daniela. "Grazie, angeli del fango", La Repubblica, 02/11 (1986). URL: https://ricerca.repubblica.it/repubblica/archivio/repubblica/1986/1 1 /02/grazie-angeli-del-fango.html (26/05/2020).

Pataki, Andrea. 2009. "Remoistenable Tissue Preparation and its Practical Aspects". Restaurator 30: 51-60. DOl: https://doi.org/10.1515/rest.004.

Pellizzari, Bartolomeo. 1759. Vocabolario bresciano e toscano compilato per facilitare a' bresciani col mezzo della materna loro lingua il ritrovamento de' vocaboli Modi di dire e Proverbj Toscani a quella corrispondenti. Brescia: Pietro Pianta.

Perusini, Giuseppina. 2012. II manuale di Christian Koester e il restauro in Italia e in Germania dal 1780 al 1830. Firenze: Edifir.

Perusini, Giuseppina. 2013. Simon Horsin-Déon e il restauro in Francia alla metà del XIX secolo. Firanze: Edifir.

Petrukova, Tatyana, and Stephen Bonadies. 1993. "Sturgeon glve for painting consolidation in Russia." In Journal of American Institute for Consrvation 32(1): 23-31. DOI: 10.1179/019713693806066483.

Pianigiani, Ottorino. 1937. Vocabolario etimologico della lingua italiana. Milano: Sonzogno.

Polymer Chemistry Innovations. Aquazol. URL: https://www. polychemistry.com/ aquazol.

Priori, Gianfranco, and Maria V. Quattrini. 2005. "La caratterizzazione delle carte orientali." Bollettino ICR 10-11: 134-150.

Priori, Gianfranco, and Maria V. Quattrini. 2007. "Sulle tracce della carta orientale." Bollettino ICR 14: 150-154. 
Prunetti, Michelangelo. 1818. Saggio pittorico ed analisi delle pitture più famose esistenti in Roma; con il compendio delle vite de' più eccellenti pittori. Roma: Salvioni.

Rinaldi, Simona. 2000. "II metodo Pettenkofer in Italia (1865-1892): cause ed effetti della rigenerazione delle vernici." In Bollettino D'Arte 112: 117-125.

Rinaldi, Simona. 2007. Restauri pittorici e allestimenti museali a Roma tra Settecento e Ottocento. Firenze: Edifir.

Rinaldi, Simona. 2014. Memorie al magnetofono. Mauro Pelliccioli si racconta a Roberto Longhi. Firenze: Edifir.

Roche, Alain, Silvia Ottolini, and Davide Riggiardi. 2009. Studio meccanico del potere consolidante di alcuni adesivi in rapporto a cariche e pigmenti utilizzati in pittura. Proc. of the 4th International Congress "Colore e Conservazione - materiali e metodi nel restauro delle opere policrome mobili", 21-22 of November 2008, CESMAR7. Saonara (PD): II Prato.

Roche, Alain. 2008. "Per una nuova lettura del concetto di adesione e decoesione: aspetti chimico-fisici e meccanici". In Postprints: The Care of Painted Surfaces. Materials and methods for consolidation, and scientific methods to evaluate their effectiveness. CESMAR7 International Conference, Milan, 10-11 November 2006. 61-72. Padova: Il Prato.

Roche, Alain. 2015. "Influenza dei difetti sulla resistenza alla rottura delle pellicole di pittura: condizioni di conservazione." In Tensionamento e Telai dei Dipinti Su Tela fra Tradizione e Innovazione, CESMAR7 Congress, Piazzola sul Brenta (PD), 1-31 January 2015. 50-59. Padova: II Prato.

Rofiquzzaman Raju. "Characteristics of Nonwoven Fabric. Uses and Specialty of Nonwoven Products", Textile learner, 2015. URL: https://textilelearner.blogspot.com/2015/12/characteristics-ofnonwoven-fabric-uses.html.

Rossi Doria, Matteo. 2005. "Diversificazione delle metodologie nel restauro strutturale dei dipinti di grandi formati: illustrazione di alcuni casi." In Postprints: Interim meeting: International conference on painting conservation, Universitat Politècnica de València, 9-11 Marzo 2005, 275-298. Valencia: Editorial Universitat Politècnica de València. 
Rossi Doria, Matteo. 2006. "I trattamenti di consolidamento strutturale dei dipinti su tela fra tradizione e sperimentazione: aggiornamenti a partire dalla tradizione romana." In Procesdings from Dipinti su tela. Problemi e prospettive per la conservazione, National Conference, Ferrara, 4 April. Padova: II Prato.

Rossi Doria, Matteo. 2008. "Fenomeni di deterioramento dei dipinti su tela: come costruire un approccio più meditato nei problemi di consolidamento." In Postprints: The Care of Painted Surfaces. Materials and methods for consolidation, and scientific methods to evaluate their effectiveness. CESMAR7 International Conference, Milan, 10-11 November 2006. 11 26. Padova: II Prato.

Rossi Doria, Matteo. 2013. "Requiem o recupero critico dei metodi di foderatura tradizionali." In Postprints: Lo stato dell'arte 11, 11 th IGIIC National Congress, Bologna, 10-12 October 2013, 77-88. Firenze: Nardini.

Sayed, Abu. "What Is Non-Woven Fabric? Characteristics And Uses Of NonWoven Fabric." Textile Apex, $2014 . \quad$ URL: https://textileapex.blogspot.com/2014/09/characteristics-uses-ofnon-woven.html.

Schellmann, Nanke C. 2007. "Animal glues: a review of their key properties relevant to conservation." In Studies in conservation 52(1): 55-66. DOI: 10.1179/sic.2007.52.Supplement-1.55.

Schiessl, Ulrich. 1998. "History of Structural Panel Painting Conservation in Austria, Germany, and Switzerland." In The Structural Conservation of Panel Paintings, 200-236.

Scicolone, Giovanna. 1991. II restauro dei dipinti contemporanei. Dalle tecniche di interventi tradizionali alle metodologie innovative. Firenze: Nardini Editore.

Scicolone, Giovanna. 2005. "La cinetica di degrado della cellulosa in funzione della progettazione degli interventi conservativi sui supporti cellulosici tessili." In Postprints: Interim meeting: International conference on painting conservation, Universitat Politècnica de València, 9-11 Marzo 2005, 255-274. Valencia: Editorial Universitat Politècnica de València.

Secco-Suardo, Giovanni. 2010. II restauratore di dipinti. Con introduzione di Gaetano Previati. Milano: Hoepli. 
Seeley, Nigel J. 1999. "Reversibility: Achievable Goal or Illusion." In Reversibility: Does it Exist? British Museum Occasional Papers No. 135. London: British Museum Press, pp. 161-7.

Sievens-Figueroa, Lucas, et al. 2012. "Preparation and characterization of hydroxypropyl methyl cellulose films containing stable BCS Class II drug nanoparticles for pharmaceutical applications." International Journal of Pharmaceutics 423:496-508. DOI: https://doi.org/10.1016/j.ijpharm.2011.12.001.

Signorini, Erminio, ed. 2010. Vicente Polerò Y Toledo l'Arte del Restauro. Osservazioni sul Restauro dei Dipinti. Padova: II Prato.

Skwirblies, Robert. 1998. "Restoration of artworks in the Berlin royal picture collection between 1797 and 1830 Internationalization, professionalization, institutionalization." In CeROArt [Online]. DOI: http://journals.openedition.org/ceroart/2356.

Socrates, George. 2001. Infrared and Raman Characteristic Group Frequencies. Tables and Charts. New York: John Wiley \& Sons.

Soppa, Karolina, et al. 2014. Adhesion and penetration of sturgeon glue and gelatines with different Bloom grades. Proceedings from ICOM-CC 17th Triennial Conference, 15-19 September 2014, International Council of Museums. Melbourne: J. Bridgland.

Sun, Shengtong, and Peiyi Wu. 2015. "Conformational changes in the heatinduced crystallization of poly(2-isopropyl-2-oxazoline) in the solid state." Physical Chemistry Chemical Physics 17: 31084-31092. DOI: https://doi.org/10.1039/C5CP05719A.

Taiti, Sergio, and Gastone Tognaccini. 1981. Rintelatura e fermatura del colore e la sua applicazione su nuovo supporto. In Proc. of the Convegno sul Restauro delle Opere d'Arte, 2-7 Novembre 1976, Opificio delle Pietre Dure. Firenze: Polistampa.

Tranquilli, Gloria. 1996. "Aspetti tecnici dell'attività di Pietro Edwards: metodologia di intervento e materiali utilizzati per il restauro dei dipinti su tela." In Bollettino D'Arte, 96-97: 173-188.

Tumosa, Charles S. and Marion F. Mecklenburg. 2013. "Oil Paints: The Chemistry of Drying Oils and the Potential for Solvent Disruption." in New Insights into the Cleaning of Paintings: Proceedings from the Cleaning 2010 International Conference, Universidad Politecnica de Valencia and 
Museum Conservation Institute, 51-58. Washington, DC: Smithsonian Institution.

Uzielli, Luca. 1998. "Historical Overview of Panel-Making Techniques in Central Italy". In The Structural Conservation of Panel Paintings, 110-135.

Van Och, Jos, René Hoppenbrouwers. 2003. "Mist-lining and low-pressure envelopes: an alternative lining method for the reinforcement of canvas paintings." Zeitschrift für Kunsttechnologie und Konservierung 17(1): 116128.

Vandenabeele, Peter, et al. 2000. "Analysis with micro-Raman spectroscopy of natural organic bindingmedia and varnishes used in art" In Analytica Chimica Acta407: 261-274.

Vangerow, J. 1989. Carta giapponese. Monaco.

Vasari, Giorgio. 1568. Le vite de' più eccellenti Pittori, Scultori ed Architetti. Firenze: Giunti.

Vicente-Rabanaque, Teresa, Beatriz Santamarina-Campos, and Virginia Santamarina-Campos. 2011. "De cortesanos y burgueses. Los nacionalismos como motor de la conservación y restauración." In GeConservacion, 2: 99-111.

Vicente-Rabanaque, Teresa. 2012. El restaurador de obras de arte en España durante los siglos XVIII y XIX. Nacimiento de una profesión. Valencia: Editorial Universitat Politècnica de València.

Vicente-Rabanaque, Teresa. 2013. Del restaurador de obras de arte al conservador-restaurador de bienes culturales. La consolidación disciplinar y profesional de la restauración en España (siglos XX-XXI). Valencia: Editorial Universitat Politècnica de València.

Villers, Caroline, ed. 2003. Lining Paintings. Papers from the Greenwich conference on comparative lining techniques, 1974. London: Archetype.

Wagner, Sarah S.1997. "Remoistenable Tissue, Part II: Variations on a Theme". Topics in Photographic Preservation 7: 91-91.

Wake, William C .1977. "Theories of adhesion and uses of adhesives: a review." Polymer 19(3): 291-308. DOI: https://doi.org/10.1016/00323861 (78)90223-9. 
Weddigen, Erasmus. 2005. "Introduzione alle relazioni sul minimo intervento a Thiene. Cosa significa Minimal Intervention?" In Postprints: Minimo intervento conservativo nel restauro dei dipinti, $2^{\text {nd }}$ CESMAR7 International Conference, Thiene 29-30 ottobre 2004, 5-7. Padova: II Prato.

Wehling, Bernhard, et al. 1999. "Investigation of Pigments in Medieval Manuscripts by Micro Raman Spectroscopy and Total Reflection X-Ray Fluorescence Spectrometry". MikrochimicaActa130: 253-260. DOI: https://doi.org/10.1007/BF01242913.

Williams, Scott. 2011. Analysis of Tissue Paper for Facing for Canadian Conservation Institute. Ottawa (Unpublished report).

Willis, Harry A., Veronica J.I. Zichy, and Parick J. Hendra. 1969. "The Laser-Raman and Infra-red Spectra of Poly(Methyl Methacrylate)." Polymer 10: 737746. DOI: https://doi.org/10.1016/0032-3861(69)90101-3.

Winkler, Waltraud, et al. 2003. "Fourier transform Raman spectroscopic data on the fossil resin siegburgite." Journal of Raman Spectroscopy 34 (2): 157162. DOI: https://doi.org/10.1002/jrs.971.

Wolbers, Richard, Mary McGinn, and Deborah Duerbeck. 1998. "Poly (2-Ethyl-2Oxazoline): A New Conservation Consolidant." In Painted Wood: History and Conservation. Getty Conservation Institute. Los Angeles.

Wolbers, Richard. 2000. Cleaning Painted Surfaces. Aqueous Methods. London: Archetype.

Wolbers, Richard. 2006. Un approccio acquoso alla pulitura dei dipinti. Quaderni CESMAR7, 1. Padova: il Prato.

Wolbers, Richard. 2008. "Short term mechanical properties of adhesives solvent and plasticizer effects." In Postprints: The Care of Painted Surfaces. Materials and methods for consolidation, and scientific methods to evaluate their effectiveness. CESMAR7 International Conference, Milan, 10-11 November 2006. 111-118. Padova: II Prato.

Young, Christina, and Roger D. Hibberd. 1999. "Biaxial tensile testing of paintings on canvas." In Studies in Conservation 44(2): 129-141. DOI: https://doi.org/10.1179/sic.1999.44.2.129.

Young, Christina. 1999. "Towards a better understanding of the physical properties of lining materials for paintings: interim results." In The 
Young, Christina. 2006. Sviluppo di test meccanici per vlautarei consolidanti usati per i dipinti su tela. Proceedings of VI Congresso Internazionale Colore e Conservazione. L'attenzione alle superfici pittoriche: materiali e metodi per il consolidamento e metodi scientifici per valutarne l'efficacia, November 10-11, CESMAR7. Padova: II Prato.

Zanardi, Bruno, and Giorgio Torraca. 2011. "Uno sguardo sul restauro dagli anni '50 del Novecento a oggi." In II Ponte 10: 92-116.

Zanardi, Bruno. 2007. "Bellori, Maratti, Bottari e Crespi. Intorno al restauro." In Atti della accademia nazionale dei Lincei vol. XVIII, 205-285.

Zanardi, Bruno. 2012. "Giovanni Urbani e la fondazione delle moderne foderature dei dipinti su tela. Una conversazione con Walter Conti ed Enzo Tassinari." In Bollettino ICR 24-25: 104-111. 